\title{
Gold-Silver Mining Districts, Alteration Zones, and Paleolandforms in the Miocene Bodie Hills Volcanic Field, California and Nevada
}

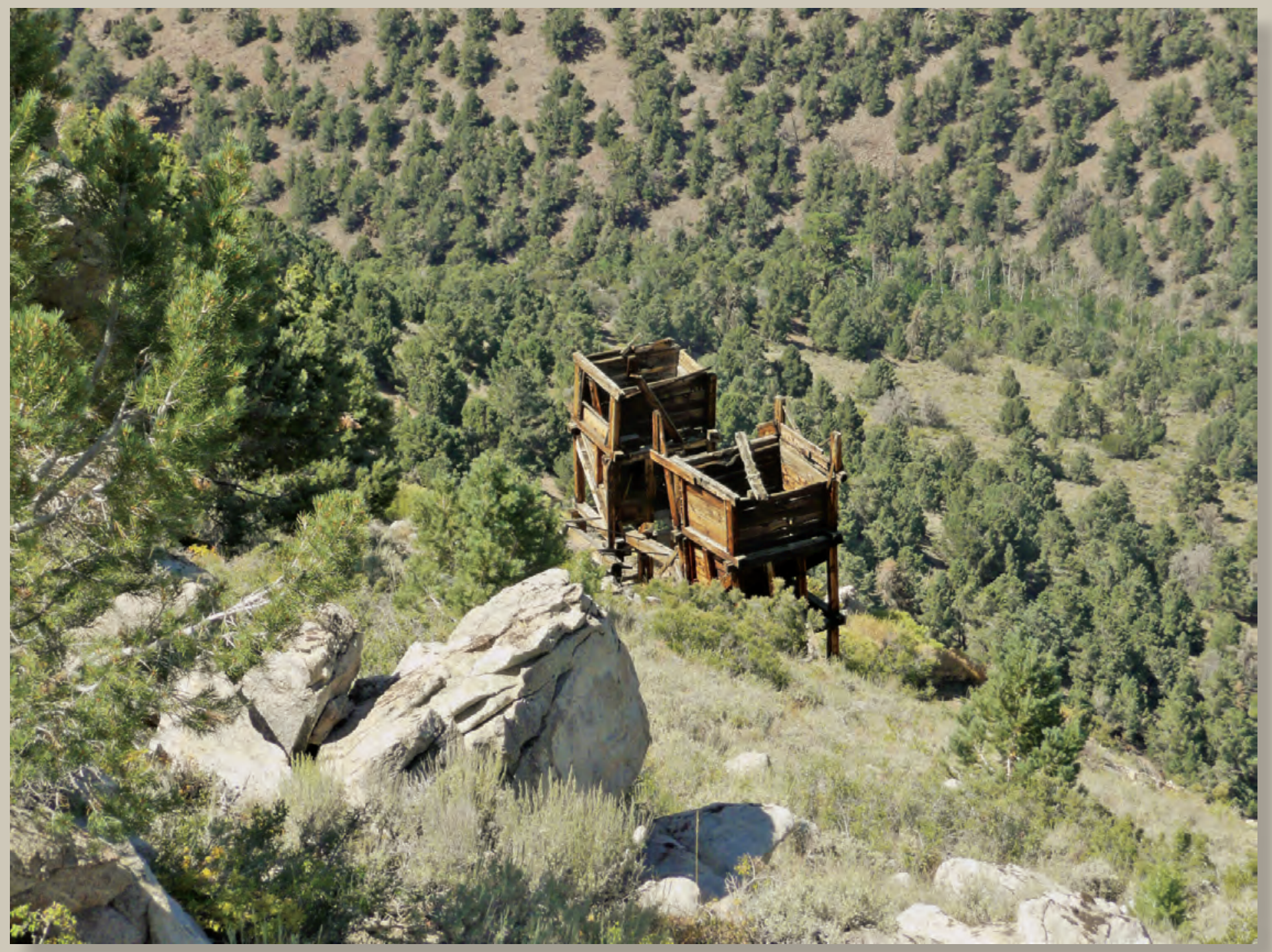

Scientific Investigations Report 2015-5012 
Cover. Photograph showing ore bins at head of aerial tramway from the Sarita Mine to the Masonic mill, Masonic Mining District. 


\section{Gold-Silver Mining Districts, Alteration Zones, and Paleolandforms in the Miocene Bodie Hills Volcanic Field, California and Nevada}

By Peter G. Vikre, David A. John, Edward A. du Bray, and Robert J. Fleck

Scientific Investigations Report 2015-5012 


\title{
U.S. Department of the Interior SALLY JEWELL, Secretary
}

\section{U.S. Geological Survey \\ Suzette M. Kimball, Acting Director}

\author{
U.S. Geological Survey, Reston, Virginia: 2015
}

For more information on the USGS - the Federal source for science about the Earth, its natural and living resources, natural hazards, and the environment-visit http://www.usgs.gov/ or call 1-888-ASK-USGS.

For an overview of USGS information products, including maps, imagery, and publications, visit http://www.usgs.gov/pubprod/.

Any use of trade, firm, or product names is for descriptive purposes only and does not imply endorsement by the U.S. Government.

Although this information product, for the most part, is in the public domain, it also may contain copyrighted materials as noted in the text. Permission to reproduce copyrighted items must be secured from the copyright owner.

Suggested citation:

Vikre, P.G., John, D.A., du Bray, E.A., and Fleck, R.J., 2015, Gold-silver mining districts, alteration zones, and paleolandforms in the Miocene Bodie Hills volcanic field, California and Nevada: U.S. Geological Survey Scientific Investigations Report 2015-5012, 160 p., http://dx.doi.org/10.3133/sir20155012. 


\section{Contents}

Abstract

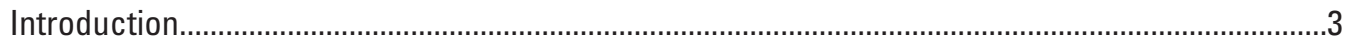

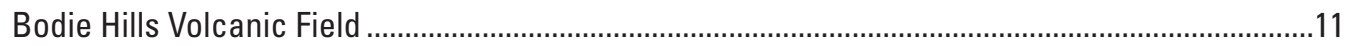

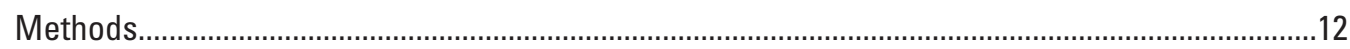

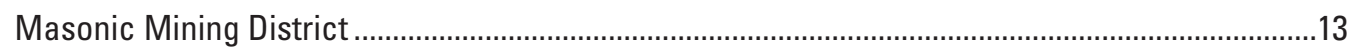

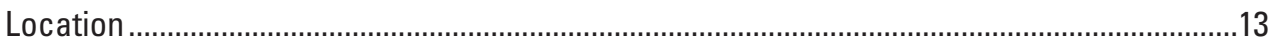

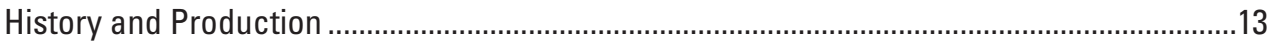

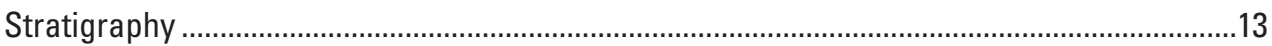

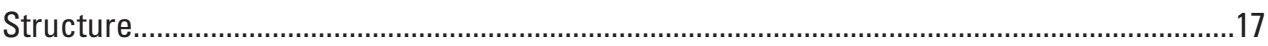

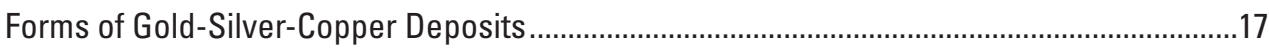

Breccias and Vein Deposits in High-Angle, Subplanar Fault Zones ...............................17

Mineral and Rock Compositions of Breccias and Vein Deposits .....................................18

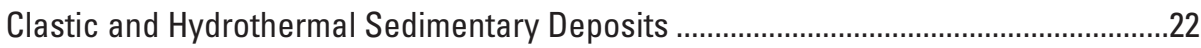

Interpretation of Clastic and Hydrothermal Sedimentary Deposits ................................22

Mineral and Rock Compositions of Clastic and Hydrothermal

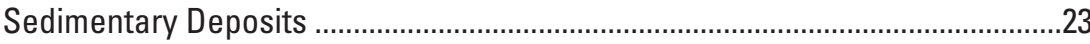

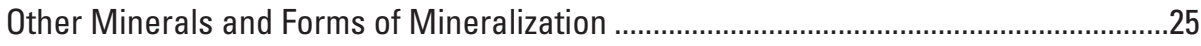

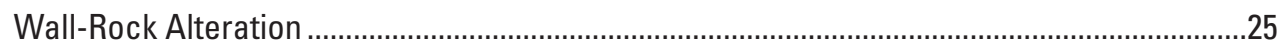

Sulfur Isotope Compositions and Equilibrium Temperatures ...........................................27

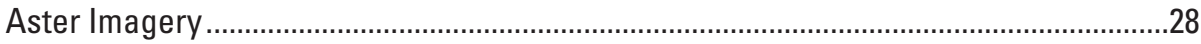

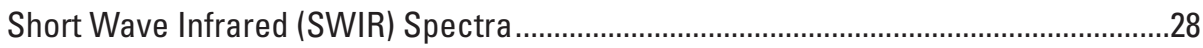

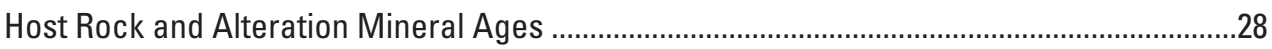

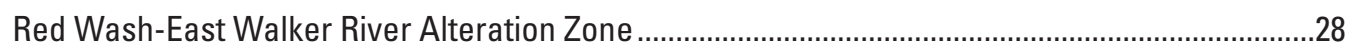

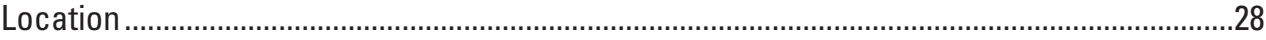

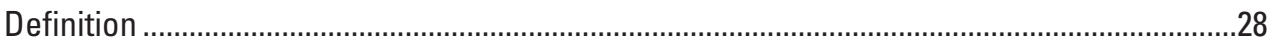

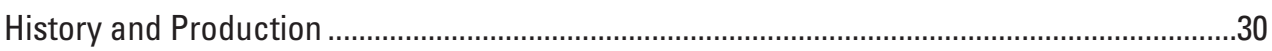

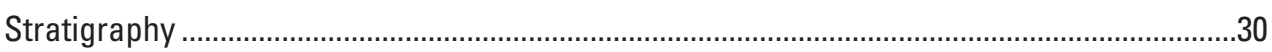

Structure

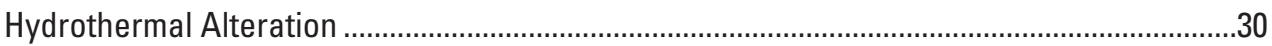

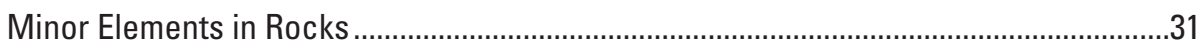

Sulfur Isotope Composition ................................................................................................31

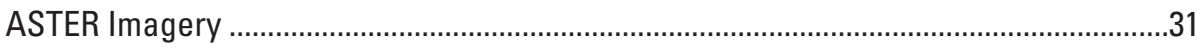

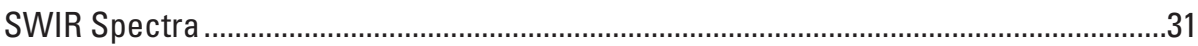

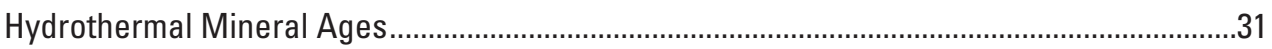

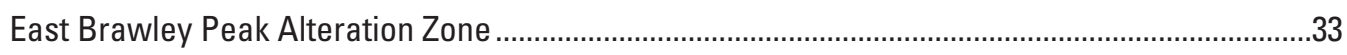

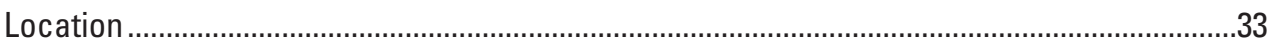

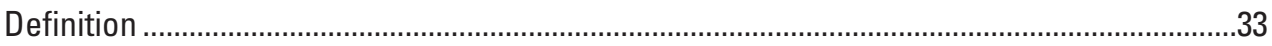

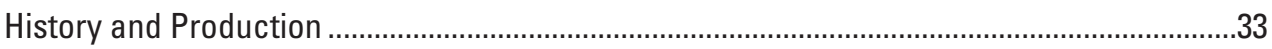

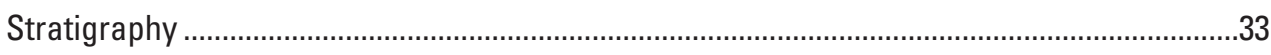

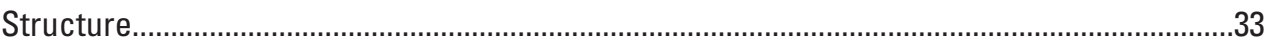




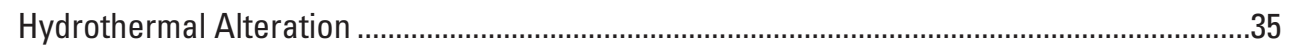

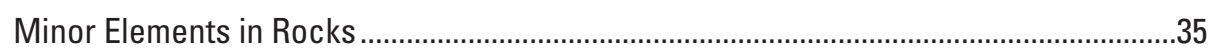

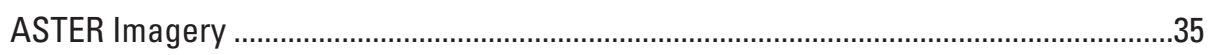

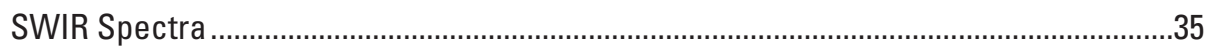

Fluid Inclusion Microthermometry and Composition..............................................................35

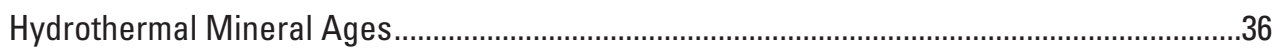

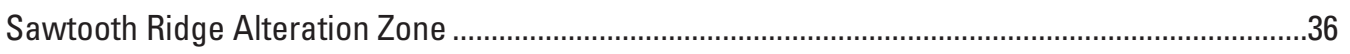

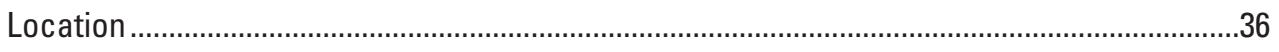

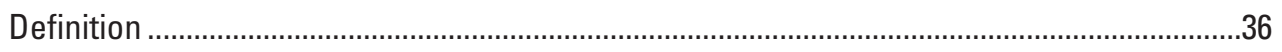

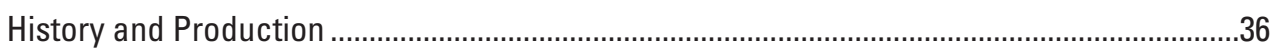

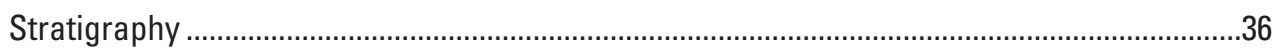

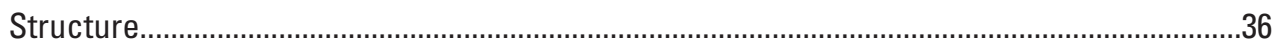

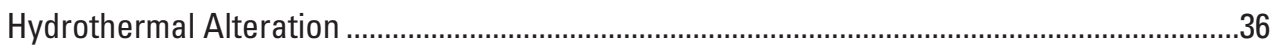

Sulfur Isotope Composition ..........................................................................................38

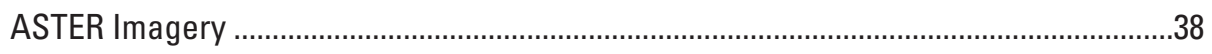

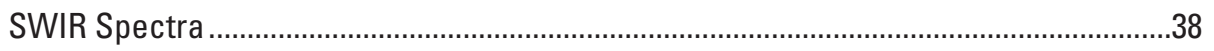

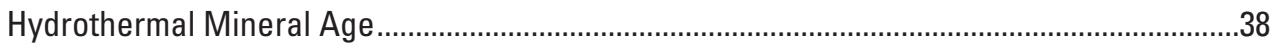

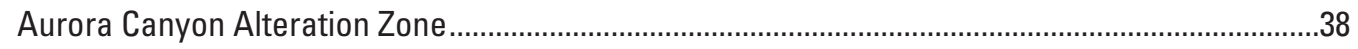

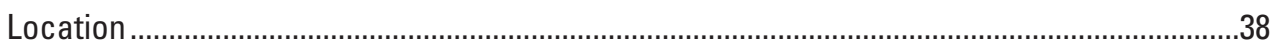

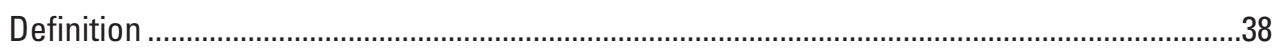

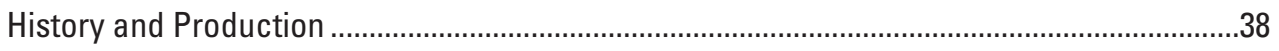

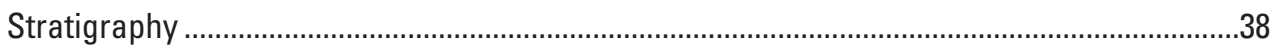

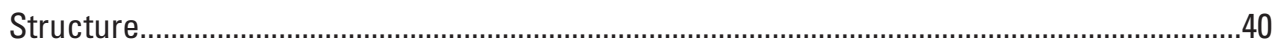

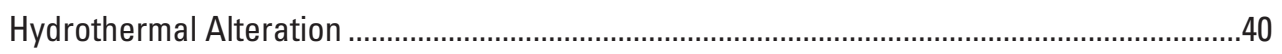

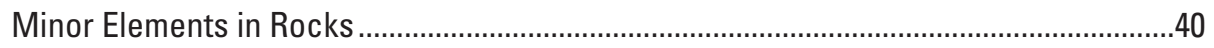

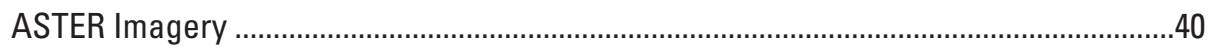

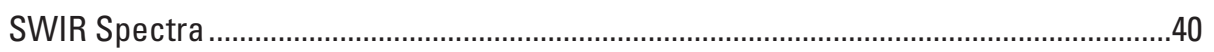

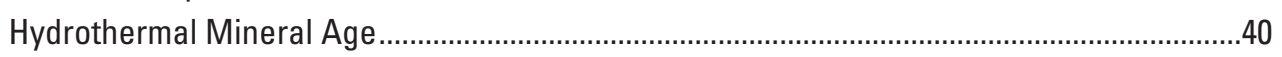

Potato Peak Alteration Zone ………………...............................................................................41

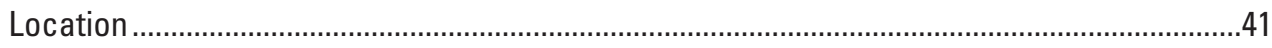

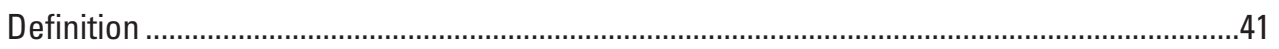

History and Production ...............................................................................................

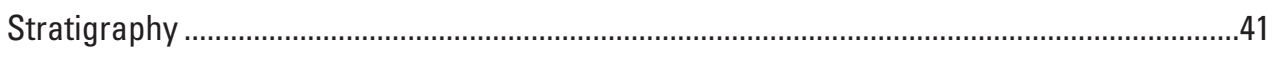

Structure

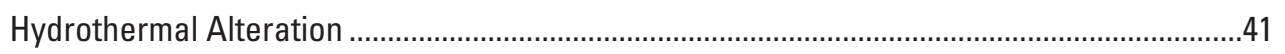

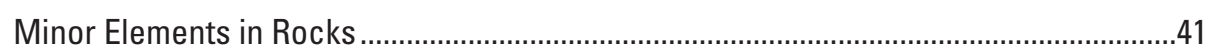

Sulfur Isotope Compositions ....................................................................................4

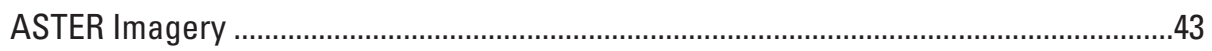

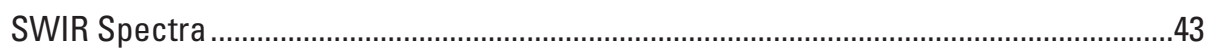

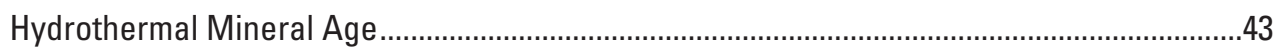

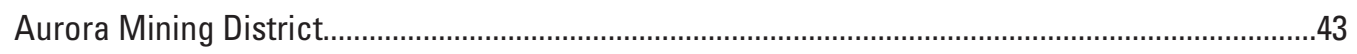

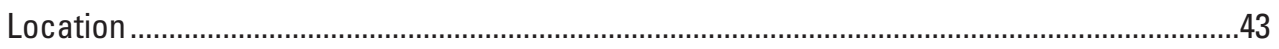

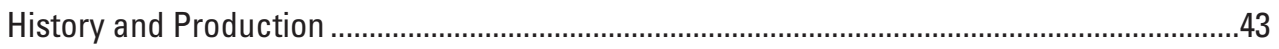

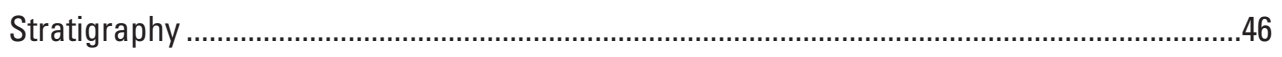

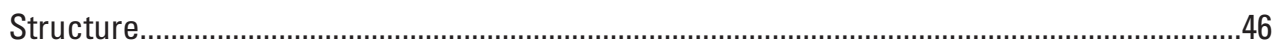


Forms of Gold-Silver Mineralization ..................................................................................4

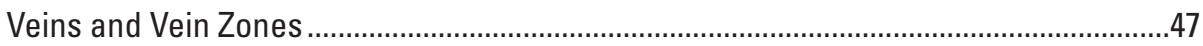

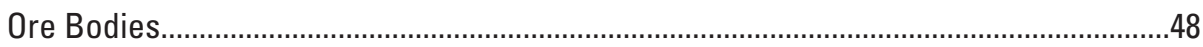

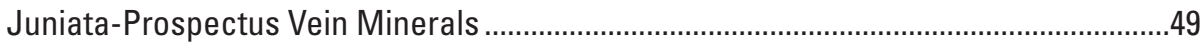

Mineral Compositions in Silver Hill and Middle Hill Veins ...............................................50

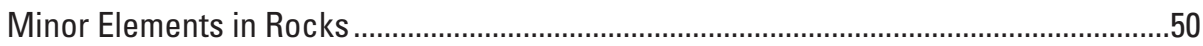

Fluid Inclusion Microthermometry and Compositions....................................................50

Sulfur Isotope Compositions of Vein Minerals................................................................53

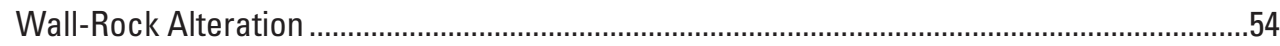

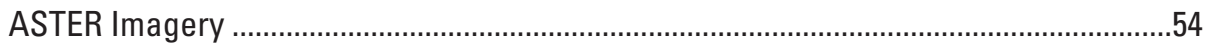

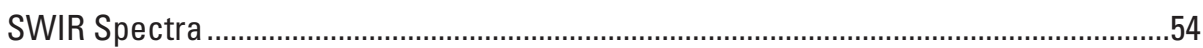

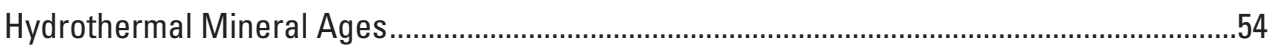

Four Corners Alteration Zone............................................................................................5

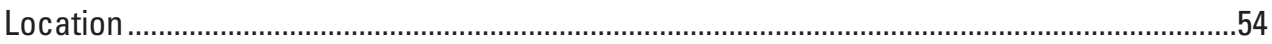

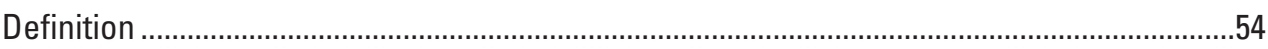

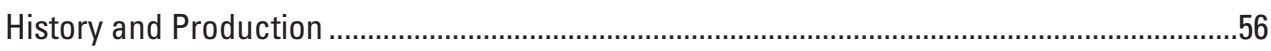

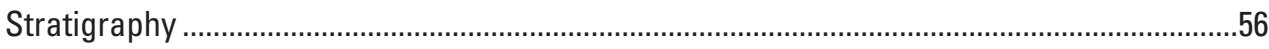

Structure

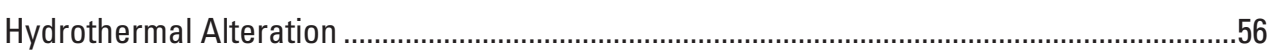

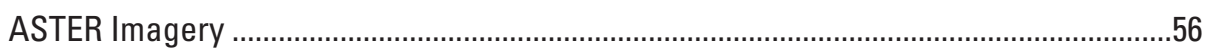

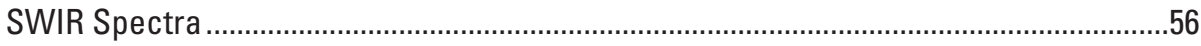

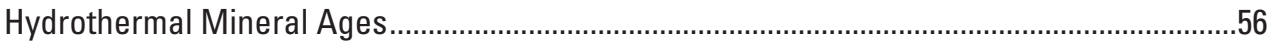

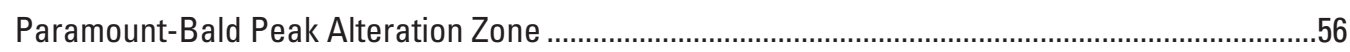

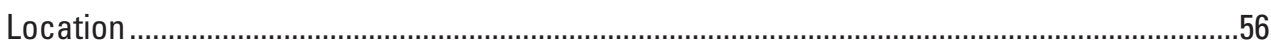

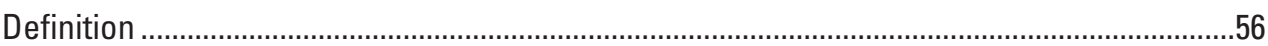

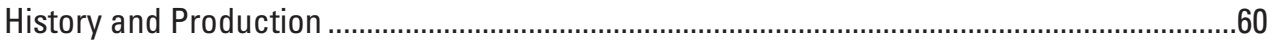

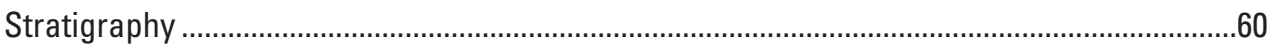

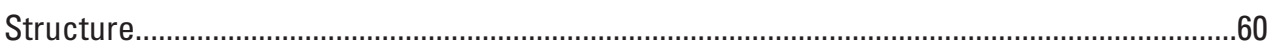

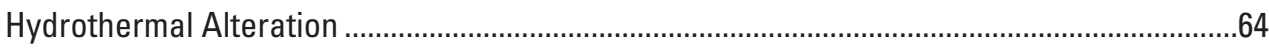

Paramount Mine Area .....................................................................................................

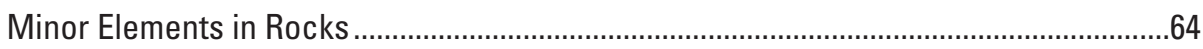

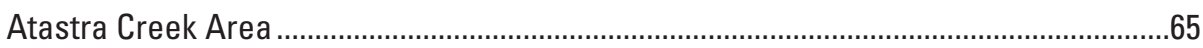

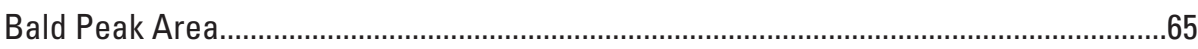

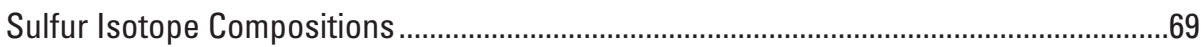

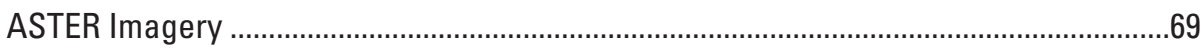

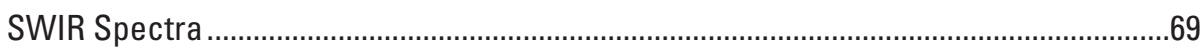

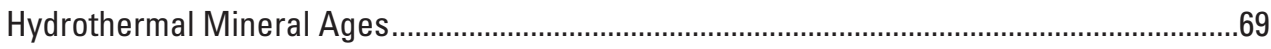

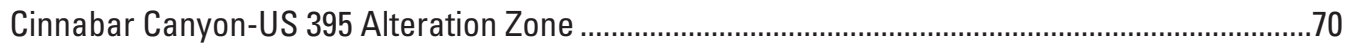

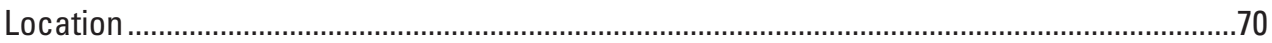

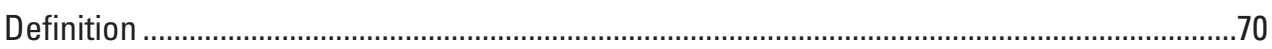

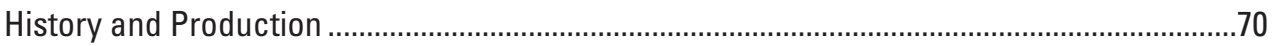

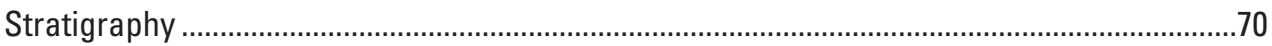

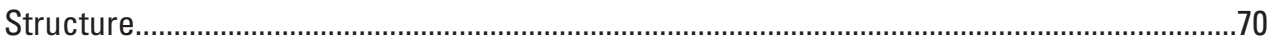

Forms of Mercury and Sulfur Mineralization ....................................................................... 


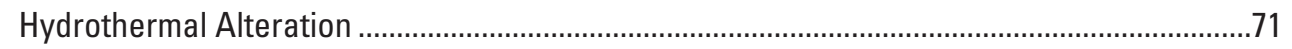

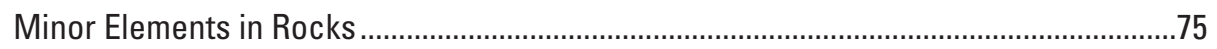

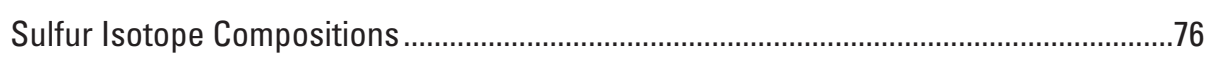

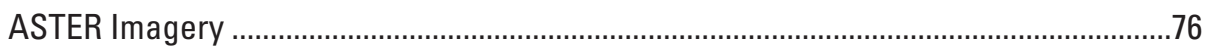

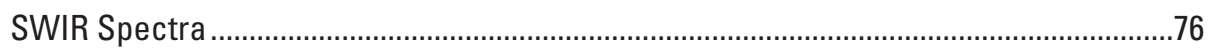

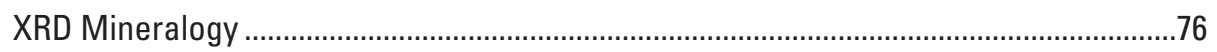

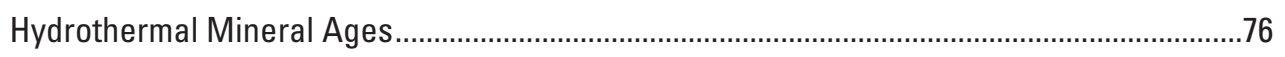

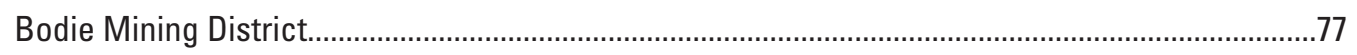

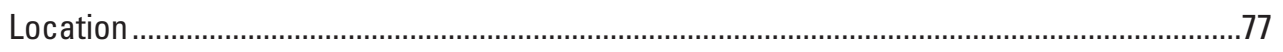

History and Production ...............................................................................................

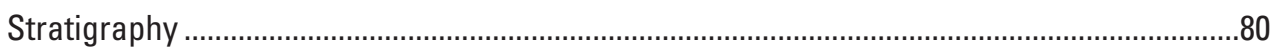

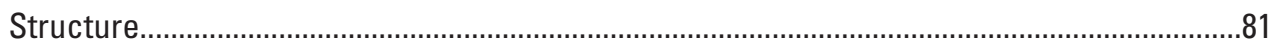

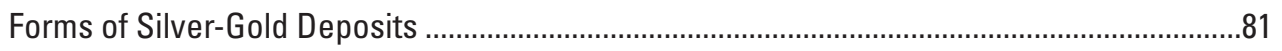

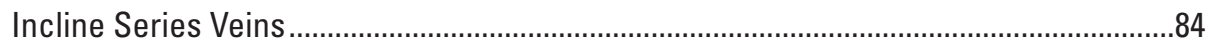

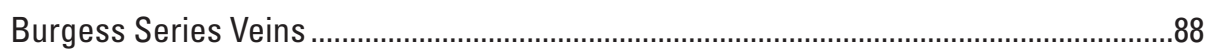

Silver Hill Series Veins ……….................................................................................

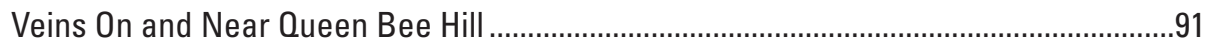

Wall-Rock Alteration ......................................................................................................91

Absolute and Relative Vein and Sinter Ages...............................................................95

Minor Elements in Veins and Wall Rocks ...................................................................95

Fluid Inclusion Microthermometry..........................................................................97

Oxygen and Hydrogen Isotope Compositions of Vein Minerals and Fluid Inclusion Water ....................................................................................................

Sulfur Isotope Compositions of Vein Minerals.............................................................97

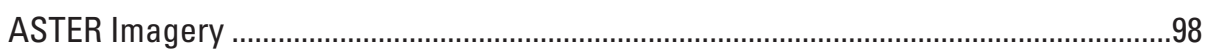

SWIR Spectra; XRD Analyses................................................................................98

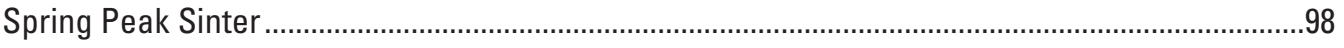

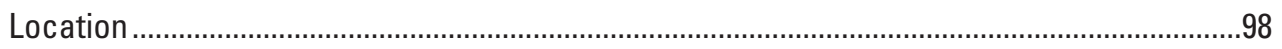

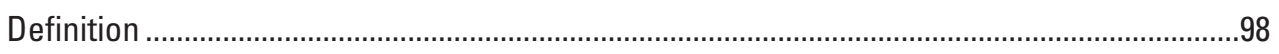

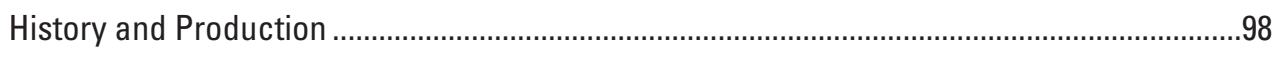

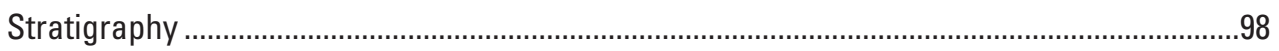

Structure

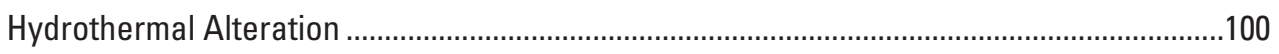

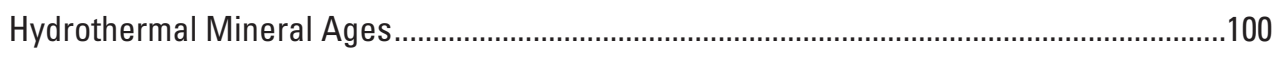

Evolution of Landforms During Assembly and Alteration of the Miocene Bodie Hills

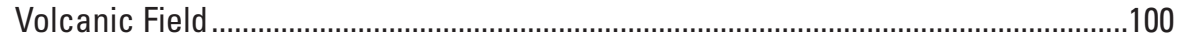

Aldrich Station Flora and Fossils in the Bodie Hills ..................................................100

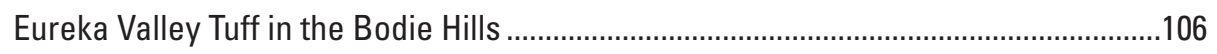

Landforms in Mining Districts and Alteration Zones ..................................................106

Synthesis [Masonic Mining District] ......................................................................107

Synthesis [Aurora Mining District] ..........................................................................109

Synthesis [Bodie Mining District] ............................................................................110

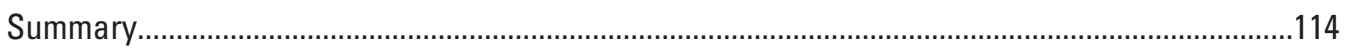

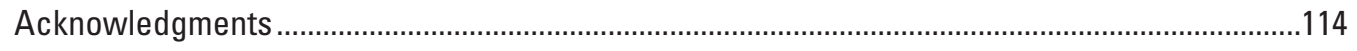

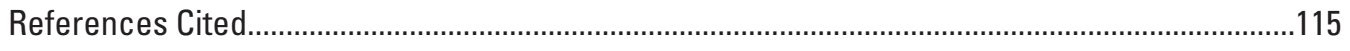

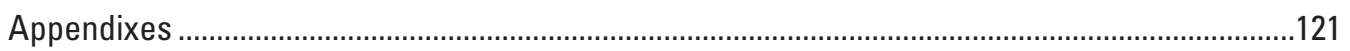




\section{Figures}

1. Map showing locations of mining districts and alteration zones in the Bodie Hills, California and Nevada

2. Geologic map of the southwestern part of the Masonic Mining District, Mono County, California, and Lyon and Mineral Counties, Nevada...

3. Geologic map of the northeastern part of the Masonic Mining District, Mono County, California, and Mineral County, Nevada

4. Images of volcaniclastic deposits in the Red Wash-East Walker River alteration zone and Masonic Mining District 16

5. Images of mineralized fault breccias and veins in the Masonic Mining District.............19

6. Secondary electron images of fault breccia, Masonic Mining District ...........................20

7. Secondary electron images of fault breccia, Masonic Mining District ..........................21

8. Secondary electron image of quartz+alunite+sulfide vein in granodiorite, Masonic Mining District . .22

9. Image of a dump sample from the Masonic Mining District, Sarita Mine .......................23

10. Images of dump samples from the Masonic Mining District, Sarita Mine ......................24

11. Images of dump samples from the Masonic Mining District, Sarita Mine .....................25

12. Secondary electron images of minerals in very fine-grained brown quartz beds from the Sarita Mine open cut, Masonic Mining District .................................................26

13. Image of a dump sample from the Masonic Mining District, Sarita Mine .......................27

14. Geologic map of the Red Wash-East Walker River alteration zone, Lyon and Mineral Counties, Nevada, and Mono County, California...

15. Advanced Spaceborne Thermal Emission and Reflection Radiometer imagery of the Red Wash-East Walker River alteration zone

16. Geologic map of the East Brawley Peak alteration zone, Mineral County, Nevada, and Mono County, California........................................................................................34

17. Geologic map of the Sawtooth Ridge alteration zone, Mineral County, Nevada, and image of a remnant bowl-shaped thermal vent.

18. Geologic map of the Aurora Canyon alteration zone, Mono County, California, and image showing a concentrically exfoliated rhyolite dome

19. Geologic map of the Potato Peak alteration zone, Mono County, California, and image showing landslides developed on altered volcaniclastic strata

20. Geologic map of the Aurora Mining District, Mineral County, Nevada ............................44

21. Image of a sample from the Aurora Mining District ......................................................49

22. Secondary electron images of an archival vein specimen from the Crocket Mine on Last Chance Hill, Aurora Mining District.

23. Secondary electron images of an archival vein specimen from the Antelope Mine, Silver Hill, Aurora Mining District

24. Secondary electron images of an archival vein specimen from the Antelope Mine, Silver Hill, Aurora Mining District .................................................................................53

25. Geologic map of the Four Corners alteration zone, Mono County, California ..................55

26. Images of hydrothermal features, Four Corners alteration zone....................................57

27. Geologic map of the Paramount-Bald Peak alteration zone, Mono County, California, and Mineral County, Nevada, showing sinters, sinter groups, and prospects

28. Geologic map of the Paramount Hg Mine area, Mono County, California, and image showing unoriented, multisized blocks of terrace sinter 
29. Images of Paramount-Bald Peak alteration zone

30. Images of hydrothermal features in the Paramount-Bald Peak alteration zone ..

31. Image showing oriented consecutive sections, graphs showing relative element concentrations, and bulk sample element concentrations of sinter from a dismembered terrace at the western base of Paramount Mine hill, Paramount-Bald Peak alteration zone.

32. Image showing oriented consecutive sections, graphs showing relative element concentrations, and bulk sample element concentrations of a chalcedonic quartz vein exposed at the upper adit of the Paramount Mine, Paramount-Bald Peak alteration zone.

33. Image showing oriented consecutive sections, graphs showing relative element concentrations, and bulk sample concentrations of sinter from sinter terrace on Atastra Creek, Paramount-Bald Peak alteration zone

34. Geologic map and schematic stratigraphic section of the Cinnabar Canyon-US 395 alteration zone, Mono County, California.

35. Images showing volcaniclastic deposits from the Cinnabar Canyon-US 395 alteration zone.

36. Cross section through the Cinnabar Canyon elemental sulfur resource, Cinnabar Canyon-US 395 alteration zone, Mono County, California

37. Geologic map of the Bodie Mining District, Mono County, California .............................78

38. Geologic cross sections of the Bodie Mining District...................................................79

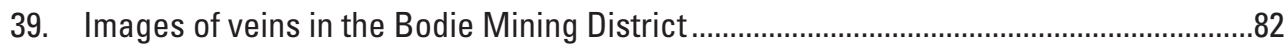

40. Secondary and backscatter electron images of samples representative of Incline series veins on Bodie Bluff, and of vein samples from the Noonday Mine near Silver Hill, Bodie Mining District

41. Secondary electron images of samples representative of Burgess series veins on Standard Hill, Bodie Mining District.

42. Secondary electron images of samples representative of Silver Hill series veins on and near Oro Mine dump, Silver Hill, Bodie Mining District.

43. Secondary electron images of samples representative of Silver Hill series veins on and near Addenda Mine, Silver Hill, Bodie Mining District.

44. Secondary electron images of samples representative of Silver Hill series veins on and near Red Cloud mine dump, Silver Hill, Bodie Mining District.

45. Secondary electron images of samples representative of Silver Hill series veins on and near Red Cloud, Contention, and Maybelle Mine dumps, Silver Hill, Bodie Mining District.

46. Image showing oriented consecutive sections, graphs showing relative element concentrations, and bulk sample element concentrations of sinter from Bodie Bluff summit, Bodie Mining District.....

47. Graph of $\mathrm{Ag}, \mathrm{As}, \mathrm{Sr}$ concentrations versus $\mathrm{Au}, \mathrm{Sb}, \mathrm{Rb}$ concentrations in sinter from the dismembered sinter terrace, sinter fragments in volcaniclastic deposits, and Incline series veins, Bodie Mining District, Bodie Bluff summit..

48. Geologic map of the Spring Peak sinter, Mineral County, Nevada, and image showing nearly intact sinter beds from the northern margin of the terrace.

49. Image of sample, and graphs showing relative element concentrations and bulk sample element concentrations of Spring Peak sinter from the $\mathrm{Hg}$ prospect in the sinter terrace, Spring Peak alteration zone

50. Image showing sample, and graphs showing relative element concentrations and bulk sample element concentrations of Spring Peak sinter from the $\mathrm{Hg}$ prospect in the sinter terrace, Spring Peak alteration zone. 
51. Image showing oriented consecutive sections, and graphs showing relative element concentrations and bulk sample element concentrations of sinter from the northern edge of the Spring Peak sinter terrace.....

52. Maps showing assembly of the Miocene Bodie Hills volcanic field, California and Nevada, from 15 to $8 \mathrm{Ma}$ based on volcanic stratigraphy, mineral deposits, alteration zones, and geochronology

\section{Tables}

1. ${ }^{40} \mathrm{Ar} /{ }^{39} \mathrm{Ar}$ dates (Ma) of igneous and hydrothermal minerals in mining districts and alteration zones of the Bodie Hills, determined by incremental heating and laser fusion.

2. Sulfur isotope compositions of sulfide and sulfate minerals and sulfur from mining districts and alteration zones, and calculated sulfur isotope equilibrium temperatures.

3. Reporting limits for element concentrations in tables 1-1 through 1-12..

4. Characteristics of Incline, Burgess, and Silver Hill series veins in the Bodie Mining District..

5. Gold and silver production and precious metal grades for mines and veins in the Bodie Mining District from 1875 to 1942, and relative value of gold and silver in bullion from 1878 to 1881

6. Vein attitudes and widths derived from surface mapping and published descriptions

1-1. Minor element concentrations in rock samples from the Masonic Mining District .....122

1-2. Minor element concentrations in rock samples from the Red Wash-East Walker River alteration zone

1-3. Minor element concentrations in rock samples from the East Brawley Peak alteration zone...

1-4. Minor element concentrations in rock samples from the Sawtooth Ridge alteration zone...

1-5. Minor element concentrations in rock samples from the Aurora Canyon alteration zone...

1-6. Minor element concentrations in rock samples from the Potato Peak alteration zone...

1-7. Minor element concentrations in rock samples from the Aurora Mining District.........133

1-8. Minor element concentrations in rock samples from the Four Corners alteration zone..

1-9. Minor element concentrations in rock samples from the Paramount-Bald Peak alteration zone...

1-10. Minor element concentrations in rock samples from the Cinnabar Canyon-US 395 alteration zone...

1-11. Minor element concentrations in rock samples from the Bodie Mining District...........149

1-12. Minor element concentrations in rock samples of Spring Peak sinter 159 


\section{Conversion Factors}

Inch/Pound to International System of Units

\begin{tabular}{lll}
\hline \multicolumn{1}{c}{ Multiply } & \multicolumn{1}{c}{ By } & \multicolumn{1}{c}{ To obtain } \\
\hline inch (in.) & Length & \\
foot (ft) & 2.54 & centimeter $(\mathrm{cm})$ \\
mile (mi) & 0.3048 & meter $(\mathrm{m})$ \\
& 1.609 & kilometer $(\mathrm{km})$ \\
\hline square mile $\left(\mathrm{mi}^{2}\right)$ & Area & \\
\hline & 2.590 & square kilometer $\left(\mathrm{km}^{2}\right)$ \\
\hline ounce, troy $(\mathrm{oz})$ & Mass & \\
ton, short $(2,000 \mathrm{lb})$ & 31.10 & gram $(\mathrm{g})$ \\
\hline
\end{tabular}

International System of Units to Inch/Pound

\begin{tabular}{lll}
\hline \multicolumn{1}{c}{ Multiply } & By & \multicolumn{1}{c}{ To obtain } \\
\hline & Length & \\
\hline centimeter $(\mathrm{cm})$ & 0.3937 & inch (in.) \\
millimeter $(\mathrm{mm})$ & 0.03937 & inch (in.) \\
micron $(\mu \mathrm{m})$ & 0.00003937 & inch (in.) \\
meter $(\mathrm{m})$ & 3.281 & foot $(\mathrm{ft})$ \\
kilometer $(\mathrm{km})$ & 0.6214 & mile $(\mathrm{mi})$ \\
\hline & Area & \\
\hline square kilometer $\left(\mathrm{km}^{2}\right)$ & 0.3861 & square mile $\left(\mathrm{mi}^{2}\right)$ \\
\hline & Mass & \\
\hline tonne, metric $(\mathrm{Mt})$ & 1.1023 & ton, short $(2000 \mathrm{lb})$ \\
\hline
\end{tabular}




\section{Acronyms and Abbreviations Used}

$\begin{array}{ll}\text { AA } & \begin{array}{c}\text { cold-vapor and hydride generation atomic } \\ \text { absorption } \\ \text { Advanced Spaceborne Thermal Emission } \\ \text { and Reflection Radiometer }\end{array} \\ \text { FA-ICPMS } & \begin{array}{l}\text { fire assay-inductively coupled plasma-mass } \\ \text { spectrometry }\end{array} \\ \text { ICP-AES-MS } & \begin{array}{l}\text { inductively coupled plasma-atomic emission } \\ \text { spectrometry-mass spectrometry }\end{array} \\ \text { LA ICP-MS } & \begin{array}{l}\text { laser ablation inductively coupled plasma- } \\ \text { mass spectrometry }\end{array} \\ \text { Ma } & \text { million years before present } \\ \text { Moz } & \text { million ounces } \\ \text { SEM } & \text { scanning electron microscopy } \\ \text { SWIR } & \text { short wave infrared radiation } \\ \text { USGS } & \text { U.S. Geological Survey } \\ \text { XRD } & \text { X-ray diffraction }\end{array}$




\section{Chemical Symbols Used}

$\begin{array}{ll}\mathbf{A g} & \text { silver } \\ \mathbf{A l} & \text { aluminum } \\ \mathbf{A s} & \text { arsenic } \\ \mathbf{A u} & \text { gold } \\ \mathbf{B a} & \text { barium } \\ \mathbf{B e} & \text { beryllium } \\ \mathbf{B i} & \text { bismuth } \\ \mathbf{C} & \text { carbon } \\ \mathbf{C a} & \text { calcium } \\ \mathbf{C d} & \text { cadmium } \\ \mathbf{C e} & \text { cerium } \\ \mathbf{C o} & \text { cobalt } \\ \mathbf{C r} & \text { chromium } \\ \mathbf{C s} & \text { cesium } \\ \mathbf{C u} & \text { copper } \\ \mathbf{F e} & \text { iron } \\ \mathbf{G a} & \text { gallium } \\ \mathbf{H g} & \text { mercury } \\ \mathbf{I n} & \text { indium } \\ \mathbf{K} & \text { potassium } \\ \mathbf{L a} & \text { lanthanum } \\ \mathbf{L i} & \text { lithium } \\ \mathbf{M g} & \text { magnesium } \\ \mathbf{M n} & \text { manganese }\end{array}$

Mo molybdenum

Na sodium

Nb niobium

Ni nickel

O oxygen

P phosphorus

$\mathbf{P b}$ lead

$\mathbf{R b}$ rubidium

S sulfur

Sb antimony

Sc scandium

Se selenium

Sn tin

Sr strontium

Te tellurium

Th thorium

Ti titanium

TI thallium

U uranium

V vanadium

W tungsten

Y yttrium

Zn zinc 


\title{
Gold-Silver Mining Districts, Alteration Zones, and Paleolandforms in the Miocene Bodie Hills Volcanic Field, California and Nevada
}

\author{
By Peter G. Vikre, David A. John, Edward A. du Bray, and Robert J. Fleck
}

\section{Abstract}

The middle-late Miocene Bodie Hills volcanic field, Mono County, California, and Mineral and Lyon Counties, Nevada, contains three precious metal mining districts, with combined production of $\sim 3.4$ million ounces (Moz) gold (Au) and $\sim 28 \mathrm{Moz}$ silver (Ag), and nine variably sized alteration zones. Minor amounts of mercury $(\mathrm{Hg})$ have been produced from three alteration zones; a significant sulfur resource has been identified in one alteration zone. The $\sim 40$ by $\sim 30$ kilometer $(\mathrm{km})$ volcanic field is made up of coalescing, 15-6 Ma, subduction-related, trachyandesite stratovolcanoes, trachydacite and rhyolite lava domes, and related volcaniclastic deposits that cover an irregular erosional surface of Paleozoic and Mesozoic metavolcanic and metasedimentary rocks and Mesozoic granitic rocks of the Sierra Nevada batholith. Hydrothermal systems that formed precious metal deposits and most alteration zones were intermittently active during and soon after the development of trachyandesite stratovolcanoes and rhyolite flow-domes at 13.4-11 Ma, and following eruption of trachyandesite to rhyolite flows, domes, and associated volcaniclastic deposits at $\sim 9-8 \mathrm{Ma}$.

In the Masonic Mining District, $\mathrm{Au}(0.056 \mathrm{Moz}), \mathrm{Ag}$ (0.04 Moz), and small amounts of copper $(\mathrm{Cu})$ were produced from 0.075 million metric tons $(\mathrm{Mt})$ of ore mostly during the period 1906-20. Deposits formed at $\sim 13.4-13.3 \mathrm{Ma}$ and $13.0 \mathrm{Ma}$, and comprise two styles of mineralization: (1) high-angle, fault breccia deposits in Mesozoic granitic rocks and 15-14 Ma trachyandesite flows; and (2) stratiform volcaniclastic and chemical sedimentary deposits in 15-14 Ma trachyandesite. Both types of deposits consist of quartz, enargite (and lesser luzonite), pyrite, small inclusions (tens of micrometers in size) and intergrowths of numerous $\mathrm{Cu}-\mathrm{As}-\mathrm{Sb}-$ Fe-Bi-Au-Ag-S-Se-Te minerals including Au-rich electrum, alunite, kaolinite and dickite, pyrophyllite, and sericite. Fault breccia deposits are enclosed by meters-wide selvages comprised of quartz, alunite, pyrite, kaolinite and dickite, pyrophyllite, sericite, and montmorillonite.
In the Aurora Mining District, an estimated 1.91 Moz of Au and $21 \mathrm{Moz}$ of Ag were recovered from 3.9 Mt of vein ore, mostly during several periods of mining: 1860-64, 1906-18, and 1988-98. The $\sim 10.5 \mathrm{Ma}$ vein system, in 13.1-12.6 Ma trachyandesite of Aurora, is comprised of numerous north- to northeast-striking en echelon segments, which have a cumulative strike length of $\sim 7.5 \mathrm{~km}$. Veins are composed of fine-grained, layered to granular quartz, sulfide minerals, electrum, sericite, potassium feldspar (K-feldspar), and paragenetically late calcite. Quartz layers locally include finely dispersed pyrite, electrum, acanthite, naumannite, sphalerite, galena, polybasite, tetrahedrite, an Ag-Au-S mineral $\left(\sim \mathrm{Ag}_{4} \mathrm{AuS}_{3}\right)$, and clumps of these minerals (millimeters to centimeters in size). Trachyandesite wall rocks proximal to veins, vein zone septa, and internal breccia fragments have been altered to sericite, K-feldspar, and pyrite. Distal, pervasively altered trachyandesite contains variable proportions of chlorite, albite, calcite, and montmorillonite, and lesser fine-grained quartz, sericite, pyrite (and iron oxides after pyrite), and epidote.

In the Bodie Mining District, 1.46 Moz of Au and 7.3 Moz of Ag were produced from 1.5 Mt of vein ore, mostly during the period 1877-1913. Deposits comprise at least three types of $\mathrm{N} \pm 30^{\circ}$-striking veins that formed from $\sim 8.9$ to $8.1 \mathrm{Ma}$ in $\sim 9 \mathrm{Ma}$ dacite of Silver Hill domes and flows. Incline series veins, the most productive vein type, consist of numerous layers (millimeters thick) of quartz \pm adularia with electrum and Ag-S-Se minerals dispersed on some layers. Burgess series veins are composed of relatively coarse-grained and less distinctly layered quartz \pm adularia, and contain as much as 5 volume percent electrum, Ag-S-Se minerals, pyrite, sphalerite, and galena. These vein types are enclosed by $<1$-meter-wide selvages of dacite altered to variable amounts of K-feldspar, quartz, sericite, and pyrite. Silver Hill series veins consist mostly of fault breccia cemented by quartz, adularia, sericite, calcite, and as much as 10 volume percent metallic minerals, predominantly sphalerite, galena, tetrahedrite, and chalcopyrite, and lesser pyrite, acanthite, electrum, bornite, hessite, and sylvanite. They are enclosed 
by selvages of dacite (meters wide) altered to quartz, pyrite, and sericite. Heterolithic volcaniclastic deposits fill a graben on Bodie Bluff, contain clasts of sinter at the highest exposed elevation (Bodie Bluff), and record the youngest volcanic and hydrothermal events in the district.

The areally extensive ( $>30$ square kilometers $\left[\mathrm{km}^{2}\right]$ ) 13.3 Ma Red Wash-East Walker River alteration zone, which formed simultaneously with the oldest $\mathrm{Au}-\mathrm{Ag}-\mathrm{Cu}$ deposits in the Masonic Mining District, and the large $\left(\sim 30 \mathrm{~km}^{2}\right)$ 8.8-8.2 Ma Cinnabar Canyon-US 395 alteration zone, which contains a significant $\mathrm{S}^{\circ}$ (native sulfur) resource (16.1 Mt@17.9 percent S) and a small Hg deposit, formed in sequences of permeable volcaniclastic rocks and subordinate 15-8.9 Ma trachyandesite flows. The zones consist of resistant quartz \pm alunite \pm pyrite-dominant hydrothermal mineral assemblages enclosed by strata variably altered to kaolinite, pyrite, sericite, pyrophyllite, and montmorillonite. The large $\left(\sim 30 \mathrm{~km}^{2}\right)$ Paramount-Bald Peak alteration zone mostly formed in a permeable sequence of rhyolite tuff, volcaniclastic strata, and lesser rhyolite (sedimentary rocks and tuff of Paramount) that accumulated in a northeast-trending basin at $\sim 10.3-9.3 \mathrm{Ma}$. These strata have been variably leached and altered to silica minerals, montmorillonite, and lesser kaolinite, dickite, and pyrite, and include groups of intact and dismembered sinter terraces, one of which is associated with the intermittently mined (1878-1968) Hg vein deposit at the Paramount Mine. Smaller alteration zones, including the $\sim 12$ Ma East Brawley Peak $\left(\sim 7.7 \mathrm{~km}^{2}\right), 11.1$ Ma Sawtooth Ridge $\left(\sim 2 \mathrm{~km}^{2}\right), 10.9$ Ma Aurora Canyon $\left(\sim 8.1 \mathrm{~km}^{2}\right)$, and 10.8 Ma Potato Peak $\left(\sim 1.3 \mathrm{~km}^{2}\right)$, formed in $\sim 15-11.2 \mathrm{Ma}$ trachyandesite, rhyolite, and volcaniclastic strata. Hydrothermal mineral assemblages in these zones are similar to those of the Red Wash-East Walker River and Cinnabar Canyon-US 395 alteration zones. Small quantities of $\mathrm{Hg}$ (tens of flasks) were produced from the Cinnabar Canyon-US 395, Paramount-Bald Peak, and Potato Peak alteration zones, but no production is recorded from the other zones. The undated ( 14-10 Ma) Four Corners alteration zone $\left(<0.02 \mathrm{~km}^{2}\right)$ consists of brecciated trachyandesite of Masonic that has been cemented by quartz and pyrite (and iron oxides after pyrite) and contains local clastic and chemical sedimentary deposits. The partially dismembered and undated sinter terrace at Spring Peak $\left(0.02 \mathrm{~km}^{2}\right)$ lies on Cretaceous granitic and metamorphic rocks, and on altered volcaniclastic deposits. Slope detritus of these strata, adjacent to the terrace, include clasts of layered veins.

Based on volcanic stratigraphy, geochronology, remnant paleosurfaces, and paleopotentiometric surfaces in mining districts and alteration zones, present landforms in the Bodie Hills volcanic field reflect incremental construction of stratovolcanoes and large- to small-volume flow-domes, magmatic inflation, and fault displacements. In the northwestern part of the field, the extensive $\left(\sim 350 \mathrm{~km}^{2}\right) 15-14$ Ma Masonic volcanic center, consisting of trachyandesite flows, domes, and volcaniclastic deposits, was erupted on Mesozoic granitic and metamorphic rocks, and intruded by 13.5-13.4 Ma and 12.9 Ma porphyritic trachyandesite. These intrusions closely correspond in age to the $\mathrm{Au}-\mathrm{Ag}-\mathrm{Cu}$ deposits in the Masonic district (13.4-13.3 Ma and $13 \mathrm{Ma}$ ) and to the areally extensive Red Wash-East Walker River alteration zone (13.3 Ma).

Paleorelief among domes of the younger intrusions, domes of older trachyandesite, and prominences of Mesozoic rocks, was meters to tens of meters (tens to hundreds of feet).

In the eastern part of the volcanic field, the 13.1-12.6 Ma Aurora volcanic center was dominated by a prominent ridge of trachyandesite $\left(\sim 130 \mathrm{~km}^{2}\right)$ flanked by lower-elevation flowdomes of trachyandesite and rhyolite. These large- and smallvolume volcanoes were emplaced on Mesozoic rocks. Parts of the volcanic center were altered at $\sim 12 \mathrm{Ma}$ (East Brawley Peak alteration zone), $11 \mathrm{Ma}$ (Sawtooth Ridge alteration zone), and 10.5 Ma during formation of $\mathrm{Au}-\mathrm{Ag}$ veins of the Aurora district. Paleorelief within the volcanic center was hundreds of meters (hundreds to $>1,000$ feet $[\mathrm{ft}]^{1}$ ) above ancestral Fletcher Valley to the north that was an established basin by $11 \mathrm{Ma}$.

From $\sim 11-9.5 \mathrm{Ma}$, pre-Tertiary rocks in the central and southwestern parts of the field were mostly covered by large- to small-volume flows and domes of trachyandesite, rhyolite, and trachydacite. These flow-domes and older volcanic uplands shed detritus into the $\sim 10.3-9.3$ Ma Paramount basin, which was nearly simultaneously altered by hydrothermal systems that produced groups of sinter terraces and subjacent, locally Hg-mineralized veins (Paramount-Bald Peak alteration zone; Paramount $\mathrm{Hg}$ Mine). At 9.5-9.3 Ma, externally sourced Eureka Valley Tuff partly filled the drainages and depressions that had been incised into volcanic uplands in the western half of the volcanic field. The distribution of Eureka Valley Tuff remnants shows that paleorelief among volcanic and pre-Tertiary landforms was tens to hundreds of meters (hundreds of feet).

From $\sim 10$ to $8 \mathrm{Ma}$, large-volume stratovolcanoes and flow-dome fields, including trachydacite of Potato Peak, dacite of Silver Hill, trachyandesite and volcaniclastic deposits of Mount Biedeman, and trachyandesite of Willow Springs, were erupted in the southern part of the volcanic field. The volcaniclastic flow sequence exposed between Cinnabar Canyon and US 395 was pervasively altered and locally mineralized with Hg and S (Cinnabar Canyon-US 395 alteration zone), nearly simultaneously with the formation of multiple $\mathrm{Au}-\mathrm{Ag}$ vein deposits in dacite flow-domes of the Bodie district at 8.9-8.1 Ma.

The present elevation of Potato Peak $(10,237 \mathrm{ft})$ is $\sim 1,100 \mathrm{ft}$ higher than the highest elevation of Eureka Valley Tuff $(9,150 \mathrm{ft})$ on Potato Peak, $4,600 \mathrm{ft}$ higher than the lowest elevation of Eureka Valley Tuff (5,600 ft) along the East Walker River, and 4,200 ft higher than Fletcher Valley. Assuming a common Eureka Valley Tuff paleoelevation at 9.3 Ma, these present elevation differences, and few significant faults in the southern part of the field, indicate that most present relief in the volcanic field reflects construction of 10-8 Ma large-volume volcanic centers, and related magmatic inflation. Relatively small increments of relief (tens to hundreds of

${ }^{1}$ Elevations are reported in feet for the purpose of comparing paleoelevations to present elevations, which are reported in feet on topographic maps.. 
meters) have been added to northwestern and eastern parts of the field by displacement along east-west, and north- to northeast-trending normal faults in the Masonic and Aurora districts, and in the Paramount basin. Pliocene volcanic rocks of the Aurora volcanic field, which initially erupted at 3.9 Ma, do not appear to be significantly offset by faults, implying that most fault displacement occurred between 9.3 and 3.9 Ma. Between 8 and 3.9 Ma, only a few small-volume, $\sim 6-5 \mathrm{Ma}$ rhyolite and dacite flow-domes were erupted.

The higher of two paleoelevation ranges estimated for the $11 \mathrm{Ma}$ Aldrich Station flora, located $\sim 22.5 \mathrm{~km}$ north of the Aurora district, is more consistent with post-Eureka Valley Tuff relief added to the volcanic field (4,200-4,600 ft). Based on the flora, paleoelevations in the 15-10 Ma Masonic and Aurora volcanic centers varied from $\sim 4,300$ to $\sim 6,900 \mathrm{ft}$. Following eruption of large-volume stratovolcanoes and flow-dome fields in the southern part of the volcanic field at 10-8 Ma, maximum paleoelevations exceeded 8,500 ft. If fossils in $\sim 11$ Ma Fletcher basin sediments are stratigraphically equivalent to Aldrich Station flora, then paleorelief may have been $\sim 10,000 \mathrm{ft}$.

\section{Introduction}

Three precious metal mining districts and nine areas of extensive hydrothermally altered rocks, or alteration zones, occur in the Bodie Hills, an upland of Tertiary-Quaternary volcanic and Mesozoic granitic and metamorphic rocks that straddles the California-Nevada state boundary between Mono Lake and the East Walker River (fig. 1). Cumulative production from the mining districts, Bodie, Aurora, and Masonic, is 3.4 million ounces (Moz) of gold (Au) and $28 \mathrm{Moz}$ of silver (Ag). Small amounts of $\mathrm{Hg}$ were produced from the Potato Peak, Paramount-Bald Peak, and Cinnabar Canyon-US 395 alteration zones; a native sulfur $\left(\mathrm{S}^{\circ}\right)$ resource in the Cinnabar Canyon-US 395 alteration zone has been identified by drilling. There are no known mineral resources in the other six alteration zones, Red Wash-East Walker River, East Brawley Peak, Sawtooth Ridge, Aurora Canyon, Four Corners, and Spring Peak. The mining districts and alteration zones formed between 13.4 and 8.1 Ma in predominantly 15-9 Ma volcanic rocks of the Bodie Hills volcanic field. Ages of hydrothermal minerals in the districts and zones are the same as, or somewhat younger than, the ages of volcanic host rocks (table 1).

Mining districts and alteration zones have been characterized briefly and integrated with the interpreted evolution of the Bodie Hills volcanic field by John and others (2012). Descriptions and genetic models of several mineral deposit types and alteration zones are included in Vikre and Henry (2011). This report provides an expanded characterization of the mining districts and alteration zones, including ${ }^{40} \mathrm{Ar} /{ }^{39} \mathrm{Ar}$ ages of igneous and hydrothermal minerals (table 1), minor element concentrations in mineralized and altered rocks, and modal, chemical and sulfur isotope compositions of hydrothermal mineral assemblages (tables 2, 3, 1-1 through 1-12). Paleohydrology, determined from attributes of mineral deposits and alteration zones, is also integrated with volcanic stratigraphy and mineral ages to reconstruct landform evolution during assembly and alteration of the volcanic field.

Descriptions of the Miocene mining districts and alteration zones are organized from the oldest (Masonic) to youngest (Spring Peak), as determined by ${ }^{40} \mathrm{Ar} /{ }^{39} \mathrm{Ar}$ ages of igneous and hydrothermal minerals and by stratigraphic constraints. Characteristics systematically described include definition of the district or alteration zone, history and production, stratigraphy, petrography, structure, forms of deposits, hydrothermal alteration, minor elements, reflectance spectra, and hydrothermal mineral ages. Fluid inclusion microthermometry and sulfur isotope compositions are also summarized for several districts and alteration zones. Small mines and prospects in pre-Tertiary rocks at the south end of Masonic Mountain, near Rancheria Gulch, and in the Aurora district (fig. 1) contain minor amounts of tungsten (W), copper $(\mathrm{Cu})$ oxide, and $\mathrm{Cu}$ sulfide minerals that probably formed during the Mesozoic. Minor amounts of placer $\mathrm{Au}$ were recovered from Bodie Creek, and from drainages on the southwest margin of the Bodie Hills (Kleinhampl and others, 1975). These pre-Tertiary and placer mineral occurrences are not described.

Volcanic (Le Bas and others, 1986) and plutonic (Streckeisen, 1976) rock unit names used herein are in accord with the International Union of Geological Sciences (IUGS) nomenclature system. The composition of each rock unit is the average composition computed from analyses in du Bray and others (2013), but the full range of compositional variation within each unit is also specified. Average abundances and grain sizes of phenocrysts in volcanic rocks are based on microscopic observations. Modal compositions of Mesozoic plutons are based on analyses of stained slabs.

The Masonic, Aurora, and Bodie Mining Districts were established, named, and renamed in the mid-1800s, in part during confirmation of the boundary between California and Nevada. In this report, the three districts are given informal dimensions that encompass all productive mines and most prospects. The nine alteration zones, named after local geographic features, are defined on the basis of significant volumes of mostly Miocene volcanic rocks in which (1) primary minerals have been partially or entirely replaced by hydrothermal minerals; and (2) fabric has been modified substantially by hydrothermal mineral replacement, brecciation, and veining, and by hydrothermal leaching. The largest alteration zones, Red Wash-East Walker River, ParamountBald Peak, and Cinnabar Canyon-US 395, record strong disequilibrium between hydrothermal fluids and permeable volcaniclastic rocks, resulting in (1) extensive volumes of discolored, fine-grained, pyritic, and low-density rocks that are susceptible to weathering; and (2) stratiform masses of densely silicified rocks that comprise resistant hills, ridges, spines, and mesa-like landforms. Visual contrasts between 


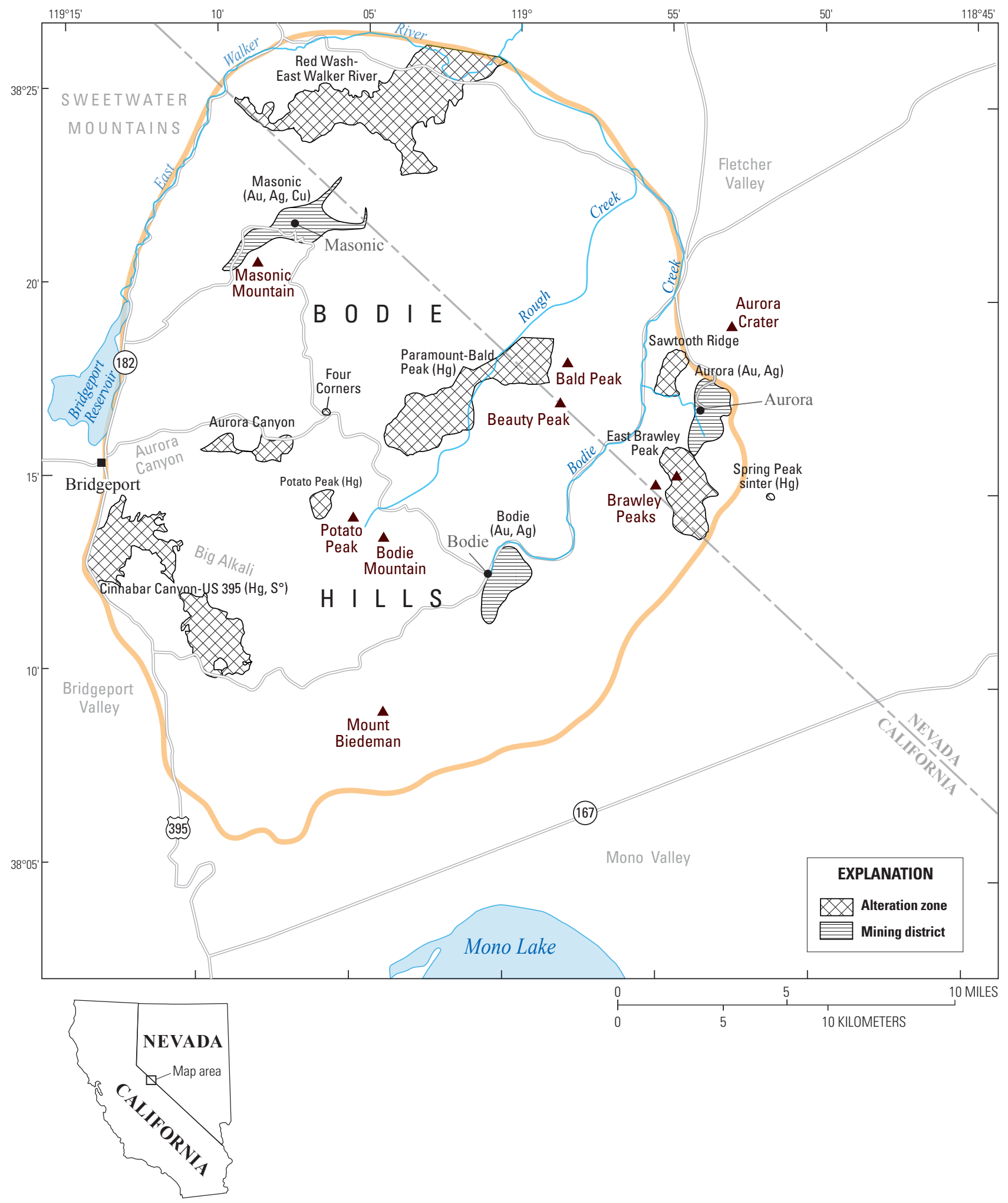

Figure 1. Map showing locations of mining districts (line pattern) and alteration zones (crosshatch pattern) in the Bodie Hills, California and Nevada; commodity produced or resource shown in parentheses. Base from Fleck and others (2015). 
Table 1. ${ }^{40} \mathrm{Ar} /{ }^{39} \mathrm{Ar}$ dates (Ma) of igneous and hydrothermal minerals in mining districts and alteration zones (AZ) of the Bodie Hills, determined by incremental heating and laser fusion. Some $\mathrm{K}-\mathrm{Ar}$ and ${ }^{40} \mathrm{Ar} /{ }^{39} \mathrm{Ar}$ dates (see footnotes) are from Kleinhampl and others (1975), Morton and others (1977), Breit (2000), and Larry Snee (written commun.); most ${ }^{40} \mathrm{Ar} /{ }^{39} \mathrm{Ar}$ dates of igneous minerals are from John and others (2012). Dates are based on Fish Canyon Tuff sanidine=28.02 Ma. Coordinates are NAD27.

[—, no data; qtz, quartz; Kspar, potassium feldspar; K, potassium; py, pyrite; chlor, chlorite]

\begin{tabular}{|c|c|c|c|c|c|c|}
\hline $\begin{array}{l}\text { Sample } \\
\text { number }\end{array}$ & $\begin{array}{l}\text { Latitude } \\
\text { (decimal } \\
\text { degrees) }\end{array}$ & $\begin{array}{l}\text { Longitude } \\
\text { (decimal } \\
\text { degrees) }\end{array}$ & Lithology and (or) location & Mineral & $\begin{array}{l}\text { Age (Ma) and } \\
\text { error (1б) }\end{array}$ & $\begin{array}{c}\text { Sample index } \\
\text { number on } \\
\text { figures }\end{array}$ \\
\hline \multicolumn{7}{|c|}{ Masonic Mining District } \\
\hline \multicolumn{7}{|c|}{ Trachyandesite of Masonic (Tma, Tmai) } \\
\hline 10-BA-9 & 38.3528 & -119.0207 & Porphyritic plug in trachyandesite of Masonic & Plagioclase & $14.998 \pm 0.019$ & - \\
\hline 098-12B & 38.38762 & -119.18139 & Lava flow in trachyandesite of Masonic & Plagioclase & $14.715 \pm 0.025$ & - \\
\hline 09-BA-7 & 38.33786 & -119.08727 & Lava flow in trachyandesite of Masonic & Plagioclase & $14.674 \pm 0.025$ & - \\
\hline 098-12D & 38.4 & -119.1194 & Lava flow in trachyandesite of Masonic & Plagioclase & $14.590 \pm 0.02$ & 4 (fig. 14) \\
\hline 10-BA-13 & 38.3515 & -119.1042 & Porphyritic dome in trachyandesite of Masonic & Plagioclase & $14.410 \pm 0.016$ & - \\
\hline $088-23 \mathrm{~F}$ & 38.31068 & -119.117 & Lava flow in trachyandesite of Masonic & Plagioclase & $14.193 \pm 0.038$ & - \\
\hline MAS10-76 & 38.38169 & -119.11534 & Hornblende andesite dome in trachyandesite of Masonic & Hornblende & $14.190 \pm 0.021$ & 7 (fig. 14) \\
\hline 10-BA-15 & 38.3413 & -119.1157 & Lava flow in trachyandesite of Masonic & Plagioclase & $14.140 \pm 0.017$ & - \\
\hline 08-BA-62 & 38.32005908 & -119.0494277 & Lava flow in trachyandesite of Masonic & Plagioclase & $14.130 \pm 0.031$ & - \\
\hline 10-BA-69 & 38.3054 & -119.1365 & Lava flow in trachyandesite of Masonic & Plagioclase & $14.107 \pm 0.014$ & - \\
\hline $098-12 \mathrm{~F}$ & 38.37542 & -119.11418 & Lava flow in trachyandesite of Masonic & Hornblende & $14.094 \pm 0.017$ & 11 (fig. 3) \\
\hline 088-22B & 38.37937 & -119.07802 & Lava flow in trachyandesite of Masonic & Plagioclase & $14.067 \pm 0.08$ & 12 (fig. 3) \\
\hline \multicolumn{7}{|c|}{ Trachyandesite of Masonic Gulch (Tamg) } \\
\hline MAS10-75 & 38.39169 & -119.11549 & $\begin{array}{l}\text { Porphyritic trachyandesite dome in trachyandesite } \\
\text { of Masonic }\end{array}$ & Plagioclase & $13.497 \pm 0.023$ & 13 (fig. 14) \\
\hline MAS10-72 & 38.40189 & -119.13718 & $\begin{array}{l}\text { Porphyritic trachyandesite dome in trachyandesite } \\
\text { of Masonic }\end{array}$ & Plagioclase & $13.485 \pm 0.017$ & 14 (fig. 14) \\
\hline MAS10-73 & 38.39643 & -119.1347 & $\begin{array}{l}\text { Porphyritic trachyandesite dome in trachyandesite } \\
\text { of Masonic }\end{array}$ & Plagioclase & $13.467 \pm 0.016$ & 15 (fig. 14) \\
\hline 098-12E & 38.39143 & -119.12397 & $\begin{array}{l}\text { Porphyritic trachyandesite dome in trachyandesite } \\
\text { of Masonic }\end{array}$ & Plagioclase & $13.441 \pm 0.026$ & 16 (fig. 14) \\
\hline \multicolumn{7}{|c|}{ Andesite of Lakeview Spring (Tals) } \\
\hline 07-BA-38 & 38.36049 & -119.14502 & Andesite of Lakeview Spring dome & Plagioclase & $12.930 \pm 0.03$ & 17 (fig. 2) \\
\hline \multicolumn{7}{|c|}{$\begin{array}{l}\text { Hydrothermal minerals } \\
\end{array}$} \\
\hline MAS12-10 (\#2) & 38.33762 & -119.15973 & Success Mine area & Alunite & $13.638 \pm 0.077$ & - \\
\hline MAS12-10 (\#1) & 38.33762 & -119.15973 & Success Mine area & Alunite & $13.398 \pm 0.081$ & - \\
\hline MAS07-1A & 38.34991667 & -119.1483167 & Chemung Mine; volcaniclastic rocks & Alunite & $13.390 \pm 0.07$ & 20 (fig. 2) \\
\hline MAS09-1A & 38.35847 & -119.13824 & Red Rock Mine area; volcaniclastic-flow sequence & Alunite & $13.370 \pm 0.11$ & 21 (fig. 2) \\
\hline MAS09-1 & 38.35783 & -119.13268 & Red Rock Mine area; volcaniclastic-flow sequence & Alunite & $13.320 \pm 0.14$ & 22 (fig. 2) \\
\hline MAS07-3 & 38.35968 & -119.12682 & $\begin{array}{l}\text { Sarita mine; hydrothermal and clastic } \\
\text { sedimentary strata }\end{array}$ & Alunite & $13.260 \pm 0.05$ & 23 (fig. 2) \\
\hline 07-BA-40 & 38.36546 & -119.11607 & Pittsburg-Liberty Mine; granodiorite & Alunite & $13.020 \pm 0.05$ & 24 (fig. 2) \\
\hline $088-22 \mathrm{~A}$ & 38.36731 & -119.10727 & Maybell Mine; granodiorite & Alunite & $13.018 \pm 0.061$ & 25 (fig. 3) \\
\hline MAS11-2B & 38.36064 & -119.08681 & Perrini Mine, trachyandesite, upper dump & Alunite & $12.960 \pm 0.020$ & 26 (fig. 3) \\
\hline MAS11-1 & 38.36041 & -119.08369 & Perrini Mine, trachyandesite, lower dump & Alunite & $12.956 \pm 0.014$ & 27 (fig. 3) \\
\hline \multicolumn{7}{|c|}{ Basin-fill of Fletcher Valley } \\
\hline 08SB032 & 38.34561 & -118.95589 & Unwelded tuff, Fletcher Valley sediments & Plagioclase & $11.075 \pm 0.041$ & - \\
\hline \multirow[t]{2}{*}{$10-B A-62$} & 38.36327 & -119.00635 & Tephra, Fletcher Valley sediments & Plagioclase & $10.582 \pm 0.023$ & - \\
\hline & & & & Biotite & $10.464 \pm 0.042$ & - \\
\hline \multicolumn{7}{|c|}{ Red Wash-East Walker River AZ } \\
\hline \multicolumn{7}{|c|}{ Hydrothermal minerals } \\
\hline RW08-1 & 38.41123 & -119.12414 & Quartz-alunite matrix breccia & Alunite & $13.340 \pm 0.035$ & 28 (fig. 14) \\
\hline MAS10-55 & 38.41419 & -119.10259 & Quartz-alunite matrix breccia & Alunite & $13.270 \pm 0.02$ & 29 (fig. 14) \\
\hline \multicolumn{7}{|c|}{ East Brawley Peak AZ } \\
\hline \multicolumn{7}{|c|}{ Hydrothermal minerals } \\
\hline 89EB002 & - & - & Altered andesite, East Brawley Peak & Alunite & ${ }^{1,2} 13.7 \pm 0.5$ & - \\
\hline FA66 & 38.2375 & -118.9008 & Silicified andesite, south slope East Brawley Peak & Alunite & ${ }^{1,2} 12.34 \pm 0.04$ & - \\
\hline AUR10-3 & 38.23752 & -118.89919 & Silicified andesite, south slope East Brawley Peak & Alunite & $11.954 \pm 0.016$ & - \\
\hline
\end{tabular}


Table 1. ${ }^{40} \mathrm{Ar} /{ }^{39} \mathrm{Ar}$ dates (Ma) of igneous and hydrothermal minerals in mining districts and alteration zones (AZ) of the Bodie Hills, determined by incremental heating and laser fusion. Some K-Ar and ${ }^{40} \mathrm{Ar} /{ }^{39} \mathrm{Ar}$ dates (see footnotes) are from Kleinhampl and others (1975), Morton and others (1977), Breit (2000), and Larry Snee (written commun.); most ${ }^{40} \mathrm{Ar} /{ }^{39} \mathrm{Ar}$ dates of igneous minerals are from John and others (2012). Dates are based on Fish Canyon Tuff sanidine=28.02 Ma. Coordinates are NAD27.-Continued

[-, no data; qtz, quartz; Kspar, potassium feldspar; K, potassium; py, pyrite; chlor, chlorite]

\begin{tabular}{|c|c|c|c|c|c|c|}
\hline $\begin{array}{l}\text { Sample } \\
\text { number }\end{array}$ & $\begin{array}{l}\text { Latitude } \\
\text { (decimal } \\
\text { degrees) }\end{array}$ & $\begin{array}{c}\text { Longitude } \\
\text { (decimal } \\
\text { degrees) }\end{array}$ & Lithology and (or) location & Mineral & $\begin{array}{l}\text { Age (Ma) and } \\
\text { error }(1 \sigma)\end{array}$ & $\begin{array}{c}\text { Sample index } \\
\text { number on } \\
\text { figures }\end{array}$ \\
\hline \multicolumn{7}{|c|}{ Sawtooth Ridge AZ } \\
\hline \multicolumn{7}{|c|}{ Volcanic rocks } \\
\hline 077-9C & 38.27661 & -118.93036 & Porphyritic lava flow in rhyolite of Del Monte Canyon & Plagioclase & $11.258 \pm 0.14$ & - \\
\hline 077-9D & 38.27661 & -118.93036 & Porphyritic lava flow in rhyolite of Del Monte Canyon & Plagioclase & $11.197 \pm 0.03$ & - \\
\hline 077-9C & 38.27661 & -118.93036 & Porphyritic lava flow in rhyolite of Del Monte Canyon & Sanidine & $11.187 \pm 0.02$ & - \\
\hline 077-9D & 38.28562 & -118.92803 & Porphyritic lava flow in rhyolite of Del Monte Canyon & Sanidine & $11.136 \pm 0.02$ & - \\
\hline 10-BA-21 & 38.30315 & -118.8974 & Glassy lava flow in rhyolite of Aurora Creek & Sanidine & $11.181 \pm 0.022$ & - \\
\hline 10-BA-20 & 38.31679 & -118.91129 & Glassy pyroxene rhyolite, rhyolite of Aurora Creek & Plagioclase & $11.177 \pm 0.013$ & - \\
\hline \multicolumn{7}{|c|}{ Hydrothermal mineral } \\
\hline SAW11-9 & 38.29036 & -118.91657 & Brecciated rhyolite of Aurora Creek & Alunite & $11.105 \pm 0.018$ & - \\
\hline \multicolumn{7}{|c|}{ Aurora Canyon AZ } \\
\hline \multicolumn{7}{|c|}{ Hydrothermal mineral } \\
\hline PP09-10A1 & 38.25309 & -119.13844 & Silicified breccia matrix & Alunite & $10.870 \pm 0.07$ & - \\
\hline \multicolumn{7}{|c|}{ Volcanic rocks } \\
\hline 098-13D & 38.27655 & -119.16062 & Porphyritic plug in trachyandesite of Clark Canyon & Plagioclase & $11.341 \pm 0.017$ & - \\
\hline 09-BA-43 & 38.26358 & -119.16825 & $\begin{array}{l}\text { Porphyritic lava flow in trachyandesite of } \\
\text { Clark Canyon }\end{array}$ & Plagioclase & $11.268 \pm 0.11$ & - \\
\hline $088-21 \mathrm{~A}$ & 38.27363 & -119.13962 & Flow dome in trachyandesite of Aurora Canyon & Plagioclase & $10.358 \pm 0.025$ & - \\
\hline 098-13B & 38.26802 & -119.13218 & Porphyritic intrusion in rhyolite of Bodie Hills & Sanidine & $9.813 \pm 0.027$ & - \\
\hline 088-24B & 38.25504 & -119.14115 & $\begin{array}{l}\text { Porphyritic lava flow in trachyandesite of } \\
\text { Willow Springs }\end{array}$ & Plagioclase & $8.575 \pm 0.22$ & - \\
\hline $088-24 \mathrm{~A}$ & 38.25278 & -119.13951 & Porphyritic dome in rhyolite of Big Alkali & Plagioclase & $6.201 \pm 0.026$ & - \\
\hline 098-13A & 38.25754 & -119.12788 & Porphyritic dome in rhyolite of Big Alkali & Plagioclase & $6.173 \pm 0.028$ & - \\
\hline $09-B A-42$ & 38.27001 & -119.14887 & Porphyritic dome in rhyolite of Big Alkali & Biotite & $5.455 \pm 0.026$ & - \\
\hline \multicolumn{7}{|c|}{ Potato Peak AZ } \\
\hline \multicolumn{7}{|c|}{ Hydrothermal mineral } \\
\hline $08-B A-46$ & 38.2443 & -119.10385 & Matrix of silicified breccia & Alunite & $10.830 \pm 0.06$ & - \\
\hline \multicolumn{7}{|c|}{ Rhyolite of Bodie Hills } \\
\hline $08-B A-50$ & 38.24816 & -119.09663 & Rhyolite & Sanidine & $9.757 \pm 0.013$ & - \\
\hline \multicolumn{7}{|c|}{ Trachydacite of Potato Peak } \\
\hline $088-24 \mathrm{D}$ & 38.22678 & -119.10376 & Porphyritic lava flow & Plagioclase & $9.090 \pm 0.04$ & - \\
\hline 108-12B & 38.23830 & -119.00784 & Porphyritic biotite-hornblende dacite & Biotite & $9.032 \pm 0.022$ & - \\
\hline 098-13C & 38.25072 & -119.09223 & Biotite rhyolite/dacite & Plagioclase & $8.998 \pm 0.021$ & - \\
\hline $088-24 \mathrm{C}$ & 38.24786 & -119.11208 & Porphyritic lava flow & Plagioclase & $8.996 \pm 0.025$ & - \\
\hline 08-BA-68 & 38.1932 & -119.0684 & Porphyritic trachyandesite flow & Plagioclase & $8.99 \pm 0.02$ & - \\
\hline 098-10C & 38.24919 & -119.09203 & Biotite-hornblende dacite & Plagioclase & $8.982 \pm 0.023$ & - \\
\hline $108-12 \mathrm{~A}$ & 38.24252 & -119.04825 & Porphyritic biotite-hornblende dacite & Plagioclase & $8.963 \pm 0.016$ & - \\
\hline 08-BA-61 & 38.2077 & -119.1017 & Block and ash flow & Plagioclase & $8.93 \pm 0.7$ & - \\
\hline 088-24E & 38.21809 & -119.10188 & Biotite-hornblende dacite & Plagioclase & $8.925 \pm 0.03$ & - \\
\hline 088-21E & 38.23457 & -119.08582 & Porphyritic lava flow & Plagioclase & $8.860 \pm 0.05$ & - \\
\hline 088-21B & 38.2642 & -119.0750 & Porphyritic trachyandesite flow & Plagioclase & $8.84 \pm 0.13$ & - \\
\hline 088-21D & 38.2433 & -119.09209 & Porphyritic lava flow & Plagioclase & $8.810 \pm 0.07$ & - \\
\hline $10-B A-46$ & 38.1738 & -119.1151 & Porphyritic trachyandesite flow & Plagioclase & $8.779 \pm 0.013$ & - \\
\hline $10-\mathrm{BA}-66$ & 38.17250 & -119.10125 & Porphyritic lava flow & Plagioclase & $8.749 \pm 0.019$ & - \\
\hline
\end{tabular}


Table 1. ${ }^{40} \mathrm{Ar} /{ }^{39} \mathrm{Ar}$ dates (Ma) of igneous and hydrothermal minerals in mining districts and alteration zones (AZ) of the Bodie Hills, determined by incremental heating and laser fusion. Some K-Ar and ${ }^{40} \mathrm{Ar} /{ }^{39} \mathrm{Ar}$ dates (see footnotes) are from Kleinhampl and others (1975), Morton and others (1977), Breit (2000), and Larry Snee (written commun.); most ${ }^{40} \mathrm{Ar} /{ }^{39} \mathrm{Ar}$ dates of igneous minerals are from John and others (2012). Dates are based on Fish Canyon Tuff sanidine=28.02 Ma. Coordinates are NAD27.-Continued

[—, no data; qtz, quartz; Kspar, potassium feldspar; K, potassium; py, pyrite; chlor, chlorite]

\begin{tabular}{|c|c|c|c|c|c|c|}
\hline $\begin{array}{l}\text { Sample } \\
\text { number }\end{array}$ & $\begin{array}{l}\text { Latitude } \\
\text { (decimal } \\
\text { degrees) }\end{array}$ & $\begin{array}{l}\text { Longitude } \\
\text { (decimal } \\
\text { degrees) }\end{array}$ & Lithology and (or) location & Mineral & $\begin{array}{l}\text { Age (Ma) and } \\
\text { error }(1 \sigma)\end{array}$ & $\begin{array}{c}\text { Sample index } \\
\text { number on } \\
\text { figures }\end{array}$ \\
\hline \multicolumn{7}{|c|}{ Aurora Mining District } \\
\hline \multicolumn{7}{|c|}{ Volcanic rocks } \\
\hline $00-\mathrm{BA}-16$ & 38.2708 & -118.8908 & Porphyritic lava flow in trachyandesite of Aurora & Hornblende & ${ }^{3} 13.130 \pm 0.44$ & - \\
\hline $00-B A-26$ & 38.2542 & -118.8841 & Porphyritic lava flow in trachyandesite of Aurora & Hornblende & ${ }^{3} 13.130 \pm 0.08$ & - \\
\hline $108-10 \mathrm{~A}$ & 38.27293 & -118.91272 & Fine-grained pyroxene trachyandesite of Aurora & Plagioclase & $12.58 \pm 0.024$ & - \\
\hline $108-10 \mathrm{C}$ & 38.2805 & -118.9062 & $\begin{array}{l}\text { Porphyritic lava flow in trachyandesite of West } \\
\text { Brawley Peak }\end{array}$ & Plagioclase & $11.514 \pm 0.019$ & - \\
\hline $10-B A-21$ & 38.30315 & -118.8974 & Porphyritic lava flow in rhyolite of Aurora Creek & Sanidine & $11.181 \pm 0.022$ & - \\
\hline 10-BA-27 & 38.275 & -118.9045 & $\begin{array}{l}\text { Porphyritic intrusion(?) in rhyolite of East } \\
\text { Brawley Peak }\end{array}$ & Sanidine & $11.178 \pm 0.016$ & - \\
\hline 10-BA-20 & 38.3168 & -118.9113 & $\begin{array}{l}\text { Sparsely porphyritic lava flow in rhyolite of } \\
\text { Aurora Creek }\end{array}$ & Plagioclase & $11.177 \pm 0.013$ & - \\
\hline \multicolumn{7}{|c|}{ Hydrothermal minerals } \\
\hline ESM & - & - & Altered andesite wall rock, Esmeralda vein & Illite & ${ }^{1,2} 12.2 \pm 0.3$ & - \\
\hline CH8Z1 & 38.28361 & -118.86889 & $\begin{array}{l}\text { Andesite altered to qtz-Kspar-K-mica-py-chlor; } \\
\text { Juniata vein }\end{array}$ & Whole rock & $2,410.9 \pm 0.3$ & - \\
\hline AU-1/58/DD61 & 38.266 & -118.9 & Esmeralda vein & K-feldspar & ${ }^{2,3} 10.47 \pm 0.1$ & - \\
\hline AU-2/59/DD61 & 38.28437 & -118.8934 & Last Chance Hill, Del Monte shaft dump & K-feldspar & ${ }^{2,3} 10.35 \pm 0.05$ & - \\
\hline FA1 & 38.2931 & -118.8914 & Prospectus vein & Adularia & ${ }^{1,2} 10.04 \pm 0.03$ & - \\
\hline 37 & - & - & Quartz-adularia vein & Adularia & ${ }^{2,5} 10.6 \pm 0.2$ & - \\
\hline \multicolumn{7}{|c|}{ Four Corners AZ } \\
\hline \multicolumn{7}{|c|}{ Trachyandesite of Aurora Canyon } \\
\hline $088-23 \mathrm{~A}$ & 38.27852 & -119.10021 & Porphyritic flow dome & Biotite & $10.580 \pm 0.03$ & - \\
\hline 088-23B & 38.27831 & -119.09908 & Porphyritic flow dome & Biotite & $10.540 \pm 0.05$ & - \\
\hline 088-23D & 38.28113 & -119.10206 & Porphyritic flow dome & Biotite & $10.460 \pm 0.032$ & - \\
\hline $088-25 \mathrm{~A}$ & 38.27322 & -119.09077 & Porphyritic flow dome & Plagioclase & $10.430 \pm 0.03$ & - \\
\hline 088-23B & 38.27831 & -119.09908 & Porphyritic flow dome & Plagioclase & $10.310 \pm 0.02$ & - \\
\hline $088-23 \mathrm{~A}$ & 38.27852 & -119.10021 & Porphyritic flow dome & Plagioclase & $10.270 \pm 0.11$ & - \\
\hline 088-23D & 38.28113 & -119.10206 & Porphyritic flow dome & Plagioclase & $10.270 \pm 0.05$ & - \\
\hline \multicolumn{7}{|c|}{ Paramount-Bald Peak AZ } \\
\hline \multicolumn{7}{|c|}{ Volcanic rocks } \\
\hline 09-BA-35 & 38.2905 & -119.0464 & Porphyritic dacite plug & Biotite & $11.269 \pm 0.034$ & - \\
\hline 077-8B & 38.2833 & -119.0562 & Porphyritic dacite plug & Sanidine & $11.160 \pm 0.03$ & - \\
\hline $077-8 \mathrm{C}$ & 38.27145 & -119.07783 & Flow dome in trachyandesite of Aurora Canyon & Biotite & $10.467 \pm 0.04$ & - \\
\hline $077-8 \mathrm{C}$ & 38.27145 & -119.07783 & Flow dome in trachyandesite of Aurora Canyon & Sanidine & $10.447 \pm 0.01$ & - \\
\hline $077-8 \mathrm{C}$ & 38.27145 & -119.07783 & Flow dome in trachyandesite of Aurora Canyon & Plagioclase & $10.426 \pm 0.03$ & - \\
\hline 08-BA-65 & 38.3107146 & -118.978084 & Glassy lava flow in rhyolite of Bald Peak & Sanidine & $9.686 \pm 0.01$ & - \\
\hline 09-BA-49 & 38.26389 & -119.04748 & Trachydacite ignimbrite in Eureka Valley Tuff & Biotite & $9.267 \pm 0.019$ & - \\
\hline \multicolumn{7}{|c|}{ Cinnabar Canyon-US 395 AZ } \\
\hline \multicolumn{7}{|c|}{ Trachyandesite of Mount Biedeman } \\
\hline $108-9 \mathrm{~A}$ & 38.1654 & -119.0982 & Biotite hornblende andesite lava & Plagioclase & $9.947 \pm 0.019$ & - \\
\hline $108-12 \mathrm{~F}$ & 38.1634 & -119.0992 & Glassy porphyritic andesite lava & Plagioclase & $9.939 \pm 0.024$ & - \\
\hline 10-BA-61 & 38.1401 & -119.0155 & Glassy block and ash flow & Plagioclase & $9.676 \pm 0.061$ & - \\
\hline $6-215-1$ & 38.1344 & -119.0825 & Hornblende andesite lava & Plagioclase & ${ }^{3} 9.24 \pm 0.008$ & - \\
\hline 098-11E & 38.1110 & -119.1584 & Hornblende andesite lava & Plagioclase & $9.019 \pm 0.028$ & - \\
\hline 09-BA-22 & 38.1430 & -119.1797 & Pyroxene andesite flow & Plagioclase & $8.996 \pm 0.10$ & - \\
\hline 09SB015A & 38.1231 & -119.1484 & Porphyritic trachyandesite lava & Plagioclase & $8.895 \pm 0.06$ & - \\
\hline
\end{tabular}


Table 1. ${ }^{40} \mathrm{Ar} /{ }^{39} \mathrm{Ar}$ dates (Ma) of igneous and hydrothermal minerals in mining districts and alteration zones (AZ) of the Bodie Hills, determined by incremental heating and laser fusion. Some K-Ar and ${ }^{40} \mathrm{Ar} /{ }^{39} \mathrm{Ar}$ dates (see footnotes) are from Kleinhampl and others (1975), Morton and others (1977), Breit (2000), and Larry Snee (written commun.); most ${ }^{40} \mathrm{Ar} /{ }^{39} \mathrm{Ar}$ dates of igneous minerals are from John and others (2012). Dates are based on Fish Canyon Tuff sanidine=28.02 Ma. Coordinates are NAD27.-Continued

[-, no data; qtz, quartz; Kspar, potassium feldspar; K, potassium; py, pyrite; chlor, chlorite]

\begin{tabular}{|c|c|c|c|c|c|c|}
\hline $\begin{array}{l}\text { Sample } \\
\text { number }\end{array}$ & $\begin{array}{l}\text { Latitude } \\
\text { (decimal } \\
\text { degrees) }\end{array}$ & $\begin{array}{l}\text { Longitude } \\
\text { (decimal } \\
\text { degrees) }\end{array}$ & Lithology and (or) location & Mineral & $\begin{array}{l}\text { Age (Ma) and } \\
\text { error }(1 \sigma)\end{array}$ & $\begin{array}{c}\text { Sample index } \\
\text { number on } \\
\text { figures }\end{array}$ \\
\hline \multicolumn{7}{|c|}{ Hydrothermal minerals } \\
\hline CC09-9D1 & 38.19869 & -119.1705 & Matrix of silicified breccia in altered dacite(?) & Alunite & $8.820 \pm 0.29$ & - \\
\hline CC09-9D2 & 38.19869 & -119.1705 & Veins cutting silicified breccia & Alunite & $8.680 \pm 0.02$ & - \\
\hline $39509-3 \mathrm{~K}$ & 38.20793 & -119.22751 & Partially leached clasts in volcaniclastic deposits & Alunite & $8.169 \pm 0.013$ & - \\
\hline \multicolumn{7}{|c|}{ Trachyandesite of Willow Springs } \\
\hline 088-24B & 38.25504 & -119.14115 & Porphyritic hornblende-pyroxene trachyandesite & Plagioclase & $8.575 \pm 0.022$ & - \\
\hline 08-BA-51 & 38.17449 & -119.15441 & Dacite flow breccia & Plagioclase & $8.305 \pm 0.017$ & - \\
\hline $088-24 \mathrm{~F}$ & 38.20176 & -119.08978 & Olivine-pyroxene trachyandesite & Plagioclase & $8.154 \pm 0.02$ & - \\
\hline 077-7B & 38.19178 & -119.1524 & Lava flow & Biotite & $8.124 \pm 0.03$ & - \\
\hline 077-7B & 38.19178 & -119.1524 & Lava flow & Plagioclase & $8.094 \pm 0.03$ & - \\
\hline 077-7B & 38.19178 & -119.1524 & Lava flow & Hornblende & $8.073 \pm 0.02$ & - \\
\hline 077-7A & 38.19178 & -119.1524 & Lava flow & Plagioclase & $8.053 \pm 0.02$ & - \\
\hline 077-7A & 38.1786 & -119.19476 & Lava flow & Biotite & $8.002 \pm 0.04$ & - \\
\hline \multicolumn{7}{|c|}{ Dacite of Hot Springs Canyon } \\
\hline $39509-10$ & 38.21532 & -119.22755 & Lava flow & Plagioclase & $8.070 \pm 0.017$ & - \\
\hline \multicolumn{7}{|c|}{ Bodie Mining District } \\
\hline \multicolumn{7}{|c|}{ Dacite of Silver Hill } \\
\hline $108-12 \mathrm{E}$ & 38.20763 & -118.96489 & Porphyritic biotite-hornblende dacite & Plagioclase & $9.140 \pm 0.020$ & 1 \\
\hline 09-BA-26 & 38.2036 & -119.00021 & Block and ash flow in dacite of Silver Hill & Biotite & $9.132 \pm 0.02$ & 2 (fig. 37) \\
\hline $108-12 \mathrm{C}$ & 38.18925 & -118.98343 & Porphyritic clinopyroxene-biotite dacite & Plagioclase & $9.088 \pm 0.014$ & 3 \\
\hline $077-6 \mathrm{~F}$ & 38.18809 & -119.00854 & Dome in dacite of Silver Hill & Plagioclase & $9.088 \pm 0.03$ & 4 (fig. 37) \\
\hline 08-BA-66 & 38.1863 & -119.0568 & Block and ash flow & Plagioclase & $9.07 \pm 0.024$ & 5 \\
\hline $108-12 \mathrm{D}$ & 38.17315 & -118.97800 & Porphyritic oxyhornblende-biotite dacite & Plagioclase & $9.017 \pm 0.014$ & 6 \\
\hline $077-7 \mathrm{~F}$ & 38.20252 & -119.0263 & Late intrusion in dacite of Silver Hill & Plagioclase & $8.925 \pm 0.03$ & 7 (fig. 37) \\
\hline \multicolumn{7}{|c|}{ Silver Hill series veins } \\
\hline 09-BA-28I & 38.2015 & -119.0036 & Red Cloud Mine dump & Adularia & $8.852 \pm 0.013$ & 8 (fig. 37) \\
\hline BOD09-3 & 38.20146 & -119.0048 & Red Cloud Mine dump & Adularia & $8.628 \pm 0.014$ & 9 (fig. 37) \\
\hline BOD09-5 & 38.2043 & -119.0066 & Oro Mine dump & Adularia & $8.473 \pm 0.007$ & 10 (fig. 37) \\
\hline AU-18/65/DD61 & 38.201 & -119.004 & Red Cloud Mine dump & Adularia & $2,38.46 \pm 0.02$ & 11 (fig. 37) \\
\hline \multicolumn{7}{|c|}{ Burgess series veins } \\
\hline BOD11-3B & 38.21257 & -119.00402 & Layered vein; Upper Hobart Tunnel dump & Adularia & $8.542 \pm 0.025$ & 12 (fig. 37) \\
\hline 11-BA-22 & 38.21257 & -119.00402 & Bodie Mine dump & Adularia & $8.498 \pm 0.005$ & 13 (fig. 37) \\
\hline BOD11-4E & 38.21257 & -119.00402 & Bodie Mine dump & Adularia & $8.426 \pm 0.003$ & 14 (fig. 37) \\
\hline AU-16/63/DD61 & 38.215 & -119.004 & Roseklip open-cut, southeast slope Standard Hill & Adularia & $2,38.38 \pm 0.02$ & 15 (fig. 37) \\
\hline \multicolumn{7}{|c|}{ Incline series veins } \\
\hline $077-6 \mathrm{~A}$ & 38.2149 & -119.0037 & Upper southeast slope Standard Hill & Adularia & $8.290 \pm 0.02$ & 16 (fig. 37) \\
\hline AU-17/64/DD61 & 38.215 & -118.997 & Tioga Mine dump & Adularia & $2,38.28 \pm 0.04$ & 17 (fig. 37) \\
\hline 11-BA-7G & 38.2042 & -119.00649 & Oro Mine dump & Adularia & $8.217 \pm 0.012$ & 18 (fig. 37) \\
\hline 11-BA-21 & 38.2037 & -119.00919 & Noonday Mine dump & Adularia & $8.124 \pm 0.006$ & 19 (fig. 37) \\
\hline \multicolumn{7}{|c|}{ Uncorrelated veins } \\
\hline 12-BA-17 & 38.21961 & -119.00083 & $\begin{array}{l}\text { Euhedrons in lenticular vug in narrow vein; dump, } \\
\text { top of Bodie Bluff }\end{array}$ & Adularia & $8.358 \pm 0.029$ & 20 (fig. 37) \\
\hline BOD11-3A & 38.21961 & -119.00354 & $\begin{array}{l}\text { Euhedrons in lenticular vug in narrow vein; Upper } \\
\text { Hobart Tunnel dump }\end{array}$ & Adularia & $8.194 \pm 0.005$ & 21 (fig. 37) \\
\hline
\end{tabular}

${ }^{1}$ Breit (2000); age standard not provided; location coordinates for some samples not provided.

${ }^{2}$ Age standard not provided and age may have been calculated using Taylor Creek rhyolite age=27.84 Ma.

${ }^{3}$ Analysis by L. Snee.

${ }^{4}$ Morton and others, 1977.

${ }^{5} \mathrm{~K}$ leinhampl and others, 1975. 
Table 2. Sulfur isotope compositions $(\%)$ of sulfide and sulfate minerals and sulfur $\left(S^{\circ}\right)$ from mining districts and alteration zones, and calculated sulfur (S) isotope equilibrium temperatures.

[Some analyses are from Vikre (2000) and Vikre and Henry (2011); others were provided by Simon Poulson (University of Nevada Reno, Reno, Nev.). Sulfur isotope equilibrium temperatures $\left(\mathrm{T}^{\circ} \mathrm{C} \mathrm{SO}_{4}\right.$-py) were calculated from fractionation equations in Field and Fifarek (1985). AZ, alteration zone; en, enargite; py, pyrite; ISV, Incline series vein; BSV, Burgess series vein; FV, Fortuna vein; SHSV, Silver Hill series vein; -, no data]

\begin{tabular}{|c|c|c|c|c|c|c|}
\hline Sample number & Mineral & Location & $\begin{array}{l}\delta^{34} S \text { sulfide } \\
\text { minerals }\end{array}$ & $\delta^{34} S^{\circ}$ & $\begin{array}{c}\delta^{34} \text { S alunite; } \\
\text { barite }\end{array}$ & $\mathrm{T}^{\circ} \mathrm{CSO}_{4}^{-\mathrm{py}}$ \\
\hline \multicolumn{7}{|c|}{ Masonic Mining District } \\
\hline \multicolumn{7}{|c|}{ Sarita Mine } \\
\hline MAS07-3 & Enargite & Mill loading bin reject & -10.4 & - & - & ${ }^{1} 192 ;$ en=py \\
\hline MAS07-3A & Alunite & Mill loading bin reject & - & 一 & 18.1 & - \\
\hline \multicolumn{7}{|c|}{ Red Rock Mine } \\
\hline MAS09-1 & Alunite & Mine dump, hillside & - & - & 13.4 & - \\
\hline MAS09-1 & Pyrite & Mine dump, hillside & -11.0 & - & - & 231 \\
\hline MAS09-1 & Enargite & Mine dump, hillside & $-10.5 ;-10.2$ & - & - & 1238; 228; en=py \\
\hline MAS09-1 & Alunite & Mine dump, hillside & - & - & 14.5 & - \\
\hline MAS09-3a & Enargite & Mine dump & -12.2 & 一 & - & - \\
\hline \multicolumn{7}{|c|}{ Chemung Mine } \\
\hline MAS07-1A & Alunite & Cut & - & - & 15.4 & - \\
\hline MD82-2A & Sulfur & Mill dump & - & -16.8 & - & - \\
\hline MD82-2A & Sulfur & Mill dump & - & -16.5 & - & - \\
\hline MD82-2A & Sulfur & Mill dump & - & -16.9 & - & - \\
\hline MD88-1s & Pyrite & Mill dump & -9.4 & - & - & - \\
\hline MD88-4s & Luzonite & Mill dump & -11.8 & - & - & - \\
\hline MD88-1Bs & Barite & Mill dump & - & - & 13.6 & - \\
\hline MD88-3As & Alunite & Mill dump & 一 & - & 7.1 & - \\
\hline \multicolumn{7}{|c|}{ Pittsburg-Liberty Mine } \\
\hline MAS10-62 & Pyrite & Dump on Masonic Gulch & -10.6 & - & - & 218 \\
\hline MAS10-62 & Alunite & Dump on Masonic Gulch & - & - & 15.1 & - \\
\hline \multicolumn{7}{|c|}{ Perini Mine } \\
\hline MAS11-2B & Pyrite & Upper dump on Red Wash & -9.4 & - & - & 188 \\
\hline MAS11-2B & Alunite & Upper dump on Red Wash & - & - & 19.6 & - \\
\hline MAS11-3B & Enargite & Upper dump on Red Wash & -12.2 & - & - & ${ }^{1} 167$; en=py \\
\hline \multicolumn{7}{|c|}{ Maybell-Alton Jack Mine } \\
\hline MAS08-21 & Pyrite & Middle dump & -10.0 & - & - & - \\
\hline MAS08-22 & Pyrite & Lower dump & -8.0 & - & - & - \\
\hline \multicolumn{7}{|c|}{ Aspen Grove Mine } \\
\hline MAS08-23 & Pyrite & Prospect dump & -7.9 & - & - & 198 \\
\hline MAS08-23 & Enargite & Prospect dump & 0.2 & - & - & 1283; en=py \\
\hline MAS08-23 & Alunite & Prospect dump & - & - & 19.9 & - \\
\hline \multicolumn{7}{|c|}{ Red Wash-East Walker River AZ } \\
\hline RW08-1 & Alunite & Western end of AZ & - & - & 20.60 & - \\
\hline \multicolumn{7}{|c|}{ Sawtooth Ridge AZ } \\
\hline SAW11-9 & Alunite & Del Monte Creek & - & - & -3.2 & - \\
\hline \multicolumn{7}{|c|}{ Potato Peak AZ } \\
\hline РОTPK08-1 & Cinnabar & Alta Plana Mine open cut & -10.30 & - & - & - \\
\hline РОТРК08-1 & Cinnabar & Alta Plana Mine open cut & -9.80 & - & - & - \\
\hline РОТРК08-1 & Barite & Alta Plana Mine open cut & - & - & 11.60 & - \\
\hline 08-BA-46 & Alunite & Alta Plana Mine open cut & - & - & 16.30 & - \\
\hline
\end{tabular}


Table 2. Sulfur isotope compositions $(\%)$ of sulfide and sulfate minerals and sulfur $\left(\mathrm{S}^{\circ}\right)$ from mining districts and alteration zones, and calculated sulfur (S) isotope equilibrium temperatures.-Continued

[Some analyses are from Vikre (2000) and Vikre and Henry (2011); others were provided by Simon Poulson (University of Nevada Reno, Reno, Nev.). Sulfur isotope equilibrium temperatures $\left(\mathrm{T}^{\circ} \mathrm{C} \mathrm{SO}_{4}\right.$-py) were calculated from fractionation equations in Field and Fifarek (1985). AZ, alteration zone; en, enargite; py, pyrite; ISV, Incline series vein; BSV, Burgess series vein; FV, Fortuna vein; SHSV, Silver Hill series vein; -, no data]

\begin{tabular}{|c|c|c|c|c|c|c|}
\hline Sample number & Mineral & Location & $\begin{array}{l}\delta^{34} S \text { sulfide } \\
\text { minerals }\end{array}$ & $\delta^{34} S^{\circ}$ & $\begin{array}{c}\delta^{34} S \text { alunite; } \\
\text { barite }\end{array}$ & $\mathrm{T}^{\circ} \mathrm{CSO}_{4}-\mathrm{py}$ \\
\hline \multicolumn{7}{|c|}{ Aurora District } \\
\hline K011 & Sulfides & Antelope $\mathrm{Mine}^{2}$ & 8.3 & - & - & - \\
\hline K229 & Sulfides & Antelope $\mathrm{Mine}^{2}$ & -8.7 & - & - & - \\
\hline K147 & Sulfides & Amador Mine ${ }^{2}$ & 10.6 & - & - & - \\
\hline K155 & Sulfides & Amador Mine ${ }^{2}$ & 10.9 & - & - & - \\
\hline K208 & Sulfides & Martinez Tunnel $^{2}$ & -8.5 & - & - & - \\
\hline K2079 & Sulfides & Wide West Mine & -7 & - & - & - \\
\hline AUR12-1A & Pyrite & New Esmeralda Mine cut & -6.3 & - & - & - \\
\hline AUR12-2A & Sulfides & Esmeralda vein, $\mathrm{S}$ end & $-5.4 ;-2.4$ & - & - & - \\
\hline \multicolumn{7}{|c|}{ Paramount-Bald Peak AZ } \\
\hline PM08-1A & Cinnabar & Paramount Mine upper adit & -4.70 & - & - & - \\
\hline PM08-1B & Cinnabar & Paramount Mine upper adit & -5.30 & - & - & - \\
\hline \multicolumn{7}{|c|}{ Cinnabar Canyon-US 395 AZ } \\
\hline $\mathrm{CC} 08-1$ & Cinnabar & Calmono Mine dump & -0.1 & - & - & - \\
\hline $\mathrm{CC} 08-1$ & Cinnabar & Calmono Mine dump & -0.7 & - & - & - \\
\hline 08-BA-54A & Alunite & drainage $\mathrm{W}$ of Cinnabar Canyon & - & - & 2.5 & - \\
\hline CAMO91-1As & Sulfur & DDH core ${ }^{3}$ & - & -4.6 & - & - \\
\hline CAMO91-1Bs & Sulfur & DDH core $^{3}$ & - & -5.2 & - & - \\
\hline $\mathrm{CCD} 7$ & Sulfur & DDH core; surface discards & - & -4.7 & - & - \\
\hline CCD7 & Sulfur & DDH core; surface discards & - & -4.7 & - & - \\
\hline CCD8B & Sulfur & DDH core; surface discards & - & - & - & - \\
\hline CCD8B & Pyrite 1 & DDH core; surface discards & -8.0 & - & - & - \\
\hline CCD16 & Pyrite 2 & DDH core; surface discards & -9.8 & - & - & - \\
\hline CCD16 & Barite & DDH core; surface discards & - & - & 1.1 & - \\
\hline \multicolumn{7}{|c|}{ Bodie Mining District } \\
\hline BOD11-11A & Pyrite & Bodie Mine dump; ISV & 1.4 & - & - & - \\
\hline OD 7604 & Sulfides & Standard Mine, 528 level; FV ${ }^{4}$ & 0.6 & - & - & - \\
\hline CSMMM-1793 & Sulfides & Jupiter Mine; BSV ? ${ }^{5}$ & -2.4 & - & - & - \\
\hline CSMMM-7045 & Sulfides & Mono Mine; $\mathrm{BSV}^{5}$ & -4.7 & - & - & - \\
\hline CSMMM-7638 & Sulfides & Belvedere Mine; $\mathrm{BSV}^{5}$ & 0.3 & - & - & - \\
\hline BOD09-7 & Acanthite & Lent Mine dump; BSV? & -1.8 & - & - & - \\
\hline BOD11-1 & Galena & Oro Mine dump; SHSV & -1.5 & - & - & - \\
\hline BOD11-1F & Chalcopyrite & Oro Mine dump; SHSV & -0.1 & - & - & - \\
\hline CSMMM-5304 & Sulfides & Oro Mine, 520 level; SHSV 5 & -0.9 & - & - & - \\
\hline BOD11-2A & Tetrahedrite & Contention Mine dump; SHSV & 0.5 & - & - & - \\
\hline BOD11-5 & Tetrahedrite & Red Cloud Mine dump; SHSV & -3.4 & - & - & - \\
\hline BOD11-22B & Chalcopyrite & S slope Bodie Bluff; SHSV & 0.1 & - & - & - \\
\hline CSMMM-2009 & Sulfides & Addenda Mine, 500 level; SHSV 5 & -0.0 & - & - & - \\
\hline CSMMM-7568 & Tetrahedrite & West Noonday Mine; SHSV 5 & 0.6 & - & - & - \\
\hline
\end{tabular}

${ }^{1}$ Temperature calculated based on pyrite-alunite fractionation.

${ }^{2}$ Keck collection, University of Nevada Reno (Reno, Nev.).

${ }^{3}$ Sample provided by M. Ward.

${ }^{4}$ Mackay-Stanford collection, University of Nevada Reno (Reno, Nev.).

${ }^{5}$ California State Mining and Mineral Museum collection (Mariposa, Calif.). 
Table 3. Reporting limits (concentration range) for element concentrations in tables A-1 through A-12.

[Concentrations were determined by fire assay-inductively coupled plasmamass spectrometry (Au, Pd, Pt), cold-vapor and hydride generation atomic absorption $(\mathrm{Hg})$, hydride generation atomic absorption (Se), automated sulfur analyzer (S), and inductively coupled-atomic emission spectrometrymass spectrometry (all other elements); ppm, part per million; ppb, part per billion]

\begin{tabular}{|c|c|c|}
\hline \multirow{2}{*}{$\begin{array}{r}\text { Element } \\
\text { Aluminum, } \mathrm{Al}\end{array}$} & \multicolumn{2}{|c|}{ Concentration range } \\
\hline & $0.01 \%$ & $15 \%$ \\
\hline Antimony, $\mathrm{Sb}$ & $0.05 \mathrm{ppm}$ & $1 \%$ \\
\hline Arsenic, As & $1 \mathrm{ppm}$ & $1 \%$ \\
\hline Barium, Ba & $5 \mathrm{ppm}$ & $1 \%$ \\
\hline Beryllium, Be & $0.1 \mathrm{ppm}$ & $100 \mathrm{ppm}$ \\
\hline Bismuth, Bi & $0.04 \mathrm{ppm}$ & $1 \%$ \\
\hline Cadmium, $\mathrm{Cd}$ & $0.1 \mathrm{ppm}$ & $1 \%$ \\
\hline Calcium, $\mathrm{Ca}$ & $0.01 \%$ & $40 \%$ \\
\hline Cerium, $\mathrm{Ce}$ & $0.05 \mathrm{ppm}$ & $0.10 \%$ \\
\hline Cesium, Cs & $0.05 \mathrm{ppm}$ & $0.10 \%$ \\
\hline Chromium, $\mathrm{Cr}$ & $1 \mathrm{ppm}$ & $1 \%$ \\
\hline Cobalt, Co & $0.1 \mathrm{ppm}$ & $1 \%$ \\
\hline Copper, $\mathrm{Cu}$ & $0.5 \mathrm{ppm}$ & $1 \%$ \\
\hline Gallium, Ga & $0.05 \mathrm{ppm}$ & $500 \mathrm{ppm}$ \\
\hline Gold & $1 \mathrm{ppb}$ & $10 \mathrm{ppm}$ \\
\hline Indium, In & $0.02 \mathrm{ppm}$ & $0.05 \%$ \\
\hline Iron, $\mathrm{Fe}$ & $0.01 \%$ & $50 \%$ \\
\hline Lanthanum, $\mathrm{La}$ & $0.5 \mathrm{ppm}$ & $0.10 \%$ \\
\hline Lead, $\mathrm{Pb}$ & $0.5 \mathrm{ppm}$ & $5 \%$ \\
\hline Lithium, Li & $1 \mathrm{ppm}$ & $5 \%$ \\
\hline Magnesium, $\mathrm{Mg}$ & $0.01 \%$ & $15 \%$ \\
\hline Manganese, Mn & $5 \mathrm{ppm}$ & $5 \%$ \\
\hline Mercury, $\mathrm{Hg}$ & $0.02 \mathrm{ppm}$ & not provided \\
\hline Molybdenum, Mo & $0.05 \mathrm{ppm}$ & $1 \%$ \\
\hline Nickel, Ni & $0.5 \mathrm{ppm}$ & $1 \%$ \\
\hline Niobium, $\mathrm{Nb}$ & $0.1 \mathrm{ppm}$ & $0.1 \%$ \\
\hline Palladium, Pd & $1 \mathrm{ppb}$ & $10 \mathrm{ppm}$ \\
\hline Phosphorous, $\mathrm{P}$ & $50 \mathrm{ppm}$ & $1 \%$ \\
\hline Platinum, Pt & $0.5 \mathrm{ppb}$ & $10 \mathrm{ppm}$ \\
\hline Potassium, K & $0.01 \%$ & $15 \%$ \\
\hline Rubidium, Rb & $0.2 \mathrm{ppm}$ & $1 \%$ \\
\hline Scandium, Sc & $0.1 \mathrm{ppm}$ & $0.10 \%$ \\
\hline Selenium, Se & $0.2 \mathrm{ppm}$ & 4 ppm \\
\hline Silver, Ag & $1 \mathrm{ppm}$ & $1 \%$ \\
\hline Sodium, $\mathrm{Na}$ & $0.01 \%$ & $15 \%$ \\
\hline Strontium, Sr & $0.5 \mathrm{ppm}$ & $1 \%$ \\
\hline Sulfur, S & $0.01 \%$ & $5 \%$ \\
\hline Sulfur, S & $0.05 \%$ & $35 \%$ \\
\hline Tellurium, Te & $0.1 \mathrm{ppm}$ & $0.05 \%$ \\
\hline Thallium, Tl & $0.1 \mathrm{ppm}$ & $1 \%$ \\
\hline Thorium, Th & $0.2 \mathrm{ppm}$ & $1 \%$ \\
\hline Tin, Sn & $0.1 \mathrm{ppm}$ & $0.10 \%$ \\
\hline Titanium, Ti & $0.01 \%$ & $15 \%$ \\
\hline Tungsten, W & $0.1 \mathrm{ppm}$ & $1 \%$ \\
\hline Uranium, U & $0.1 \mathrm{ppm}$ & $1 \%$ \\
\hline Vanadium, V & $1 \mathrm{ppm}$ & $1 \%$ \\
\hline Yttrium, Y & $0.1 \mathrm{ppm}$ & $1 \%$ \\
\hline Zinc, Zn & $1 \mathrm{ppm}$ & $5 \%$ \\
\hline
\end{tabular}

gray, green, and purplish, unaltered to propylitically altered andesite, dacite, and rhyolite, and the beige to red-brown coloration of pervasively altered rocks have been used to approximate the areal extent of alteration zones. The margins of alteration zones are marked by a transition outward from pervasive discoloration and primary mineral hydrolysis to alteration mineral assemblages that are confined to fracture selvages and phenocrysts. However, because of map scale, margin irregularities, and transitional contacts, small volumes of less-altered rocks are included within alteration zones, and small volumes of pervasively altered rocks are excluded.

Descriptions of mining districts and alteration zones in the Bodie Hills provide information on characteristics that may be useful to exploration programs and mineral resource assessments. In addition, the evolution of landforms presented in this report is pertinent to the tectonic history of the Sierra Nevada and western Great Basin.

\section{Bodie Hills Volcanic Field}

The Bodie Hills comprise a $>700$ square kilometers $\left(\mathrm{km}^{2}\right)$, 15-6 Ma volcanic field north of Mono Lake, California. The field consists of coalescing stratovolcanoes and lava domes that were assembled onto an irregular pre-Tertiary surface composed of Paleozoic and Mesozoic metavolcanic and metasedimentary rock, and Cretaceous granitic rocks of the Sierra Nevada batholith $\sim 8$ kilometers $(\mathrm{km})$ to the west (Eaton and others, 1978; John and others, 2012). The field includes $\sim 25$ major eruptive units that comprise four trachyandesite stratovolcanoes emplaced along the margins of the field, and numerous, more centrally located, silicic trachyandesite to rhyolite flow-dome complexes. The $\sim 40$ by $\sim 30 \mathrm{~km}$ field is in the southern segment of the ancestral Cascades magmatic arc, a subduction-related alignment of predominantly andesitic eruptive rocks that parallels the western margin of North America from southern Nevada to British Columbia. Compositions of most Bodie Hills volcanic rocks closely resemble those of subduction magmas worldwide, with $\mathrm{SiO}_{2}$ varying from 50 to 77 weight percent, and high $\mathrm{K}, \mathrm{Ba} / \mathrm{Nb}, \mathrm{Ba} / \mathrm{Ta}$, and $\mathrm{La} / \mathrm{Nb}$ (see table 3 for a complete list of elemental abbreviations). Most of the rocks are porphyritic, commonly containing $15-35$ volume percent phenocrysts of plagioclase, pyroxene, hornblende, and biotite. Geophysical data imply that the volcanic rocks were derived from shallow $(<2 \mathrm{~km}$ deep), subjacent magma reservoirs that solidified to low-density plutons (John and others, 2012). The field is within the Walker Lane, a major northwesttrending zone of right-lateral structural accommodation between the Pacific and North American plates (Stewart, 1988, 1992). It is northwest of and marginal to the Mina deflection, a complex, northeast-trending structural zone of faults that offset Walker Lane faults north of the Bodie Hills to the east (Stewart, 1988; Hardyman and Oldow, 1991; Oldow, 1992; Oldow, 2003; Wesnousky, 2005; Faulds and Henry, 2008). Present elevations of volcanic rocks in the field are between $\sim 6,500$ feet (ft) $(\sim 1,970$ meters $[\mathrm{m}])$, the elevation of Bridgeport Valley, and $10,240 \mathrm{ft}(\sim 3,110 \mathrm{~m})$, the elevation of Potato Peak. 


\section{Gold-Silver Mining Districts, Alteration Zones, and Paleolandforms in the Miocene Bodie Hills Volcanic Field}

Trachyandesite stratovolcanoes and trachydacite to rhyolite dome complexes in the Bodie Hills are as much as $16 \mathrm{~km}$ in diameter. Most formed during two periods of eruptive activity: trachyandesite stratovolcanoes at 14.7-12.9 Ma, and trachyandesite-dacite complexes at 9.2-8.0 Ma (John and others, 2012). Smaller rhyolite domes and flow-domes were emplaced from $\sim 6.2$ to $5.5 \mathrm{Ma}$ (John and others, 2012). The Miocene volcanic rocks are interbedded with, and overlain by, conglomerate and sandstone of Fletcher and Bridgeport Valleys (Gilbert and Reynolds, 1973). Following a 2 m.y. (million year) hiatus in volcanism, postsubduction rocks of the $\sim 3.9-0.1 \mathrm{Ma}$, bimodal (trachybasalt to rhyolite), high-K Aurora volcanic field erupted unconformably onto rocks of the Bodie Hills volcanic field (Gilbert and others, 1968; Al-Rawi, 1969; Chesterman and Gray, 1975; Kleinhampl and others, 1975; Lange and others, 1993).

The scarcity of dikes in the volcanic field indicates a low horizontal component of stress in the middle and late Miocene. However, veins and faults in the three mining districts mark a change in strain vectors during evolution of the field from transtension, characteristic of Walker Lane tectonism, to extension at $\sim 10 \mathrm{Ma}$ when subduction ceased at the latitude of the Bodie Hills (Atwater and Stock, 1998). Compared to other volcanic fields in the southern segment of the Cascades arc, the prevalence of stratovolcanoes and domes of intermediate to silicic composition and absence of mafic rocks in the Bodie Hills may signify that a relatively thick crust lies beneath the volcanic field. Mafic, mantle-derived magma differentiated within this crust to form predominantly silicic eruptives with uniformly porphyritic texture (John and others, 2012). Plagioclase, pyroxene, hornblende, and biotite phenocrysts are present in most of the volcanic rocks. Olivine phenocrysts occur in some andesites; sanidine and quartz phenocrysts are present in most rhyolites. The groundmass of most rocks contains variable microphenocryst assemblages, chiefly plagioclase, but also Fe-Ti oxide minerals, clinopyroxene, and less commonly, hornblende and (or) biotite. Common accessory minerals are apatite and zircon.

\section{Methods}

Descriptions of mining districts and alteration zones are based on mapping and geophysical surveys, on published and unpublished reports and maps, and on samples collected and borrowed from archival repositories for mineral identification and textural analysis by petrography, X-ray diffraction (XRD), scanning electron microscopy (SEM), and short wave infrared spectrometry (SWIR). Other samples were collected for radioisotopic dating, and for determination of sulfur isotope compositions and minor element concentrations. Remotely sensed spectra, Advanced Spaceborne Thermal Emission and Reflection Radiometer (ASTER) data, were analyzed to determine the large-scale distribution and characteristics of hydrothermal mineral assemblages throughout the Bodie Hills.

Archival samples were borrowed from the Keck Museum at the University of Nevada Reno (Reno, Nevada), and from the California State Mining and Mineral Museum (Mariposa, California). Instrumental analyses (XRD, SEM, geochronology, isotope compositions, and element concentrations) were performed in laboratories at the U.S. Geological Survey (Menlo Park, California; Denver, Colorado), University of Nevada Reno (Reno, Nevada), and SGS Mineral Services (Toronto, Canada). SWIR analyses of hand samples used a portable infrared mineral analyzer (PIMA).

Some K-Ar and ${ }^{40} \mathrm{Ar} /{ }^{39} \mathrm{Ar}$ ages used in this investigation are from Kleinhampl and others (1975), Morton and others (1977), Breit (2000), John and others (2012), and Larry Snee (unpublished analyses). Additional ${ }^{40} \mathrm{Ar} /{ }^{39} \mathrm{Ar}$ ages (Ma) of igneous and hydrothermal minerals were determined by the incremental heating (multi-step) and laser fusion (single-step) methods (table 1). Following neutron irradiation of a single split of a sample, radiogenic ${ }^{40} \mathrm{Ar}$ and potassium-derived ${ }^{39} \mathrm{Ar}$ from neutron activation were simultaneously measured (for example, Dalrymple and Lanphere, 1974; McDougall and Harrison, 1999). Heating to release Ar was provided by laser, induction furnace, or resistance furnace. A series of incremental heating steps that comprises more than 50 percent of the total argon release, and in which each step gives an age within two standard deviations of the mean, defines a "plateau" age (Fleck and others, 1977). Laser fusion and furnace experiments that release all Ar from the sample in a single heating step provide "laser-fusion" or "total-gas" ages. Ages calculated by mathematically recombining the Ar released in all steps of incremental-heating experiments are referred to as "integrated" ages. Uncertainties for all Ar ages are reported at 1 standard error of the weighted mean (Renne and others, 2009).

Some sulfur isotope compositions $\left(\delta^{34} \mathrm{~S}\right)$ of sulfide minerals, sulfate minerals, and native sulfur $\left(\mathrm{S}^{\circ}\right)$ used in this investigation are from Vikre (2000) and Vikre and Henry (2011; table 2). Additional $\delta^{34} \mathrm{~S}$ values were determined by Simon Poulson (University of Nevada Reno) using a Eurovector model 3028 elemental analyzer interfaced to a Micromass IsoPrime stable isotope ratio mass spectrometer, and following the methods of Giesemann and others (1994) and Grassineau and others (2001). The $\delta^{34} \mathrm{~S}$ values are reported in units of per mil, part per thousand (\%o) versus VCDT (Vienna Canyon Diablo troilite), and have an uncertainty of $\pm 0.2 \%$. Sulfur isotope equilibrium temperatures were calculated from fractionation equations in Field and Fifarek (1985).

Geochemical analyses were obtained under a U.S. Geological Survey contract with SGS Mineral Services. Element concentrations were determined using several multielement analytic methods with variable reporting limits (given as concentration ranges in table 3 ). Analytic methods included fire assay (FA)-inductively coupled plasma mass spectrometry (ICPMS) for Au, Pd, Pt, cold-vapor atomic absorption (AA) for $\mathrm{Hg}$, hydride generation $\mathrm{AA}$ for $\mathrm{Se}$, and inductively coupled plasma-atomic emission spectrometry-mass spectrometry (ICP-AES-MS) for all other elements except sulfur. Sulfur concentrations were determined using an automated sulfur analyzer. These methods were selected to include elements of economic interest ( $\mathrm{Au}, \mathrm{Ag}, \mathrm{Hg}, \mathrm{As}, \mathrm{Sb}, \mathrm{Te}, \mathrm{Se}, \mathrm{Sn}, \mathrm{Cu}, \mathrm{Pb}, \mathrm{Zn}$, and $\mathrm{S}$ ). 
Atomic proportions of minerals and some mineral identities shown on SEM images were determined using integrated software. Atomic proportions of electrum were normalized to one. Atomic proportions of sulfide, selenide, and telluride minerals were calculated to positive integers of S, Se, or Te atoms, with the number of $\mathrm{S}, \mathrm{Se}$, or Te atoms corresponding to atoms per formula unit of the petrographically identified mineral. For minerals in which petrographic characteristics and atomic proportions do not correspond to documented minerals, atomic proportions were iteratively calculated relative to positive integers of $\mathrm{S}$ atoms to produce positive integers, or integers plus fractions, of other major atoms (for example, $\mathrm{Cu}, \mathrm{Ag}$ ). Comparison of atomic proportions of analyzed chalcopyrite to stoichiometric chalcopyrite, and replicate analyses, suggest an accuracy of \pm 0.2 atoms.

\section{Masonic Mining District}

\section{Location}

Secs. 14, 15, 16, 17, 20, 21, 22, 23, 29, 30, T. 6 N., R. 26 E., Mono County, California, Lyon County, Nevada (fig. 1)

\section{History and Production}

Gold was discovered in the Masonic Mining District in the 1860s by placer miners from Monoville (abandoned; originally located on Virginia Creek near Conway Summit), who named the district after the Freemasonry fraternal organization. In the latter half of the 19th century, mining activity in the Bodie Hills was focused on high-grade Au-Ag veins at Aurora and Bodie, and little development took place at Masonic until 1900-1902 when the Jump-Up-Joe and Pittsburg-Liberty Mines were located. Three towns were established: Upper, Middle, and Lower Masonic had a combined population that reached $\sim 1,000$. Gold and lesser Ag and $\mathrm{Cu}$ production occurred mainly during the period 1906-20 (McLaughlin, 1915; Eakle, and others, 1917; Eakle and McLaughlin, 1919; Sampson, 1940). Production was sporadic because mining small, irregular deposits was often unprofitable, and because Au recovery by different milling operations was, at best, marginally successful. Episodic but short-lived mining revivals with small and mostly unrecorded production took place from the 1920s to 1960s (Sampson, 1940; Jenkins, 1951; Wedertz, 1969; Mono County Historical Society 2004 Newsletter).

Production totals are incompletely known because of the numerous small and episodic mining operations that spanned five or more decades. Total district production from 1902 through 1959 is estimated at 55,800 ounces (oz) of $\mathrm{Au}$, and $39,000 \mathrm{oz}$ of $\mathrm{Ag}$ from 75,000 tons $(\mathrm{t})$ of ore; minor amounts of $\mathrm{Cu}$ were also recovered (Long and others, 1998). The first ore shipment in 1907 (to the Selby, California, smelter), from the Pittsburg-Liberty Mine, consisted of $17 \mathrm{t}$ valued at $\$ 1,040$ per ton, or about 50 troy ounces per ton (opt) Au if all value was gold (at $\sim \$ 20 / \mathrm{oz}$ ). Pittsburg-Liberty production is estimated at $\$ 600,000$ to $\$ 700,000$ ( $\sim 30,000$ to 35,000 oz of $\mathrm{Au}$, if all value was $\mathrm{Au}$; Eakle and McLaughlin, 1919). Sarita Mine production was $\$ 425,000(\sim 20,000 \mathrm{oz}$ of $\mathrm{Au}$, if all value was $\mathrm{Au}$ ), and Chemung Mine production was 3,700 oz of $\mathrm{Au}$ (R.T. Wilson and W.A. Rehrig, written commun., 1987). Ore grades at the Sarita and Lakeview Mines were reportedly 0.2-2 opt Au (Eakle and McLaughlin, 1919). An unpublished assay plan ( 1930s) of Sarita underground levels shows similar Au grades. An unpublished (1935) map of the Perrini Mine underground workings includes eight samples containing trace- 0.18 opt $\mathrm{Au}$, and $0.6-30.02$ opt Ag over widths of 2-6.7 ft (R.T. Wilson and W.A. Rehrig, written commun., 1987). Drilling programs by several mining companies in the 1980s identified a resource of $\sim 180,000$ tons at 0.15 opt $\mathrm{Au}$ at the Sarita Mine (R.T. Wilson and W.A. Rehrig, written commun., 1987). It appears that some of this resource was mined from an open cut on the northwest side of New York Hill since the 1980s, although processing facilities for this excavation are not evident.

\section{Stratigraphy}

Published geologic maps and lithologic descriptions of the Masonic Mining District include those in Eakle and McLaughlin (1919), Johnson (1951), Vikre and Henry (2011), and John and others (2012). The oldest rocks in the district are Jurassic(?) metavolcanic rocks (Jmv) that are extensively exposed at lower elevations on Masonic Mountain $(9,195 \mathrm{ft})$. These pre-Tertiary rocks, thought to represent metasomatized rhyolite (Johnson, 1951), form pendants in Mesozoic granitic rocks (Kg; fig. 2). Mesozoic granitic rocks consist of palegray to pinkish-gray, hypidiomorphic granular, equigranular to porphyritic granodiorite and minor monzogranite that comprise Masonic Mountain; a smaller mass of granodiorite is exposed about $6 \mathrm{~km}$ to the east (John and others, 2012). The medium-grained, 95.2 Ma granodiorite (Robinson and Kistler, 1986) contains prominent, euhedral, perthitic, pink potassium feldspar megacrysts $2-5$ centimeters $(\mathrm{cm})$ long, and about 3 volume percent red-brown biotite (Johnson, 1951; John and others, 2012; du Bray and others, 2013). The granitic rocks form a plutonic mass covered in most places by trachyandesite of Masonic.

The trachyandesite of Masonic is pale- to medium-darkgray, gray-green, and purplish, and variably porphyritic, and includes basaltic trachyandesite, trachydacite, basaltic andesite, and andesite. It comprises interbedded lava flows and mostly small-volume plugs and domes of trachyandesite that were erupted from 15 to $14 \mathrm{Ma}$ (Tma, table 1), and includes associated volcaniclastic deposits (Tvc; figs. 2, 3, 4). Trachyandesite flows and volcaniclastic deposits aggregate tens to hundreds of meters in thickness. Combined, the lava flows, intrusions, and volcaniclastic deposits that make up the trachyandesite of Masonic define the nearly circular Masonic stratovolcano in the northwestern part of the Bodie Hills volcanic field (John and others, 2012). 


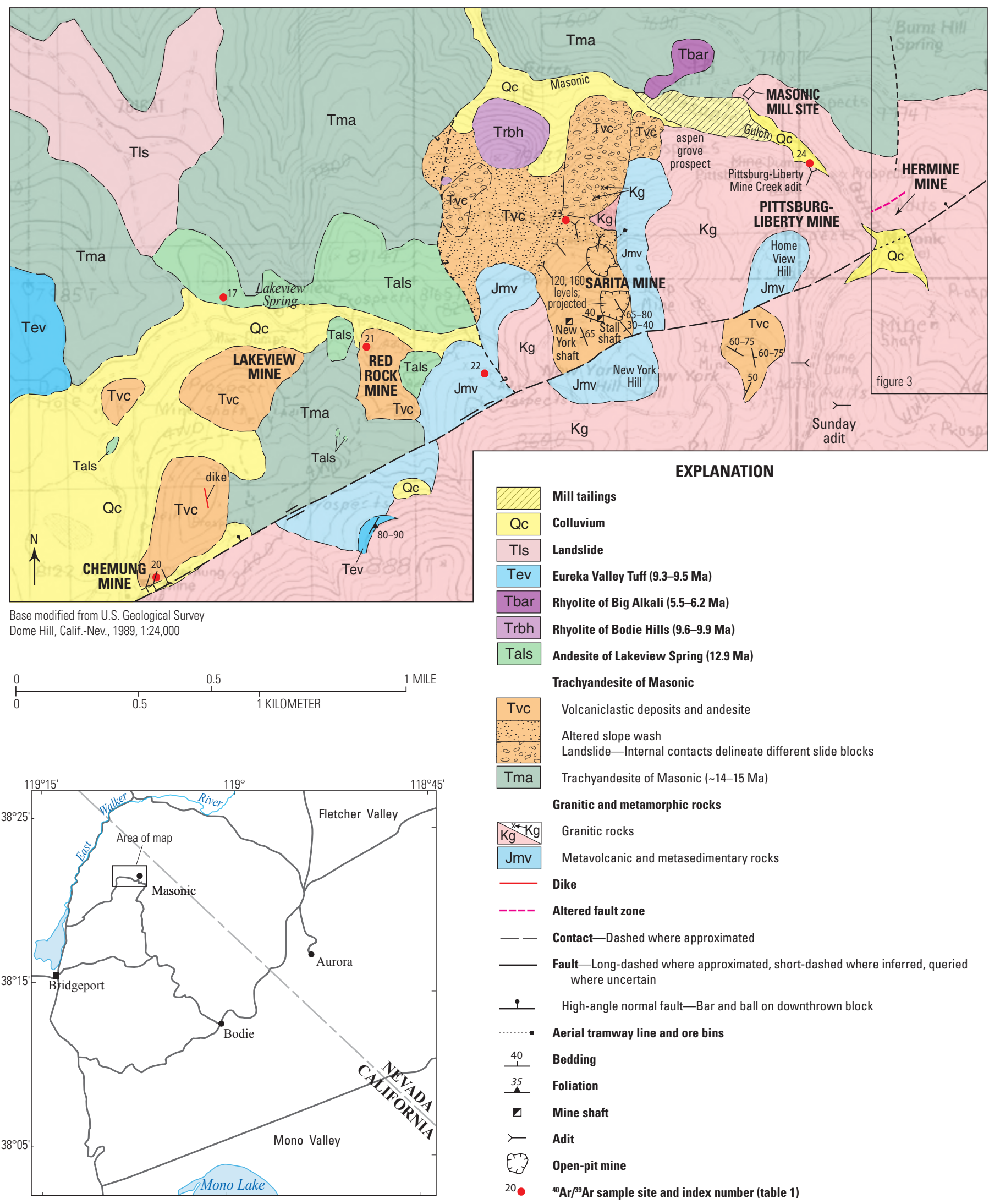

Figure 2. Geologic map of the southwestern part of the Masonic Mining District, Mono County, California, and Lyon and Mineral Counties, Nevada. Aerial tramway ore bins (also shown on report cover) are 120 m northeast of the Sarita Mine adit that accesses the 120 and 160 levels. 


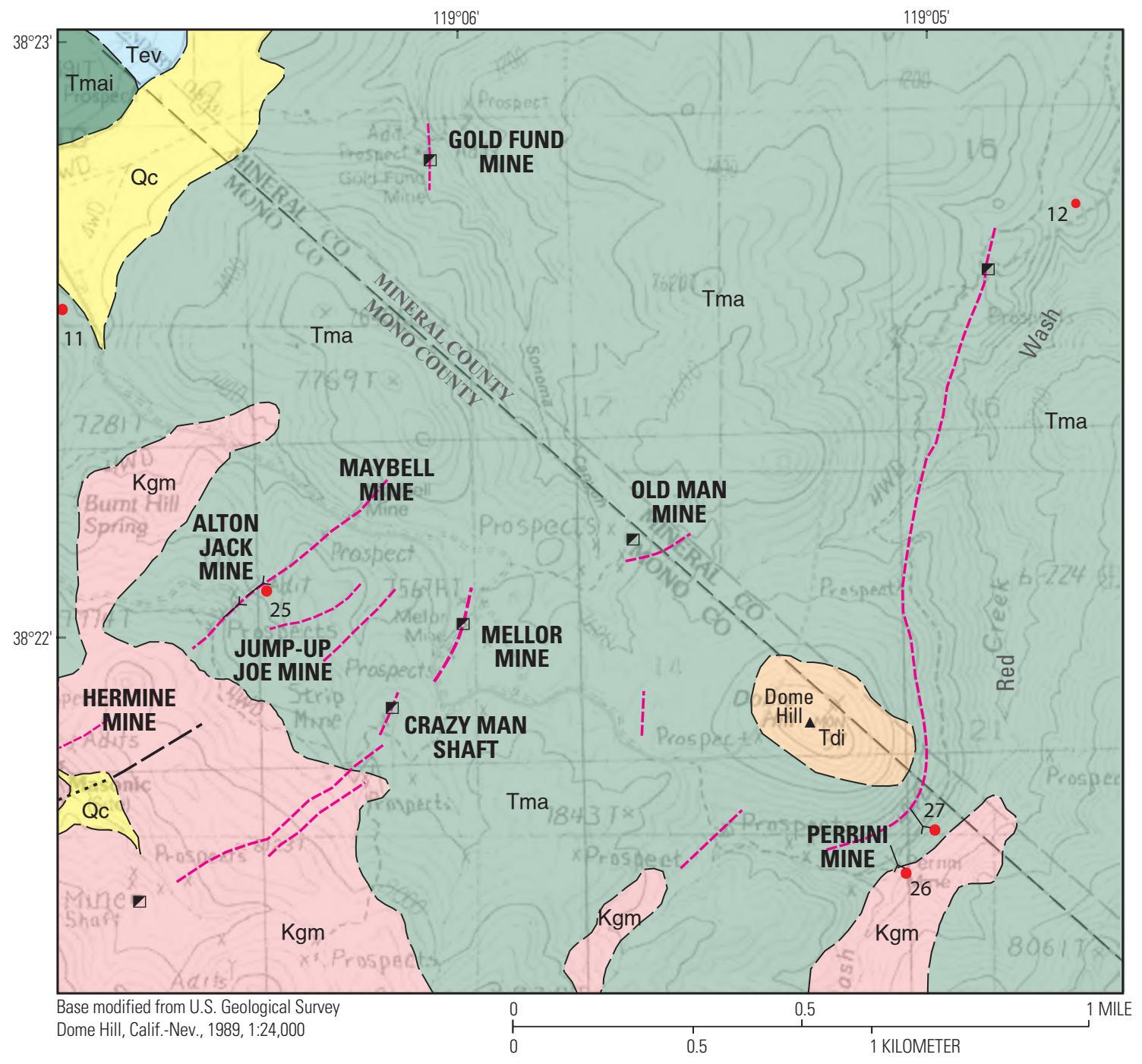

\section{EXPLANATION}
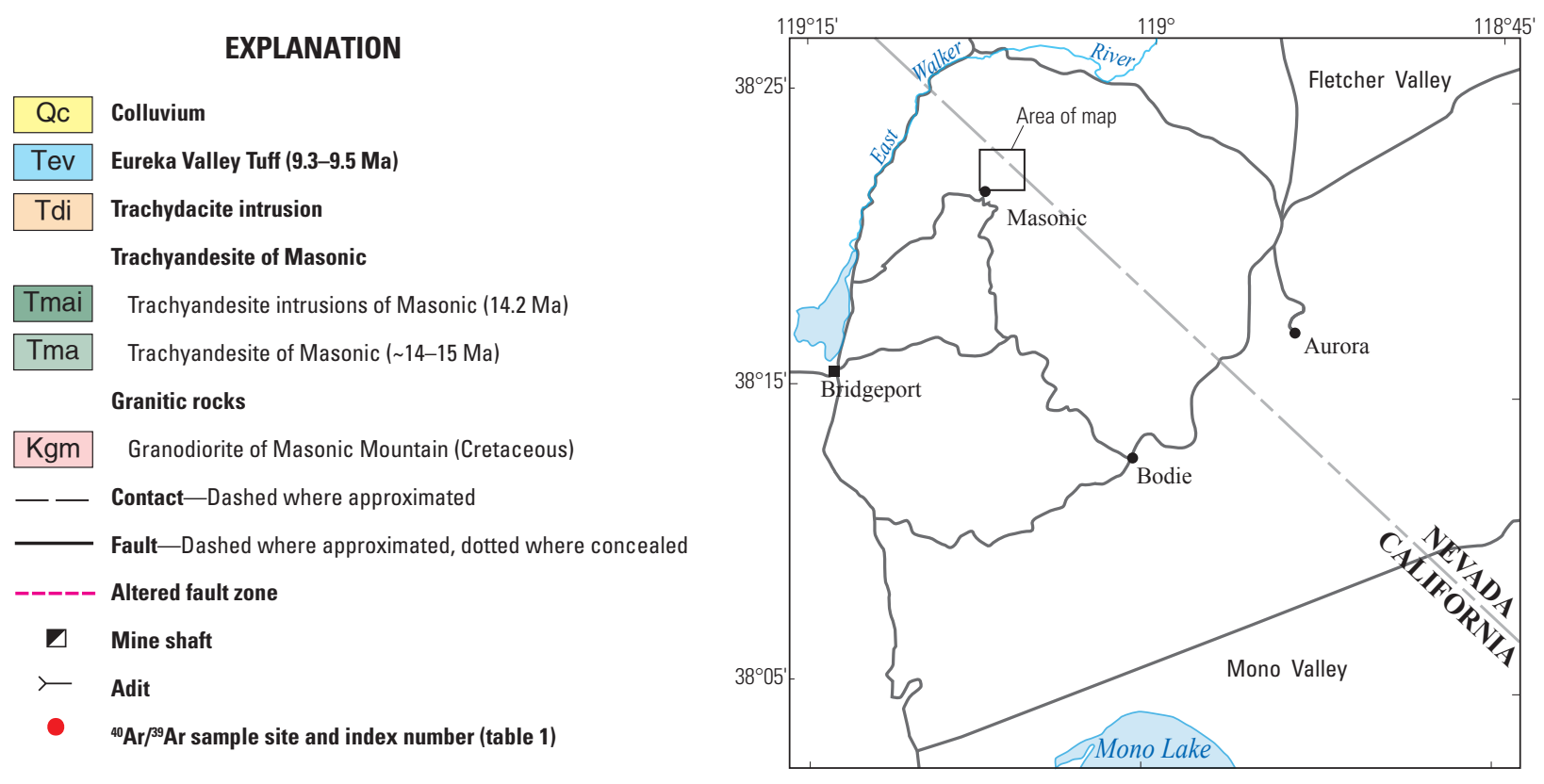

Figure 3. Geologic map of the northeastern part of the Masonic Mining District, Mono County, California, and Mineral County, Nevada. 

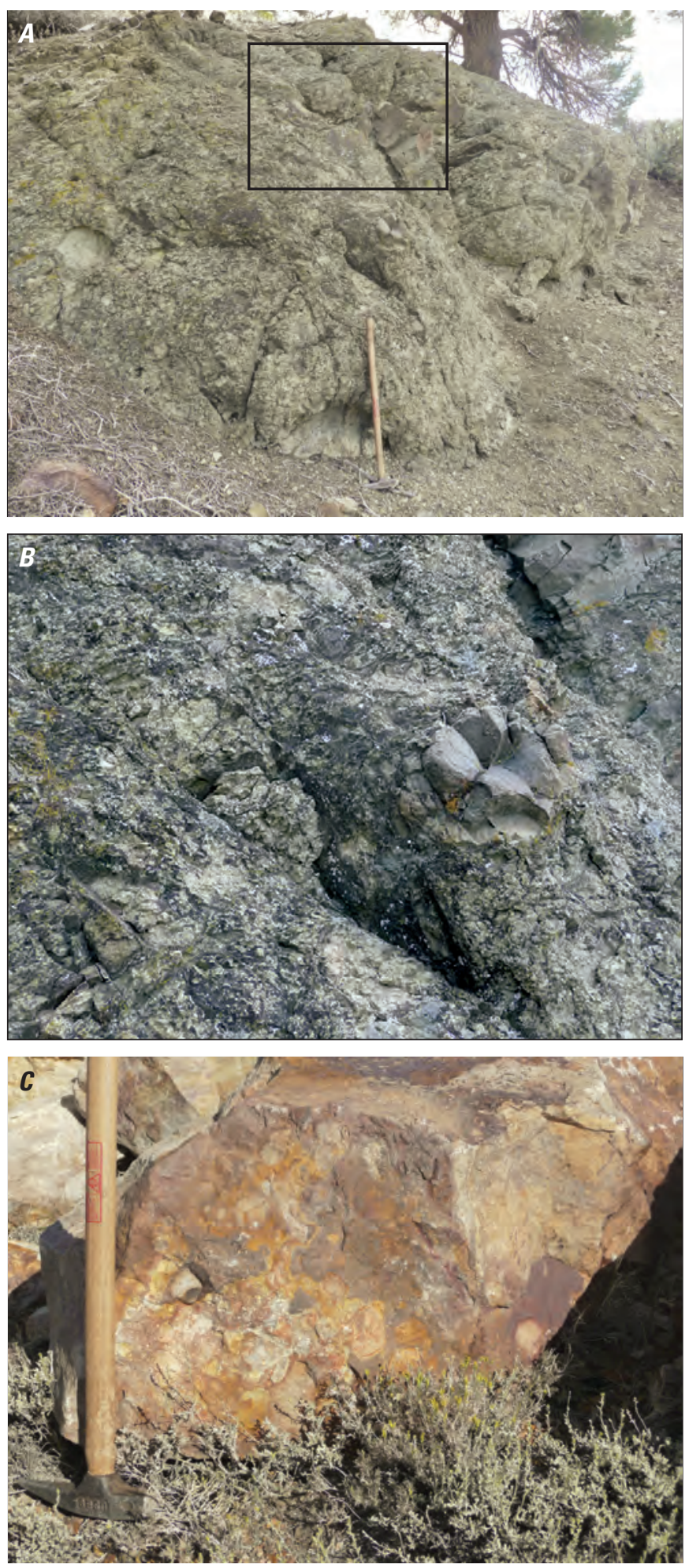

Figure 4. Images of volcaniclastic deposits in the Red WashEast Walker River alteration zone and Masonic Mining District. A, Propyliticly altered debris flow in trachyandesite of Masonic, hill 6696 (elevation), and Red Wash-East Walker River alteration zone. Hammer for scale. $B$, Closeup view of black rectangle shown in $A$. C, Volcaniclastic deposits replaced by quartz, alunite, kaolinite, and pyrite (weathered to iron oxides), Sarita Mine. Hammer for scale.
Trachyandesite flows and intrusions contain 2-53 volume percent phenocrysts of plagioclase, clinopyroxene, hornblende, and trace amounts of biotite and olivine in a variably devitrified groundmass or, less commonly, in a felty intergrowth of plagioclase, opaque oxides, and clinopyroxene. Euhedral, acicular hornblende phenocrysts (2-5 millimeters $[\mathrm{mm}])$ are a distinctive constituent in many places. Volcaniclastic deposits include laharic debris flows and lesser block and ash-flow deposits. These strata are massively to distinctly bedded, generally poorly sorted, clast- to matrix-supported, mass wasting deposits with a clay- and ash-rich matrix (fig. 4). Clasts are $1 \mathrm{~cm}$ to several meters in diameter, angular to subangular, and principally consist of volcanic rock fragments similar to the associated trachyandesite lavas and intrusions.

Between the Masonic Mining District and the Red WashEast Walker River alteration zone (fig. 1) some trachyandesite flows were erupted from small plugs marked by low-relief spires, generally meters in dimension, with steep foliations and joints. Conical to rounded hills in the northern and northeastern parts of the district comprise a group of larger trachyandesite and trachydacite domes that are the same age as trachyandesite flows $(15.0,14.4$, and 14.2 Ma porphyritic and hornblende andesite plug and domes; Tmai, fig. 3; table 1), or younger than trachyandesite flows (13.5-13.4 Ma trachyandesite of Masonic Gulch; Tamg, table 1; undated trachydacite intrusion of Dome Hill; Tdi, fig. 3). Trachyandesite of Masonic also has been intruded by $12.9 \mathrm{Ma}$ andesite of Lakeview Spring (Tals, fig. 2; table 1; John and others, 2012) that forms small-volume domes north of Masonic Mountain. The medium-pale-gray, moderately porphyritic andesite contains about 16 volume percent phenocrysts of plagioclase, hornblende, clinopyroxene, and trace amounts of olivine set in a moderately devitrified groundmass. Plagioclase phenocrysts are characteristically larger than those in most rocks in the Bodie Hills volcanic field.

Trachyandesite of Masonic west, northwest, and north of Masonic Mountain is overlain by 9.5-9.3 Ma Eureka Valley Tuff (Eureka Valley Tuff; Tev, figs. 2, 3; Pluhar and others, 2009; John and others, 2012), and by Miocene and younger sedimentary deposits, including Fletcher Valley basin-filling fanglomerate, talus (Qfg and Qt, respectively), landslide deposits northwest of Lakeview Spring (Tls, fig. 2), perched terrace gravels, and perched fluviolacustrine sediments ( $\mathrm{Tg}$ and Ts, respectively). The Eureka Valley Tuff is a grayishblack, moderately porphyritic trachydacite ash-flow tuff. It contains about 13 volume percent phenocrysts of plagioclase, biotite, clinopyroxene, and trace amounts of hornblende set in a grayish-black to iron-stained, reddish-brown, glassy groundmass. Clasts are composed of the same phenocrysts and matrix. In the Bodie Hills, where tuff is moderately to densely welded, most exposures appear to fill paleochannels. Abundance of biotite suggests that most Eureka Valley Tuff exposures in the Bodie Hills correlate with the lower, Tollhouse Flat Member, but upper member deposits also could be present. 
Basin-fill of Fletcher Valley consists of fanglomerate and braided stream deposits (Tfg, at least $200 \mathrm{~m}$ thick) that contain well-rounded volcanic pebbles and, in places, interbedded felsic tephra. The braided stream deposits are moderately well-sorted, clast-supported sandstone and siltstone that contain $0.1-2 \mathrm{~mm}$ subangular detrital clasts composed of plagioclase and lesser quartz. Mafic silicate minerals (clinopyroxene $>$ olive-green hornblende $>$ biotite) comprise about 1 volume percent of detrital grains. These deposits also contain lithologically diverse volcanic rock fragments. Interbedded tephra deposits have dates of $11.7 \mathrm{Ma}$ (Gilbert and Reynolds, 1973), 11.07 Ma (John and others, 2012), and 10.6-10.5 Ma (table 1). Landslide deposits northwest of Lakeview Spring (Tls) consist predominantly of altered volcaniclastic-flow sequence detritus derived from the northwest side of Masonic Mountain, and also include clasts of Eureka Valley Tuff, Mesozoic granitic rocks, metamorphic rocks, and andesite of Lakeview Spring. The unconsolidated, perched terrace gravels (Tg) vary from thin veneers to massive deposits of poorly sorted, silt- to boulder-size clasts in a sandy to silty matrix. Clasts include cobbles of Mesozoic granitic rocks, petrified wood, Eureka Valley Tuff, and diverse volcanic rocks. The semiconsolidated, gray- to dark-gray, perched fluviolacustrine sediments (Ts) are predominantly relatively well-sorted and distinctly bedded, coarse sand, sand, and silt.

In the Masonic Mining District and in the Red Wash-East Walker River alteration zone, large volumes of interstratified volcaniclastic deposits and trachyandesite lava flows were pervasively altered to hydrothermal mineral assemblages that include quartz, alunite, kaolinite, pyrophyllite, and pyrite (mostly weathered to iron oxides). Adjacent to and gradational with these quartz-alunite-altered volcaniclastic-flow sequences, are large volumes of less-altered, gray-green and purple lava and debris flows (figs. 2,3) in which phenocrysts are partly to entirely replaced by chlorite, montmorillonite, iron oxide minerals, sericite (fine-grained white mica containing K), and calcite (propylitic alteration). Thin veneers (tens of meters thick) of quartz-alunite-altered sequence strata that overlie pre-Tertiary rocks on the west and north sides of Masonic Mountain (Tvc, figs. 2, 3) contain the $\mathrm{Au}-\mathrm{Ag}-\mathrm{Cu}$ deposits at the Sarita, Lakeview, and Chemung Mines. Thicker quartz-alunite-altered sequences are exposed between Sonoma Canyon and Red Wash, south of the East Walker River.

The quartz-alunite-altered volcaniclastic-flow sequences have been designated separate stratigraphic units by others (for example, Red Wash volcanics and Masonic Gulch volcanics, Johnson, 1951). Based on igneous and hydrothermal mineral ages, chemistry, petrography, and stratigraphy (John and others, 2012), the altered sequences reflect contrasting primary permeability among largely conformable volcaniclastic deposits and lava flows rather than separate lithologic units. More permeable volcaniclastic deposits and interstratified volcaniclastic-flow sequences have been intensely altered and discolored, whereas thicker sequences of homogenous flows have largely retained primary mineralogy and darker coloration. The volcaniclastic-flow sequences are cogenetic eruptives with limited lateral continuity (common on the flanks of stratovolcanoes) and their designation as separate map units is not warranted.

\section{Structure}

North and west of Masonic Mountain, trachyandesite of Masonic has been displaced along west-east and northeaststriking, high-angle normal faults (fig. 2). Down-to-the-north displacement along these faults, estimated at tens of meters, enabled preservation of relatively thick sections of the volcaniclastic-flow sequence along the East Walker River, and preservation of perched gravel terraces and fluviolacustrine sediments between the Masonic Mining District and East Walker River. Faults bounding granitic rocks on the west side of Masonic Mountain (Johnson, 1951; Stanford Geological Survey, 1961; John and others, 2012) are subparallel to mineralized structures and are inferred to have been active both during and after hydrothermal events in the district.

Mineralized structures in the Masonic Mining District are attributed to stress accommodation within the Walker Lane transtensional structural zone of strike-slip displacement, extension, and rotated tectonic blocks. Attitudes of these structures and kinematic indicators are consistent with maximum horizontal extension and compression oriented $\mathrm{N} 60^{\circ} \mathrm{W}$ and $\mathrm{N} 30^{\circ} \mathrm{E}$, respectively (John and others, 2012).

\section{Forms of Gold-Silver-Copper Deposits}

Two forms of Au-Ag-Cu deposits occur in the Masonic Mining District (1) breccia and vein deposits in high-angle, subplanar fault zones, and (2) clastic and hydrothermal sedimentary deposits.

\section{Breccias and Vein Deposits in High-Angle, Subplanar Fault Zones}

Faults that contain mineralized breccias and veins are part of a north- to northeast-trending, curvilinear series of en echelon faults that extend for $\sim 6.5 \mathrm{~km}$ along the west and north sides of Masonic Mountain, and north of Masonic Mountain along Red Wash (figs. 2, 3). Individual fault segments are vertical to near-vertical, tens to several hundreds of meters long, and strike $\mathrm{N} 15^{\circ} \mathrm{W}-\mathrm{N} 60^{\circ} \mathrm{E}$. Most mineralized faults occur in granodiorite, metavolcanic rocks, and trachyandesite of Masonic north of Masonic Mountain, although the Chemung and Red Rock Mine workings follow high-angle fault zones partly in a volcaniclastic-flow sequence (fig. 2). District production was mostly derived from near-vertical, $\mathrm{N} 15-20^{\circ} \mathrm{W}$-striking faults in granodiorite and metavolcanic rocks in the Pittsburgh-Liberty Mine. Other small mines north of the Pittsburgh-Liberty, including Hermine, Maybell, Mellor, and Perrini (fig. 3), were excavated in similar north- to 
northeast-striking, high-angle faults in granodiorite and trachyandesite of Masonic, but produced little or no ore. None of these mines are deeper than $\sim 60 \mathrm{~m}(\sim 200 \mathrm{ft})$. Stopes exposed at several mines indicate that mineable fault segments were as much as $2 \mathrm{~m}$ wide (fig. 5).

Based on textures of mineral assemblages, alunite dates, and sulfur isotope compositions, the sulfide, telluride, sulfate and silicate minerals, and electrum, described below and imaged by scanning electron microscopy (SEM), are largely if not entirely hypogene. Some complex $\mathrm{Cu}-\mathrm{As}-\mathrm{Sb}-$ Fe-Bi-Pb-Ba-Al-Te-S-O phases may have been produced during weathering of sulfide minerals, or may represent submicron intergrowths of sulfide and oxide minerals. Iron oxide minerals that marginally replace pyrite are interpreted to have formed during weathering, and mineral assemblages in fault breccia and veins that formed during weathering are not further characterized.

Mineralized fault breccias consist of angular to subrounded clasts (millimeters to centimeters in size) of trachyandesite and pre-Tertiary rocks that have been variably replaced by quartz, alunite, pyrite (commonly weathered to iron oxide minerals), and lesser kaolinite, dickite, pyrophyllite, and diaspore. Some clasts consist of fine-grained to chalcedonic, gray to white quartz \pm pyrite (partly to entirely weathered to iron oxides) in which little to no primary texture is evident (fig. 5). Fault breccias are locally multigenerational. Clasts that have been completely replaced by fine-grained white-gray quartz are juxtaposed with voids that represent leached clasts, and with clasts of porphyritic volcanic rocks in which phenocrysts have been leached. Breccia clasts in faults at the Perrini and Chemung Mines are replaced by quartz+pyrite(iron oxides) \pm alunite, but many retain porphyritic texture.

Similar to altered clasts, breccia matrices consist predominantly of quartz, alunite, pyrite (iron oxides), and kaolinite, but locally include small amounts of pyrite, enargite, numerous other metallic minerals, and barite. Enargite in some samples is intergrown with quartz, pyrite, and alunite in centimeter-sized aggregates (fig. 5). Breccia matrices of dump samples from the Chemung Mine contain discrete crystals and intergrowths of pyrite, chalcopyrite, electrum, enargite, sphalerite, naumannite, and pyrrhotite; some enargite is encrusted on breccia clasts. The source of these samples is uncertain because the Chemung mill also processed ore from the Success, Sarita, and Lakeview Mines; sulfur $\left(\mathrm{S}^{\circ}\right)$ in some samples links them to the Success Mine (Vikre, 2000).

Well-defined planar veins having sharp wall-rock contacts are relatively uncommon in the district. Veins cutting breccias in fault zones were mined with enclosing breccia at the Pittsburg-Liberty Mine, and, to a lesser extent, at the Red Rock and Lakeview Mines. The relationship between breccias and veins is evident in dump samples from the lower Pittsburg-Liberty Mine in Masonic Gulch that mostly consist of granodiorite that was altered to quartz+alunite+pyrite, brecciated, and cemented by dense fine-grained quartz+pyrite. Mineralized granodiorite breccia is cut by planar veins (millimeters to centimeters in size) composed of fine-grained, vuggy quartz, pyrite, and lesser enargite (fig. 5). Veins in the volcaniclastic-flow sequence at the Red Rock and Lakeview Mines are centimeters wide, and consist of fine- to mediumgrained, locally banded quartz, and lesser alunite, pyrite, and enargite.

\section{Mineral and Rock Compositions of Breccias and Vein Deposits}

Samples of mineralized fault breccia from upper Pittsburgh-Liberty Mine dumps (fig. 2) consist of completely silicified clasts that have been cemented by dense to porous (leached) matrices of fine-grained, gray to white quartz and aggregates of pyrite, enargite, famatinite, alunite, and lesser barite (millimeters to centimeters in size; fig. 5). Enargite and famatinite contain a large variety of $<10 \mu \mathrm{m}$ mineral inclusions of predominantly gold, silver, and copper minerals, based on semiquantitative SEM analyses. Gold minerals include Au-rich electrum $\left(\mathrm{Au}_{>0.8} \mathrm{Ag}_{<0.2}\right.$ with minor $\left.\mathrm{Cu}\right)$, an $\mathrm{Au}-\mathrm{Cu}-\mathrm{Ag}$ alloy $\left(\sim \mathrm{Au}_{7.1} \mathrm{Cu}_{2} \mathrm{Ag}_{0.9}\right)$, an $\mathrm{Au}-\mathrm{Ag}-\mathrm{S}$ mineral $\left(\sim \mathrm{Au}_{2} \mathrm{Ag}_{1.7} \mathrm{~S}_{2}\right)$, a Cu-Ag-Au-Se-S mineral with variable $\mathrm{Cu} / \mathrm{Ag} / \mathrm{Au}$, and an $\mathrm{Au}-\mathrm{Ag}$-Se mineral. Silver minerals are naumannite ( $\sim \mathrm{Ag}_{2} \mathrm{Se}$ with minor $\mathrm{Cu}$ and $\left.\mathrm{Fe}\right)$, and an $\mathrm{Au}-\mathrm{Ag}$ $\mathrm{Cu}$-Se mineral $\left(\sim \mathrm{Ag}_{4.5} \mathrm{Au}_{1.3} \mathrm{Cu}_{1.2} \mathrm{Se}_{3}\right)$. Copper minerals include $\sim \mathrm{Cu}_{6} \mathrm{Bi}_{1.7} \mathrm{~S}_{5} ; \mathrm{Cu}_{3} \mathrm{Bi}_{2} \mathrm{~S}_{5}$ with minor Se; $\mathrm{Cu}_{4.3} \mathrm{As}_{1.2} \mathrm{Sb}_{0.1} \mathrm{~S}_{5} ; \mathrm{Cu}_{1.5} \mathrm{~S}$ with minor $\mathrm{Sb} ; \mathrm{Cu}_{2.3} \mathrm{~S}$ with minor $\mathrm{Se} ; \mathrm{Cu}_{5} \mathrm{Ag}_{0.5} \mathrm{Fe}_{0.4} \mathrm{Se}_{3} \mathrm{~S}{ }_{1.3}$ (possibly athabascaite); $\mathrm{Cu}_{3} \mathrm{As}_{2}$ with minor $\mathrm{Sb}, \mathrm{Au}, \mathrm{Fe}, \mathrm{S}$; and a $\mathrm{Cu}$-Se mineral (figs. 6, 7). Atomic proportions of some $\mathrm{Cu}-\mathrm{S}$ inclusions correspond to those of digenite. Textures of $\mathrm{Cu}$-As-O minerals intergrown with enargite and famatinite appear to be hypogene.

A sample from the lower Pittsburgh-Liberty adit dump in Masonic Gulch (figs. 2; 5) consists of Mesozoic granodiorite that has been altered to quartz and alunite, and cut by millimeter to $\sim 1 \mathrm{~cm}$ veins of quartz, pyrite, enargite (As/Sb weight percent $\sim 1.2-11$; minor $\mathrm{Te}$ ), famatinite ( $\mathrm{As} / \mathrm{Sb}$ weight percent $\sim 0.3-0.8)$, and lesser goldfieldite $\left(\mathrm{Cu}_{12}(\mathrm{Te}, \mathrm{Sb}, \mathrm{As})_{4} \mathrm{~S}_{13}\right)$. Numerous minerals with variable $\mathrm{Cu}-\mathrm{Sb}-\mathrm{As}-\mathrm{Zn}-\mathrm{Te}-\mathrm{S}$, and variable $\mathrm{Cu}-\mathrm{Bi}-\mathrm{S}-\mathrm{Se}$, occur as intergrowths with, and inclusions in, pyrite, famatinite, and goldfieldite (fig. 8). Atomic proportions of many intergrown and inclusion phases in Pittsburg-Liberty Mine samples may represent submicron-sized intergrowths of several minerals (based on backscattered electron images), or undocumented minerals. Dump samples from Lakeview and Red Rock Mines consist of quartz, alunite, "goldfieldite" (with minor $\mathrm{Zn}$ ), naumanite (with minor Te and S), argentite, and an Ag-Te-Se-S mineral.

Bulk samples of the imaged sections contain 27.6 and 53.9 parts per million (ppm) Au, 136 and 395 ppm $\mathrm{Ag}, 92.1$ and $149 \mathrm{ppm} \mathrm{Pb}, 26.9$ and $461 \mathrm{ppm} \mathrm{Sn},>10 \mathrm{ppm}$ $\mathrm{Hg},>500 \mathrm{ppm} \mathrm{Te}$, and $>1,000 \mathrm{ppm} \mathrm{As}, \mathrm{Ba}, \mathrm{Bi}, \mathrm{Cu}$, and $\mathrm{Sb}$ (table 1-1; Se was not determined). Other bulk samples from the Success, Chemung, and Pittsburgh-Liberty Mine dumps contain concentrations of minor elements that are broadly similar to, or lower than, concentrations in mineralized fault breccia from upper Pittsburgh-Liberty dumps. 

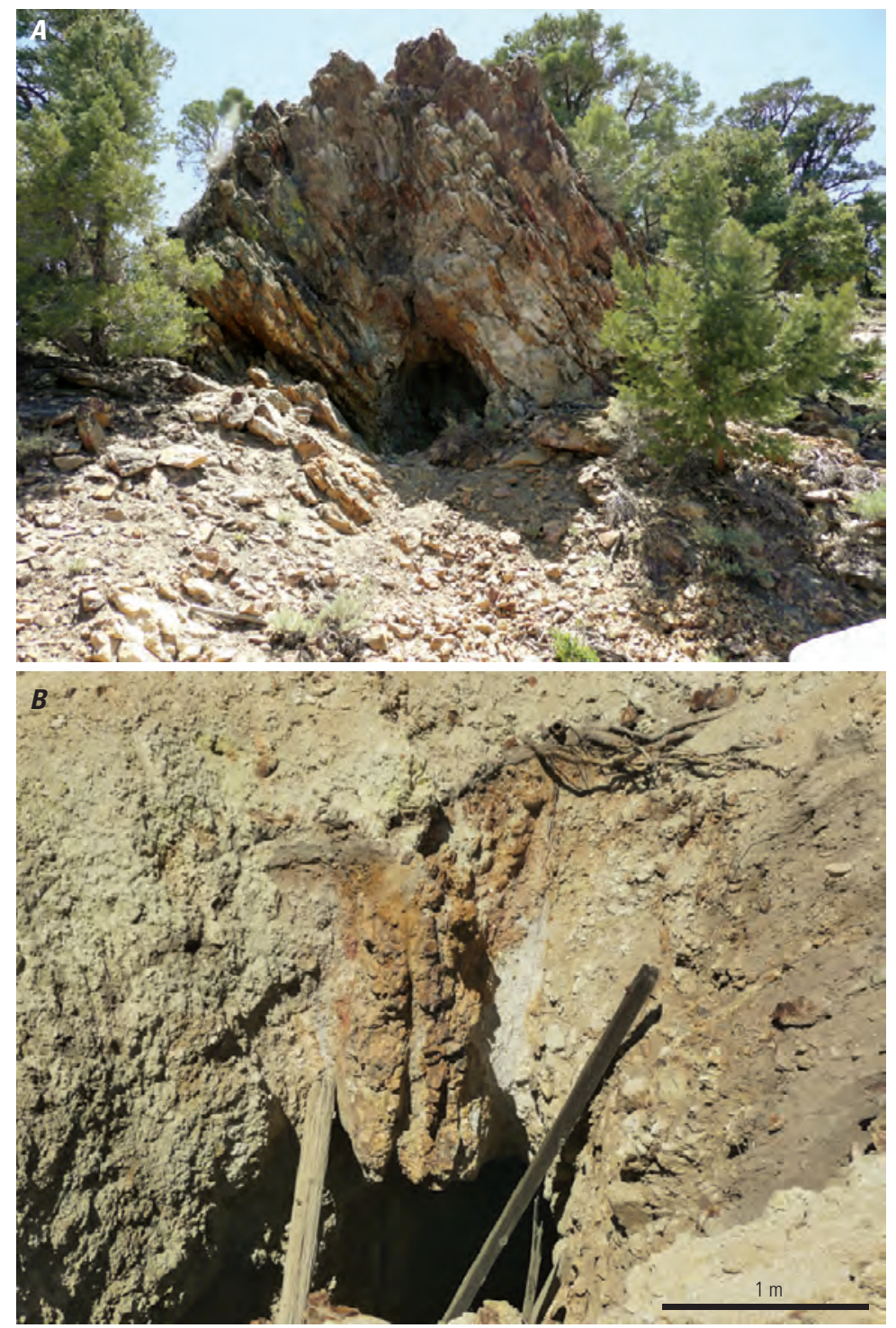

$\boldsymbol{C}$

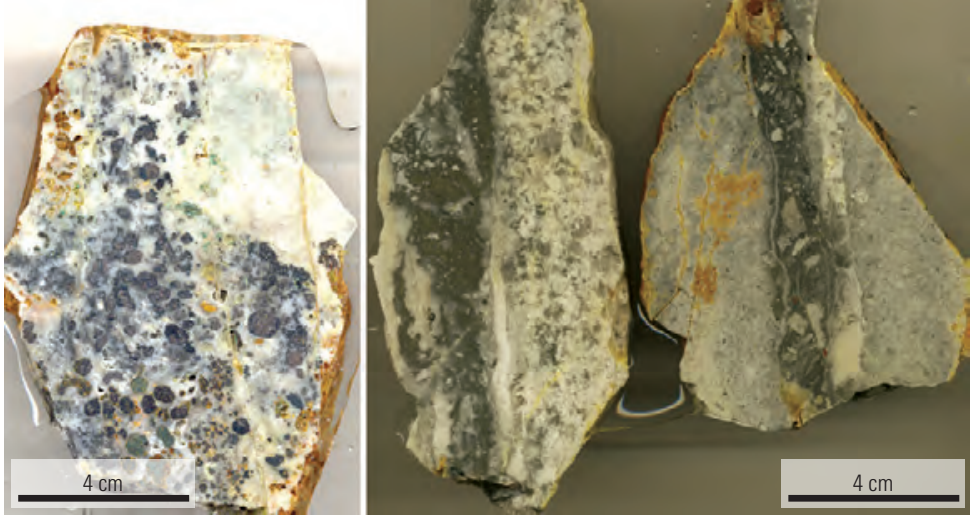

Figure 5. Images of mineralized fault breccias and veins in the Masonic Mining District. $A, B, \sim \mathrm{N}$-S-trending fault breccias cemented by quartz, alunite, and pyrite; $A$, Maybell-Alton Jack Mine upper adit (elevation 7,750 ft) and $B$, Mellor Mine shaft (elevation $~ 7,600 \mathrm{ft}$; fig. 2). $C$, Fault breccia replaced by fine-grained quartz, alunite, pyrite, enargite, gold, and numerous other $\mathrm{Cu}-\mathrm{As}-\mathrm{Sb}-\mathrm{Bi}-\mathrm{Fe}-\mathrm{Te}-\mathrm{Se}-\mathrm{S}$ minerals, unnamed mine dump, upper Pittsburg-Liberty Mine workings, $0.5 \mathrm{~km}(1,650 \mathrm{ft}$ ) east of New York Hill (sample MAS09-3b, elevation $~ 8,350 \mathrm{ft}$; fig. 2). $D$, Quartz+pyrite+alunite+enargite veins cutting granodiorite (left sample, Pittsburg-Liberty Mine, creek adit dump, elevation $\sim 7,500 \mathrm{ft}$ ) and trachyandesite (right sample, Red Rock Mine dump, elevation $~ 8,080 \mathrm{ft}$; fig. 2). 

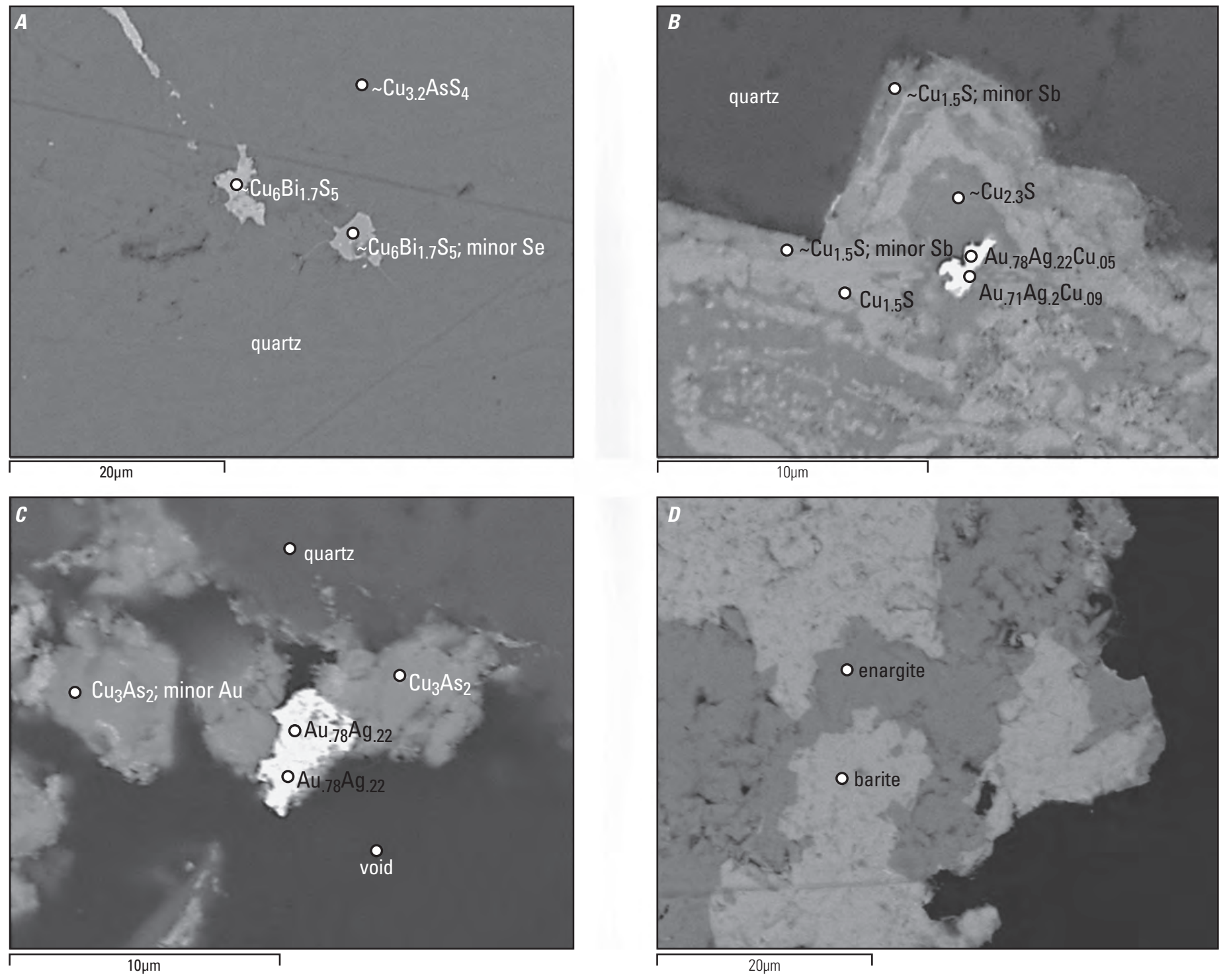

Figure 6. Secondary electron images of fault breccia shown in figure 5 C, Masonic Mining District (sample MAS09-3b, elevation $~ 8,350 \mathrm{ft}$ ). Mineral identifications and approximate atomic proportions in this figure and in figures 7,8, and 9 were determined petrographically and by scanning electron microscopy algorithms. Imaged phases include quartz, barite, enargite, a Cu-Bi-S mineral $\left(\sim \mathrm{Cu}_{6} \mathrm{Bi}_{1.7} \mathrm{~S}_{5}\right)$, a Cu-As mineral $\left(\sim \mathrm{Cu}_{3} \mathrm{As}{ }_{2}\right)$, Au-rich electrum with minor $\mathrm{Cu}$, and Cu-S minerals $\left(\sim \mathrm{Cu}_{1.5} \mathrm{~S} ; \sim \mathrm{Cu}_{2.3} \mathrm{~S}\right)$. 

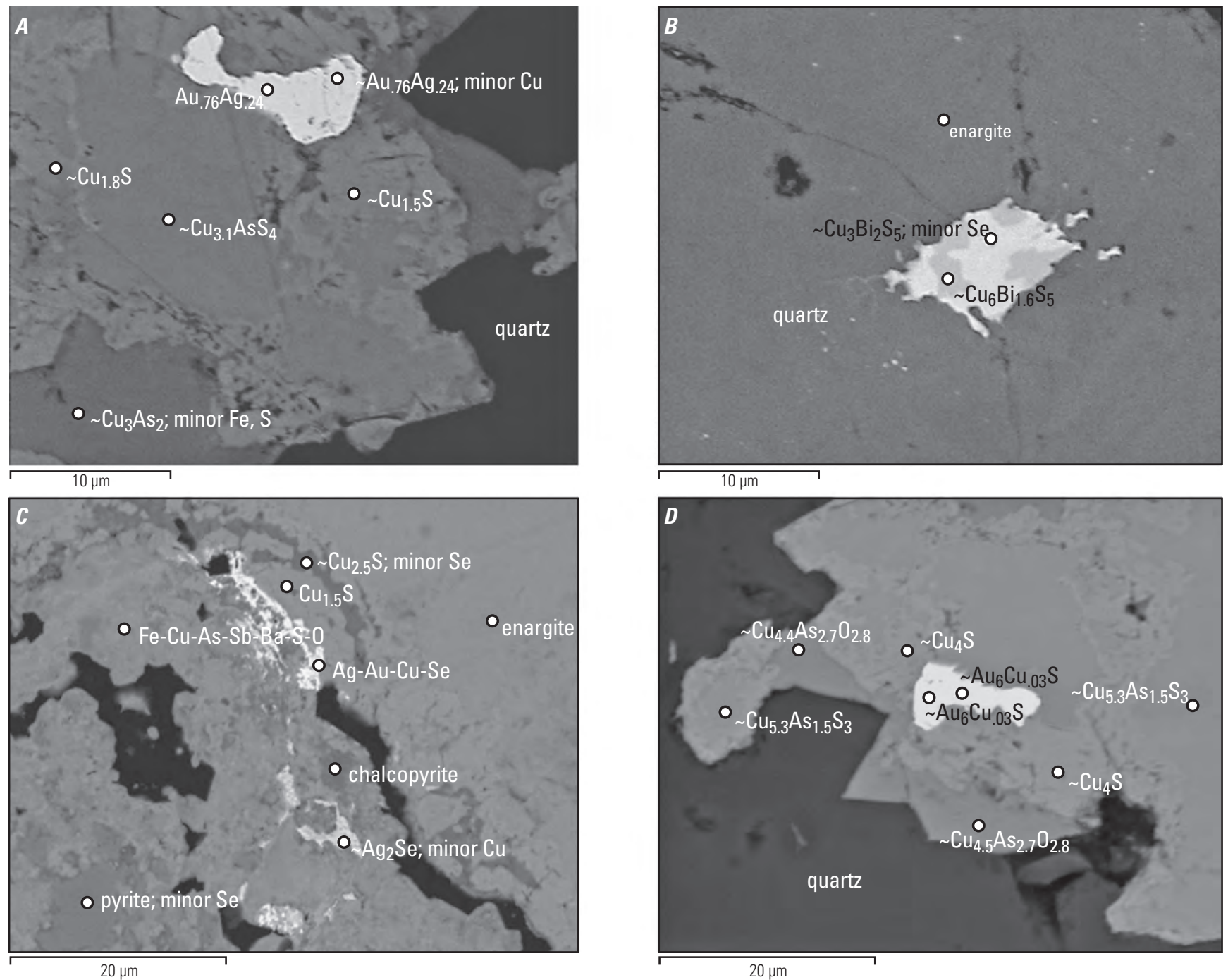

Figure 7. Secondary electron images of fault breccia shown in figure $5 C$, Masonic Mining District (sample MAS09-3b, elevation $\sim 8,350 \mathrm{ft})$. Imaged phases include quartz, enargite, a Cu-As mineral ( $\left.\sim \mathrm{Cu}_{3} \mathrm{As}_{2}\right)$, Au-rich electrum with minor $\mathrm{Cu}$, chalcopyrite, naumannite, Cu-S minerals ( $\left.\mathrm{Cu}_{1.5} \mathrm{~S} ; \sim \mathrm{Cu}_{1.8} \mathrm{~S} ; \sim \mathrm{Cu}_{2.5} \mathrm{~S} ; \mathrm{Cu}_{4} \mathrm{~S}\right), \mathrm{Cu}-\mathrm{Bi}-\mathrm{S}$ minerals $\left(\sim \mathrm{Cu}_{6} \mathrm{Bi}_{1.6} \mathrm{~S}_{5} ; \mathrm{Cu}_{3} \mathrm{Bi}_{2} \mathrm{~S}_{5}\right), \mathrm{Cu}-\mathrm{As}_{-} \mathrm{S}$ minerals $\left(\sim \mathrm{Cu}{ }_{5.3} A s_{1.5} \mathrm{~S}_{3}\right.$; $\left.\sim \mathrm{Cu}_{3.1} \mathrm{AsS}_{4}\right)$, and an Au-S mineral ( $\left.\sim \mathrm{Au}_{8.6} \mathrm{~S}_{1.4}\right)$. Some multielement analytical sites may represent submicrometer intergrowths of several minerals (see $B, \mathrm{Ag}$-Au-Cu-Se, for example), or partially oxidized Cu-As-S minerals (see $D, \sim \mathrm{Cu}_{4.4} \mathrm{As}_{2.7} \mathrm{O}_{2.8^{\prime}}$ for example). 


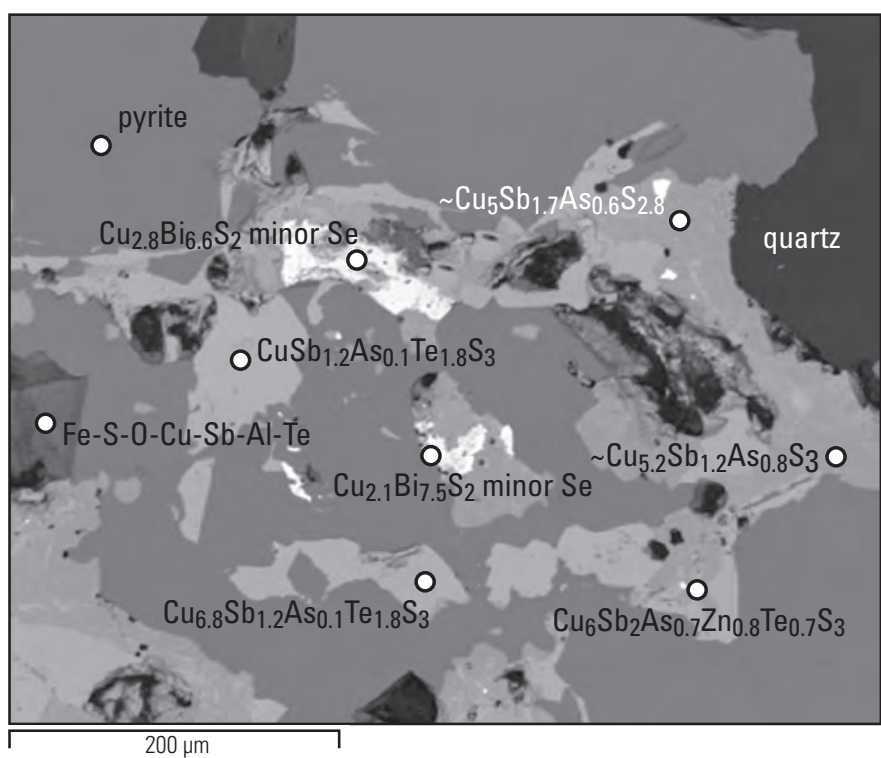

Figure 8. Secondary electron image of quartz+alunite+sulfide vein in granodiorite shown in figure $5 D$, left sample, Masonic Mining District (Pittsburg-Liberty Mine, creek adit dump, sample MD83-2, site 2A, elevation 7,500 ft). Imaged phases include quartz, pyrite, $\mathrm{Cu}-\mathrm{Bi}-\mathrm{S}$ minerals, $\mathrm{Cu}-\mathrm{Sb}$-As-S minerals, and Cu-Sb-As-Te-Zn-S minerals.

If gold-bearing inclusions in enargite (described previously) are representative of $\mathrm{Au}$ occurrences in the district, then the absence of placer deposits and historically difficult gold recovery can be attributed to a predominance of micron-sized Au minerals. However, visible Au has been reported at several mines (Success, Chemung, Maybell, and Jump-Up Joe Mines; Eakle and others, 1917; Johnson, 1951; R.H. Kern, written commun., 1977; F.M. Smith, written commun., 1984). Gold at the Chemung Mine is described as "fine particles in milky quartz", and "very fine particles in chalcedonic bands" in vugs (R.H. Kern, written commun., 1977). Gold at the Maybell Mine is described as " $+1 \mathrm{~mm}$ pieces" in fine-grained quartz (F.M. Smith, written commun., 1984). Such relatively coarse Au apparently was not sufficiently abundant to form placer deposits.

\section{Clastic and Hydrothermal Sedimentary Deposits}

Distinctive, mineralized clastic and hydrothermal bedding sets occur within the volcaniclastic-flow sequence at the Sarita and Lakeview Mines (fig. 2). Opencut and underground workings of these mines do not clearly follow structures and thus attest to lateral dispersion of precious metals within parts of the sequence. Mineralized bedding sets are best exposed at the Sarita Mine on New York Hill and in mine workings on the adjacent hill $\sim 0.5 \mathrm{~km}(\sim 1,650 \mathrm{ft})$ to the east, where the volcaniclastic-flow sequence unconformably overlies granodiorite and pendants of pre-Tertiary metavolcanic rocks (fig. 2). At the Sarita Mine, volcaniclastic-flow strata are as much as $\sim 90 \mathrm{~m}\left(300 \mathrm{ft}\right.$ ) thick, strike $\mathrm{N} 30-70^{\circ} \mathrm{W}$, and dip $30-80^{\circ} \mathrm{SW}$. On the hill to the east, these strata are tens of meters thick, have variable northwest-northeast strikes, and dip $50^{\circ} \mathrm{NW}$ to $75^{\circ} \mathrm{NE}$.

At the Sarita Mine, $\mathrm{Au}, \mathrm{Ag}$, and $\mathrm{Cu}$ were recovered from ore initially mined underground in the early 1900s and between 1951 and 1989, from an open cut on the northwest slope of New York Hill (the cut postdates the mine photograph in Jenkins (1951) and predates an unpublished mining company map dated 1989). The underground workings, open cut, and Au resource are in a zone of silicified, relatively well-sorted volcaniclastic strata that contains bedding sets of very fine-grained, quartz-rich chemical sedimentary strata that trend north-northeast. Similar mineralized strata were mined from a small open cut and underground workings on the hill to the east. At the Sarita Mine, the 120 (haulage) and 160 levels on an unpublished ( late 1930s) map outline roughly circular areas, about $145 \mathrm{~m}$ in diameter, of rib assays that vary mostly between 0.1 and $1 \mathrm{opt} \mathrm{Au}$ (converted from dollar values at \$35/oz). Based on descriptions in Eakle and others (1917) and Eakle and McLaughlin (1919), these levels apparently represent two of five juxtaposed, stratiform ore bodies. The ore bodies were as much as $10 \mathrm{~m}$ thick, indistinctly bounded, and within $\sim 48 \mathrm{~m}$ of the surface. Ore reportedly consisted of dense to porous chalcedony and brecciated "chert" with seams of yellow-brown clay (Eakle and others, 1917; Eakle and McLaughlin, 1919; Jenkins, 1951). The Sarita open cut may coincide with one of the upper ore bodies, as two shafts and numerous small stopes occur south and west of the cut at the same or higher elevations (fig. 2).

\section{Interpretation of Clastic and Hydrothermal Sedimentary Deposits}

Based on examination of dump samples and limited mine exposures, mineralized strata at lower elevations, including the 120 haulage level, are predominantly coarse, unsorted volcaniclastic deposits that are variably silicified and leached. Leached to partially leached breccia clasts, $\leq 5 \mathrm{~cm}$ in dimension, are represented by voids and by skeletal aggregates of fine-grained quartz, alunite, and kaolinite that largely reflect original clastic texture. Some voids are encrusted with millimeter-sized alunite euhedral crystals and mixtures of alunite and kaolinite. Matrix of the volcaniclastic deposits consists of dense, fine-grained quartz with variable amounts of pyrite and alunite. Small amounts of enargite occur with iron oxides in fractures and in leached clast sites.

Mineralized strata at higher elevations, including the open cut, comprise two distinct bedding sets (a) sequences of alternating, relatively poorly to well-sorted volcaniclastic beds and thinly laminated brown and white beds ( $\leq 1 \mathrm{~mm}$ thick) of very fine-grained anhedral quartz with minor pyrite, hematite, enargite, and other minerals (fig. 9); and (b) sequences of thinly laminated brown and white beds of very fine-grained quartz $\pm \mathrm{Fe}-\mathrm{Cu}-\mathrm{S}-\mathrm{O}$ minerals that conformably and unconformably overlie coarser, relatively unsorted volcaniclastic beds (fig. 10). A conformable layer of relatively coarse-grained enargite+iron oxide and millimeter-sized, euhedral quartz 


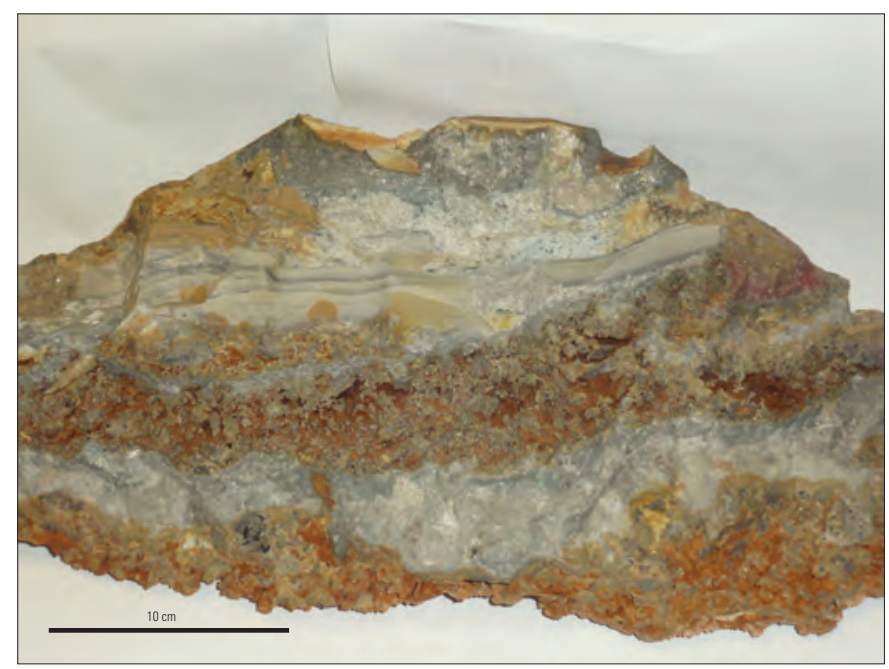

Figure 9. Image of a dump sample from the Masonic Mining District, Sarita Mine (elevation $~ 8,400 \mathrm{ft}$ ). Semiconformable set of beds that includes silicified and leached, coarse volcaniclastic detritus, variably sorted gravel and sand beds, and very finegrained white quartz beds. Subsequence a (described in text).

crystals commonly occur between quartz bed sequences (such as sequence [a], described previously) and voids (leached clast sites). Enargite+iron oxide+fine-grained quartz also form millimeter-wide veins that cut thinly laminated, brown quartz beds and feather into layers of enargite+iron oxide-vuggy quartz. Sedimentary structures in thinly laminated, brown and white quartz beds include channel scour and fill, crossbedding, soft-sediment folds and slumps with sag micro-faults, and bed draping on clasts. Supersaturation textures in these beds are reflected by very fine-grained quartz and sulfide minerals, and by intergrowths of pyrite+hematite in hopper-like cubic euhedral crystals.

Based on sedimentary textures, structures, and stratigraphy, and on grain sizes and mineral modes, thinly laminated quartz beds in both bedding sets are interpreted to have precipitated from aqueous fluid (1) intermittently with volcaniclastic detritus; (2) conformably and unconformably on hummocky surfaces of unsorted and sorted volcaniclastic deposits; and (3) in depressions and spaces among blocks of silicified and leached, coarse volcaniclastic deposits. Paragenetically, the coarse volcaniclastic deposits were silicified following deposition of sorted volcaniclastic beds (such as sequence [a], described previously), and subsequently partially leached. These silicified and partially leached volcaniclastic strata were then eroded and slumped, creating channels in, and voids between, silicified and leached blocks that were filled with brown and white quartz beds (such as sequence [b], described previously), and with fine and coarse volcaniclastic detritus. The presence of angular leached dropstones in thinly laminated white and brown beds of sequence b (fig. 11) supports these paragenetic interpretations. Given the fairly steep present attitudes of these strata in the vicinity of New York Hill (described previously), slumping was most likely caused by uplift or tilting associated with faulting, and (or) with slope failure enhanced by deflation related to hydrothermal leaching of volcaniclastic strata. Vein and vug-filling quartz, enargite, and iron oxide that cut and conformably overlie, respectively, brown quartz beds constitute the youngest hydrothermal event that affected sequence b strata. Hydrous fluids that altered, leached, and mineralized the volcaniclastic deposits and chemical beds may have circulated in north-northwest to northeast-striking faults that contain the slightly younger mineralized breccias and veins. However, district-scale faults directly associated with $\mathrm{Au}-\mathrm{Ag}-\mathrm{Cu}$ deposits at the Sarita Mine and east of New York Hill are not evident at present levels of exposure.

Based on textures of mineral assemblages, alunite dates, and sulfur isotope compositions, the sulfide, telluride, sulfate and silicate minerals, and electrum in fault breccias and veins, and in sedimentary deposits, are hypogene. Some iron oxide minerals that occur with pyrite and enargite may also be hypogene. Iron oxide minerals that marginally replace pyrite, occur in fractures, and encrust void margins, are interpreted to have formed during weathering. These supergene iron oxide minerals and other minerals in sedimentary deposits that formed during weathering are not further characterized.

\section{Mineral and Rock Compositions of Clastic and Hydrothermal Sedimentary Deposits}

Thinly laminated, brown and white beds of very finegrained quartz at the Sarita Mine contain small amounts of very fine-grained pyrite, iron oxide, and enargite, in places intergrown with goldfieldite, a $\mathrm{Cu}-\mathrm{Sn}-\mathrm{S}$ mineral (with minor $\mathrm{Se}$ and $\mathrm{Sb}$ ), a Bi-Se-Mo-S mineral (with minor $\mathrm{Cu}$ ), and numerous $\mathrm{Cu}-\mathrm{Bi}-\mathrm{As}-\mathrm{Te}-\mathrm{Sb}-\mathrm{Pb}-\mathrm{S}-\mathrm{O}$ minerals (fig. 12). Other quartz beds include complexly zoned pyrite(?) crystals that are pseudomorphically replaced by cores and concentric to partially annular zones of multielement phases. These euhedral crystals consist of (1) cores of iron oxide phases \pm quartz with 1-9.8 weight percent $\mathrm{Si}, \mathrm{S}, \mathrm{Cu}$, and $\mathrm{Sb}$, and with 1-3 weight percent $\mathrm{Cu}, \mathrm{As}, \mathrm{Sb}, \mathrm{Si}$, and $\mathrm{S}$, and quartz with 1-3 weight percent $\mathrm{Al}$, Fe, and $\mathrm{S}$; (2) medial zones of Fe-Cu-Sb-As-Si-S$\mathrm{Ca}-\mathrm{O}$, local Ba, W, Ag, Bi, and quartz; and (3) margins of iron oxides or multiphase margins with 1-9.8 weight percent $\mathrm{Si}$, $\mathrm{S}, \mathrm{Cu}$, and $\mathrm{Sb}$; one multiphase margin consists of iron oxides with $<1-7$ weight percent $\mathrm{Cu}, \mathrm{Sb}, \mathrm{Si}$, and $\mathrm{S}$, and $\mathrm{Cu}-\mathrm{Fe}-\mathrm{Sb}-$ As-Si-Ca-O. Some pyrite remains in medial zones, along with minor barite, and in $<1 \mu \mathrm{m}$ inclusions in iron oxides with minor $\mathrm{Cu}$ and $\mathrm{Se}$. These zoned euhedral crystals appear to be remnants of pyrite and $\mathrm{Cu}-\mathrm{As}-\mathrm{Sb}$ minerals, and other $\mathrm{Se}$ and Ag minerals that have been re-equilibrated in iron oxide and quartz-dominant zones. However, it is unclear if these zoned pseudomorphs were produced by hypogene or supergene processes, although the presence of sulfide minerals in the dense, finely laminated quartz beds suggests limited weathering.

Samples (collected from 2007 to 2012) of clastic and chemical (hydrothermal) sedimentary strata with enargite from Sarita Mine exposures and dumps contain elevated 
Figure 10. Images of dump samples from the Masonic Mining District, Sarita Mine (elevation $\sim 8,400 \mathrm{ft}$ ). $A$, Silicified and leached, sorted gravel and sand-sized clastic beds unconformably overlain by channel-filling sets of very finegrained, brown quartz beds, and an unleached, coarse volcaniclastic deposit. Dark-gray beds contain pyrite. $B$, Very fine-grained white and brown quartz beds filling depressions in silicified and leached volcaniclastic deposits. $C$, Very fine-grained brown quartz beds filling fractures in silicified and brecciated trachyandesite, and overlain by a conformable vuggy layer of enargite+iron oxide(pyrite)+euhedral quartz. $D$, Very fine-grained brown quartz beds cut by a coarser-grained, quartz-enargite-iron oxide(pyrite) vein that is contiguous with a conformable layer of enargite+iron oxide (pyrite)-euhedral quartz. $E, A$ bed of enargite+pyrite ( 2 mm thick) within a set of very fine-grained, white quartz beds that fills a channel in brecciated trachyandesite. Subsequence b (described in text).

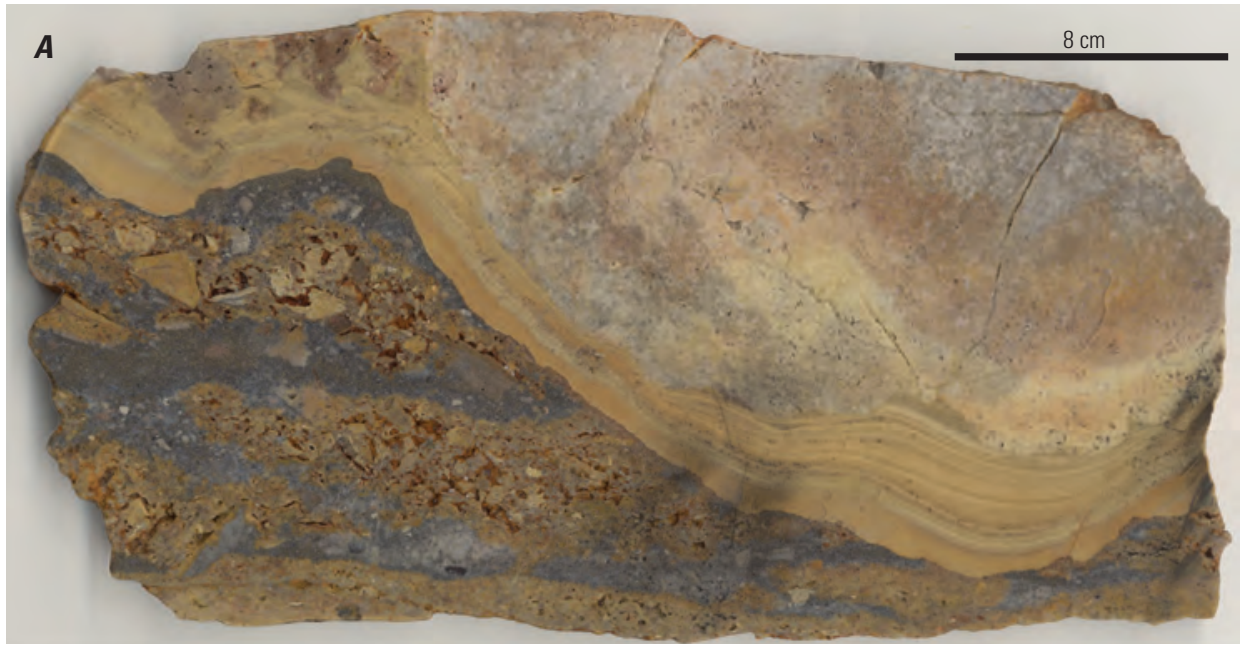

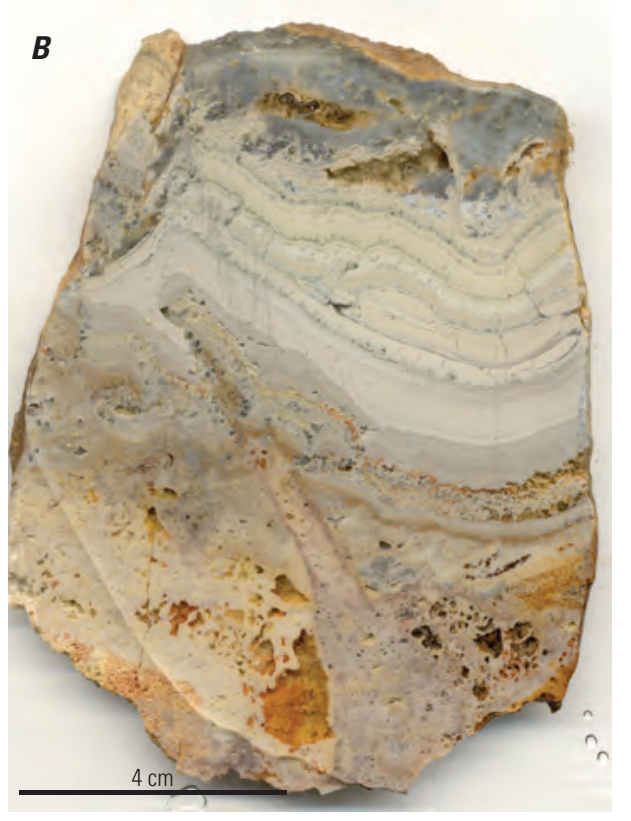
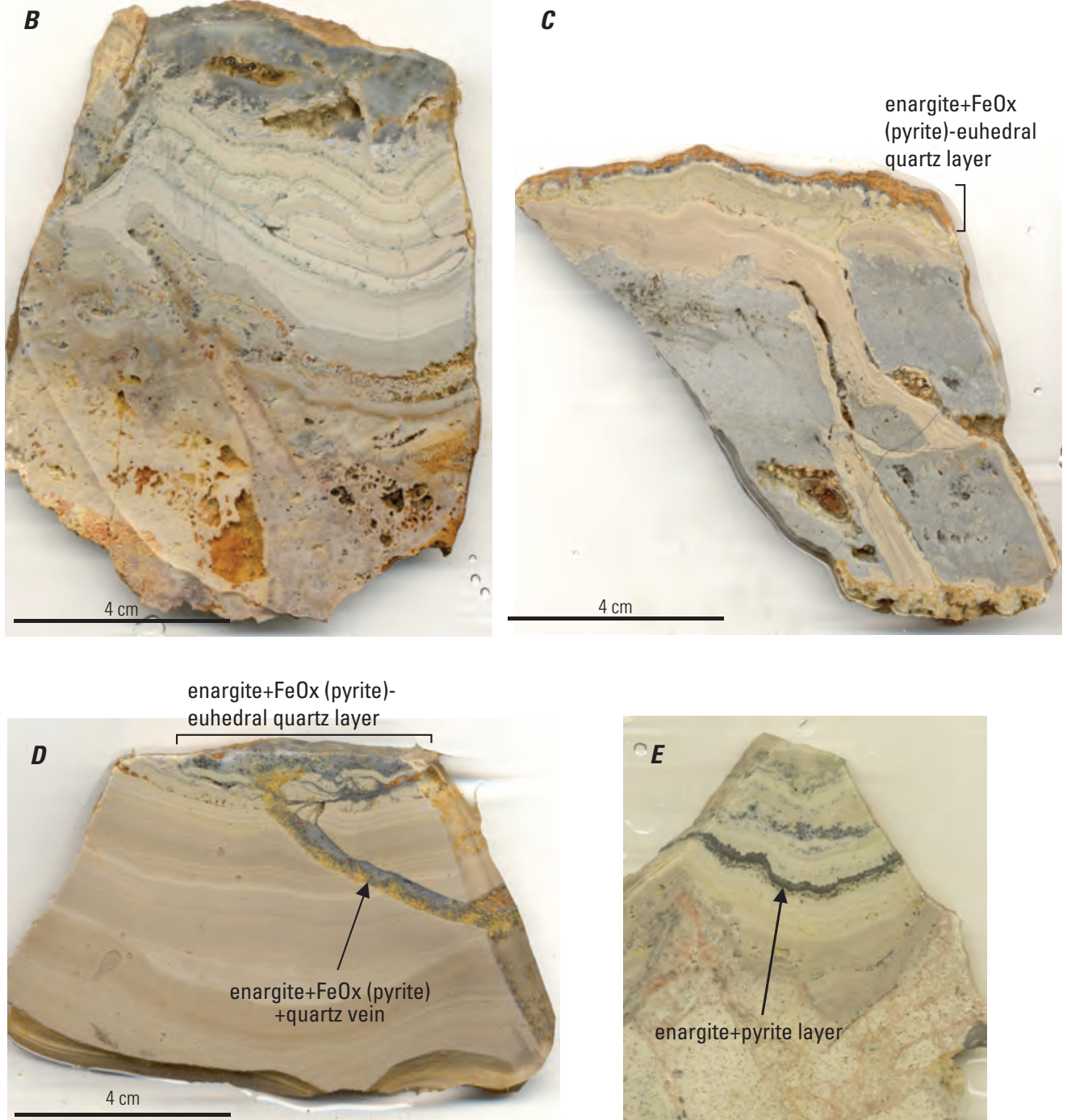

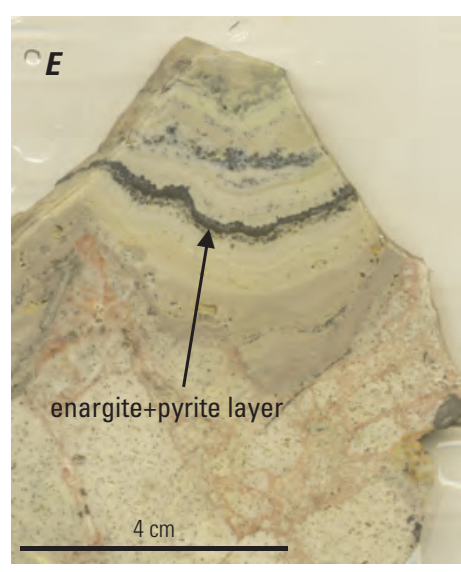



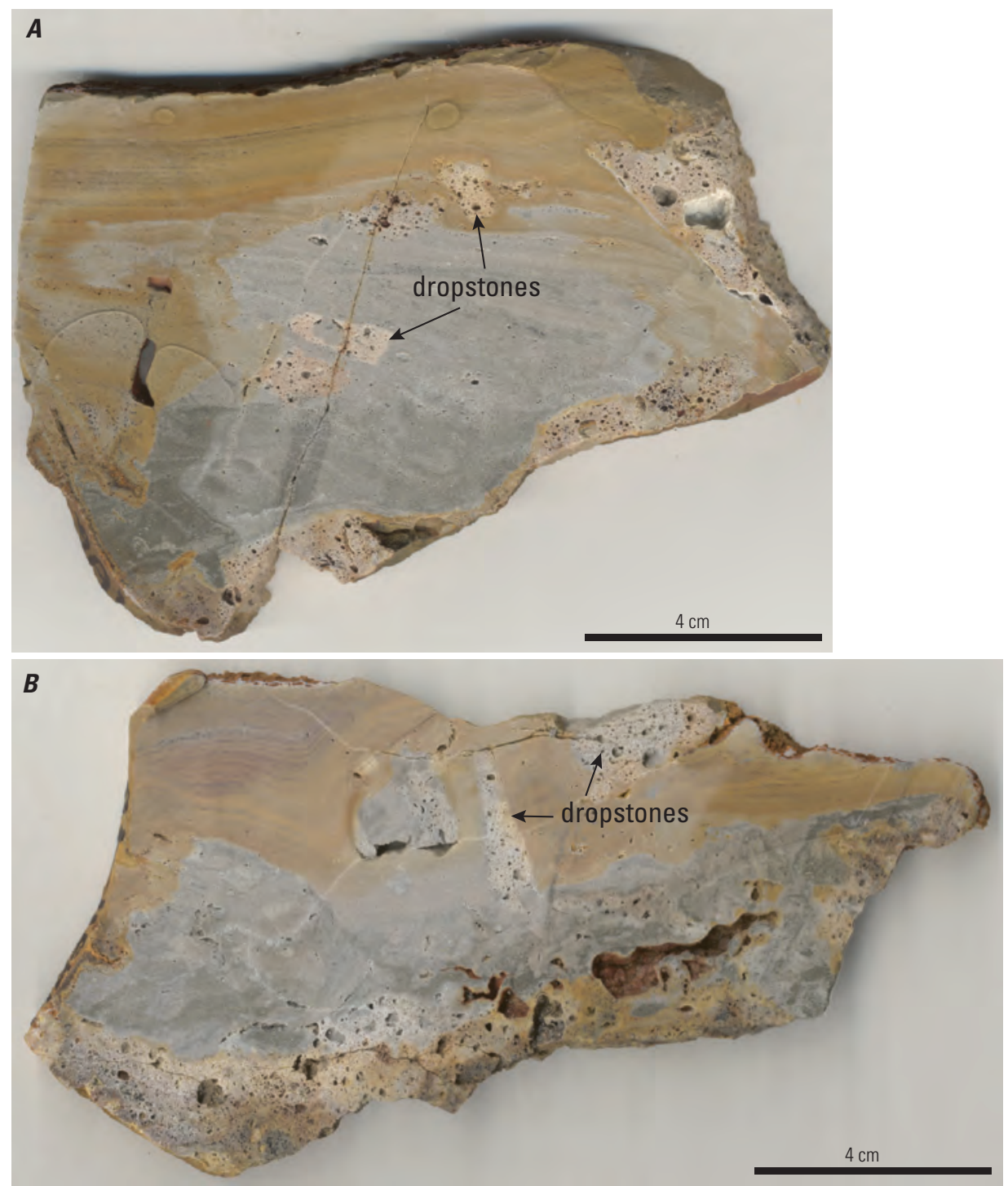

Figure 11. Images of dump samples from the Masonic Mining District, Sarita Mine (elevation $\sim 8,400 \mathrm{ft}$ ). Silicified and leached volcaniclastic deposits overlain by very fine-grained white and brown quartz beds with dropstones of leached trachyandesite. Subsequence b (described in text). concentrations of $\mathrm{Au}$ (9.2-82.3 ppm), $\mathrm{Ag}$ (15-238 ppm), Bi ( 57-3,110 ppm), $\mathrm{Cu}(\sim 73-1,310 \mathrm{ppm}), \mathrm{Pb}(\sim 98-216 \mathrm{ppm})$, $\mathrm{Hg}$ ( 2-86 ppm), Se ( 6-198 ppm), and $\sim 100-860 \mathrm{ppm}$ $\mathrm{As}, \mathrm{Ba}, \mathrm{Sb}$, and Te. Other samples (collected in 1988) contain higher $\mathrm{Hg}$ (16-43 ppm), Ag (<300 ppm), and Sb $(<4,600 \mathrm{ppm})$, in addition to elevated concentrations of As (174-3,107 ppm), and Te (<3,220 ppm; table 1-1). The elevated element concentrations in these bulk samples reflect the presence of numerous $\mathrm{Cu}-\mathrm{Bi}-\mathrm{As}-\mathrm{Te}-\mathrm{Sb}-\mathrm{Pb}-\mathrm{Sn}-\mathrm{Se}-\mathrm{S}-\mathrm{O}$ minerals and also indicate the presence of additional $\mathrm{Au}-$ and Ag-bearing phases.

\section{Other Minerals and Forms of Mineralization}

Other minerals reported in the Masonic Mining District include tellurides, bismuthinite, argentite, bornite, and cinnabar (for example, Johnson, 1951). Although telluride minerals and bismuthinite were not identified in the samples examined, high concentrations of $\mathrm{Te}$ and $\mathrm{Bi}$ in bulk samples (table 1-1) imply the presence of telluride minerals and possibly bismuthinite in addition to the Te and $\mathrm{Bi}$ minerals imaged (figs. 6, 7, 8, 9). Other forms of mineralization in the district include (1) a $0.6-1.2$-m-wide quartz vein in granodiorite at the Sunday Mine that contains sparse 3-4 mm crystals of galena and pyrite; and (2) discontinuous, $<30$-cm-wide quartz veins with minor pyrite and chalcopyrite in pre-Tertiary metavolcanic rocks southeast of the Success Mine near McMillan Spring. Other quartz veins occur in the granodiorite of Masonic Mountain. However, all of these veins differ in form, mineralogy, and structural control from the mineralized fault breccias and veins described previously.

\section{Wall-Rock Alteration}

Mineralized faults are bordered by dense to porous selvages of brecciated trachyandesite and granodiorite, or by trachyandesite flows that are extensively replaced by quartz, alunite, iron oxides (weathered pyrite), and lesser dickite, 

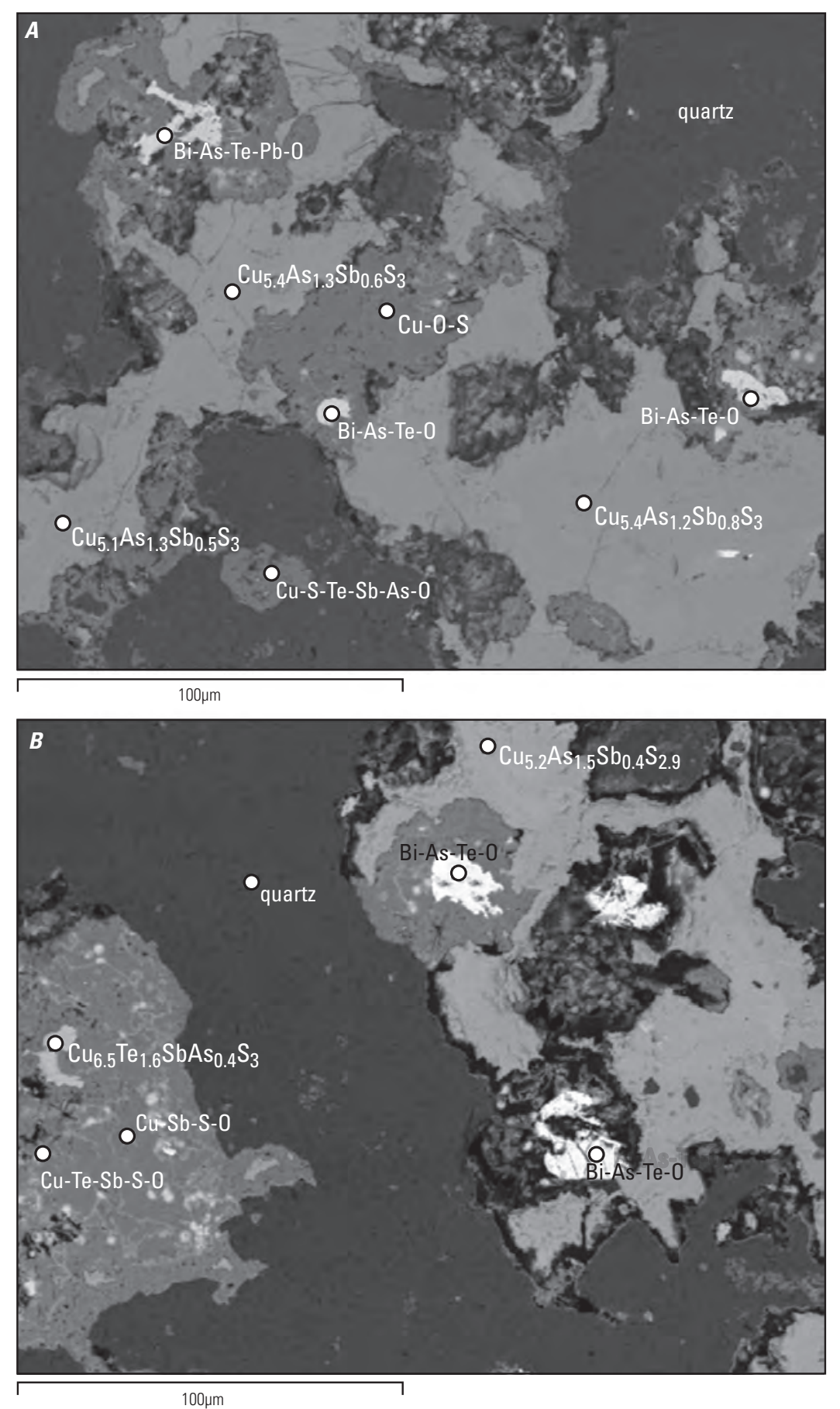

Figure 12. Secondary electron images of minerals in very fine-grained brown quartz beds from the Sarita Mine open cut, Masonic Mining District (fig. 2). $A$ and $B$ correspond to sample MAS07-3A (elevation $\sim 8,300 \mathrm{ft}$ ). Imaged phases include quartz, a Cu-As-Sb-S mineral ( $\left.\sim \mathrm{Cu}_{5.2} \mathrm{As}_{1.3} \mathrm{Sb}_{0.6} \mathrm{~S}_{2.9}\right)$, a Cu-Te-Sb-As-S mineral $\left(\sim \mathrm{Cu}_{5.2} \mathrm{Te}_{1.3} \mathrm{Sb}_{0.8} \mathrm{As}_{0.3} \mathrm{~S}_{2.4}\right)$, and several Cu-Bi-As-Te-Pb-S-O minerals or mineral intergrowths. 
pyrophyllite, and diaspore. Wide fault zones (for example, Maybell-Alton Jack Mine structures; fig. 3) are represented by resistant ridges as much as $15 \mathrm{~m}$ wide and $5 \mathrm{~m}$ high (fig. 5) in which primary rock textures in breccia clasts and flows are partly to entirely obscured. Narrower, meters-wide selvages of trachyandesite adjacent to other stoped fault breccias (for example, Mellor and Perrini Mines), largely retain primary igneous texture; phenocrysts and matrices in these selvages are replaced by pink to white mixtures of fine-grained alunite, kaolinite, pyrite, iron oxides after pyrite, and other clay minerals. With increasing distance from faults, illite and montmorillonite become the dominant replacement minerals. Wall-rock hydrothermal mineral associations are mainly the same as, and contiguous with, hydrothermal minerals in adjacent fault breccias that were stoped. Stoped fault breccias are distinguished by greater abundances of quartz, sulfide minerals, and precious metals.

Hydrothermal alteration associated with mineralized clastic and chemical sedimentary deposits is coextensive with those strata, as described previously. Lateral permeability of volcaniclastic deposits within the volcaniclastic-flow sequence on the west and northwest sides of Masonic Mountain enabled pervasive hydrothermal alteration; the quartz-alunite-pyritekaolinite alteration mineral association is fairly homogenous throughout these rocks. The presence of silicified and leached volcaniclastic deposits, clastic and chemical quartz beds, and $\mathrm{Au}-\mathrm{Ag}-\mathrm{Cu}-\mathrm{Fe}$ sulfide minerals distinguish mineralized strata in the vicinity of New York Hill. Lateral boundaries of mineralized strata appear to be gradational, whereas vertical boundaries are largely stratigraphic, based on the absence of significant mineralization in underlying pre-Tertiary rocks. Volcaniclastic deposits and brecciated trachyandesite on Sarita Mine dumps, and lateral to mineralized strata at lower elevations, have been extensively replaced by quartz, alunite, and kaolinite, and cut by millimeter-wide veins composed of fine-grained quartz and alunite (fig. 13). On New York Hill, metavolcanic rocks in workings near the Sarita open cut have been altered to clay minerals, and granitic and metavolcanic rocks exposed on the hill to the east are extensively silicified and cut by planar and stockwork quartz veins. Density and competency contrasts between altered volcaniclastic-flow strata and subjacent pre-Tertiary rocks, and slopes oversteepened by fault displacement, caused masses of altered rocks tens of meters in dimension to slide down the north side of New York Hill (fig. 2).

\section{Sulfur Isotope Compositions and Equilibrium Temperatures}

Most sulfur isotope values $\left(\delta^{34} \mathrm{~S}\right)$ for enargite, pyrite, and luzonite vary from -7.9 to $-12.2 \%$, and values for alunite vary from 13.4 to $19.9 \%$ (table 2 ). No clear compositional differences exist between the two forms of mineralization (breccia and vein deposits in fault zones; clastic and hydrothermal sedimentary deposits). One higher $\delta^{34} \mathrm{~S}_{\text {enargite }}$ value $(0.2 \%)$, and one lower $\delta^{34} \mathrm{~S}_{\text {alunite }}$ value (7.1\%; table 2$)$ presumably reflect sample impurity because both minerals occur in sulfide-sulfate mixtures.

The relatively low $\delta^{34} \mathrm{~S}$ sulfide and relatively high $\delta^{34} \mathrm{~S}$ sulfate values of most samples are consistent with disproportionation of magmatic $\mathrm{SO}_{2}$ into $\mathrm{H}_{2} \mathrm{~S}$ and $\mathrm{SO}_{4}{ }^{2-}$ (Rye, 2005) during the formation of both deposit types. Disproportionation occurs when $\mathrm{SO}_{2}$ derived from magma degassing condenses in overlying groundwater at temperatures $<400{ }^{\circ} \mathrm{C}$ :

$$
2 \mathrm{SO}_{2}+\mathrm{H}_{2} \mathrm{O}=\mathrm{H}_{2} \mathrm{~S}+\mathrm{SO}_{4}{ }^{2-}+2 \mathrm{H}^{+}
$$

Groundwater acidified by this reaction decomposes silicate rocks to hydrothermal mineral assemblages dominated by quartz, alunite, and pyrite. $\mathrm{K}^{+}, \mathrm{Fe}^{2+}$, and $\mathrm{Al}^{3+}$, solubilized during silicate mineral decomposition, react with aqueous $\mathrm{SO}_{4}{ }^{2-}$ and $\mathrm{H}_{2} \mathrm{~S}$ to form alunite and pyrite with markedly different sulfur isotope values.

Calculated sulfur isotope equilibrium temperatures $\left(\delta^{34} \mathrm{~S}_{\text {sulfide }}-\delta^{34} \mathrm{~S}_{\text {sulfate }}\right)$ of coexisting pyrite, enargite, and alunite in samples from the Red Rock and Sarita Mine dumps are 228,231 , and $238^{\circ} \mathrm{C}$, and $192{ }^{\circ} \mathrm{C}$ (all calculations are based on pyrite-alunite fractionation; table 2; Vikre and Henry, 2011). Calculated sulfur isotope equilibrium temperatures of coexisting pyrite and alunite from the lower dump of the Pittsburgh-Liberty Mine, from a small mine dump in Masonic Gulch ("aspen grove" mine), and from the lower Perrini Mine dump, are 218,198 , and $188^{\circ} \mathrm{C}$, respectively (table 2 ).

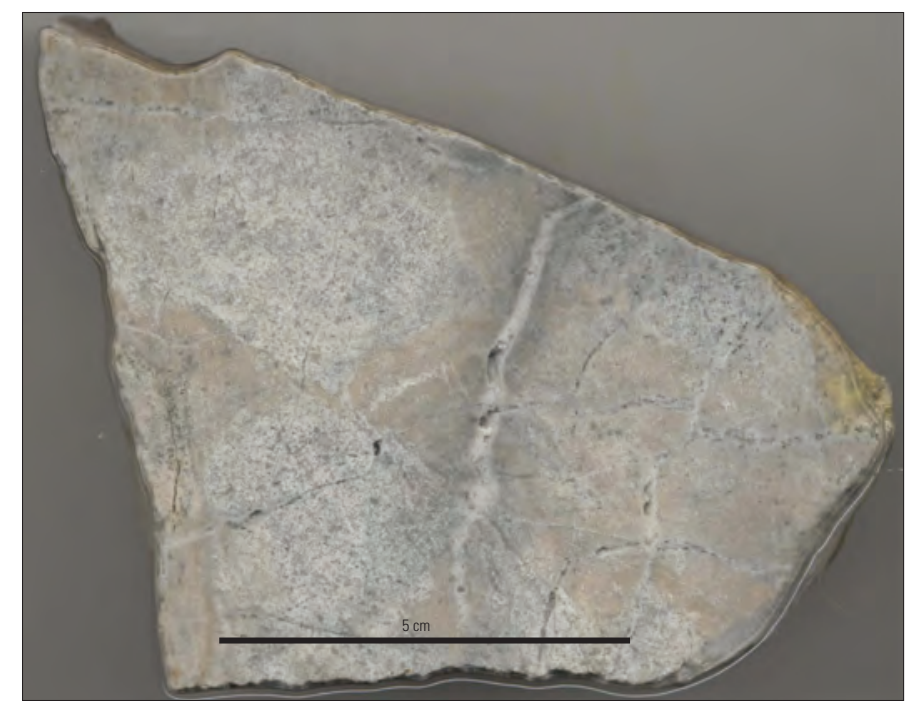

Figure 13. Image of a dump sample from the Masonic Mining District, Sarita Mine (elevation $~ 8,200 \mathrm{ft}$ ). Trachyandesite of Masonic that has been altered to quartz, alunite, kaolinite, and pyrite, brecciated, and cemented by veins of fine-grained quartz and alunite. 


\section{Aster Imagery}

ASTER imagery of the Masonic Mining District (Rockwell, 2010) shows a fairly uniform cluster of pixels that corresponds to kaolinite, montmorillonite, illite, and locally, quartz on Masonic Mountain, and on granitic rocks and trachyandesite of Masonic to the northeast to Masonic Gulch. Several clusters of pixels that correspond to alunite and kaolinite are coincident with the Sarita Mine and altered slide blocks on the north slope of New York Hill, and on the hill $\sim 0.5 \mathrm{~km}$ east of New York Hill. Smaller and more diffuse groups of alunite \pm kaolinite pixels are coincident with the Red Rock Mine, the Pittsburg-Liberty Mine, the north slope of Masonic Gulch above (lower) Masonic town site, and the Lakeview Mine. Four relatively dense clusters of alunite pixels are coincident with the landslides north of the Lakeview Mine (Tls, fig. 2).

\section{Short Wave Infrared (SWIR) Spectra}

SWIR spectra of hydrothermally altered and mineralized hand samples correspond to the same minerals identified by field and petrographic examination. Trachyandesite of Masonic on the Success, Chemung, Maybell-Alton Jack, and Perrini Mine dumps contains alunite, kaolinite, dickite and lesser pyrophyllite and illite. Granodiorite and metavolcanic rocks on New York Hill, and on Sarita and PittsburgLiberty Mine dumps, contain alunite, kaolinite, dickite, and lesser pyrophyllite.

\section{Host Rock and Alteration Mineral Ages}

The granodiorite that encloses mineralized faults is $\sim 98 \mathrm{Ma}$ (Robinson and Kistler, 1986). Based on ${ }^{40} \mathrm{Ar} /{ }^{39} \mathrm{Ar}$ ages of plagioclase and hornblende in unaltered flows and domes, trachyandesite of Masonic is $\sim 15-14$ Ma (table 1). The volcaniclastic-flow sequence that hosts $\mathrm{Au}-\mathrm{Ag}-\mathrm{Cu}$ mineralization in the central and southern parts of the district has not been directly dated; however, stratigraphic relations indicate that the age of the volcaniclastic-flow sequence is probably close to the youngest ages determined for trachyandesite of Masonic ( $14 \mathrm{Ma})$, and could be as young as $13.3 \mathrm{Ma}$, the age of alunite in clastic and chemical sedimentary deposits at the Sarita Mine. Locally altered porphyritic trachyandesite domes in the northern part of the district are $13.5-13.4 \mathrm{Ma}$ (table 1). Unaltered andesite of Lakeview Spring in the southwestern part of the district is $\sim 12.9 \mathrm{Ma}$ (fig. 2; table 1).

The ${ }^{40} \mathrm{Ar} /{ }^{39} \mathrm{Ar}$ dates of hydrothermal alunite mostly consist of two groups. Alunite in the volcaniclastic-flow sequence in the southwestern part of the district (Sarita, Red Rock, and Chemung Mines) is $13.4-13.3 \mathrm{Ma}$; one alunite date near the Success Mine is 13.6 Ma (table 1). With the exception of the 13.6 alunite date, the older alunite dates are similar to the dates of alunite in the Red Wash-East Walker River alteration zone (table 1); they are slightly younger than the ages of porphyritic trachyandesite domes (trachyandesite of Masonic Gulch) north of the district. Alunite in fault breccias in granodiorite and trachyandesite in the northern part of the district is $\sim 13 \mathrm{Ma}$ (Pittsburgh-Liberty, Maybell-Alton Jack, and Perrini Mines; table 1), and is indistinguishable from the age of andesite of Lakeview Spring when analytical error is considered.

\section{Red Wash-East Walker River Alteration Zone}

\section{Location}

Secs. 2, 31, 32, Tps. 6 and 7 N., R. 26 E. (incompletely surveyed); secs. 31, 32, 33, 34, 35, 36, T. 7 N., R. 26 E., Lyon County, Nevada (fig. 1)

\section{Definition}

The Red Wash-East Walker River alteration zone (RW-EWR AZ; fig. 14) is the western part of a larger, approximately west-east-trending alteration zone between the East Walker River and Fletcher Valley. The western part of the zone described here is bordered on the west and northeast by the East Walker River, and occurs entirely in volcaniclastic strata and lavas of trachyandesite of Masonic. In the vicinity of Red Wash, the alteration zone bifurcates with (1) an east-northeast-trending branch that extends across meanders of the East Walker River into Fletcher Valley, and (2) a more diffuse branch that extends south along Red Wash and southeast of Red Wash for $\sim 2 \mathrm{~km}$. To the north, the zone is covered by Tertiary and Quaternary sediments and colluvium (in part, Tfg, Ts, and Tg; fig. 14; John and others, 2012). The minimum dimensions of the western part of the zone are $\sim 12 \mathrm{~km}$ west-east and $<1-6 \mathrm{~km}$ north-south $\left(\sim 22 \mathrm{~km}^{2}\right.$; figs. 1 , 14). The entire zone from the East Walker River to Fletcher Valley covers at least $30 \mathrm{~km}^{2}$.

The approximately west-east-oriented, central part of the zone consists of volcaniclastic strata and lesser trachyandesite lavas that have been pervasively altered to quartz, alunite, and other minerals described below. Numerous small areas of quartz-alunite-kaolinite-altered rocks occur within $1 \mathrm{~km}$ south and north of the central part of the zone. Because of mapping scale and alteration zone definition, some of these outliers are not shown on figure 14. Between contiguous quartz-alunitekaolinite-altered rocks of the zone and the Masonic Mining District (south of the area of fig. 14), extensive volumes of trachyandesite of Masonic have been partially altered to chlorite, sericite, clay minerals, calcite, and pyrite, which have mostly weathered to iron oxide minerals. 


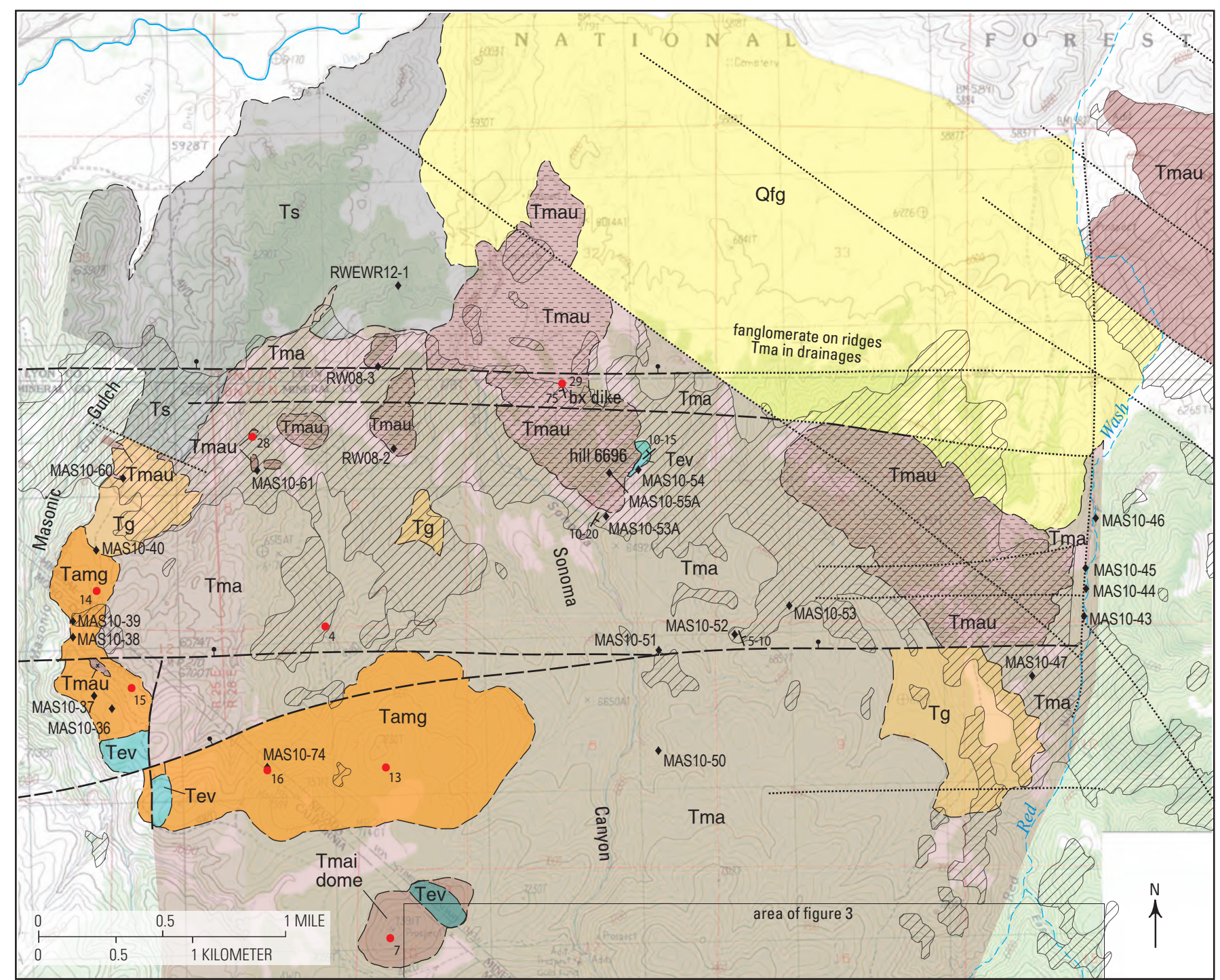

\section{EXPLANATION}

\begin{tabular}{|c|l}
\hline Qfg & Fanglomerate \\
\hline $\mathrm{yn}$ & Terrace gravels \\
\hline $\mathrm{Tn}$ & Fluviolacustrine sediments \\
\hline Tev & Eureka Valley Tuff (9.3-9.5 Ma) \\
\hline Tamg & $\begin{array}{l}\text { Trachyandesite of Masonic Gulch (13.4-13.5 } \\
\text { Ma) - Locally altered to clay minerals }\end{array}$ \\
\hline
\end{tabular}

Ma) - Locally altered to clay minerals and pyrite

\section{Trachyandesite of Masonic ( 14-15 Ma)}

Tmau Volcaniclastic-flow sequence, pervasively altered to quartz, alunite, kaolinite, and illite/montmorillonite

Tma Trachyandesite of Masonic

Tmai Trachyandesite intrusions of Masonic

DIT Areas of contiguous quartz+alunite \pm kaolinite-altered trachyandesite, volcaniclastic deposits, and colluvial clasts; from ASTER imagery (fig. 15)

- - Contact—Dashed where approximated Fault-Dashed where approximated

- High-angle normal fault-Bar and ball on downthrown block

$\stackrel{40}{\perp}$ Bedding

35 Foliation

$\checkmark \quad$ Mine shaft

$\succ \quad$ Adit

.......... Color air photo (CAP) lineament

- Analytic sample site and number

- $\quad{ }^{40} \mathrm{Ar} /{ }^{\beta 9} \mathrm{Ar}$ sample site and index number (table 1)

Figure 14. Geologic map of the Red Wash-East Walker River alteration zone, Lyon and Mineral Counties, Nevada, and Mono County, California. 


\section{History and Production}

Despite its relatively large size, no production is recorded for the RW-EWR AZ. Approximately 15 scattered and small prospect pits and trenches have been excavated, mostly in and adjacent to resistant exposures of volcaniclastic rocks and flows of trachyandesite of Masonic that are replaced by quartz, alunite, kaolinite, pyrite (iron oxide), and minor pyrophyllite. The workings presumably sought precious metals or Hg. Drill roads and drill cuttings, probably from exploration for precious metals $\sim 1980-2000$, are evident in secs. 5, 6, T. 7 N., R. 26 E. between Masonic Gulch and Sonoma Canyon, and in secs. 34, 35, T. 7 N., R. 26 E. southeast of the confluence of Red Wash and the East Walker River. Exploration leases for alunite, uranium, and clay minerals were filed in the 1970s over parts of the alteration zone (Gilbert, 1976).

\section{Stratigraphy}

The RW-EWR AZ is in volcaniclastic strata and trachyandesite flows of trachyandesite of Masonic (fig. 14). Volcaniclastic strata are predominantly debris flows that are as much as $\sim 60 \mathrm{~m}$ thick, and are nearly completely replaced by hydrothermal minerals. Less altered (propylitized) debris flows in one exposure consist of greenish-gray, rounded, and poorly sorted blocks of trachyandesite ( $<0.7 \mathrm{~m}$ in dimension) in a fine-grained matrix of comminuted andesite (fig. 4). Bedding, reflected approximately by outcrop orientation, strikes $\mathrm{N} 30^{\circ} \mathrm{E}$ and dips $10-20^{\circ} \mathrm{NW}$. Beneath and south of the volcaniclastic deposits are green to greenish-gray trachyandesite flows that have been variably altered to chlorite, mica-clay minerals, calcite, and pyrite (iron oxides).

Adjacent north-south and west-east alignments of porphyritic trachyandesite domes (trachyandesite of Masonic Gulch) occur $\sim 1-1.5 \mathrm{~km}$ south of the central part of the alteration zone at the northern margin of the Masonic Mining District (fig. 14). The domes rise tens of meters above adjacent flows of trachyandesite of Masonic that have been variably altered to chlorite, mica-clay minerals, calcite, and pyrite (iron oxides). East of Masonic Gulch, the domes are partly overlain by Eureka Valley Tuff (Tev) and perched terrace gravels (Tg). Based on four ${ }^{40} \mathrm{Ar} /{ }^{39} \mathrm{Ar}$ ages of plagioclase, the domes are 13.5-13.4 Ma, $\sim 0.5$ m.y. younger than the trachyandesite of Masonic lavas that they intrude (table 1). The porphyritic domes consist of 12-20 volume percent plagioclase crystals (1-4 mm), 3-5 volume percent subhedral and euhedral hornblende and clinopyroxene $(0.5-3.5 \mathrm{~mm})$, and $<1$ volume percent subhedral biotite $(0.5-1.2 \mathrm{~mm})$ in a pale-tan to olive-green matrix composed of partly devitrified glass, submillimeter-sized plagioclase, hornblende, biotite, pyroxene, and small amounts of apatite. Parts of the domes are altered to mica-clay minerals and pyrite (iron oxides).

Semiconsolidated gray- to dark-gray, fluviolacustrine sediments cover the north side of the alteration zone between Sonoma Canyon and East Walker River (Ts, fig. 14). These relatively well-sorted and distinctly bedded, coarse sands, sands, and silts are distinguished from other basin-fill and colluvial deposits by color, sorting, bedding, and sparse, rounded heterolithic clasts that are mostly $<10 \mathrm{~cm}$ in dimension. Gray sediments west of Masonic Gulch are overlain by thin (meters thick) gravel deposits consisting of rounded heterolithic cobbles and lesser boulders that partially cover several of the low, flat-topped ridges of trachyandesite south of the zone (Tg, fig. 14). Slopes of most north-south drainages that flank these ridges are partially covered with cobbles, which represent remnants of more extensive colluvial terraces that accumulated south of a more contiguous west-east landform of silicified volcaniclastic deposits. The gray sediments and dissected gravel terraces, together with west-east and northeast-trending normal faults between the Masonic Mining District and the alteration zone, suggest (1) uplift of Masonic Mountain and the district relative to the alteration zone since $11 \mathrm{Ma}$, the approximate age of the oldest basin-fill of Fletcher Valley (table 1); and (2) deposition during at least two hydrologic regimes based on differing clast size and sorting within the sedimentary deposits.

\section{Structure}

Structures that may have channeled hydrothermal fluids into permeable volcaniclastic strata and trachyandesite to form the RW-EWR AZ are evident at contrasting scales. Veins and crosscutting breccias, described below, are common within the alteration zone, but most can be traced for only a few meters to a few tens of meters and are not aligned. On the scale of the entire zone, linear and slightly curvilinear structures are conspicuous on color air photos and, to a lesser extent, on ASTER imagery (Rockwell, 2010). Within the alteration zone these lineaments trend predominantly west-east and northwestsoutheast (figs. 14, 15). Because of their linearity, these structures most likely represent postalteration faults, but little to no stratigraphic displacement can be demonstrated. A northsouth lineament along Red Wash may displace the zone east of Red Wash to the north, although evidence of stratigraphic offset also is minimal (John and others, 2012). Furthermore, silicified carapaces of volcaniclastic strata, which cap most uplands in the RW-EWR AZ, are not significantly displaced vertically, nor do they appear to be displaced laterally. The lateral dimensions of the zone are probably controlled by a series of en echelon west-east faults with minor vertical and lateral displacement, and by local breccias, which were likely conduits for hydrothermal fluids.

\section{Hydrothermal Alteration}

Topographic definition of the RW-EWR AZ is reflected by the west-east series of flat-topped to rounded landforms with resistant, silicified carapaces that are flanked by recessive-weathering slopes of clay-mica-pyrite-altered volcaniclastic strata and trachyandesite flows. The farthest 
western part of the alteration zone consists of low, en echelon ridges and small spires, mostly meters in dimension, of silicified volcaniclastic strata and trachyandesite that commonly are brecciated and cemented by quartz and alunite. These resistant ridges and spires in part occur in clay-mica-pyritealtered trachyandesite and locally protrude through overlying Tertiary-Quaternary sedimentary deposits. Outcrops of the silicified strata vary in color from gray to mottled, intense red-brown and beige, depending on iron oxide abundance, and have hackly to dense, smooth surfaces. In contrast, clay-micapyrite-altered volcaniclastic strata and trachyandesite are beige to reddish-brown with rough surfaces, although most exposures have largely degraded into fine talus.

Silicified volcaniclastic strata and trachyandesite flows consist of very fine-grained aggregates of quartz and alunite, and lesser pyrophyllite, dickite, and kaolinite (figs. 14, 15). Alunite and clay minerals also occur in breccia matrices, and in irregular and discontinuous, millimeter-thick veins, usually with quartz. At least three sets of crosscutting breccias and veins are evident. The youngest breccia matrices are locally vuggy, with vugs encrusted by submillimeter-sized, euhedral quartz, and rarely by euhedral alunite. The interpreted age of alteration, $\sim 13.3 \mathrm{Ma}$ (table 1), is based on the ages of relatively coarse-grained matrix alunite (samples RW08-1 and MAS10-55, fig. 14) of the youngest breccias. Older veins and breccia matrices consist of fine-grained to microcrystalline aggregates of quartz \pm alunite. Breccia clasts are gray to beige, and consist of very fine-grained aggregates of quartz \pm alunite \pm pyrite. Some relict trachyandesite clasts comprise very fine-grained gray quartz with casts of leached phenocrysts. On recessively weathered slopes adjacent to carapaces, breccia clasts and matrices consist of quartz+clay-mica minerals \pm pyrite.

\section{Minor Elements in Rocks}

Although the exploration workings are in or near the most intensively altered rocks, they have exposed no obvious evidence of element concentrations. Most minor element analyses of 26 rock samples indicate zero to somewhat elevated concentrations of metals and other elements (table 1-2). Samples of intensely altered rocks contain variably elevated concentrations of $\mathrm{Hg}(1-5.2 \mathrm{ppm})$, As (205; 477 ppm), Bi (1-7 ppm), Co ( 6; 30 ppm), Cu (148; $189 \mathrm{ppm}), \mathrm{Mo}$ (21-168 ppm), $\mathrm{Pb}$ (66-258 ppm), and Te ( 1-7 ppm). Elevated concentrations of Ba, W, Se, Sr, Cr, $\mathrm{Mn}$, and Ni occur in individual samples. Samples with sulfur abundances $>1$ volume percent and $>1,000 \mathrm{ppm}$ Ba contain alunite, pyrite, and barite.

\section{Sulfur Isotope Composition}

The sulfur isotope value $\left(\delta^{34} \mathrm{~S}\right)$ of matrix alunite in a dated sample (RW08-1) of brecciated and silicified volcaniclastic strata is $20.6 \%$ (table 2). This $\delta^{34} \mathrm{~S}$ value is consistent with disproportionation of magmatic $\mathrm{SO}_{2}$ (Rye, 2005) as the fundamental process responsible for pervasive quartz-alunitepyrite (iron oxides) alteration of the volcaniclastic strata and trachyandesite flows.

\section{ASTER Imagery}

ASTER spectra of the RW-EWR AZ (fig. 15; Rockwell, 2010) show that an extensive quartz-alunite \pm pyrophyllite association spatially coincides with erosionally resistant, stratiform carapaces of volcaniclastic strata that form the westeast alignment of landforms. Pixels interpreted as representing kaolinite and montmorillonite are within and north of the main area of quartz-alunite-pyrophyllite-altered rocks. Many of these pixels are coincident with Tertiary-Quaternary sedimentary deposits that contain altered clasts, but exposures of clay-altered trachyandesite beneath sedimentary deposits in drainages, and in Red Wash, indicate that, for the most part, the pixels represent bedrock. East of Red Wash, kaolinitemontmorillonite-altered rocks overlap and extend south of the area of quartz-alunite-pyrophyllite-altered rocks. These alteration patterns continue east-northeast into Fletcher Valley.

\section{SWIR Spectra}

SWIR analyses of representative samples from the RW-EWR AZ confirm the presence of alunite, pyrophyllite, dickite, kaolinite, and montmorillonite in and adjacent to the resistant stratiform carapaces of altered volcaniclastic strata.

\section{Hydrothermal Mineral Ages}

Within the RW-EWR AZ, alunite in the matrices of silicified breccias near Masonic Gulch, and near Sonoma Canyon, has ${ }^{40} \mathrm{Ar} /{ }^{39} \mathrm{Ar}$ dates of $13.34 \pm 0.035 \mathrm{Ma}$ and $13.27 \pm 0.02 \mathrm{Ma}$, respectively (fig. 14; table 1). These alunite dates are analytically indistinguishable from the dates of alunite at the Sarita, Red Rock, and Chemung Mines in the Masonic Mining District $\sim 5 \mathrm{~km}$ south of the RW-EWR AZ. They are slightly younger than the ages of porphyritic domes of trachyandesite of Masonic Gulch (13.5-13.4 Ma; table 1) in the northern part of the Masonic Mining District, $\sim 1-1.5 \mathrm{~km}$ south of the central part of the alteration zone (fig. 3 ). 

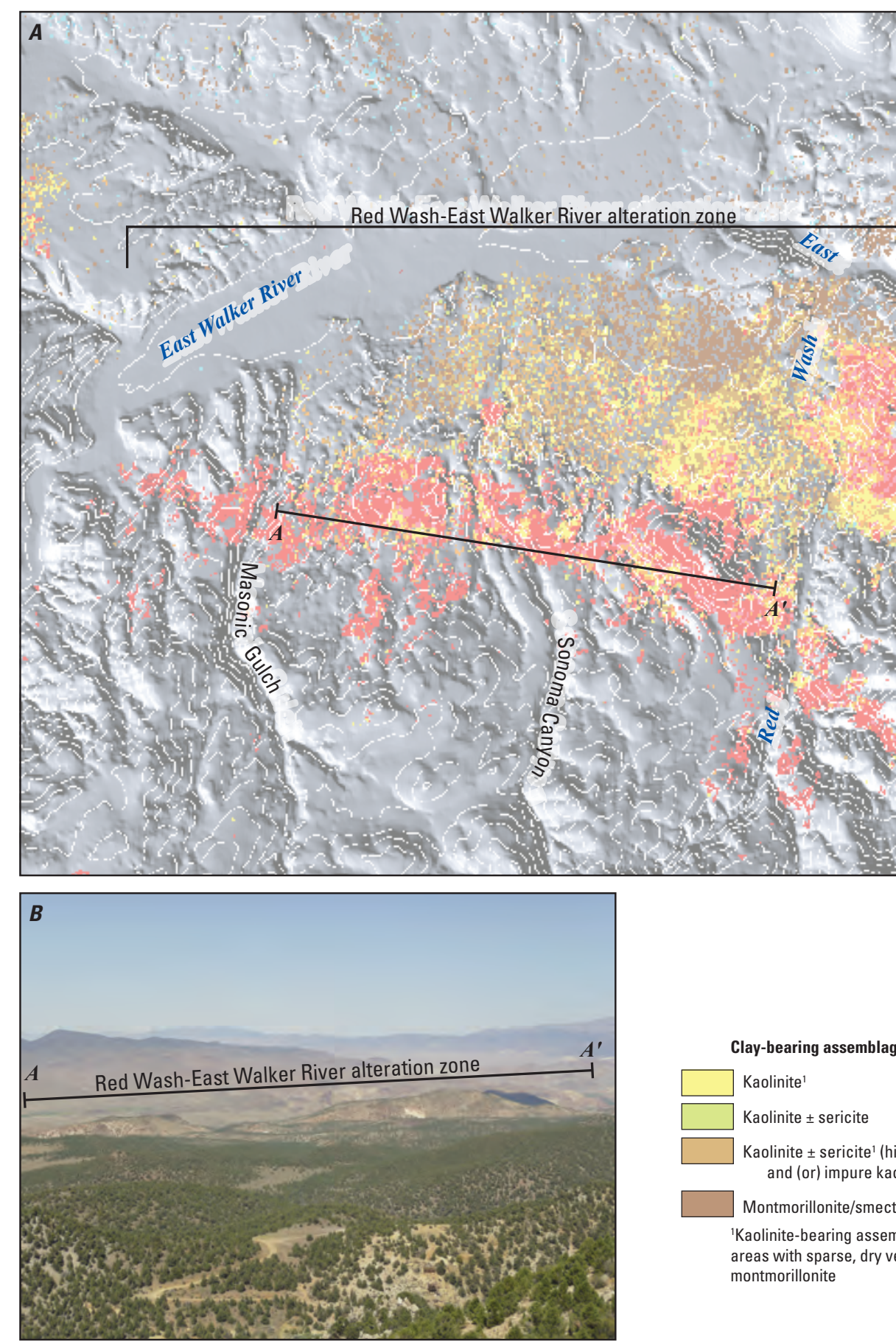

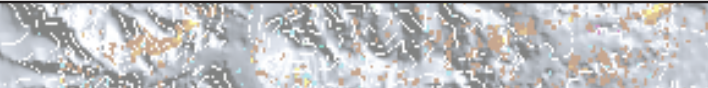

EXPLANATION

\section{Clay-bearing assemblages}

Kaolinite

Kaolinite \pm sericite

Kalinite \pm sericite' (high-albedo surfaces with minor and (or) impure kaolinite, often supergene

Montmorillonite/smectite, or low-abundance sericite 'Kaolinite-bearing assemblages may be misidentified in areas with sparse, dry vegetation \pm sericite or montmorillonite

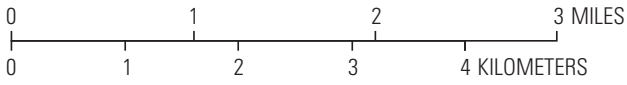

\section{Sulfate-bearing assemblages}

Possible prophyllite $( \pm \text { alunite })^{2}$

Alunite $( \pm \text { prophyllite })^{2}$

Natroalunite, or alunite and minor kaolinite ${ }^{2}$

Alunite and kaolinite ${ }^{2}$

Jarosite \pm gypsum, or ferric iron and hydrous quartz

Gypsum \pm clays

${ }^{2}$ These assemblages may represent areal mixtures of

clay/mica and dry vegetation, or areas of sensor

instability related to low or high surface albedo 


\section{East Brawley Peak Alteration Zone}

\section{Location}

Secs. 24, 25, 36, T. 5 N., R. 27 E.; secs. 30, 31, T. 5 N., R. 28

E., Mineral County, Nevada; secs. 4, 5, T. 4 N., R. 28 E., Mono County, California (fig. 1)

\section{Definition}

The East Brawley Peak alteration zone (EBP AZ; fig. 16) is southwest of the adjacent Aurora Mining District, and lies mostly north of the California-Nevada border. It has a northsouth dimension of $\sim 4.5 \mathrm{~km}$, an average west-east dimension of $\sim 1.7 \mathrm{~km}\left(\sim 7.7 \mathrm{~km}^{2}\right)$, and is approximately centered on East Brawley Peak. The alteration zone is underlain predominantly by trachyandesite of Aurora, bordered to the west by trachyandesite of West Brawley Peak, and bordered to the north by rhyolite of Del Monte Canyon and rhyolite of East Brawley Peak (fig. 16). To the northeast and south, quartz-alunitepyrite-dominant mineral assemblages of the EBP AZ grade into propylitically altered trachyandesite of Aurora. To the east, the EBP AZ adjoins a west-east-aligned zone of variably altered Tertiary and pre-Tertiary rocks that includes the Spring Peak sinter (fig. 16). Temporal relationships of the Spring Peak sinter, the EBP AZ, and the Aurora Mining District, have not been determined by geochronology.

\section{History and Production}

No production is recorded from the EBP AZ. A drilling access road to the top of East Brawley Peak was constructed in the 1980s(?), and at least one hole was drilled from a site $\sim 0.2 \mathrm{~km}$ north of the summit. Several shallow bulldozer excavations near the summit may predate the drill access road and site.

\section{Stratigraphy}

Most of East Brawley Peak is mantled by slope wash consisting of strongly silicified rocks exposed on and near the summit, and on the hill $\sim 1 \mathrm{~km}$ south of the summit. Based on relict textures in silicified and subjacent altered rocks, and on exposures in the Aurora Mining District, the EBP AZ is underlain entirely by trachyandesite of Aurora. The trachyandesite of Aurora forms a series of moderate-volume lava flows and associated laharic debris flows and volcaniclastic deposits similar to those included in the trachyandesite of Masonic. The abundance of debris flows interbedded with compositionally equivalent lava flows, both intruded by numerous small, intermediate-composition intrusions, suggests that these rocks comprise a stratovolcano centered near the Aurora Mining District. Trachyandesite of Aurora is a medium- to pale-gray, moderately porphyritic trachyandesite, and includes andesite and trachydacite. It contains about 3-42 volume percent phenocrysts, trachytically layered in some places, of plagioclase, distinctive 1-5 mm hornblende euhedra, and trace amounts of clinopyroxene and biotite set in a moderately devitrified groundmass.

$\mathrm{K}$-Ar ages of trachyandesite of Aurora range from 15.8 to $13.8 \mathrm{Ma}$ (Silberman and McKee, 1972; Kleinhampl and others, 1975). More precise ${ }^{40} \mathrm{Ar} /{ }^{39} \mathrm{Ar}$ dates of hornblende and plagioclase are 13.13-12.58 Ma (table 1). Based on ${ }^{40} \mathrm{Ar} /{ }^{39} \mathrm{Ar}$ dates of plagioclase, unaltered trachyandesite of West Brawley Peak, which overlies altered rocks of the EBP AZ, is 11.51-11.32 Ma (table 1; John and others, 2012).

\section{Structure}

Breit (2000) attributed structural control of the EBP $\mathrm{AZ}$ to a $\mathrm{N} 75^{\circ} \mathrm{W}$-striking "left-stepping dilational jog in a $\mathrm{N} 45^{\circ} \mathrm{W}$-striking strike-slip fault near the summit of East Brawley Peak." This fault pair is defined by the distribution of silicified trachyandesite, $\mathrm{N} 75^{\circ} \mathrm{W}$-striking quartz veins, and high temperature, saline fluid inclusions in quartz fragments in veins atop East Brawley Peak that may have been transported upward from a deep source. On a regional scale, the northsouth Esmeralda vein, which trends into the EBP AZ, other N $40-70^{\circ}$ E-trending veins in the Aurora Mining District, and the structures atop East Brawley Peak, may be related to right lateral faults produced by $\mathrm{N} 40-45^{\circ} \mathrm{W}$-oriented shear (Sylvester, 1988; Breit, 2000). However, northwest-trending structures with significant oblique displacement have not been recognized elsewhere in the Bodie Hills.

Figure 15. (Facing page) $A$, Advanced Spaceborne Thermal Emission and Reflection Radiometer (ASTER) imagery of the Red Wash-East Walker River alteration zone (after Rockwell, 2010). $B$, Image showing view to the northeast of the alteration zone. 


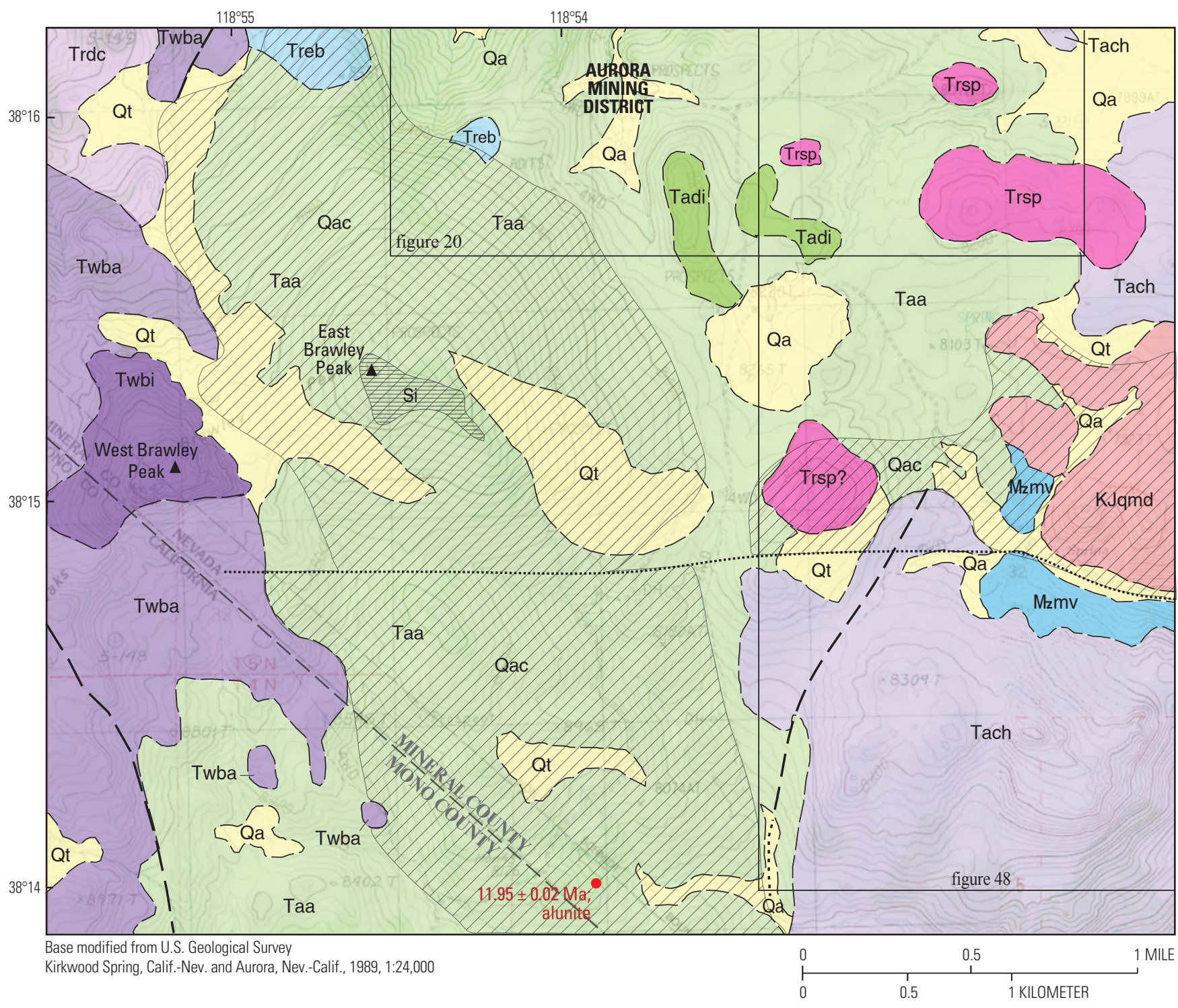

\section{EXPLANATION}

\section{Alluvium and talus}

Aurora Volcanic Field (Pliocene)

Tach Trachyandesite of Cedar Hill

Trsp

Rhyolite of Spring Peak

Trachyandesite of Aurora (Miocene) - Si,

silicified trachyandesite on summit of

East Brawley Peak; Oac, trachyandesite

variably altered to quartz, alunite,

kaolinite, dickite, illite, and

montmorillonite

\section{Bodie Hills Volcanic Field (Miocene)}

Trdc Rhyolite of Del Monte Canyon

Treb

Twbi

Rhyolite of East Brawley Peak

Trachyandesite intrusion of West Brawley Peak

Trachyandesite of West Brawley Peak

\section{Granitic and metamorphic rocks}

KJqmd Quartz monzodiorite of Aurora (Cretaceous or Jurassic)

Mzmv Metavolcanic rocks (Mesozoic)

- Contact-Dashed where approximated

- Fault-Dashed where approximated, dotted where concealed

Color air photo (CAP) lineament

${ }^{40} \mathrm{Ar} /{ }^{\beta} \mathrm{Ar}$ sample site, age, mineral

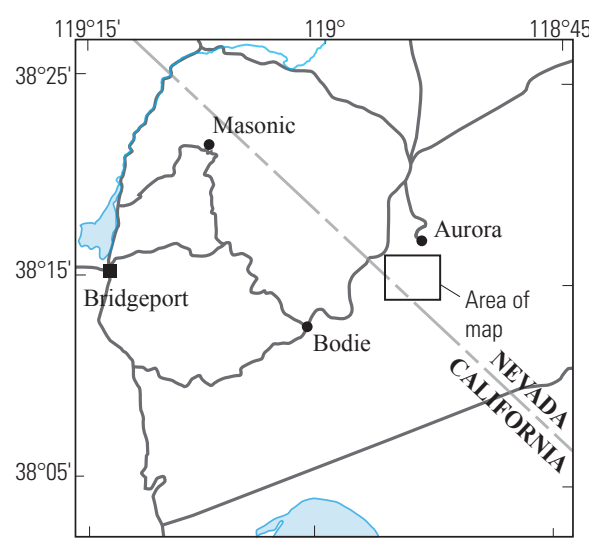

Figure 16. Geologic map of the East Brawley Peak alteration zone, Mineral County, Nevada, and Mono County, California, modified from Breit (2000) and John and others (2012). 
A west-east lineament that is conspicuous on color aerial photography (CAP lineament; fig. 16) trends through the EBP $\mathrm{AZ}$ and is coincident with the southern border of the west-east zone of altered rocks that includes the Spring Peak sinter (fig. 16). Although stratigraphic displacement of Miocene and Pliocene volcanic rocks along this lineament has not been recognized, Pliocene trachyandesite of Cedar Hill straddles the lineament. This relationship suggests that, if the lineament is a fault, then displacement along it is pre-Pliocene. High-angle displacement along this lineament may have contributed to relief and the relatively large amount of erosion of the Aurora Mining District.

\section{Hydrothermal Alteration}

According to Breit (2000), hydrothermal alteration minerals within the EBP AZ are vertically zoned. Quartzalunite-kaolinite-pyrite-altered trachyandesite and vuggy silica (presumably hydrothermal and residual quartz) are dominant between 8,050 and 8,800 ft elevation, and pervasively silicified and brecciated trachyandesite is dominant from 8,800 to 9,400 ft elevation (summit of East Brawley Peak). Laterally adjacent to quartz-alunite-kaolinite-altered trachyandesite on East Brawley Peak, are zones of "intermediate argillic alteration" (Breit, 2000) and propylitically altered trachyandesite.

Alteration mineral assemblages within the EBP AZ appear to grade to the north into propylitically altered trachyandesite of Aurora in the Aurora Mining District, but the transition occurs on slopes mantled by silicified trachyandesite shed from the summit of East Brawley Peak. Hydrothermal mineral ages indicate that the Aurora veins are younger than the EBP AZ. Detailed mapping, geochronology, and paragenetic examinations required to determine the relationship of the EBP AZ to veins of the Aurora Mining District, and to the Spring Peak alteration zone, have not been completed.

\section{Minor Elements in Rocks}

Breit (2000) reported elevated Ti (>1 weight percent) and $\mathrm{Zr}$ in samples of pervasively silicified trachyandesite, and somewhat elevated concentrations of $\mathrm{Au}, \mathrm{Ag}, \mathrm{As}, \mathrm{Sb}, \mathrm{Hg}, \mathrm{Cu}$, $\mathrm{Pb}, \mathrm{Bi}, \mathrm{Mo}, \mathrm{Se}, \mathrm{Te}$, and $\mathrm{Ba}$ in a small percentage of samples categorized as argillized, argillized and iron-stained, propylitized, silicified, silicified and iron-stained, and vein rock. This geochemical characterization was derived from three sets of samples collected during 1967-68, 1988, and 1992 that were analyzed by different methods.

\section{ASTER Imagery}

ASTER imagery (Rockwell, 2010) of the EBP AZ shows clusters of pixels on East Brawley Peak and on the hill to the south that represent quartz-alunite \pm pyrophyllite and lesser kaolinite. The clusters are spatially coincident with silicified trachyandesite of Aurora that contains variable amounts of alunite. Scattered pixels that represent sericite are distributed near the south and southeast margins of the zone. On the north-northeast side of the alteration zone, quartzalunite \pm pyrophyllite-altered trachyandesite and kaolinitealtered trachyandesite terminate rather abruptly against relatively dense pixelation that represents sericite-altered trachyandesite of Aurora in the Aurora Mining District.

\section{SWIR Spectra}

SWIR spectral analyses of rock samples within the EBP AZ show that recessively weathered greenish, altered trachyandesite of Aurora in the saddle on the summit of East Brawley Peak contains montmorillonite. Veins and breccia matrix in silicified trachyandesite north of the summit consist of dickite; adjacent trachyandesite wall rocks contain dickite and kaolinite. Trachyandesite of Aurora and rhyolite of East Brawley Peak(?), north and south of the summit, contain alunite, dickite, kaolinite, montmorillonite, illite, and illite/montmorillonite.

\section{Fluid Inclusion Microthermometry and Composition}

Breit (2000) described narrow cryptocrystalline quartz veins near the summit of East Brawley Peak that contain quartz fragments with four populations of fluid inclusions, and silicate melt inclusions. One type of inclusion containing halite and other daughter minerals homogenized to liquid at $\mathrm{T} \geq 470{ }^{\circ} \mathrm{C}$; another type contains liquid $\mathrm{CO}_{2}$. According to Breit (2000) high homogenization temperatures and the presence of silicate melt inclusions suggest that these quartz fragments are magmatic in origin and were transported upward from an unexposed intrusion. 


\section{Hydrothermal Mineral Ages}

Breit (2000) reported $\mathrm{K}-\mathrm{Ar}$ and ${ }^{40} \mathrm{Ar} /{ }^{39} \mathrm{Ar}$ dates of $13.7 \pm 0.5 \mathrm{Ma}$ and $12.34 \pm 0.04 \mathrm{Ma}$, respectively, for alunite from East Brawley Peak. The ${ }^{40} \mathrm{Ar} /{ }^{39} \mathrm{Ar}$ date of $11.954 \pm 0.016 \mathrm{Ma}$ (sample AUR10-3, table 1) was obtained for alunite on the south slope of East Brawley Peak (approximately the same location as the samples dated by Breit). This latter alunite occurs as millimeter-sized crystals that encrust fractures and irregular pockets in silicified and leached trachyandesite of Aurora. The alunite dates are older than ${ }^{40} \mathrm{Ar} r{ }^{39} \mathrm{Ar}$ dates of K-feldspar in veins in the Aurora Mining District, which range in age from 10.5 to $10.0 \mathrm{Ma}$ (table 1).

\section{Sawtooth Ridge Alteration Zone}

\section{Location}

Secs. 12, 13, T. 5 N., R. 27 E., Mineral County, Nevada (fig. 1)

\section{Definition}

The Sawtooth Ridge alteration zone (SR AZ; fig. 17) is mostly in rhyolite of Aurora Creek (11.18 $\pm 0.01 \mathrm{Ma}$, table 1; John and others, 2012) that has been altered to quartz and opaline silica, alunite, and clay minerals. The SR AZ covers $\sim 2 \mathrm{~km}^{2}$ immediately north of Aurora Creek and adjoins the Aurora Mining District to the south and east. It is distinguished from alteration of rhyolite of Aurora Creek in the northern part of the Aurora Mining District by alteration mineral associations, by age (11.105 $\pm 0.018 \mathrm{Ma}$, table 1$)$, and by the presence of Aurora district veins ( 10-10.5 Ma, table 1) in rhyolite of Aurora Creek east of the Aurora cemeteries, but not in altered rocks of the zone to the west.

\section{History and Production}

No production is recorded from the SR AZ. A prospect near the north edge of the zone was excavated in brecciated rhyolite with dense iron oxide matrix. Roads in the southern part of the zone, west of the Aurora cemeteries, apparently provided access to drill sites, but most have been partly reclaimed and no drill cuttings were identified. A small open cut and shaft in rhyolite of Aurora Creek east of the SR $\mathrm{AZ}$ expose narrow quartz veins that most likely represent a northern extension of Aurora district veins.

\section{Stratigraphy}

The rhyolite of Aurora Creek consists of coalescing domes and proximal flows of flow-banded rhyolite and subordinate lithic-rich tuff that are gray where unaltered and beige to white where altered (fig. 17). The rhyolite is overlain to the west and northeast by trachyandesite of Del Monte (11 Ma), to the southwest by nearly coeval rhyolite of Del Monte Canyon (11.2 Ma; John and others, 2012), and to the north and northeast by late Pleistocene trachyandesite of Aurora Crater (north and northeast of the area of fig. 16). Rhyolite of Aurora Creek overlies trachyandesite of Aurora ( 13.1-12.6 Ma; table 1), which is extensively exposed immediately south of the SR AZ in the Aurora Mining District. Trachyandesite of West Brawley Peak ( 11.5 Ma, table 1) crops out in the north part of the alteration zone and is locally clay-altered.

\section{Structure}

No faults transect rhyolite of Aurora Creek within the area of figure 17, nor can any be demonstrably projected into the SR AZ from available geologic maps (John and others, 2012).

\section{Hydrothermal Alteration}

Alteration of rhyolite of Aurora Creek within the SR $\mathrm{AZ}$ is most pervasive in an area bounded by Aurora Creek to the south and extending about $2.5 \mathrm{~km}$ north of Aurora Creek (fig. 17). In this area, rhyolite is variably altered to quartz and opal, and lesser amounts of alunite, kaolinite, montmorillonite, and illite. Sparse feldspar and biotite phenocrysts commonly are replaced by sericite and clay minerals. The most intensely altered rocks are flow breccias or breccias related to dome emplacement on the ridge top north of Aurora Creek (fig. 17). The high point on that ridge was known as "Mt. Chalcedony" during the main period of production in the Aurora Mining District (Wasson, 1878). On Sawtooth Ridge between Mt. Chalcedony and the Aurora cemeteries, thermal vents are represented by small, bowl-shaped depressions of layered chalcedonic quartz and oncoids, or quartz spheres that were turbulently agglomerated (Lynne, 2012; fig. 17). Abundant alunite occurs in chalcedonic quartz stockwork veins and in matrices of brecciated rhyolite $\sim 135 \mathrm{~m}$ below the oncoidal thermal vents.

Float blocks of layered quartz veins that strongly resemble Aurora district veins are sporadically distributed in and east of the Aurora cemeteries. Narrow quartz veins (millimeters to centimeters thick) are exposed in a small open cut in rhyolite of Aurora near the eastern margin of figure 17 (sample AUR11-19). Montmorillonite in light-colored tuff exposed along haul roads to the Esmeralda mill northeast of the cut (fig. 17, sample AUR11-18) may also be related to vein mineralization in the Aurora Mining District. 


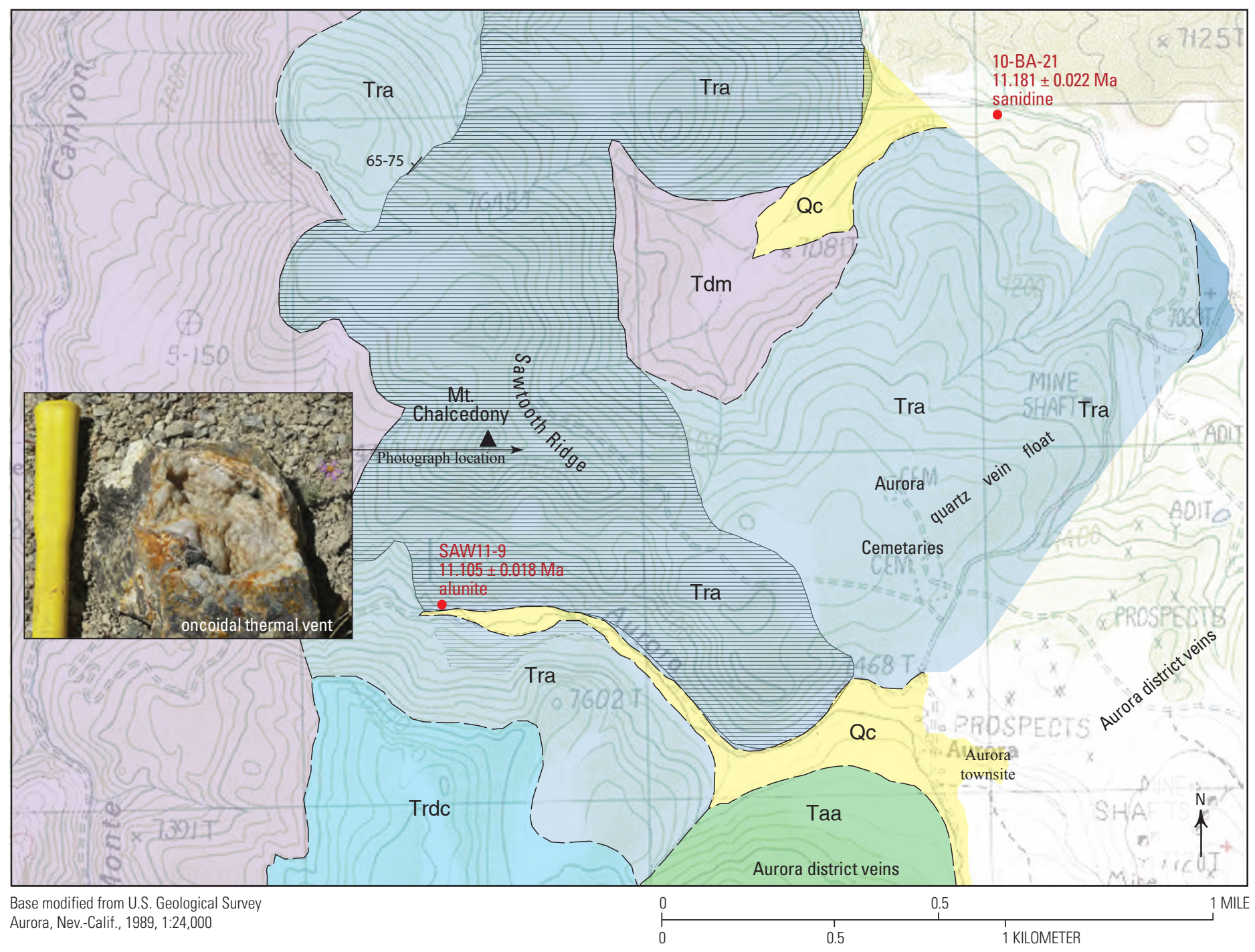

\section{EXPLANATION}

\begin{tabular}{|c|c|}
\hline Qc & Colluvium \\
\hline Tdm & Trachyandesite of Del Monte \\
\hline Trdc & Rhyolite of Del Monte Canyon \\
\hline Tra & Rhyolite of Aurora Creek \\
\hline & Tuff \\
\hline & Silica-alunite-kaolinite alteration \\
\hline Taa & Trachyandesite of Aurora \\
\hline-- & Contact-Dashed where approximated \\
\hline$\stackrel{65-75}{+}$ & Bedding \\
\hline - & ${ }^{40} \mathrm{Ar} /{ }^{39} \mathrm{Ar}$ sample site $-N u m b e r$, age, miner \\
\hline
\end{tabular}

Figure 17. A, Geologic map of the Sawtooth Ridge alteration zone, Mineral County, Nevada. $B$, Image of a remnant bowlshaped thermal vent consisting of layered chalcedonic quartz and turbulently agglomerated, spherical quartz oncoids.

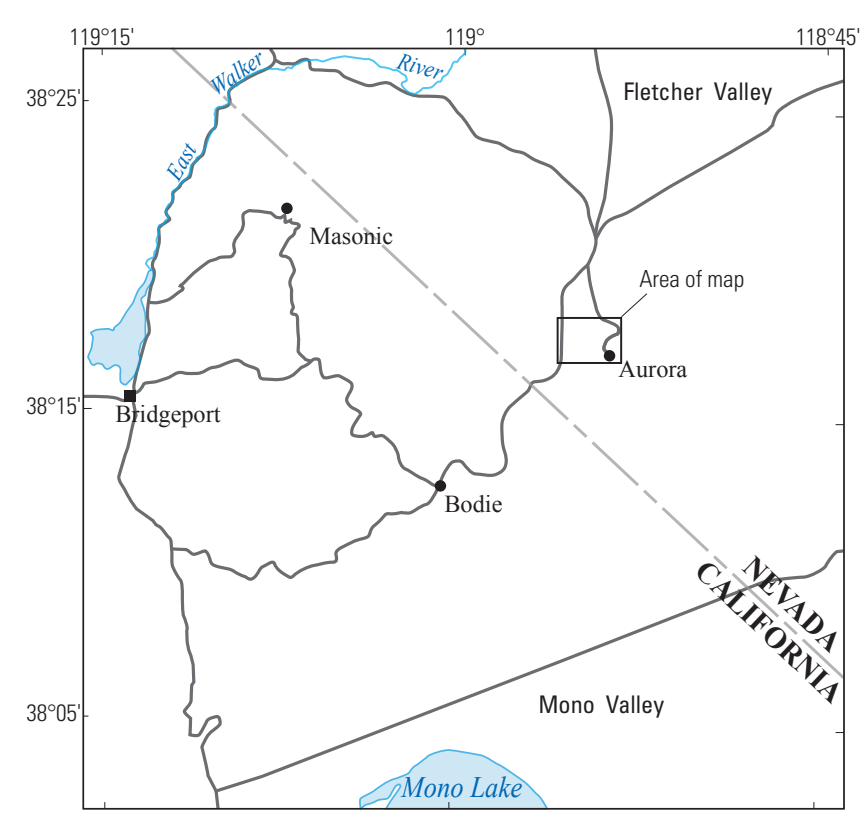


Most samples of altered rhyolite in the SR AZ do not contain elevated concentrations of minor elements; however, several samples of rhyolite and iron oxide-matrix breccia contain variably elevated concentrations of Ag, As, $\mathrm{Hg}, \mathrm{Mo}$, $\mathrm{Rb}, \mathrm{Sb}, \mathrm{Sr}$, and Te (table 1-4).

\section{Sulfur Isotope Composition}

Alunite in veined and brecciated rhyolite below oncoidal thermal vents that was collected for ${ }^{40} \mathrm{Ar} /{ }^{39} \mathrm{Ar}$ dating has a $\delta^{34} \mathrm{~S}$ value of $-3.2 \%$ (table 2 ), and is not associated with sulfide minerals. This isotope composition and the absence of sulfide minerals indicate that SR AZ alunite formed by near-surface oxidation of $\mathrm{H}_{2} \mathrm{~S}$ (steam-heated environment of Rye, 2005).

\section{ASTER Imagery}

ASTER imagery (Rockwell, 2010) shows that the SR AZ is coincident with a central area of relatively dense pixels that correspond to alunite \pm kaolinite and lesser quartz, surrounded by a more diffusely altered area of illite-altered rocks.

\section{SWIR Spectra}

SWIR spectra of hand samples of rhyolite of Aurora Creek from the SR AZ correspond to opal, alunite, kaolinite, dickite, and montmorillonite.

\section{Hydrothermal Mineral Age}

Alunite ( \pm chalcedonic quartz) matrix that cements angular clasts of brecciated rhyolite of Aurora Creek (fig. 17, sample SAW11-9) has a ${ }^{40} \mathrm{Ar} /{ }^{39} \mathrm{Ar}$ date of $11.105 \pm 0.018 \mathrm{Ma}$ (table 1).

\section{Aurora Canyon Alteration Zone}

\section{Location}

Secs. 17, 18, 19, 20, 21, 30, 31, T. 5 N., R. 26 E. (unsurveyed); sec. 24, T. 5 N., R. 25 E. (unsurveyed), Mono County, California (fig. 1)

\section{Definition}

The Aurora Canyon alteration zone (AC AZ; fig. 18) is a contiguous volume of predominantly trachyandesite of Masonic that has been extensively altered to quartz \pm alunite, pyrite (iron oxides), mica, and clay minerals. The AC AZ occurs in and south of Aurora Canyon, has west-east and north-south dimensions of 4.5 and $2.3 \mathrm{~km}$, respectively, and covers $\sim 8.1 \mathrm{~km}^{2}$. The AC AZ is overlain by younger volcanic rocks to the south (trachydacite of Potato Peak and trachyandesite of Willow Springs), and may be coextensive with the Potato Peak alteration zone $\sim 2 \mathrm{~km}$ to the southeast. Alteration intensity within the AC AZ decreases to the west and east into unaltered trachyandesite of Clark Canyon; small internal areas of unaltered trachyandesite are mostly represented by float.

\section{History and Production}

No production is recorded from the AC AZ, consistent with the small scale of surface disturbance, scattered prospect pits, trenches, and drill roads. Roads in the eastern part of the alteration zone probably provided drill site access, although no drill cuttings were identified. Ages of these workings and roads are unknown, but the absence of reclamation suggests that they predate land use regulations of the Federal Land Policy Management Act (FLPMA) of 1976.

\section{Stratigraphy}

Trachyandesite of Masonic flows and debris flows ( 15-14 Ma) were erupted and extensively altered prior to emplacement of younger volcanic rocks that intrude and enclose the AC AZ (fig. 18). Younger, unaltered rocks include trachyandesite of Aurora Canyon (10.6-10.3 Ma; John and others, 2012), rhyolite of Bodie Hills (9.9-9.7 Ma) near the center of the AC AZ, trachydacite of Potato Peak (9.1-8.8 Ma) to the southeast, and trachyandesite of Willow Springs (8.6-8.0 Ma) to the southwest. Unaltered trachyandesite of Clark Canyon (11.3 Ma; John and others, 2012) is exposed west of the alteration zone. Trachyandesite of Willow Springs that unconformably overlies altered trachyandesite flows comprise domelike landforms that partly filled depressions between resistant hills and ridges of altered trachyandesite. Three prominent domes of rhyolite of Big Alkali (6.2-5.5 Ma) have intruded the alteration zone; the internal structure of these domes is depicted by a small concentrically foliated “half" dome in NW1/4/NW'1/4 sec. 31, T. 5 N., R. 26 E. (fig. 18). The youngest deposits in the AC AZ consist of colluvium that accumulated in recessively weathered areas of clay-altered trachyandesite, and in active drainages.

The trachyandesite of Clark Canyon forms a series of small-volume plugs, arrayed along an east-northeast trend in Aurora Canyon, and includes a small-volume lava flow about $1.5 \mathrm{~km}$ south of Aurora Canyon. The trachyandesite of Aurora Canyon forms a discontinuous series of small-volume lava domes; coarse block and ash flow deposits and (or) carapace breccias are preserved along the margins of some domes. The trachydacite of Potato Peak forms an elliptical eruptive center of moderate volume consisting of coalesced lava flows and exogenous flow domes. The trachyandesite of Willow Springs forms a north-northwest elongate set of moderate-volume, coalesced, lava domes and flows. These four units contain 6-38 volume percent phenocrysts of plagioclase, clinopyroxene, hornblende, and biotite that are locally trachytically 


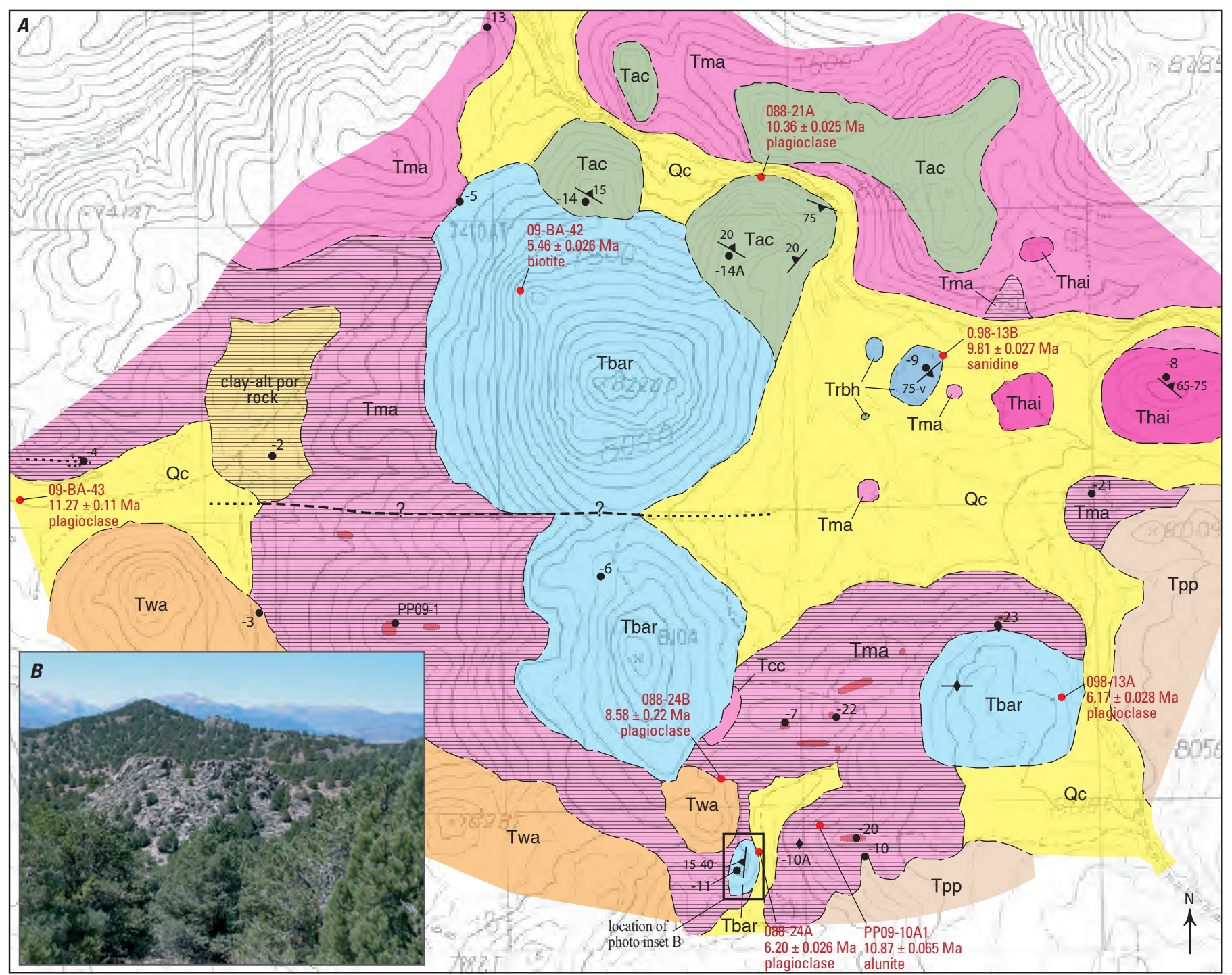

Base modified from U.S. Geological Survey

Bridgport, Calif., and Dome Hill, Calif.-Nev., 1989, 1:24,000

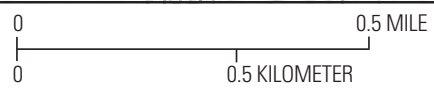

\section{EXPLANATION}

\begin{tabular}{|c|c|c|c|}
\hline Qc & Colluvium & - & Contact \\
\hline Tbar & Rhyolite of Big Alkali & & Fault—Dashed where \\
\hline Twa & Trachydacite of Willow Springs & & $\begin{array}{l}\text { approximated, dotted where } \\
\text { concealed }\end{array}$ \\
\hline Tpp & Trachydacite of Potato Peak & $\stackrel{35}{\sim}$ & Foliation \\
\hline Trbh & Rhyolite of Bodie Hills & $\vdash$ & Vertical foliation \\
\hline Tac & Trachydacite of Aurora Canyon & $\bullet$ & Sample locality \\
\hline Thai & Hornblende andesite intrusion & & ${ }^{40} \mathrm{Ar} /{ }^{39} \mathrm{Ar}$ sample site-Number, \\
\hline Ima & $\begin{array}{l}\text { Trachyandesite of Masonic- } \\
\text { Line-patterned where hydrothermally } \\
\text { altered; dense red color shows } \\
\text { quartz-alunite ledge }\end{array}$ & $\therefore$ & age, mineral \\
\hline
\end{tabular}

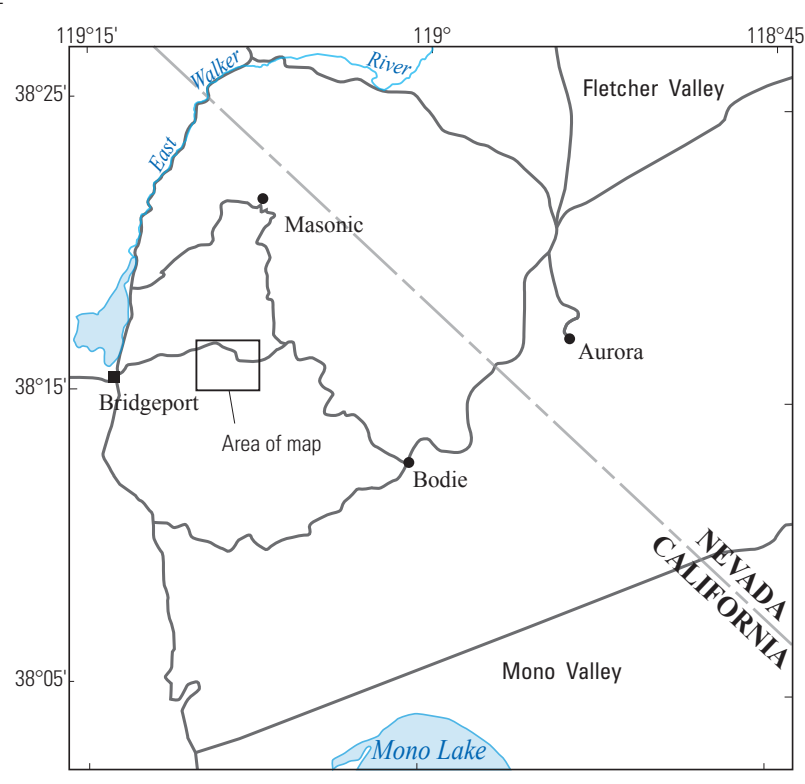

Figure 18. A, Geologic map of the Aurora Canyon alteration zone, Mono County, California. $B$, Image showing a concentrically exfoliated rhyolite dome (unit Tbar, rhyolite of Big Alkali) near the southern map boundary. 
aligned. Trachyandesite of Willow Springs contains rare olivine phenocrysts, and plagioclase phenocrysts in this unit are characteristically larger than those in most rocks of the Bodie Hills volcanic field.

Rhyolite of Bodie Hills forms a series of small-volume lava domes, many with carapace and (or) basal flow breccias. It contains 1-23 percent phenocrysts of plagioclase, quartz, sanidine, biotite, hornblende, and rarely clinopyroxene in locally glassy and flow-banded matrix. The rhyolite of Big Alkali forms a prominent north-trending array of low-volume domes. It contains $6-42$ volume percent phenocrysts of plagioclase, hornblende, and biotite, and trace amounts of quartz and sanidine. Small exposures of hornblende andesite along the Aurora Canyon road in the eastern part of the AC AZ contain prominent hornblende phenocrysts.

\section{Structure}

No faults have been identified in the AC AZ, and the distribution of alteration mineral associations and lithology does not require significant fault displacement. However, a west-east $\left( \pm 10^{\circ}\right)$ structural trend is implied by the distribution of altered trachyandesite, by alignment of resistant exposures of quartz-altered trachyandesite, and by west-east and east-northeast-trending linear ridges of silicified breccia (fig. 18). On a larger scale, rhyolite of Big Alkali domes in the AC AZ are roughly collinear with a north-south alignment of other rhyolite of Big Alkali domes to the south and north (John and others, 2012). Although the rhyolite domes are $\sim 4-5$ m.y. younger than the AC AZ, their alignment may reflect an older structure that controlled alteration within the zone. The AC AZ is the same age as the Potato Peak alteration zone, but is $\sim 1,000 \mathrm{ft}(\sim 300 \mathrm{~m})$ lower in elevation, and the two alteration zones may be displaced by an unrecognized fault. Alternatively, the Potato Peak alteration zone has been elevated relative to the Aurora Canyon alteration zone by magmatic inflation during construction of the Potato Peak stratovolcano.

\section{Hydrothermal Alteration}

Within the AC AZ, nearly all trachyandesite of Masonic has been altered to assemblages dominated by quartz \pm alunite, clays, and mica. Quartz-altered trachyandesite consists of gray to light-brown, very fine-grained to microcrystalline quartz in which some relict feldspar phenocrysts are discernible. Most quartz-altered trachyandesite has been brecciated and locally veined. Breccia matrices and veins, mostly $<5 \mathrm{~mm}$ in width, consist of very fine-grained to microcrystalline quartz, and quartz+alunite \pm pyrite (iron oxides). Quartz-alunite-pyritealtered trachyandesite and silicified breccia are erosionally resistant, capping hills and forming linear ridges as much as 5 meters high and meters to tens of meters long. These resistant ledges are flanked by recessively weathered zones of trachyandesite (tens of meters wide) altered to alunite, clay-mica minerals, pyrite (mostly weathered to iron oxides), and lesser chlorite. Kaolinite, where present, is proximal to quartz-alunite-pyrite-altered trachyandesite, whereas clay minerals distal to quartz-altered trachyandesite are dominated by illite and montmorillonite. An altered porphyritic rock that rests on altered trachyandesite in a small basin (SW4/SW4 $\mathrm{S} 30, \mathrm{~T} 5 \mathrm{~N}, \mathrm{R} 26 \mathrm{E}$ ) is characterized by polygonally desiccated soil, indicative of expandable clays, recessive weathering, sparse ground flora and little outcrop.

\section{Minor Elements in Rocks}

Eight samples of quartz-alunite-pyrite(iron oxides)- and clay-pyrite(iron oxides)-altered trachyandesite of Masonic, and silicified breccia, contain very low concentrations of $\mathrm{Au}$ (most $<5$ parts per billion [ppb]) and $\mathrm{Ag}(<1 \mathrm{ppm}$; table 1-5). Several samples contain elevated concentrations of $\mathrm{Hg}(\sim 2-21 \mathrm{ppm})$, As (81-480 ppm), Bi ( $\sim 1-5 \mathrm{ppm})$, Te $(\sim 2-4 \mathrm{ppm})$, and $\mathrm{Sb}$ (tens of ppm). As much as several percent sulfur, and Ba concentrations $>1,000 \mathrm{ppm}$, reflect the presence of alunite, pyrite, and probably barite, although no barite was observed.

\section{ASTER Imagery}

ASTER imagery of the AC AZ (Rockwell, 2010) shows alunite \pm pyrophyllite and lesser alunite + kaolinite, and kaolinite-dominant pixels coincident with altered trachyandesite of Masonic. Kaolinite, alunite+kaolinite, and kaolinite/ montmorillonite pixels are coincident with altered porphyritic rock in $\mathrm{SW}^{1} 1 / 4 \mathrm{SW}^{1} 1 / 4 \mathrm{sec} .30$, T. 5 N., R. 26 E. Although these rocks are pervasively altered, pixels that represent alteration mineral assemblages are discontinuously distributed in small clusters because of tree (pinion pine) cover, unaltered float of younger volcanic rocks, and imagery resolution.

\section{SWIR Spectra}

Hand samples of quartz-alunite-clay-altered trachyandesite and silicified breccia have SWIR wavelength absorption bands characteristic of alunite, dickite, jarosite, and possibly montmorillonite, which support ASTER imagery interpretations and field observations. A sample of the altered porphyritic rock contains montmorillonite.

\section{Hydrothermal Mineral Age}

Alunite in the matrix of silicified breccia near the exfoliated half dome (fig. 18) has a ${ }^{40} \mathrm{Ar} /{ }^{39} \mathrm{Ar}$ date of $10.87 \pm 0.065 \mathrm{Ma}$ (table 1 ). This alunite date is analytically indistinguishable from the date of alunite at the Alta Plana Mine in the Potato Peak alteration zone $(10.83 \pm 0.06 \mathrm{Ma}$, table 1) $\sim 1 \mathrm{~km}$ to the southeast. 


\section{Potato Peak Alteration Zone}

\section{Location}

Secs. 33, 34, T. 5 N., R. 26 E.; secs. 3, 4, T. 4 N., R. 26 E. (unsurveyed), Mono County, California (fig. 1)

\section{Definition}

The Potato Peak alteration zone (PP AZ; fig. 19) on the northwest slope of Potato Peak consists of a contiguous volume of volcaniclastic rocks, thought to be trachyandesite of Masonic (John and others, 2012), that is extensively altered to quartz, and assemblages comprised of quartz, alunite, mica-clay minerals, and pyrite (iron oxides). The roughly circular area of altered strata covers $\sim 1.3 \mathrm{~km}^{2}$ and is entirely enclosed by younger volcanic rocks (trachydacite of Potato Peak; rhyolite of Bodie Hills), and by colluvium. Some altered strata beneath slope wash have been exposed by landslides. The PP AZ extends under cover to the north, east, and northwest where it may be contiguous with the Aurora Canyon alteration zone.

\section{History and Production}

Mercury from the Alta Plana Mine, an open cut in the central part of the alteration zone, was recovered $\sim 1942$ (Holmes, 1965) in a retorting mill (dismantled) at the mouth of Aurora Canyon. Mill feed included cinnabar in brecciated and silicified volcaniclastic rocks. The dimensions of mine workings and volume of mill calcines suggest that production was probably no more than tens of flasks of $\mathrm{Hg}$. Trenches and small excavations tens to hundreds of meters northeast of the Alta Plana Mine in clay-altered and silicified volcaniclastic rocks contain no obvious metallic minerals other than pyrite.

\section{Stratigraphy}

Volcaniclastic rocks in the alteration zone consist of debris flows derived from volcanic uplands associated with trachyandesite of Masonic that predate the trachydacite of Potato Peak and the present Potato Peak landform (fig. 19). Because of pervasive alteration, the volcaniclastic rocks are mottled gray, beige, and white, and are only exposed in mine workings and landslide scarps. These strata consist of as much as 70 volume percent angular, subangular, and subrounded clasts of aphanitic and faintly porphyritic volcanic rocks (millimeters to centimeters in size) that have been replaced by forms of hydrothermal silica, clay minerals, pyrite (iron oxides), and lesser alunite. Matrices are composed of variable proportions of the same hydrothermal minerals. No unaltered exposures were observed, and bedding and foliation are not evident.

Altered and partly leached rocks, exposed in landslide scarps and toes $\sim 0.5 \mathrm{~km}$ southeast and south of the Alta Plana Mine, include several textural varieties of porphyritic rocks.
These pre-alteration porphyritic rocks are either interstratified flows or intrusions within volcaniclastic strata, all of which may be trachyandesite of Masonic.

\section{Structure}

Exposure of the PP AZ through younger rocks is a consequence of erosional resistance of silicified landforms (below), and slope failure caused by unstable mica-clayaltered substrates. A fault northeast of the Alta Plana Mine is marked by a linear ridge of silicified breccia, but displacement could not be determined and is probably small. The PP AZ is coeval with the Aurora Canyon alteration zone but is 1,000 or more feet higher in elevation; the two alteration zones may have been displaced by an unrecognized fault on the west side of the PP AZ or by magmatic inflation during assembly of the large Potato Peak flow-dome complex (fig. 19).

\section{Hydrothermal Alteration}

The Alta Plana Hg Mine is in a resistant knob, a few tens of meters in dimension, composed of light-gray to beige, finegrained to microcrystalline, slightly vuggy quartz that replaced volcaniclastic strata. Near-vertical joint sets, one of which strikes $\sim \mathrm{N} 70^{\circ} \mathrm{W}$, give parts of the knob a columnar aspect. Silicified volcaniclastic deposits on the west and northwest sides of the knob exposed by mining have been brecciated and cemented by at least three matrices that consist of (1) dense, gray, fine-grained to microcrystalline quartz and lesser opaline silica; (2) soft, white to beige kaolinite and alunite; and (3) fine-grained quartz, cinnabar, barite, jarosite, and voids. Cinnabar also occurs in millimeter-thick veins and on irregular fractures in densely silicified volcaniclastic strata.

A north-south-oriented, resistant ridge composed of silicified, multigenerational, pyritic breccia $\sim 0.5 \mathrm{~km}$ northeast of the Alta Plana Mine has been explored by shallow cuts and trenches. Mottled gray-brown volcaniclastic rocks exposed in workings near this ridge consist of subangular to angular clasts (millimeters to centimeters in size) of fine-grained to microcrystalline quartz and variable amounts of white clay minerals. The altered clasts are enclosed by white to gray matrices of fine-grained to microcrystalline clay minerals and quartz, and up to 20 volume percent voids lined with submillimeter quartz crystals. Some gray, fine-grained quartz clasts are pocked with small voids where phenocrysts have been leached.

\section{Minor Elements in Rocks}

Samples of breccia with quartz-cinnabar matrix from the Alta Plana Mine (table 1-6) contain 1.9-17 weight percent Hg, and 64-900 ppb Au. These samples and four others from the alteration zone contain elevated concentrations of $\mathrm{Hg}$ (several parts per million to percents), As (tens to hundreds of parts per million), Bi ( $\sim 1-19 \mathrm{ppm}), \mathrm{Te}(\sim 1-3 \mathrm{ppm}), \mathrm{Sb}$ (as much as tens of parts per million), and sulfur (as much as several percent), presumably residing in cinnabar, pyrite, and lesser barite and alunite. 
A

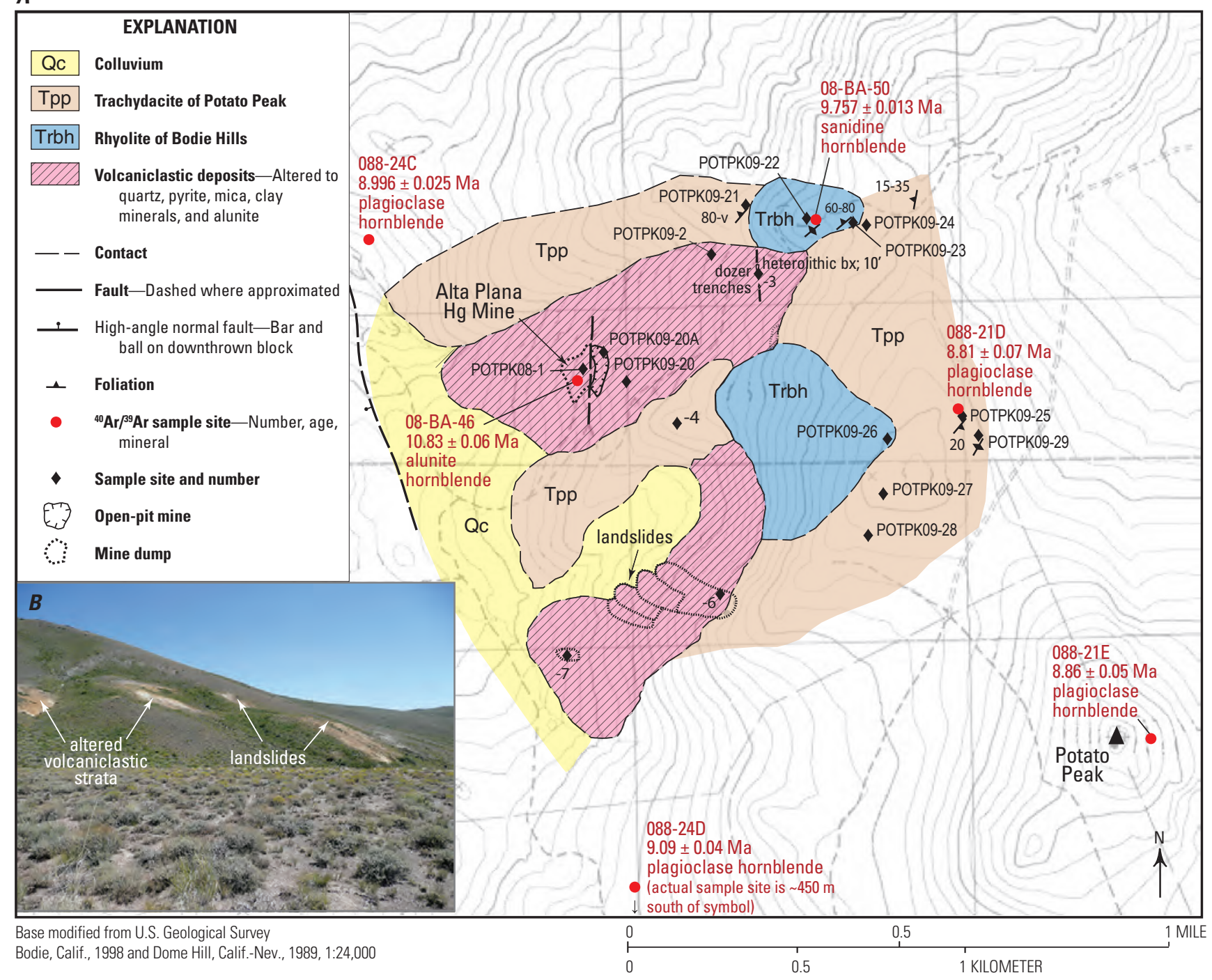

Figure 19. $A$, Geologic map of the Potato Peak alteration zone, Mono County, California. $B$, Image showing landslides developed on altered volcaniclastic strata.

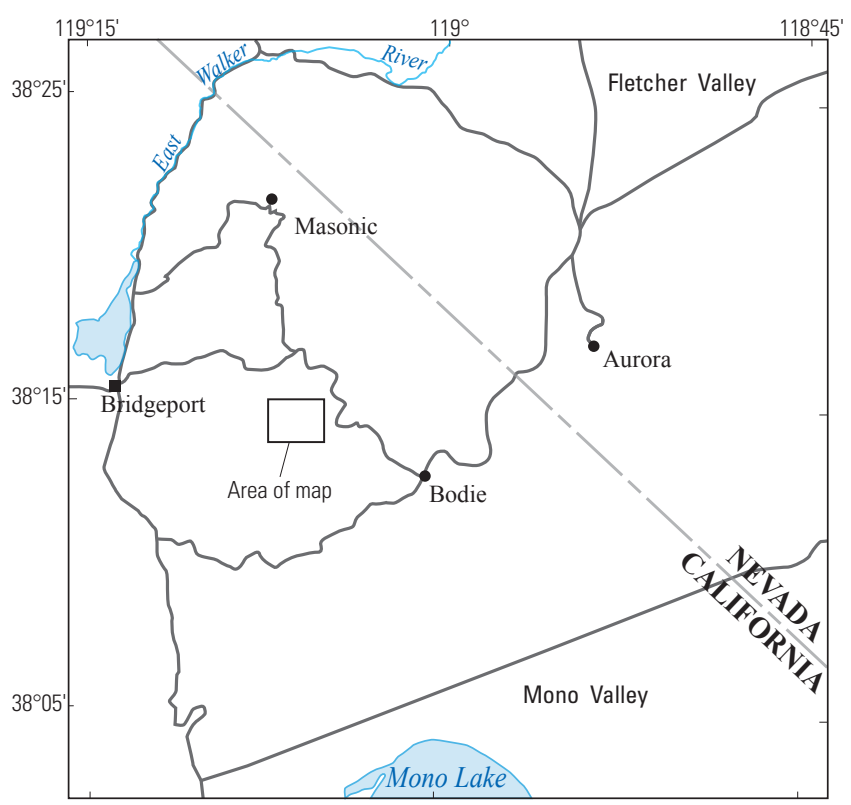




\section{Sulfur Isotope Compositions}

The $\mathrm{S}$ isotope compositions $\left(\delta^{34} \mathrm{~S}\right)$ of matrix cinnabar in a sample of brecciated and silicified volcaniclastic rocks in the Alta Plana Mine are -10.3 and $-9.8 \%$ (table 2). Alunite and barite in matrices of breccia samples from the mine have $\delta^{34} \mathrm{~S}$ values of 16.3 and $11.6 \%$, respectively. The low $\delta^{34} \mathrm{~S}$ sulfide and high $\delta^{34} \mathrm{~S}$ sulfate values are consistent with disproportionation of magmatic $\mathrm{SO}_{2}$ (Rye, 2005) during formation of the alteration zone. Sulfur isotope equilibrium temperatures were not calculated because cinnabar, alunite, and barite do not coexist in the samples examined.

\section{ASTER Imagery}

ASTER imagery (Rockwell, 2010) of the PP AZ shows small clusters of pixels that correspond to quartz and alunite \pm kaolinite centered on the Alta Plana Mine and on the ridge of silicified breccia to the northeast.

\section{SWIR Spectra}

Based on SWIR analyses of hand samples, breccia from the Alta Plana Mine consists of quartz, probable opal, jarosite, kaolinite, alunite, and topaz. Mica-clay minerals in altered volcaniclastic rocks in mine workings near the ridge of silicified breccia northeast of the Alta Plana Mine are dickite and probable halloysite, based on SWIR and XRD analyses. Alteration minerals in porphyritic rocks exposed in landslide scarps southeast and south of the Alta Plana Mine include illite and dickite.

\section{Hydrothermal Mineral Age}

Alunite in the matrix of silicified breccia from the Alta Plana $\mathrm{Hg}$ Mine has a ${ }^{40} \mathrm{Ar} /{ }^{39} \mathrm{Ar}$ date of $10.83 \pm 0.06 \mathrm{Ma}$ (table 1), which is analytically indistinguishable from the date of alunite in the Aurora Canyon alteration zone $(10.87 \pm 0.07 \mathrm{Ma}) \sim 2 \mathrm{~km}$ to the northwest.

\section{Aurora Mining District}

\section{Location}

Secs. 9, 10, 17, 18, 19, 20, 30, T. 5 N., R. 28 E., Mineral

County, Nevada (fig. 1)

\section{History and Production}

Gold-silver veins were discovered in 1860 in an area of the Bodie Hills initially called the Esmeralda Mining District and thought to be in Mono County, California. The
Esmeralda Mining District was soon thereafter renamed the Aurora Mining District, and in 1864 was found by a state boundary survey to be in Nevada Territory (originally Esmeralda County, now Mineral County, Nevada). The towns of Esmeralda and Aurora were established in the early 1860s. Most underground mining occurred between 1860 and 1864 (Stretch, 1867; Wasson, 1878; Clarke, 1882; Hill, 1915), when the population of the district exceeded 6,000. After 1864, production declined precipitously, and by 1865 mining stocks were worth less than "Confederate script" (Wasson, 1878). By 1880, production had decreased to $907 \mathrm{oz} \mathrm{Au}$ and 4,834 oz Ag recovered from 250 t of ore (King and others, 1885). During the early 20th Century $(\sim 1906-18)$, estimated production of 0.6 Mt@0.15 opt Au equivalent (Lawrence, 1987; Couch and Carpenter, 1943; Stone, 1982) was derived from cyanidation of tailings and from small amounts of ore recovered from dumps and old workings (Vanderburg, 1937). In the late 1940s, $\sim 10,000$ t of ore containing $>1$ opt Au (Stone, 1982; Tingley, 1990) were produced from underground mining of the Juniata vein system (fig. 20). Production since the 1980s has been derived from opencut and underground mining of the Humboldt-Hilton, Prospectus, Juniata, and Ann vein systems on Martinez and Humboldt Hills, and in the New Esmeralda area, 4.2 km northeast of the Prospectus vein (Gilbert, 1976; Osborne, 1985; Shaddrick, 1989; Tingley, 1990; Knudsen and Prenn, 2002). From $\sim 1988$ to 1998 these vein systems yielded an estimated $0.3-0.4 \mathrm{Moz} \mathrm{Au}$ and $0.5-0.8 \mathrm{Moz} \mathrm{Ag}$ from 3 to $4 \mathrm{Mt}$ of ore that graded $\sim 0.1$ opt $\mathrm{Au}$ (Knudsen and Prenn, 2002; Nevada Bureau of Mines and Geology, 2009). Production during this period was derived from separate mining operations and may have been counted twice or more in total district production. Measured and indicated resources include a bulk-mineable resource of $\sim 31 \mathrm{Mt} @ 0.031$ opt $\mathrm{Au}$, and an underground resource of $0.19 \mathrm{Mt} @ 0.5$ opt Au (Nevada Bureau of Mines and Geology, 2009). Perlite deposits on Aurora and Bodie Creeks, and on a tributary of Bodie Creek, north and northwest of the district have been episodically mined at small scales (Archbold, 1966).

Total district production reported by Long and others (1998) for the period 1860-1995 is $1.817 \mathrm{Moz} \mathrm{Au}$, 20.605 Moz Ag, and 3.86 Mt of ore. Total production through 1998 was estimated by Knudsen and Prenn (2002) at $1.91 \mathrm{Moz} \mathrm{Au}$. These production totals are largely based on dollar values of bullion and estimated $\mathrm{Au} / \mathrm{Ag}$ from the most productive period (1860-64), when an estimated 1.5 Moz $\mathrm{Au}$ was recovered (Wasson, 1878; Angel, 1881; Ferguson, 1929; Vanderburg, 1937; Couch and Carpenter, 1943).

Accurate weight records do not exist for most early production. Production through 1869, estimated at \$2.4-29.5M (Wasson, 1878; Ross, 1961), was in part reconstructed from recollections of shipping agents and newspaper accounts, as most shipping and assay records were lost or destroyed. Early Aurora production may include initial production from the Bodie Mining District that was milled at Aurora (Blake, 1869; Angel, 1881; Wasson, 1878; Vanderburg, 1937). Furthermore, $\mathrm{Au} / \mathrm{Ag}$ used to convert value to weight varied considerably 


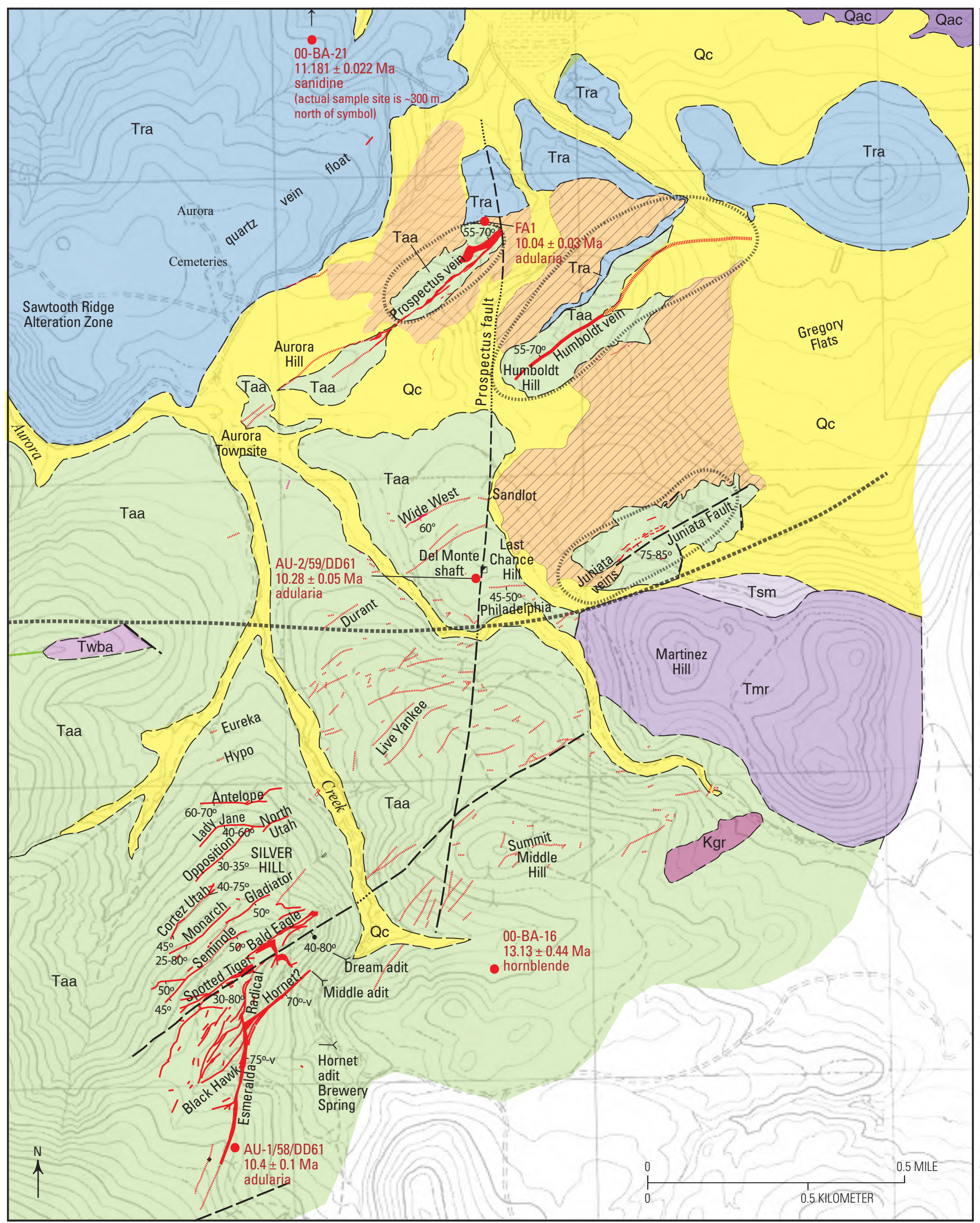

Base modified from U.S. Geological Survey

Aurora, Nev.-Calif., 1989, 1:24,000 
EXPLANATION

\begin{tabular}{|c|c|}
\hline 1 & Mine dumps and disturbed ground \\
\hline Qc & Colluvium and volcaniclastic deposits (Quaternary-Pliocene) \\
\hline Qaca & Trachyandesite of Aurora Crater (Pleistocene) \\
\hline $\mathrm{Tmr}$ & Rhyolite of Martinez Hill (Pliocene) \\
\hline Tsm & Sedimentary rocks of Martinez Hill (Pliocene and Miocene) \\
\hline Tra & Rhyolite of Aurora Creek (Miocene) \\
\hline Twba & Trachyandesite of West Brawley Peak (Miocene) \\
\hline Taa & Trachyandesite of Aurora (Miocene) \\
\hline & Granitic rocks \\
\hline Kgr & Cretaceous granite \\
\hline - - & Contact—Dashed where approximated \\
\hline & Fault-Dashed where approximated, dotted where concealed \\
\hline 40 & Bedding \\
\hline 40 & Foliation \\
\hline 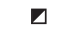 & Mine shaft \\
\hline$\succ$ & Adit \\
\hline ベק & Quartz vein zones-Numbers indicate dip \\
\hline 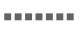 & Color air photo (CAP) lineament \\
\hline 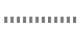 & Open-pit mine \\
\hline
\end{tabular}

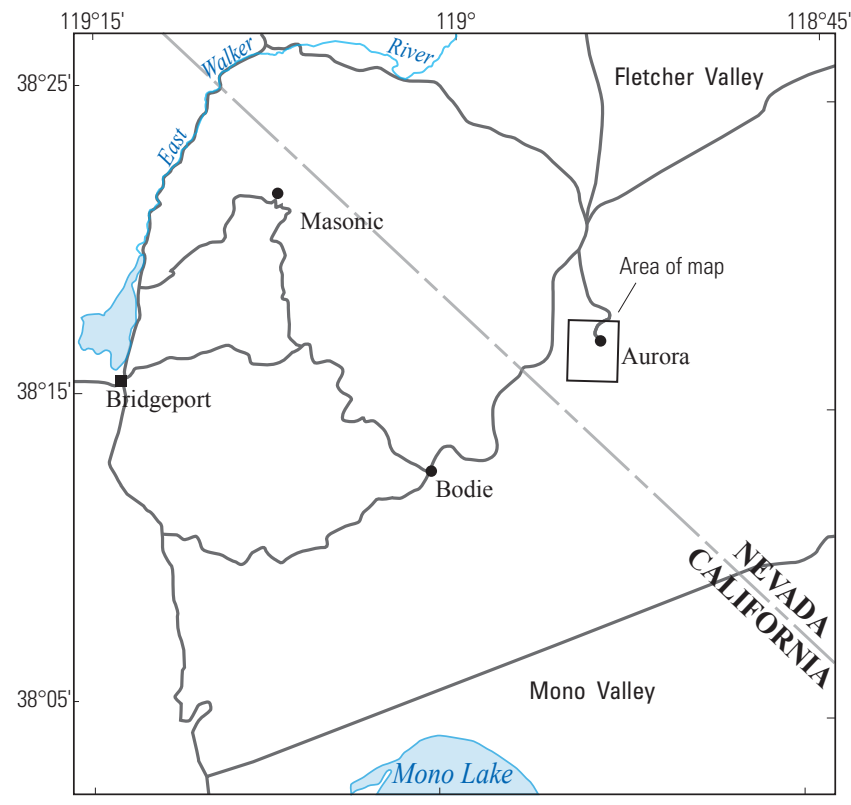

- ${ }^{40} \mathrm{Ar} /{ }^{39} \mathrm{Ar}$ sample site-Number, age, mineral

Figure 20. (Facing page) Geologic map of the Aurora Mining District, Mineral County, Nevada. Geology and vein locations and names modified from Hill (1915), Lawrence (1987), Osborne (1985), Shaddrick (1989), Knudsen and Prenn (2002), and John and others (2012). 
Gold-Silver Mining Districts, Alteration Zones, and Paleolandforms in the Miocene Bodie Hills Volcanic Field

by reference (Hill, 1915; Ferguson, 1929) and mine (Osborne, 1985). From "detailed records" Knudsen and Prenn (2002) estimated a grade of $>2$ opt Au for the first $1.5 \mathrm{Moz}$, implying $\leq 3 \mathrm{Mt}$ of ore. This tonnage would have been derived from underground vein mining mostly during the 1860 s. Based on dimensions of veins, stopes, dumps, and tailings, estimated ore tonnage and recovered Au seem unrealistically high, unless a large volume of early tailings was eroded and (or) Au grades were tens to hundreds of ounces per ton. Wasson (1878) stated that during the first few years "many thousands of tons were milled that produced several thousand dollars per ton." However, specimens of such multiounce ore apparently were not archived.

\section{Stratigraphy}

Mesozoic granitic and metavolcanic rocks and Tertiary trachyandesite and rhyolite are exposed in the eastern and southeastern parts of the district (Hill, 1915; John and others, 2012; fig. 20). Trachyandesite of Aurora ( 13.1-12.6 Ma; table 1), which encloses nearly all veins, unconformably overlies Mesozoic quartz monzodiorite of Aurora and metavolcanic rocks. It is exposed in a roughly elliptical area, $\sim 10 \mathrm{~km}$ north-south by $\sim 5 \mathrm{~km}$ west-east, which is largely defined by younger volcanic rocks. Trachyandesite of Aurora may be as much as $400 \mathrm{~m}$ thick if exposures between the top of East Brawley Peak and granite on the east slope of Middle Hill are unfaulted. Trachyandesite flows and volcaniclastic strata on Middle, Silver, and Martinez Hills have been intruded by porphyritic rocks, including rhyolite and latite dikes and plugs (Lawrence, 1987; Osborne, 1985; Knudsen and Prenn, 2002; John and others, 2012). Altered trachyandesite of Aurora on and south of East Brawley Peak, adjacent to the southwest edge of the district, comprises the East Brawley Peak alteration zone.

Rhyolite of Aurora Creek (11.2 Ma; table 1), rhyolite of Del Monte Canyon ( 11.2 Ma; John and others, 2012), trachyandesite of Del Monte (11 Ma), and trachyandesite of West Brawley Peak ( 11. 5-11.3 Ma; John and others, 2012) unconformably overlie trachyandesite of Aurora to the north, northwest, and west. Rhyolite of Aurora Creek forms a group of small-volume lava domes and includes minor cogenetic pyroclastic flow deposits, especially in the lower reaches of Bodie Creek. It contains 1-9 volume percent phenocrysts of plagioclase and rare quartz, sanidine, hornblende, clinopyroxene, and biotite in a glassy groundmass. Altered flowdomes of rhyolite of Aurora Creek north of Aurora Creek and northwest of the Aurora town site comprise the Sawtooth Ridge alteration zone (fig. 20). Veins in rhyolite of Aurora Creek in and northeast of the Aurora cemeteries, represented largely by float, closely resemble veins in trachyandesite of Aurora.
Rhyolite of Del Monte Canyon forms a set of lowvolume lava domes and associated pyroclastic deposits that are well-bedded, lithic rich, and underlie the lava flows. It contains 6-26 volume percent phenocrysts of plagioclase, quartz, hornblende, biotite, and sanidine in glassy (perlitic in places) to moderately devitrified groundmass. The trachyandesite of Del Monte, which includes basaltic trachyandesite and trachydacite, forms a discontinuous, north-trending series of exposures that consist of lava flows and associated, heterogeneous, laharic debris flow and volcaniclastic deposits. It contains 0-50 volume percent phenocrysts of plagioclase, biotite, clinopyroxene, and hornblende in a weakly devitrified groundmass. The trachyandesite of West Brawley Peak forms a series of lava flows erupted from the moderate-volume composite volcano centered on West Brawley Peak. It contains $\sim 10-35$ volume percent phenocrysts of plagioclase, hornblende, biotite, clinopyroxene, and trace amounts of olivine in a moderately devitrified groundmass. Plagioclase phenocrysts in trachyandesite of West Brawley Peak are characteristically larger (commonly $>1 \mathrm{~cm}$ ) than those in most rocks of the Bodie Hills volcanic field.

Pliocene-Pleistocene rocks of the Aurora volcanic field (John and others, 2012) overlie the trachyandesite of Aurora and other premineralization rocks north, east, and south of the district. These rocks include the rhyolite of Martinez Hill, sedimentary rocks of Martinez Hill, trachydacite of Aurora Peak, trachyandesite of Aurora Crater, and various other trachyandesite and trachydacite lava flows of the Aurora volcanic field. These eruptive rocks vary in age from 3.4 to $0.1 \mathrm{Ma}$ (Gilbert and others, 1968; Silberman and McKee, 1972; Lange and others, 1993; Lange and Carmichael, 1996). Based on drill hole intercepts near Fletcher Junction, $\sim 4 \mathrm{~km}$ north of the Aurora Mining District, trachyandesite of Aurora Crater covers $\sim 150 \mathrm{~m}$ of unaltered colluvial deposits that overlie at least $455 \mathrm{~m}$ of altered mafic tuffs and lacustrine deposits (Nevada Exploration Inc., 2013). These strata comprise basin-fill of Fletcher Valley (Tfv of John and others, 2015), and alteration of the mafic tuffs and lacustrine deposits is interpreted to have coincided with formation of Aurora veins.

\section{Structure}

Predominant faults in the district contain quartz veins that number in the hundreds if all the short and unaligned vein segments are counted (Brady's map of Aurora and Esmeralda, 1862; fig. 20). Fault sets (and veins in them) presumably reflect stress accommodation within the Walker Lane transtensional structural zone of strike-slip displacement and extension. Vein attitudes and kinematic indicators in the Aurora Mining District are consistent with maximum horizontal extension oriented $\mathrm{N} 60^{\circ} \mathrm{W}$ and maximum horizontal compression oriented $\mathrm{N} 30^{\circ} \mathrm{E}$, similar to those of mineralized structures in the Masonic Mining District (John and others, 2012). 
Most veins strike $\mathrm{N} 45-70^{\circ} \mathrm{E}$ and dip $20-75^{\circ} \mathrm{SE}$, reflecting fault orientations in which the veins formed. Episodic displacement along northeast-striking faults created dilatancies in which vein minerals precipitated, as evidenced by distinct opposing layers of vein minerals, by numerous narrow crosscutting veins in wall rocks, and to a lesser extent, by several generations of internal wall-rock fragments in wide veins.

Several short vein segments, the prominent Esmeralda vein, and the Prospectus Fault, strike north-south to $\mathrm{N} 10^{\circ} \mathrm{E}$, and dip at high angles or are vertical. These veins and the Prospectus Fault define a second significant structural trend in the district. Post-vein, right-lateral movement of at least $545 \mathrm{~m}$ on the Prospectus Fault has been invoked to explain offset of veins and rhyolite of Aurora Creek in the eastern part of the district from veins and rhyolite in the western part (fig. 20; Hill, 1915; Green, 1964; Osborne, 1985, 1991). Other pre-(?) and post-vein faults (not shown of fig. 20) include a $\mathrm{N} 10-30^{\circ} \mathrm{W}$-trending set on Middle Hill, $\mathrm{N} 70^{\circ} \mathrm{W}$ faults that are most prominent on East Brawley Peak (Silberman and others, 1995; Lawrence, 1987; Breit, 2000), and a west-east set that has dismembered and laterally displaced northeast-striking veins for as much as $15 \mathrm{~m}$ (Knudsen and Prenn, 2002). Postvein faults offset alteration zones and volcaniclastic deposits in the vicinity of the Juniata vein system (fig. 20; Osborne, 1985).

Thin seams of gouge, mostly in hanging walls of veins, and fluvial gravels interpreted as sag deposits (Knudsen and Prenn, 2002), also attest to post-vein strike-slip movement. Clasts of 2.5 Ma Martinez rhyolite in the sag deposits, coupled with the absence of clasts of trachyandesite of Aurora Crater ( 0.25 Ma; Silberman and McKee, 1972), constrain sag deposit ages and at least some postmineralization fault displacement to $<2.5 \mathrm{Ma}$. A west-east lineament that is conspicuous on color aerial photography (CAP lineament, fig. 20) separates veins on Last Chance Hill and Humboldt from Martinez Hill and veins on Middle Hill and Silver Hill. This lineament may mark a fault that displaced some veins and volcanic strata down-to-the-north.

Veins apparently extend northeast of the district under colluvium and trachyandesite of Aurora Crater to the New Esmeralda area where veins similar to those in the Aurora Mining District were mined underground in the 1860s and by open cut in the 1990s. The presence of veins beneath Aurora Crater north of the district has been proposed based on float and geochemical anomalies in the tributary of Bodie Creek that drains the district to the north. Other evidence of covered veins includes altered and geochemically anomalous strata intersected in drill holes (Nevada Exploration Inc., 2013). Float of chalcedonic and layered quartz veins, and a mined vein in rhyolite of Aurora Creek $\sim 0.5 \mathrm{~km}$ northeast of Aurora cemeteries, may be coeval with veins in trachyandesite of Aurora; the rhyolite may contain or cover other veins. Poorly exposed veins also have been intersected by drill holes southeast of the Juniata Mine (Osborne, 1985), and additional veins may be covered by rhyolite of Martinez Hill.

\section{Forms of Gold-Silver Mineralization}

\section{Veins and Vein Zones}

All precious metal production in the Aurora Mining District has been derived from veins mined underground prior to $\sim 1950$, and mined by open pit in the 1980s, 1990s, and early 2000s. Between 1860 (when the district was discovered) and 1862 , more than 300 veins were located and named on Silver, Middle, Last Chance, Humboldt, and Martinez Hills (Brady's map of Aurora and Esmeralda, 1862). Ore was produced from $\sim 30$ veins. Other veins are exposed in the New Esmeralda area $\sim 4.2 \mathrm{~km}$ northeast of the Prospectus vein. Although partially covered by younger strata, the Aurora district vein system apparently extends northeast from Silver Hill to at least the New Esmeralda area, a distance of $\sim 7.5 \mathrm{~km}$.

Many of the early claim locations covered segments and branches of veins that, based on structural and textural characteristics, can be grouped into vein zones (fig. 20). Vein zones on Silver Hill consist of meters-thick tabular segments of layered quartz veins and subparallel, centimeters-thick layered quartz veins that occur commonly in the footwall of thicker vein segments. Thick vein segments are contiguous along strike for tens to hundreds of meters, although thicknesses and dips vary considerably over short strike distances. Extremities of vein zones are marked by thin anastomosed veins that merge with fractures. With the exception of the Esmeralda vein zone, which strikes $\mathrm{N} 10^{\circ} \mathrm{E}$ and dips $75^{\circ} \mathrm{E}-\mathrm{vertical}$, vein zones on Silver Hill predominantly strike $\mathrm{N} 40^{\circ} \mathrm{E}$ and dip $50 \pm 20^{\circ} \mathrm{SE}$. One of the largest vein zones, the Spotted Tiger-Bald Eagle, is $\sim 0.6 \mathrm{~km}$ long, dips $30-80^{\circ} \mathrm{SE}$, and is as much as $\sim 9 \mathrm{~m}$ thick (fig. 20).

Thick veins consist of tens to $>100$ laterally symmetrical layers of fine-grained and chalcedonic quartz. Central and internal layers commonly enclose small (centimeter dimensions) voids lined with millimeter-sized or smaller quartz crystals; other layers consist of opposed centimeter-sized euhedral quartz crystals. Adularia is sparingly present in some quartz layers, but most has been replaced by quartz or sericite. Calcite is uncommon in layers, although calcite pseudomorphs and perimorphs are present in most veins. They form unoriented "blades" of fine-grained quartz, and tabular voids enclosed by fine-grained quartz crystals, respectively ("lattice-type" bladed quartz after calcite; Etoh and others, 2002); both forms occur in centimeter-wide layers that are as much as 50 volume percent void. Ore in vein zones reportedly occurred as discontinuous layers (submillimeters to centimeters thick) and clots (millimeters to centimeters wide) of fine-grained sulfide minerals, electrum, and sericite that alternate with quartz layers and constituted as much as several volume percent of the vein.

The Prospectus, Humboldt, Juniata, and New Esmeralda vein systems, and some veins on Last Chance Hill, were inaccessible during the period of this investigation because of active milling operations (ore transported from the Midas district, Humboldt County, Nevada). The N50-60 E-trending 
Prospectus-Humboldt vein system is exposed for $\sim 1,850 \mathrm{~m}$, and consists of veins that vary in width from $<30 \mathrm{~cm}$ to $9.1 \mathrm{~m}$ and dip $55-70^{\circ} \mathrm{NW}$ (Osborne, 1985). The Juniata vein system consists of three subparallel veins that strike $\mathrm{N} 60-85^{\circ} \mathrm{E}$, dip $75-85^{\circ} \mathrm{SE}$, and are as much as $15 \mathrm{~m}$ thick. Descriptions and images of these vein systems in Osborne (1985) demonstrate a similarity to Silver Hill vein zones. The New Esmeralda vein system is exposed in an open pit in secs. 9, 10, T. 5 N., R. 28 E. The vein system in the pit consists of six layered veins that are $1-1.5 \mathrm{~m}$ wide, and numerous narrower veins between and adjacent to wider veins. Wide veins strike $\sim \mathrm{N} 30^{\circ} \mathrm{E}$ and dip $\sim 75^{\circ} \mathrm{NW}$. Based on attitudes of chalcedonic sediments that filled a void internal to quartz layers, original vein dips were $50-70^{\circ}$ (fig. 21).

Present vein dips may be $\sim 5-25^{\circ}$ steeper than vein dips during deposition. If present vein declinations have been reversed by fault displacement, then the dip change approaches vertical. However, no stratigraphic evidence for significant tilting exists, and present and original vein attitudes apparently differ by no more than a few degrees.

A second type of vein zone consists of numerous closely spaced, subparallel quartz veins, quartz-matrix breccias, and internal trachyandesite septa that collectively define a tabular geometry. These vein zones are tens to hundreds of meters long and meters to tens of meters wide; most dip steeply southeast (for example, Wide West and other veins on Last Chance Hill and Middle Hill; fig. 20). Within these vein zones, individual veins are centimeters to tens of centimeters wide and consist of fine-grained to chalcedonic quartz in which layering is less pronounced or absent. Tabular quartz-matrix breccias, also centimeters to tens of centimeters wide, consist of centimeter-sized fragments of trachyandesite in matrices of fine-grained to chalcedonic quartz, lesser K-feldspar, sericite, and calcite, and rare sulfide minerals, mostly pyrite. Calcite is typically coarse-grained (millimeter-sized crystals) and usually occurs in central parts of veins and matrices, suggesting a late paragenetic position. Fluorite, mostly in cubic crystals, is locally found in veins near the Del Monte shaft (fig. 20) on surfaces of fine-grained drusy quartz, and encrusted by similar quartz; it is also paragenetically late. Trachyandesite between closely spaced veins, and trachyandesite fragments in breccias, are densely silicified or replaced by quartz-sericite-pyrite assemblages. Internal trachyandesite septa in wide vein zones are altered to propylitic assemblages.

A third type of vein zone is represented solely by the $\mathrm{N} 10^{\circ} \mathrm{E}$-striking, near-vertical Esmeralda-Radical vein zone on Silver Hill (fig. 20), which was the district discovery site in 1860. The Esmeralda-Radical vein zone is as much as $18 \mathrm{~m}$ wide (Hill, 1915) and is the widest in the district, and among the longest at $0.8 \mathrm{~km}$. It consists of a resistant tabular mass that includes several generations of quartz breccia and stockwork (arbitrarily distinguished by relative matrix and clast proportions) that include trachyandesite clasts, much like the Comstock Lode (Vikre, 1989). Breccia matrices and stockwork veins are composed of quartz, lesser K-feldspar, sericite, and calcite, and uncommon sulfide minerals (mostly pyrite). Euhedral quartz crystals in vugs and veins vary in size from submillimeters to centimeters. Most calcite is internal to quartz in matrices, implying a late paragenetic position. Trachyandesite clasts are largely replaced by fine-grained to chalcedonic quartz, K-feldspar, and pyrite; some K-feldspar has been altered to sericite.

\section{Ore Bodies}

Mines in the Aurora Mining District are largely inaccessible, mineralized samples on dumps are sparse, and documented archival ore specimens are few and small (most are centimeter in size). Descriptions of 19th century mining, stopes, and ore occurrences, mostly from early literature and unpublished reports (Clarke, 1882; Hill, 1915; Payne, 1965; Lawrence, 1987; Shaddrick, 1989; Rhoden, 1992), are uneven in detail, and ore bodies can only be described generally. Ore produced from 1860 to 1864 apparently contained several or more ounces per ton gold. As described by Hill (1915), ore occurred in rich "streaks," as much as $15 \mathrm{~cm}$ wide, that consisted of quartz, adularia, tetrahedrite, pyrite, chalcopyrite, $\mathrm{Au}$ (presumably electrum), and a Au-Ag-Se phase. The value of $\mathrm{Au}$ in early mined ores exceeded that of $\mathrm{Ag}$, where reported, by 2-5 times (Burchard, 1884), implying Au/Ag of $\sim 0.13-0.31$ (gold $=\$ 20.68 / \mathrm{oz}$; silver $=\$ 1.29 / \mathrm{oz}$ ).

Ore within vein zones on Silver Hill raked downdip at high angles. It usually was positioned along or internal to hangingwalls or footwalls, and seldom comprised entire vein widths. Clarke (1882) described the high-grade ores (called "rich chambers"), which were mined out by 1864 , as occurring in wider parts of otherwise barren veins. Five such chambers were mined from a 1,500 ft-long section of the Utah-Cortez vein on Silver Hill. One chamber that extended from the surface to $-150 \mathrm{ft}$, was $50-75 \mathrm{ft}$ long, $20-25 \mathrm{ft}$ wide, and contained 20,000 $\mathrm{t} @ \sim 5$ opt Au. Unmineralized parts of the vein were $3 \mathrm{ft}$ wide. Ore in Antelope vein on Silver Hill averaged $\sim 7-15$ opt Au equivalent (Lawrence, 1987). On Last Chance Hill, five high-grade ore shoots in the Wide West vein were 60-120 ft below the surface, 16-60 ft wide, and 100-200 ft long (Lawrence, 1987). Some veins were mined to depths of $500 \mathrm{ft}$, but most stoping terminated tens to several hundreds of feet below the surface. At $800 \mathrm{ft}$ in the Del Monte and Juniata shafts, heavy water flows prevented deeper excavation (Burchard, 1884). Veins have been intercepted in drill holes at depths exceeding $300 \mathrm{~m}$, although on Silver Hill, veins transitioned downward from contiguous veins (meters wide) at the surface to narrower, low-grade to barren, zones of stockwork veins and silicification (Lawrence, 1987; Rhoden, 1992). 


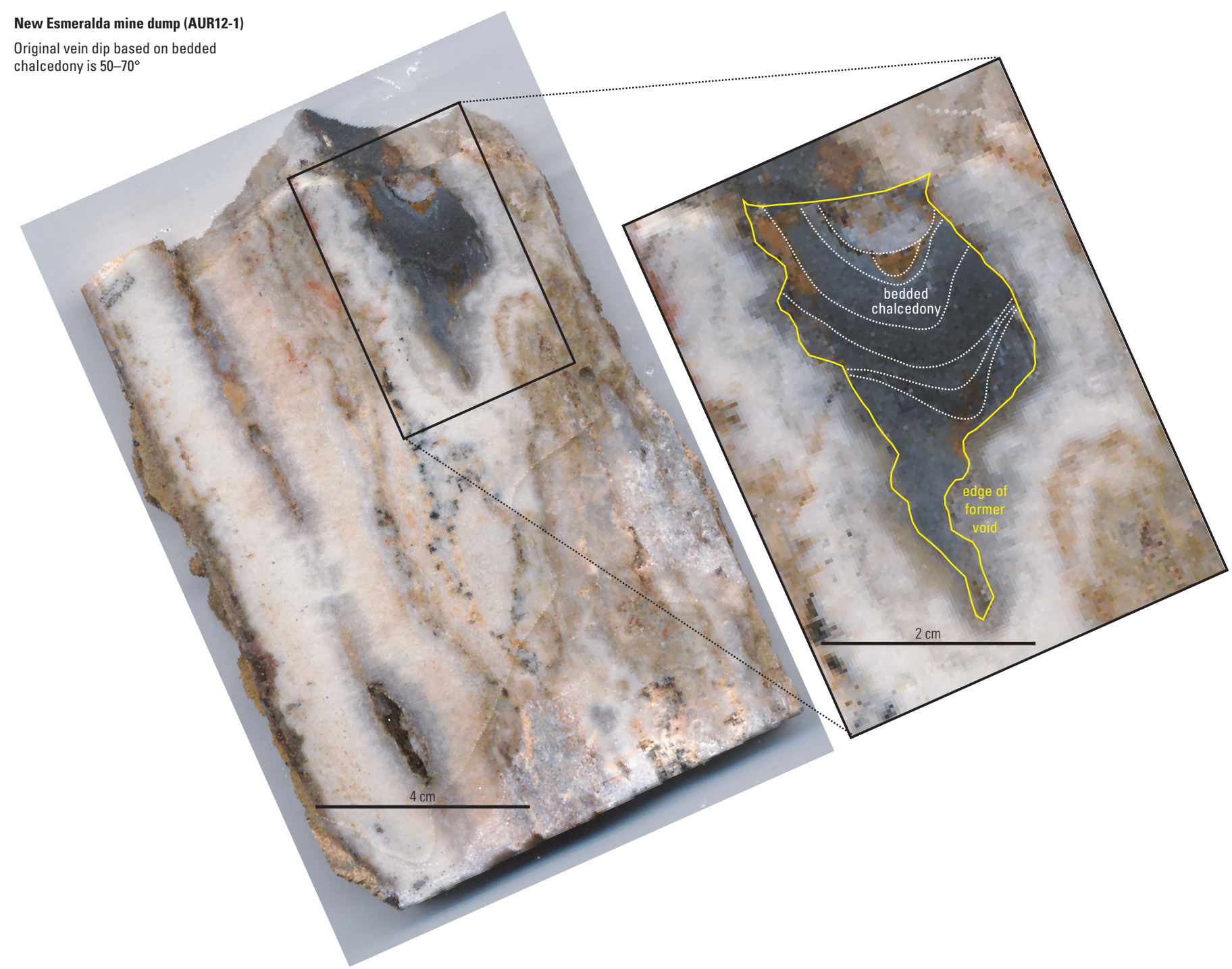

Figure 21. Image of a sample from the Aurora Mining District. Layered vein from New Esmeralda Mine dump with a restored $65^{\circ}$ dip based on bedded chalcedonic sediments that filled an internal void (enlarged inset on left). Relative to $\sim 75^{\circ}$ dips of wide veins exposed in the high wall, vein declinations may have changed since deposition ( $10.5 \mathrm{Ma})$ by $5^{\circ}$ to as much as $80^{\circ}$ if declinations are reversed.

\section{Juniata-Prospectus Vein Minerals}

Detailed published descriptions of vein mineral assemblages, textures, and paragenetic relationships are limited to veins in the northeastern part of the district (Osborne, 1985). The Juniata and Prospectus vein systems consist of variable proportions of quartz, adularia, pyrite, chlorite, electrum, acanthite, naumannite, bromargyrite, and barite that comprise three partially cospatial depositional stages: early barren, ore stage, and post-ore stage barren. In Juniata veins, stage 1 mineralization is mainly situated along vein margins. It consists of trachyandesite fragments with as much as 30 volume percent pyrite that are cemented by crustiform quartz and lesser calcite that is replaced by quartz \pm adularia. At higher elevations, most stage 1 quartz has colloform or botryoidal textures. Stage 2, the ore stage, consists of greenish-tinted quartz+adularia that has textural and grain size similarities to stage 1 . In stage 2 , electrum, with variable $\mathrm{Au} / \mathrm{Ag}$, acanthite, naumannite, and pyrite are closely associated. Stage 3 is characterized by crustiform vuggy quartz and replacement of calcite by quartz. Throughout the Juniata vein, $\mathrm{Au} / \mathrm{Ag}$ decreases with depth. 


\section{Mineral Compositions in Silver Hill and Middle Hill Veins}

Based on petrographic and semiquantitative SEM and XRD analyses, metallic minerals in archival specimens and dump samples from the Antelope, Wide West, Martinez, Crocket (figs. 22, 23, 24), and Amador Mines include pyrite, acanthite (with minor amounts of $\mathrm{Se}, \mathrm{Cu}$, and $\mathrm{Sb}$ ), naumannite, sphalerite (with minor $\mathrm{Cd}$ and no detectable Fe or $\mathrm{Mn}$ ), galena, polybasite $\left(\sim \mathrm{Ag}_{15} \mathrm{Cu}_{2.6} \mathrm{Sb}_{1.5} \mathrm{As}_{0.7} \mathrm{Se}_{0.7} \mathrm{~S}_{11}\right)$, tetrahedrite $\left(\sim\left(\mathrm{Cu}_{7} \mathrm{Ag}_{3} \mathrm{Zn}_{2}\right)_{12} \mathrm{Sb}_{4.2} \mathrm{~S}_{13}\right)$, chalcopyrite, arsenopyrite, and a Ag-Au-S mineral $\left(\sim \mathrm{Ag}_{4} \mathrm{AuS}_{3}\right)$. SEM analyses also suggest the presence of submicrometer intergrowths of Ag-Au-Sb-S-Se minerals, because atomic proportions of many metallic phases do not match those of documented minerals. Two compositional groups of electrum, $\sim \mathrm{Ag}_{0.5 \pm 0.1} \mathrm{Au}_{0.5 \pm 0.1}$ and $\sim \mathrm{Ag}_{0.2 \pm 0.1} \mathrm{Au}_{0.8 \pm 0.1}$, may be present within a single petrographic section; variable electrum compositions may, in part, reflect the absence of buffering by an Ag phase. Based on textures of mineral assemblages and on the absence of copper and iron oxide minerals, most imaged minerals are interpreted to be hypogene. Some Ag-As-Au-S phases that enclose other sulfide minerals may be all or part supergene.

In addition to the imaged minerals, pearcite, proustite, covellite, and barite have been reported (Vanderburg, 1937; Osborne, 1985; Knudsen and Prenn, 2002). Breit (2000) reported Te concentrations of as much as $20 \mathrm{ppm}$ in vein samples analyzed by bulk methods, but no Te minerals were identified during this investigation.

\section{Minor Elements in Rocks}

Samples of veins and altered wall rock (mostly trachyandesite of Aurora), collected and analyzed in 1967-68 by the U.S. Geological Survey (Breit, 2000), contain elevated concentrations of $\mathrm{Au}, \mathrm{Ag}, \mathrm{As}, \mathrm{Sb}, \mathrm{Hg}, \mathrm{F}, \mathrm{Mo}, \mathrm{Te}, \mathrm{Cu}, \mathrm{Pb}$, $\mathrm{Zn}$, and $\mathrm{W}$, with the highest values in vein samples. The distribution of $\mathrm{W}$ abundances in altered trachyandesite and vein samples was interpreted by Breit (2000) as evidence that Silver Hill was the hottest and deepest part of the Aurora district vein system. Other geochemical zonation, including decreasing $\mathrm{Ag} / \mathrm{Au}$ and $\mathrm{As} / \mathrm{Sb}$, and, to an extent, decreasing Te, Mo, W, and Sn concentrations northeast from Silver Hill, was attributed by Breit (2000) to a hydraulic (topographic) gradient, to regional zoning of coeval alteration on East Brawley Peak and Aurora veins, or to separate hydrothermal cells within the Aurora vein system. Minor element concentrations in 14 samples of trachyandesite wall rocks of the Juniata and Prospectus vein systems include local, elevated concentrations of Mo, Ag, As, F, and Hg (Osborne, 1985). Elevated minor element concentrations in 13 vein samples from mine dumps throughout the district (table 1-7) include $\mathrm{Au}$ (0.51-84.8 ppm),
Ag (6-1,370 ppm), Hg (0.43-1.18 ppm), As (257-4,290 ppm), $\mathrm{Bi}(\sim 4-37 \mathrm{ppm}), \mathrm{Cu}(131-1,090 \mathrm{ppm})$, Mo ( 53-1,310 ppm), $\mathrm{Sb}(\sim 21-275 \mathrm{ppm}), \mathrm{Se}(\sim 1-203 \mathrm{ppm})$, and Te ( 4-16 ppm). One or two samples contain elevated concentrations of $\mathrm{Co}$, $\mathrm{Mn}, \mathrm{Bi}, \mathrm{Pb}, \mathrm{Tl}$, and (or) $\mathrm{Zn}$.

\section{Fluid Inclusion Microthermometry and Compositions}

Fluid inclusion microthermometric data have been obtained from samples of the Juniata, Wide West, Humboldt, and other veins (Nash, 1972; Osborne, 1985; Knudsen and Prenn, 2002), and one fluid stable isotope composition is reported (O’Neil and Silberman, 1974). However, most analyzed samples are not precisely located or paragenetically well constrained. The following microthermometry summary is derived largely from Knudsen and Prenn (2002), supplemented by deductions regarding spatial relationships among veins.

Fluid temperature ranges implied by inclusion homogenization in samples of vein quartz in the main part of the district (Silver, Middle, Last Chance, Aurora, and Humboldt Hills) are $<180,190-240$, and $>250^{\circ} \mathrm{C}$; most fluid salinities are less than a few weight percent $\mathrm{NaCl}$ equivalent. These temperature ranges correspond to different veins and to different layers and stages within veins. The episodic presence of K-feldspar in quartz samples with $190-240{ }^{\circ} \mathrm{C}$ fluids, and sericite alteration of wall-rock feldspars, suggests that fluid $\mathrm{pH}$ was controlled by the K-feldspar-muscovite stability boundary at near-neutral $\mathrm{pH}$. Inclusion populations inferred to represent boiling at $<180{ }^{\circ} \mathrm{C}$ occur in some clear quartz crystals, and apparently represent late-stage fluids. Inclusions with homogenization temperatures $>250{ }^{\circ} \mathrm{C}$ have salinities of 3-6 weight percent $\mathrm{NaCl}$ equivalent; some contain a daughter mineral that may be dawsonite. Lower inclusion homogenization temperatures $\left(<200^{\circ} \mathrm{C}\right)$ in New Esmeralda area veins broadly correlate with relatively abundant chalcedonic quartz, implying shallower depths of formation. Temperature-elevation relationships of fluid inclusion populations show no clear district-wide trends, and in Juniata Mine samples they imply a "reversed" thermal gradient because populations with higher temperatures occur in vein samples collected near the present surface.

Fluid inclusions in quartz, most closely associated paragenetically with ore minerals in the Wide West vein and in veins on Silver Hill, homogenize at $230-236^{\circ} \mathrm{C}$, have salinities of $1-3$ weight percent $\mathrm{NaCl}$ equivalent, and boiled intermittently, requiring minimum quartz depositional depths of $260 \mathrm{~m}$ (Haas, 1971) below the potentiometric surface. Relative to the present elevation of the Wide West vein $(\sim 7,600 \mathrm{ft})$, a paleopotentiometric surface (paleowater table) was at $\sim 8,460 \mathrm{ft}$. Relative to present elevations of stoped veins on Silver Hill, $\sim 7,800 \mathrm{ft}$ at the Antelope vein to $8,400 \mathrm{ft}$ at the 

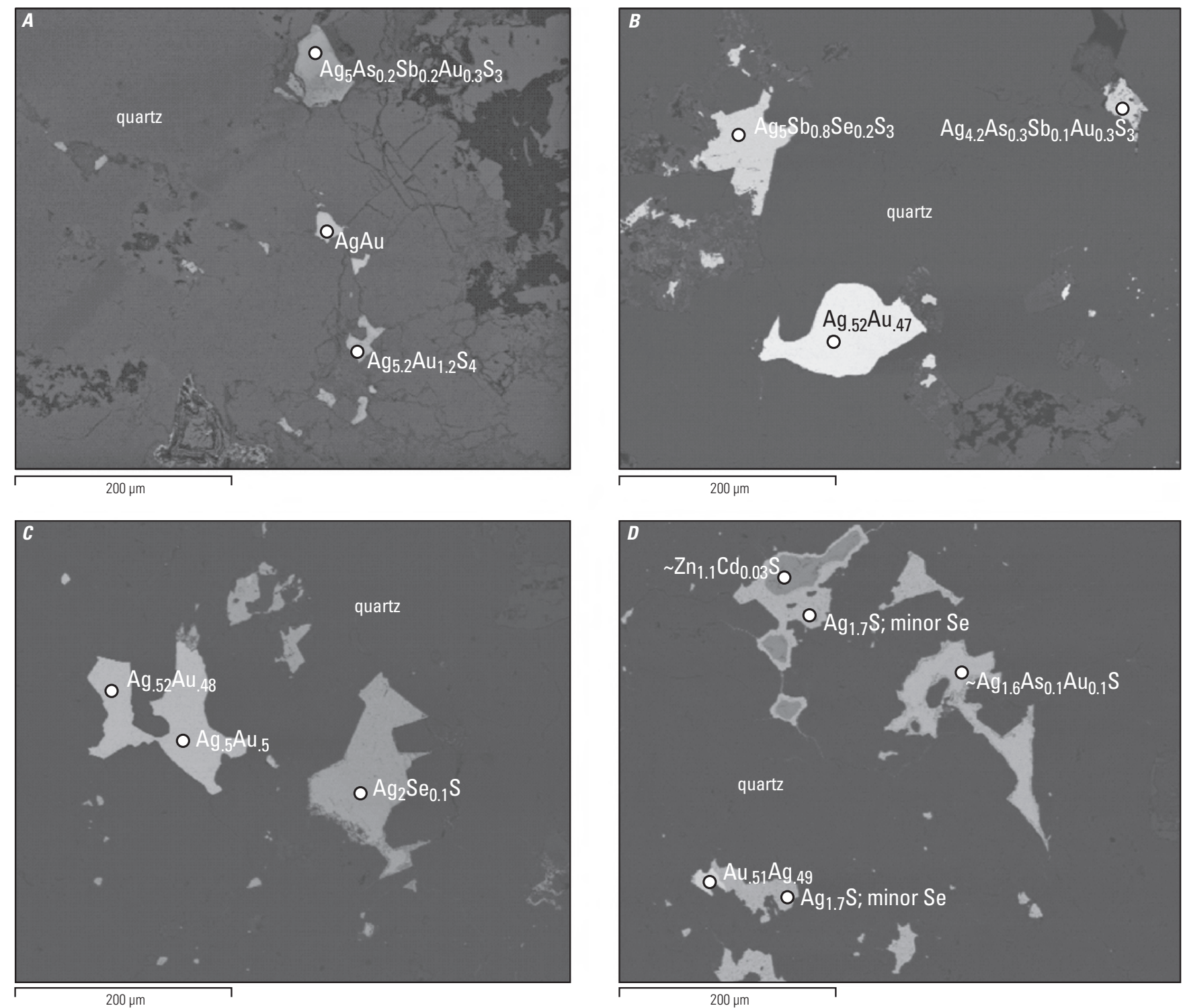

Figure 22. Secondary electron images of an archival vein specimen from the Crocket Mine on Last Chance Hill, Aurora Mining District. $A, B, C$, and $D$ correspond to specimen K2085 (Keck museum collection, University of Nevada Reno). Mineral identifications and approximate atomic proportions for these images, and for images in figures 23 and 24 , were determined petrographically and by scanning electron microscopy algorithms. Imaged phases include quartz, electrum with subequal Au and Ag, a Ag-As-Sb-Au-S mineral or intergrowth of minerals, Ag-Au-S $\left(\sim \mathrm{Ag}_{5.2} \mathrm{Au}_{12} \mathrm{~S}_{4}\right), \mathrm{Ag}$-Sb-S-Se $\left(\sim \mathrm{Ag}_{5} \mathrm{Sb}_{0.8} \mathrm{~S}_{3} \mathrm{Se} \mathrm{e}_{02}\right)$, acanthite with minor Se, and sphalerite with minor Cd. 

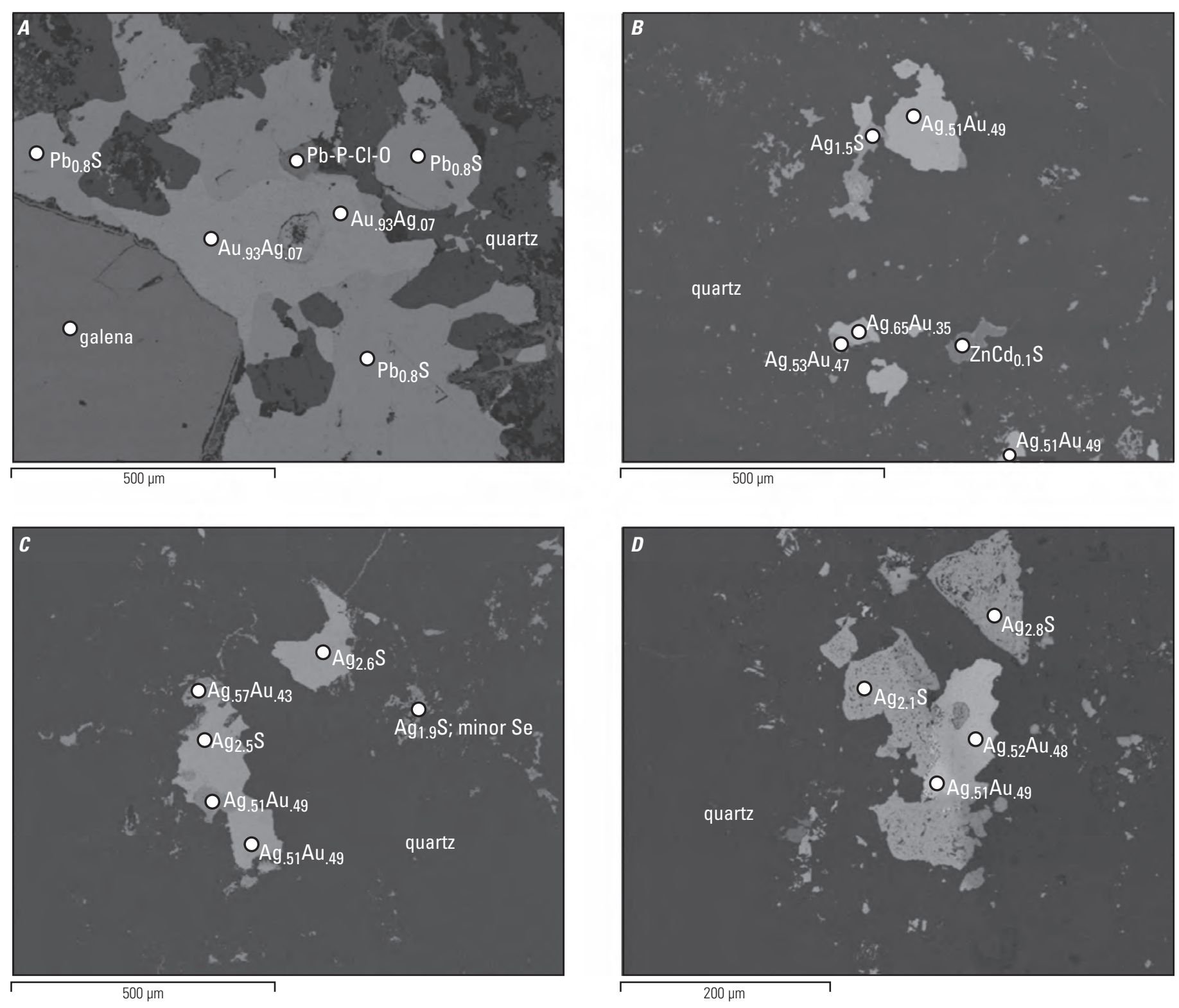

Figure 23. Secondary electron images of $A$, an archival vein specimen from the Antelope Mine, Silver Hill, Aurora Mining District (specimen K011, Keck museum collection, University of Nevada Reno). B, C, D, An archival vein specimen from the Martinez Mine, Martinez Hill, Aurora Mining District (specimen K208, Keck museum collection, University of Nevada Reno). Imaged phases include quartz, galena, electrum with variable $\mathrm{Au}$ and $\mathrm{Ag}$, acanthite with minor Se, and sphalerite with minor $\mathrm{Cd}$. 

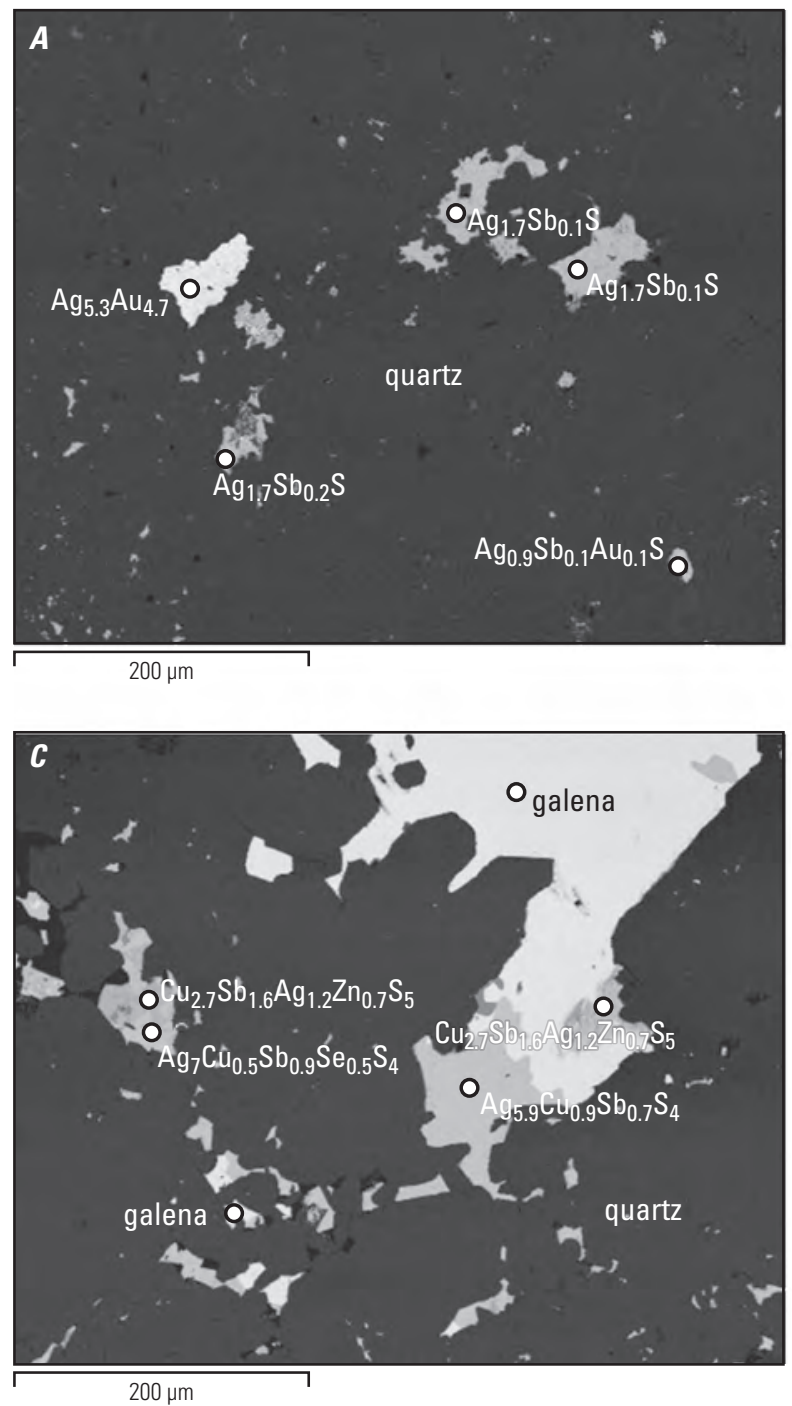

southern extremity of the Esmeralda vein (fig. 20), paleopotentiometric surfaces were at $8,660-9,260 \mathrm{ft}$. Although there is no identified Esmeralda vein microthermometry to further constrain paleoelevations, a paleopotentiometric surface at 9,260 ft is near the present elevation of East Brawley Peak ( $\sim 9,400 \mathrm{ft}), \sim 1.3 \mathrm{~km}$ southwest of the Esmeralda vein. The summit of East Brawley Peak consists of densely silicified and clay-altered trachyandesite of Aurora. However, East Brawley Peak alteration zone assemblages include $\sim 12 \mathrm{Ma}$ alunite, and Aurora district veins formed at 10.5-10 Ma (table 1), precluding a close temporal link between the alteration zone and veins.

The stable isotope composition of fluid in an unattributed vein sample, determined by bulk analysis, is within the range of present meteoric waters in the Great Basin $\left(\delta \mathrm{D}=-124 \%\right.$; calculated $\delta^{18} \mathrm{O}_{250}{ }^{\circ} \mathrm{C}=-12 \%$; O'Neil and Silberman, 1974).

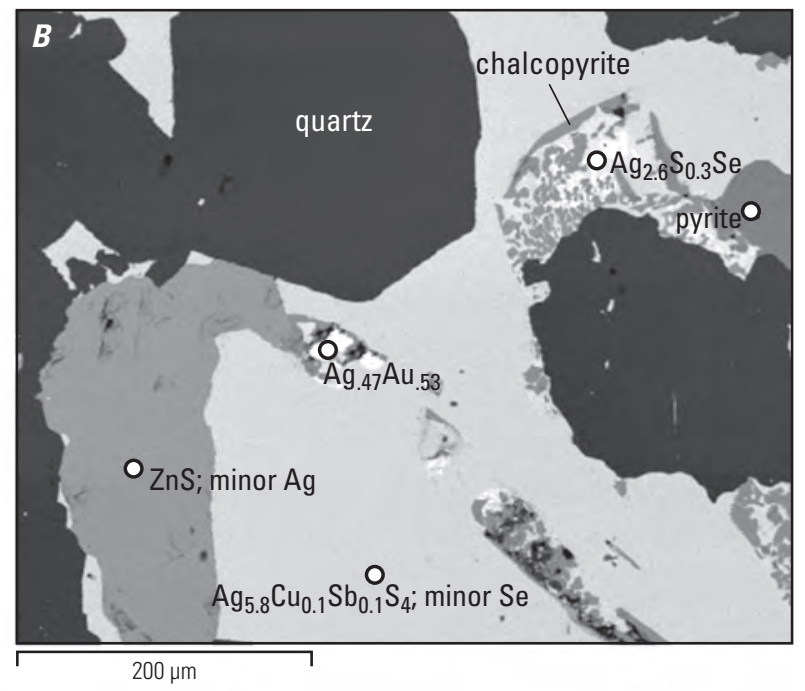

Figure 24. Secondary electron images of $A$, an archival vein specimen from the Antelope Mine, Silver Hill, Aurora Mining District (specimen K229, Keck museum collection, University of Nevada Reno). B, C, An archival vein specimen from the Wide West Mine, Last Chance Hill, Aurora Mining District (specimen K2079, Keck museum collection, University of Nevada Reno). Imaged phases include quartz, electrum with subequal $\mathrm{Au}$ and $\mathrm{Ag}$, a $\mathrm{Ag}$-Sb-S mineral $\left(\sim \mathrm{Ag}_{1.7} \mathrm{Sb} \mathrm{b}_{0.1} \mathrm{~S}\right)$, a Ag-Sb-Au-S mineral $\left(\sim \mathrm{Ag}_{0.9} \mathrm{Sb}_{0.1} A \mathrm{u}_{0.1} \mathrm{~S}\right)$, a Ag-Cu-Sb-S-Se mineral, a Cu-Sb-Ag-Zn-S mineral, chalcopyrite, sphalerite, pyrite, and galena.

\section{Sulfur Isotope Compositions of Vein Minerals}

The $\delta^{34} \mathrm{~S}$ values of sulfide minerals in Aurora district veins vary from -8.7 to $10.9 \%$ (table 2 ). This relatively large range may, in part, reflect sample quality in that most analyzed samples contain small proportions of sulfide minerals and large proportions of vein quartz. High $\delta^{34} \mathrm{~S}$ values $(10.9,10.6$, and $8.3 \%$ ) may indicate unrecognized sulfate minerals in the analyzed samples. Low $\delta^{34} \mathrm{~S}$ values $(-8.7$, $-8.5,-8.3,-7.0$, and $-6.3 \%$ ) are similar, in part, to those of sulfide minerals in the Masonic Mining District (table 2), which are consistent with $\mathrm{SO}_{2}$ disproportionation. Therefore, Aurora vein sulfide minerals may record sulfide-sulfate isotope fractionation, or several sulfur sources. Detailed paragenetic, geochronologic, and microthermometric investigations are needed to resolve temporal relationships among the numerous hydrothermal mineral assemblages in the vicinity of Aurora (East Brawley Peak, Spring Peak, and Sawtooth Ridge alteration zones). 


\section{Wall-Rock Alteration}

Several styles of hydrothermal alteration have modified volcanic rocks that enclose Aurora district veins. The trachyandesite of Aurora, the host rock for nearly all veins, has been altered throughout the district by partial to complete replacement of plagioclase, hornblende, clinopyroxene, and biotite phenocrysts, and matrix minerals, to variable proportions of chlorite, albite, calcite, montmorillonite, and lesser fine-grained quartz, sericite, and pyrite (iron oxides). Although few continuous exposures exist, these gray-green to greenish propylitized rocks apparently extend to contacts with younger rocks. The critical relationship between propylitized trachyandesite that encloses the Esmeralda vein and quartzalunite-clay-mica-altered trachyandesite of Aurora of the East Brawley Peak alteration zone is masked by float, and crosscutting relationships that might distinguish the two alteration assemblages have not been observed. The distribution of epidote, which occurs in thin veins $(\leq 1 \mathrm{~mm})$ in trachyandesite on mine dumps along Aurora Creek east of the Esmeralda vein (for example, Dream adit), may reflect older, high temperature fluids that formed the East Brawly Peak alteration zone. Elevated fluid temperatures in altered rocks on East Brawley Peak, and minor element zonation in the Aurora Mining District (Breit, 2000) also support alteration of trachyandesite of Aurora in the southwestern part of the district prior to vein deposition.

Gray-lavender trachyandesite adjacent and internal to Aurora district veins is variably replaced by quartz and K-feldspar, which partially obscure primary porphyritic texture. Light-gray to beige trachyandesite, adjacent to and in vein zones, reflects alteration of $\mathrm{K}$-feldspar to sericite, illite, quartz, pyrite, and montmorillonite, and replacement of trachyandesite phenocrysts and matrices by these minerals. In densely veined trachyandesite, quartz replacement is more pronounced between and adjacent to veins. Quartz-K-feldsparsericite-illite-pyrite-montmorillonite alteration grades distally from veins into propylitized trachyandesite, although pyrite is most abundant in vein selvages and in internal fragments of trachyandesite. Vein K-feldspar and sericite occur in aggregates, seams, and pockets (millimeters to centimeters in size) in quartz.

\section{ASTER Imagery}

ASTER imagery (Rockwell, 2010) of the Aurora Mining District shows diffuse and small clusters of pixels that extend from Silver Hill to Gregory Flat (fig. 20); these pixels correspond to illite and lesser quartz. Densely clustered pixels coincident with the Prospectus, Humboldt, and Juniata open pits, dumps, and tailings correspond to quartz and montmorillonite \pm kaolinite.

\section{SWIR Spectra}

SWIR analyses of hand samples of propylitized trachyandesite from the Del Monte shaft, and from other mine dumps on Last Chance Hill and Silver Hill, show weak spectra characteristic of illite and montmorillonite, and less-prevalent chlorite and epidote. Brecciated and veined rhyolite of Aurora Creek in the small open cut $\sim 0.6 \mathrm{~km}$ northeast of the Aurora cemeteries contains kaolinite and montmorillonite.

\section{Hydrothermal Mineral Ages}

The ${ }^{40} \mathrm{Ar}{ }^{39} \mathrm{Ar}$ dates of adularia from the Esmeralda vein, and in a vein sample from the Del Monte shaft dump are $10.47 \pm 0.1 \mathrm{Ma}$ and $10.35 \pm 0.05 \mathrm{Ma}$, respectively (fig. 20; table 1). Breit (2000) reported a ${ }^{40} \mathrm{Ar} /{ }^{39} \mathrm{Ar}$ date of $10.04 \pm 0.03 \mathrm{Ma}$ for adularia in the Prospectus vein. Kleinhampl and others (1975) reported a K-Ar date of $10.6 \pm 0.2 \mathrm{Ma}$ for adularia in an unnamed quartz-adularia vein. Morton and others (1977) reported a K-Ar date of $10.9 \pm 0.3 \mathrm{Ma}$ for trachyandesite altered to quartz, K-feldspar, sericite, pyrite, and chlorite in or near the Juniata vein. Breit (2000) reported $\mathrm{a}^{40} \mathrm{Ar} /{ }^{39} \mathrm{Ar}$ date of $12.2 \pm 0.3 \mathrm{Ma}$ for illite in altered wall rocks adjacent to the Esmeralda vein.

Most hydrothermal mineral dates are $\sim 2-3$ m.y. younger than the age range of trachyandesite of Aurora ( 13.1-12.6 Ma; table 1$)$, the host rock for nearly all veins, and $\sim 1.5-2$ m.y. younger than alunite in trachyandesite of Aurora on East Brawley Peak ( 12 Ma; table 1) adjacent to Silver Hill. No known magmatism in the Aurora Mining District is coeval with vein and most hydrothermal mineral dates, whereas in the Masonic and Bodie Mining Districts, igneous rocks are coeval with, or $\sim 0.5$ m.y. older than, hydrothermal mineral dates (table 1). However, most feldspar and biotite dates of Rhyolite of Bodie Creek and Trachyandesite of Del Monte, $\sim 4-5 \mathrm{~km}$ southwest and north, respectively, of the Aurora townsite (fig. 20), are $\sim 10-11 \mathrm{Ma}$ (Fleck and others, 2015), indicating the presence of magmas near the Aurora Mining District during vein deposition.

\section{Four Corners Alteration Zone}

\section{Location}

Sec. 15, T. 5 N., R. 26 E., Mono County, California (fig. 1)

\section{Definition}

The Four Corners alteration zone (FC AZ) is defined by low outcrops of silicified, volcanic-hydrothermal breccia that cover $<0.02 \mathrm{~km}^{2}$ immediately northwest of the intersection of roads to Masonic, Aurora Canyon, Cow Camp, and Bodie (Four Corners; fig. 25). 


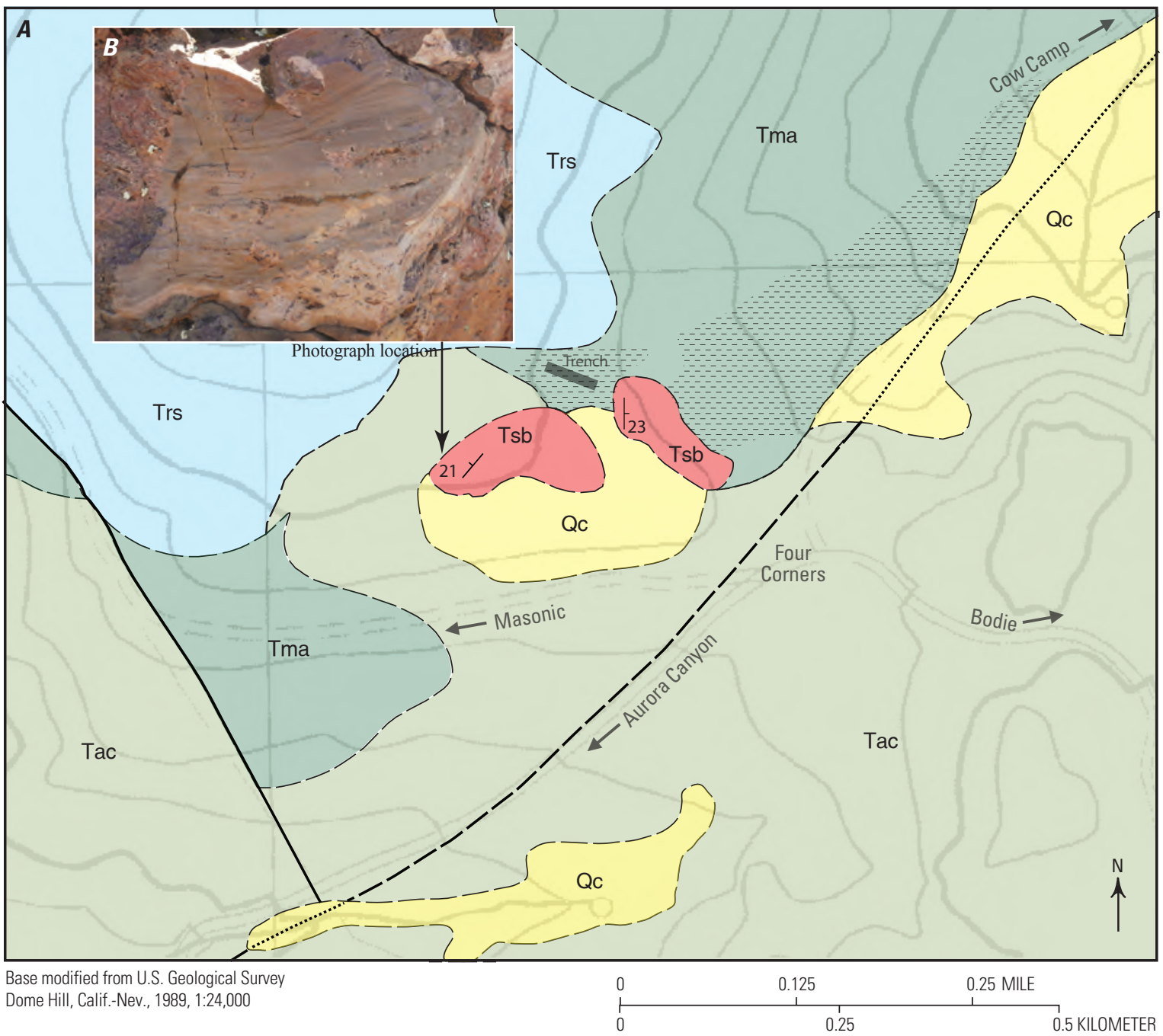

EXPLANATION

\begin{tabular}{|c|c|}
\hline Qc & Colluvium \\
\hline Tac & Trachyandesite of Aurora Canyon \\
\hline Trs & Rhyolite of Rock Springs Canyon \\
\hline Tsb & Silicified breccia \\
\hline Tma & Trachyandesite of Masonic \\
\hline$=$ & Paleosol \\
\hline & Contact-Dashed where approximated \\
\hline & Fault—Dashed where approximated \\
\hline$\stackrel{40}{\perp}$ & Bedding \\
\hline
\end{tabular}

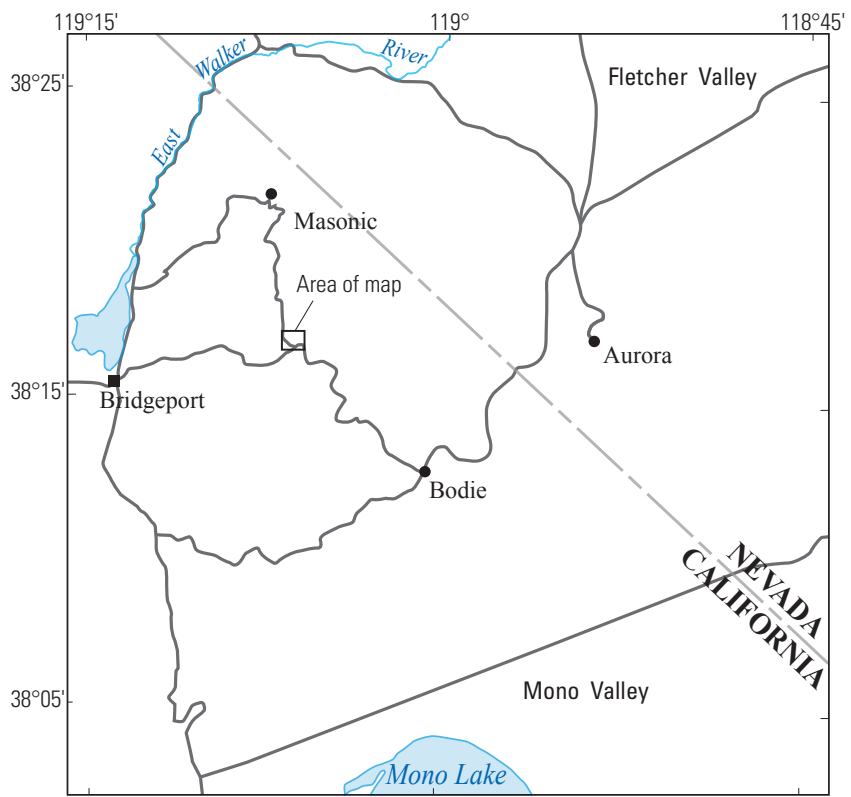

Figure 25. A, Geologic map of the Four Corners alteration zone, Mono County, California. $B$, Image showing figure $26 C$ and location. 


\section{History and Production}

No production is recorded from the FC AZ. A short bulldozer cut in argillized trachyandesite of Masonic, about $50 \mathrm{~m}$ north of the silicified breccia outcrops, is the only surface disturbance indicative of mechanized mineral exploration. Extensive production of tools and implements by Native Americans is evident from the scatter of locally derived obsidian flakes.

\section{Stratigraphy}

Two low outcrops of silicified breccia lying on a paleosol in a window of the trachyandesite of Masonic are exposed between domes of rhyolite of Rock Springs Canyon to the north and trachyandesite of Aurora Canyon to the south (fig. 25). The rhyolite of Rock Springs Canyon forms two prominent, small-volume, aphyric lava domes that include flow lobes entirely composed of grayish-black obsidian. It contains trace to 3 volume percent phenocrysts of plagioclase, sanidine, hornblende, and biotite in a weakly devitrified, locally glassy groundmass.

The two outcrops of silicified breccia are crudely bedded and form an outward-dipping semicircle that is tentatively interpreted as eruption breccias and overlying hydrothermal sediments. These features partly outline a hydrothermal eruption crater that was centered about $200 \mathrm{~m}$ west of the road intersection (figs. 25, 26). A prominent zone of dark-red clay underlies the breccias and overlies the trachyandesite of Masonic on the north and east sides of the breccias and extends approximately $700 \mathrm{~m}$ northeast along Cow Camp road. The clay zone is interpreted as a paleosol developed on the trachyandesite of Masonic, although parts of the clay zone near the breccia outcrops may have a hydrothermal origin and formed at the same time as the breccias. The breccias contain a variety of shallow hydrothermal features including finely bedded and crossbedded siliceous sediments filling small open spaces (cavern fill) and silicified hematitic muds and dripstones (fig. 26).

\section{Structure}

The silicified outcrops are crudely bedded with north to northeast strikes and shallow $\left(\sim 20^{\circ}\right)$ northwest to east dips (fig. 25). A proposed northeast-trending fault southeast of the breccia outcrops has no apparent temporal relationship to the alteration zone.

\section{Hydrothermal Alteration}

Breccia clasts and matrix consist of quartz, hematite, jarosite, kaolinite, and montmorillonite. Ten samples of silicified breccia and sediments contain low concentrations of $\mathrm{Au}$ $(\leq 5-61 \mathrm{ppb})$ and $\mathrm{Ag}(<1 \mathrm{ppm}$; table 1-8). All samples contain tens to $>100 \mathrm{ppm} \mathrm{Sb}$, and several samples contain elevated concentrations of $\mathrm{Hg}(6-15 \mathrm{ppm})$, As (hundreds to several thousand parts per million), $\mathrm{Bi}(\sim 2-135 \mathrm{ppm})$, and $\mathrm{Pb}$ (hundreds of parts per million); one sample contains $18 \mathrm{ppm} \mathrm{Te}$.

\section{ASTER Imagery}

No hydrothermal minerals were identified from ASTER imagery.

\section{SWIR Spectra}

Based on SWIR analyses, two samples of red clay underlying the breccia outcrops contain montmorillonite and kaolinite. Silicified breccias locally are coated by orangecolored jarosite \pm montmorillonite.

\section{Hydrothermal Mineral Ages}

Hydrothermal minerals in the FC AZ have not been dated. Field relations indicate that the alteration zone is younger than $\sim 15-14$ Ma trachyandesite of Masonic and older than the 10.6-10.3 Ma trachyandesite of Aurora Canyon (table 1).

\section{Paramount-Bald Peak Alteration Zone}

\section{Location}

Tps. 5 and 6 N., Rs. 26 and 27 E., mostly unsurveyed, Mono County, California, and Mineral County, Nevada (fig. 1)

\section{Definition}

The Paramount-Bald Peak alteration zone (PBP AZ) is in the central and northeastern part of the Bodie Hills volcanic field and mostly coincides with the sedimentary rocks and tuff of Paramount (Tpst, fig. 27). The alteration zone includes three principal exposures of strongly altered rocks in a 1- to $3-\mathrm{km}$-wide, northeast-elongate area that extends about $12 \mathrm{~km}$ from the northeast flank of Potato Peak to the north side of Bald Peak. The largest exposure is in the southwestern part of the alteration zone, covers about $12 \mathrm{~km}^{2}$, and includes the Paramount Hg Mine. The southwest and central exposures most likely are contiguous beneath lava flows of the Pliocene Beauty Peak volcano. 
$\boldsymbol{A}$

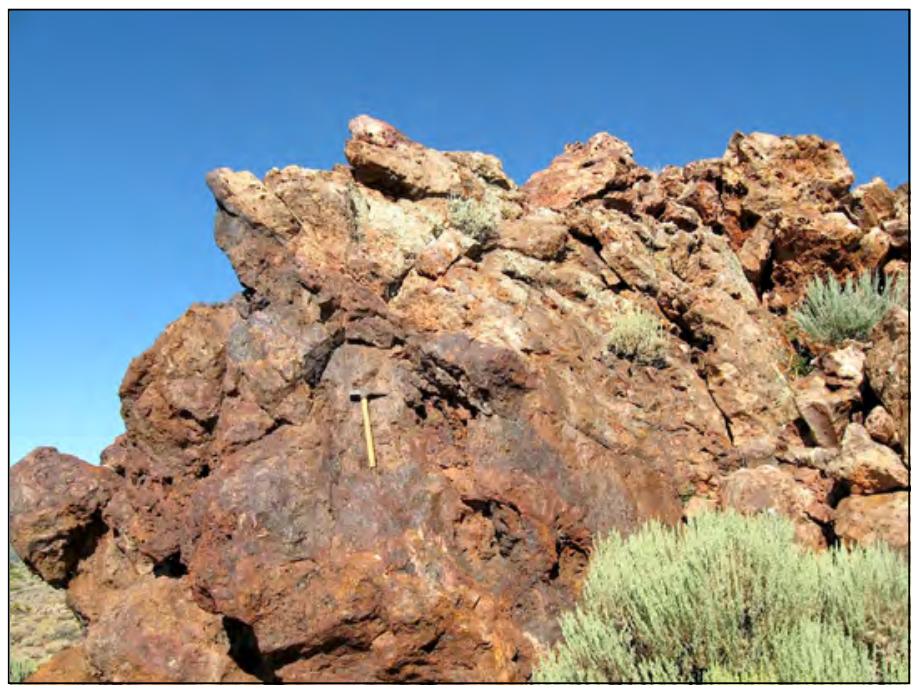

C

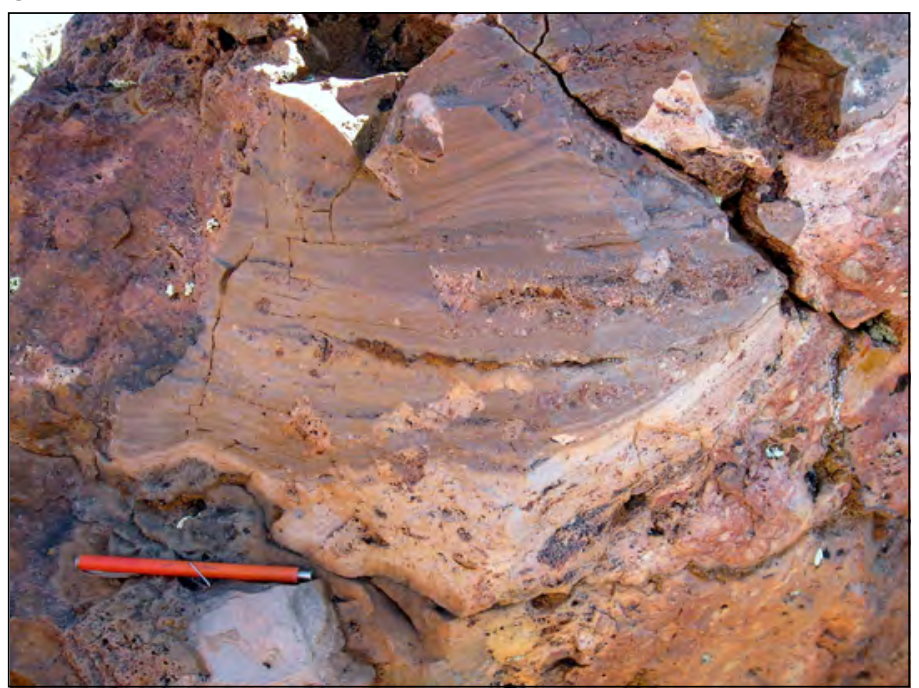

B

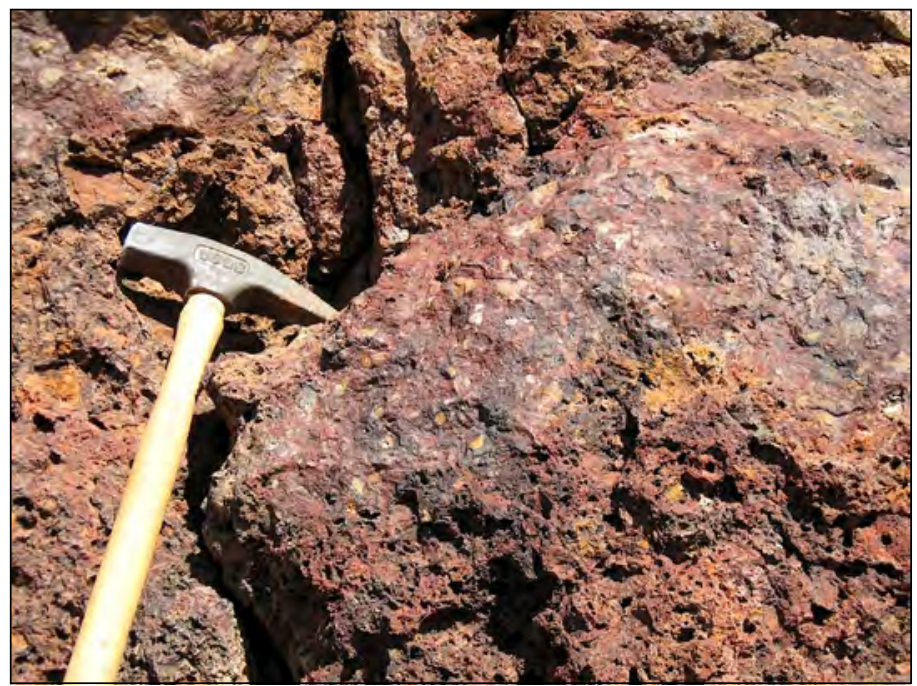

D

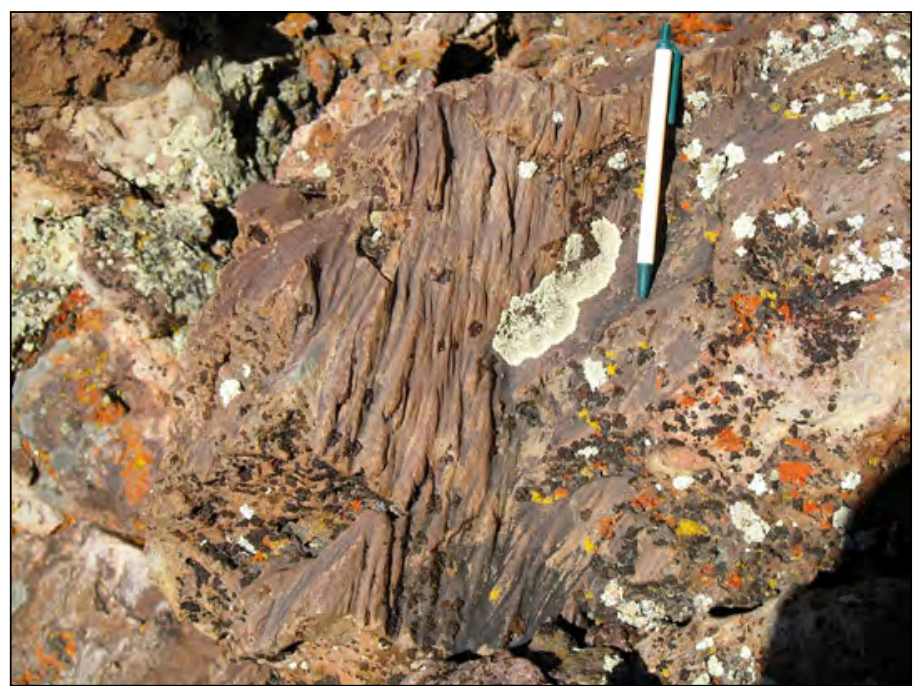

Figure 26. Images of hydrothermal features, Four Corners alteration zone. A, Outcrop of crudely bedded silicified breccia. Lower part of outcrop is hematite-rich and massive, whereas upper part contains layers of gray, finely bedded sedimentary strata. $B$, Close up view of massive hematite-rich silicified breccia in lower part of outcrop. $C$, Finely crossbedded, chemical and clastic sedimentary beds filling cavity in silicified breccia. $D$, Silicified hematitic mud coating cavity surface. Branching texture of grooves and ridges suggests flow from top to bottom. 


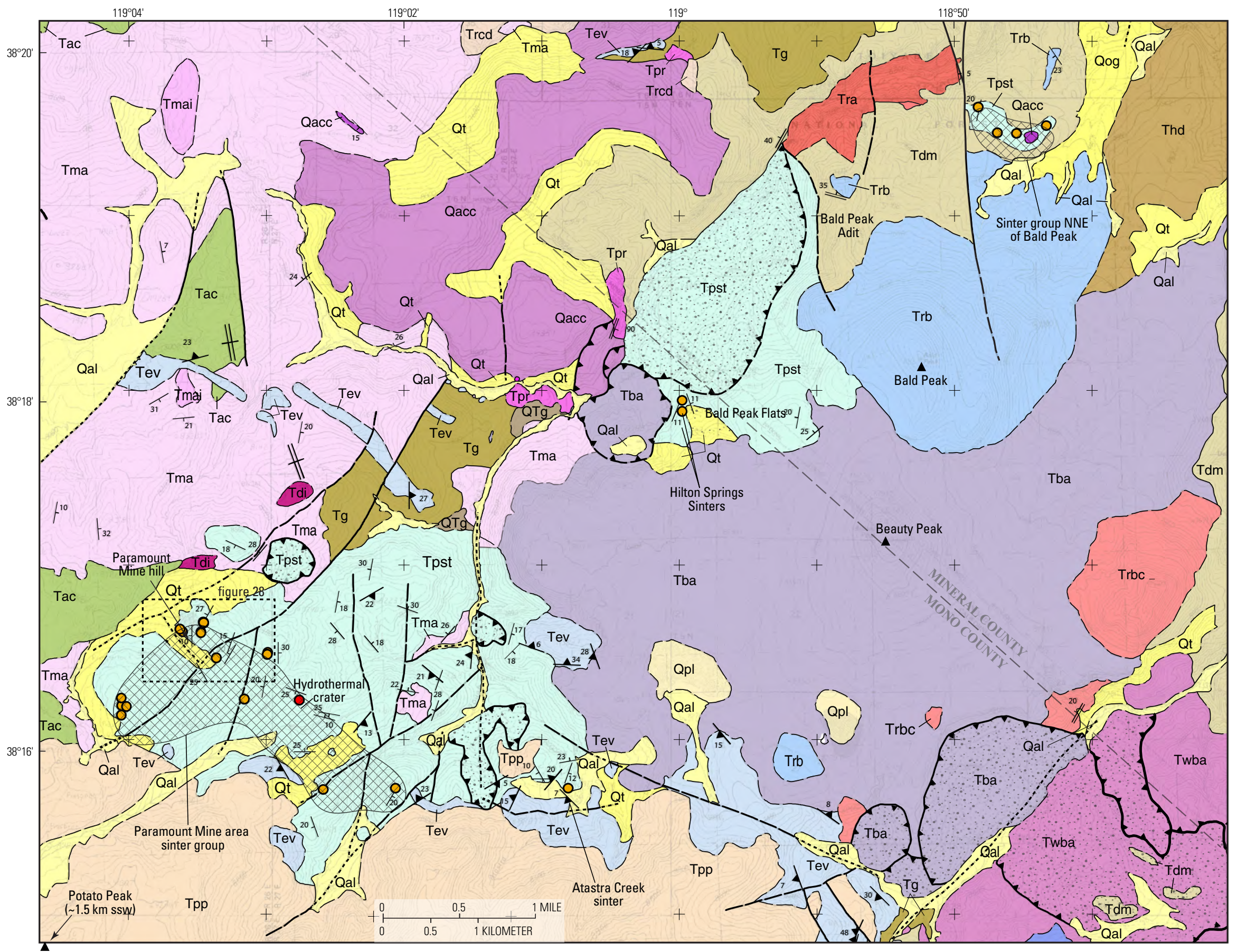




\section{EXPLANATION}

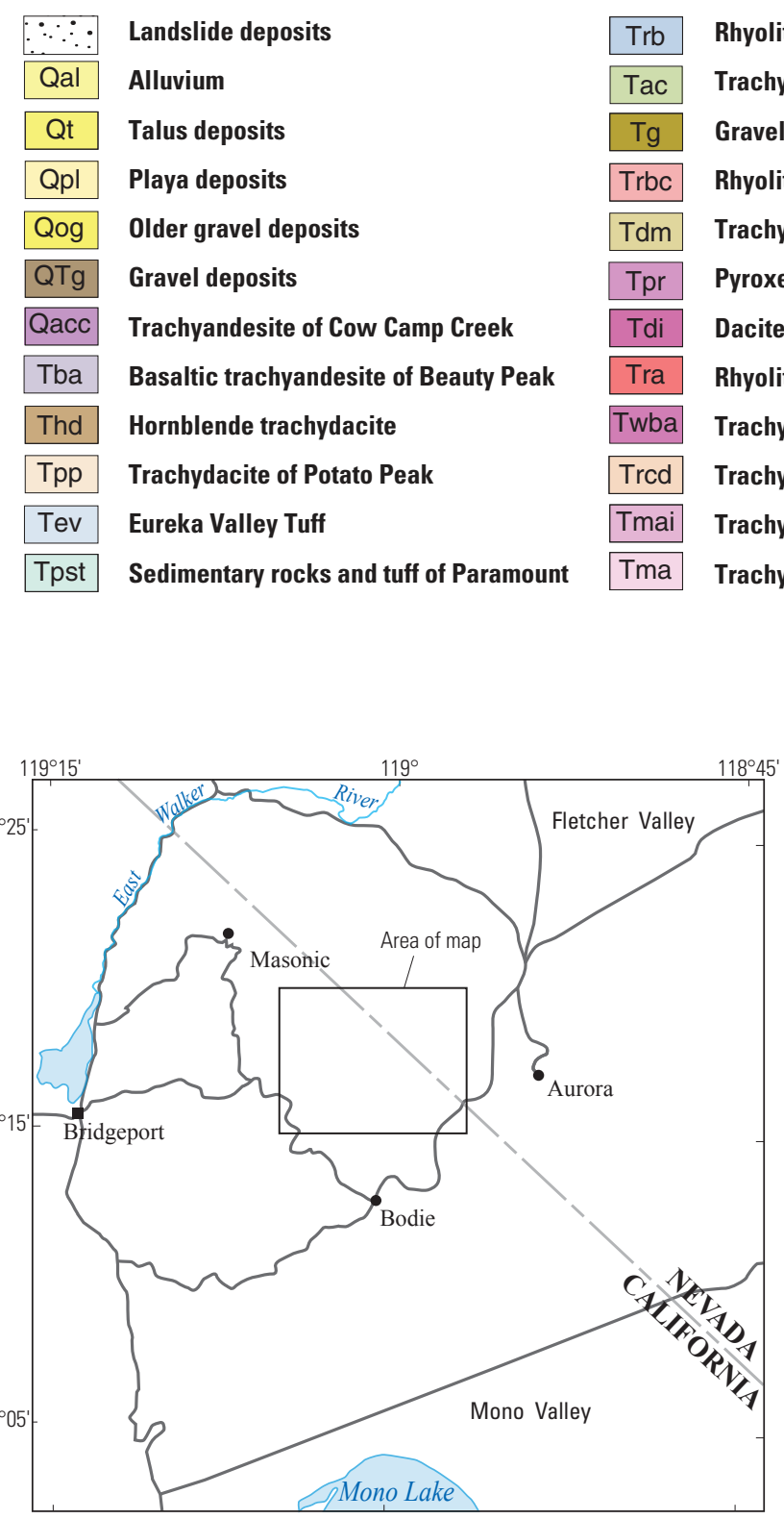

Figure 27. (Facing page) Geologic map of the Paramount-Bald Peak alteration zone, Mono County, California, and Mineral County, Nevada, showing sinters, sinter groups, and prospects discussed in the text (modified from John and others, 2012). 


\section{History and Production}

The Paramount Hg Mine is in the southwestern part of the alteration zone (sec. 13 [projected], T. 5 N., R. 26 E.). Numerous small prospects, trenches, and drill roads have been excavated near the Paramount Mine and in the vicinity of Bald Peak in the central part of the zone. Although Homestake Mining Company explored the area in the 1980s, drill roads and cuttings west of Bald Peak may include pre-1976 Federal Land Policy and Management Act (FLPMA) exploration because of limited to no site reclamation. At the Paramount Mine, $\mathrm{Hg}$ was recovered from a chalcedonic quartz vein exposed by two adits, tens of meters of underground workings, and two large trenches (fig. 28). The vein was mined about 1878 (Whiting, 1888), and from 1941 to 1944 at a reported grade of 1.5-5 pounds (lbs) of $\mathrm{Hg}$ per ton (Holmes, 1965). According to an unpublished historical compendium filed with regulatory agencies for drilling permitting in 2009, $400 \mathrm{t}$ were also mined and processed in 1968. The volume of calcines associated with a dismantled retorting facility at the lower adit and reported mercury grades indicate that total $\mathrm{Hg}$ production was probably tens of flasks. The historical compendium also lists trench excavation in the late 1960s, and drilling programs by Homestake, Molycorp, Noranda, and Equinox from 1981 to 1991 . From 2006 to 2010, approximately 10 holes were permitted and (or) drilled by Cougar Gold at the mine and at various sites on the hill southwest of the mine.

\section{Stratigraphy}

Sedimentary rocks and tuff of Paramount cover most of the PBP AZ (John and others, 2012). This stratigraphic sequence lies on the north and west flanks of the $\sim 9.7 \mathrm{Ma}$ rhyolite of Bald Peak dome. It includes abundant rhyolite tuffs inferred to have erupted from Bald Peak, and rhyolite-rich detritus shed from the dome into the shallow, northeast-elongate Paramount basin (fig. 27). The sequence unconformably overlies $\sim 15$ to $14 \mathrm{Ma}$ trachyandesite of Masonic, $\sim 11.3$ Ma trachydacite intrusions, $\sim 11$ Ma trachyandesite of Del Monte, $\sim 11.3$ Ma trachydacite intrusions, and $\sim 10.6$ to 10.4 Ma domes of the trachyandesite of Aurora Canyon. Altered sedimentary rocks of the sequence may be temporally equivalent to unaltered coarse gravel deposits that extend northeastward into Fletcher Valley (Tg, fig. 27). A prominent dark-red paleosol developed locally on rocks underlying the sequence is exposed $\sim 0.75 \mathrm{~km}$ northeast of the Paramount Mine. The sequence is overlain by $\sim 9.4 \mathrm{Ma}$ Eureka Valley Tuff, by lava flows of $\sim 9$ to 8.7 Ma trachydacite of Potato Peak, and by basaltic trachyandesite lava flows of the Pliocene Beauty Peak volcano.

The sedimentary rocks and tuff of Paramount consist of interbedded, crystal-poor, lithic-rich and pumice-rich rhyolite tuff, minor, sparsely porphyritic, flow-banded rhyolite (possibly intrusive), and poorly sorted volcaniclastic rocks that include volcanic conglomerate, sandstone, and siltstone. Several sinter terraces and numerous sinter beds are dispersed throughout the alteration zone (figs. 27, 28, 29, 30). Pyroclastic rocks vary from unwelded, pumice-rich ash flows that locally contain abundant clasts of nearly aphyric flow-banded rhyolite and porphyritic trachyandesite and dacite lavas, to finely bedded, possibly water lain, crystal-poor air fall tuffs. Clastic sedimentary rocks contain clasts of porphyritic volcanic rocks, including quartz-bearing dacite(?), and less-abundant sparsely porphyritic, flow-banded rhyolite. The sequence may be as much as $200 \mathrm{~m}$ thick on the west side of Rough Creek, although irregular dips and complex structure preclude an accurate estimate of thickness in most locations. The sedimentary rocks and tuff are pinkish-gray to pale-redpurple, nearly aphyric, weakly to strongly hydrothermally altered and locally iron stained. Pyroclastic rocks contain trace amounts of plagioclase and quartz phenocrysts in a recrystallized ashy groundmass. The tuff contains abundant, $0.5-10 \mathrm{~cm}$ unflattened pumice blocks and exotic lithic fragments composed of porphyritic, intermediate-composition lava and nearly aphyric rhyolite lava.

The rhyolite of Bald Peak contains trace to 10 volume percent fine-grained phenocrysts of quartz, sanidine, and lesser biotite and clinopyroxene in hydrated to devitrified glass.

\section{Structure}

The structure of the PBP AZ is poorly understood because of discontinuous stratigraphy within the sequence, pervasive hydrothermal alteration, numerous large landslides, and lack of a detailed geologic map of most of the alteration zone. Faults on figure 27 are inferred on the basis of offset contacts between the sedimentary rocks and tuff of Paramount and underlying lava flows (trachyandesites of Masonic and Del Monte), prominent linear zones of silicification, and variable elevations of sinter terraces. The sedimentary rocks and tuff of Paramount appear to fill a shallow northeast-trending basin (Paramount basin) on the northern and western flanks of the Bald Peak rhyolite dome which probably formed during emplacement of the dome (fig. 27; John and others, 2012). The Paramount basin appears to be bounded by northeast-striking growth(?) faults that were active during sediment deposition in the basin. A series of north-striking faults apparently displaces sinter terraces to progressively lower elevations from about 9,090 ft on the hill southwest of the Paramount Mine, to $8,700 \mathrm{ft}$ at the Paramount Mine, $8,080 \mathrm{ft}$ in Atastra Creek, 7,800 ft on the west side of Bald Peak, and $\sim 7,200 \mathrm{ft}$ on the north side of Bald Peak (fig. 27). The pattern of inferred northeast and north-striking faults is similar to fault patterns observed in the Masonic and Aurora Mining Districts (John and others, 2012). 


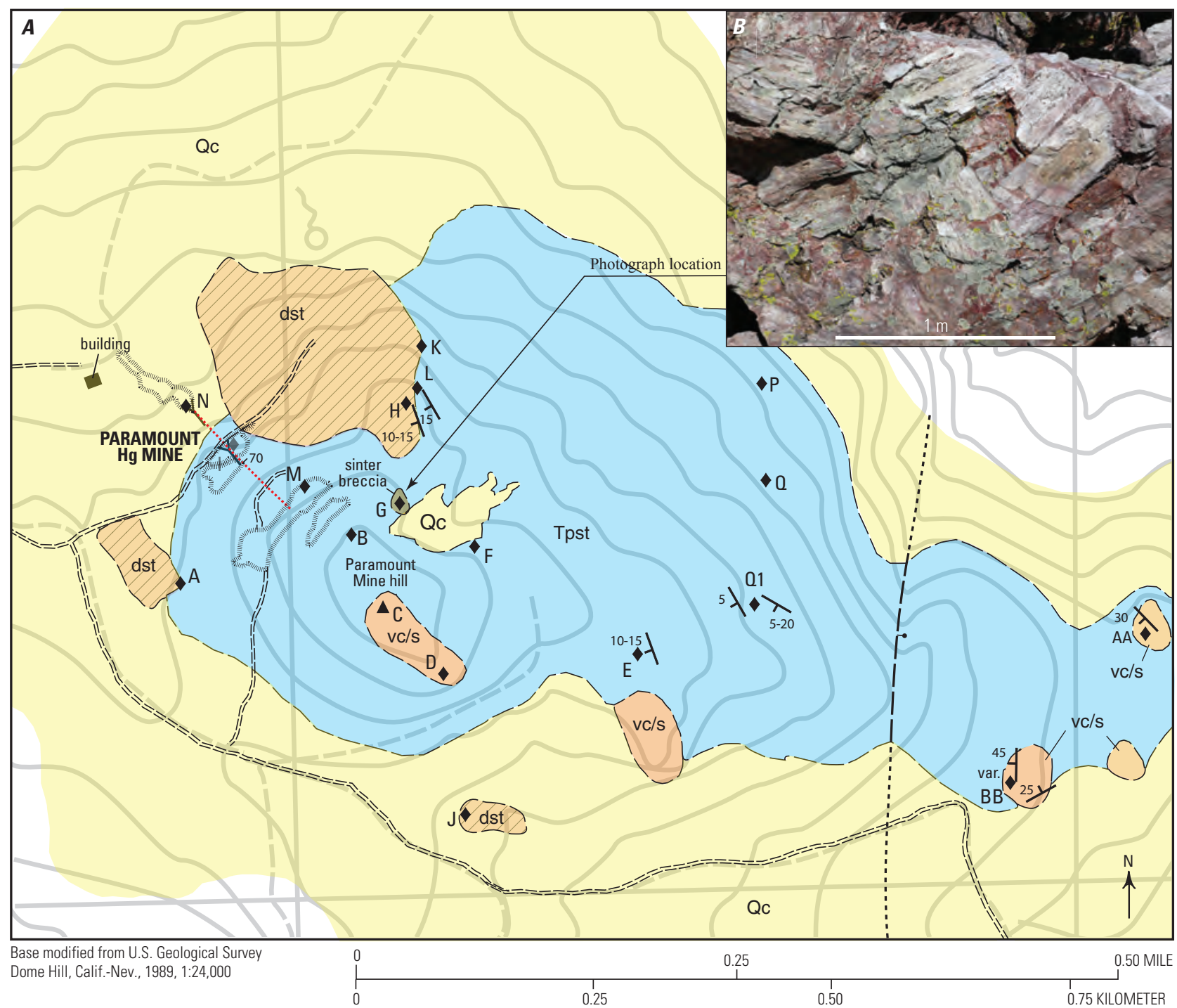

\section{EXPLANATION}

\begin{tabular}{|c|c|}
\hline Qc & Colluvium \\
\hline dst & Dismembered sinter terrace \\
\hline $\mathrm{vc} / \mathrm{s}$ & Strongly silicified volcaniclastic rocks $(T p s t) \pm$ sinter \\
\hline Tpst & $\begin{array}{l}\text { Sedimentary rocks and tuff of Paramount (John and } \\
\text { others, 2012)_-Pervasively altered to quartz, } \\
\text { montmorillonite, and lesser kaolinite and pyrite }\end{array}$ \\
\hline (........... & Quartz-cinnabar-pyrite vein \\
\hline- & Contact-Dashed where approximated \\
\hline & $\begin{array}{l}\text { Fault-Dashed where approximated, dotted where } \\
\text { concealed }\end{array}$ \\
\hline - & $\begin{array}{l}\text { High-angle normal fault-Bar and ball on downthrown } \\
\text { block }\end{array}$ \\
\hline 40 & Bedding \\
\hline 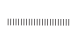 & Mine dump or trench \\
\hline$\Delta \mathrm{K}$ & Sample site and letter \\
\hline
\end{tabular}

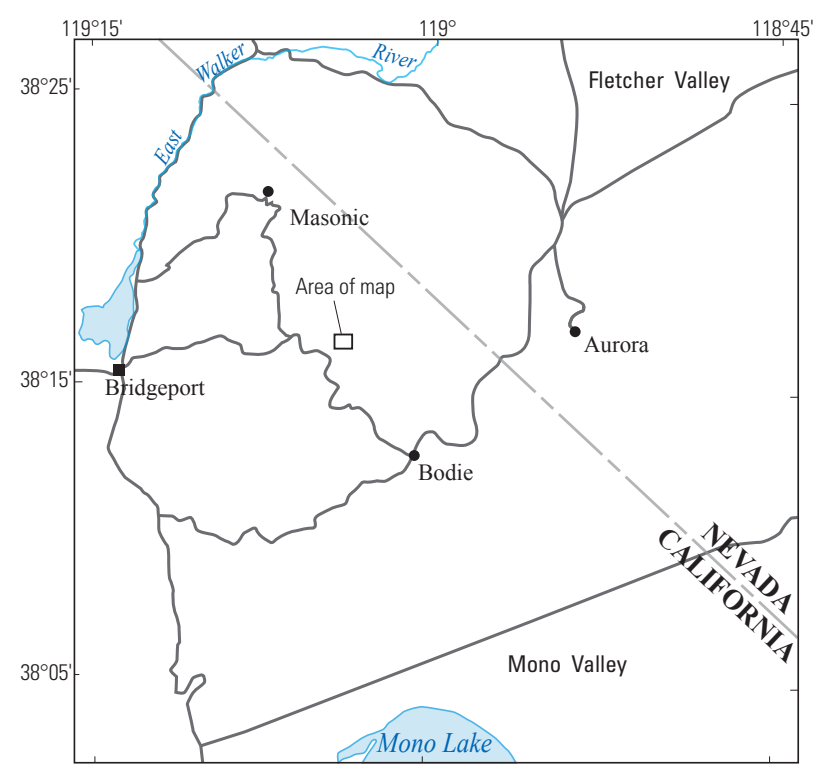

Figure 28. $A$, Geologic map of the Paramount $\mathrm{Hg}$ Mine area, Mono County, California. $B$, Image showing unoriented, multisized blocks of terrace sinter cemented by fine-grained quartz and minor iron oxide minerals (similar to figure $30 \mathrm{G}$ ). 

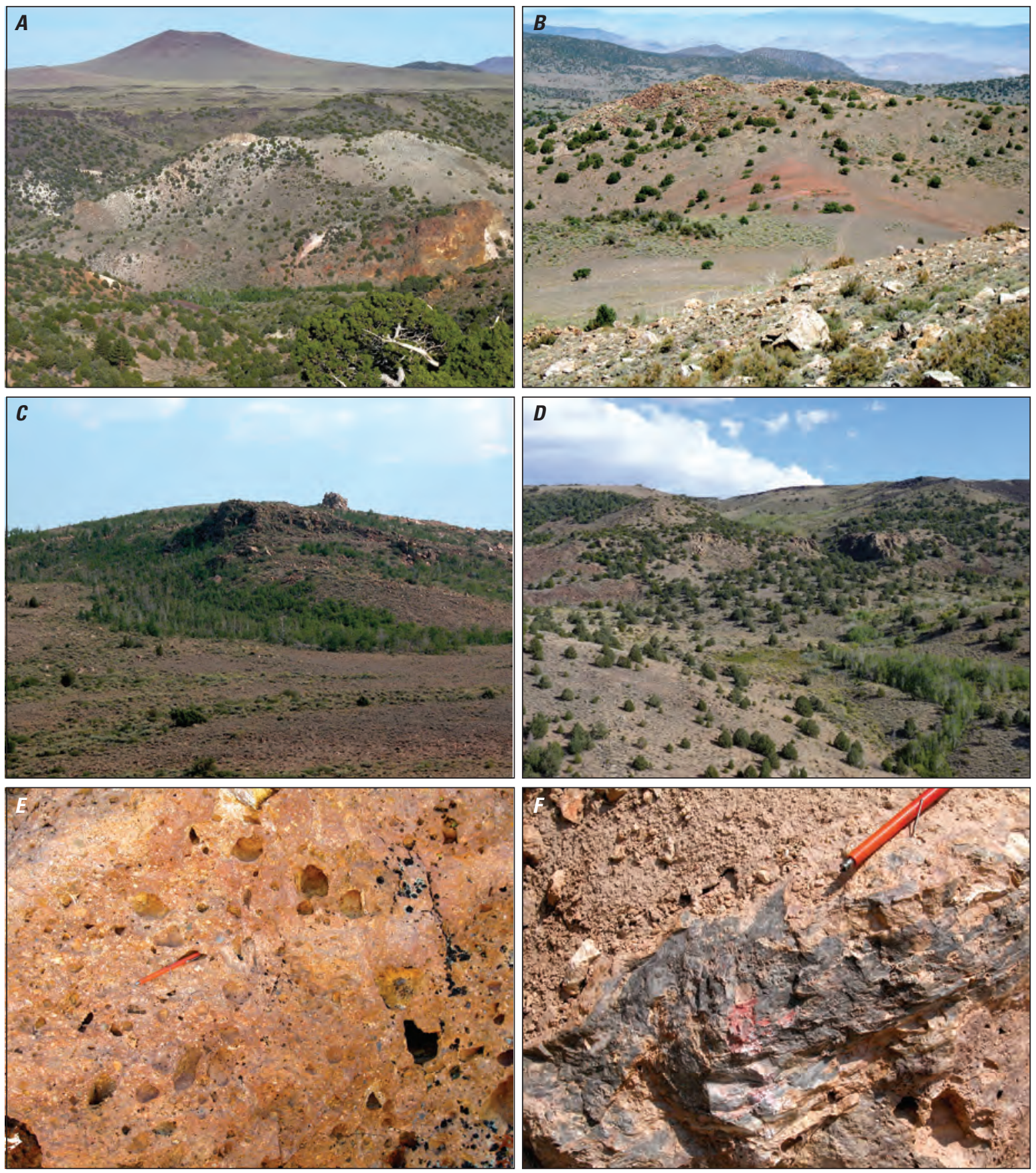

Figure 29. Images of Paramount-Bald Peak alteration zone. $A$, View looking east at altered rocks in the southwest part of the Paramount basin overlain by unaltered lava flows from Pliocene Beauty Peak volcano (Tba). B, View looking northeast from Paramount Mine at a hill composed of altered sedimentary rocks and tuff of Paramount (Tpst) unconformably overlying a red paleosol developed in underlying trachyandesite of Masonic (Tma). C, View looking southwest at Paramount Mine hill from the hill in center of $B$. Paramount Mine hill consists of dismembered sinter terraces and altered volcaniclastic rocks. $D$, View of silicified ledges of the Hilton Springs prospect overlain by Beauty Peak lava flows (Tba) at upper right. Most of the rocks in the foreground are part of a large landslide. $E$, Typical leached, argillically altered, pumiceous volcaniclastic deposits in sedimentary rocks and tuff of Paramount (Tpst). F, Cinnabar in a chalcedonic quartz vein at the Paramount Mine. 

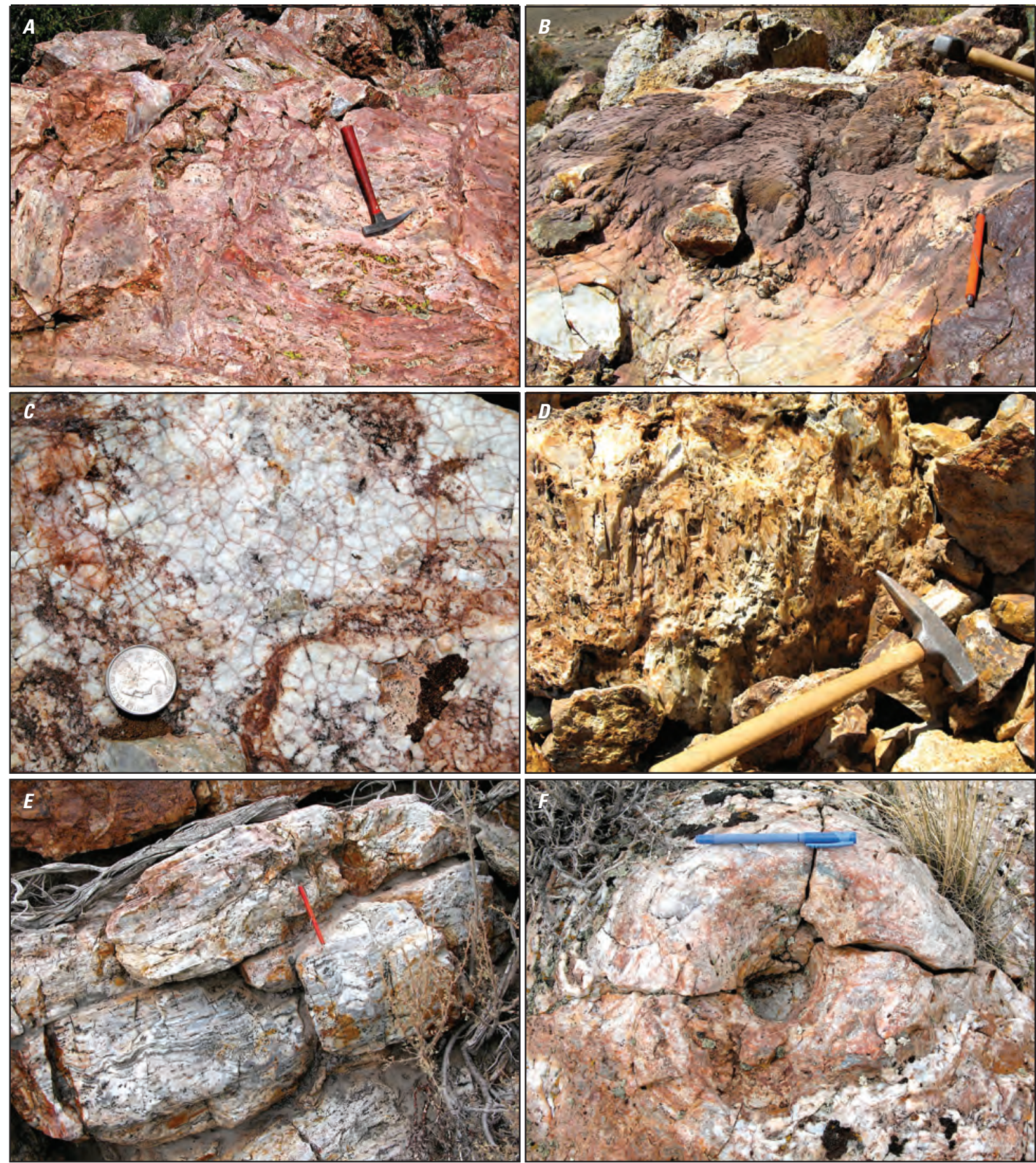

Figure 30. Images of hydrothermal features in the Paramount-Bald Peak alteration zone. $A$, Brecciated sinter recemented with red chalcedonic quartz on the northwest side of Paramount Mine hill. $B$, Flow textures in siliceous, hematitic, mud-sized sedimentary strata that coat silicified volcaniclastic rocks about $1 \mathrm{~km}$ southeast of the Paramount Mine. $C$, Desiccation cracks in thin pool(?) sinter bed in silicified volcaniclastic rocks on top of Paramount Mine hill. $D$, Quartz vein showing replacement texture of coarse bladed carbonate on south side of hill about $1 \mathrm{~km}$ southwest of the Paramount Mine. $E$, Sinter beds in Atastra Creek. F, Hydrothermal fluid vent on the sinter terrace in Atastra Creek. 


\section{Hydrothermal Alteration}

Sedimentary rocks and tuff of Paramount are pervasively altered throughout the Paramount basin. Older units underlying and along margins of the basin also are altered locally, whereas younger units surrounding or overlying the basin generally are unaltered (small exposures of the basal(?) member of the Eureka Valley Tuff are locally altered in Atastra Creek). Three types of alteration affected sedimentary rocks and tuff of Paramount (1) silicification, (2) advanced argillic (kaolinite \pm dickite) alteration, and (3) intermediate argillic (montmorillonite \pm kaolinite) alteration. Propylitic alteration assemblages (montmorillonite, illite/smectite, chlorite(?), and calcite) occur locally in underlying, intermediate composition lava flows and volcaniclastic rocks. Variable amounts of iron oxide minerals and jarosite are widespread, and relict pyrite is present in some silicified rocks.

Intermediate argillic alteration assemblages, the most common assemblages in strata of the Paramount basin, are manifested by variable leaching of pumice and volcanic rock clasts that left a porous residue of silica and clay minerals (fig. 29E). SWIR spectrographic analyses indicate that the clay minerals are montmorillonite and lesser kaolinite. These leached and clay-altered rocks are white, beige, or pale green. Pyrite casts are scarce to absent suggesting that this alteration type included little pyrite. With increasing silica content, intermediate argillic alteration grades into silicification as exposed in the bluffs on the southeast side of Paramount Hill (fig. 28).

Smaller areas of intense silicification and advanced argillic alteration occur locally within the broad expanse of strata that are altered to intermediate argillic assemblages. Silicified rocks consist of variably colored, commonly iron oxide-stained, chalcedonic silica and lesser quartz. Domains that contain relict, disseminated, fine-grained pyrite occur locally. Silicified rocks generally form bold outcrops and comprise both elongate cliff-forming ledges and more tabular bodies. Breccia zones are common within silicified rocks.

Small zones of advanced argillic alteration locally surround or underlie zones of silicified rock, notably near sinters. Kaolinite is the predominant clay mineral, although dickite is present in several locations including in narrow veins beneath the sinter terrace on Atastra Creek. Alunite was not confirmed in hand samples, although interpretation of ASTER imagery shows alunite occurrences in several places on the southwest side of the Paramount basin (Rockwell, 2010).

Sinter occurs in thin beds $(<0.3 \mathrm{~m})$ interstratified with strongly silicified volcaniclastic rocks, and forms terraces, several meters in thickness, that generally overlie silicified volcaniclastic rocks (figs. 27, 28, 29). The largest exposures of sinter are near the Paramount Mine (below). Another large sinter terrace, $\sim 5 \mathrm{~m}$ thick, crops out on the west side of Atastra Creek about $1.25 \mathrm{~km}$ southeast of its confluence with Rough Creek. This terrace overlies kaolinite-altered volcaniclastic rocks. A small funnel-shaped vent, desiccation cracks, and filamental bacteria mats are exposed on the upper surface of the terrace (fig. 30). Dark-gray siltstone that underlies part of the terrace may represent mud pot deposits. A third, large terrace is exposed in cliffs above Rough Creek about $2.7 \mathrm{~km}$ north-northeast of Bald Peak at the northeast end of the alteration zone (fig. 27). Porous, poorly indurated sinter $\sim 5 \mathrm{~m}$ thick is exposed for $\sim 50 \mathrm{~m}$ along strike. More strongly indurated sinter, locally containing fossilized reeds, forms thin terraces and clusters of sinter blocks at several other locations in this area of volcaniclastic rocks (fig. 27).

Quartz veins, and quartz-chalcedony veins and stockworks are broadly distributed in the Paramount basin (fig. 27). Veins and stockworks occur (1) at the Paramount Hg Mine, (2) on the top and south side of the hill $1.5 \mathrm{~km}$ southwest of the Paramount Mine, (3) on the east side of Atastra Creek east of the sinter terrace, (4) near sinter beds on the west side of Bald Peak (Hilton Springs or Golden Beauty prospect), (5) on the west side of Bald Peak along the California-Nevada state boundary (Bald Peak Flats prospect), and (6) about $1.2 \mathrm{~km}$ northwest of Bald Peak (Bald Peak Adit prospect).

\section{Paramount Mine Area}

The chalcedonic quartz vein mined for mercury in the Paramount Mine trends $\mathrm{N} 50^{\circ} \mathrm{W}$, dips $70^{\circ} \mathrm{NE}$, and is as much as $2 \mathrm{~m}$ wide. It is exposed in mine workings on the west side of a low domal hill composed of silicified and illite-clay mineral-altered volcaniclastic rocks (Paramount Hill; fig. 28). The vein consists of dense chalcedonic quartz and lesser clay minerals, and small amounts of pyrite, cinnabar, and metacinnabar. The clay minerals, mostly montmorillonite and kaolinite, occur in irregular, millimeter-wide seams and in centimeter-sized pockets that represent partially leached wall-rock fragments. Clasts and matrix of volcaniclastic deposits exposed in trenches across the vein and at the upper adit are altered to kaolinite and lesser opaline silica and montmorillonite for several meters on both sides of the vein. Remnants of at least five sinter terraces, and a sixth disaggregated and silicified terrace (figs. 28, 29), are adjacent to the vein on the west and north sides of the hill, at the southeast base of the hill, and $\sim 0.8 \mathrm{~km}$ east of the mine. The former terraces have been dismembered by substrate deflation and freezing; they are represented by areas of closely spaced, rotated blocks of sinter and volcaniclastic strata, many of which are meters in dimension. Occurrences of disaggregated and silicified sinter are indicative of gravitational instability during terrace construction.

\section{Minor Elements in Rocks}

Samples from the sinter terraces on the north and west side of Paramount hill contain variably elevated concentrations of $\mathrm{Au}$ (as much as $32 \mathrm{ppb}), \mathrm{Ag}(<1 \mathrm{ppm}), \mathrm{Hg}$ $(\leq 2.7 \mathrm{ppm}), \mathrm{As}(\leq 90 \mathrm{ppm}), \mathrm{Sb}(\leq 396 \mathrm{ppm})$, and $\mathrm{W}(\leq 14.4$ ppm; table 1-9). Two samples of finely laminated, dark-gray chalcedonic pool sinter(?) from the top of Paramount Hill contain elevated concentrations of $\mathrm{Au}(0.92 ; 3.57 \mathrm{ppm}), \mathrm{Ag}(3$; 6 ppm), $\mathrm{Hg}$ (1.5; $4.3 \mathrm{ppm})$, As (19; 38 ppm), Sb (82; 130 ppm) 
and $\mathrm{Tl}(1.8 ; 4.7 \mathrm{ppm})$. Samples of quartz-chalcedony veins and altered wall rocks from the flat ridge southeast of Paramount hill contain locally elevated concentrations of $\mathrm{Au}$ (7-740 ppb), Ag (<1-13 ppm), Hg (<1,600 ppm), As (<170 ppm), Ba (217-1,500 ppm), Sb (<916 ppm), and W $(<28.9 \mathrm{ppm})$.

Minor element concentrations along a continuous traverse orthogonal to sinter beds (determined by LA ICPMS; fig. 31), include local (submillimeter) enrichment of $\mathrm{Hg}$, $\mathrm{Ag}, \mathrm{Bi}, \mathrm{As}, \mathrm{Pb}$, and $\mathrm{Cu}$. Bulk analyses of the traversed beds show a slightly elevated $\mathrm{Hg}$ concentration; concentrations of other elements are within the range of other bulk sinter samples. Minor element concentrations along a continuous traverse across the chalcedonic quartz vein mined for $\mathrm{Hg}$ (fig. 32) include local (submillimeter) enrichment of $\mathrm{Au}, \mathrm{Ag}$, $\mathrm{S}, \mathrm{Hg}, \mathrm{Fe}, \mathrm{As}, \mathrm{Sb}, \mathrm{Cu}, \mathrm{Mo}, \mathrm{Sn}$, and $\mathrm{Zn}$. Bulk analyses of the traversed vein indicate elevated concentrations of $\mathrm{Hg}, \mathrm{Au}$, $\mathrm{Sb}$, and $\mathrm{S}$ that are within the range of other vein samples, but many other elements have elevated concentrations at the millimeter scale (for example, $\mathrm{Cu}, \mathrm{Mo}$, and $\mathrm{Zn}$ ) that are not elevated in bulk samples.

A rotary drill hole sited in the vicinity of the Paramount Mine encountered "volcanic breccias and pyroclastic rocks to a depth of 230 feet", and "dacite and andesite flows" from 230 to $425 \mathrm{ft}$, the total depth of the hole (Silberman and Berger, 1985). The andesite and dacite flows are likely either the trachyandesite of Masonic or trachyandesite of Aurora Canyon (fig. 27). Alteration of these rocks includes "moderate to intense silicification, argillic alteration, and chloritization" with 2-10 volume percent pyrite. Minor element concentrations in cuttings include intervals of $>1 \mathrm{ppm} \mathrm{Au}$ (maximum $1.9 \mathrm{ppm}$ ) from 100 to $160 \mathrm{ft}$ above the oxide-sulfide boundary, and $0.5-1 \mathrm{ppm} \mathrm{Au}$ from 215 to $240 \mathrm{ft}$. These intervals partly coincide with chalcedonic quartz veins. Other elevated element concentrations include As (mostly hundreds to $>1,000 \mathrm{ppm}$ ), Sb (mostly hundreds of parts per million), $\mathrm{Tl}$ (parts per million to tens of parts per million), $\mathrm{Ag}$ (mostly parts per million), and $\mathrm{Hg}$ (parts per million to several tens of parts per million; Silberman and Berger, 1985). These and other element concentrations (B, Mn, Sr, Ba, Cr, Mo, Ni, Zn, $\mathrm{Pb}, \mathrm{V}, \mathrm{Co}$, and $\mathrm{Cu}$ ) have marginal to no clear relationship to the $>1 \mathrm{ppm}$ Au zone, the oxide-sulfide interface, and to the total sulfide content.

Veins as much as $0.3 \mathrm{~m}$ wide on the hill $1.5 \mathrm{~km}$ southwest of the Paramount Mine contain internal fragments of volcaniclastic wall rocks. These veins are enveloped by centimeter-wide selvages of wall rocks altered proximally to kaolinite and distally to illite/montmorillonite, both of which occur with minor amounts of pyrite; these minerals are interpreted as hypogene. The veins are prominently to indistinctly layered. The centers of most veins are elongate voids partly filled with tabular encrustations of submillimeter, euhedral quartz crystals on relict bladed calcite crystals (perimorphs), most of which have been leached. Vein samples contain variably elevated concentrations of $\mathrm{Au}(<2 \mathrm{ppm}), \mathrm{Ag}$ ( $<7 \mathrm{ppm}), \mathrm{Hg}(<34 \mathrm{ppm}$ ), As (tens to hundreds of parts per million), $\mathrm{Ba}(<2,500 \mathrm{ppm}), \mathrm{Sb}$ (tens to hundreds of parts per million), and $\mathrm{Tl}(<13.7 \mathrm{ppm}$; table 1-9).

\section{Atastra Creek Area}

In the Atastra Creek sinter terrace, minor element concentrations, determined by LA ICP-MS, along a continuous traverse orthogonal to sinter beds (fig. 33) include local (submillimeter) enrichment of $\mathrm{Sb}, \mathrm{As}, \mathrm{Ag}, \mathrm{Hg}, \mathrm{Tl}, \mathrm{Sr}, \mathrm{Ba}, \mathrm{Cu}$, $\mathrm{Pb}$, and $\mathrm{Fe}$. Bulk analyses of the traversed beds also show slightly elevated concentrations of some of these elements (As, $\mathrm{Hg}, \mathrm{Sb}$, and $\mathrm{Tl}$ ).

In a road bed east of the Atastra Creek sinter terrace, blue-gray, pyritic, chalcedonic quartz veins are poorly exposed in a window of Miocene rocks beneath Pliocene basaltic trachyandesite of Beauty Peak lava flows. The veins are as much as $4 \mathrm{~cm}$ wide, contain 5-10 percent pyrite, and are within kaolinite-montmorillonite-altered lower(?) member rocks of the Eureka Valley Tuff. Vein samples contain low concentrations of $\mathrm{Au}(<5 \mathrm{ppb})$, and $\mathrm{Ag}(<1 \mathrm{ppm})$, and elevated concentrations of $\mathrm{Hg}$ (4.7-13.4 ppm), As (47-122 ppm), Sb (96-255 ppm), and W (70-123 ppm; table 1-9).

\section{Bald Peak Area}

Chalcedony veins and thin beds of sinter are exposed at the Hilton Springs (Golden Beauty) prospect on the west side of Bald Peak overlooking Rough Creek (fig. 27). Several narrow zones of centimeter-wide, sheeted chalcedony-pyrite veins cut strongly argillized and silicified sedimentary rocks and tuff of Paramount that underlie Pliocene Beauty Peak lava flows. The veins strike north-northeast and dip $75-90^{\circ} \mathrm{NW}$. Samples of vein and silicified, pyritic wall rock contain elevated concentrations of $\mathrm{Au}$ (1.6-2.6 ppm), Ag (7-18 ppm), $\mathrm{Hg}$ (4-44 ppm), As (290-640 ppm), Ba (<2,800 ppm), Sb (55-77 ppm), and W (5-16 ppm; table 1-9). Several thin $(\leq 2 \mathrm{~cm})$ beds of dark-gray to black, very finely laminated chalcedonic sinter are interbedded with or overlie silicified sedimentary rocks of the unit (figs. 29, 30). Samples of the silicified sedimentary rocks and sinter contain variably elevated concentrations of $\mathrm{Au}(0.02-0.5 \mathrm{ppm}), \mathrm{Ag}(1-8 \mathrm{ppm})$, $\mathrm{Hg}(0.2-5 \mathrm{ppm})$, As (40-380 ppm), Ba (<2,500 ppm), Sb (220-370 ppm), and W (3-21 ppm; table 1-9).

Beds of silicified sedimentary rocks and tuff of Paramount are cut by narrow (mostly $<2 \mathrm{~cm}$ ) opal-chalcedony veins at the Bald Peak Flats prospect along the CaliforniaNevada boundary about $1 \mathrm{~km}$ west-southwest of Bald Peak (fig. 27). Several zones (meters wide) containing banded veins (centimeters thick) strike north-northeast to northeast and dip steeply to the southeast. L.J. Peters (written commun., 2004) reported partial chemical analyses for six vein samples from the Bald Peak Flats prospect: $\mathrm{Au}(<3-106 \mathrm{ppb}), \mathrm{Ag}$ (0.08-0.54 ppm), As (99-1,290 ppm), and Hg (1.6-49 ppm). 

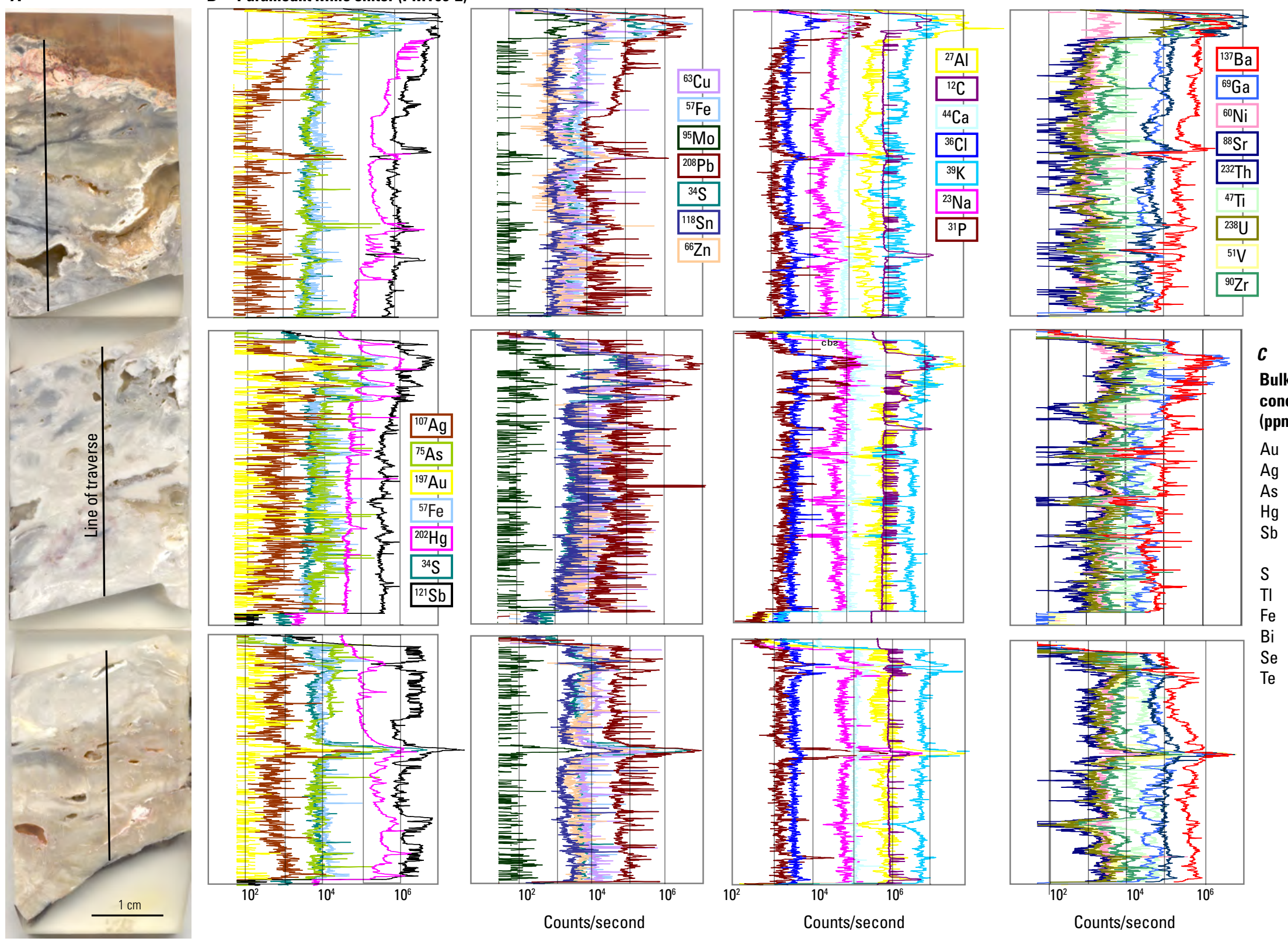

Bulk

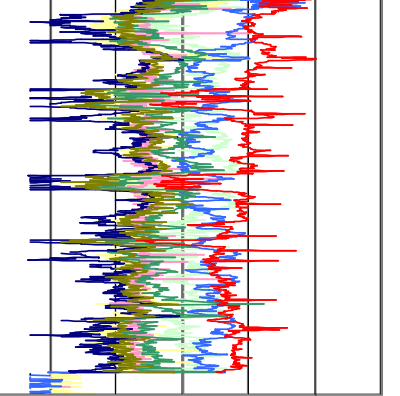

concentration (ppm; ICP-MS)

$\mathrm{Au} \quad 61 \mathrm{ppb}$ $\mathrm{Ag}<1$ As $<30$

$\mathrm{Hg} \quad 1,600$

Sb 644
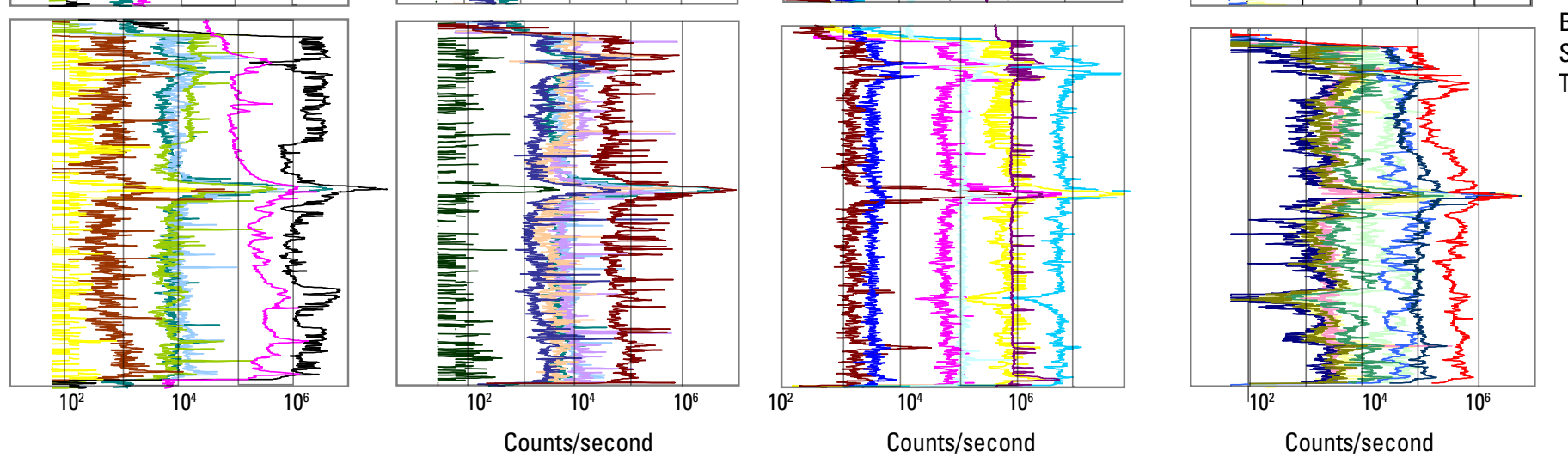

$0.05 \%$ $\quad<0.5$ $0.06 \%$

Figure 31. A, Image showing oriented consecutive sections of sinter from a dismembered terrace at the western base of Paramount Mine hill, Paramount-Bald Peak alteration zone. $B$, Graphs showing relative element concentrations in sinter measured in counts per second (counts/second) by laser ablation inductively coupled plasma-mass spectrometry (LA ICP-MS). C, Bulk sample element concentrations determined by inductively coupled plasma-mass spectrometry (ICP-MS). Locally elevated (millimeter-scale) element concentrations include $\mathrm{Au}, \mathrm{Ag}, \mathrm{S}, \mathrm{Hg}, \mathrm{Fe}, \mathrm{As}, \mathrm{Sb}, \mathrm{Mo}, \mathrm{Cu}, \mathrm{Pb}, \mathrm{Zn}$, and numerous other elements, only some of which are elevated in the bulk sample. 

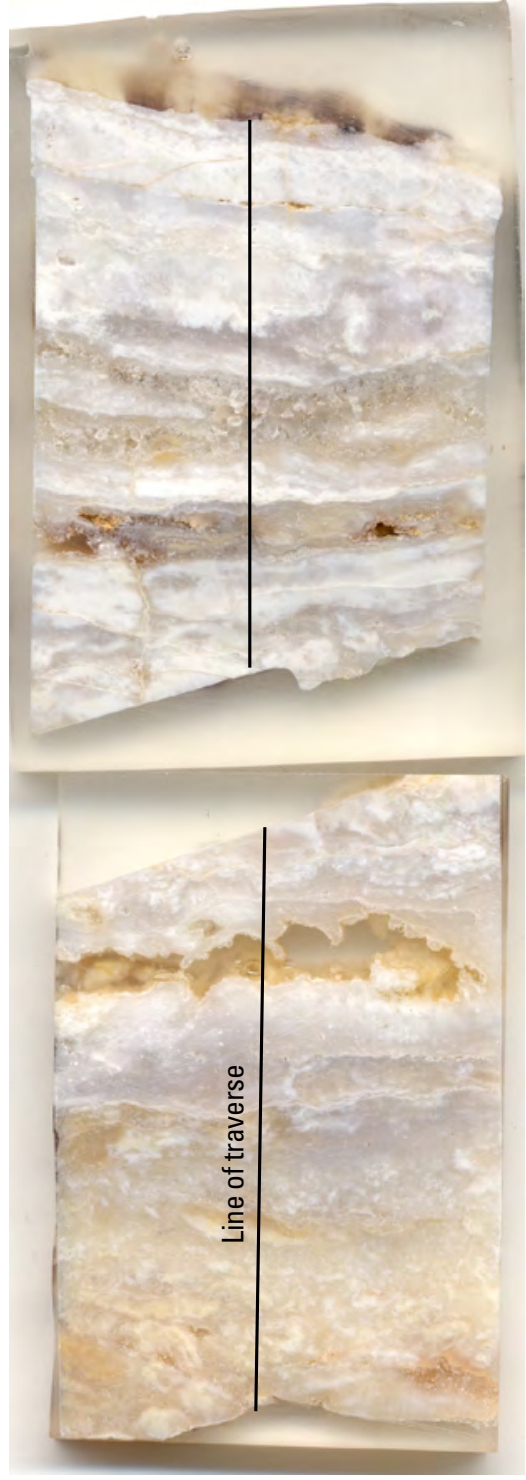

$1 \mathrm{~cm}$
B Paramount Mine vein (PMT06-3)
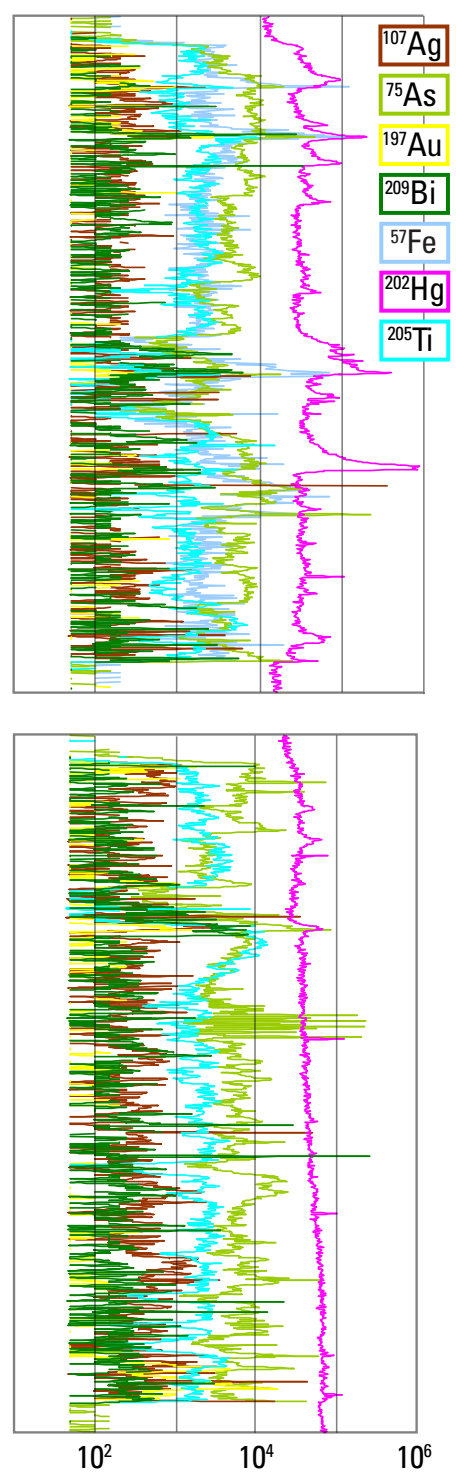

Counts/second
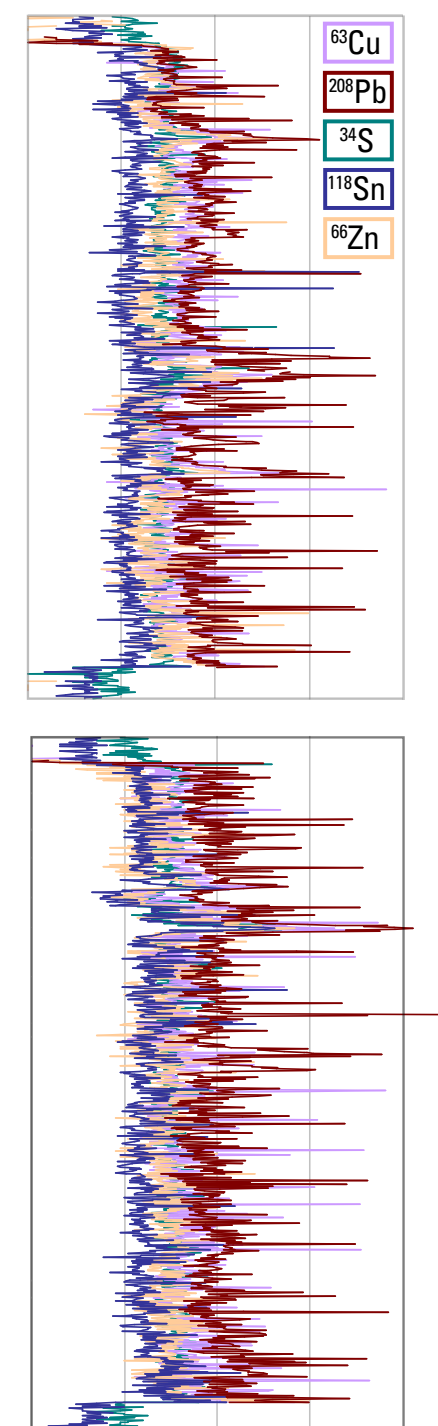

$10^{3}$

Counts/second
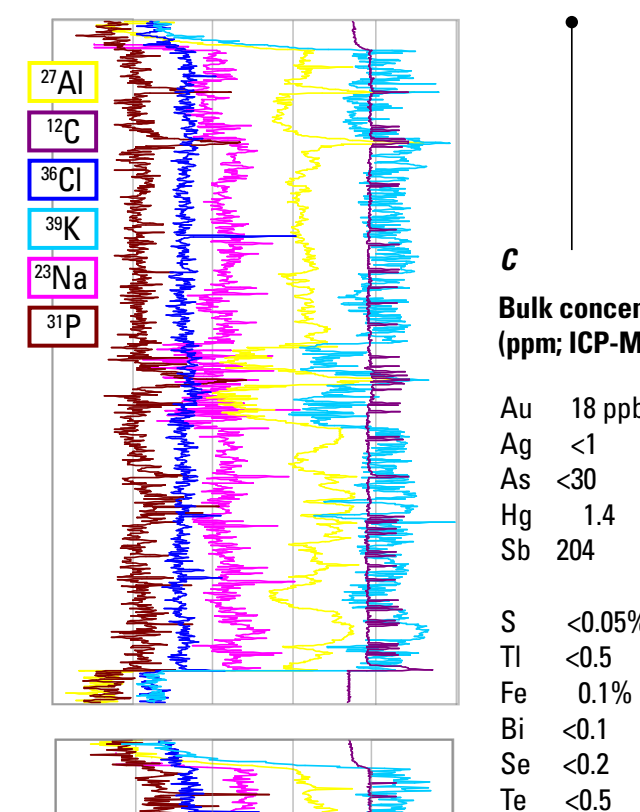

Bulk concentration (ppm; ICP-MS)

\section{$\mathrm{Au} \quad 18 \mathrm{ppb}$}

Ag $<1$

As $<30$

$\mathrm{Hg} \quad 1.4$

Sb 204

S $<0.05 \%$

TI $<0.5$

$0.1 \%$

$\begin{aligned} \mathrm{Bi} & <0.1 \\ \mathrm{Se} & <0.2\end{aligned}$

$<0.5$

Figure 32. A, Image showing oriented consecutive sections of a chalcedonic quartz vein exposed at the upper adit of the Paramount Mine, Paramount-Bald Peak alteration zone (fig. 28). B, Graphs showing relative element concentrations in quartz vein measured in counts per second (counts/second) by laser ablation inductively coupled plasma-mass spectrometry (LA ICP-MS). C, Bulk sample element concentrations determined by inductively coupled plasma-mass spectrometry (ICP-MS). Locally elevated (millimeter-scale) element concentrations include $\mathrm{Au}, \mathrm{Ag}, \mathrm{Hg}, \mathrm{Bi}, \mathrm{Fe}, \mathrm{As}, \mathrm{S}, \mathrm{Sn}, \mathrm{Cu}, \mathrm{Pb}, \mathrm{Zn}$, and other elements, only some of which are elevated in the bulk sample. 
$\boldsymbol{A}$

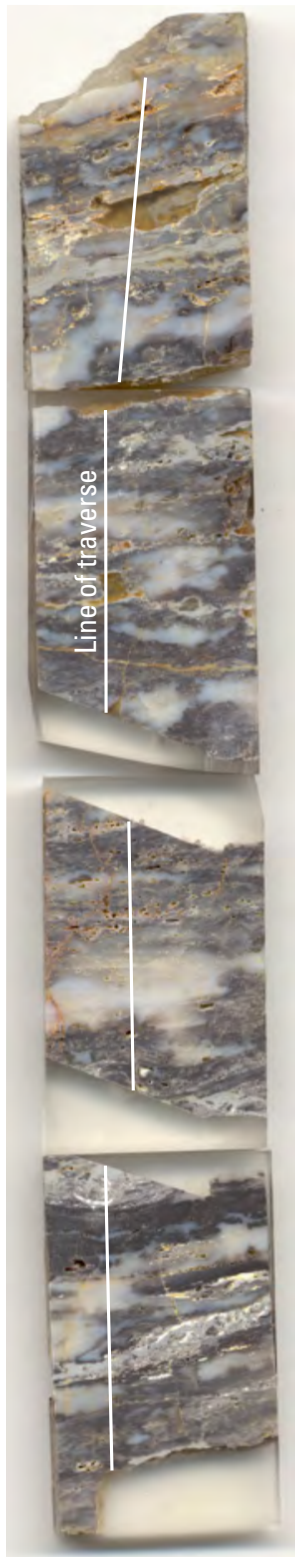

$1 \mathrm{~cm}$
B Atastra Creek sinter (ATAS06-1)
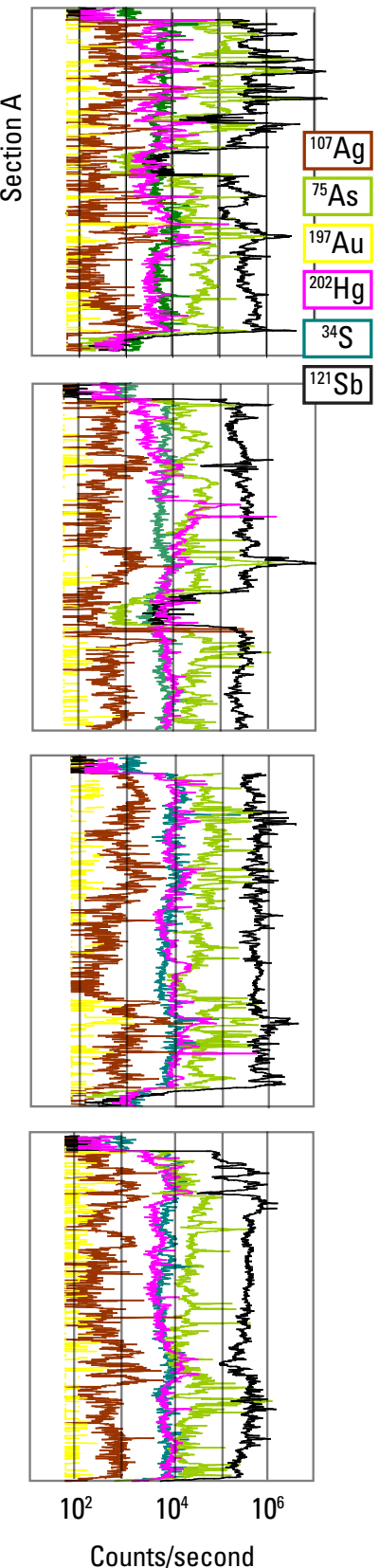

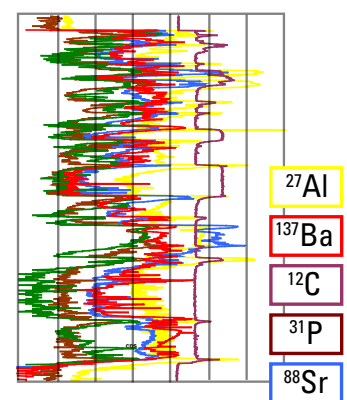

${ }^{27} \mathrm{Al}$
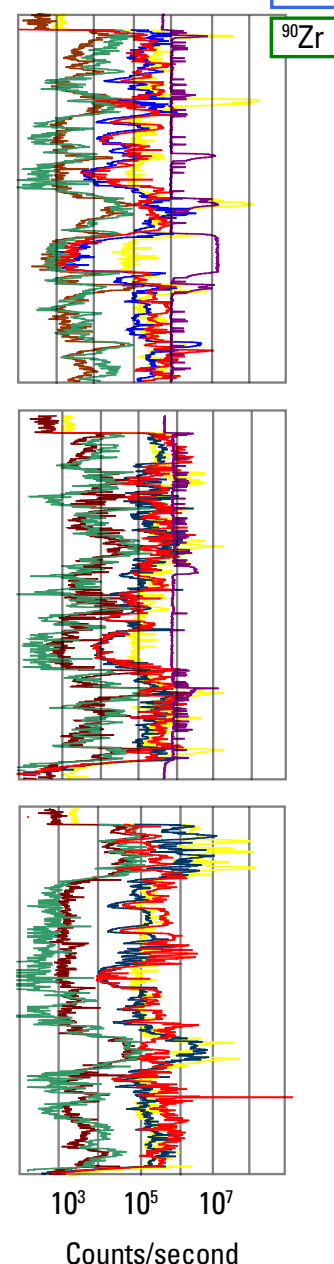
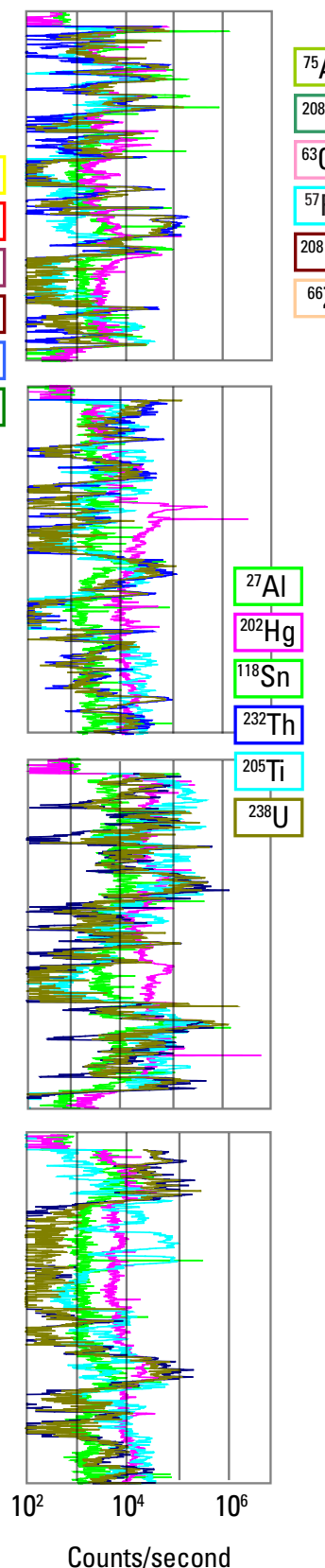

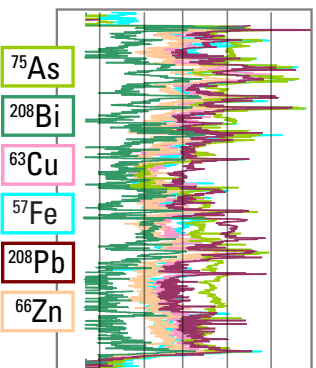

Section A (expanded)
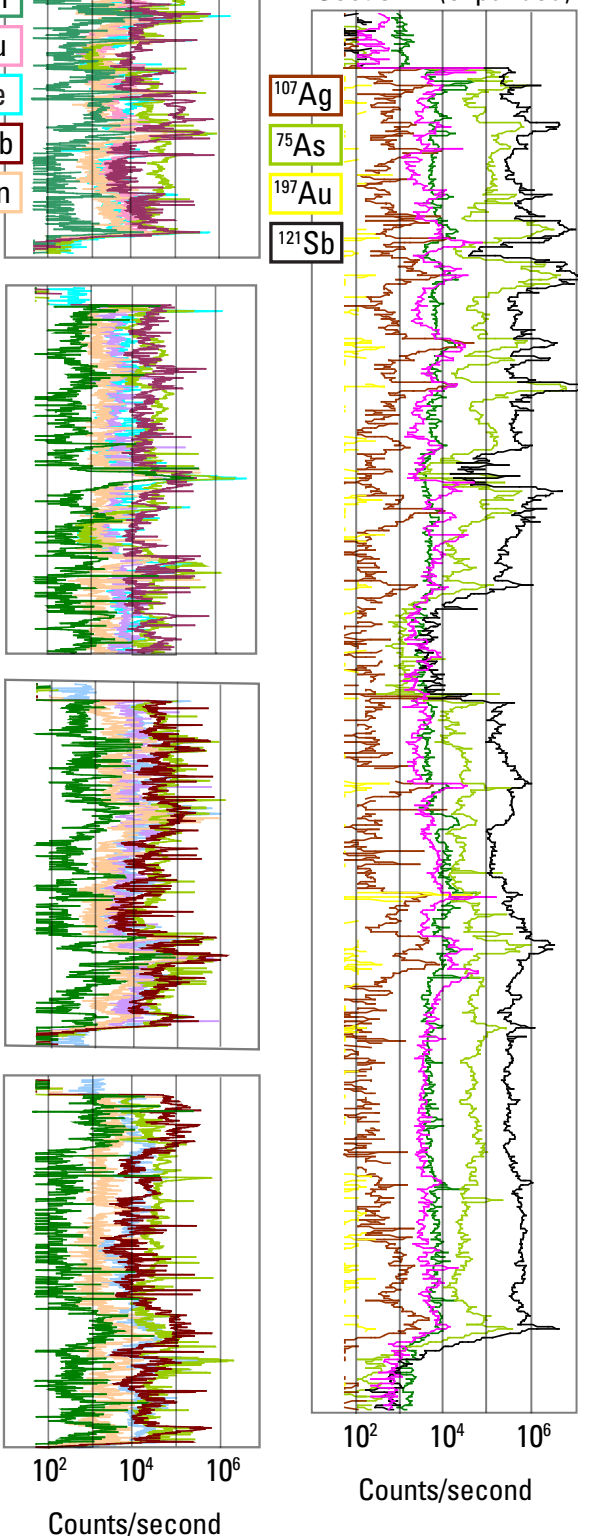

Bulk concentration (ppm; ICP-MS)

$\mathrm{Au} \quad 4 \mathrm{ppb}$

$\mathrm{Ag}<1$

As 80

$\mathrm{Hg} \quad 1.6$

$\mathrm{Sb} 364$

S $\quad<0.05 \%$

TI $\quad 1.8$

$\mathrm{Fe} \quad 0.05 \%$

$\mathrm{Bi}<0.1$

Se $<0.2$

Te $<0.5$

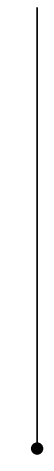

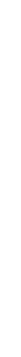


The Bald Peak adit prospect lies about $1.2 \mathrm{~km}$ northwest of Bald Peak and encompasses a discontinuously exposed, north-northeast-trending zone of quartz-chalcedony veins and stockworks as much as $700 \mathrm{~m}$ long by $250 \mathrm{~m}$ wide (fig. 27; L.J. Peters, written commun., 2004). Veins and silicified breccia zones are within porphyritic trachyandesite of Del Monte lava flows. The Bald Peak adit is near the south end of the prospect, where a cliff-forming silicified fault zone contains an $\sim 2$-m-wide, massive to banded, locally brecciated, milky white quartz vein. The vein strikes $\sim \mathrm{N} 15^{\circ} \mathrm{E}$, dips $80^{\circ} \mathrm{SE}-$ $80^{\circ} \mathrm{NW}$, and splits into several thinner veins that pinch out at the south end of the cliff face. Several other zones of narrow (centimeters wide) north-northeast-striking, steeply dipping, chalcedonic quartz-pyrite veins are exposed near the south end of the prospect. Wall rocks of these veins are altered to montmorillonite \pm kaolinite. Quartz veins exposed in bulldozer cuts in the northern part of the prospect consist of brecciated, iron oxide stained, white chalcedonic quartz as much as $0.3 \mathrm{~m}$ wide. Some veins are banded with vuggy centers and bladed textures that suggest quartz replacement of carbonate minerals. Vein samples from the Bald Peak adit prospect contain as much as $5.4 \mathrm{ppm} \mathrm{Au,} 12.3 \mathrm{ppm} \mathrm{Ag,} \mathrm{1,900} \mathrm{ppm} \mathrm{As,} \mathrm{and}$ 6.6 ppm Hg (L.J. Peters, written commun., 2004).

\section{Sulfur Isotope Compositions}

Two samples of cinnabar from the Paramount Mine have similar $\delta^{34} \mathrm{~S}$ values of -5.3 and $-4.7 \%$ (PM08-1A; PM08-1B; table 2). These values are slightly higher than some $\delta^{34} \mathrm{~S}$ values of sulfide minerals in the Aurora Mining District, and slightly lower than values of cinnabar in the Cinnabar Canyon-US 395 alteration zone, and most values of sulfide minerals in Bodie district veins. Paramount Mine cinnabar $\delta^{34} \mathrm{~S}$ values may reflect sulfide-sulfate fractionation. However, the presence of sulfate minerals is unsubstantiated; additional sulfur isotope analyses are required to adequately characterize sulfur geochemistry of this very large alteration zone.

\section{ASTER Imagery}

ASTER imagery (Rockwell, 2010) of the PBP AZ shows widely scattered pixels and five fairly contiguous pixel clusters that correspond to groups of hydrothermal minerals.
Pixel clusters that coincide with northeast-elongate, silicified outcrops along upper Rough Creek about 2.5-3 km southeast of the Paramount Mine contain abundant alunite and kaolinite. The largest contiguous cluster of pixels $(\sim 0.35$ by $0.2 \mathrm{~km})$ on the west side of Atastra Creek west of the sinter terrace corresponds to leached tuff containing abundant smectite and (or) kaolinite and quartz. Other pixel clusters near the confluence of Atastra and Rough Creeks, and on the west side of Rough Creek, correspond to leached tuff that contains quartz, smectite, and kaolinite, and to kaolinite and alunite, respectively. However, no alunite was identified by PIMA spectroscopy in samples collected from several of these clusters.

\section{SWIR Spectra}

SWIR spectra of $\sim 50$ hydrothermally altered and mineralized hand samples from the PBP AZ show that montmorillonite and kaolinite are the dominant clay minerals, and that mixed-layer illite/smectite is less common. Kaolinite is most abundant near sinter outcrops. Alunite, illite, and chlorite were not identified in the analyzed hand samples.

\section{Hydrothermal Mineral Ages}

No hydrothermal minerals in the PBP AZ have been dated. However, based on ${ }^{40} \mathrm{Ar} /{ }^{39} \mathrm{Ar}$ ages of underlying and overlying rock units, sedimentary rocks and tuff of Paramount were hydrothermally altered between $\sim 9.7$ and $9.3 \mathrm{Ma}$. The pervasively altered sedimentary rocks contain abundant clasts of flow-banded, nearly aphyric rhyolite that may have been derived from the $\sim 9.7$ Ma Bald Peak lava dome (John and others, 2012). In most parts of the Paramount basin, altered sedimentary rocks and tuff of Paramount are overlain by unaltered 9.4 Ma Eureka Valley Tuff. The lower part of the Eureka Valley Tuff near Atastra Creek is altered, but that alteration occurred after emplacement of the older, $>9.7 \mathrm{Ma}$ Tollhouse Flat member (Pluhar and others, 2009) of the Eureka Valley Tuff. In Atastra Creek and in other parts of the southwestern Paramount basin, unaltered lava flows of $\sim 9.0$ to 8.8 Ma trachydacite of Potato Peak overlie altered Paramount basin rocks.

Figure 33. (Facing page) $A$, Image showing oriented consecutive sections of sinter with black beds from the sinter terrace on Atastra Creek, Paramount-Bald Peak alteration zone (fig. 27). $B$, Graphs showing relative element concentrations in sinter measured in counts per second (counts/second) by laser ablation inductively coupled plasma-mass spectrometry (LA ICP-MS). C, Bulk sample concentrations determined by inductively coupled plasma-mass spectrometry (ICP-MS). Sinter section A is expanded at right to show (millimeterscale) elevated concentrations of $\mathrm{Au}, \mathrm{Ag}, \mathrm{Hg}, \mathrm{Sb}$, and $\mathrm{As}$. These elements and other elements that are locally concentrated (including $\mathrm{Sn}, \mathrm{TI}, \mathrm{Cu}, \mathrm{Pb}, \mathrm{Zn}$, and $\mathrm{Fe}$ ) are mostly not elevated in the bulk sample. 


\section{Cinnabar Canyon-US 395 Alteration Zone}

\section{Location}

Secs. 2, 3, 4, 9, 10, 11, 13, 14, 15, 16, 23, 24, 25, 26, 36, T. 4 N., R. 25 E. (unsurveyed); secs. 19, 29, 30, 31, T. 4 N., R. 26 E. (unsurveyed), Mono County, California (fig. 1)

\section{Definition}

The Cinnabar Canyon-US 395 alteration zone (CC-395 AZ) is defined by a contiguous volume of rock, mostly volcaniclastic deposits and lesser porphyritic volcanic rocks, which have been pervasively hydrothermally altered to quartz, chalcedony, opaline silica, clay minerals, alunite, and pyrite. Altered rocks extend north and west from the mouth of Cinnabar Canyon to highway US 395, and are partly covered by unaltered trachyandesite of Willow Springs (fig. 34). The alteration zone may be several times larger (approaching $30 \mathrm{~km}^{2}$ ) than exposed. Along and south of Clearwater Creek, alteration intensity decreases abruptly at the contacts of altered rocks and Paleozoic metasedimentary rocks and at contacts of younger rhyolite domes. Much of the alteration zone in secs. 23, 24, 25, T. 4 N., R. 25 E., including the sulfur resource, is covered by colluvium.

\section{History and Production}

Production recorded from the CC-395 AZ consists of 10 flasks of mercury recovered in 1923 at the Calmono (Old Timer) Mine (Holmes, 1965), $0.3 \mathrm{~km}$ south of Cinnabar Hill (sec. 19, T. 4 N., R. 26 E.; sec. 24, T. 4 N., R. 25 E.; fig. 34). A nearby drill-defined sulfur resource, known as the Cinnabar Canyon sulfur deposit, contains $16.1 \mathrm{Mt}$ at 17.9 weight percent $\mathrm{S}^{\circ}$ (sec. 19, T. 4 N., R. 26 E.; sec. 24, T. 4 N., R. 25 E.; Ward, 1992; Vikre and Henry, 2011).

\section{Stratigraphy}

The oldest rocks in the CC-395 AZ, exposed at the mouth of Cinnabar Canyon, are Paleozoic metasedimentary rocks (Chesterman and Gray 1975; fig. 34). In the vicinity of Cinnabar Canyon, Paleozoic metasedimentary rocks are unconformably overlain by a sequence of altered volcaniclastic deposits and largely coextensive porphyritic lava flows (volcaniclastic-flow sequence) in low-relief, domelike landforms. This sequence, which comprises most of the CC-295 AZ, was included in the Willow Springs Formation of Chesterman and Gray (1975), but has been correlated with sedimentary rocks and debris flows of Mount Biedeman ( 9.9-8.9 Ma; table 1). Unaltered and variably altered flows that unconformably overlie altered sequence strata are included in trachyandesite of Willow Springs and dacite of Hot Springs Canyon, respectively (fig. 34; John and others,
2012). In the CC-395 AZ, altered sequence strata, trachyandesite, and dacite have been intruded and partly covered by rhyolite of Big Alkali (John and others, 2012), which includes rhyolites in the Mount Biedeman and Willow Springs Formations of Chesterman and Gray (1975). Within the CC-395 AZ, trachyandesite of Willow Springs is $\sim 8.6-8.0 \mathrm{Ma}$, and dacite of Hot Springs Canyon is $~ 8.1 \mathrm{Ma}$. Rhyolite of Big Alkali, north of Cinnabar Hill, is $\sim 5.5 \mathrm{Ma}$ (fig. 34; table 1).

The Paleozoic metasedimentary rocks are dark-gray to black, hornfels and quartzite (Chesterman and Gray, 1975). These Ordovician and Silurian strata are likely correlative with similar rocks exposed in the Log Cabin Mine and Ritter Range roof pendants in the Sierra Nevada (Kistler, 1966; Chesterman and Gray, 1975). Sedimentary rocks and debris flows of Mount Biedeman consist of poorly sorted lahar, block-and-ash flow, and associated sedimentary deposits shed from the flanks of the Mount Biedeman stratovolcano $\sim 8 \mathrm{~km}$ east-southeast of the CC-395 AZ. To the south, these strata are intercalated with trachyandesite of Mount Biedeman lava flows. Clast populations in sedimentary rocks and debris flows are dominated by trachyandesite of Mount Biedeman. Most block-and-ash flow deposits are brownish-black, clast supported, and include an ashy matrix. Light-gray, recessively weathering lahar deposits are massive, poorly sorted, and contain silt- to boulder-size clasts in an ash- to clay-rich matrix. The sedimentary facies of this unit consists of matrix-supported deposits that contain rounded, compositionally diverse clasts several centimeters to $0.5 \mathrm{~m}$ in diameter.

In the CC-395 AZ, volcaniclastic deposits of the volcaniclastic-flow sequence have been pervasively altered and weather recessively except where silicified. Exposures on the hill marked by conspicuous cuts in clay-altered volcaniclastic deposits (clay-cut hill; fig. 34), and in drainages $1 \mathrm{~km}$ west of Cinnabar Canyon and $\sim 0.2 \mathrm{~km}$ north of Clearwater Creek, consist of chaotic to well-sorted, subrounded to subangular, centimeter- to millimeter-sized clasts of porphyritic volcanic rocks in soft gray-green to beige matrices composed of sand to ash-sized particles (figs. 34, 35). Conformable porphyritic flows occur mostly near the top of the sequence as blocky to locally tiered outcrops. Flows contain variable abundances of partly altered to relict phenocrysts of plagioclase, hornblende, and biotite in a green-gray to beige aphanitic matrix.

Based on the abundance of altered colluvial clasts, deflated surfaces in sec. 24, T. 4 N., R. 25 E., and stratigraphic sections (Ward, 1992), surficial deposits that cover altered volcaniclastic rocks in areas of low relief in the CC-395 AZ are likely meters to a few tens of meters thick.

\section{Structure}

The distribution of exposed altered rocks indicates that the CC-395 AZ is elongate northwest-southeast. However, alteration was strongly controlled by lateral permeability in the volcaniclastic-flow sequence, much of the alteration zone is partly covered by unaltered trachyandesite of Willow Springs, and the overall extent of the alteration zone may be more 
equidimensional. Faults that may have served as conduits for hydrothermal fluid circulation in sequence strata are not widely evident. Northwest-striking faults that bound the sulfur resource near Cinnabar Hill presumably have controlled alteration of sequence strata that contain the resource (Ward, 1992). Normal displacement along the northern fault, which corresponds to a northwest-trending linear escarpment of silicified sequence strata, is interpreted to have down-dropped sequence strata to the south. This fault apparently served as a conduit for hydrothermal solutions; displacement along it confined all sulfur to the footwall block. Lineaments on color air photos suggest that this fault extends to highway US 395. Two west-east-trending structures may slightly displace altered and postalteration rocks near Cinnabar Canyon (fig. 34). Other predominantly north- and northwest-striking faults were mapped by Chesterman and Gray (1975) in the vicinity of the $\mathrm{S}^{\circ}$ resource and north and northwest of the resource.

The west side of the alteration zone is bordered by surficial deposits of Bridgeport Valley. These basin-fill deposits unconformably overlie altered sequence strata and are juxtaposed against them along a northwest-striking fault that is subparallel to US 395 (fig. 34).

\section{Forms of Mercury and Sulfur Mineralization}

The Calmono (Old Timer) Hg Mine, in the drainage at the south base of Cinnabar Hill (fig. 34), consists of shallow pits, cuts, a caved shaft, and remnants of a retorting (recovery) facility. Based on examination of dump samples, cinnabar occurs in thin veins and coats fractures in clay-altered porphyritic flows, and was likely the source of $\mathrm{Hg}$ production.

The Cinnabar Canyon sulfur resource, located immediately northwest of Cinnabar Hill, is $\sim 60-135 \mathrm{~m}$ below the surface (figs. 34,36 ). Its lateral dimensions are $\sim 545 \mathrm{~m}$ northwest to southeast, and $\sim 275 \mathrm{~m}$ southwest to northeast. The resource was identified in core and reverse circulation holes drilled for gold by Homestake Mining Company and Amselco Minerals Inc. in the late 1980s. The resource occurs in volcaniclastic-flow sequence strata that are altered to stratiform, subhorizontal assemblages of silica, clay minerals, pyrite, sulfur, and minor amounts of gypsum, barite, and cinnabar.

The following description of the sulfur resource is condensed from Ward (1992) and supplemented by observations derived from mapping and examination of discarded pieces of core at drill sites (Vikre and Henry, 2011). Several tens to $>100 \mathrm{~m}$ of sequence strata are replaced by fine-grained quartz over the sulfur resource (fig. 36). These resistant rocks crop out on and northwest of Cinnabar Hill but rarely contain sulfur. Below and lateral to the stratiform silicification, sequence strata are partially to entirely replaced by clay minerals and opaline silica. Beneath opaline silica-clay alteration is a section of sequence strata $\sim 35-60 \mathrm{~m}$ thick that is replaced by fine-grained quartz, 0 to $>20$ volume percent pyrite, and 0 to
$>20$ weight percent sulfur. Based on IR and XRD analyses, and on petrographic examination of discarded drill core, these altered strata also contain small amounts of anatase, gypsum, barite, and cinnabar. The paragenetically late gypsum, barite, and cinnabar encrust fractures and voids that represent leached rock fragments and phenocryst sites in sequence strata. Sulfur-mineralized sequence strata grade downward into "weakly argillized" sequence strata that contain significant sulfur in several drill holes. Sulfur occurs in several forms (1) replacements of plagioclase phenocrysts and matrices of lava flows and volcaniclastic deposits, with variable amounts of quartz and pyrite, and (2) open-space filling of fractures and breccia matrices. Sulfur grades are highest in the upper and lower parts of the resource, possibly reflecting lithologic control (contrasting fluid permeability). The resource is confined on the northeast and south by faults. To the southwest and northwest, decreasing sulfur/pyrite defines a gradational limit to the resource.

\section{Hydrothermal Alteration}

Adjacent to and distal from the sulfur resource, volcaniclastic deposits of the volcaniclastic-flow sequence have been pervasively altered to quartz, chalcedony, opaline silica, clay minerals, alunite, pyrite (iron oxides), and small amounts of sulfur (figs. 34, 35). Interbedded porphyritic flows are variably altered; thin flows are pervasively altered and thick flows are less altered. This lithologic control of fluid circulation is evident in numerous places including the area immediately south of the Calmono Hg Mine, and on the south side of the clay-cut hill where altered volcaniclastic deposits and lesser porphyritic flow rocks have been excavated for clay minerals (fig. 34). The predominant mineral in white-colored excavations on the clay-cut hill is montmorillonite, as determined by XRD.

Volcaniclastic deposits on the upper part of Cinnabar Hill are white to beige where they are completely replaced by fine-grained quartz with local iron oxide minerals on fractures; millimeter to centimeter-wide voids from leached clasts and phenocrysts are common in these resistant exposures. At lower elevations on Cinnabar Hill and throughout most of the CC-395 AZ, volcaniclastic deposits are gray-green and beige to yellow-brown to red-brown, depending on proportions of clay minerals (montmorillonite, kaolinite), iron oxide minerals (limonite, hematite, jarosite), and alunite (fig. 35). On the east side of Cinnabar Canyon, east and south of Cinnabar Hill, volcaniclastic deposits locally form resistant knobs of opaline silica that also contain clay minerals and alunite.

Breccias and veins crop out at several locations northwest and west of Cinnabar Hill. Brecciated porphyritic volcanic rocks within the volcaniclastic-flow sequence $\left(\mathrm{NW}^{1 / 4} / \mathrm{NE}^{1 / 4} \mathrm{NW}^{1 / 4} 4 \mathrm{sec} .24\right.$, and $\mathrm{SE}^{1 / 4} \mathrm{SW}^{1 / 4} / \mathrm{SW}^{1 / 4} \mathrm{sec}$. 13, T. 4 N., R. 25 E.) consist of subrounded, centimeter-sized clasts of partly leached vuggy silica in a white matrix of fine-grained to microcrystalline quartz, alunite, and kaolinite 


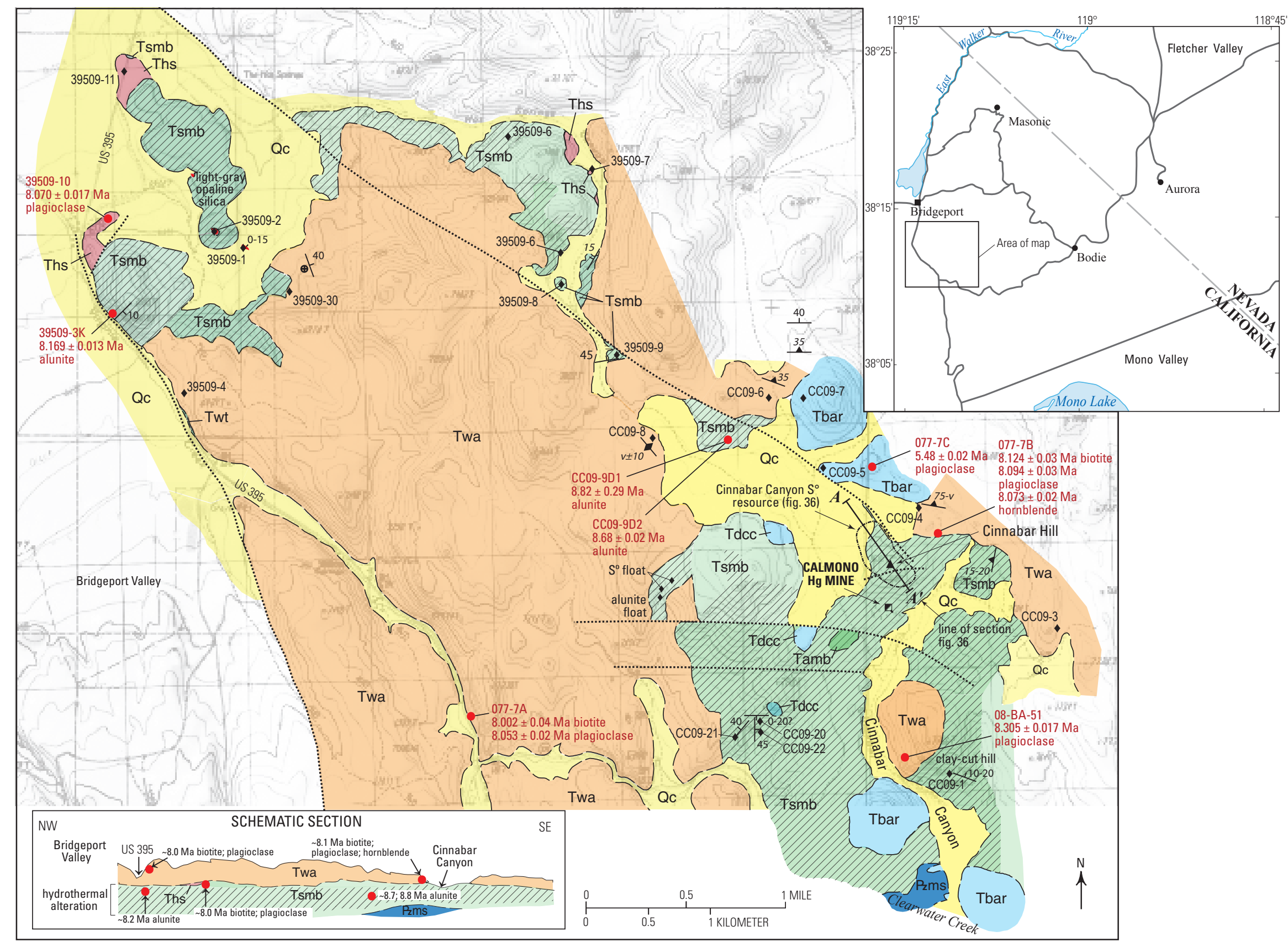

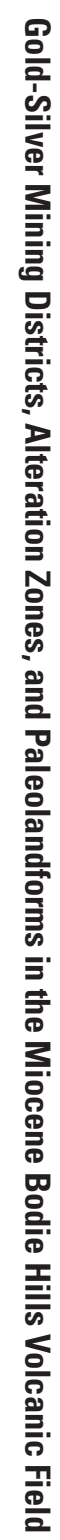

Base modified from U.S. Geological Survey

Big Alkali, Calif., 1989, 1:24,000 


\section{EXPLANATION}

\begin{tabular}{|c|c|}
\hline Qc & Colluvium \\
\hline Tbar & Rhyolite of Big Alkali \\
\hline Ths & Dacite of Hot Springs Canyon \\
\hline Twa & $\begin{array}{l}\text { Trachyandesite of Willow Springs (dacite of Chesterman and } \\
\text { Gray, 1975) }\end{array}$ \\
\hline Tdcc & Trachydacite of Cinnabar Canyon \\
\hline Tamb & Trachyandesite of Mount Biedeman \\
\hline Tsmb & $\begin{array}{l}\text { Sedimentary rocks and debris flows of Mount } \\
\text { Biedeman-Includes volcaniclastic deposits, pyroclastic } \\
\text { deposits, and porphyritic andesite (Twt and Twd of } \\
\text { Chesterman and Gray, 1975); pervasively altered to quartz, } \\
\text { opaline silica (red polygons), clay minerals, pyrite and } \\
\text { alunite (line-pattern) }\end{array}$ \\
\hline
\end{tabular}

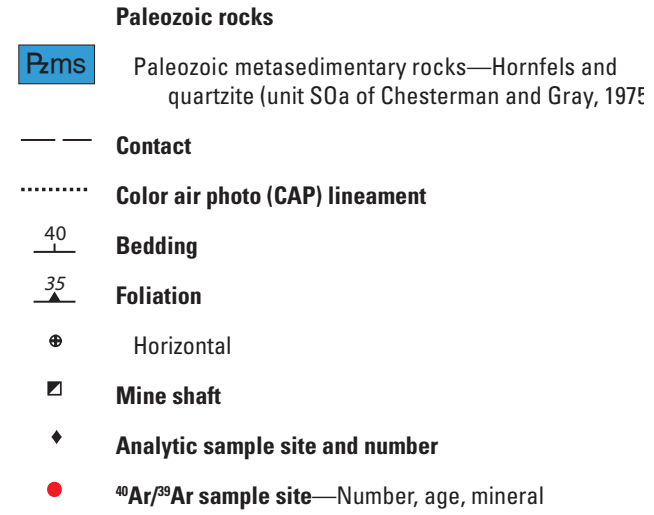

- ${ }^{40} \mathrm{Ar} /{ }^{39} \mathrm{Ar}$ sample site-Number, age, mineral

Figure 34. (Facing page) Geologic map and schematic stratigraphic section of the Cinnabar Canyon-US 395 alteration zone, Mono County, California, in part modified after Chesterman and Gray (1975) and John and others (2012). 
Figure 35. Images showing volcaniclastic deposits from the Cinnabar Canyon-US 395 alteration zone. $A$, Volcaniclastic deposits on clay-cut hill, Cinnabar Canyon, altered to montmorillonite, kaolinite, and lesser illite. $B$, Sorted and bedded volcaniclastic deposits in a drainage $1 \mathrm{~km}$ west of Cinnabar Canyon, $0.2 \mathrm{~km}$ north of Clearwater Creek, altered to montmorillonite and kaolinite; beds strike N-S, dip $65^{\circ} \mathrm{E}$; attitude of indistinctly bedded overlying debris flows $30 \mathrm{~m}(\sim 100 \mathrm{ft})$ uphill is $\sim \mathrm{W}-\mathrm{E}, 0-20^{\circ} \mathrm{S}$. C, Debris flows exposed in a layback along US $395, \sim 8 \mathrm{~km}$ ( $\sim 5 \mathrm{mi})$ south of Bridgeport, California, altered mostly to alunite, kaolinite, and quartz; vertical face is $\sim 4 \mathrm{~m}$.
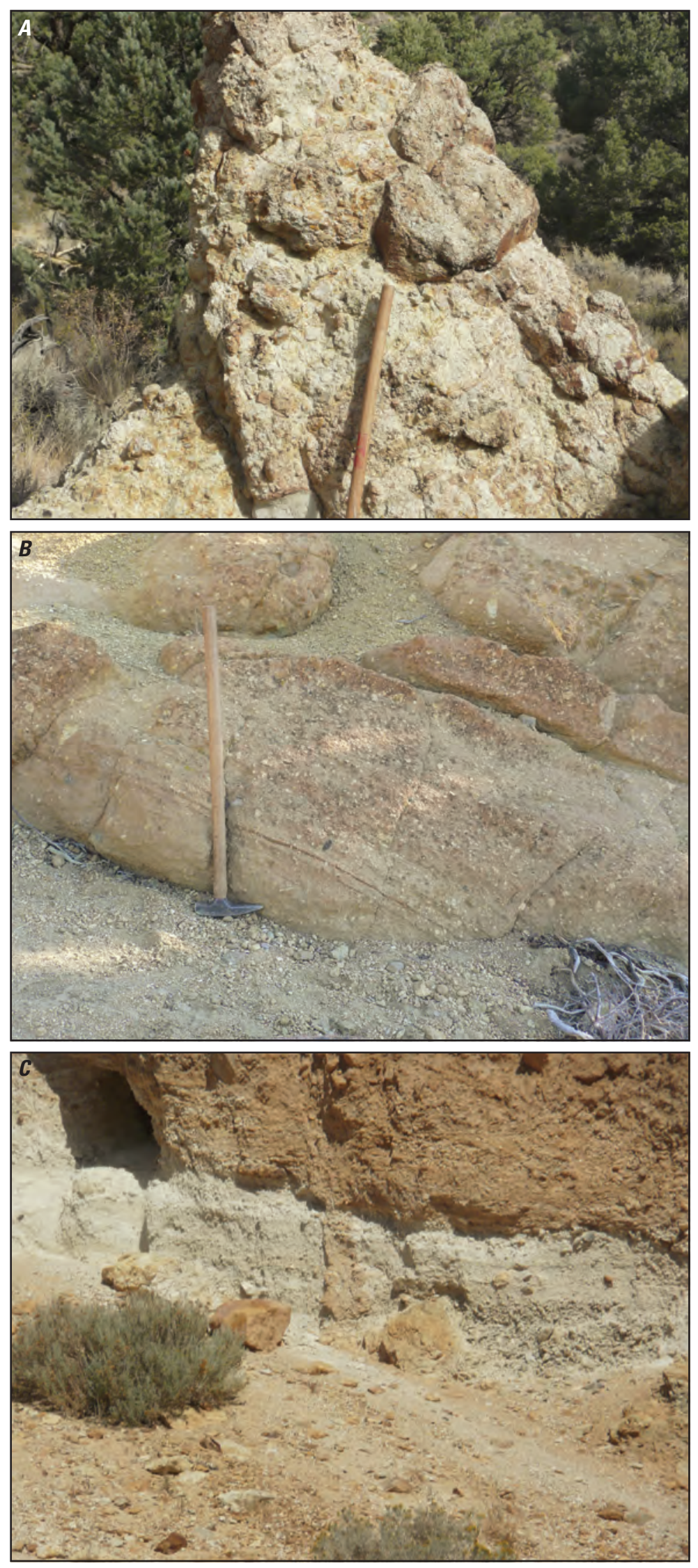


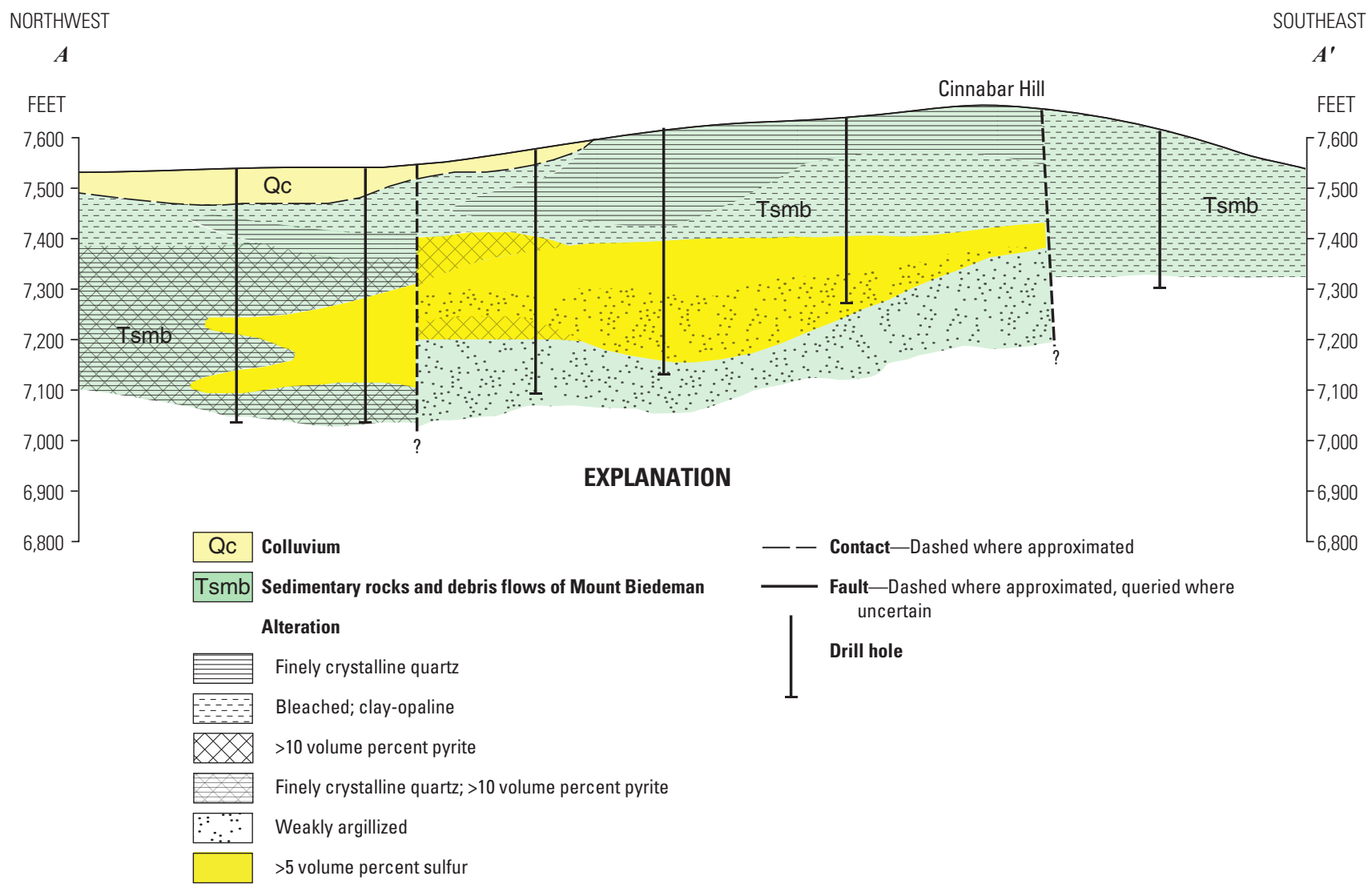

Figure 36. Cross section (northwest-southeast) through the Cinnabar Canyon elemental sulfur resource (after Ward, 1992), Cinnabar Canyon-US 395 alteration zone, Mono County, California. Location of section is shown on figure 34.

in variable proportions. Narrow veins, millimeters wide, consist of the same minerals as the breccia matrix. Similar brecciated rocks within the volcaniclastic-flow sequence in the north-south drainage, about $2 \mathrm{~km}$ west-southwest of Cinnabar Hill, contain small amounts of sulfur in leached clasts.

Vegetation contrasts partially delineate the alteration zone. Pervasively and intensely altered volcaniclastic deposits support piñon pine but relatively little ground cover. Ponderosa pine trees near Cinnabar Hill grow in soils derived from opaline silica-clay-alunite-altered volcaniclastic strata, but are rare elsewhere in the Bodie Hills except in the Red Wash-East Walker River alteration zone. Unaltered trachyandesite of Willow Springs that partially overlies the altered volcaniclastic-flow sequence is relatively densely covered by piñon pine.

\section{Minor Elements in Rocks}

Thirty-eight samples of altered rocks and core scraps from the sulfur resource drill sites (table 1-10) contain variably elevated concentrations of $\mathrm{Hg}(1-337 \mathrm{ppm}), \mathrm{Ag}$ (2-20 ppm), As (92-396 ppm), Bi ( 11-216 ppm), Pb ( 71-7,510 ppm), Sb ( 14-231 ppm), and Te (1-8.7 ppm). A few samples contain elevated $\mathrm{Co}, \mathrm{Ni}$, and $\mathrm{Sr}$ concentrations. The highest Au concentration is $0.084 \mathrm{ppm}$; Au concentrations in most samples are at or below the $\sim 0.005 \mathrm{ppm}$ detection limit. Barium concentrations exceed 1,000 ppm in many samples; a number of samples contain several percent $\mathrm{S}$, apparently reflecting the presence of barite, alunite and other sulfate minerals, and sulfur. Elevated $\mathrm{As}, \mathrm{Bi}, \mathrm{Pb}$, and $\mathrm{Sb}$ concentrations also allow for the presence of metallic sulfide minerals. 


\section{Sulfur Isotope Compositions}

Sulfur isotope $\left(\delta^{34} \mathrm{~S}\right)$ values of sulfur, cinnabar, and pyrite in altered sequence strata (encountered in drill holes) that contain the sulfur resource, vary from -5.2 to $-4.7 \%,-0.7$ to $-0.2 \%$, and -9.8 to $-8.0 \%$, respectively (table 2 ; Vikre and Henry, 2011). The $\delta^{34} \mathrm{~S}$ value of barite in drill core is $1.1 \%$. Alunite in an altered sequence sample from the drainage $\sim 2 \mathrm{~km}$ west of Cinnabar Hill has a $\delta^{34} \mathrm{~S}$ value of $2.5 \%$. These sulfur isotope compositions are difficult to interpret because of paragenetic and age differences among analyzed minerals, and possible sample impurity. Disproportionation of magmatic $\mathrm{SO}_{2}$ most likely caused alteration of sequence strata, but the $\delta^{34} \mathrm{~S}$ values allow variable parent sulfur isotope compositions and (or) equilibrium temperatures. Further, the $\sim 0.65$ m.y. spread of ${ }^{40} \mathrm{Ar} /{ }^{39} \mathrm{Ar}$ ages of alunite implies that several separate magmatic-hydrothermal events altered sequence strata.

Interpretation of sulfur isotope chemistry requires additional, paragenetically controlled analyses of minerals throughout the CC-395 AZ.

\section{ASTER Imagery}

ASTER imagery (Rockwell, 2010) of the CC-395 AZ shows spatial associations of alunite, kaolinite, illite, montmorillonite, and quartz. The distribution of these minerals is discontinuous because of spectral resolution, colluvium, trees, and unaltered trachyandesite of Willow Springs that cover altered sequence strata. Surficial deposits in low relief parts of the alteration zone overlie clay-alunite-altered sequence rocks; spectral reflectance of altered colluvial clasts mimics that of altered sequence rocks.

Alteration mineral abundances and associations are variable within the CC-395 AZ. Breccias and sequence strata that underlie Cinnabar Hill and the low-relief hills south of the Calmono Hg Mine and east of Cinnabar Canyon contain alunite, kaolinite, montmorillonite, and lesser illite. Alteration minerals on the east slope of Cinnabar Hill and on hills underlain by porphyritic flows west of Cinnabar Hill are mostly kaolinite and montmorillonite. Alteration minerals in the drainage parallel to and $\sim 2 \mathrm{~km}$ west of Cinnabar Canyon, on the south slope of the clay-cut hill, and in volcaniclastic strata south of this hill, are mostly kaolinite and montmorillonite with lesser illite and alunite. Cinnabar Hill, which consists of fine-grained quartz and chalcedony, and the sulfur resource to the northwest that is covered by surficial deposits, are coincident with spectral responses indicative of very sparse illite and montmorillonite. These variable alteration mineral associations, coupled with alunite ages and sulfur isotope analyses, are consistent with several alteration events in the CC-395 AZ.

\section{SWIR Spectra}

Based on SWIR analyses, hydrous minerals in hand samples of altered volcaniclastic strata and porphyritic flows in the CC-395 AZ include montmorillonite, illite, kaolinite, alunite, and opal, supporting field observations and ASTER imagery.

\section{XRD Mineralogy}

Two samples of core scraps from drill sites over the Cinnabar Canyon sulfur deposit consist of quartz, pyrite, sulfur, and trace amounts of anatase.

\section{Hydrothermal Mineral Ages}

The ${ }^{40} \mathrm{Ar}{ }^{39} \mathrm{Ar}$ dates of alunite in the matrix of brecciated porphyritic rocks within the volcaniclastic-flow rock sequence $\sim 1 \mathrm{~km}$ northwest of the sulfur resource, and of alunite in veins cutting porphyritic rocks $\left(\mathrm{NW}^{1 / 4} \mathrm{NE}^{1 / 4} \mathrm{NW}^{1 / 4} \mathrm{sec}\right.$. 24 , and $\mathrm{SE}^{1 / 4} \mathrm{SW}^{1} 1 / 4 \mathrm{SW}^{1} / 4$ sec. 13 , T. 4 N., R. 25 E.; fig. 34), are $8.82 \pm 0.29 \mathrm{Ma}$ and $8.68 \pm 0.02 \mathrm{Ma}$, respectively (fig. 34; table 1). Alunite that has partly replaced fragments in volcaniclastic strata in the US 395 layback $\sim 8 \mathrm{~km}$ south of Bridgeport, California, is $8.17 \pm 0.01 \mathrm{Ma}$ (fig. 34; table 1).

Although no sulfur isotope analyses are available, the alunite dates are consistent with stratigraphic ages (table 1), and the dated alunites are considered hypogene. The range in alunite dates indicates that sequence strata were altered two or more times. The alunite dates are broadly contemporaneous with magmatism represented by 8.6-8.0 Ma trachyandesite of Willow Springs (table 1). 


\section{Bodie Mining District}

\section{Location}

Secs. 9, 10, 16, 17, 20, 21, 28, 29, T. 4 N., R. 27 E., Mono

County, California (fig. 1)

\section{History and Production}

The Bodie Mining District has a storied history because of very rich Au-Ag ore and a citizenry that often was indifferent to law. The district and town that provided services were named by companions of one of the discoverers, W.S. Bodey, who died in 1860, the year following discovery. A later intentional misspelling, Bodie, was permanently adopted for both.

Bodie history has been recounted by Browne (1865), Wasson (1878), Burchard (1881), Wedertz (1969), and Piatt (2003). Placer $\mathrm{Au}$, discovered in 1859 in the shallow drainage east of the Red Cloud Mine dump, led to the location of Au-Ag veins shortly thereafter. In the early 1860 s, veins on Standard Hill (earlier named Bunker Hill and High Peak Hill) and Bodie Bluff were mined seasonally because of inaccessibility during winter, summer, and fall water shortages, and perception that the Aurora Mining District was more prospective, even though Bodie veins were extolled by mining notables B. Silliman and W.P. Blake (Wasson, 1878). The small amounts of ore produced from these veins were initially hauled kilometers west for processing in perennial Rough Creek, and some ore was processed at Aurora. The Empire (stamp) mill, constructed in 1864 at the base of the north slope of Bodie Bluff, processed ore from veins that became the Syndicate Mine, and from the Bullion née Bunker Hill vein on Standard Hill, which in 1877 was renamed the Standard vein of the Standard Mine (figs. 37, 38). In that year, 1,000 tons of Standard vein ore, processed at the Empire mill, averaged $\$ 45$ per ton $(\sim 2.3$ opt $\mathrm{Au}$ at the prevailing price of $\sim$ 20/oz); a subsequent lot of 10,000 tons netted $\$ 428$ per ton ( 21.4 opt Au). Rapid development of the Standard and other veins ensued in late 1877, and the Standard mill was built. In 1878, the high-grade Fortuna, Burgess, and Bruce veins were discovered in the adjacent Bodie Mine. Some ores from these veins averaged $\$ 600$ per ton $(\sim 30$ opt $\mathrm{Au})$ and electrum clogged stamps in the Empire mill. Over the next three years, large volumes of very rich ore were produced from the Standard vein, which became the largest source of ore in the district, and from veins in the Bodie Mine. In the early $1880 \mathrm{~s}$ the population of Bodie was an estimated 8,000.

From 1877 to 1882 , numerous additional mines were developed on veins on Bodie Bluff, Silver Hill, and Queen Bee Hill, and in lower ground between these hills. Despite locally high assays and higher expectations (for example, Burchard, 1881; 1882; 1884), little to no ore was found in most mines. Insufficient milling capacity or water shortages delayed ore processing, which led to owner impatience, investor pressure, and construction of numerous mills, most of which were idled within one year. Optimism, neighbor envy, stock manipulation, and assessments also empowered mining companies to excavate shafts and exploration crosscuts well below the water table, which was encountered at $\sim 400-780 \mathrm{ft}$. The costs of water control and deep exploration turned most mining companies into assessment companies whose main legacies were multicompartment shafts, mammoth Comstock Lode-scale pumping and hoisting facilities, and fleeced investors. Small amounts of ore were recovered from the dewatered Fortuna vein on the 700, 800, and 1,000 levels of the Lent shaft (fig. 37), but most nonproductive mines had ceased operating by the end of 1884 . The Lent and another deep water-control shaft, the Red Cloud (fig. 37), were deepened and dewatered several times during the 1880s, but little to no ore was found at depth. The virtual absence of ore $\sim 600 \mathrm{ft}$ below the surface on Bodie Bluff and Standard Hill is attributed to relatively low $\mathrm{Au}-\mathrm{Ag}$ grades, narrow vein widths, and the high cost of mining in water at depth.

In the $1890 \mathrm{~s}$, mining was revived when electricity replaced wood-fueled steam power, and gravity-Washoe pan processing was converted to cyanidation. Efficiencies and lower operating costs derived from these technologies enabled profitable reworking of tailings and dumps, and production from low-grade narrow veins (1-4 inches) above the 500 level of the Standard Mine until 1913, when narrow-vein ore was depleted. After closure of the Standard Mine, cyanidation of mine waste and leasing (Eakle and McLaughlin, 1919) resulted in episodic production through the 1930s, including a short-lived attempt by the Treadwell-Yukon Company, Ltd. in 1929-32, to mill dumps and dewatered sulfide veins in the connected Red Cloud-Noonday-Oro Mines. From 1936 to 1942, the Roseklip Mining Company processed 346,000 tons of dumps from the Bulwer Tunnel (used to access the Standard Mine; fig. 37), Standard and Bodie Mine dumps, and tailings from Silver Hill mills. The company also mined $\sim 55,000$ tons of narrow veins from surface excavations in the vicinity of the Standard, Bodie, and Con Pacific shafts, and produced $\sim 21,170 \mathrm{oz} \mathrm{Au}$ and $\sim 562,000 \mathrm{oz} \mathrm{Ag}$ (estimated from bullion value at gold $=\$ 35 / \mathrm{oz}$, and silver $=\$ 0.70 / \mathrm{oz}$; tables 6 and 7 ; Chesterman and others, 1986).

Based on bullion value and weight of $\mathrm{Au}$ and $\mathrm{Ag}$ produced from 1877 to 1882, ore grades in mines on Standard Hill and Bodie Bluff varied from $\sim 1$ to several opt $\mathrm{Au}$, and contained several opt Ag. During this period, parts of veins that contained less than $\sim 1$ opt Au were often not mined. Gold grades in ore produced from mines near Silver Hill were in the same range, but Ag grades were tens or more opt. However, Silver Hill vein ore was seldom defined by Ag values, in part because some to most Ag was in sulfide minerals and not economically recoverable. Most ore mined after the mid-1890s was lower grade because electrification, cyanidation, and surface mining decreased extraction and processing costs, and because high-grade ore had been depleted. 


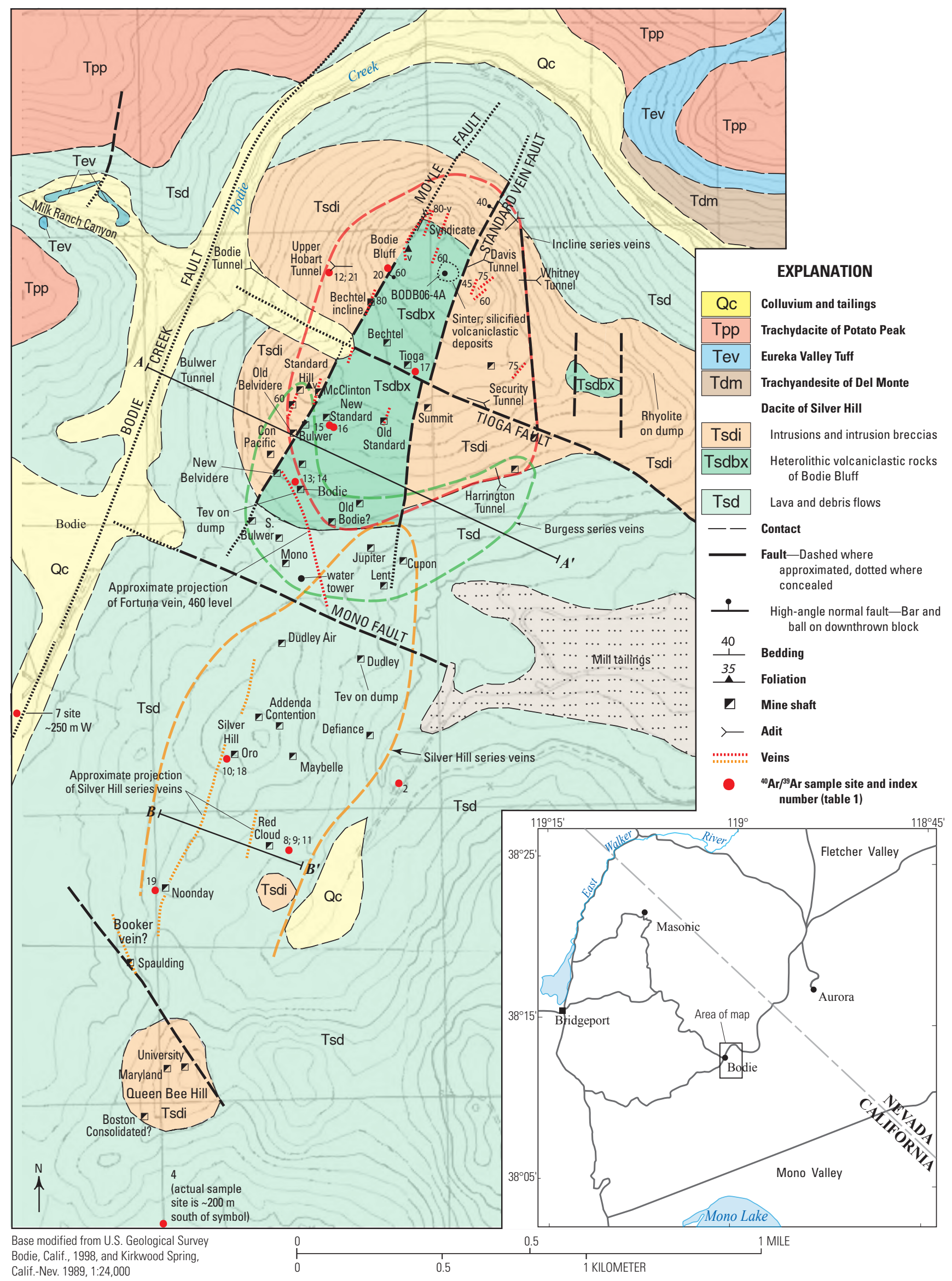


Figure 37. (Facing page) Geologic map of the Bodie Mining District, Mono County, California, modified from Chesterman and others (1986), and John and others (2012). Cross section sections $A-A^{\prime}$ and $B-B^{\prime}$ shown in figure $38 A, B$, respectively.
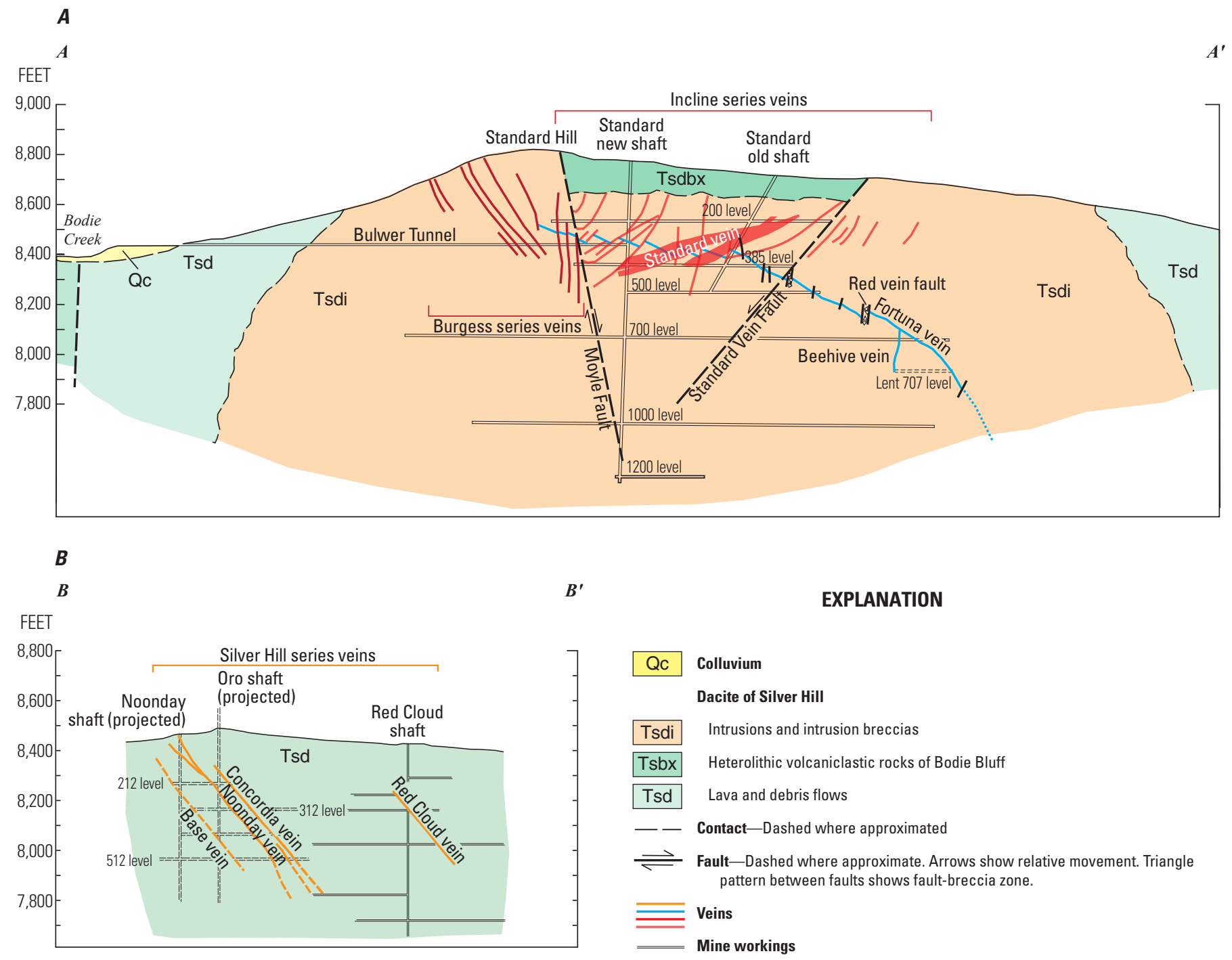

EXPLANATION

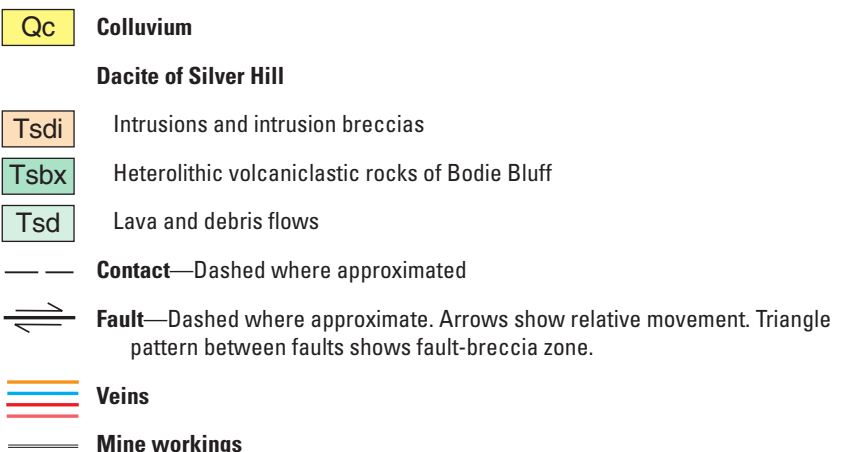

Figure 38. Geologic cross sections of the Bodie Mining District. $A$, West-northwest to east-southeast cross section through the Standard Mine, modified from Chesterman and others (1986), Whiting (1888), Brown (1908), and Piatt (2003), showing distribution of Incline and Burgess series veins, and the Fortuna vein. Eureka Valley Tuff on the Bodie Mine dump (fig. 37) indicates that the stratigraphy on the west side of the section is incompletely represented. $B$, Approximately west-northwest to east-southeast cross section through the Red Cloud shaft, modified from sections in the Bodie Consolidated Mining Company Collection (2003; University of Nevada Reno, Special Collections), showing distribution of Silver Hill series veins. Mine workings, veins, and faults are approximately positioned because of inconsistencies among source sections. Section locations are shown in figure 37. Vertical and horizontal scales are equivalent. Proj., projected. 
Gold-Silver Mining Districts, Alteration Zones, and Paleolandforms in the Miocene Bodie Hills Volcanic Field

Recorded production from 1859 to 1955 is $1.456 \mathrm{Moz}$ $\mathrm{Au}$, and 7.280 Moz Ag recovered from 1.5 Mt of ore (Long and others, 1998). Significant amounts of ore (>10,000 oz $\mathrm{Au}$ ) were produced from the Standard, Bodie, Noonday, and Bulwer Mines. Smaller production (tens to several thousand ounces of $\mathrm{Au}$, estimated from production values in Burchard, 1881) came from the Bechtel, Red Cloud, Syndicate, Belvidere, Bodie Tunnel, and Oro Mines. The Tioga, Mono, and Lent Mines produced no or small amounts of ore despite extensive workings and large dumps. Primary functions of the Lent and Red Cloud Mines were to dewater and provide access to productive neighboring mines. Based on maps of underground workings (Chesterman and others, 1986), other sizeable mines on and near Silver Hill, including the Contention, Addenda, and Maybelle, accessed veins encountered in the Noonday and Oro Mines. No production has been verified for mines south of the Noonday Mine (fig. 37).

A resource of 24.6 Mt @ 0.07 opt Au and 0.42 opt $\mathrm{Ag}$ was identified in the 1980s (Long and others, 1998) by drilling on Standard Hill and Bodie Bluff. A larger but lower grade resource estimate of $75 \mathrm{Mt} @ 0.037$ opt Au and 0.08 opt $\mathrm{Ag}$ is reported by Hollister and Silberman (1995a). This resource includes $\sim 25 \mathrm{Mt} @ 0.04-0.05$ opt Au in oxidized rocks (Chesterman and others, 1986; Hollister and Silberman, 1995a) that could be mined by open pit and processed by heap leaching. These resources consist of closely spaced narrow veins, vein stockworks, and breccias between and branching from larger veins that were mined from $\sim 1877$ to 1942 (Hollister and Silberman, 1995a). In 1997, the mining claims that include the resources and nearly all old mines were added to the Bodie State Historic Park (Bodie Consolidated Mining Company Collection, 2003), which is managed by the California Department of Parks and Recreation.

\section{Stratigraphy}

Veins are nearly entirely within dacitic to andesitic intrusions, flows, debris flows, block-and-ash flows, and other volcaniclastic deposits (Silver Hill volcanic series of Chesterman and others, 1986; dacite of Silver Hill of John and others, 2012; other stratigraphic units are described by Gumble and others, 1991); these host rocks are collectively referred to hereinafter as dacite of Silver Hill. According to Brown (1908), wall-rock fragments internal to veins that were encountered during mining include a fine-grained, coal-black lithology. These fragments are likely Eureka Valley Tuff, which comprises some of the Bodie and Dudley Mine dumps on the south slope of Standard Hill and northeast of Silver Hill, respectively (fig. 37). The 9.5-9.3 Ma Eureka Valley Tuff (John and others, 2012) on these dumps is cut by quartzadularia veins and breccias that are $8.9-8.1$ Ma elsewhere in the district (table 1). Eureka Valley Tuff on Standard Hill and Bodie Bluff is entirely concealed by flows, debris flows, and talus adjacent to domes of dacite of Silver Hill that comprise these landforms.
Domical intrusions and associated debris flows of dacite of Silver Hill were emplaced over a short time interval, 9.1-8.9 Ma (table 1). Bodie Bluff, Standard Hill, Queen Bee Hill (fig. 37), and Sugarloaf (Sugarloaf is $\sim 0.1 \mathrm{~km}$ south of fig. 37) are cored by flow-banded dacite intrusions (dacite plugs of Chesterman and others, 1986); the most productive veins occur in these intrusions on Standard Hill and Bodie Bluff. Veins on Silver Hill, and other veins between Standard Hill, Queen Bee Hill, and Silver Hill, occur in biotitehornblende dacite flows, associated block-and-ash flows, and debris flows. Biotite-hornblende flows also are exposed on the south slopes of Bodie Bluff and Standard Hill, and south of Queen Bee Hill. In mine workings, endogenous flow-domes are reportedly as much as $700 \mathrm{ft}$ thick (Chesterman and others, 1986).

The dacite of Silver Hill is medium-light-gray to light-brownish-gray, moderately porphyritic, and commonly massive but locally flow laminated. It contains $15-30$ percent phenocrysts of plagioclase, hornblende, and biotite, and trace amounts of quartz and (or) sanidine in a moderately devitrified (rarely glassy) groundmass. Regionally, the dacite forms a series of lava domes that coalesce to a roughly circular area. Debris flows associated with the dacite of Silver Hill are lightgray to very pale-orange, recessive-weathering, poorly sorted, matrix-supported deposits that were shed during the lateral collapse of lava domes. Clast populations are dominated by dacite of Silver Hill blocks as much as several meters in diameter that commonly are prismatically jointed, but include clasts of older volcanic rocks of the Bodie Hills volcanic field, especially trachyandesite of Mount Biedeman. A weakly consolidated ash and clay-rich matrix is present in isolated outcrops, yielding residual surfaces strewn with large-boulder lag deposits.

Heterolithic volcaniclastic deposits on the top and south slope of Bodie Bluff are bounded to the west and east by northeast-trending, graben-forming faults, which both offset and contain mineralized veins. These deposits, as much as $60 \mathrm{~m}$ thick, are composed of subangular, altered clasts of dacite, mostly centimeters in dimension, and other, uncorrelated volcanic rocks in a fine-grained matrix of comminuted rock fragments and ash (figs. 37, 38). On the summit of Bodie Bluff, the deposits include a dismembered sinter terrace and local sinter fragments. Adjacent to, between, and above veins, dacite intrusions, dacite flows, and volcaniclastic deposits have been altered to zoned associations of hydrothermal minerals.

Porphyritic lavas and block-and-ash flows of trachydacite of Potato Peak (9.1 to 8.8 Ma; John and others, 2012) overlie dacite of Silver Hill to the north and west of the district. Eureka Valley Tuff is exposed $\sim 1 \mathrm{~km}$ northeast of Bodie Bluff and in Milk Ranch Canyon west of Bodie Bluff where it underlies dacite of Silver Hill and trachydacite of Potato Peak (fig. 37). Based on exposures of Eureka Valley Tuff in Milk Ranch Canyon, Eureka Valley Tuff in the Bodie and Dudley Mines is $\sim 5-8 \mathrm{~m}$ thick. 


\section{Structure}

In the Bodie Mining District, flows and volcaniclastic strata of dacite of Silver Hill originated from, and were domed by, three or more dacite intrusions, creating a north-northeasttrending landform that extends from Bodie Bluff south to Sugarloaf (Wisser, 1960; Chesterman and others, 1986). Tensional fissures and fan-pattern sheeting created by flexure are thought to have localized veins (Whiting, 1888; Wisser, 1960; Chesterman and others, 1986), at least on Bodie Bluff.

The landform is segmented by northeast-striking and west-northwest-striking fault sets (Whiting, 1888; McLaughlin, 1907; Brown, 1908; Chesterman and others, 1986; fig. 37). Two northeast-striking faults with opposing dips, the Moyle and Standard vein faults, define the graben on Bodie Bluff. The graben contains volcaniclastic deposits that cover much of the summit and south slope of Bodie Bluff. The normal Moyle Fault strikes $\mathrm{N} 38^{\circ} \mathrm{E}$, dips $60-70^{\circ} \mathrm{SE}$, is $0.6 \mathrm{~m}$ wide according to Chesterman and others (1986), and had combined pre and postmineralization displacement of at least $60 \mathrm{~m}$ based on the thickness of volcaniclastic deposits in the graben. According to Brown (1908), the Moyle Fault is $10-40 \mathrm{ft}$ wide and is represented on the surface by a northeast-striking, 3-4.5 m high scarp west of the Standard Mine shaft. The Standard Vein Fault strikes $\sim \mathrm{N} 10-20^{\circ} \mathrm{E}$, dips $60-70^{\circ} \mathrm{NW}$, and apparently had pre and postmineralization displacement similar to the Moyle Fault (Chesterman and others, 1986). These synmineral faults contain and displace mineralized veins; they also offset sinter in volcaniclastic deposits and veins in the subsurface from adjacent veins in dacite of Silver Hill (figs. 37, 38). Atop Bodie Bluff, volcaniclastic deposits include a small, dismembered sinter terrace, small pool sinters, and angular clasts of sinter (fig. 39G). These structural and stratigraphic relationships attest to at least two periods of vein and sinter deposition, and demonstrate that volcaniclastic deposits on Bodie Bluff accumulated during hydrothermal events.

The west-northwest-striking, near-vertical Tioga and Mono Faults, on and south of Bodie Bluff, respectively, are also marked by topographic depressions. Normal, downto-the-south displacement of as much as $150 \mathrm{~m}$ along the Tioga Fault occurred prior to mineralization (Chesterman and others, 1986). Along the Mono Fault, flows and volcaniclastic deposits of dacite of Silver Hill have been displaced $150 \mathrm{~m}$ right-laterally and down-to-the-south. The Mono Fault is $\sim 30 \mathrm{~m}$ wide and altered to montmorillonite near the Bodie State Park water tower (Chesterman and others, 1986). Distribution of altered rocks and absence of the Fortuna and other veins on Standard Hill and Bodie Bluff south of the Mono Fault, suggested to Chesterman and others (1986) that displacement on the Mono Fault predates mineralization. However, temporal relationships among vein types and associated wall-rock alteration, do not clearly constrain timing and magnitude of fault displacements. Other unnamed faults, including a northwest-striking, $60^{\circ} \mathrm{E}$-dipping, premineralization fault that extends from Queen Bee Hill to the Spaulding Mine, offset stratigraphy of dacite of Silver Hill (Chesterman and others, 1986).
North-northeast-trending normal faults, one of which projects through the Bodie town site (Bodie Creek Fault, fig. 37), may offset trachydacite of Potato Peak and Eureka Valley Tuff from dacite of Silver Hill. Although the elevations of Eureka Valley Tuff in the Bodie and Dudley Mines, and of possible Eureka Valley Tuff fragments in veins (Brown, 1908), are unknown, Eureka Valley Tuff encountered underground is apparently above 8,200 ft, the lowest elevation of stoping in nearly all mines. Displacement of Eureka Valley Tuff in mines relative to Eureka Valley Tuff in Milk Ranch Canyon at 8,500-8,400 $\mathrm{ft}$ cannot be verified, but is probably not more than tens of meters.

\section{Forms of Silver-Gold Deposits}

All precious metal production was derived from veins, vein stockworks, and fault breccias that were mined underground prior to $\sim 1936$, and from small open cuts in the late 1930s and early 1940s. Different vein types were initially recognized by Whiting (1888), and further characterized by Brown (1908), Chesterman and others (1986), and Hollister and Silberman (1995b). Three vein types, distinguished by mineralogy, textures, $\mathrm{Au} / \mathrm{Ag}$, distribution, and to an extent, age, have been termed the Incline, Burgess, and Silver Hill series veins (figs. 37, 38). Brown (1908) classified a fourth vein type, based in part on attitudes and relative ages, that is represented by the Fortuna vein, although differences between Burgess series veins and the Fortuna vein, based on mine dump and archival specimens, are not straightforward. Incline series veins are prominently exposed on Bodie Bluff and Standard Hill, whereas Silver Hill series veins, which mostly occur south of the Mono Fault, rarely crop out. Some Incline and Burgess series veins are exposed in stopes, and in (1930s) open cuts on the south slope of Standard Hill. However, most Burgess veins and the Fortuna vein were encountered underground and do not crop out, or are covered by detritus and mine waste. Characteristics of these four vein types, synthesized from incomplete exposure, dump samples, archival specimens, adularia ages (table 1), and published descriptions, reveal marked to subtle differences among the vein types, summarized in table 4 .

A small group of veins in the vicinity of Queen Bee Hill (fig. 37) was extensively developed, produced little to no ore, and appears to be entirely oxidized by weathering. The relationship, other than spatial, of these veins to other vein types is incompletely known, and published descriptions are limited; dump samples provide some vein characteristics that are briefly described.

Based on textures of mineral assemblages, adularia dates, sulfur isotope compositions, and the absence of copper and other oxide minerals, the sulfide, selenide, telluride, and silicate minerals, and electrum, described below and imaged, are nearly entirely hypogene. Iron oxide minerals that marginally replace pyrite are interpreted to have formed during weathering, and mineral assemblages in veins that formed during weathering are not described. 


\section{A. Bodie Tunnel Dump}

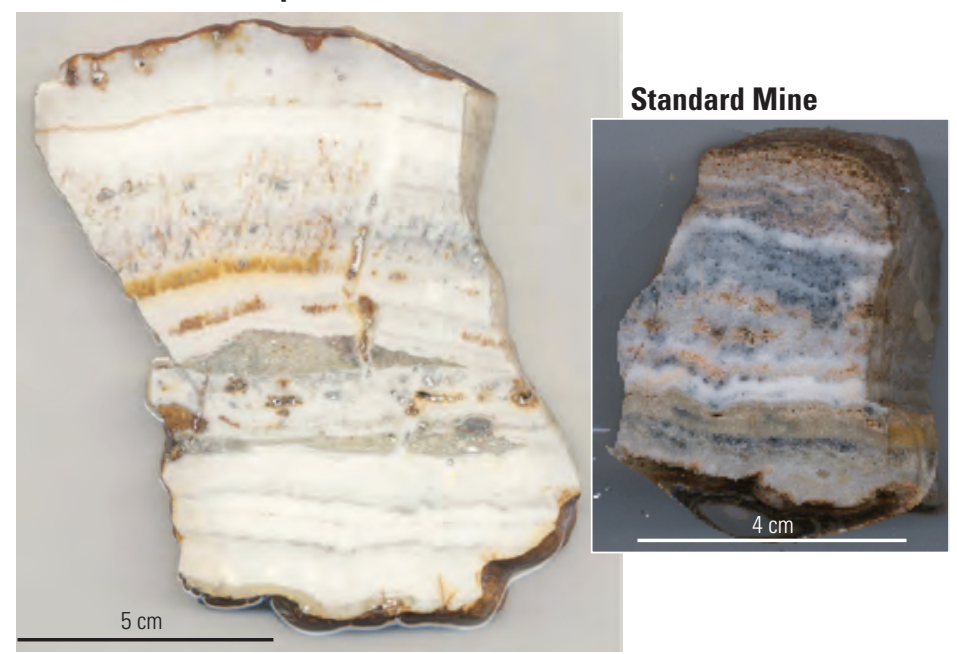

\section{B. Belvedere Mine}

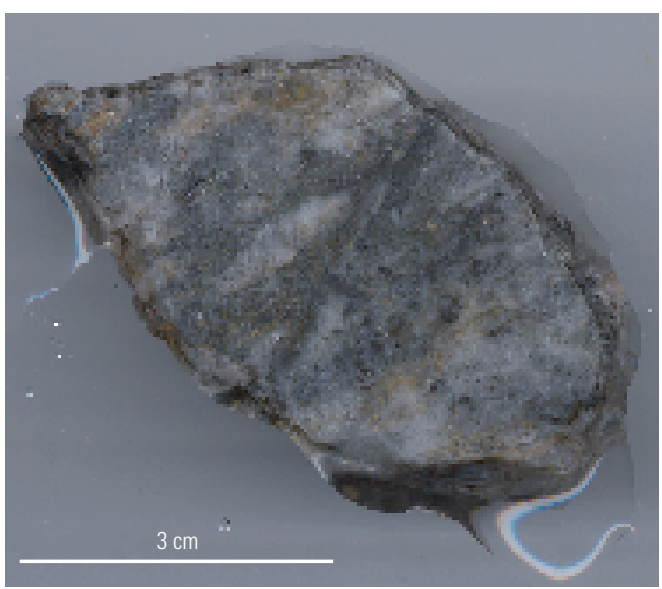

\section{Fortuna Vein, Standard Mine}

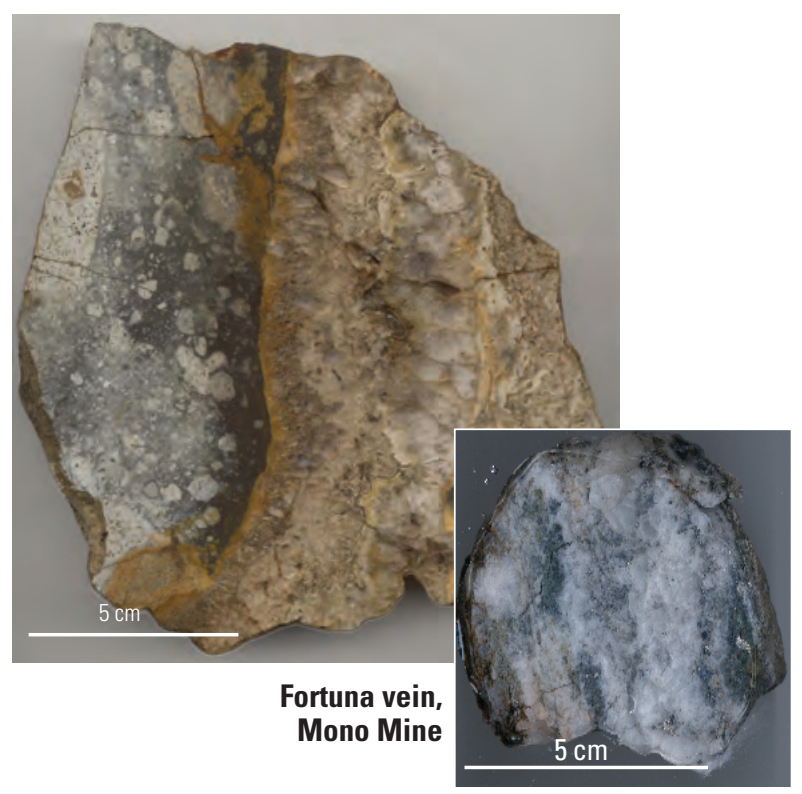

\section{E. Oro Mine, 520 level}

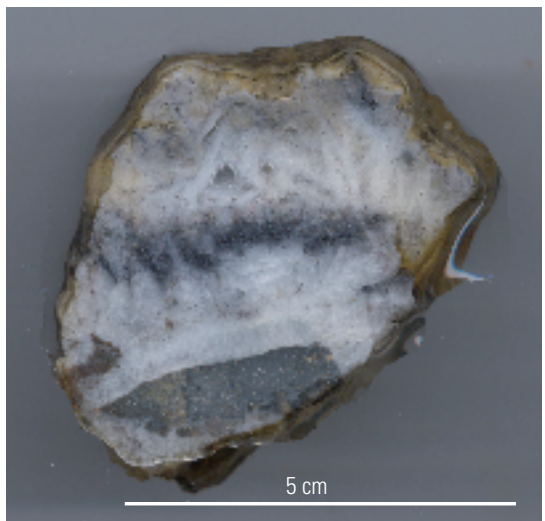

\section{Red Cloud Mine}
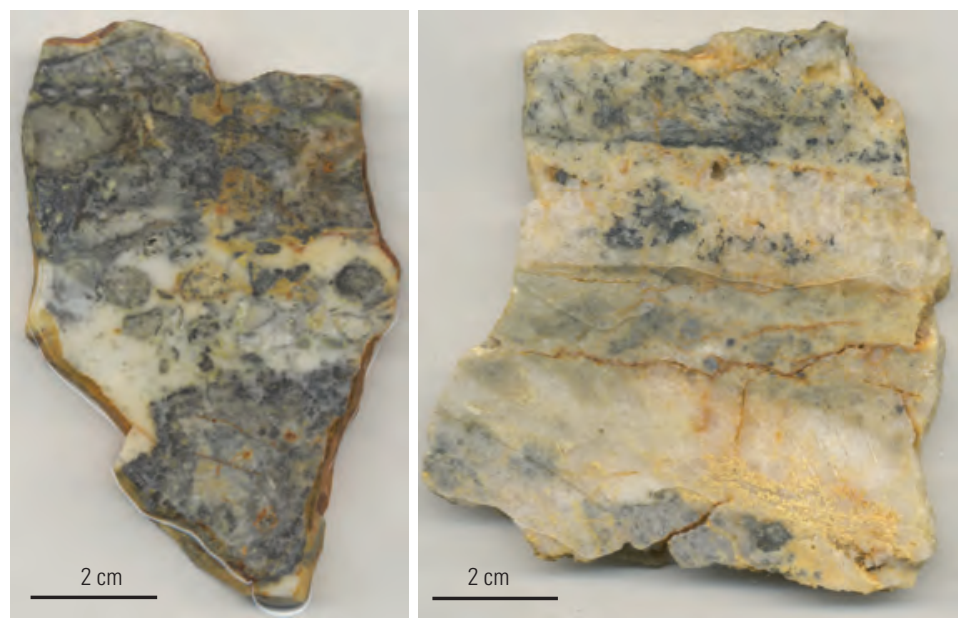

G. Sinter clast in volcaniclastic deposits, Bodie Bluff

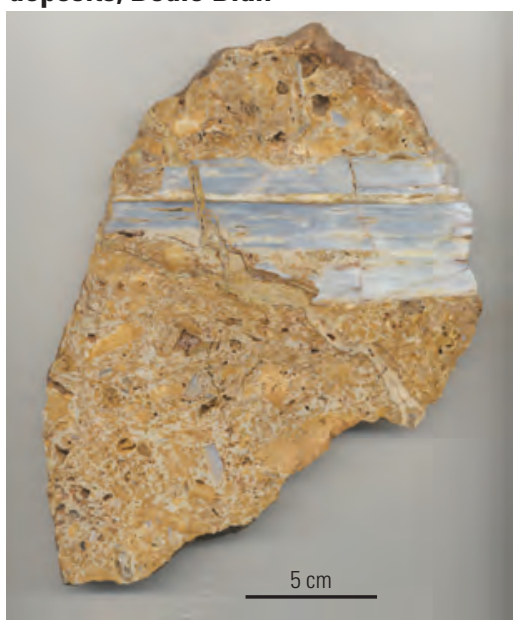


Figure 39. (Facing page) Images of veins in the Bodie Mining District. $A$, Incline series veins, Bodie Tunnel dump, and Standard Mine (inset image; California State Mining and Mineral Museum collection specimen 660). B, Burgess series vein, Belvidere Mine (California State Mining and Mineral Museum collection specimen 7638). C, Fortuna vein, Standard Mine, 528 level (Mackay-Stanford collection specimen OD 7604) and Mono Mine (inset image; California State Mining and Mineral Museum collection specimen 7045). D, Silver Hill series veins, Red Cloud Mine dump, east of Silver Hill. E, Silver Hill series vein (Oro vein), Oro Mine, 520 level (California State Mining and Mineral Museum collection specimen 5304). F, Silver Hill series vein (Oro vein), Addenda Mine, 560 level (California State Mining and Mineral Museum collection specimen 2009). $G$, Sinter fragments in volcaniclastic deposits, Bodie Bluff summit. Mine locations and veins shown on figures 37 and 38.

Table 4. Characteristics of Incline, Burgess, and Silver Hill series veins in the Bodie Mining District. Distribution of vein series is shown on figures 37 and 38.

[Ag, silver; Ag, gold; As, arsenic; Cu, copper; Fe, iron; S, sulfur; Sb, antimony; Se, selenium; Sn, tin; Te, tellurium; FeOx, iron oxides; wt, weight; v, vertical]

\begin{tabular}{|c|c|c|c|c|c|c|}
\hline $\begin{array}{l}\text { Vein } \\
\text { series }\end{array}$ & Distribution & Attitude; width & $\begin{array}{c}\mathrm{Au} / \mathrm{Ag} \\
\text { (wt) }\end{array}$ & Textures and minerals & Wall-rock alteration & $\begin{array}{l}\text { Age } \\
\text { (Ma) }\end{array}$ \\
\hline Incline & $\begin{array}{l}\text { Bodie Bluff; } \\
\text { Standard Hill; } \\
\text { Noonday Mine }\end{array}$ & $\begin{array}{l}\text { Mostly } \mathrm{N}-\mathrm{N} 20 \pm 5^{\circ} \mathrm{E} \\
\mathrm{v}-40^{\circ} \mathrm{W} \text { and } \mathrm{E} \\
\text { mostly } \leq 1.2 \mathrm{~m}\end{array}$ & $\geq 0.4$ & $\begin{array}{l}\text { Tens to hundreds of } \leq 1 \mathrm{~mm}- \\
\text { thick, planar to slightly undu- } \\
\text { lating layers of fine-grained } \\
\text { quartz, lesser adularia, and } \\
\text { less than } 1 \text { percent electrum, } \\
\text { acanthite, and other sulfide } \\
\text { minerals; minor parage- } \\
\text { netically late calcite (mostly } \\
\text { quartz perimorphs) }\end{array}$ & $\begin{array}{l}\text { 9,000-8,600 ft: centime- } \\
\text { ters-thick selvages of } \\
\text { quartz, K-feldspar, illite, } \\
\text { minor pyrite (FeOx); } \\
\text { distal illite, chlorite, } \\
\text { montmorillonite, calcite }\end{array}$ & $\sim 8.3-8.1$ \\
\hline Burgess & $\begin{array}{l}\text { South slope of } \\
\text { Standard Hill } \\
\text { and Bodie Bluff } \\
\text { below 8,700 ft } \\
\text { elevation and } \\
\text { north of Mono } \\
\text { Fault }\end{array}$ & $\begin{array}{c}\mathrm{N} 25^{\circ} \mathrm{E}, \mathrm{v}-70^{\circ} \mathrm{E} \\
\sim 4-0.1 \mathrm{~m}\end{array}$ & $>0.5(?)$ & $\begin{array}{l}\text { Pronounced to indistinct, } \\
\text { several to tens of submil- } \\
\text { limeter to centimeter-thick } \\
\text { layers of quartz, adularia } \\
\text { (often quartz perimorphs), } \\
\text { and lesser calcite (mostly } \\
\text { quartz perimorphs), and as } \\
\text { much as several percent elec- } \\
\text { trum, sphalerite, galena, and } \\
\text { Ag-Au-Cu-As-S-Se phases } \\
\text { mostly in quartz layers; some } \\
\text { layers consist of millimeter to } \\
\text { centimeter euhedrons/subhe- } \\
\text { drons of quartz, adularia, and } \\
\text { calcite (quartz perimorphs) }\end{array}$ & $\begin{array}{l}\text { 8,700-8,400 ft: centime- } \\
\text { ters-thick selvages of } \\
\text { K-feldspar, quartz, clino- } \\
\text { chlore, pyrite (FeOx); } \\
\text { distal illite, chlorite, } \\
\text { montmorillonite, calcite }\end{array}$ & $8.5-8.4$ \\
\hline $\begin{array}{l}\text { Silver } \\
\text { Hill }\end{array}$ & $\begin{array}{l}\text { Vicinity of Silver } \\
\text { Hill; north to } \\
\text { Bodie Bluff } \\
\text { below } \sim 8,500 \mathrm{ft} \text {; } \\
\text { south to Queen } \\
\text { Bee Hill }\end{array}$ & $\begin{array}{l}\text { Mostly N-N20E, } \\
\quad \sim 50^{\circ} \mathrm{E} \\
\quad<2 \mathrm{~m}\end{array}$ & $\leq 0.04$ & $\begin{array}{l}\text { Fault breccia fragments } \\
\text { replaced by quartz and } \\
\text { minor sulfide minerals, and } \\
\text { cemented by fine-grained } \\
\text { to vuggy quartz, adularia, } \\
\text { several to greater than } 10 \text { per- } \\
\text { cent opaque minerals, clay } \\
\text { minerals, barite, and calcite; } \\
\text { opaque minerals include } \\
\text { electrum, sphalerite, galena, } \\
\text { pyrite, acanthite, tetrahedrite, } \\
\text { chalcopyrite, bornite, hessite, } \\
\text { and numerous Ag-Au-Sb-As- } \\
\text { S-Te-Se and Cu-Fe-Sn-S-Ag- } \\
\text { As phases }\end{array}$ & $\begin{array}{l}8,500-8,400 \mathrm{ft}: \text { meters- } \\
\text { thick selvages of quartz, } \\
\text { illite, kaolinite, montmo- } \\
\text { rillonite, pyrite }\end{array}$ & $8.9-8.5$ \\
\hline
\end{tabular}




\section{Incline Series Veins}

Incline series veins include the main Standard vein, the most productive vein in the district, and other productive veins in the Standard, Bodie, Bulwer, Bechtel, and Syndicate Mines on Standard Hill and Bodie Bluff (Whiting, 1888; Brown, 1908; figs. 37, 38). Based on vein texture, $\mathrm{Au} / \mathrm{Ag}$, adularia dates, and mineralogy, some veins on the Noonday and Oro Mine dumps south of Silver Hill are similar to Incline series veins. However, Silver Hill series veins were also developed in the Noonday Mine, and variable $\mathrm{Au} / \mathrm{Ag}$ (weight; table $5 \mathrm{~A}$ ) may reflect mining economics and different vein types. From 1877 to 1881 , ore was produced from several tens of individual Incline series veins, or segments thereof. By 1908, more than 100 narrow and low-grade veins had been identified between wider, stoped veins (Brown, 1908); some of these veins were mined prior to closure of the Standard Mine in 1913. On Standard Hill and Bodie Bluff, Incline series veins are distributed from the Moyle Fault, where they occur only in the hanging wall, to east of the Standard vein Fault, whereas spatially associated but older Burgess series veins are largely confined to the footwall of the Moyle Fault in Standard Hill according to Brown (1908; fig. 38). Incline series veins apparently accounted for most district $\mathrm{Au}$ and $\mathrm{Ag}$ production, although Burgess series veins were also highly productive. Ore produced simultaneously from both vein series in mines on Standard Hill was not recorded separately.

Incline series veins predominantly strike $\mathrm{N} 20 \pm 5^{\circ} \mathrm{E}$, most are vertical or dip steeply east and southeast on the west side of Bodie Bluff and on Standard Hill, and most dip steeply to moderately $\left(85-40^{\circ}\right)$ west and northwest on the east side of Bodie Bluff (figs. 37, 38; table 6). The Standard vein on the section in Chesterman and others (1986) dips $\sim 20^{\circ} \mathrm{W}$; other sources assign dips of $\sim 40-80^{\circ} \mathrm{W}$, and the vein as portrayed (fig. 38) may consist of closely spaced, more steeply dipping vein segments. In the early years of mining, these inwardly opposing dips engendered the concept of a central Veta Madre (Mother Vein; promoted by B. Silliman and W.P. Blake), the mythical large vein at depth from which narrower, nearersurface veins branch. A Veta Madre was never found but became a rationale for deep exploration.

The Standard vein and other high-grade Incline and Burgess series veins stoped in the Standard and adjacent mines extend for as much as $900 \mathrm{~m}$ along strike, but were mined no deeper than $\sim 150 \mathrm{~m}$ below the surface $(90 \mathrm{~m}$ in the Bodie Mine). Incline series veins that were mined during the most productive period, 1877-81, varied in width from $<1$ to 27 m (McLaughlin, 1907; Brown, 1908; figs. 37, 38; table 5). Multiple closely spaced veins, and brecciated and mineralized wall rock on both sides of some veins, or segments thereof, often enabled mining (Whiting, 1888). Two or more parallel to subparallel veins as much as $1 \mathrm{~m}$ wide and separated by centimeter- to meter-thick wall-rock septa are commonly exposed in shaft collars and stopes. "Enrichers" or small veins that crossed thicker veins or branched into the footwall and contained high-grade $\mathrm{Au}$, also enhanced minability; however, enrichers generally followed larger veins, were not spatially associated with intramineralization faults, and may represent a younger vein series. Based on surface stopes and mine dumps, Incline series veins in dacite of Silver Hill on Bodie Bluff and Standard Hill are competent with sharp, planar, and often unsheared wall-rock contacts. Mining of these veins required little timbering, except where veins and vein sets exceeded several meters in width (for example, the Standard vein).

South of the Standard Mine, Incline series veins were stoped in the Bodie Mine, but farther south on Standard Hill, and at depths below $\sim 150$ meters, veins narrowed to unmineable low-grade or unmineralized fissures and seams. Productive Incline series veins also declined in width and grade north and northeast of the Standard Mine where they were stoped in the Bechtel, Upper Hobart, Syndicate, and other mines near the summit and on the north and northwest slopes of Bodie Bluff (fig. 37). Combined production of these mines was small (several tens of thousands of ounces of $\mathrm{Au}$ ).

Many Incline series veins on Bodie Bluff and Standard Hill were covered by colluvium. Other veins represented by thin seams at the surface were identified first by subsurface mining. Upward stoping of Incline series veins terminated at the contact of dacite and volcaniclastic deposits because relatively wide veins in dacite below the contact branched into unmineable, thin veins and seams in volcaniclastic deposits, or could not be followed into volcaniclastic deposits (Whiting, 1888; fig. 38). The stratigraphic control of hydrothermal mineral assemblages by physical properties of host rocks has been documented elsewhere in the Great Basin (for example, Vikre, 2007; Vikre and Henry, 2011). The restricted vertical interval of ore in Incline series veins, and smaller grain size of quartz in veins on the summit of Bodie Bluff relative to grain size of quartz in veins encountered in the Bodie and Bulwer Tunnels $\sim 180 \mathrm{~m}$ deeper (fig. 38 ), are cited as evidence for vertical zonation of vein mineral assemblages (Silberman and Chesterman, 1991; Wisser, 1960; Gumble and others, 1991).

Incline series veins are composed predominantly of fine-grained quartz, variable amounts of adularia, and minor metallic minerals (mostly $<1$ volume percent) in planar to slightly undulating layers (millimeters wide) that parallel wallrock contacts (fig. 39A). Narrow veins (millimeters to a few centimeters wide) consist of several parallel and symmetrical layers, whereas wider veins consist of tens to $>100$ layers; the frequency of layers containing metallic minerals determined minability of veins. Central quartz layers in some veins enclose lenticular vugs lined with quartz pseudomorphs and perimorphs that replace or encrust bladed calcite. Less commonly, central layers (millimeters to centimeters thick) consist of relatively coarse-grained calcite that locally constitutes several to tens of volume percent of veins. These calcite layers are mostly, if not entirely, paragenetically later than quartz ( \pm adularia \pm sulfide mineral) layers.

Metallic minerals include electrum, acanthite, and other sulfide minerals; iron and manganese oxides in weathered veins mark sites of sulfide minerals and attest to former calcite. Anhedral electrum and sulfide minerals occur in 
Table 5. Gold and silver production and precious metal grades for mines and veins in the Bodie Mining District from 1875 to 1942, and relative value of gold and silver in bullion from 1878 to 1881 .

[Gold and silver production and precious metal grades converted, in part, from gold and silver bullion values using $\$ 20.67 / \mathrm{oz}$ gold $(\mathrm{Au})$ and $\$ 1.29 / \mathrm{oz}$ silver $(\mathrm{Ag})$ (average or single assay values from Addenda, Jupiter and Noonday Mines; Burchard, 1882; 1884; Whiting, 1888; Eakle and McLaughlin, 1919; Chesterman and others,1986; University of Nevada Reno library special collections NC323).

Some vein type assignments are based on mine location and dump/archival vein sample characteristics. Relative value of gold and silver in bullion, 1878-1881 is as reported in Burchard (1881) and King and others (1885). Au, gold; Ag, silver; e, estimated; oz, ounce]

\begin{tabular}{|c|c|c|c|c|}
\hline \multicolumn{5}{|c|}{ Gold and silver production and precious metal grades from 1875 to 1942} \\
\hline $\begin{array}{c}\text { Period/ } \\
\text { year }\end{array}$ & Mine, vein & Au & $\mathrm{Ag}$ & $\mathrm{Au} / \mathrm{Ag}$ \\
\hline \multicolumn{5}{|c|}{ Incline series veins } \\
\hline $1875-76$ & Syndicate Mine & $1,788 \mathrm{oz}$ & $4,332 \mathrm{oz}$ & 0.41 \\
\hline 1879 & Noonday Mine, Keystone vein & $543 \mathrm{oz}$ & $1,349 \mathrm{oz}$ & 0.40 \\
\hline 1883 & Syndicate Mine & $4,143 \mathrm{oz}$ & $4,940 \mathrm{oz}$ & 0.84 \\
\hline 1883 & Standard main vein & $49,100 \mathrm{oz}$ & $258,937 \mathrm{oz}$ & 0.45 \\
\hline 1883 & Standard main vein & $1.65 \mathrm{oz} /$ ton & $3.14 \mathrm{oz} / \mathrm{ton}$ & 0.53 \\
\hline 1900 & Standard Mine, above 500 level & $\mathrm{e} 20,160 \mathrm{oz}$ & $\mathrm{e} 28,160 \mathrm{oz}$ & 0.72 \\
\hline 1912 & Standard Mine & $5.43 \mathrm{oz} / \mathrm{ton}$ & $0.35 \mathrm{oz} /$ ton & 15.5 \\
\hline \multicolumn{5}{|c|}{ Burgess series veins } \\
\hline 1879 & Bulwer Mine & $737 \mathrm{oz}$ & $1,089 \mathrm{oz}$ & 0.68 \\
\hline 1879 & Bodie Mine & $656 \mathrm{oz}$ & 1,269 & 0.52 \\
\hline $1936-42$ & Roseklip cuts, tailings and dumps & $21,171 \mathrm{oz}$ & $561,904 \mathrm{oz}$ & 0.04 \\
\hline \multicolumn{5}{|c|}{$\begin{array}{ll}\text { Fortuna vein } \\
\end{array}$} \\
\hline 1883 & Bodie Mine, Fortuna vein & $5,085 \mathrm{oz}$ & $109,800 \mathrm{oz}$ & 0.05 \\
\hline \multicolumn{5}{|c|}{ Silver Hill series veins } \\
\hline 1881 & Noonday Mine, Concordia vein & $2.3 \mathrm{oz} /$ ton & $361 \mathrm{oz} /$ ton & 0.006 \\
\hline 1881 & Noonday Mine, Concordia vein & $6 \mathrm{oz} / \mathrm{ton}$ & $53 \mathrm{oz} /$ ton & 0.11 \\
\hline 1881 & Red Cloud Mine, Concordia vein & $13.5 \mathrm{oz} /$ ton & $2,679 \mathrm{oz} /$ ton & 0.005 \\
\hline 1881 & Red Cloud Mine, Red Cloud vein & $1 \mathrm{oz} / \mathrm{ton}$ & $32.3 \mathrm{oz} /$ ton & 0.03 \\
\hline 1881 & Addenda Mine & $5.4 \mathrm{oz} /$ ton & $130 \mathrm{oz} /$ ton & 0.04 \\
\hline 1881 & Jupiter Mine & $7.25 \mathrm{oz} / \mathrm{ton}$ & $3,333 \mathrm{oz} /$ ton & 0.002 \\
\hline \multicolumn{5}{|c|}{ Relative value of gold and silver in bullion from 1878 to 1881} \\
\hline Year & Mine, vein & Au \% & $\mathrm{Ag} \%$ & $\mathrm{Au} / \mathrm{Ag}$ \\
\hline \multicolumn{5}{|c|}{ Incline and Burgess series veins } \\
\hline 1878 & Standard main vein & 92.3 & 7.5 & 12.3 \\
\hline 1879 & Standard & 92 & 8 & 11.5 \\
\hline 1880 & Standard & 93 & 7 & 13.3 \\
\hline 1879 & Syndicate & 93 & 7 & 13.3 \\
\hline 1880 & Syndicate & 93 & 7 & 13.3 \\
\hline \multicolumn{5}{|c|}{ Burgess series veins } \\
\hline 1879 & Bulwer & 92 & 8 & 11.5 \\
\hline 1880 & Bulwer & 93 & 7 & 13.3 \\
\hline 1880 & Belvidere & $37 ?$ & $63 ?$ & $0.59 ?$ \\
\hline \multicolumn{5}{|c|}{ Fortuna vein } \\
\hline 1879 & Bodie & 85 & 15 & 5.7 \\
\hline 1880 & Bodie & 59.5 & $41.5[\mathrm{sic}]$ & 1.4 \\
\hline \multicolumn{5}{|c|}{ Silver Hill series veins } \\
\hline 1879 & Noonday & 70 & 30 & 2.3 \\
\hline 1880 & North Noonday & 41 & 59 & 0.6 \\
\hline \multicolumn{5}{|c|}{ Queen Bee Hill veins } \\
\hline 1881 & Boston Consolidated & 75 & 25 & 3 \\
\hline
\end{tabular}


Table 6. Vein attitudes and widths derived from surface mapping and published descriptions.

[Burchard, 1881, 1882, 1884; Whiting, 1888; Brown, 1908; Wedertz, 1969; Chesterman and others, 1986; Piatt, 2003). Some veins are shown on figures 37 and 38. ave., average; ft, feet; v, vertical; —, no data; <, less than]

\begin{tabular}{|c|c|c|c|c|c|}
\hline Mine & Vein & Level & Strike $\left({ }^{\circ}\right)$ & $\operatorname{Dip}\left({ }^{\circ}\right)$ & Width (ft) \\
\hline \multicolumn{6}{|c|}{ Incline series veins } \\
\hline \multirow[t]{5}{*}{ Standard } & \multirow[t]{5}{*}{ Main vein } & Surface & $\mathrm{N} 20 \mathrm{E} \pm 5$ & $60 \mathrm{~W}$ & 4 \\
\hline & & 200 & - & $78 \mathrm{~W}$ & $15-25$ \\
\hline & & 385 & - & $40 \mathrm{~W}$ & $<90$ \\
\hline & & - & - & - & ave. 20 \\
\hline & & 700 & - & - & 8 \\
\hline North Standard & - & - & - & - & $3.5-6$ \\
\hline \multirow[t]{2}{*}{ Bechtel } & \multirow[t]{2}{*}{ - } & 440 & - & - & $3-5$ \\
\hline & & 512 & - & steep W & $3-12$ \\
\hline Bodie Tunnel & - & - & - & - & 6 \\
\hline \multicolumn{6}{|c|}{ Burgess series veins } \\
\hline Bodie & Burgess; Bruce & - & N25E & 75-85E; v & - \\
\hline Belvedere & - & 600 & - & - & 14 \\
\hline Con Pacific & - & 400 & - & - & 5 \\
\hline Bulwer & Ralston; Stonewall & 400 & - & - & $2-4$ \\
\hline South Bulwer & - & 550 & - & steep E-v. & 6 \\
\hline \multicolumn{6}{|c|}{ Fortuna vein } \\
\hline \multirow[t]{2}{*}{ Bodie } & \multirow[t]{2}{*}{ Fortuna } & 300 & N10-20W & $20-30 \mathrm{E}$ & $0.2-12$ \\
\hline & & 600 & - & $45 \mathrm{E}$ & ave. 20 \\
\hline \multicolumn{6}{|c|}{ Silver Hill series veins } \\
\hline Jupiter & - & 500 & - & - & 2 \\
\hline Goodshaw & - & 600 & - & - & 4 \\
\hline \multirow[t]{3}{*}{ Red Cloud } & \multirow[t]{2}{*}{$\begin{array}{l}\text { Red Cloud; Packard } \\
\text { \&Morton }\end{array}$} & - & N20E & steep E & - \\
\hline & & 400 & - & - & $2-10$ \\
\hline & Concordia & 600 & - & - & 6 \\
\hline \multirow[t]{2}{*}{ Noonday } & Keystone & - & N10-40E & $80 \mathrm{E}$ & $2-5$ \\
\hline & - & 500 & - & - & $5-20$ \\
\hline \multirow[t]{2}{*}{ Addenda/Contention } & - & 500 & - & - & $7-8$ \\
\hline & \multicolumn{3}{|c|}{ Queen Bee Hill veins } & & \\
\hline \multirow[t]{2}{*}{ Boston Consolidated } & - & 200 & - & - & $2-5$ \\
\hline & & 400 & - & - & $2-4$ \\
\hline University & - & 382 & - & - & $2-22$ \\
\hline Champion & - & 400 & - & - & ave. 5 \\
\hline
\end{tabular}

discrete crystals and in submillimeter aggregates that appear to be texturally coeval with quartz. In low-grade samples of multilayer veins, these crystals and aggregates form small dark specks that are sparsely distributed in one or a few layers of fine-grained white quartz. In samples with elevated $\mathrm{Au}$ and $\mathrm{Ag}$ grades, larger clots (millimeters to centimeters in size) and small dendrites of electrum and sulfide minerals accentuate quartz layers (fig. 39A, inset image). Metallic minerals identified and semiquantified by optical and scanning electron microscopy include electrum with subequal proportions of $\mathrm{Au}$ and $\mathrm{Ag}, \mathrm{Ag}-\mathrm{Au}-\mathrm{S}-\mathrm{Se}$ minerals (including possible uytenbogaardtite, $\mathrm{Ag}_{3} \mathrm{AuSSe}_{2}$, and $\mathrm{AuAgS}$ (Barton and others, 1978; Barton, 1980), acanthite with minor Se, and chalcopyrite (fig. 40). A few bulk vein samples contain elevated concentrations of $\mathrm{As}$ and $\mathrm{Sb}$ (table 1-11), suggesting the local presence of Ag-As-Sb-S minerals. Vein minerals, including molybdenite and scheelite, previously identified on mine dumps on Bodie Bluff and Standard Hill (Hollister and Silberman, 1995a; 1995b), were not found during this investigation.

Gold/silver by weight and value in Incline (and Burgess) series veins are relatively high ( $\geq 0.40$ and $>11$, respectively) compared to Silver Hill series veins and the Fortuna vein (mostly $<0.1$ and $<6$, respectively; table 5). The Au and Ag contents of veins correspond spatially to associated placer deposits in that high $\mathrm{Au} / \mathrm{Ag}$ placers were mined on the slopes of Bodie Bluff and Standard Hill, whereas low Au/Ag placers were recovered from Silver Hill slopes (Whiting, 1888). 


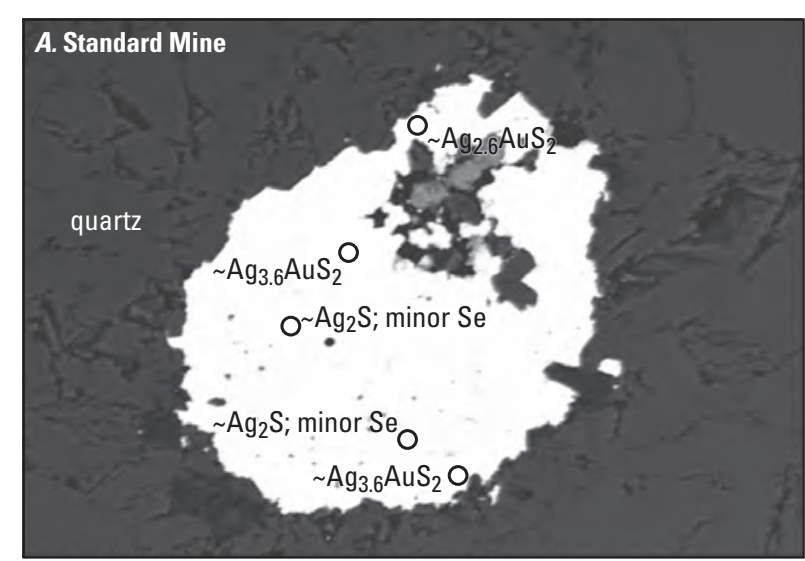

$\longdiv { 2 0 \mu \mathrm { m } }$
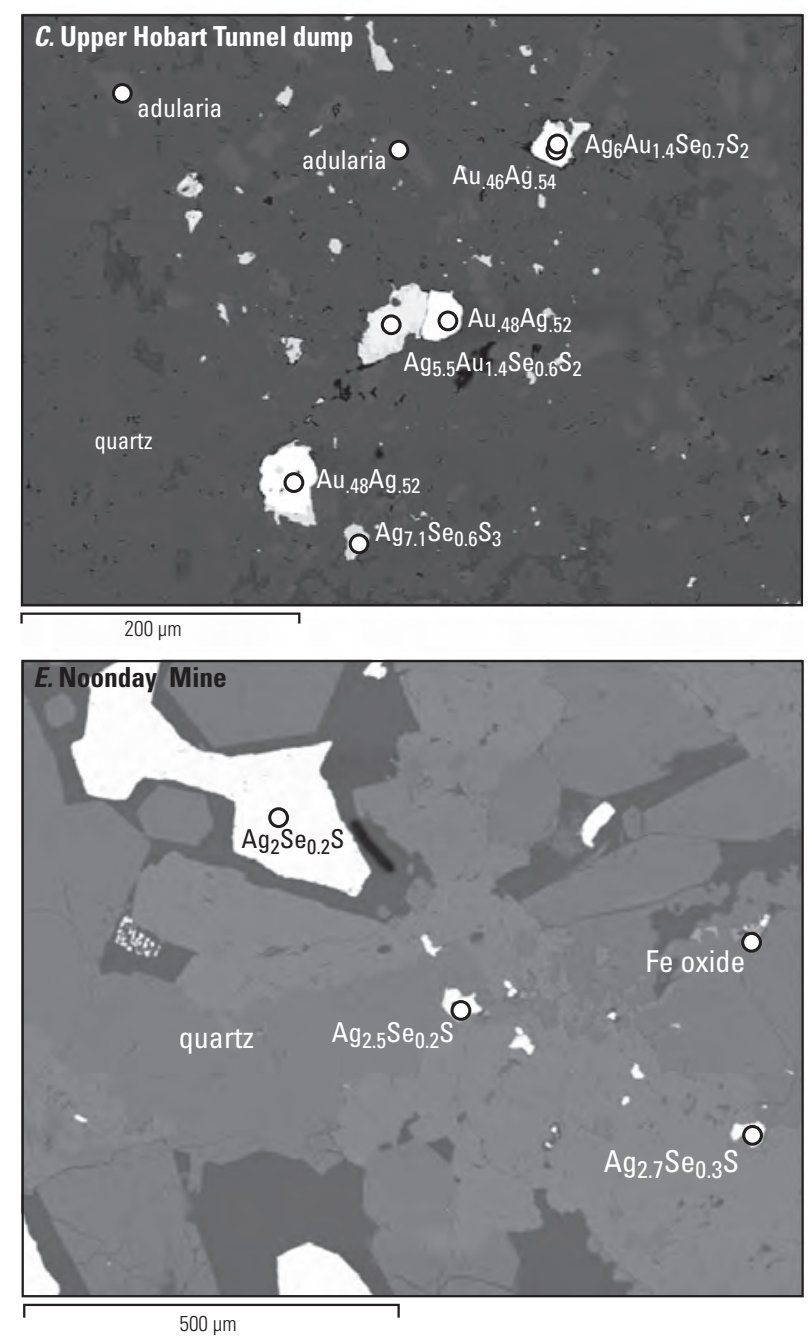
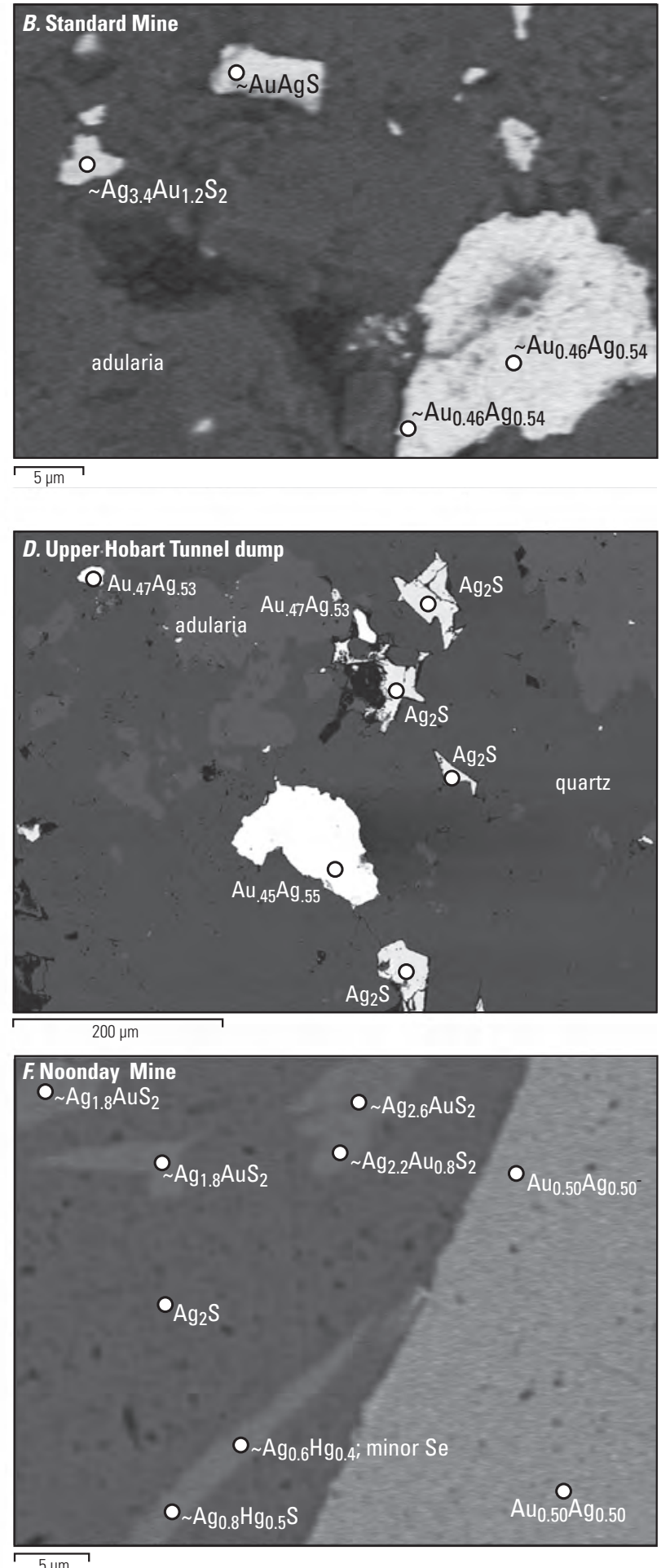

Figure 40. Secondary and backscatter electron images of samples representative of Incline series veins on Bodie Bluff, and of vein samples from the Noonday Mine near Silver Hill, Bodie Mining District. Mineral identifications and approximate atomic proportions for these images, and for images in figures $41,42,43,44$, and 45 , were determined petrographically and by scanning electron microscopy algorithms. $A$ and $B$ correspond to specimen CSMMM-660, Standard Mine (California State Mining and Mineral Museum collection; fig. 38). $C$ and $D$ correspond to sample 11-BA-26B, Upper Hobart Tunnel dump (fig. 37). $E$ and $F$ correspond to specimens 5074 and KM-952, respectively, Noonday Mine (Keck museum collection, University of Nevada, Reno; fig. 37). Imaged phases include quartz, adularia, acanthite (some with minor $\mathrm{Se}$ ), electrum with subequal $\mathrm{Au}$ and $\mathrm{Ag}, \mathrm{Ag}$-Au-S minerals ( $\mathrm{Ag}_{3} \mathrm{AuS}_{2}$, possibly uytenbogaardtite; $\left.\sim \mathrm{AuAgS} ; \sim \mathrm{Ag}_{2} \mathrm{AuS}_{2}\right), \mathrm{Ag}$-S-Se minerals $\left(\sim \mathrm{Ag}_{7.1} \mathrm{Se}_{0.6} \mathrm{~S}_{3} ; \sim \mathrm{Ag}_{2.5} \mathrm{Se}_{0.2} \mathrm{~S} ; \sim \mathrm{Ag}_{2.7} \mathrm{Se}_{0.3} \mathrm{~S}\right)$, and $\mathrm{Ag}-\mathrm{Hg}$-S-Se minerals. Mine locations are shown on figure 37 . 
Incline series veins are, in part, parallel to northeaststriking tabular breccias that offset the Fortuna vein and may constitute intrusive breccias or decomposed dikes (Whiting, 1888; Brown, 1908; Gumble and others, 1991; for example, Red vein Fault, also known as "Red ledge", or "Red vein" fig. 38). These high-angle, meter-wide, iron oxide-rich breccias, encountered in the Standard, Bodie, Bulwer, and other mines on Standard Hill and Bodie Bluff, may be coeval with overlying volcaniclastic deposits. Based on composition (Turner, 1908), the Red ledge/vein could be altered rhyolite in which $\mathrm{K}_{2} \mathrm{O}$ has been added (potassic alteration) and $\mathrm{CaO}$ and $\mathrm{Na}_{2} \mathrm{O}$ were reduced by hydrolysis of plagioclase. Spatial relationships among breccias encountered underground and potassically altered breccias that cut dacite, described by Silberman and Berger (1985), Silberman and Chesterman (1991), Gumble and others (1991), and Herrera and others (1993), are uncertain. These latter breccias consist of rock fragments partially replaced by K-feldspar, and matrices composed of quartz, adularia, and hematite. Matrices of other breccias at higher elevations consist of quartz, adularia, illite, calcite, and zeolites. Some of these breccias are parallel and adjacent to veins, and locally include mineralized quartzadularia vein clasts (Silberman and Berger, 1985; Silberman and Chesterman, 1991; Gumble and others, 1991; Herrera and others, 1993); however, paragenetic relationships among these breccias and specific vein series are also uncertain.

\section{Burgess Series Veins}

Burgess series veins, based on underground exposures, were originally thought to exist exclusively on the south and west slopes of Standard Hill west of the Moyle Fault (Brown, 1908; Chesterman and others, 1986). However, samples of veins similar to Burgess series veins occur on mine dumps on the south slope of Bodie Bluff north of the Mono Fault, suggesting wider distribution (figs. 37, 38). Burgess series veins were stoped in the Standard, Bodie, Belvidere, Con Pacific, Bulwer, and other mines where they are cut by Incline series veins. Burgess series veins (individually named Bruce, Burgess, Incline, Gildea, Bullion, Ralston, and Cook) strike $\mathrm{N} 25^{\circ} \mathrm{E}$, dip steeply southeast or are vertical, and extend as much as $900 \mathrm{~m}$ along strike, although profitable segments had strike lengths of $180 \mathrm{~m}$ or less (Brown, 1908). They were stoped no deeper than $\sim 180 \mathrm{~m}$ below the summit of Standard Hill (fig. 38). Burgess series veins exposed in the open cut on the south slope of Standard Hill are mostly centimeters wide, and many veins contained sufficient Au to be mineable at widths of $\sim 2 \mathrm{~cm}$. Gold in some veins occurred in "hard quartz" cohesive with wall rock, or in shaley clay-sand partings (Whiting, 1888; Brown, 1908), increasing ore widths as much as $\sim 4.2 \mathrm{~m}$ (table 6 ).

Most Burgess series veins consist of relatively coarsegrained quartz and adularia (compared to Incline series vein minerals) in indistinct to pronounced layers that parallel wall-rock contacts and that may be defined by thin seams and septa $(<1 \mathrm{~mm})$ of micaceous minerals (fig. 39B). Some layers contain as much as several volume percent of relatively coarse-grained metallic minerals and "axial comb-textured" quartz layers (Brown, 1908; Chesterman and others, 1986). Vein interstices of dump samples on upper elevations of Standard Hill are commonly vuggy, and some are encrusted by quartz and (or) euhedral adularia crystals with dimensions of as much as several centimeters. These euhedral crystals further distinguish Burgess series veins from Incline and Silver Hill series veins.

Vein minerals identified and semiquantified optically and by SEM include quartz, adularia, an euhedral to subhedral $\mathrm{Mg}-\mathrm{Fe}-\mathrm{Al}-\mathrm{Si}-\mathrm{O}$ mineral (possibly clinochlore), Au-rich electrum, low Fe- and low-Cd sphalerite, and galena - all of which are intergrown in apparent textural equilibrium (fig. $41 \mathrm{~A}, \mathrm{~B}$, $C$ ). Other metallic minerals, some in submicrometer mineral aggregates, include electrum with subequal proportions of $\mathrm{Au}$ and $\mathrm{Ag}$, acanthite with minor Se and $\mathrm{Zn}$, and mixed Ag-Au-S-Se and Au-S-Cu-As phases (fig. 41D, E, F). A few bulk vein samples contain elevated abundances of $\mathrm{As}, \mathrm{Sb}$, and other elements (table 1-11), suggesting the local presence of Ag-As-Sb-S and other minerals.

The Fortuna vein, which was the source of most production from the Bodie Mine and likely the only source of production from the Mono Mine, is not exposed at the surface. In mine workings it is cut by numerous faults (described in previous section "Incline Series Veins") and by Incline and Burgess series veins (fig. 38). The Fortuna vein strikes $\mathrm{N} 10-20^{\circ} \mathrm{W}$, dips $20-30^{\circ} \mathrm{NE}$ on the 300 level of the Bodie Mine, and $\sim 45^{\circ} \mathrm{NE}$ on the 600 level (table 6). It varies in width from centimeters to $\sim 6 \mathrm{~m}$, as brecciated and mineralized wall rocks often enabled thin vein segments to be mined. It was stoped for as much as $\sim 110 \mathrm{~m}$ along strike and $\sim 300 \mathrm{~m}$ downdip, but below the 600 level it was mostly unmineable. On the 600 level of the Bodie Mine, the centimeter-wide, Ag-rich Beehive vein splits from the Fortuna vein (fig. 38). The Beehive vein was mined for $\sim 45$ vertical meters, and apparently is the deepest stoped vein in the northern part of the district. About $230 \mathrm{~m}$ below the surface, the Beehive vein narrowed to seams and thin veins of weakly mineralized quartz enclosed by wall rocks more decomposed than at higher levels (Brown, 1908).

To the southeast, the Fortuna vein was intersected on the 1000 level of the Standard Mine, and in the Lent (707 and 1200 levels) and Dudley Mines (figs. 37, 38). Deep vein segments consisted of isolated bunches and narrow veins of quartz in sheeted zones of clay-altered, pyritic wall rocks (Brown, 1908). Although Au-Ag minerals and relatively abundant sphalerite were encountered locally, few of the deep segments contained sufficient $\mathrm{Au}$ and $\mathrm{Ag}$ to warrant mining. Wall rocks of the Fortuna vein are described as pyritic and "much decomposed" compared to wall rocks adjacent to Incline series veins (Brown, 1908).

Archival specimens of the Fortuna vein from the Standard and Mono Mines (fig. 39 C) include two texturally distinct zones. A 5-cm-wide zone in the Standard Mine specimen consists of wall-rock fragments (centimeters to millimeters in size) cemented by very fine-grained adularia, 

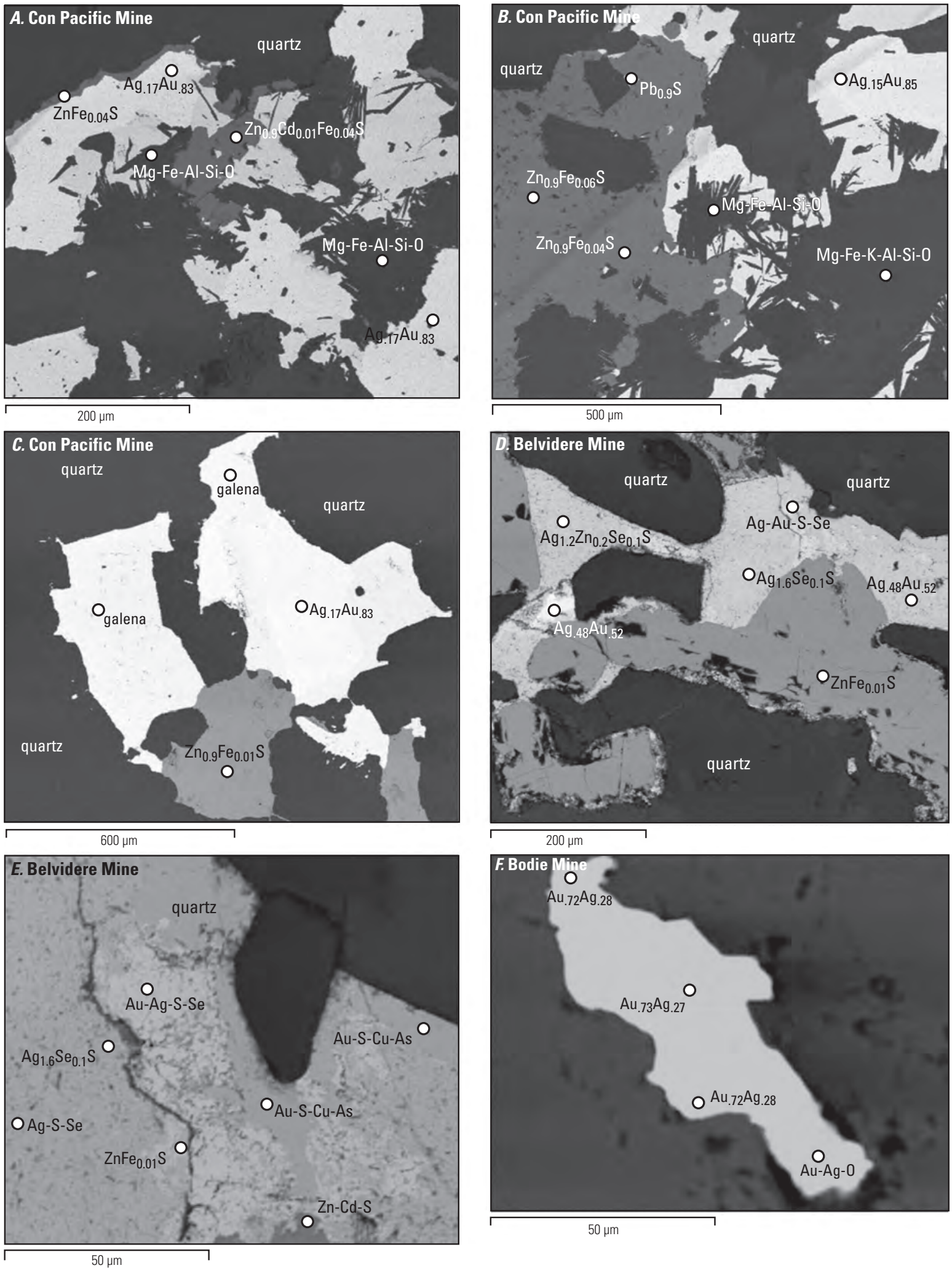

Figure 41. Secondary electron images of samples representative of Burgess series veins on Standard Hill, Bodie Mining District. $A, B$, and $C$ correspond to specimen 4260, Con Pacific Mine (Keck museum collection, University of Nevada, Reno). $D$ and $E$ correspond to sample B0D11-4A, Belvidere Mine dump. Fcorresponds to sample B0D11-13, Bodie Mine dump. Imaged phases include quartz, electrum with variable $\mathrm{Au}$ and $\mathrm{Ag}$, sphalerite with minor $\mathrm{Fe}$ and $\mathrm{Cd}$, a $\mathrm{Mg}$-Fe-Al-Si-0 mineral (possibly clinochlore), galena, a Ag-S-Se mineral $\left(\sim \mathrm{Ag}_{16} \mathrm{Se}_{01} \mathrm{~S}\right)$, and a $\mathrm{Ag}$-Au-S-Se mineral or mineral intergrowth. Mine locations are shown on figure 37. 
quartz, and minor pyrite. This zone sharply borders a complex zone of similar width (represented in both specimens) that consists of distinct layers of fine-grained quartz (millimeters to centimeters thick), euhedral quartz crystals, adularia, finely dispersed electrum and $\mathrm{Ag}$ sulfide minerals, and wavy layers of chalcedonic quartz (millimeters to centimeters wide). An irregular, centimeter-wide layer of brown and white chalcedonic quartz borders the zone of brecciated wall-rock fragments. In addition to the observed minerals, reported metallic minerals include magnetite, chalcopyrite, pyrargyrite, $\mathrm{Ag}$, kerargyrite [sic], iron oxides, and copper oxides (Brown, 1908), some of which were apparently produced by weathering. Argentite was described as occurring, in part, in thin films between apices of quartz crystals in druses.

\section{Silver Hill Series Veins}

Silver Hill series veins include veins on and near Silver Hill (fig. 37), only a few of which crop out. Maps and sections of underground workings (Chesterman and others, 1986; Bodie Consolidated Mining Company Collection, 2003) indicate that most Silver Hill series veins trend $\mathrm{N}-\mathrm{N} 20^{\circ} \mathrm{E}$, and dip $50^{\circ} \mathrm{E}$ (fig. 38), although the near-vertical Booker(?) vein exposed in workings of the Spaulding Mine south of Silver Hill trends $\mathrm{N} 15^{\circ}$ W. Silver Hill series veins were extensively developed in the Noonday, Oro, Contention, Maybelle, Addenda, Dudley, and Red Cloud Mines. Small amounts of ore were recovered in the Oro, Addenda and Red Cloud Mines, but only the Noonday Mine had significant production. However, some Noonday Mine production apparently was derived from Incline series veins. Based on mine dumps, Silver Hill series veins may have been mined at the south base of Bodie Bluff several hundred meters north of the Mono Fault. If this interpretation is correct, then significant displacement along the Mono Fault apparently predates formation of Silver Hill series veins.

Compared to Incline and Burgess series veins, Silver Hill series veins are distinctly Ag-rich. Gold/silver by weight and value in Silver Hill veins are $\leq 0.04$ and $\leq 3$, respectively, although ratios are based mostly on ore grades and small production (table 5). Gold/silver and other characteristics (including adularia dates) of veins on the Noonday Mine dump suggest that ore mined in 1879 (Keystone vein) was derived from veins similar to Incline series veins, whereas ore mined in 1880-81 (Concordia vein) was derived from Silver Hill series veins (table 5). Alternatively, high $\mathrm{Au} / \mathrm{Ag}$ in ore mined prior to 1880 and lower $\mathrm{Au} / \mathrm{Ag}$ in ore mined 1-2 in later years may attest to ore selectively mined for high gold content, because mills were not designed to recover silver in sulfide minerals, or to possible supergene enrichment.

Ore in Silver Hill series veins was mostly recovered from a >1-m-wide segment of the Concordia vein (fig. 38; table 4). Reported stope dimensions between the 450 and 700 levels are $\sim 120$ meters along strike, and $\sim 75$ meters downdip (Chesterman, and others, 1986). Small amounts of ore were recovered from a 1.2-m-wide segment of the Red Cloud vein with reported stope dimensions between the 256 and 592 levels of $\sim 35$ meters along strike and $\sim 350 \mathrm{ft}$ downdip (Chesterman, and others, 1986).

Vein textures and minerals in the Corcordia, Red Cloud, and Oro veins are described by Whiting (1888), Brown (1908), Chesterman and others (1986), and Hollister and Silberman (1995a). The Concordia vein consists of fragments of dacite cemented by fine-grained and vuggy white quartz, coarsegrained calcite, quartz pseudomorphs after calcite, clay gouge, tetrahedrite, pyrargyrite, and pyrite. The Red Cloud vein is mostly gouge and crushed quartz, but varies along strike from narrow, parallel, anastomosing veins to contiguous "ribbon" quartz and calcite a few centimeters to $1.2 \mathrm{~m}$ wide. On the $700 \mathrm{ft}$ level, the Red Cloud vein consists of quartz, quartz after calcite, coarse-grained calcite, and fine-grained adularia, tetrahedrite, pyrite, galena, pyrite, chalcopyrite, and minor amounts of sphalerite and pyrargyrite (fig. 39D). The Oro vein in the Oro and Addenda Mines consists of quartz, coarse-grained calcite, tetrahedrite, stephanite, pyrargyrite, pyrite, and galena, and minor barite (fig. 39E, F). Major oxides in bulk samples of Silver Hill series veins vary from 4.2 to 21.9 weight percent $\mathrm{Al}_{2} \mathrm{O}_{3}, 1.2-11.3$ weight percent $\mathrm{K}_{2} \mathrm{O}, 0.1-7.1$ weight percent $\mathrm{FeO}$, and $<1$ weight percent $\mathrm{MgO}, \mathrm{CaO}, \mathrm{Na}_{2} \mathrm{O}$, and $\mathrm{TiO}_{2}$ (calculated from element concentrations, table 1-11).

Vein minerals identified and semiquantified by optical and SEM (fig. 42) include quartz, mica-clay minerals, adularia, and metallic minerals in aggregates of anhedral crystals. The mineralogy of the aggregates varies somewhat between mines and among samples from individual mines. Samples from the Oro Mine dump consist of quartz, adularia, minor amounts of barite, low Fe-sphalerite, galena, acanthite, Ag-Sb-As-S minerals, $\mathrm{Cu}-\mathrm{Fe}-\mathrm{S}-\mathrm{Ag}$-As minerals, and electrum with subequal proportions of $\mathrm{Au}$ and $\mathrm{Ag}$. Silver minerals, some of which are euhedral, and electrum are paragenetically later than sphalerite and galena (fig. 42A, $B$ ). In an archival specimen from the Addenda Mine, anhedral intergrowths of hessite $\left(\mathrm{Ag}_{2} \mathrm{Te}\right)$, electrum with subequal proportions of $\mathrm{Au}$ and $\mathrm{Ag}$, tetrahedrite, chalcopyrite, bornite (not imaged), and an $\mathrm{Ag}-\mathrm{Te}-\mathrm{Cu}-\mathrm{S}$ phase are intergrown with euhedral and subhedral quartz crystals (fig. $43 A, B, C$ ). Samples from the Red Cloud and Contention Mine dumps (figs. 44A, $B$, $C ; 45 A, B, C)$ consist of assemblages that are similar to the Addenda Mine specimen, but also include galena, sphalerite, acanthite, and $\mathrm{Ag}-\mathrm{Au}-\mathrm{Te}, \mathrm{Cu}-\mathrm{Fe}-\mathrm{Sn}-\mathrm{S}$, and $\mathrm{Ag}-\mathrm{S}-\mathrm{Fe}$ minerals. Sylvanite, acanthite, and bornite (not imaged) were identified in separate Red Cloud Mine samples. A dump sample from the Maybelle Mine consists of quartz, acanthite with minor Se, naumannite, an Ag-Sb-S mineral, an Ag-Sb-Se-Fe-S phase, and low Fe-sphalerite; silver minerals are paragenetically later than sphalerite and some fill spaces between euhedral quartz crystals (fig. 45D). Bulk samples of veins contain markedly elevated concentrations of elements of these minerals and phases as well as high concentrations of $\mathrm{Hg}, \mathrm{Bi}, \mathrm{Cd}$ and numerous other chalcophile elements (table 1-11). Tellurium concentrations are markedly anomalous in most samples. 

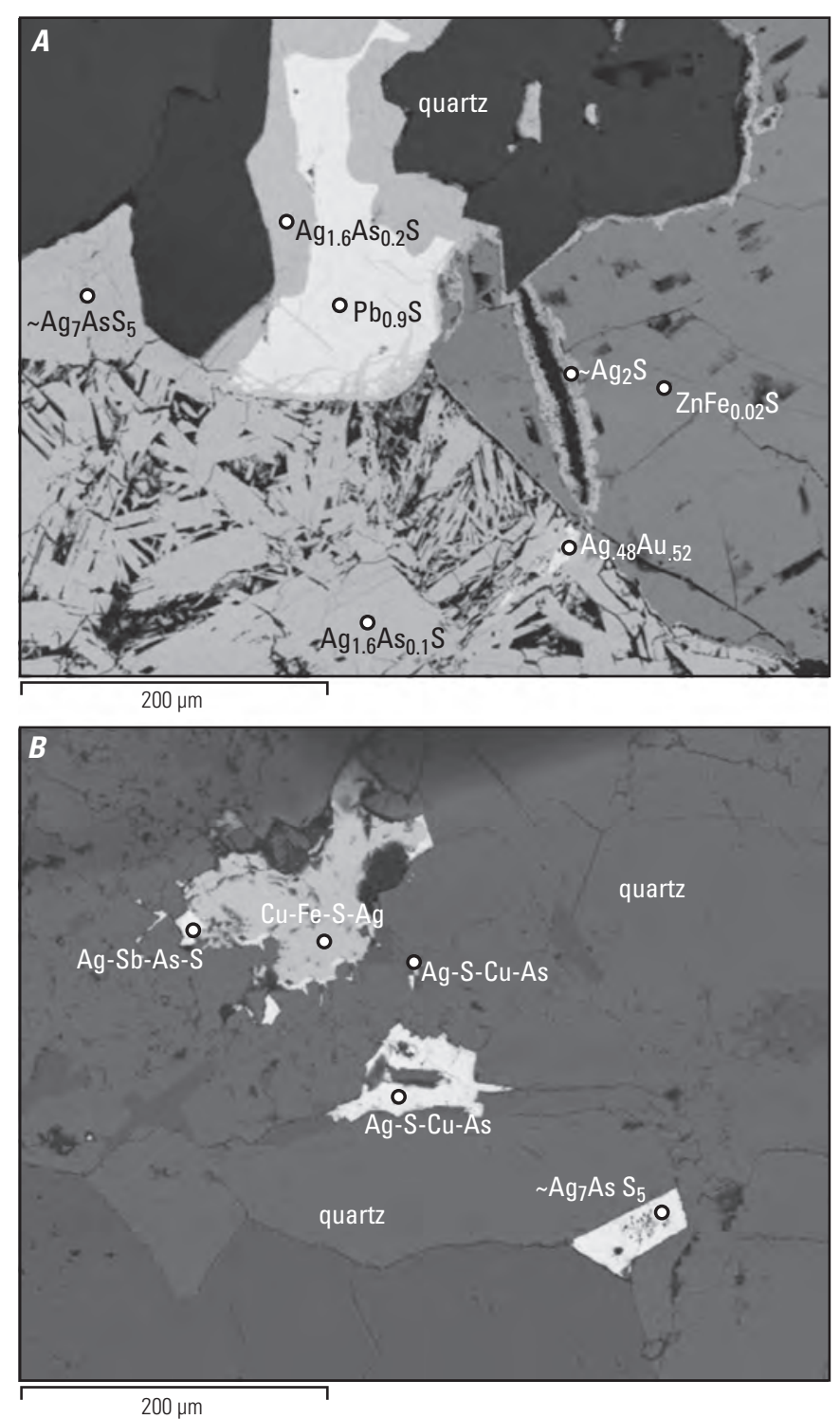

Figure 42. Secondary electron images of samples representative of Silver Hill series veins on and near Silver Hill, Bodie Mining District. $A$ and $B$ correspond to samples BOD11-1D and BOD11-1H, respectively, Oro Mine dump. Imaged phases include quartz, galena, sphalerite, acanthite, electrum with subequal $\mathrm{Au}$ and $\mathrm{Ag}$, Ag-As-S minerals $\left(\sim \mathrm{Ag}_{1.6} \mathrm{As}_{0.2} \mathrm{~S} ; \sim \mathrm{Ag}_{7} \mathrm{AsS}_{5}\right)$, and several Ag-SbAs-Fe-Cu-S minerals or mineral intergrowths. Mine locations are shown on figure 37.
In addition to low $\mathrm{Au} / \mathrm{Ag}$ and textures, vein mineralogy clearly distinguishes Silver Hill series veins from all other vein types. Dump samples of Silver Hill veins with elevated $\mathrm{Au}$ and $\mathrm{Ag}$ concentrations typically contain several percent to $>10$ percent sulfide minerals, predominantly sphalerite, galena, tetrahedrite, and chalcopyrite, whereas other vein types rarely contain more than 1 percent metallic minerals. Other common and distinguishing minerals in Silver Hill series veins are electrum, pyrite, acanthite, bornite, hessite, and sylvanite. Hessite and other Te minerals, tetrahedrite and other $\mathrm{Cu}-\mathrm{Ag}$ $\mathrm{Sb}$-As-S sulfosalt minerals, bornite, and possibly barite occur exclusively in Silver Hill series veins.

\section{Veins On and Near Queen Bee Hill}

No production is recorded for veins in the vicinity of Queen Bee Hill in the southern part of the district (fig. 37). Small amounts of \$30-150 per ton ore were found on the 300 and 500 levels of the Maryland Consolidated Mine (Queen Bee Hill), but quantities apparently were insufficient to mill (Chesterman and others, 1986). Limited Au and Ag data suggest that $\mathrm{Au} / \mathrm{Ag}$ in these veins is similar to $\mathrm{Au} / \mathrm{Ag}$ of Silver Hill series veins (table 5; Hollister and Silberman, 1995b). The Booker(?) vein, between Queen Bee Hill and the Noonday Mine, and vein pieces on the University, Maryland, and Boston Consolidated Mine dumps, consist of quartz, calcite, quartz pseudomorphs after calcite, and pyrite. Veins on Queen Bee Hill are $<1 \mathrm{~m}$ wide and extend to at least $800 \mathrm{ft}$ below the surface, but at depth are mostly composed of calcite, based on the prevalence of calcite in pieces of vein on dumps.

\section{Wall-Rock Alteration}

Alteration of volcanic rocks varies with elevation, latitude, vein series, and proximity to veins. It is, in part, lithologically controlled. Matrix of lag blocks of volcaniclastic deposits on the summit of Bodie Bluff (9,000 ft) has been pervasively replaced by very fine-grained quartz and lesser pyrite (iron oxides). Small embayments in some blocks are filled with thin deposits of finely layered, microcrystalline quartz, some of which are draped over rock fragments. The blocks are adjacent to partially excavated clasts of sinter (probably the sinter with reed casts described by Herrera and others, 1993). They represent silicification of volcaniclastic matrices and pool sinter subjacent to a small sinter terrace that subsequently has been dismembered by deflation and frost heaving. Clasts in volcaniclastic deposits include dacite of Silver Hill, uncorrelated porphyritic volcanic rocks, and small (centimeter-sized) angular to tabular, layered fragments of very fine-grained white quartz. Although the white quartz fragments resemble layered Incline series veins at the same elevation (fig. 37, 39A), they contain concentrations of $\mathrm{Au}, \mathrm{Ag}$, $\mathrm{As}, \mathrm{Sb}, \mathrm{Rb}$, and $\mathrm{Sr}$ that are indistinguishable from those in terrace sinter, but differ distinctly from those in adjacent Incline series veins (fig. 39; table 1-11). The silicified volcaniclastic 

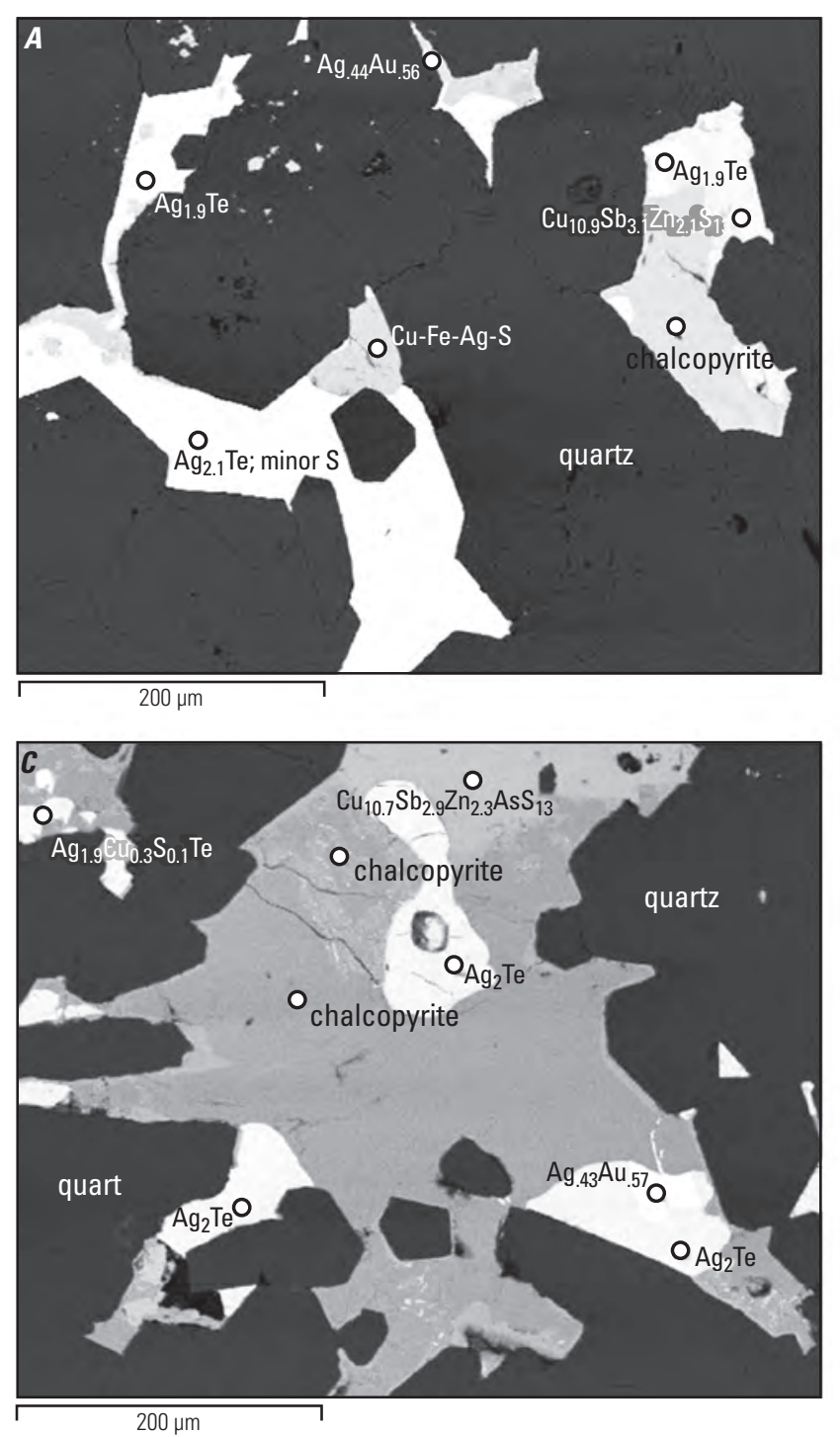

deposits and sinter are the upper strata of the $\sim 60$-m-thick sequence of volcaniclastic deposits that accumulated in the graben on Bodie Bluff (fig. 38; Chesterman and others, 1986; Silberman and Berger, 1985; Silberman and Chesterman, 1991; Herrera and others, 1993).

Volcaniclastic deposits in near-surface mine workings on Bodie Bluff, including the upper $100 \mathrm{ft}$ of the old Standard shaft, were reportedly soft and decomposed, and covered veins in underlying dacite (Whiting, 1888; Brown, 1908). Brown (1908) described "dead zones" of fractured and decomposed ("pulpy") andesite on Bodie Bluff that predated veins but did not maintain open conduits for mineralizing fluids. It is unclear from Brown's descriptions whether "dead zones" included decomposed volcaniclastic deposits. Matrix, and to a lesser extent, clasts of volcaniclastic deposits on mine dumps at lower elevations on the south slope of Bodie Bluff have been altered to K-feldspar, illite, and montmorillonite, but primary clastic textures are preserved.

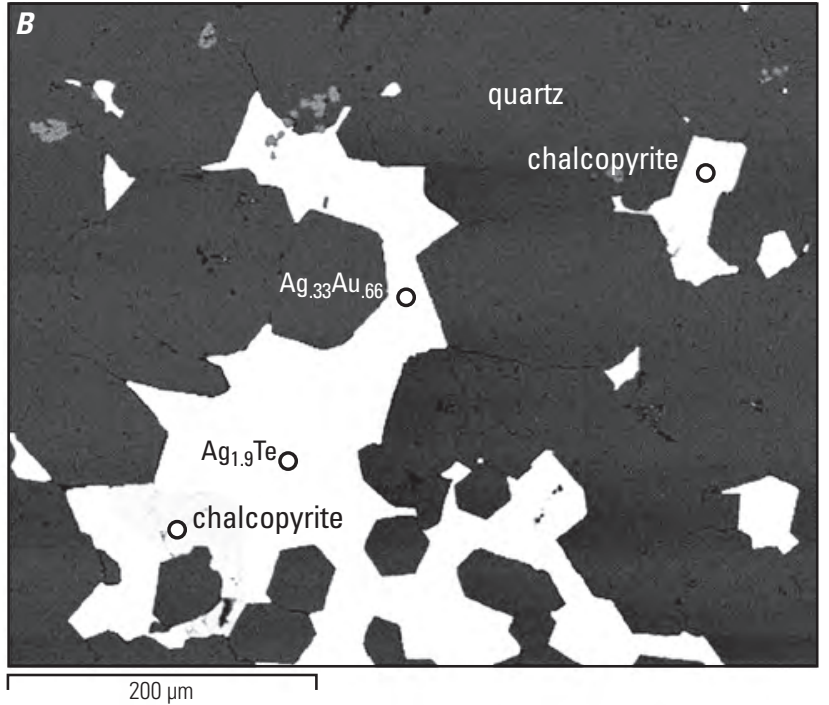

Figure 43. Secondary electron images of samples representative of Silver Hill series veins on and near Silver Hill, Bodie Mining District. $A, B$, and $C$ correspond to specimen K016, Addenda Mine (Keck museum collection, University of Nevada, Reno). Imaged phases include quartz, electrum with subequal $\mathrm{Au}$ and $\mathrm{Ag}$, hessite, chalcopyrite, tetrahedrite, a Cu-Fe-Ag-S mineral, and a $\mathrm{Ag}-\mathrm{Te}-\mathrm{Cu}-\mathrm{S}$ mineral $\left(\sim \mathrm{Ag}_{1.9} \mathrm{Cu}_{0.3} \mathrm{~S}_{0.1} \mathrm{Te}\right)$. Location of the Addenda Mine is shown on figure 37 .

A few meters east and tens of meters west of the blocks of silicified volcaniclastic deposits and sinter, dacite, at approximately the same elevation, contains Incline series veins (centimeters to tens of centimeters thick). The veins consist of layers of very fine-grained quartz and lesser adularia. Some narrow veins contain internal voids lined with euhedral quartz and lesser adularia crystals. Adjacent to veins, centimeter-thick selvages of altered dacite consist of quartz, subequal amounts of illite and K-feldspar, and several percent iron oxide that have replaced phenocrysts and matrix without substantially modifying primary texture.

At elevations several hundreds of meters below the summit of Bodie Bluff, vein selvages and brecciated dacite adjacent to Incline and Burgess series veins on the south slope of Standard Hill $(8,588 \mathrm{ft})$ consist of aggregates of quartz and $\mathrm{K}$-feldspar in which grain sizes approach $1 \mathrm{~mm}$. Adjacent to Incline series veins, illite partially replaces K-feldspar in some aggregates, occurs in small seams between quartz 

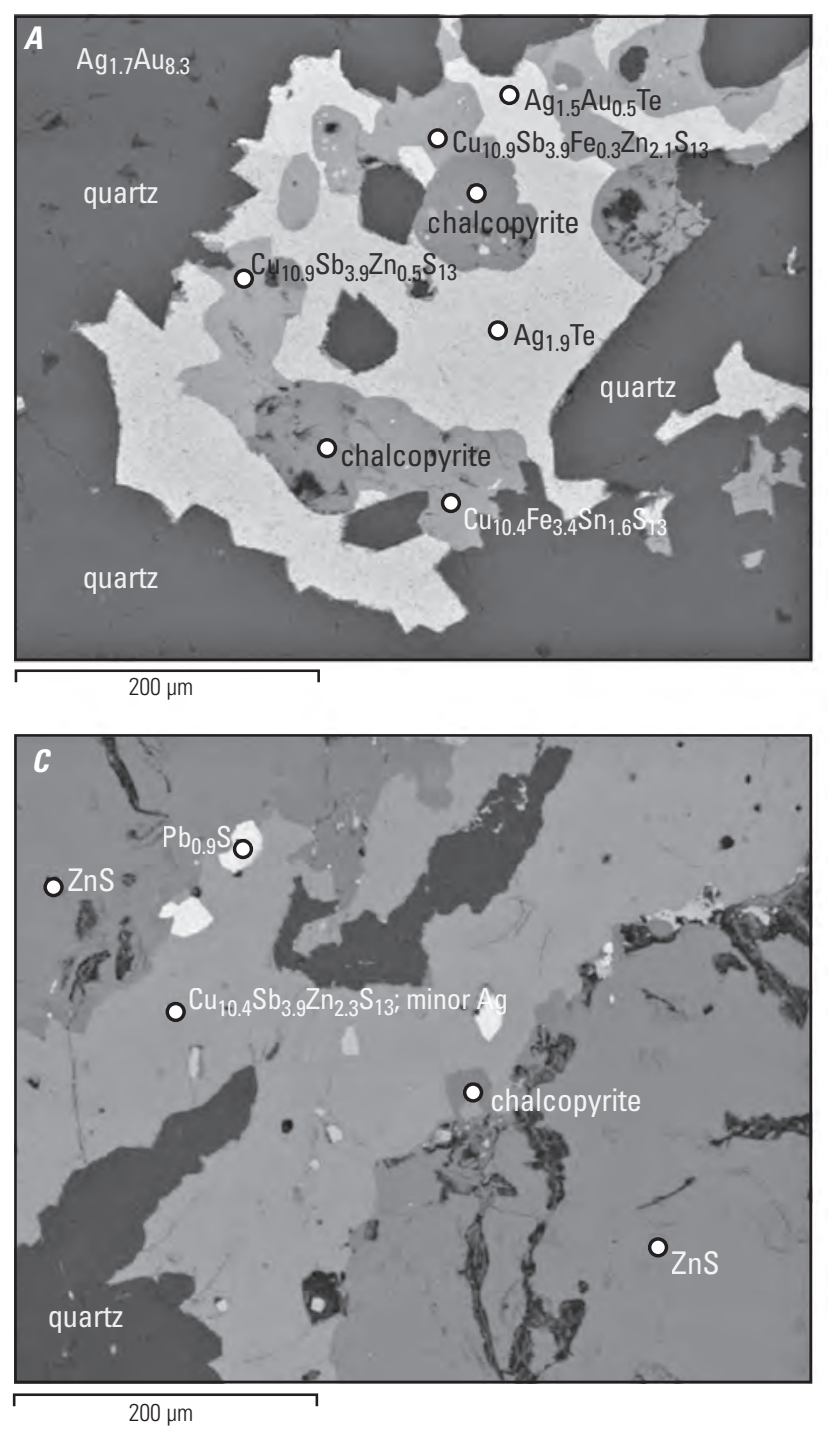

layers in veins, and with quartz, K-feldspar, and pyrite, partially replaces dacite fragments in veins and breccias. Centimeter-thick wall-rock selvages adjacent to Burgess series veins consist predominantly of $\mathrm{K}$-feldspar, subequal to lesser amounts of quartz and clinochlore (XRD analysis), and $<2$ volume percent pyrite (weathered to iron oxide minerals or jarosite). These minerals also cement brecciated dacite near veins. An archival sample of dacite adjacent to the Fortuna vein on the 526 level of the Standard Mine consists mostly of K-feldspar, with lesser quartz and $\sim 2$ volume percent pyrite.

Vertical zonation of alteration mineral assemblages has been described by O'Neil and others (1973) and Herrara and others (1993). Pervasive K-feldspar-dominant alteration assemblages extend about 100-150 m beneath Bodie Bluff. Mass balance calculations based on major oxide and minor element analyses of unaltered and altered rocks (O’Neil and others, 1973) demonstrate enrichment of $\mathrm{K}$ and $\mathrm{Rb}$ and depletion of $\mathrm{Na}, \mathrm{Ca}, \mathrm{Mg}$, and $\mathrm{Sr}$ in dacite adjacent to veins

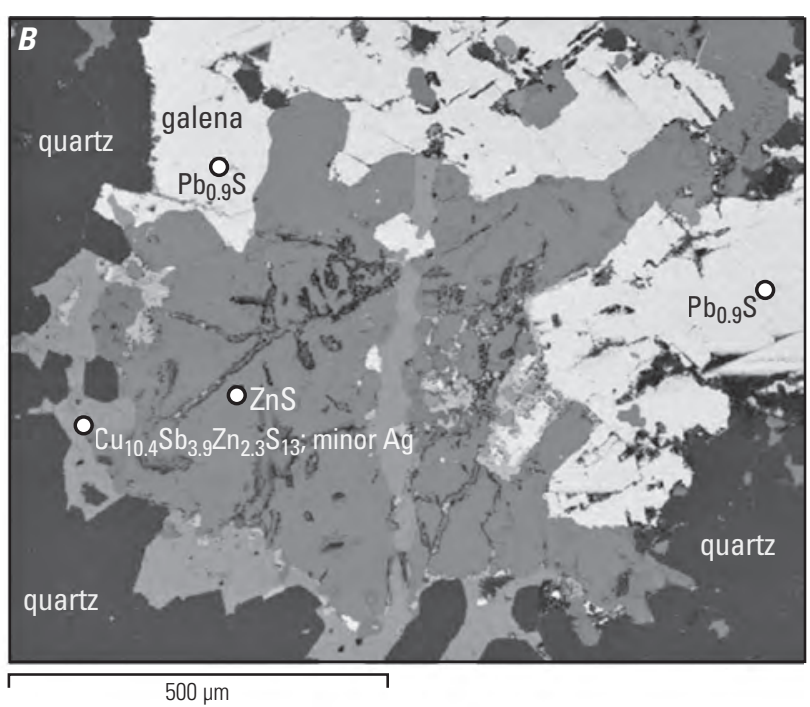

Figure 44. Secondary electron images of samples representative of Silver Hill series veins on and near Silver Hill, Bodie Mining District. A corresponds to sample B0D11-5A, Red Cloud Mine dump. $B$ and $C$ correspond to sample B0D11-5C, Red Cloud Mine dump. Imaged phases include quartz, hessite, an $\mathrm{Ag}$-Au-Te mineral $\left(\sim \mathrm{Ag}_{1.5} \mathrm{Au}_{0.5} \mathrm{Te}\right)$, tetrahedrite, chalcopyrite, a Cu-Fe-Sn-S mineral, galena, and sphalerite. Location of the Red Cloud Mine is shown on figure 37 .

on Bodie Bluff; Si and Al abundances were not changed significantly by alteration processes at these high elevations. Wall-rock selvages of altered dacite adjacent to veins narrow with increasing depth. At depth, selvages include sericite that has replaced K-feldspar, and below $\sim 8,500 \mathrm{ft}$ may include kaolinite in addition to quartz and pyrite. Distal to veins, feldspar and mafic phenocrysts in dacite are variably altered to chlorite, illite, montmorillonite, calcite, and lesser pyrite and zeolite minerals. Epidote is uncommon and spatially unrelated to veins, but may be coeval with these distal propylitic alteration minerals.

Alteration mineral associations in dacite spatially associated with Silver Hill series veins consist of quartz, illite, kaolinite, montmorillonite, and pyrite (iron oxides). Variable proportions of these minerals have replaced phenocrysts and matrices as much as tens of meters from veins. Although few veins are exposed near Silver Hill, wall rocks on mine dumps display more pervasive clay-mica alteration than altered 

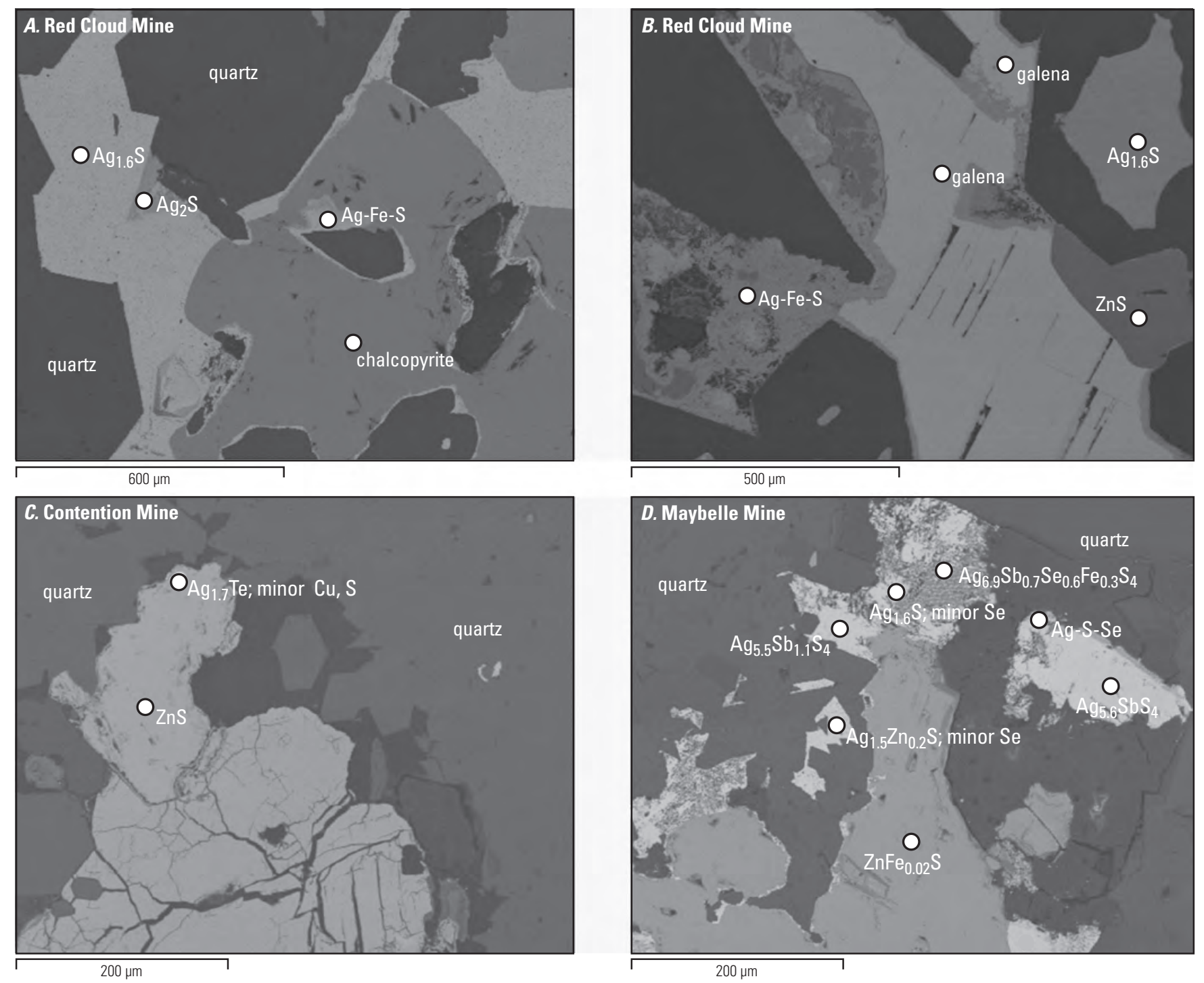

Figure 45. Secondary electron images of samples representative of Silver Hill series veins on and near Silver Hill, Bodie Mining District. $A$ and $B$ correspond to sample B0D09-3C, Red Cloud Mine dump. $C$ corresponds to sample B0D09-4A, Contention Mine dump. $D$ corresponds to sample BOD09-6, Maybelle Mine dump. Imaged phases include quartz, acanthite with minor Se, chalcopyrite, galena, sphalerite, hessite, a Ag-Fe-S mineral, Ag-Sb-S minerals, a Ag-Zn-S mineral, a Ag-S-Se mineral, and a Ag-Sb-Se-Fe-S mineral or mineral intergrowth. Mine locations are shown on figure 37. 
wall rocks associated with other vein series. The smooth, beige-colored dumps in the vicinity of Silver Hill contrast sharply with dumps on Standard Hill and Bodie Bluff, which are dominated by reddish-brown to green, angular blocks of $\mathrm{K}$-feldspar- and illite-altered dacite.

\section{Absolute and Relative Vein and Sinter Ages}

Based on ${ }^{40} \mathrm{Ar} /{ }^{39} \mathrm{Ar}$ adularia dates, Incline series veins vary in age from $\sim 8.3-8.1 \mathrm{Ma}$ (table 1). They are exposed mostly on Bodie Bluff and Standard Hill (fig. 37), but also are represented on the Noonday Mine and Oro Mine dumps which are linked by underground workings. Burgess series veins and Silver Hill series veins, which are distinguished from Incline series veins by textures, vein mineral assemblages, and wallrock alteration, vary in age from $\sim 8.5$ to $8.4 \mathrm{Ma}$ and $\sim 8.9$ to $8.5 \mathrm{Ma}$, respectively (table 1 ). However, there are no exposures from which the relative vein ages assigned by Brown (1908), or those determined by ${ }^{40} \mathrm{Ar} /{ }^{39} \mathrm{Ar}$ geochronology, can be verified. Based on adularia dates, contrasting minor element concentrations (fig. 46; table 1-11), and common elevations (fig. 37), Incline series veins postdate sinter atop Bodie Bluff, and sinter may be temporally equivalent to Burgess or Silver Hill series veins. The Fortuna vein has not been dated. If the crosscutting relationships among veins shown on figure 38 are valid, then the Fortuna vein is older than Incline and Burgess series veins.

Narrow veins (millimeters to centimeters wide) on Bodie Bluff that are juxtaposed with mined Incline and Burgess series veins consist of quartz and adularia layers with internal lenticular vugs containing millimeter quartz and adularia crystals. Adularia dates of $8.4 \mathrm{Ma}$ and $8.2 \mathrm{Ma}$ (table 1, uncorrelated veins), and to an extent, wall-rock alteration suggest that these veins are temporally associated with Burgess and Incline series veins, respectively, although there are no metallic minerals that might confirm associations. The narrow vein ages, coupled with the spread in adularia dates within vein series, imply that a succession of hydrothermal events followed eruption of dacite of Silver Hill at $\sim 9.1-8.9 \mathrm{Ma}$ (table 1 ). The $\sim 8.9-8.1$ span of hydrothermal events in the Bodie Mining District is partly contemporaneous with $\sim 8.6-8.0$ Ma trachydacite of Willow Springs, and with the Cinnabar Canyon-US 395 alteration zone ( 8.8-8.2 Ma; table 1), $\sim 8 \mathrm{~km}$ or more west of the district (fig. 1).

\section{Minor Elements in Veins and Wall Rocks}

The distribution of minor elements and oxygen isotope values in veins and wall rocks has been determined in numerous investigations (Silberman and Berger, 1985; O'Neil and others, 1973; Silberman, 1991; Silberman and Chesterman, 1991; Herrera and others, 1993; Hollister and Silberman, 1995a; 1995b). Concentrations of As, Zn, Sb, Mn, Ba, and Sr in veins vary from low parts per million to hundreds of parts per million, whereas $\mathrm{Au}, \mathrm{Hg}, \mathrm{Ag}, \mathrm{Tl}, \mathrm{B}, \mathrm{Co}, \mathrm{Cu}, \mathrm{Ni}$, and $\mathrm{Pb}$ concentrations vary from low parts per million to tens of parts per million. Many published analytical data sets overlap and spatial gradients among element concentrations are mostly inconsistent or difficult to recognize. Minor element distributions from numerous sources are synthesized as follows.

The vertical distribution of minor elements in sinter and Incline series veins from the top $(\sim 9,000 \mathrm{ft})$ to the base $(\sim 8,400 \mathrm{ft})$ of Bodie Bluff shows both variation and relative constancy. Sinter $(9,000 \mathrm{ft})$ contains $<1 \mathrm{ppm} \mathrm{Au}$, $\mathrm{Hg}$, and $\mathrm{Tl}, \sim 180 \mathrm{ppm} \mathrm{As}, \sim 280 \mathrm{ppm} \mathrm{Sb}$, and low ppm concentrations of $\mathrm{Cu}, \mathrm{Pb}$, and $\mathrm{Zn}$. At $\sim 8,720 \mathrm{ft}$ (Upper Hobart Tunnel), $\mathrm{Au}$ and $\mathrm{Ag}$ concentrations in Incline series veins $(\sim 0.1-100 \mathrm{ppm})$ are 10 or more times higher than at $8,400 \mathrm{ft}$ (Bodie Tunnel), whereas concentrations of $\mathrm{Sb}(1-\sim 60 \mathrm{ppm})$, $\mathrm{Hg}(0.01-\sim 11 \mathrm{ppm}), \mathrm{Tl}$ (<7.5 ppm), Cu ( 2-70 ppm), Zn ( 10-100 ppm), and $\operatorname{Sr}(\sim 100-800$ ppm) are broadly similar. Arsenic ( 2-490 ppm), Mn ( 8-10,000 ppm), Pb $(\sim 2-80 \mathrm{ppm})$, and $\mathrm{Ba}(10-1,100 \mathrm{ppm})$ concentrations are generally elevated in Bodie Tunnel samples relative to samples from higher elevations.

Gradients in the vertical distribution of minor elements in altered dacite are more difficult to interpret because all high-elevation samples contain quartz veins, whereas samples from lower elevations do not. Elements that display relatively consistent concentrations at 9,000 and 8,400 ft include As (190 to $6 \mathrm{ppm}$, respectively), $\mathrm{Zn}$ (low to $110 \mathrm{ppm}$ ), and $\mathrm{Sb}$ (130 to low ppm). Gold, Ag, Tl, and $\mathrm{Hg}$ concentrations vary little with elevation. Other minor element concentrations are elevated locally, but variations show minimal or no correlation with elevation.

Lateral distribution of $\mathrm{Sr}, \mathrm{Rb}, \mathrm{Au}$, and oxygen isotopes in dacite wall rocks and a $0.6-\mathrm{m}$-wide Incline series vein in the Upper Hobart Tunnel show higher Sr ( 100-700 ppm) and $\mathrm{Rb}(\sim 130-400 \mathrm{ppm})$ concentrations, and higher ${ }^{18} \mathrm{O}$ values ( $\sim-0.1$ to $-2.1 \%$ ) in dacite, and higher Au concentrations $(0.04-4.2 \mathrm{ppm})$ in the vein. Slight gradients are implied by decreasing $\mathrm{Sr}$ and $\mathrm{Rb}$ and increasing ${ }^{18} \mathrm{O}$ values with distance from the vein, although sample density is inadequate to substantiate trends. Concentrations of $\mathrm{Zn}, \mathrm{Ag}$, As, and $\mathrm{Tl}$ in dacite either decrease abruptly with distance from the dacitevein contact $(\mathrm{Ag}, \mathrm{Tl})$, or display no systematic trend $(\mathrm{Zn}, \mathrm{As})$. $\delta^{18} \mathrm{O}$ values in other whole rock and phenocryst samples from Bodie Bluff and Standard Hill indicate variable exchange between dacite and meteoric water.

Concentrations of $\mathrm{Au}, \mathrm{Ag}, \mathrm{Cu}$ and other elements in veins on Bodie Bluff and Standard Hill, in Silver Hill series ("polymetallic") veins, in veins on Queen Bee Hill, and in wall rocks have been compared by Hollister and Silberman (1995b). Silver-gold ratios in veins and wall rocks at 9,000 ft on Bodie Bluff (presumably Incline series veins) are 2.3 and 21 , respectively, and at 8,400 ft are 19 and 31. Silver-gold ratios in Silver Hill series veins and wall rocks are 244 and 43 , respectively, and in veins and wall rocks on Queen Bee Hill are 6.6 and 104, respectively. $\mathrm{Cu}-\mathrm{Au}$ ratios in Silver Hill series veins are several orders of magnitude higher than in Bodie Bluff and Queen Bee Hill veins. These element 

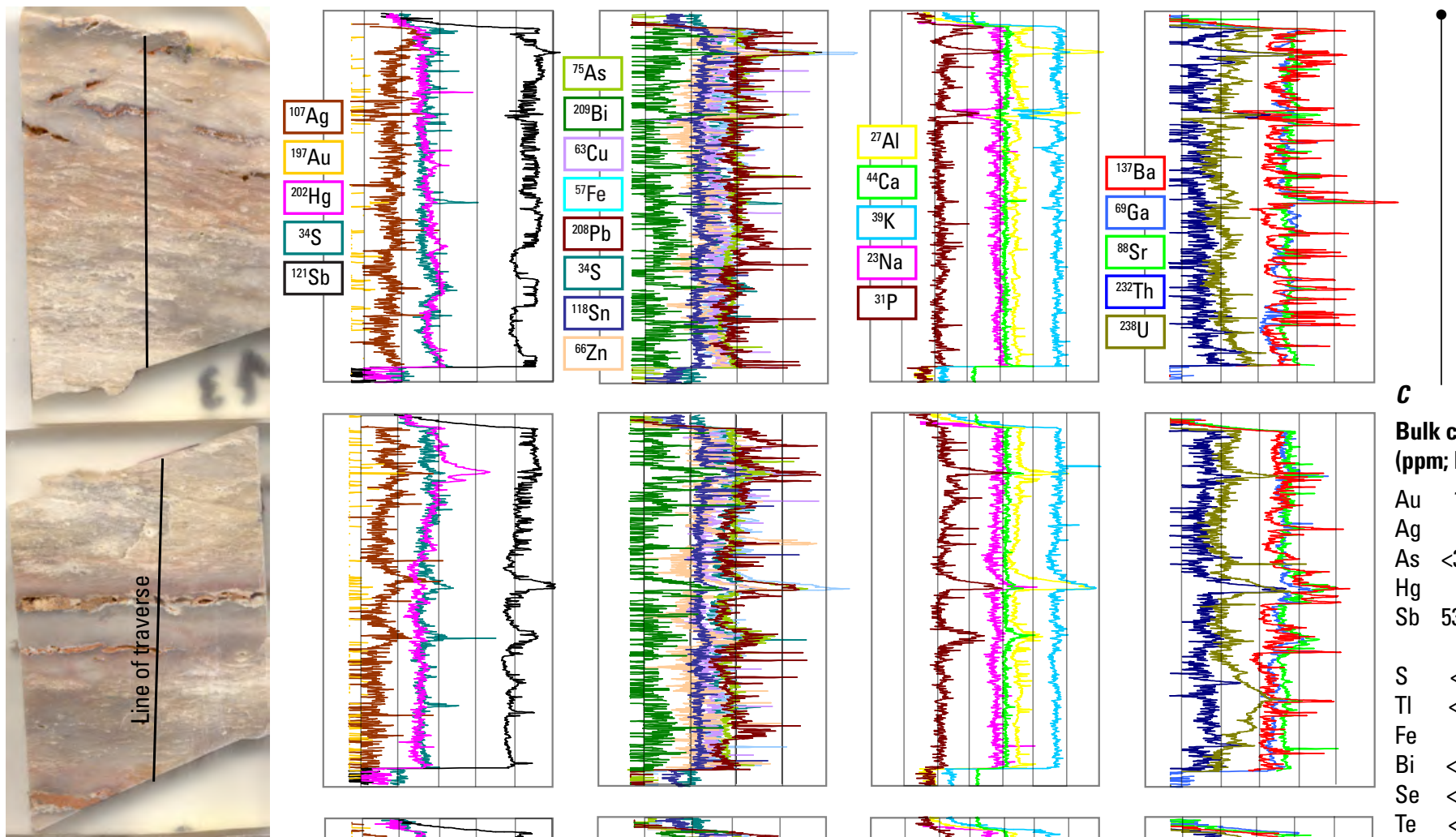

Bulk concentration

\section{(ppm; ICP-AES-MS)}

$\mathrm{Au} \quad 11 \mathrm{ppb}$

$\mathrm{Ag} \quad 1$

As $<30$

$\mathrm{Hg} \quad 0.4$

Sb 539
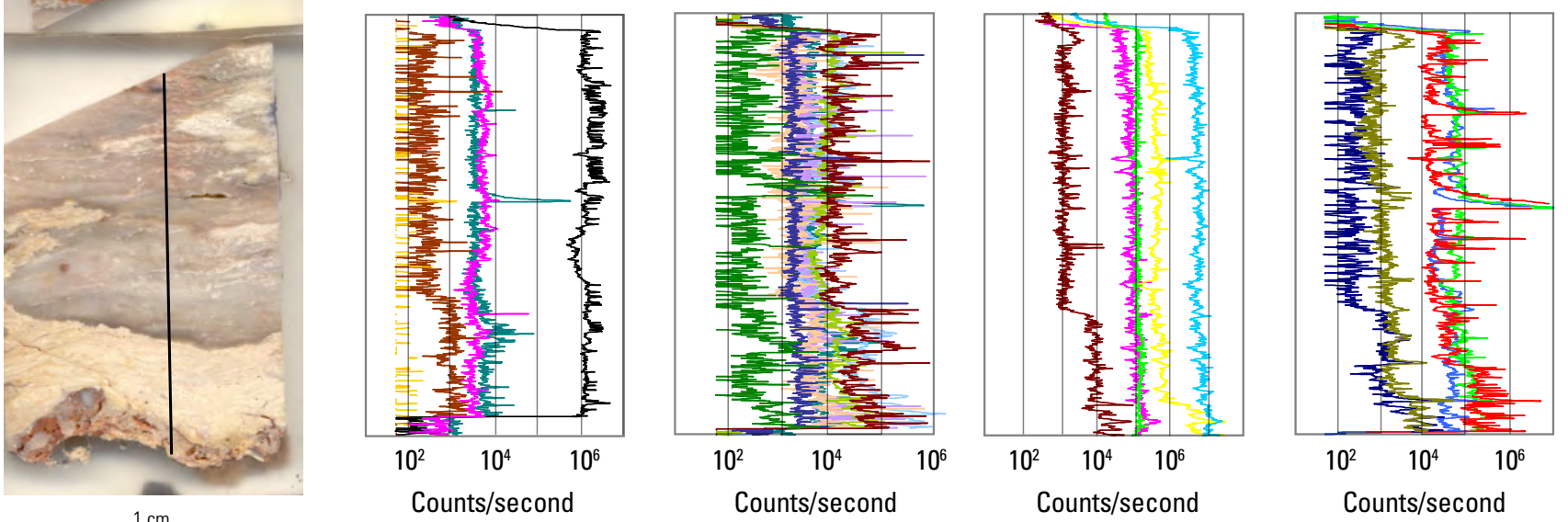

Figure 46. A, Image showing oriented consecutive sections of sinter from Bodie Bluff summit, Bodie Mining District (B0DB06-4A; fig. 37). B, Graphs showing relative element concentrations in sinter measured in counts per second (counts/second) by laser ablation inductively couple plasma-mass spectrometry (LA ICP-MS). $C$, Bulk sample element concentrations determined by inductively coupled plasma-atomic emission spectrometry-mass spectrometry (ICP-AES-MS). Locally elevated (millimeterscale) element concentrations include $\mathrm{Au}, \mathrm{Ag}, \mathrm{Hg}, \mathrm{S}, \mathrm{Sb}, \mathrm{Cu}, \mathrm{As}, \mathrm{Fe}, \mathrm{Sn}, \mathrm{Bi}, \mathrm{Zn}, \mathrm{Pb}$, and $\mathrm{Ba}$, most of which are not elevated in the bulk sample. 
concentrations and ratios in veins, at least, are corroborated by vein mineralogy described previously, and by production records (table 5).

Minor element concentrations in sinter atop Bodie Bluff $(9,000 \mathrm{ft}$; fig. 37) were determined for possible element correlations between sinter and veins (Vikre, 2007). Element concentrations, determined by LA ICP-MS along a continuous traverse orthogonal to sinter beds, include local (submillimeter scale) enrichment of $\mathrm{Ag}, \mathrm{Sb}, \mathrm{Hg}, \mathrm{S}, \mathrm{Bi}, \mathrm{As}, \mathrm{Fe}, \mathrm{Cu}, \mathrm{Pb}, \mathrm{Ba}$, and other elements (fig. 46). Bulk analyses of the traversed sinter beds, and of other sinter samples (table 1-11), show elevated concentrations of $\mathrm{Sb}, \mathrm{Hg}, \mathrm{As}, \mathrm{Tl}$, and $\mathrm{Se}$, but some elevated concentrations at the millimeter scale (for example, Ag, Bi) are not elevated in bulk samples. Based on these analyses, sinter cannot be correlated unequivocally with any specific vein series (table 1-11).

Elevated concentrations of $\mathrm{Sb}, \mathrm{Hg}, \mathrm{As}$, and $\mathrm{Pb}$ in some bulk sinter samples and in Silver Hill series veins broadly correspond, whereas $\mathrm{Au}, \mathrm{Ag}, \mathrm{Bi}, \mathrm{Cu}, \mathrm{Se}, \mathrm{Sn}, \mathrm{Te}$, and $\mathrm{Zn}$ are enriched in Silver Hill series veins but not in sinter. Element concentration correlations between Incline and Burgess series veins and sinter are fewer and include similar $\mathrm{As}, \mathrm{Pb}$, and $\mathrm{Sb}$ concentrations in some samples (table 1-11). Sinter and Incline series veins at the same elevation on the summit of Bodie Bluff contain, in part, similar As, $\mathrm{Sr}$, and $\mathrm{Sb}$ concentrations, but $\mathrm{Au}$ and $\mathrm{Ag}$ concentrations in sinter are as much as two orders of magnitude lower than those in veins (fig. 47).

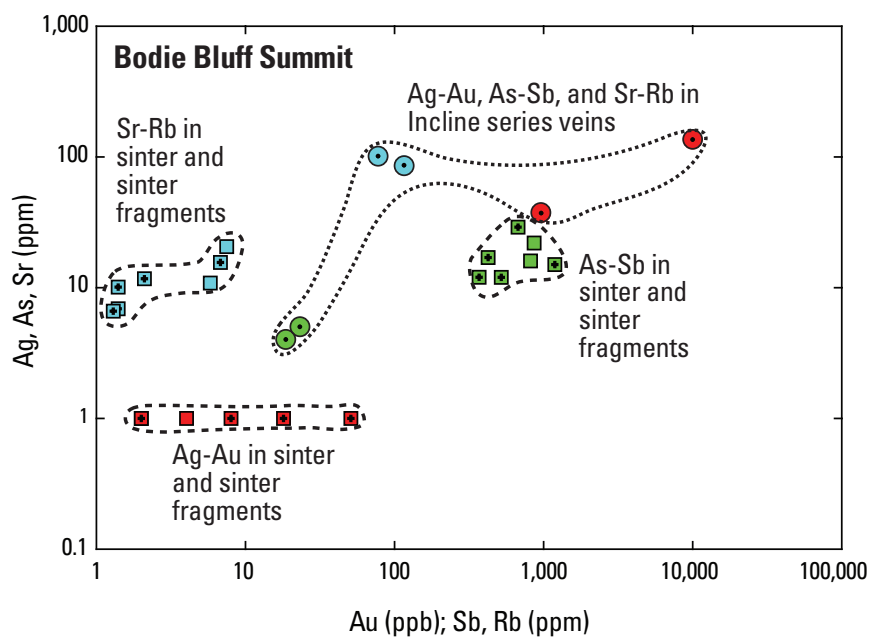

\section{EXPLANATION}

$\square$ Sinter (dismembered sinter terrace)

$\boxplus$ Sinter fragments (in volcaniclastic deposits

$\odot$ Incline series veins

Figure 47. Graph of $\mathrm{Ag}, \mathrm{As}, \mathrm{Sr}$ concentrations versus $\mathrm{Au}, \mathrm{Sb}$, $\mathrm{Rb}$ concentrations in sinter from the dismembered sinter terrace, sinter fragments in volcaniclastic deposits, and Incline series veins, Bodie Mining District, Bodie Bluff summit. Elevation of all samples is $8,960 \pm 20 \mathrm{ft}$.

\section{Fluid Inclusion Microthermometry}

Limited fluid inclusion microthermometric analyses and petrographic descriptions of fluid inclusions have been published. A fluid inclusion "filling temperature" of $245^{\circ} \mathrm{C}$ and salinity of 0.3 weight percent $\mathrm{NaCl}$ equivalent in a sample of vein quartz from the McClinton Mine dump (atop Standard Hill, $\sim 8,720 \mathrm{ft}$; presumably an Incline series vein), were determined by J.T. Nash and reported by O'Neil and others (1973). Hollister and Silberman (1995b) described saturated fluid inclusions (containing as many as four daughter minerals) in a polymetallic vein sample from the vicinity of Silver Hill (presumably a Silver Hill series vein), but provided no microthermometric data.

\section{Oxygen and Hydrogen Isotope Compositions of Vein Minerals and Fluid Inclusion Water}

Oxygen isotope values of vein quartz \pm adularia, and hydrogen isotope values of fluid inclusion water in vein quartz \pm adularia, were determined by O'Neil and others (1973) and O'Neil and Silberman (1974) for samples from the McClinton Mine dump and Upper Hobart Tunnel (fig. 37; presumably Incline series veins), Red Cloud Mine dump (presumably Silver Hill series veins), and of the Fortuna vein (fig. 38). The $\delta^{18} \mathrm{O}$ values of water in equilibrium with quartz, calculated at an assumed fractionation temperature of $250{ }^{\circ} \mathrm{C}$, vary from -3.0 to $-0.1 \%$; the $\delta \mathrm{D}$ values of water vary from -108.1 to $-97.6 \%$. These isotope values imply that vein components were transported by, and deposited from, meteoric water-dominated fluid, and very high water-rock ratios during hydrothermal events. The $\delta \mathrm{D}$ values of kaolinite and K-mica, -133.2 and $-127.3 \%$, respectively, are also compatible with meteoric water-mineral equilibration. Lower equilibrium temperatures of $228{ }^{\circ} \mathrm{C}$ and $123{ }^{\circ} \mathrm{C}$ were calculated for coexisting quartz and calcite in a vein sample from the Red Cloud Mine dump; the temperature differences reflect different experimentally determined quartz-water fractionations (O'Neil and others, 1973; O'Neil and Silberman, 1974).

\section{Sulfur Isotope Compositions of Vein Minerals}

The $\delta^{34} \mathrm{~S}$ values of sulfide minerals in Bodie district veins were determined for comparison with those of hydrothermal minerals in other mining districts and alteration zones in the Bodie Hills volcanic field (table 2). In Bodie district veins, $\delta^{34} \mathrm{~S}$ values vary by $\sim 6 \%$ ( $(-4.7$ to $1.4 \%$ ) with a mode of $\sim 0 \%$, indicative of a reduced and fairly isotopically homogenous source; the values are broadly similar to values of sulfide melt inclusions in mantle rocks (Chaussidon and others, 1989) and are consistent with a magmatic source of sulfur. The $\sim 0 \%$ mode and near absence of hypogene sulfate minerals distinguish Bodie district veins from sulfide-sulfate mineral assemblages in the Masonic Mining District, and in the Red Wash-East Walker River, Sawtooth Ridge, Potato 
Peak, and Cinnabar Canyon-US 395 alteration zones. The $\delta^{34} \mathrm{~S}$ values of sulfide and sulfate minerals at Masonic and most alteration zones reflect disproportionation of magmatic $\mathrm{SO}_{2}$ (Rye, 2005). The $\delta^{34} \mathrm{~S}$ values of Bodie district veins have much less variance than those of Aurora district veins. The larger range in values at Aurora may reflect unrecognized sulfate minerals, or more than one sulfur source.

\section{ASTER Imagery}

ASTER imagery of the Bodie Mining District (Rockwell, 2010) shows a fairly contiguous cluster of pixels in the area between the Mono Fault and Silver Hill that corresponds to kaolinite, smectite, smectite/montmorillonite, and quartz. Less dense pixel clusters, coincident with Standard Hill and Bodie Bluff, correspond to illite, smectite/montmorillonite, and quartz. Diffuse pixels, coincident with the area between Bodie Bluff and Queen Bee Hill, correspond to illite.

\section{SWIR Spectra; XRD Analyses}

SWIR and XRD analyses of hand samples and subsamples show that altered dacite, adjacent to Incline series veins on Standard Hill, contains illite, K-feldspar, quartz, and small amounts of pyrite (iron oxides). Dacite adjacent to Burgess series veins contains clinochlore, and possible montmorillonite, in addition to quartz, K-feldspar, and small amounts of pyrite (iron oxides). Altered volcaniclastic strata and dacite on Bodie Bluff (Tioga Mine dump) contain illite/ smectite, and montmorillonite. Hydrothermal minerals in dump samples of Silver Hill series veins include adularia and illite in addition to quartz.

\section{Spring Peak Sinter}

\section{Location}

Sec. 34, T. 5 N., R. 28 E., Mineral County, Nevada (fig. 1)

\section{Definition}

The Spring Peak sinter consists of a partially dissected sinter terrace with west-east and north-south dimensions of $\sim 0.2$ and $0.1 \mathrm{~km}$, respectively $\left(0.02 \mathrm{~km}^{2}\right.$; fig. 48$)$. The terrace overlies altered volcaniclastic deposits and Cretaceous granitic and Mesozoic metamorphic rocks on a low west-east ridge. The ridge is near the eastern margin of an area of erratically altered trachyandesite of Aurora, Pliocene volcanic rocks, and Cretaceous granitic rocks that extends south and east from the Aurora Mining District and East Brawley Peak (figs. 16, 48). Temporal relationships between the Aurora Mining District, the East Brawley Peak alteration zone, Spring Peak sinter, and the west-east zone of altered rocks that underlie the Spring Peak sinter have not been completely determined.

\section{History and Production}

No production is recorded from the Spring Peak sinter terrace or subjacent rocks. Small prospect pits were excavated in altered volcanic and pre-Tertiary rocks west, northwest, and east of the terrace, and a small prospect pit in the terrace exposes opaline silica with minor amounts of cinnabar. Cinnabar also occurs in chalcedonic and opaline sinter at the eastern edge of the terrace. Small pieces (centimeters in dimension) of layered vein, some of which contain elevated gold and silver values, lie on the south slope of the sinter-capped, west-east ridge. Nineteen, relatively shallow holes $(\leq 505 \mathrm{ft}$ deep; Kinetic Gold Corp., 2013) were drilled in the 1980s to determine if precious metal deposits occur beneath or lateral to the sinter terrace. Recent geological mapping, geochemical analyses, and geophysical interpretation have been used to correlate layered vein float with sinter and other alteration mineral assemblages (Kinetic Gold Corp., 2013). The Spring Peak sinter and subjacent rocks represent a relatively intact sinter-vein system that contains elevated concentrations of $\mathrm{Au}$, $\mathrm{Ag}, \mathrm{Hg}, \mathrm{Sb}$, and $\mathrm{As}$.

\section{Stratigraphy}

The oldest rocks in the vicinity of the Spring Peak sinter are Cretaceous granitic rocks, and Mesozoic metamorphic rocks, presumably correlative with rocks of the Excelsior Formation (Al-Rawi, 1969; Silberman and others, 1995; Breit, 2000; divided by Speed, 1977 into the Mina, Gold Range, and Black Dyke formations). Thin (meters-thick) altered volcaniclastic strata underlie the sinter terrace and unconformably overlie pre-Tertiary rocks on the west end of a small hill tens of meters $(>100 \mathrm{ft})$ east of the terrace. The terrace has a maximum thickness of $\sim 5 \mathrm{~m}$ at its northeastern edge, but is $<1 \mathrm{~m}$ thick elsewhere where it is largely dismembered into meter-sized blocks and smaller clasts of float. Much of the northeastern terrace margin consists of large to small blocks (meters in dimension) that are slightly tilted (fig. 48). The gray- to brown-weathering volcaniclastic substrate is moderately well-sorted and bedded, sand and silt. Larger feldspar and quartz fragments (centimeter-sized) in sand beds were apparently derived from subjacent Cretaceous granitic rocks.

Cretaceous granitic rocks consist of very light-gray to yellowish-gray hypidiomorphic granular, porphyritic quartz monzodiorite with prominent, euhedral, perthitic, pink potassium feldspar megacrysts $2-3 \mathrm{~cm}$ long. The mediumgrained quartz monzodiorite contains about two percent tan- to greenish-brown biotite, mostly replaced by chlorite. Mesozoic metamorphic rocks intruded by quartz monzodiorite in the Spring Peak sinter area are similar to those in the Masonic Mining District. 
A

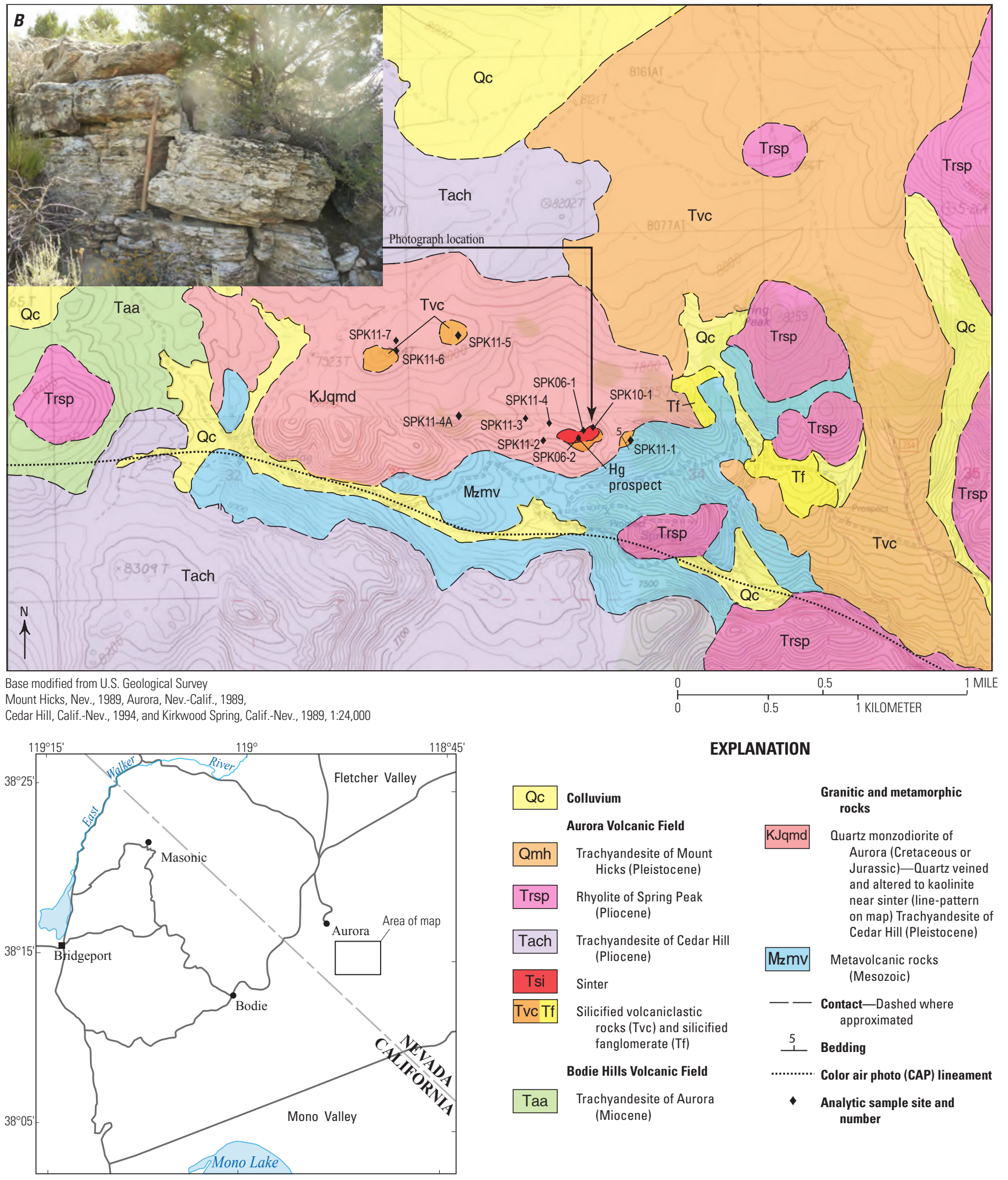

Figure 48. A, Geologic map of the Spring Peak sinter, Mineral County, Nevada, modified from Breit (2000) and John and others (2012). $B$, Image showing nearly intact sinter beds from the northern margin of the terrace. 


\section{Structure}

No obvious structures control the morphology of the Spring Peak sinter terrace. A prominent west-east lineament on color air photos (CAP lineament; fig. 48) borders the terrace to the south. This lineament extends to the west through the southern part of the East Brawley Peak alteration zone (fig. 16), and may have regionally displaced veins in the Aurora Mining District.

\section{Hydrothermal Alteration}

Sinter consists of bedded chalcedonic quartz, opaline silica, and hackly voids (former rock fragments and bioherms) that contain small amounts of illite and montmorillonite. Minor cinnabar and a dark-green mineral, possibly nontronite $\left(\mathrm{Na}_{0.3} \mathrm{Fe}^{3+}{ }_{2} \mathrm{Si}_{3} \mathrm{AlO}_{10}(\mathrm{OH})_{2} \cdot 4\left(\mathrm{H}_{2} \mathrm{O}\right)\right)$, occur locally in bedding planes and along fractures, and are finely dispersed in chalcedonic silica. Volcaniclastic strata beneath the sinter have been pervasively silicified, and contain as much as several percent pyrite, small amounts of kaolinite, and a few $<1 \mathrm{~mm}$-thick quartz veins.

Quartz monzodiorite, along the western part of the low west-east ridge that is partially covered by the sinter terrace, has been altered to opaline silica and kaolinite. Local exposures of quartz monzodiorite with disrupted texture apparently represent a weathering surface that predates hydrothermal alteration. Layered quartz veins (centimeters wide) occur in float at sub-sinter elevations on the south side of the ridge of quartz monzodiorite. These veins consist of fine-grained quartz, K-feldspar, and minor sericite.

Samples of sinter and subjacent rocks contain as much as $27 \mathrm{ppm} \mathrm{Hg}$, tens to $>1,000 \mathrm{ppm} \mathrm{As}$, and hundreds to $>1,000 \mathrm{ppm} \mathrm{Sb}$ (table 1-12). A few samples contain elevated concentrations of $\mathrm{Au}$ (tens to $>126 \mathrm{ppb}$ ), Ag, Ba, Mo, and W. Higher Au concentrations (several parts per million) were encountered in drill holes and in samples of layered vein float (Kinetic Gold Corp., 2013). Minor element concentrations, determined by LA ICP-MS, along continuous traverses orthogonal to sinter beds (figs. 49, 50, 51) define local (submillimeter) enrichments of $\mathrm{Au}, \mathrm{Ag}, \mathrm{Hg}, \mathrm{S}, \mathrm{As}, \mathrm{Bi}, \mathrm{Tl}$, $\mathrm{Fe}$, and other elements. Bulk analyses of the traversed beds indicate slightly to markedly elevated concentrations of $\mathrm{Au}$, $\mathrm{Sb}, \mathrm{Hg}$, and $\mathrm{Fe}$, but many elements with elevated concentrations at the millimeter scale (for example, $\mathrm{As}, \mathrm{Bi}, \mathrm{Tl}$, and $\mathrm{Ag}$ ) are not anomalously concentrated in bulk samples.

\section{Hydrothermal Mineral Ages}

Spring Peak sinter has not been dated directly, but its age is somewhat constrained stratigraphically. Altered rhyolite (possibly Pliocene rhyolite of Spring Peak) and silicified Tertiary fanglomerate in the west-east zone of altered rocks that includes the sinter terrace (fig. 48) imply that the sinter is Pliocene or younger.

\section{Evolution of Landforms During Assembly and Alteration of the Miocene Bodie Hills Volcanic Field}

Characteristics of mining districts and alteration zones, coupled with volcanic stratigraphy and geochronology, can be used to reconstruct Miocene landform evolution during the assembly, alteration, and erosion of the Bodie Hills volcanic field. Detailed mapping and dating of volcanic rocks, Au-Ag$\mathrm{Cu}$ deposits, and alteration zones has enabled identification of erosional paleosurfaces (lithologic contacts between volcanic flows and volcaniclastic deposits) closest in age to the hydrothermal systems. In several mining districts and alteration zones, hydrologic paleosurfaces (surfaces during hydrothermal activity) are marked by remnant terrace and pool sinters. In eroded mineralized and altered areas, the relative elevations of paleopotentiometric surfaces (groundwater saturation surfaces) can be estimated from vein fluid inclusion microthermometry, vein sulfur isotope equilibrium temperatures, and more generally, alteration mineral assemblages. Based on climatic evidence (Aldrich Station flora), potentiometric surfaces in the Bodie Hills during the middle Miocene were largely equivalent to hydrologic surfaces. Comparison among present elevations of erosional paleosurfaces, hydrologic paleosurfaces, and paleopotentiometric surfaces above exposed veins can be used to estimate (1) thicknesses of host rocks, veins, and mineralized and altered rocks that have been eroded; (2) postmineralization fault displacements; and (3) depths at which high-grade sections of veins and mineral deposits formed. The restoration of paleosurfaces and paleotopography within mining districts and alteration zones, based on fluid dynamics, volcanic stratigraphy, and geochronology, enables larger scale reconstruction of landforms as they evolved the during assembly and alteration of the entire volcanic field (fig. 52). Key datums for this reconstruction are the Aldrich Station flora and Eureka Valley Tuff.

\section{Aldrich Station Flora and Fossils in the Bodie Hills}

The $\sim 11$ Ma Aldrich Station flora (Axelrod, 1956; Evernden and James, 1964; Gilbert and Reynolds, 1973; Millar, 1996), 22.5 km north of the Aurora Mining District, occurs in tuffaceous shales that accumulated during Bodie Hills volcanism (fig. 52B). The flora consists of riparian species that grew in fluviolacustrine basins, and species representative of conifer forests and live oak woodlands that grew on bordering volcanic uplands with hundreds of feet or relief. The prevailing subhumid climate was more equable than present climate with $\sim 64 \mathrm{~cm}$ or more of winter and summer precipitation. In basins, groundwater saturation was at or above land surface, whereas in volcanic uplands, groundwater saturation was apparently within meters below the surface. 


\section{A}

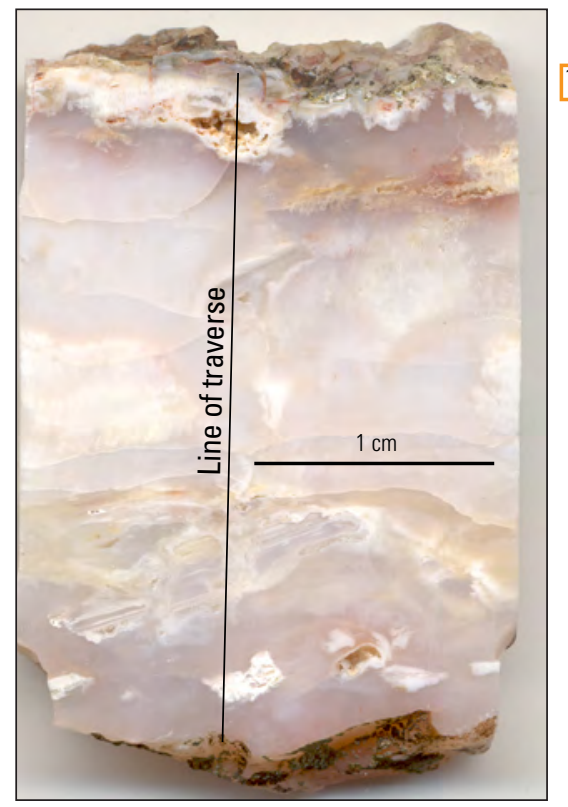

B Spring Peak sinter I. (SPK06-2)

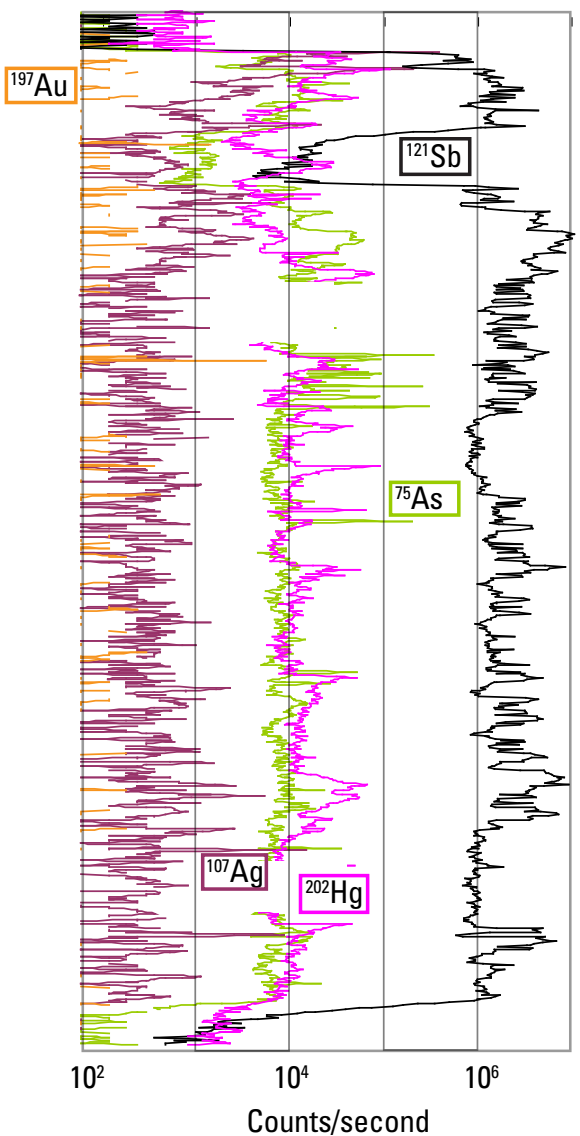

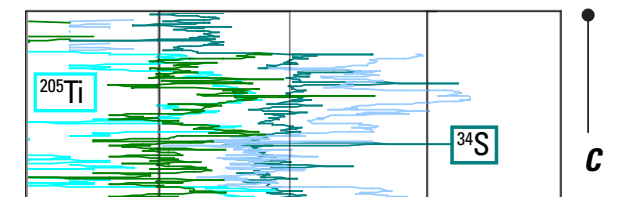

Bulk concentration (ppm; ICP-AES-MS)

$\mathrm{Au} \quad 6 \mathrm{ppb}$

$\mathrm{Ag}<1$

As $<30$

$\mathrm{Hg} \quad 0.1$

Sb 835

$\begin{array}{ll}\mathrm{S} & <0.05 \% \\ \mathrm{Tl} & <0.5\end{array}$

TI $<0.5$

Fe $\quad 0.04 \%$

Bi $<0.01$

Figure 49. $A$, Image of sample of Spring Peak sinter from the $\mathrm{Hg}$ prospect in the sinter terrace, Spring Peak alteration zone (fig. 48). $B$, Graphs showing relative element concentrations in sinter measured in counts per second (counts/second) by laser ablation inductively coupled plasma-mass spectrometry (LA ICP-MS). C, Bulk sample element concentrations determined by inductively coupled plasma-atomic emission spectrometry-mass spectrometry (ICPAES-MS). Locally elevated (millimeter-scale) element concentrations include $\mathrm{Au}, \mathrm{Hg}, \mathrm{Ag}$, Sb, Fe, and $\mathrm{S}$. 


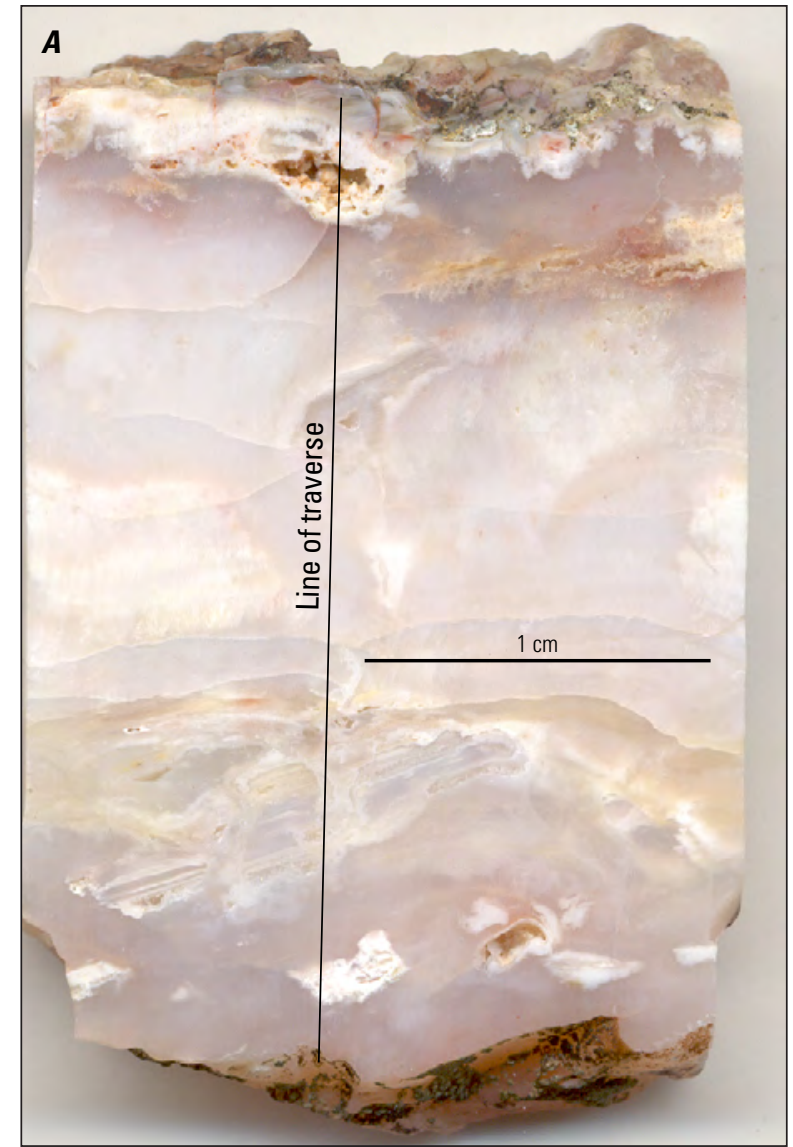

B Spring Peak sinter II. (SPK06-2)
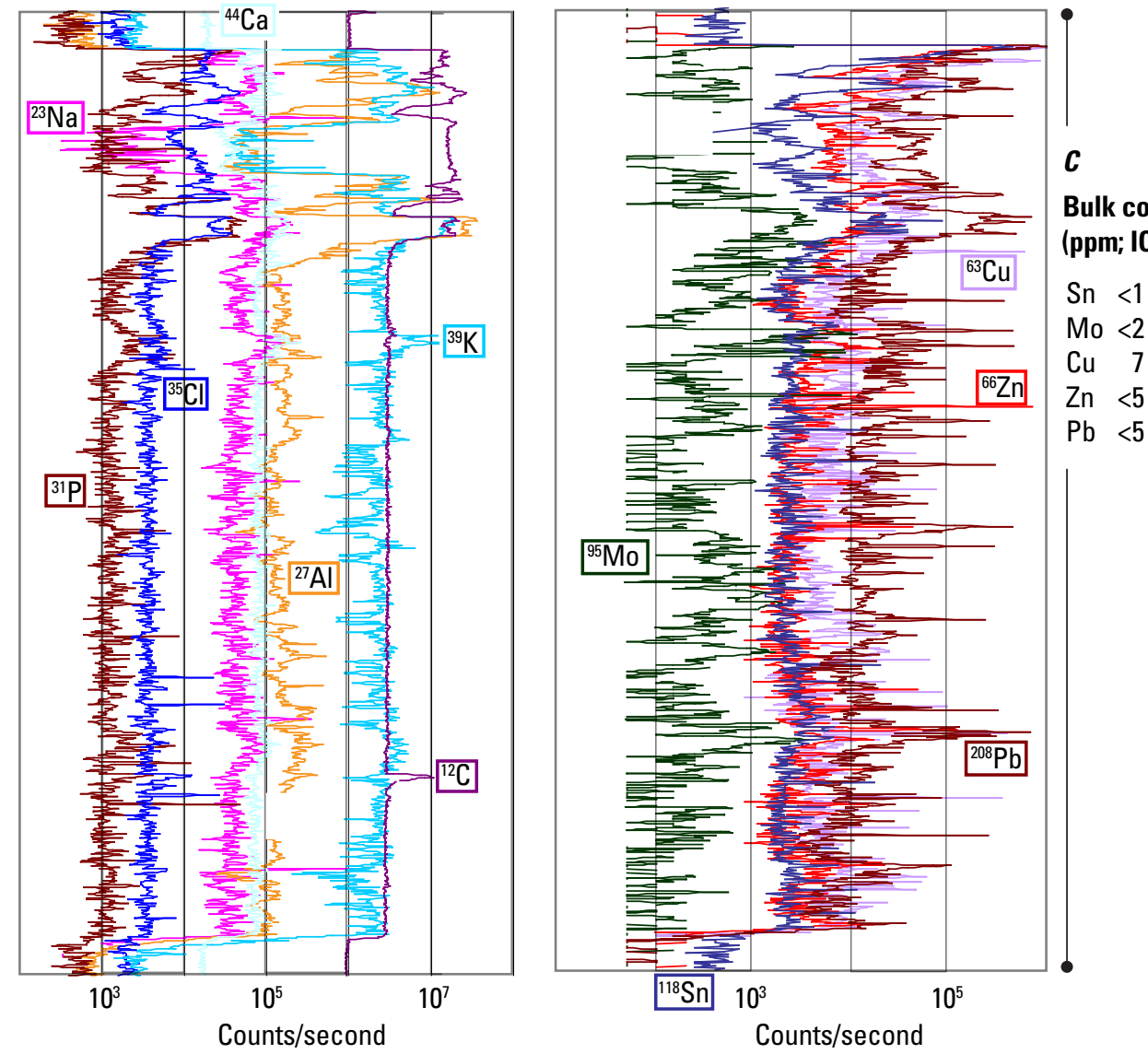

Figure 50. A, Image of sample of Spring Peak sinter from the $\mathrm{Hg}$ prospect in the sinter terrace, Spring Peak alteration zone (fig. 48). $B$, Graphs showing relative element concentrations in sinter measured in counts per second (counts/second) by laser ablation inductively coupled plasma-mass spectrometry (LA ICP-MS). C, Bulk sample element concentrations determined by inductively coupled plasma-atomic emission spectrometry-mass spectrometry (ICP-AES-MS). Same section as in figure 49 showing additional elements. Locally elevated (millimeter-scale) element concentrations include $\mathrm{Sn}, \mathrm{Mo}, \mathrm{Cu}, \mathrm{Zn}, \mathrm{Pb}, \mathrm{K}, \mathrm{Al}, \mathrm{Ca}$, and $\mathrm{P}$. 
$\boldsymbol{A}$
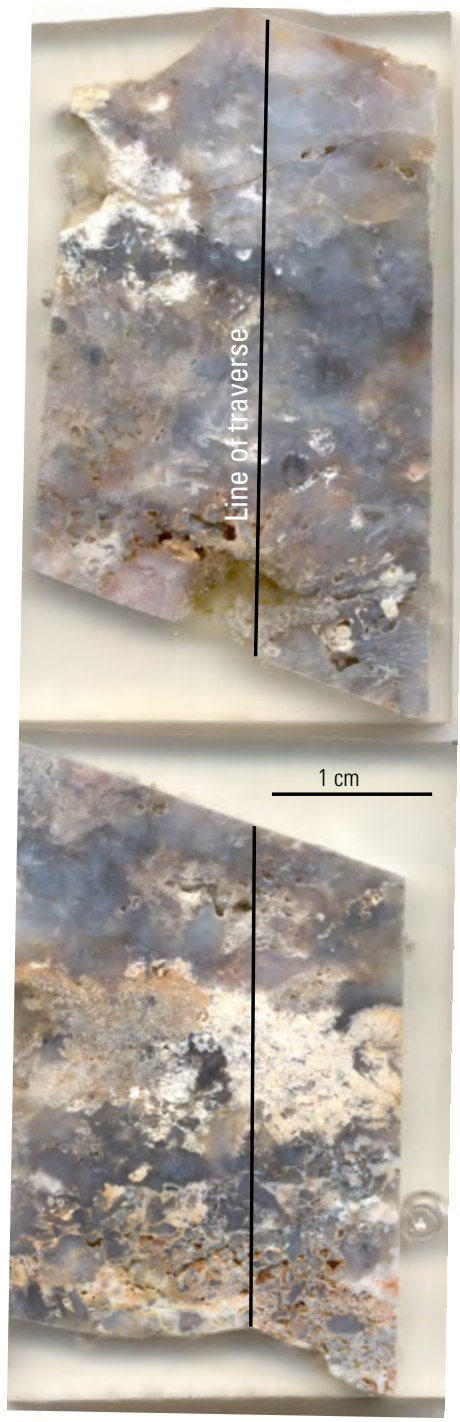

B Spring Peak sinter III. (SPK06-3)
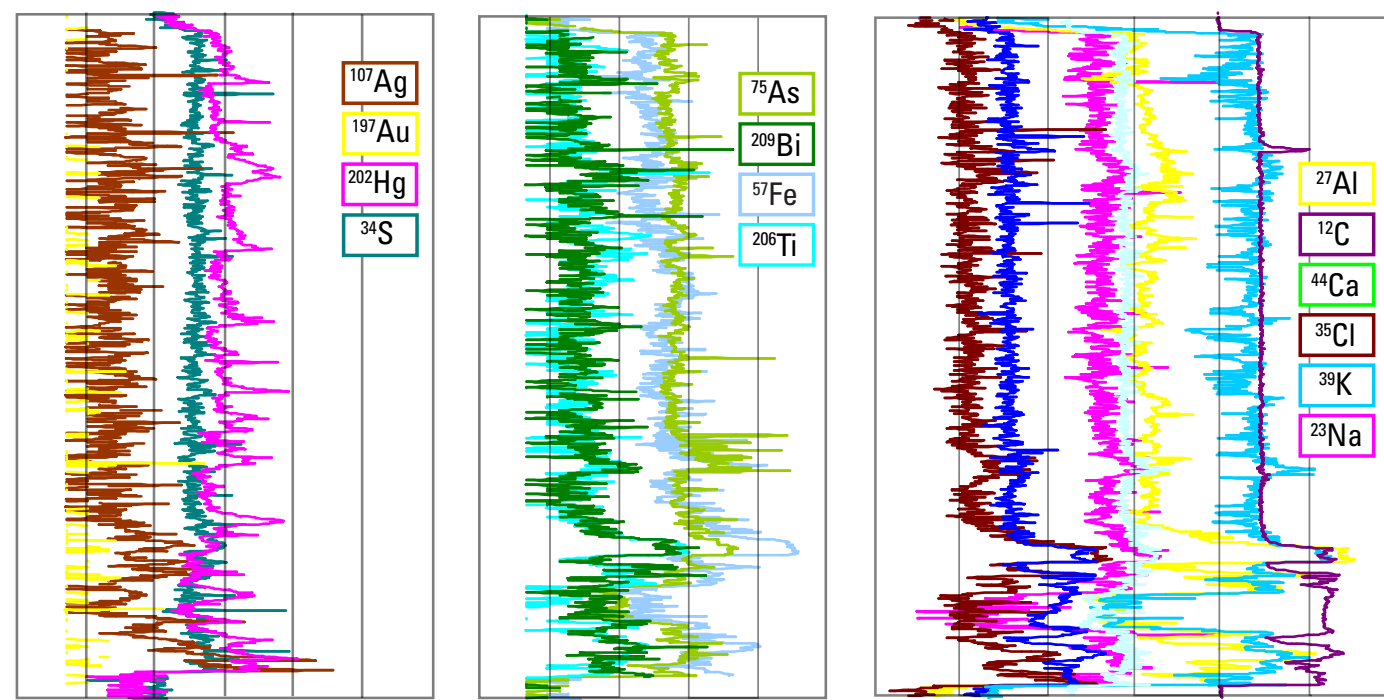

C

Bulk concentration (ppm; LA ICP-MS)

$\mathrm{Au} \quad 53 \mathrm{ppb}$ $\mathrm{Ag}<1$ $\mathrm{Hg} \quad 1.02$ S $\quad<0.05 \%$
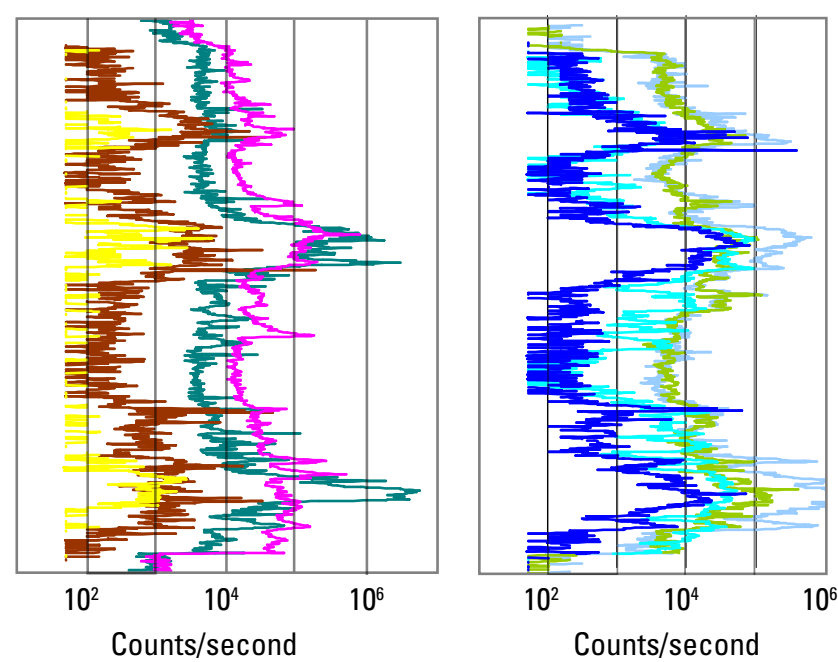

Figure 51. $A$, Image of oriented consecutive sections of sinter from the northern edge of the Spring Peak sinter terrace (fig. 48). $B$, Graphs showing relative element concentrations in sinter measured in counts per second (counts/second) by laser ablation inductively coupled plasma-mass spectrometry (LA ICP-MS). C, Bulk sample element concentrations determined by inductively coupled plasma-atomic emission spectrometry-mass spectrometry (ICP-AES-MS). Locally elevated (millimeter-scale) element concentrations include $\mathrm{Au}, \mathrm{Ag}, \mathrm{Hg}, \mathrm{S}, \mathrm{As}, \mathrm{Bi}, \mathrm{Tl}, \mathrm{Fe}, \mathrm{K}, \mathrm{Al}, \mathrm{Na}$, and Ca. 

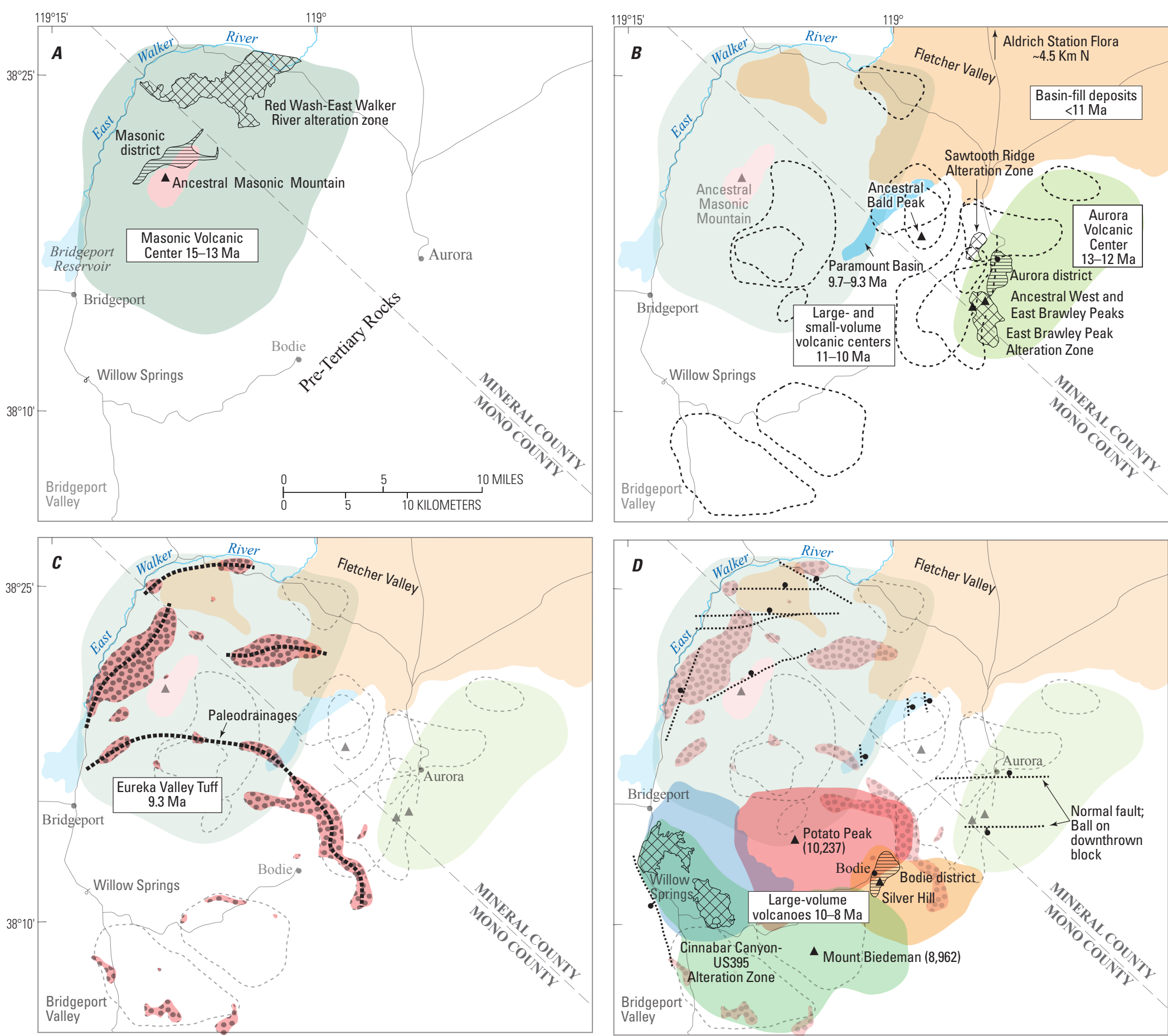
Figure 52. (Facing page) Maps showing assembly of the Miocene Bodie Hills volcanic field, California and Nevada, from 15 to $8 \mathrm{Ma}$ based on volcanic stratigraphy (John and others, 2012), mineral deposits, alteration zones, and geochronology. $A$, Northwestern part of the field, 15-13 Ma, consisting of the Masonic volcanic center (green-gray), which includes 15-14 Ma trachyandesite of Masonic and associated volcaniclastic strata, 13.5-12.9 Ma trachyandesite domes, 13.4-13.3 and 13 Ma Au-Ag-Cu deposits of the Masonic Mining District (horizontal line pattern), and the 13.3 Ma Red Wash-East Walker River alteration zone (cross-hatch pattern). Pre-Tertiary rocks are uncolored. $B$, Eastern, central, southwestern, and northeastern parts of the field, 13-9.3 Ma, and the Masonic volcanic center (from $A$; subdued green-gray). The Aurora volcanic center (yellow-green) includes 13-12 Ma trachyandesite of Aurora, 12 Ma East Brawley Peak alteration zone (cross-hatch pattern), and $10.5 \mathrm{Ma}$ Au-Ag vein deposits of the Aurora Mining District (horizontal line pattern). The 11.1 Ma Sawtooth Ridge alteration zone (cross-hatch pattern) is adjacent to the Aurora volcanic center to the northwest. Central and southwestern parts of the field (uncolored) include 11-10 Ma large- to small-volume flows and domes of trachyandesite, rhyolite, and trachydacite (dashed-line enclosures), some of which cover rocks of the Masonic and Aurora volcanic centers, and 9.7-9.3 Ma Paramount basin (Paramount-Bald Peak alteration zone; blue). Basin-fill deposits of ancestral Fletcher Valley (brown) north of the Aurora volcanic center, and covering parts of the Masonic volcanic center are $\sim 11 \mathrm{Ma}$. $C$, Northwestern, central, and southwestern parts of the field at $9.3 \mathrm{Ma}$, and the Masonic volcanic center (subdued green-gray), Aurora volcanic center (subdued yellow-green), large- to small-volume flows and domes (subdued dashed line enclosures), the Paramount basin (subdued blue,) and ancestral Fletcher Valley (brown; from $A$ and $B$ ). Eureka Valley Tuff (Eureka Valley Tuff; 9.5-9.3 Ma; red with dot pattern), derived from the Little Walker caldera $20 \mathrm{~km}$ to the west of Bridgeport, filled depressions and paleochannels (dark, short dashed lines), defined by semialigned Eureka Valley Tuff remnants, in the Masonic volcanic center, and among large- and small-volume flows and domes. $D$, Southeastern part of the field, $10-8 \mathrm{Ma}$, older volcanic and sedimentary strata (from $A, B$, and $C$, subdued), and $<9.3 \mathrm{Ma}$ normal faults. Large-volume stratovolcano and flow-dome complexes include 10-9 Ma trachyandesite of Mount Biedeman (green), $\sim 9 \mathrm{Ma}$ trachydacite of Potato Peak (red), 9 Ma dacite of Silver Hill (orange), and 8.6-8 Ma trachyandesite of Willow Springs (blue), and contain the 8.8-8.2 Ma Cinnabar Canyon alteration zone (and $\mathrm{S}^{\circ}$ resource; cross-hatch pattern), and the 8.5-8.1 Ma Au-Ag vein deposits of the Bodie Mining District (horizontal line pattern). 
Although Aldrich Station sediments and flora may not have been derived directly from Bodie Hills volcanism and vegetation, they broadly reflect climate and geography of the region as evidenced by stratigraphic relationships and by three occurrences of plant litter in the northern part of the Bodie Hills. (1) North and northwest of the Aurora Mining District, at elevations of $\sim 7,900 \mathrm{ft}(\sim 2.39 \mathrm{~km})$, petrified wood fragments in sedimentary rocks of Fletcher Valley (Tfv of John and others, 2015), deposited on $\sim 11$ Ma trachyandesite of Del Monte and beneath 9.3 Ma Eureka Valley Tuff, are contemporaneous with Aldrich Station flora. (2) A cored drill hole $\sim 6.4 \mathrm{~km}$ north of the Aurora townsite (fig. 20) encountered gold-bearing sand and gravel beneath $\sim 0.5-0.1$ Ma trachyandesite of Aurora Crater (Lange and others, 1993; Lange and Carmichael, 1996), and overlying altered lacustrine sediments that contain carbonized plant fragments (Nevada Exploration Inc., 2013). The cored stratigraphy, which ranges in elevation from 5,470 to $\sim 6,100 \mathrm{ft}$ ( $<1.66$ to $\sim 1.85 \mathrm{~km}$ ), corresponds to sedimentary rocks of Fletcher Valley; the goldbearing sand and gravel apparently record erosion of Aurora Mining District Au-Ag veins, and the altered sediments may be similar in age to those veins $(\sim 10.5 \mathrm{Ma})$. (3) In the Bodie Mining District, a 14-in.-diameter silicified tree trunk was found in the drainage west of the Bulwer shaft at $\sim 8,400 \mathrm{ft}$ ( 2.45 km; Brown, 1908; fig. 37).

Bodie Hills fossils attest to the presence of woody plants and near-surface groundwater saturation from $\sim 11 \mathrm{Ma}$, the initial sedimentation of Fletcher Valley, to $\sim 8.5 \mathrm{Ma}$, the formation of the youngest veins in the Bodie Mining District. Fossil elevations indicate either (1) hundreds to more than $2,000 \mathrm{ft}$ of relief in the Bodie Hills during this period, or (2) differential displacement of fossil-bearing strata since $\sim 11 \mathrm{Ma}$ by magmatic inflation and (or) faults. Paleoelevation estimates of the Aldrich Station flora, which vary by method, are 2,000 to 2,500 ft ( $\sim 0.6$ to $0.8 \mathrm{~km}$; Axelrod, 1956) and $\sim 4,300$ to $6,900 \mathrm{ft}$ ( $\sim 1.3$ to $2.1 \mathrm{~km}$; Wolfe, 1995; Wolfe and others, 1997), implying that paleoelevations in the Bodie Hills during flora accumulation, and initial Fletcher Valley sedimentation, were either entirely lower than present elevations, or near present elevations.

\section{Eureka Valley Tuff in the Bodie Hills}

There are few stratigraphic markers among the domes, lavas, debris flows, and sedimentary strata that make up the Bodie Hills volcanic field, and none is regionally distributed. Remnants of externally sourced, 9.5-9.3 Ma Eureka Valley Tuff in the western and central parts of the field (fig. 52) provide critical stratigraphic, structural, and age datums. Dense to moderate welding, high glass content, confinement of thickest exposures (tens of meters) to the deeply incised East Walker River drainage, and distance from source vents (20-40 km) east of the Little Walker caldera; Pluhar and others, 2009), attest to the low viscosity (high fluidity) of the ash flows. Although fluidal ash flows can be deposited on slopes
(Fisher and Schmincke, 1984), Eureka Valley Tuff exposures in the Bodie Hills are the farthest east from their source, and waning momentum mostly confined deposition to drainages and depressions. Meandering alignments of thinner remnants at higher elevations likely reflect paleotributaries, and isolated remnants mark depressions or eroded channels. Coarse gravel deposits beneath some Eureka Valley Tuff remnants suggest locally steep pre-Eureka Valley Tuff drainage gradients. Therefore, it is assumed that Eureka Valley Tuff filled drainages and depressions to an approximately common elevation, and that basal contacts of Eureka Valley Tuff provide a broad, 9.3 Ma elevation datum. Present elevations of remnants span $\sim 3,550 \mathrm{ft}$ from the East Walker River west of the Elbow $(\sim 5,600 \mathrm{ft}$; fig. 1) to the north slope of Potato Peak $(\sim 9,150 \mathrm{ft})$. This relief was imposed since 9.3 Ma, and indicates that most present relief in the Bodie Hills was caused by magmatic inflation and (or) fault displacement since 9.3 Ma.

\section{Landforms in Mining Districts and Alteration Zones}

\section{Masonic Mining District}

The Au-Ag-Cu deposits at Masonic occur in a sequence of Miocene volcaniclastic deposits and trachyandesite lavas (trachyandesite of Masonic), and in Mesozoic rocks. Deposit ages comprise two groups, one $\sim 13.4-13.3 \mathrm{Ma}$, and the other $\sim 13 \mathrm{Ma}$. Both groups of deposits are younger than trachyandesite lavas ( 15-14 Ma, fig. 2; table 1) but are similar to the ages of nearby trachyandesite intrusions $(\sim 13.5-13.4$ and 12.9 Ma, table 1), demonstrating that the deposits formed nearly simultaneously with emplacement of intrusions.

Eureka Valley Tuff (9.5-9.3 Ma) overlies Mesozoic rocks and trachyandesite of Masonic in the southwestern and northwestern parts of the district, and constrains relative elevations of erosional paleosurfaces and fault displacements in the northwestern part of the Bodie Hills. Eureka Valley Tuff lies on granodiorite and metavolcanic rocks on the northwest and south slopes of Masonic Mountain at 8,600 and 8,775 ft, respectively (fig. 2). It lies on trachyandesite of Masonic at 7,000 to $7,100 \mathrm{ft}$ near the $13.5-13.4 \mathrm{Ma}$ trachyandesite domes (fig. 14). These contacts, which represent a common $9.3 \mathrm{Ma}$ erosional paleosurface, imply $\sim 1,800 \mathrm{ft}$ of down-to-the north displacement of the domes since $\sim 9.3 \mathrm{Ma}$, relative to Eureka Valley Tuff on Masonic Mountain. This displacement can be attributed to mapped (figs. 2, 14) and unrecognized, downto-the-north faults, and (or) to domical uplift of the southern part of the district. About 600-800 ft of normal displacement occurred along a northeast-striking fault that extends through the Chemung Mine and across Masonic Gulch at the site of Masonic middle town (fig. 2). This fault separates Eureka Valley Tuff at 8,600 and 8,775 ft on Masonic Mountain east and southeast of the Chemung Mine from Eureka Valley Tuff at $8,000 \mathrm{ft}, 0.8 \mathrm{~km}(0.5 \mathrm{mi})$ north-northwest of the Chemung Mine. 
Movement on west-east-striking faults on the north side of the 13.5-13.4 Ma trachyandesite domes has displaced trachyandesite of Masonic several hundreds of feet down-tothe-north (fig. 14). This estimate is based on the difference in elevation of moderately extensive exposures of Eureka Valley Tuff near the domes (7,000 to 7,100 ft) and a small exposure of Eureka Valley Tuff in the Red Wash-East Walker River alteration zone $(6,695 \mathrm{ft})$. Therefore, post-9.3 Ma displacement of the Red Wash-East Walker Rive alteration zone relative to Masonic Mountain could exceed 2,100 ft (fig. 14). This cumulative estimate of post-Eureka Valley Tuff displacement is comparable to the elevation differences between Eureka Valley Tuff on Masonic Mountain and Eureka Valley Tuff at 6,400 to 6,600 ft along the East Walker River west of Masonic Mountain. The deposition of Eureka Valley Tuff on Mesozoic granodiorite indicates that pre-Tertiary rocks of Masonic Mountain were exposed at 9.3 Ma and possibly earlier. However, granitic and metamorphic clasts have not been recognized in 15-14 Ma altered volcaniclastic-flow sequences in the Masonic Mining District.

In the southwestern part of the district, a hydrologic paleosurface is represented by 13.4-13.3 Ma volcaniclasticpool sinter deposits at the Sarita Mine (fig. 5). The present elevation of these sinters, $\sim 8,400 \mathrm{ft}$, is as much as $200 \mathrm{ft}$ higher than altered volcaniclastic strata at the Red Rock, Lakeview, and Chemung Mines, 400 ft higher than the intrusive contact of 12.9 Ma Lakeview Spring domes and trachyandesite of Masonic, and $400 \mathrm{ft}$ higher than the $9.3 \mathrm{Ma}$ erosional paleosurface at 8,000 ft represented by Eureka Valley Tuff on trachyandesite of Masonic, $0.5 \mathrm{~km}$ west of the domes (fig. 2). Although the dome-trachyandesite contact is intrusive, the nearby $9.3 \mathrm{Ma}$ erosional paleosurface implies little erosion of domes and adjacent trachyandesite of Masonic between 12.9 and 9.3 Ma. The elevation differences among the volcaniclastic-pool sinter deposits, volcaniclastic strata, and slightly younger domes have several possible explanations (1) displacement of the Lakeview Spring domes and volcaniclastic strata at the Red Rock, Lakeview, and Chemung Mines relative to the volcaniclastic-pool sinter deposits at the Sarita Mine by faulting; (2) emplacement of Lakeview Spring domes after displacement of the volcaniclastic-pool sinter deposits by faulting; and (3) volcaniclastic-pool sinter landforms with hundreds of feet of relief. Several lines of evidence, including temporal and elevational relationships among Lakeview Spring domes and Eureka Valley Tuff, and sulfur isotope equilibrium temperatures of hydrothermal mineral assemblages, suggest that fault displacement, explanation (1), accounts best for the elevation differences.

Sulfur isotope equilibrium temperatures of coexisting pyrite and alunite at four mines range from 188 to $231^{\circ} \mathrm{C}$ (table 2). These temperatures equate to minimum hydrologic paleodepths of $\sim 430-1,000 \mathrm{ft}$, respectively (estimated graphically from figure 2 in Haas, 1971), assuming that pyrite and alunite precipitated simultaneously in low-salinity water. Relative to the Sarita Mine hydrologic paleosurface, present elevations of mineral pairs at the Pittsburgh-Liberty Mine
$(-720 \mathrm{ft})$, aspen grove prospect $(-840 \mathrm{ft})$, and Perini Mine $(-1,040 \mathrm{ft})$, are broadly similar to estimated paleodepths regardless of alunite age, implying that deposits north and east of the Sarita Mine have not been greatly displaced relative to the Sarita Mine since $\sim 13 \mathrm{Ma}$, the age of the youngest alunite. However, if the relative hydrologic paleodepth $(\sim 1,000 \mathrm{ft})$ based on the Red Rock Mine isotope equilibrium temperature $\left(231^{\circ} \mathrm{C}\right)$ is accurate, then the Sarita Mine sinters (elev $\sim 8,400 \mathrm{ft}$ ) have been displaced down-to-the-northeast as much as $250 \mathrm{~m}(\sim 800 \mathrm{ft})$, relative to volcaniclastic strata at the Red Rock Mine (elev 8,200 ft), since $\sim 13.3 \mathrm{Ma}$.

The terraces of landslide debris and fanglomerate $\sim 0.5 \mathrm{~km}$ northwest of the Lakeview Mine (Tls, fig. 2) include weathered clasts of Eureka Valley Tuff (at least on present surfaces), indicating that some, if not all, mass wasting represented by landslide debris has taken place since $9.3 \mathrm{Ma}$. Deformation and mass wasting are also recorded by relatively steep and variable west-southwest dips $\left(>40^{\circ}\right)$ of originally near-horizontal, 13.4-13.3 Ma volcaniclastic-pool sinter deposits at the Sarita Mine, and by large slide blocks and slope wash of altered volcaniclastic strata immediately north of the Sarita Mine (fig. 2). Although the timing of mass wasting at Sarita relative to the displacement and erosion of Eureka Valley Tuff is unconstrained, these catastrophic erosion features reflect unstable edifices of altered, volcaniclastic, pool sinter deposits that were episodically(?) created by uplift. Based on displacement of Eureka Valley Tuff, uplift of Masonic Mountain relative to volcaniclastic strata at the Red Rock, Lakeview, Chemung, and Sarita Mines primarily occurred since 9.3 Ma along the normal, northeast-striking fault on the northwest side of Masonic Mountain. However, between 12.9 and 9.3 Ma, Sarita Mine sinters may have been displaced downward relative to Lakeview Spring domes and volcaniclastic strata at the Red Rock, Lakeview, and Chemung Mines along a north-trending fault provisionally located between the domes and the Sarita Mine (fig. 2). This fault could account for the disparity among hydrologic paleodepths derived from sulfur isotope equilibrium temperatures.

\section{Synthesis}

Paleosurfaces, stratigraphy, structure, and ages of hydrothermal and igneous minerals enable conditional reconstruction of the geologic and geomorphic evolution of the Masonic Mining District. The volcaniclastic rocks and lavas (trachyandesite of Masonic) that accumulated in depressions or on slopes northwest of Masonic Mountain from $\sim 15$ to $14 \mathrm{Ma}$ were altered and $\mathrm{Au}-\mathrm{Ag}-\mathrm{Cu}$-mineralized at 13.4-13.3 Ma. These strata were bordered to the southeast by an upland of Mesozoic granodiorite and metamorphic rocks, and to the west, northwest, and south by trachyandesite lavas and domes, the sources of volcaniclastic detritus that filled depressions. At $13 \mathrm{Ma}$, similar $\mathrm{Au}-\mathrm{Ag}-\mathrm{Cu}$ mineralization formed in high-angle fault zones north of Masonic Mountain. The vertical extent of mineable deposits range from the 
paleosurface (marked by the volcaniclastic-pool sinter deposits at the Sarita Mine) to $\sim 300 \mathrm{~m}(\sim 1,000 \mathrm{ft})$ below the surface in the Pittsburg-Liberty Mine. Uplift of the Masonic Mountain landform by fault displacement may have begun at $\sim 13 \mathrm{Ma}$, but present relief largely reflects uplift since 9.3 Ma. Post-9.3 Ma differential displacement of volcaniclastic rocks and lavas (trachyandesite of Masonic), volcaniclastic-pool sinter deposits, trachyandesite intrusions, and Eureka Valley Tuff in the district relative to Eureka Valley Tuff along the East Walker River north and west of Masonic Mountain, cumulatively totals at least $640 \mathrm{~m}(\sim 2,100 \mathrm{ft})$.

\section{Aurora Mining District}

The $\sim 10.5 \mathrm{Ma} \mathrm{Au}-\mathrm{Ag}$ veins at Aurora are nearly entirely in $\sim 13.1-12.6$ Ma trachyandesite of Aurora; a few veins are in 11.2 Ma rhyolite of Aurora Creek (table 1). Other premineralization eruptive rocks that overlie trachyandesite of Aurora on the north and west sides of the district are 11.5-11.0 Ma trachyandesite of West Brawley Peak and 11 Ma trachyandesite of Del Monte. Rhyolite of Bodie Creek (10.2-9.7 Ma), which partly coincides in age with veins, unconformably overlies trachyandesite of Del Monte $\sim 5 \mathrm{~km}$ west of the district. Pliocene and Pleistocene eruptive rocks (3.4-0.1 Ma) unconformably overlie trachyandesite of Aurora and Mesozoic rocks on the northeast, east, and south sides of the district.

Pre and postmineralization landform aspect and relief can be broadly estimated from (1) paleohydrology implied by vein textures, dimensions, and abundance, and by wall-rock alteration; (2) fluid inclusion microthermometry of vein quartz; (3) comparison among several erosional paleosurface elevations (contacts) during vein mineralization and present elevations of premineralization rocks; and (4) postmineralization fault displacement. Vein textures represent open-space filling of tabular conduits that, based on present vein elevations of $\sim 7,200$ to $8,400 \mathrm{ft}$, may have had vertical dimensions of $>360 \mathrm{~m}(>1,200 \mathrm{ft})$. Vertical dimensions of veins, high vein density, pervasive alteration between veins, and large water/ rock volumes implied by quartz $\delta^{18} \mathrm{O}$ and fluid inclusion $\delta \mathrm{D}$ values (O’Neil and Silberman, 1974), collectively imply water saturation of trachyandesite of Aurora hundreds of meters below the paleosurface during mineralization.

Low-salinity fluid inclusion populations in veins are interpreted to represent boiling at $\sim 230{ }^{\circ} \mathrm{C}$ (and lower temperatures; Osborne, 1985; Knudsen and Prenn, 2002), which requires a potentiometric surface $\sim 300 \mathrm{~m}(\sim 1,000 \mathrm{ft})$ above fluid inclusion sample elevations (Haas, 1971). Although elevations of some fluid inclusion samples are not well documented, the paleopotentiometric surface elevation above located Juniata vein samples in the northeastern part of the district (present elevation $\sim 7,400 \mathrm{ft}$; fig. 20), relative to present vein elevations, was $\sim 8,400 \mathrm{ft}$. If the trachyandesite of Aurora was water-saturated at the surface, as implied by paleohydrologic evidence and Miocene climate, then potentiometric surfaces and erosional paleosurfaces were at the same elevation during mineralization. If similar fluids formed the Esmeralda-Radical vein, with a present upper elevation of $\sim 8,400 \mathrm{ft}$, then paleosurface elevations in the southwestern part of the district would have exceeded 9,000 ft. Present maximum elevations of $\sim 11 \mathrm{Ma}$ premineralization volcanic rocks (rhyolite of Aurora Creek; trachyandesite of Del Monte; trachyandesite of West Brawley Peak), those rocks closest in age to vein age (John and others, 2012), vary from $\sim 7,800$ to $9,400 \mathrm{ft}$. The premineralization trachyandesite of Aurora that underlies East Brawley Peak $(9,400 \mathrm{ft})$ was altered to resistant quartz \pm alunite assemblages at $\sim 12 \mathrm{Ma}$. If premineralization volcanic rocks were not displaced by postmineralization faults, and if resistant rocks atop East Brawley Peak were not eroded significantly, then paleosurface elevations above veins ranged from $\sim 180 \mathrm{~m}(\sim 600 \mathrm{ft})$ higher than volcanic landforms north and west of the district to the approximate elevation of East Brawley Peak in the southwest part of the district.

These lines of evidence and assumptions imply that Aurora district veins formed in a prominent northeast-trending ridge of trachyandesite of Aurora. The ridge extended northeast from East Brawley Peak at least $14 \mathrm{~km}$ to the New Esmeralda veins. Adjacent volcanic landforms to the west and northwest were as much as $180 \mathrm{~m}(\sim 600 \mathrm{ft})$ lower than ridge elevations. To the north, northeast, and east of the ridge, terrain sloped downward to the lower elevations in Fletcher Valley, which began filling with detritus at $11 \mathrm{Ma}$ (table 1). The upper elevation of gold-bearing sand and gravel beneath 0.5-0.1 Ma trachyandesite of Aurora Crater $(\sim 6,100 \mathrm{ft}$; Nevada Exploration, Inc. 2013) is similar to elevations in Fletcher Valley $2 \mathrm{~km}$ north of Aurora Crater. These colluvial deposits are interpreted to postdate $\sim 10.5 \mathrm{Ma}$ Aurora veins, and support relatively low elevation surfaces north of Aurora during vein erosion.

Oncoidal thermal vents in altered rhyolite of Aurora Creek (fig. 17) $\sim 0.5 \mathrm{~km}$ northwest of the Aurora town site (fig. 20), also support the existence of a ridgelike landform during vein formation. These vents, at $\sim 7,600 \mathrm{ft}$ elevation, are $\sim 120 \mathrm{~m}$ ( $\sim 400 \mathrm{ft})$ above, and presumably coeval with, steamheated 11.1 Ma alunite (SAW11-9; table 1). They are $\sim 60 \mathrm{~m}$ $(\sim 200 \mathrm{ft})$ below the highest present elevation of rhyolite of Aurora Creek. The vents mark a hydrologic paleosurface along the northwest margin of the district that existed $\sim 0.6$ m.y. before vein formation. The Juniata vein system potentiometric surface (interpreted as equivalent to the paleosurface; present elevation $\sim 8,400 \mathrm{ft}$ ) on the northeast-trending Aurora paleoridge was $\sim 240 \mathrm{~m}(\sim 800 \mathrm{ft})$ higher than the oncoidal

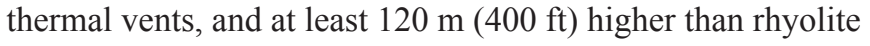
of Aurora Creek.

Although the extent and orientation of an Aurora paleoridge are constrained by vein distribution and paleohydrology, the proposed relief among 11-10 Ma volcanic landforms is less well constrained because of possible postmineralization fault displacement and erosion. No fluid inclusion microthermometry is available for the EsmeraldaRadical and other Silver Hill veins; these veins may have been displaced upward relative to veins to the northeast by one or more faults. A west-east lineament, prominent on color 
air photography and marked by topographic gradients and stream course deflections on Silver, Middle, and Last Chance Hills (CAP lineament, fig. 20), may correspond to a fault that extends west from the district to Beauty Peak. The lineament apparently offsets $\sim 2.5 \mathrm{Ma}($ ?) sedimentary rocks of Martinez Hill that are exposed north of Martinez Hill and in mine open pits from rhyolite of Martinez Hill (Osborne, 1991; Knudsen and Prenn, 2002; fig. 20). Down-to-the-north displacement along this inferred fault may have offset vein systems on Humboldt Hill and Last Chance Hill to elevations lower than those of veins on Silver Hill and Middle Hill. Therefore, the original vertical extent of veins may have been $<360 \mathrm{~m}$ $(<1,200 \mathrm{ft}$ ). Right-lateral displacement along this prospective fault also may have displaced veins to the northeast, increasing areal vein distribution, although other west-east faults in the Bodie Hills have left-lateral displacement. A second, prominent west-east air-photo lineament south of Brawley Peaks coincides with the stream course south of Spring Peak sinter (fig. 48). This inferred fault may mark the southern margin of a postmineralization, fault-elevated structural block that contains East Brawley Peak and Silver and Middle Hill veins. Restoration of displacement on the west-east faults would decrease elevation differences between the Aurora paleoridge and adjacent premineralization volcanic rocks as well as among veins. Accounting for postmineralization erosion could further reduce the estimated 11-10 Ma relief at Aurora by tens to more than one hundred meters.

The absence of significant placer gold in the district suggests that the present level of erosion, or as much as $300 \mathrm{~m}$ $(\sim 1,000 \mathrm{ft})$ below the paleosurface, approximately coincides with the top of high-grade ( $\mathrm{Au}-\mathrm{Ag}$ ) vein mineral assemblages. Most ore was mined from within $\sim 150 \mathrm{~m}(\sim 500 \mathrm{ft})$ below the present surface, indicating that the vertical interval of elevated Au-Ag grades was $~ 300-450 \mathrm{~m}(\sim 1,000-1,500 \mathrm{ft})$ below the paleosurface. Alternatively, gold in veins was too fine-grained to form mineable placer deposits, and the absence of placer has little relationship to depths of ore formation.

\section{Synthesis}

Landforms in the Aurora Mining District at 10.5 Ma during $\mathrm{Au}-\mathrm{Ag}$ vein formation consisted of a northeast-elongate, $\sim 14 \mathrm{~km}$ ridge of 13.1-12.6 Ma trachyandesite of Aurora. Based on characteristics of veins and altered wall rocks, and relative elevations of contacts, hydrologic paleosurfaces, and paleopotentiometric surfaces among trachyandesite of Aurora and adjacent volcanic rocks, the ridge stood as much as several hundreds of meters above flow-domes of 11.5-11.0 Ma rhyolite and trachyandesite to the west, north, and east. Present relief, the distribution and elevation of veins, and the absence of Au placer deposits, may be partly attributed to antithetical displacement along two west-east faults that elevated ancestral West and East Brawley Peaks, and caused $\sim 300 \mathrm{~m}(\sim 1,000 \mathrm{ft})$ of erosion of the trachyandesite paleoridge and veins to the tops of high-grade $\mathrm{Au}-\mathrm{Ag}$ mineral assemblages.

\section{Bodie Mining District}

The 8.9-8.1 Ma Au-Ag veins at Bodie are $\sim 1.0-0.4 \mathrm{Ma}$ younger than dacite of Silver Hill (9.1-8.9 Ma; table 1), the host rock of all Bodie veins. Dacite of Silver Hill is overlain by slightly younger trachydacite of Potato Peak (9.1-8.7 Ma) within $1 \mathrm{~km}$ west, north, and northeast of the district (fig. 37). Trachydacite of Potato Peak is unaltered, lacks veins, and is not known to cover veins. Veins and remnant sinter are exposed at the top of Bodie Bluff at $\sim 9,000 \mathrm{ft}$. Trachydacite of Potato Peak exposures near Bodie vary in elevation from $\sim 8,200$ to $10,168 \mathrm{ft}$, on the summit of Bodie Mountain. These elevations are $\sim 800 \mathrm{ft}$ lower and nearly $1,200 \mathrm{ft}$ higher than the highest veins on Bodie Bluff. Eureka Valley Tuff (9.5-9.3 Ma) in Milk Ranch Canyon, $\sim 1 \mathrm{~km}$ north of the town of Bodie, underlies dacite of Silver Hill, although the substrate is not exposed. Approximately $1 \mathrm{~km}$ northeast of Bodie Bluff, it overlies $11 \mathrm{Ma}$ trachyandesite of Del Monte, indicating that dacite of Silver Hill does not extend very far north of Bodie Bluff. At both locations, Eureka Valley Tuff is overlain by trachydacite of Potato Peak.

Sinter atop Bodie Bluff formed on, and possibly within, a 60 m-thick sequence of volcaniclastic deposits that accumulated in a graben between north-northeast-striking, antithetically dipping faults (figs. 37, 38). Open tensional fractures with opposing dips, flanking and beneath the graben, were filled by Incline series and Burgess series veins. Incline series veins occur in dacite of Silver Hill on both sides of the graben at the same elevation as sinter. If sinter is coeval with adjacent veins, then it has been displaced downward relative to veins along the graben faults, and Incline series veins formed within $\sim 60 \mathrm{~m}$ (the thickness of volcaniclastic deposits) of the paleosurface marked by the sinter. Alternatively, if sinter is younger than Incline series veins, then sinter and grabenfilling volcaniclastic rocks are $\sim<8.2 \mathrm{Ma}$, the youngest age of adularia in Incline series veins on Bodie Bluff (table 1). This latter interpretation requires that Incline series veins on Bodie Bluff have been significantly eroded, sinter is temporally associated with Silver Hill series veins $(\sim 8.2 \mathrm{Ma})$ or a younger hydrothermal event, and the graben formed between 8.2 and $<8.1 \mathrm{Ma}$.

Regardless of relative and absolute ages of veins and sinter atop Bodie Bluff, the association of sinter and veins, and nearly identical ages of dacite of Silver Hill and trachydacite of Potato Peak, require that Potato Peak rocks either (1) thinly covered dacite of Silver Hill on Bodie Bluff and were eroded prior to sinter deposition, or (2) never covered Bodie Bluff. These possible stratigraphic relationships, and the absence of dacite of Silver Hill north of the district, imply that present relief of the Bodie Bluff landform, considered an intrusion by Chesterman and others (1986), ostensibly reflects eruptive topology. On a regional scale, the Bodie Mining District formed near the northwestern edge of the dacite of Silver Hill dome field where the field is partly onlapped by the eastern extent of Potato Peak flows. Faulting may have elevated Bodie Bluff somewhat along hypothesized bounding faults 
(for example, Bodie Creek and Mono faults; fig. 37) but fault displacement, other than graben-forming faults, has not been quantified. Incline series veins occur on both side of the Tioga Fault, and Silver Hill series veins occur on both sides of the Mono Fault, suggesting that displacement along these faults was small.

Domal uplift has been proposed to explain Bodie Bluff relief (Wisser, 1960); episodic doming could account for both tensional fractures filled by Incline series veins, and the apical graben. However, the attitudes of the Fortuna vein and Silver Hill series veins, which consist mostly of replaced fault breccia and gouge and lesser open-space filling, are not plausibly explained by tensional strain. The Fortuna vein may be related to a transtensional structural regime that preceded doming, although a relatively abrupt stress field transition is required given the small differences in vein ages.

High-grade (Au-Ag) Incline series veins on Standard Hill (elev $\sim 8,840 \mathrm{ft}$ ) are $\sim 50 \mathrm{~m}(\sim 160 \mathrm{ft}$ ) lower than veins and sinter atop Bodie Bluff. Although temporal relationships between veins and sinter are imprecisely known, the vertical distance between sinter and ore-grade veins in other Tertiary vein districts varies considerably (compare Sherlock, 2005; Vikre, 2007). If sinter atop Bodie Bluff postdates Incline series veins and older Burgess series veins, then vein ore on Standard Hill formed $>50 \mathrm{~m}(>165 \mathrm{ft})$ below the paleosurface. Since little ore was mined deeper than $\sim 150 \mathrm{~m}(\sim 500 \mathrm{ft})$, the vertical range of ore in Incline series and Burgess series veins (fig. 38) was $>50-200 \mathrm{~m}(>165-660 \mathrm{ft}$ ) below the paleosurface. Silver Hill series veins, with the exception of veins mined in the Noonday Mine, contained small quantities of ore, and archival samples from the Noonday, Addenda, Oro, and Red Cloud Mines (fig. 40) were all obtained within $600 \mathrm{ft}$ of the surface. If vein samples on the Jupiter, Cupon, and other mine dumps on the south slope of Bodie Bluff (fig. 37) are the same age as Silver Hill series veins, then ore-grade mineralization in Silver Hill series veins formed at least $200-360 \mathrm{~m}$ ( $\sim 660-1,200 \mathrm{ft}$ ) below the paleosurface (fig. 38). Fluid inclusion microthermometry could provide paleoelevational control among vein types that would constrain (1) temporal and spatial relationships of sinter to veins, (2) paleodepths of ore deposition, and (3) quantification of postmineralization erosion and fault displacement.

\section{Synthesis}

Time-space relations among volcanic stratigraphy, vein types, and sinter support the following succession of magmatic and hydrothermal events in the Bodie Mining District (1) eruption of dacite flows that covered the southern part of the district; (2) intrusion of dacite into older dacite flows to form Bodie Bluff and other topographically high domes; (3) fracture-filling along the southern margin of the dacite intrusion at Bodie Bluff by Burgess series veins; (4) doming of the dacite intrusion by magmatic inflation, creating tensional fractures that were filled by Incline series veins; (5) transtensional faulting of dacite flows; some faults became Silver Hill series veins; and (6) further doming of Bodie Bluff, creating an extensional depression that filled with volcaniclastic deposits and sinter. Magmas younger than dacite of Silver Hill that could have domed Bodie Bluff prior to, and after deposition of Incline series veins are not represented in the Bodie Mining District. The nearest volcanic rocks coeval with veins are flows and domes of 8.6-8.0 Ma trachyandesite of Willow Springs, $\sim 10 \mathrm{~km}$ to the west. Igneous rocks that are somewhat older than veins include 9.9-8.9 Ma trachyandesite of Mount Biedeman, $\sim 10 \mathrm{~km}(\sim 6.3 \mathrm{mi})$ to the southwest, and 9.1-8.7 Ma trachydacite of Potato Peak that borders the western side of the district.

\section{Alteration Zones}

Variable evidence within alteration zones constrains paleosurfaces, paleolandforms, fault displacements, and erosion depths. The relationship of a paleosurface in the Sawtooth Ridge alteration zone to paleolandforms in the Aurora Mining District is described in previous sections of this report. Paleolandforms and postalteration evolution of the Red Wash-East Walker River, Four Corners, Paramount-Bald Peak, Aurora Canyon, Potato Peak, and Cinnabar CanyonUS 395 alteration zones can be reconstructed broadly from stratigraphy, geochronology, and characteristics of hydrothermal mineral assemblages.

The Red Wash-East Walker River alteration zone includes two temporal markers and hydrothermal mineral assemblages that somewhat constrain landforms. The zone formed at $\sim 13.3 \mathrm{Ma}$, based on alunite ages, mostly in a volcaniclasticflow sequence within $\sim 15-14$ Ma trachyandesite of Masonic (table 1). Altered volcaniclastic-flow rocks were partially covered at 9.5-9.3 Ma by Eureka Valley Tuff, a remnant of which is on the top east side of hill 6,696 (elevation 6,696 ft; fig. 14). Pervasive lateral silicification of permeable volcaniclastic strata presumably minimized erosion of these rocks during the $\sim 3.7$ m.y. of exposure prior to deposition of Eureka Valley Tuff. Landforms at 9.3 Ma are envisioned as a series of low hills and shallow depressions aligned in a $\sim 20 \mathrm{~km}$ westeast zone with north-south dimensions of 2-5 km (Rockwell, 2010). These low hills were underlain by debris and lavas flows that were variably leached and clay-altered by steam and other gases that condensed in matrices and discontinuous fissures. Depressions among hills consisted of bleached and unvegetated flows that were saturated with groundwater acidified by gas condensation. Fissures (fluid conduits) were most prevalent in the central part of the zone, where lateral permeability in volcaniclastic strata led to pervasive precipitation of silica minerals in leached rocks and fissures, and in subsurface water-saturated flows. Adjacent, less-fractured lavas were variably altered to clay-mica minerals and lesser pyrite.

Variable permeability in the Red Wash-East Walker River alteration zone is reflected by present inverse topography of the resistant, flat-topped hills of quartz-alunite-clay-altered debris flows that have deflected drainages. The resistant hills are flanked by recessively weathering, clay-altered lavas partially covered by gravel terraces (fig. 14). The erosional 
surface represented by the Eureka Valley Tuff contact ( 6,650 ft elevation) on hill 6,696 is several hundreds of feet (tens to $>100 \mathrm{~m}$ ) higher than elevations of Eureka Valley Tuff (5,600 to 6,200 feet; John and others, 2015) along the East Walker River north of the alteration zone. These elevation differences (at least $135 \mathrm{~m} ; \sim 450 \mathrm{ft}$ ) imply that the present elevation of the alteration zone, and incisement by the north-trending Masonic Gulch, Sonoma Canyon, and Red Wash drainages, occurred since $9.3 \mathrm{Ma}$. Dissection of fluviolacustrine sediments that overlie the northwestern part of the alteration zone, and gravel terraces south of the resistant central part of the zone (fig. 14), demonstrate that the Fletcher Valley basin was well established by $9.3 \mathrm{Ma}$.

Paleolandforms in the Paramount-Bald Peak alteration zone can be provisionally reconstructed from groups of subaerial terrace and pool sinters in the southwestern, central, and northeastern parts of the alteration zone. These sinter groups occur among upper strata of the $\sim 9.7-9.3$ Ma sedimentary rocks and tuff of Paramount (Tpst; fig. 27), which is constrained in age by overlying 9.3 Ma Eureka Valley Tuff and by blocks of 9.7 Ma rhyolite of Bald Peak (John and others, 2012) within the strata. In the southwestern part of the alteration zone, sinters on Paramount Mine hill and hills to the southwest and southeast (Paramount Mine area sinter group; fig. 28) have present elevations of 9,040-8,400 ft. The sinter terrace at Atastra Creek, $4.2 \mathrm{~km}$ southeast of Paramount Mine hill, is at $8,000 \mathrm{ft}$. Sinters near Hilton Springs in the central part of the alteration zone (Hilton Spring sinters; fig. 28) are at 7,800 $\mathrm{ft}$. The group of sinters $\sim 2.5 \mathrm{~km}$ north-northeast of Bald Peak have present elevations of $\sim 7,200-7,080 \mathrm{ft}$. Locally, as on Paramount Mine hill, sinter terraces protruded from slopes and do not necessarily represent maximum local paleoelevations. Furthermore, the elevationally tiered sinter groups may not be coeval or represent common paleoelevations. However, the groups formed within several hundreds of thousands of years, they occur at or near the top of sedimentary rocks and tuff of Paramount, and they likely represent a small range in paleoelevation.

Present elevation differences among sinter groups may partially reflect downward displacement to the northeast along faults. Several mapped faults offset sinter groups (fig. 27) but fault displacement may not entirely account for the nearly $2,000 \mathrm{ft}$ of elevation range among sinter groups. Alternatively, elevation differences may reflect magmatic inflation centered on Potato Peak, $\sim 5.5 \mathrm{~km}$ south-southwest of Paramount Mine hill, during voluminous Potato Peak trachydacite volcanism at $\sim 9 \mathrm{Ma}$. The $\sim 1,500 \mathrm{ft}$ elevation difference between the nearly simultaneously formed Potato Peak and Aurora Canyon alteration zones (10.8 and $10.7 \mathrm{Ma}$, respectively; table 1), 1.2 km and $\sim 4.2 \mathrm{~km}$ northwest, respectively, of Potato Peak, also is not clearly related to fault displacement. Therefore, elevation differences among sinter groups and coeval altered rocks on the north and northwest sides of Potato Peak are provisionally attributed both to fault displacement and landform inflation associated with Potato Peak magmatism. If this interpretation is correct, then much of the present relief of the southern part of the Bodie Hills volcanic field was attained by $\sim 9$ Ma.
The Four Corners alteration zone contains small pockets of chemical and clastic sediments that fill depressions in silicified breccia (fig. 20) and resemble similar deposits at the Sarita Mine. Although undated, this small alteration zone is on the range divide at an elevation of $8,600 \mathrm{ft}$ and its preservation supports a young age relative to the ages of larger alteration zones at lower elevations, which are $>8 \mathrm{Ma}$. Exposures in the Four Corners alteration zone apparently have not been modified significantly by erosion or fault displacement.

In the Cinnabar Canyon-US 395 alteration zone, a $>8 \mathrm{Ma}$ volcaniclastic-flow sequence was altered to quartz, alunite, kaolinite, and pyrite at 8.8-8.2 Ma (table 1). The altered sequence strata are $\sim 60 \mathrm{~m}$ thick where they overlie pre-Tertiary rocks along Clearwater Creek near the mouth of Cinnabar Canyon, but could be somewhat thicker to the north and northwest (possibly $400 \mathrm{ft}$ in the Cinnabar Canyon sulfur resource; fig. 36). Trachyandesite of Willow Springs ( 8.6-8.0 Ma;) overlies altered sequence strata in numerous places including Cinnabar Canyon (clay-cut hill) and Hot Springs Canyon (fig. 34). Although sequence strata are correlated with 9.9-8.9 Ma sedimentary rocks and debris flows of Mount Biedeman, the slightly younger and similar age ranges of alunite in altered sequence strata (8.8-8.2 Ma; table 1) and unaltered trachyandesite of Willow Springs indicate that exposed sequence surfaces represent a marginally eroded paleosurface. Landforms prevailing during this time resembled those of the Red Wash-East Walker River alteration zone, which consisted of lowlands and depressions of soggy, steaming ground, amidst low hills of variably leached and silicified sequence strata. Cyclic leaching and silicification in parts of the alteration zone reflect a hydrologic regime of fluctuating groundwater saturation levels into which gases derived from cooling magma(s) condensed and oxidized. The Cinnabar Canyon $\mathrm{S}^{\circ}$ resource formed in this dynamic environment subjacent to silicified volcaniclastic strata that underlie Cinnabar Hill (Vikre and Henry, 2011). Similar to the Red Wash-East Walker River alteration zone, significant erosion of the Cinnabar Canyon alteration zone was confined to larger drainages (Cinnabar Canyon; Hot Springs Canyon; fig. 34).

\section{Evolution of Landforms in the Bodie Hills Volcanic Field, 15-3.9 Ma}

Evolution of landforms can be broadly reconstructed from several lines of evidence variously described in previous sections of this report (1) paleotopography of the Aldrich Station flora north of the Bodie Hills and provisional correlation of the flora with older sedimentary deposits of Fletcher Valley; (2) paleolandforms and paleosurfaces in mining districts and alteration zones; (3) distribution and elevations of 9.5-9.3 Ma Eureka Valley Tuff; and (4) distribution, elevations, and ages of volcanoes and associated sedimentary rocks that are older and younger than Eureka Valley Tuff. Faults demonstrably older than Eureka Valley Tuff are those filled with 13.3-10.5 Ma veins and altered breccias in the Masonic and Aurora Mining Districts. Common hangingwall 
and footwall strata in these districts preclude estimation of displacement along these structures. Veins and faults in the Bodie Mining District, which are younger than Eureka Valley Tuff, have measured and suspected displacements of tens of meters or less. Most mapped or proposed faults that offset Eureka Valley Tuff also have common wall rocks. Estimates of displacement, tens of meters, are derived from elevations of contacts of Eureka Valley Tuff and underlying strata. Because of the structural and stratigraphic significance of Eureka Valley Tuff, which is distributed throughout much of the Bodie Hills, landform evolution has been reconstructed here relative to this marker.

\section{Northwestern Bodie Hills, 15-9.3 Ma}

Based on paleosurfaces and paleolandforms in the Masonic Mining District and Red Wash-East Walker River alteration zone, the northwestern part of the Bodie Hills volcanic field at $12.9 \mathrm{Ma}$ consisted of a broad upland $\left(\sim 500 \mathrm{~km}^{2}\right)$ of 15-12.9 Ma trachyandesite flows, volcaniclastic strata, and domes (Masonic volcanic center; fig. 52A). The domes (15-14, 13.5-13.4, and 12.9 Ma), included a prominent edifice south of Masonic Mountain, and protrusions of Mesozoic granitic and metamorphic rocks (ancestral Masonic Mountain) punctuated by relatively subdued upland topography. Basin-fill deposits, which contain 11-10 Ma tephra, partly cover strata of the Masonic volcanic center (fig. 52B), indicating that a depression (ancestral Fletcher Valley) existed north and northeast of Masonic Mountain by $11 \mathrm{Ma}$. By $9.5 \mathrm{Ma}$, numerous water courses incised the upland, some of which drained north to northeast toward ancestral Fletcher Valley. Paleodrainages, including the present East Walker River, subparallel water courses, and depressions west, southwest, and northwest of ancestral Masonic Mountain, are now marked by relatively thick and contiguous deposits of 9.5-9.3 Ma Eureka Valley Tuff (fig. 52C). The lowest elevation exposure of Eureka Valley Tuff, $\sim 5,600 \mathrm{ft}$ along the East Walker River north of the Masonic volcanic center, implies that detritus in the western part of Fletcher Valley was derived from uplands in the vicinity of Masonic Mountain. Present elevations of domes and Masonic Mountain relative to the highest elevation of Eureka Valley Tuff suggest that relief in the northwestern Bodie Hills at $9.5 \mathrm{Ma}$ was tens to hundreds of meters (hundreds of feet), and probably $\leq 20$ percent of present relief.

\section{Eastern Bodie Hills, 13-9.5 Ma}

In the eastern part of the Bodie Hills volcanic field, the prominent paleolandform in the Aurora Mining District and East Brawley Peak alteration zone at $\sim 10.5$ Ma was an elongate ridge of 13.1-12.6 Ma trachyandesite of Aurora (Aurora volcanic center; $\sim 130 \mathrm{~km}^{2} ; 51 \mathrm{mi}^{2}$; fig. 52B). The ridge extended $\sim 14 \mathrm{~km}$ northeast from ancestral East Brawley Peak, and was flanked to the north and west by relatively small-volume trachyandesite and rhyolite flow-dome fields $\left(\sim \leq 50 \mathrm{~km}^{2}\right)$ at similar to lower elevations. No Eureka Valley Tuff exists near Aurora to mark drainages and depressions that developed by $9.5 \mathrm{Ma}$. Basin-fill deposits that overlie 13-11 Ma eruptive rocks north of Aurora, coupled with the 11.1 Ma age of unwelded tuff in Fletcher Valley sedimentary strata (table 1), confirm that Fletcher Valley bordered the volcanic field to the north by $11 \mathrm{Ma}$. Gold-bearing sand and gravel deposits that overlie altered lacustrine strata beneath Holocene trachyandesite of Aurora Crater (Nevada Exploration Inc., 2013) also support low elevations north of the Aurora Mining District by 10.5 Ma. Relative to the basin-fill deposits, relief in the eastern Bodie Hills at 9.5 Ma was tens to hundreds of meters (hundreds of feet), probably $\leq 25$ percent of present relief.

\section{Central and Southern Bodie Hills, 15-9.5 Ma}

From $\sim 15$ to $12 \mathrm{Ma}$, Mesozoic rocks were apparently exposed between the Masonic and Aurora volcanic centers because only small-volume $\left(\sim 13 \mathrm{~km}^{2}\right)$ trachydacite of Rough Creek was erupted between those centers. From $\sim 11$ to $10 \mathrm{Ma}$, numerous large- $\left(\sim 30-50 \mathrm{~km}^{2}\right)$ to small-volume $\left(<20 \mathrm{~km}^{2}\right)$ flows and domes of trachyandesite, rhyolite, and trachydacite erupted between, north, and south of the Masonic and Aurora centers. Several large-volume flow sequences and lava domes partly covered the Masonic and Aurora centers, and contributed detritus and tuff to a central depression, the 9.7-9.3 Ma Paramount basin (fig. 52B). These permeable volcaniclastic strata were pervasively altered (Paramount-Bald Peak alteration zone) by artesian hydrothermal fluids that built numerous sinter terraces (fig. 27), several of which are associated with the Hg deposit at the Paramount Mine (fig. 28). Fluid circulation may have been driven by a concealed intrusion spatially related to $\sim 9.7$ Ma Bald Peak rhyolite.

\section{Eureka Valley Tuff, 9.5-9.3 Ma}

By 9.3 Ma, drainages and depressions among 15-10 Ma eruptive rocks and Mesozoic rocks in the central and western parts of the Bodie Hills volcanic field had been at least partly filled with ash flows and reworked tephra deposits of the externally sourced Eureka Valley Tuff (fig. 52C). Semialigned remnants and elongate exposures of Eureka Valley Tuff mark paleochannels, several of which are subparallel to the East Walker River. Present elevations of Eureka Valley Tuff exposures, contiguous with large- and small-volume volcanic centers, indicate relief of tens of meters (tens to hundreds of feet) at the time of Eureka Valley Tuff eruption.

\section{Southeastern Bodie Hills, 10-8 Ma}

Four large-volume, coalesced volcanic centers $\left(\sim 150-70 \mathrm{~km}^{2}\right)$ were emplaced in the southern Bodie Hills at 10-8 Ma (fig. 52D). From 10-9 Ma, trachydacite and associated volcaniclastic deposits formed a large flow-dome complex centered on Potato Peak while trachyandesite lava and associated debris flows were erupted from the Mount Biedeman stratovolcano, in part simultaneously with eruption of Eureka Valley Tuff. Rocks from these volcanic centers 
partly covered strata of the Masonic volcanic center, and 11-10 Ma large- and small-volume volcanoes. From 9 to $8 \mathrm{Ma}$, extensive flow-dome complexes were emplaced east (dacite of Silver Hill) and west (trachyandesite of Willow Springs) of Potato Peak. These volcanic edifices were partly altered by hydrothermal systems that formed Bodie district Au-Ag veins (8.5-8.1 Ma), the extensive Cinnabar Canyon alteration zone (8.8-8.2 Ma; fig. 52D), and the $\mathrm{S}^{\circ}$ resource in the Cinnabar Canyon alteration zone.

\section{Bodie Hills Landforms, 8-3.9 Ma}

At $8 \mathrm{Ma}$, landforms in the central and southern parts of the Bodie Hills volcanic field were dominated by the $10-8 \mathrm{Ma}$ volcanoes centered on Potato Peak and Mount Biedeman, and by adjacent, small-volume volcanoes. Since $8 \mathrm{Ma}$, only a few small-volume landforms ( 6.2-5.4 Ma rhyolite and dacite flow-domes; John and others, 2012) have been added to the Bodie Hills volcanic field. Since $8 \mathrm{Ma}$, the $10-8 \mathrm{Ma}$ volcanoes have been marginally eroded, and vent-filling plugs of trachydacite on Potato Peak (10,237 ft) and Mount Biedeman $(8,962 \mathrm{ft})$ are among the highest elevations in the Bodie Hills. At $\sim 8 \mathrm{Ma}$, the elevation difference between the top of the Potato Peak volcano and Eureka Valley Tuff beneath trachydacite of Potato Peak lava flows in the Bodie Mining District ( 8,500 ft, fig. 37), was at least 1,737 ft, discounting unquantified post-8 Ma erosion of ancestral Potato Peak. The difference in elevation between the Potato Peak volcano and Fletcher Valley at $8 \mathrm{Ma}$, assuming a common paleoelevation for Eureka Valley Tuff at Bodie, along the East Walker River, and in Fletcher Valley, would also have been 1,737 ft (or more). The present elevation difference between Potato Peak, East Walker River, and Fletcher Valley, 4,600-4,200 ft, suggests that most prevailing relief ( $>60$ percent) in the Bodie Hills has developed since $8 \mathrm{Ma}$. Given the absence of significant faults in the southern part of the volcanic field (John and others, 2012), this relief largely reflects magmatic inflation during growth of 10-8 Ma volcanoes in the southern part of the volcanic field.

Small increments of relief have been added to northwestern and eastern parts of the field by displacement along west-east, and north-northeast-striking normal faults that have been mapped or are expressed by lineaments on color air photographs (fig. 52D), although stratigraphic displacement along lineaments is not always evident. A north-northwest-trending fault that apparently borders the east side of Bridgeport Valley also contributed to relief of the volcanic field. The west-east and northeast-striking faults have displaced trachyandesite north of Masonic (fig. 14) and at Aurora (fig. 20), mostly by down-to-the-north movement of tens of meters. North of Masonic, displacement along west-east faults perched fluviolacustrine deposits relative to Fletcher Valley basin-fill. Elevations of sinter groups in the Paramount basin differ by tens to hundreds of meters $(<2,000 \mathrm{ft}$; fig. 27). These elevation differences reflect both post-9.3 Ma, down-to-the-east displacement along north-striking faults (fig. 52D), and magmatic inflation during construction of the 9 Ma Potato Peak volcano. The volcanic centers at Masonic and Aurora also may have acquired additional relief by magmatic inflation during construction of the 10-8 Ma Mount Biedeman stratovolcano, and by flow-dome complex development in the southern part of the volcanic field. Distribution of Pliocene-Holocene volcanic rocks of the Aurora volcanic field in the eastern Bodie Hills does not appear to have been significantly modified by faults, although these rocks are cut by numerous northeast-striking faults in the eastern and southeastern parts of the Bodie Hills (John and others, 2015). Other landform modifications since $8 \mathrm{Ma}$ include incision by drainages that mostly originated in the trachyandesite uplands at Masonic, Aurora, Potato Peak, and Mount Biedeman.

\section{Relief and Absolute Paleoelevations}

Pre-Eureka Valley Tuff relief in the 15-10 Ma Masonic and Aurora volcanic centers is estimated at tens to hundreds of meters (tens to $>1,000 \mathrm{ft}$ ). The highest and lowest remnants of Eureka Valley Tuff, on Potato Peak $(\sim 9,150 \mathrm{ft})$ and near the confluence of the East Walker River and Red Wash $(\sim 5,600 \mathrm{ft})$, respectively, differ in elevation by $\sim 3,550 \mathrm{ft}$. Potato Peak, which formed after emplacement of Eureka Valley Tuff, is at least 4,600 ft higher than the lowest Eureka Valley Tuff, and 4,200 ft higher than Fletcher Valley (present elevation $\sim 6,100-6,000 \mathrm{ft}$ ). The smaller elevation difference between Potato Peak and Fletcher Valley, 4,200 ft, apparently reflects $\sim 400 \mathrm{ft}$ of basin fill added since $9.3 \mathrm{Ma}$. This estimate is supported by $\sim 600 \mathrm{ft}(\sim 180 \mathrm{~m})$ of gold-bearing sand and gravel deposits in drill holes beneath Holocene trachyandesite of Aurora Crater (Nevada Exploration Inc., 2013). The colluvial deposits overlie altered lacustrine strata that may be the same age as, or older than, $10.5 \mathrm{Ma}$ Aurora district veins $\sim 4 \mathrm{~km}$ to the south. Therefore, relief within the Bodie Hills volcanic field, created by volcano construction, magmatic inflation, fault displacement, and erosion since $15 \mathrm{Ma}$, totaled at least 4,200 ft and likely exceeded 4,600 ft.

Absolute elevations during landform evolution in the Bodie Hills volcanic field can be estimated from paleoelevations of the $11 \mathrm{Ma}$ Aldrich Station flora. If elevations in the Masonic and Aurora volcanic centers at 11 Ma were 2,500$2,000 \mathrm{ft}$ (Axelrod, 1956), then elevations have increased by at least $6,100 \mathrm{ft}(\sim 1,850 \mathrm{~m})$ in the northwestern and eastern parts of the volcanic field (present elevation of Eureka Valley Tuff remnants on Masonic Mountain are 8,600 and 8,775 ft), and elevations have been increased by $\sim 8,000 \mathrm{ft}(\sim 2,425 \mathrm{~m})$ to account for the present elevation of Potato Peak. If paleoelevations of Aldrich Station flora were 4,300-6,900 ft (Wolfe, 1995; Wolfe and others, 1997), then elevations at Masonic increased by $\sim 1,700-4,300 \mathrm{ft}(\sim 515-1,300 \mathrm{~m})$, and at Potato Peak by $\sim 3,300-5,900 \mathrm{ft}(\sim 1,000-1,790 \mathrm{~m})$ since $11 \mathrm{Ma}$. If $\sim 11$ Ma sediments containing fossils in the northern Bodie Hills are stratigraphically equivalent to Aldrich Station flora, then the Bodie Hills have been elevated an additional 1,700 ft (515 m), or $\sim 3,400-7,600 \mathrm{ft}(\sim 1,030-2,300 \mathrm{~m})$, since $11 \mathrm{Ma}$. 
Therefore, based on present elevations of Eureka Valley Tuff remnants, Potato Peak, Fletcher Valley, and fossilbearing sediments, the higher paleoelevation range estimate $(4,300-6,900 \mathrm{ft})$ for Aldrich Station flora is more consistent with relief developed in the Bodie Hills since $9.3 \mathrm{Ma}$ (at least 4,200-4,600 ft; 1,279-1,400 m). Relative to Aldrich Station flora, elevations in the northwestern part of the Bodie Hills volcanic field at $9.3 \mathrm{Ma}$ were $\sim 4,300-6,900 \mathrm{ft}$, and possibly hundreds to more than 1,000 feet higher in the eastern part of the volcanic field. At $8 \mathrm{Ma}$, after eruption of large-volume stratovolcanoes and flow-dome complexes in the southern part of the Bodie Hills volcanic field, maximum elevations exceeded 8,500 ft, and could have approached 10,000 ft (ancestral Potato Peak).

\section{Summary}

Significant conclusions of this investigation are summarized as follows:

1. The 15-6 Ma Bodie Hills volcanic field consists of coalescing stratovolcanoes and lava domes that were assembled on an irregular pre-Tertiary surface of Paleozoic and Mesozoic metamorphic and Cretaceous granitic rocks. The field is part of a subduction-related alignment of predominantly andesitic eruptive rocks that parallels the western margin of North America. Volcanic rocks are predominantly trachyandesite, lesser trachydacite, and subordinate rhyolite that commonly contain phenocrysts of plagioclase, pyroxene, hornblende, biotite, sanidine, and quartz, and have compositions similar to subduction magmas elsewhere. Three Au-Ag-Cu mining districts and nine aerially extensive alteration zones, one of which contains a significant sulfur $\left(\mathrm{S}^{\circ}\right)$ resource, occur mostly in the volcanic rocks.

2. The Masonic $\mathrm{Au}-\mathrm{Ag}-\mathrm{Cu}$ Mining District (production of $0.056 \mathrm{Moz} \mathrm{Au}, 0.04 \mathrm{Moz} \mathrm{Ag}$, and minor $\mathrm{Cu}$ ) includes two styles of mineralization, $\sim 13$ Ma fault breccia and vein deposits, and $\sim 13.3 \mathrm{Ma}$ clastic and hydrothermal sedimentary deposits. Deposits occur in $\sim 15-14$ Ma trachyandesite of Masonic and pre-Tertiary rocks, and are temporally associated with $\sim 13.5$ and $\sim 13$ Ma trachyandesite and andesite domes. Both types consist of quartz, alunite, lesser kaolinite, pyrophyllite and sericite, pyrite, enargite, $\mathrm{Au}$-rich electrum, and numerous $\mathrm{Cu}-\mathrm{As}-\mathrm{Sb}-\mathrm{Fe}-$ Bi-Au-Ag-S-Se-Te minerals.

3. The Aurora Au-Ag Mining District (estimated production of $1.91 \mathrm{Moz} \mathrm{Au}$ and $21 \mathrm{Moz}$ Ag production) includes $\sim 10.5 \mathrm{Ma}$ layered quartz-adularia-sericiteelectrum-sulfide veins in $13.1-12.6$ Ma trachyandesite of Aurora that is altered to sericite, K-feldspar, pyrite, chlorite, albite, calcite, and montmorillonite.
4. The Bodie Au-Ag Mining District (production of 1.46 Moz Au and 7.3 Moz Ag) includes at least three, $\sim 8.9-8.1$ Ma quartz-adularia-sericite-sulfide-telluride vein series that are distinguished by textures, ages, and mineralogy. The vein series occur in $\sim 9$ Ma dacite of Silver Hill.

5. Alteration zones include quartz-alunite-pyrite(iron oxide)-dominant assemblages that vary in age from $\sim 13.3$ to $8.2 \mathrm{Ma}$, and quartz-kaolinite-montmorillonitedominant assemblages that are $\sim 9.7-9.3 \mathrm{Ma}$ and include sinter. The alteration zones occur in rocks that are the same age to $\sim 2 \mathrm{~m}$.y. older than hydrothermal minerals. Small amounts of $\mathrm{Hg}$ were recovered from deposits in several alteration zones (Potato Peak; Paramount-Bald Peak; Cinnabar Canyon-US 395; Spring Peak), a sulfur resource occurs in the Cinnabar Canyon-US 395 alteration zone.

6. The evolution of landforms during the assembly, alteration, and erosion of the volcanic field, based on volcanic stratigraphy, geochronology, and hydrothermal mineral assemblages, began with construction of the large 15-13 Ma Masonic and 13-12 Ma Aurora volcanic centers that mark the northwestern and northeastern parts of the field. Smaller volcanoes erupted at $\sim 11-10 \mathrm{Ma}$ in, between, and south of these centers as erosional detritus accumulated north of the field in Fletcher Valley. Distally sourced, 9.7-9.3 Ma Eureka Valley Tuff filled drainages and depressions among older volcanoes and was partly covered by nearly synchronous eruptives during construction of four large 10-8 Ma volcanoes, which comprise the southern part of the field. The scarcity of significant internal fault displacement, distribution of Eureka Valley Tuff, and elevation estimates derived from floras, suggest that the Bodie Hills volcanic field attained present elevations mostly through volcano construction and magmatic inflation, and that maximum paleoelevations $(>8,500 \mathrm{ft})$ at the end of large volume eruptions at $\sim 8 \mathrm{Ma}$ are similar to present elevations.

\section{Acknowledgments}

Numerous individuals and institutions provided maps, reports, specimens, and site access that greatly enhanced description of mining districts and alteration zones, and characterization of ores. Unpublished mine maps, geologic maps, and reports from the Masonic, Aurora, and Bodie Mining Districts by Page Blakemore, Robert Hatch, C. Hogge, Richard Kern, Peter Knudsen, Edmond Lawrence, N. Lehman, Anthony Payne, Neil Prenn, William Rehrig, David Shaddrick, Miles Silberman, Amer Smailbogevic, Scott Tregaskis, and Robert Wilson significantly supplemented published accounts. Archival mining district files maintained on-line by the 
Nevada Bureau of Mines and Geology were the source of some of these unpublished reports and maps. Simon Poulson provided some sulfur isotope analyses, Larry Snee provided several ${ }^{40} \mathrm{Ar} /{ }^{39} \mathrm{Ar}$ dates, and Jim Rytuba provided some geochemical analyses. LA ICP-MS traverses of sinter and vein sections were done under the guidance of Alan Koenig in his laboratory. Discussions and field tours of several districts and alteration zones with Ken Brook, Tony Eng, and Greg Kouzma led to productive sharing of geologic information and perspectives. Rachel Dolbier and D.D. LaPointe of the Keck Museum, University of Nevada Reno (Reno, Nevada), and Darci Moore of the California State Mining and Mineral Museum (Mariposa, California) graciously loaned archival specimens from the Aurora and Bodie Mining Districts. Mark Langner, Thomas Gunther, Joshua Heitzmann, and Tamara Sasaki of the Department of Parks and Recreation, State of California, provided ready access to Bodie State Historic Park and permission to collect samples. Thorough reviews of a draft manuscript by John Slack and Jeff Mauk led to many improvements in the final version.

\section{References Cited}

Al-Rawi, Y.T., 1969, Cenozoic history of the northern part of Mono Basin, California and Nevada: Berkeley, University of California, Ph.D. dissertation, 163 p.

Angel, M., ed., 1881, History of Nevada with illustrations and biographical sketches of its prominent men and pioneers: Oakland, Calif., Thompson and West, 680 p.

Archbold, N.L., 1966, Industrial mineral deposits of Mineral County, Nevada: Nevada Bureau of Mines and Geology Report 14, 32 p.

Atwater, Tanya, and Stock, J., 1998, Pacific-North America plate tectonics of the Neogene southwestern United States-An update: International Geology Review, v. 40, p. 375-402.

Axelrod, D.I., 1956, Mio-Pliocene floras from west-central Nevada: University of California Publications in Geological Sciences, v. 33, 322 p.

Barton, M.D., 1980, The Ag-Au-S system: Economic Geology, v. 75 , p. $303-316$.

Barton, M.D., Kieft, C., Burke, E.A.J., and Oen, I.S., 1978, Uytenbogaardtite-A new silver-gold sulfide: Canadian Mineralogist, v. 16, p. 651-657.

Blake, W.P., 1869, Report upon the precious metals: Being statistical notices of the principal gold and silver producing regions of the world represented at the Paris Universal Exposition: Washington, D.C., Government Printing Office, $369 \mathrm{p}$.
Bodie Consolidated Mining Company Collection, 2003, California Department of Parks and Recreation, Sacramento, California; microfilm copy in Special Collections, University of Nevada Reno, available at http://innopac. library.unr.edu/search $\sim$ S6?/dBodie+Consolidated+Mining+ Company/dbodie + consolidated + mining + company/-3\%2C$1 \% 2 \mathrm{C} 0 \% 2 \mathrm{CB} /$ frameset\&FF $=$ dbodie + consolidated + mining + company \& $1 \% 2 \mathrm{C} 1 \% 2 \mathrm{C}$.

Brady's map of Aurora and Esmeralda, 1862, E.J. Mathews and Company, Aurora, and Wakelee and Charles, San Francisco, available at http://www.delamare.unr.edu/Maps/ digitalcollections/nvmaps/histgeo.

Breit, F.J., 2000, Structural and temporal relationship and geochemical characteristics of the East Brawley Peak acidsulfate prospect and the adjacent Aurora adularia-sericite system: University of Nevada Reno, M.S. thesis, 219 p.

Brown, H.G., 1908, The vein-system of the Standard Mine, Bodie, Calif.: Transactions of the American Institute of Mining Engineers, v. 38, p. 343-357.

Browne, J. R., 1865, A trip to Bodie Bluff and the Dead Sea of the West: Harper's New Monthly Magazine, p. 274-284, p. 411-419.

Burchard, H.C., 1881, Report of the Director of the Mint: Washington, D.C., Government Printing Office, p. 38-47.

Burchard, H.C., 1882, Report of the Director of the Mint upon the statistics of the production of the Precious metals in the United States: Washington, D.C., Government Printing Office, p. 51-60.

Burchard, H.C., 1884, Report of the Director of the Mint upon the statistics of the production of the Precious metals in the United States during the calendar year 1883: Washington, D.C., Government Printing Office, p. 173-176.

Chaussidon, M., Albarede, F., and Sheppard, S.M.F., 1989, Sulphur isotope variations in the mantle from ion microprobe analyses of micro-sulphide inclusions: Earth and Planetary Science Letters, v. 92, p. 144-156.

Chesterman, C.W., Chapman, R.H., and Gray, C.H., 1986, Geology and ore deposits of the Bodie mining district, Mono County, California: California Division of Mines and Geology, Bulletin 206, 36 p.

Chesterman, C.W., and Gray, C.H., Jr., 1975, Geology of the Bodie 15-minute quadrangle, Mono County, California: California Division of Mines and Geology, Map Sheet 21, scale $1: 48,000$.

Clarke, H.G., 1882, Aurora, Nevada-A little of its history, past and present: The School of Mines Quarterly, v. 3, p. 133-136. 
Couch, B.F., and Carpenter, J.A., 1943, Nevada's metal and mineral production: Nevada Bureau of Mines and Geology Bulletin 37, 159 p.

Dalrymple, G.B., and Lanphere, M.A., $1974,{ }^{40} \mathrm{Ar} /{ }^{39} \mathrm{Ar}$ age spectra of some undisturbed terrestrial samples: Geochimica et Cosmochimica Acta, v. 38, p. 715-738.

du Bray, E.A., John, D.A., Box, S.E., Vikre, P.G., Fleck, R.J., and Cousens, B.L., 2013, Petrographic and geochemical data for Cenozoic volcanic rocks of the Bodie Hills, California and Nevada: U.S. Geological Survey Data Series 764, 10 p., http://pubs.usgs.gov/ds/764/.

Eakle, A.S., Huguenin, E., McLaughlin, R.P., and Waring, C.A., 1917, Mines and mineral resources of Alpine County, Inyo County, Mono County: California State Mining Bureau, Fifteenth annual report of the State Mineralogist, p. 5-175.

Eakle, A.S., and McLaughlin, R.P., 1919, Mono County: California State Mining Bureau, Report XV of the State Mineralogist, Sacramento, p. 135-175.

Eaton, G.P., Wahl, R.R., Prostka, H.J., Mahey, D.R., and Kleinkopf, M.D., 1978, Regional gravity and tectonic patterns-Their relation to late Cenozoic epeirogeny and lateral spreading in the western Cordillera, in Smith, R.B., and Eaton, G.P., eds., Cenozoic tectonics and regional geophysics of the Western Cordillera: Geological Society of America Memoir 152, p. 51-91.

Etoh, J., Izawa, E., Watanabe, K., Taguchi, S., and Sekine, R., 2002, Bladed quartz and its relationship to gold mineralization in the Hishikari low-sulfidation epithermal gold deposit, Japan: Economic Geology, v. 97, p. 1841-1851.

Evernden, J.F., and James, G.T., 1964, Potassium-Argon dates and the Tertiary floras of North America: American Journal of Science, v. 262, p. 945-974.

Faulds, J.E., and Henry, C.D., 2008, Tectonic influences on the spatial and temporal evolution of the Walker Lane-An incipient transform fault along the evolving Pacific - North American plate boundary, in Spencer, J.E., and Titley, S.R., eds., Ores and orogenesis - Circum-Pacific tectonics, geologic evolution, and ore deposits: Arizona Geological Society Digest 22, p. 437-470.

Ferguson, H.G., 1929, The mining districts of Nevada: Economic Geology, v. 24, p. 115-148.

Field, C.W., and Fifarek, R.H., 1985, Light stable-isotope systematics in the epithermal environment, in Berger, B.R., and Bethke, P.M., eds., Geology and geochemistry of epithermal systems, Reviews in Economic Geology, v. 2, p. $99-128$.

Fisher, R.V., and Schmincke, H.-U., 1984, Pyroclastic rocks: New York, Springer-Verlag, $472 \mathrm{p}$.
Fleck, R.J., du Bray, E.A., John, D.A., Vikre, P.G., Cosca, M.A., Snee, L.W., and Box, S.E., 2015, Geochronology of Cenozoic rocks in the Bodie Hills Volcanic Field, California and Nevada: U.S. Geological Survey Data Series 916, 26 p., http://dx.doi.org/10.3133/ds916.

Fleck, R.J., Sutter, J.F., and Elliot, D.H., 1977, Interpretation of discordant ${ }^{40} \mathrm{Ar} /{ }^{39} \mathrm{Ar}$ age-spectra of Mesozoic tholeiites from Antarctica: Geochimica et Cosmochimica Acta, v. 41, p. 15-32.

Giesemann, A., Jager, H.J., Norman, A.L., Krouse, H.P., and Brand, W.A., 1994, On-line sulfur-isotope determination using an elemental analyzer coupled to a mass spectrometer: Analytical Chemistry, v. 66, p. 2816-2819.

Gilbert, C.M., Christiansen, M.N., Al-Rawi, Y., and Lajoie, K.R., 1968, Structural and volcanic history of Mono Basin, California-Nevada, in Coats, R.R., and others, eds., Studies in volcanology: Geological Society of America Memoir 116, p. $275-329$.

Gilbert, C.M., and Reynolds, M.W., 1973, Character and chronology of basin development, western margin of the Basin and Range Province: Geological Society of America Bulletin, v. 84, p. 2489-2510.

Gilbert, J.R., 1976, .42 minerals inventory and analysis of the Walker Planning Unit, Carson City District, Nevada and California: Bureau of Land Management Report, document 00400009, 149 p., accessed June 2013 at http://www.nbmg.unr.edu/mdfiles/mdfiles.php.

Grassineau N.V., Mattey D.P. and Lowry D., 2001, Sulfur isotope analysis of sulfide and sulfate minerals by continuous flow-isotope ratio mass spectrometry: Analytical Chemistry, v. 73, p. 220-225.

Green, W.R., 1964, Structural control of mineralization at the Aurora mining district: University of Nevada Reno, M.S. thesis, $41 \mathrm{p}$.

Gumble, G.E., Warren, R., Whitehead, M.L., and Enders, M.S., 1991, Summary of the geology of the northern part of the Bodie mining district, Mono County, California, in Schafer, R.W., Bonham, H.F., and Silberman, M.L., eds., Diverse tectonic setting for epithermal volcanic-hosted precious metal deposits along the Nevada-California border, Great Basin Symposium Field Trip 9, Geological Society of Nevada, Reno, Nevada, p. 619-623.

Haas, J.L., 1971, The effect of salinity on the maximum thermal gradient of a hydrothermal system at hydrostatic pressure: Economic Geology, v. 66, p. 940-946. 
Hardyman, R.F., and Oldow, J.S., 1991, Tertiary tectonic framework and Cenozoic history of the central Walker Lane, Nevada, in Raines, G.L., Lisle, R.E., Schafer, R.W., and Wilkinson, W.H., eds., Geology and ore deposits of the Great Basin: Geological Society of Nevada, Symposium Proceedings, Reno, Nev., p. 279-301.

Herrera, P.A., Closs, L.G., and Silberman, M.L., 1993, Alteration and geochemical zoning in Bodie Bluff, Bodie mining district, eastern California: Journal of Geochemical Exploration, v. 48, p. 259-275.

Hill, J.M., 1915, Some mining districts in northeastern California and northwestern Nevada: U.S. Geological Bulletin 594, 200 p.

Hollister, V.F., and Silberman, M.L., 1995a, Geology and epithermal silver-gold bulk-mining targets, Bodie district, Mono County, California: Nonrenewable Resources, v. 42, p. 129-137.

Hollister, V.F., and Silberman, M.L., 1995b, Silver-gold and polymetallic quartz veins in the Bodie mining district east-central California-Are they related to a porphyry Cu-Mo system at depth?, in Pierce, F.W., and Bolm, J., eds., Porphyry copper deposits of the American Cordillera, Arizona Geological Society Digest 20, p. 297-305.

Holmes, G.H., 1965, Mercury in California, in Mercury potential of the United States: U.S. Bureau of Mines Information Circular 8252, p. 87-206.

Jenkins, O.P., 1951, Mono County: California Journal of Mines and Geology, v. 47, no. 2, p. 342-343.

John, D.A., du Bray, E.A., Blakely, R.J., Fleck, R.J., Vikre, P.G., Box, S.E., and Moring, B.C., 2012, Miocene magmatism in the Bodie Hills volcanic field, California and Nevada: A long-lived eruptive center in the southern segment of the ancestral Cascades arc: Geosphere, v. 8, p. 44-97.

John, D.A., du Bray, E.A., Box, S.E., Vikre, P.G., Rytuba, J.J., Fleck, R.J., and Moring, B.C., 2015, Geologic map of the Bodie Hills, California and Nevada: U.S. Geological Survey Scientific Investigations Map 3318, 64 p., 2 sheets, scale 1:50,000, http://dx.doi.org/10.3133/sim3318.

Johnson, R.F., 1951, Geology of the Masonic mining district, Mono County, California: University of California, M.A. thesis, $51 \mathrm{p}$.

Kinetic Gold Corp., 2013, Spring Peak Project, accessed December 14, 2013, at http://www.kineticgold.com/s/ SpringPeak.asp.

King, C., Emmons, S.F., and Becker, G.F., 1885, Statistics and technology of the precious metals: Washington, D.C., Department of the Interior, Census Office, Government Printing Office, $541 \mathrm{p}$.
Kister, R.W., 1966, Structure and metamorphism in the Mono Craters Quadrangle, Sierra Nevada: U.S. Geological Survey Belletin 1221-E, 53 p.

Kleinhampl, F.J., Davis, W.E., Silberman, M.L., Chesterman, C.W., Chapman, R.H., and Gray, C.H., 1975, Aeromagnetic and limited gravity studies and generalized geology of the Bodie Hills region, Nevada and California: U.S. Geological Survey Bulletin 1384, 38 p.

Knudsen, P., and Prenn, N., 2002, Technical report on the Esmeralda Project, Mineral County, Nevada U.S.A.: Mine Development Associates, 121 p., available at http://www. secinfo.com/dVut2.215aw.htm.

Lange, R.A., and Carmichael, I.S.E., 1996, The Aurora volcanic field, California-Nevada: oxygen fugacity constraints on the development of andesitic magma: Contributions to Mineralogy and Petrology, v. 125, p. 167-185.

Lange, R.A., Carmichael, I.S.E., and Renne, P., 1993, Potassic volcanism near Mono Basin, California_Evidence for high water and oxygen fugacities inherited from subduction: Geology, v. 21, p. 949-952.

Lawrence, E.F., 1987, Geologic report on the southern half of the Aurora mining district, Mineral County, Nevada: Bureau of Land Management Report, document 04100099, 118 p., available at http://data.nbmg.unr.edu/Public/Mining Districts/0410/04100099.pdf.

Le Bas, M.J., Le Maitre, R.W., Streckeisen, A., Zanettin, B.A., and IUGS Subcommission on the Systematics of Igneous Rocks, 1986, Chemical classification of volcanic rocks based on the total alkali-silica diagram: Journal of Petrology, v. 27, p. 745-750.

Long, K.R., DeYoung, J.H., and Ludington, S.D., 1998, Database of significant deposits of gold, silver, copper, lead, and zinc in the United States: U.S. Geological Survey Open-File Report 98-206 A, B, 33 p., available at http://pubs.usgs.gov/of/1998/0206a-b/.

McDougall, L., and Harrison, T.M., 1999, Geochronology and thermochronology by the ${ }^{40} \mathrm{Ar} /{ }^{39} \mathrm{Ar}$ method ( $2 \mathrm{~d}$ ed.): Oxford, Oxford University Press, 269 p.

McLaughlin, R.P., 1907, Geology of the Bodie district, California: Mining and Scientific Press, v. 94, p. 795-796.

McLaughlin, R.P., 1915, Masonic mining district, Mono County, California: Mining Press, p. 27-29.

Millar, C.I., 1996, Tertiary vegetation history, in Sierra Nevada Ecosystem Project, Final report to Congress, Volume II, Assessments and Scientific Basis for Management Options, Centers for Water and Wildland Resources, Report No. 37, University of California, Davis, Calif., p. 71-122. 
Mono County Historical Society 2004 Newsletter, Masonic Mining District, 4 p.

Morton, J.L., Silberman, M.L., Bonham, H.F., Garside, L.J., and Noble, D.C., 1977, K-Ar ages of volcanic rocks, plutonic rocks, and ore deposits in Nevada and eastern California-determinations run under the USGS-NBMG cooperative program: Isochron/West, no. 20, p. 19-29.

Nash, J., 1972, Fluid inclusion studies of some gold deposits in Nevada: U.S. Geological Survey Professional Paper 800-C, p. 15-19.

Nevada Bureau of Mines and Geology, 2009, The Nevada Mineral Industry 2009: Special Publication MI-2009, 180 p.

Nevada Exploration Inc., 2013, Fletcher Junction Project, accessed October 14, 2013, at http://www.nevada exploration.com/properties/fletcher/overview/.

Oldow, J.S., 1992, Late Cenozoic displacement partitioning in the northwestern Great Basin, in Craig, S.D., ed., Structure, tectonics, and mineralization of the Walker Lane: Walker Lane Symposium, proceedings volume, Geological Society of Nevada, Reno, Nev., p. 17-52.

Oldow, J.S., 2003, Active transtensional boundary zone between the western Great Basin and Sierra Nevada block, western U.S. Cordillera: Geology, v. 31, p. 1033-1036.

O’Neil, J.R., and Silberman, M.L., 1974, Stable isotope relations in epithermal Au-Ag deposits: Economic Geology, v. 69 , p. 902-909.

O’Neil, J.R., Silberman, M.L., Fabbi, B.P., and Chesterman, C.W., 1973, Stable isotope and chemical relations during mineralization in the Bodie mining district, Mono County, California: Economic Geology, v. 68, p. 765-784.

Osborne, M.A., 1985, Alteration and mineralization of the northern half of the Aurora mining district, Mineral County, Nevada: University of Nevada Reno, M.S. thesis, 93 p.

Osborne, M.A., 1991, Epithermal mineralization at Aurora, Nevada, in Raines, G.L., Lisle, R.F., Schafer, R.W., and Wilkinson, W.H., eds., Geology and ore deposits of the Great Basin, Geological Society of Nevada, Symposium Proceedings, Reno, Nevada, p. 1097-1110.

Payne, A., 1965, Geologic report Wasp and Hornet claims, Aurora mining district, Mineral County, Nevada: Bureau of Land Management Report, document 04100095, 26 p., available at http://data.nbmg.unr.edu/Public/Mining Districts/0410/04100095.pdf.

Piatt, M.H., 2003, Bodie "The mines are looking well...", a history of the Bodie mining district, Mono County, California: El Sobrante, Calif., North Day Books, 288 p.
Pluhar, C.J., Deino, A.L., King, N.M., Busby, Cathy, Huasback, B.P., Wright, Tracy, and Fischer, Collin, 2009, Lithostratigraphy, magnetostratigraphy and radio-isotopic dating of the Stanislaus Group, CA, and the age of the Little Walker caldera: International Geology Review, v. 51, p. 873-899.

Renne, P.R., Deino, A.L., Hames, W.E., Heizler, M.T., Hemming, S.R., Hodges, K.V., Koppers, A.A.P., Mark, D.F., Phillips, D., Singer, B.S., Turin, B.D., Villa, I.M., Villeneuve, M., and Wijbrans, J.R., 2009, Data reporting norms for ${ }^{40} \mathrm{Ar} /{ }^{39} \mathrm{Ar}$ geochronology: Quaternary Geochronology, v. 4, p. 346-352.

Rhoden, H.N., 1992, Exploration of Silver Hill, Aurora district, Mineral County, Nevada: Bureau of Land Management Report, document 04100087, 5 p., available at http://data.nbmg.unr.edu/Public/MiningDistricts/ 0410/04100087.pdf.

Robinson, A.C., and Kistler, R.W., 1986, Maps showing isotopic dating in the Walker Lake $1^{\circ}$ by $2^{\circ}$ quadrangle, California and Nevada: U.S. Geological Survey Miscellaneous Field Studies Map MI-1382-N, scale 1:250,000.

Rockwell, B.W., 2010, Mineral and vegetation maps of the Bodie Hills, Sweetwater Mountains, and Wassuk Range, California/Nevada, generated from ASTER satellite data: U.S. Geological Survey Scientific Investigations Map 3104, scale 1:62,000, 4 plates, pamphlet, 5 p., available at http://pubs.usgs.gov/sim/3104/.

Ross, D.C., 1961, Geology and mineral deposits of Mineral County, Nevada: Nevada Bureau of Mines and Geology Bulletin 58, 98 p.

Rye, R.O., 2005, A review of the stable-isotope geochemistry of sulfate minerals in selected igneous environments and related hydrothermal systems: Chemical Geology, v. 215, p. 5-36.

Sampson, R.J., 1940, Mineral resources of Mono County: State Mineralogist's Report XXXVI, California Journal of Mines and Geology, v. 36, no. 2, p. 117-156.

Shaddrick, D.R., 1989, The Aurora district, Nevada-Nevada Goldfields Inc. reserves and potential-A critical review, document 04100091, 49 p., available at http://data.nbmg. unr.edu/Public/MiningDistricts/0410/04100091.pdf.

Sherlock, R.L., 2005, The relationship between the McLaughlin gold-mercury deposit and active hydrothermal systems in the Geysers-Clear Lake area, northern Coast Ranges, California: Ore Geology Reviews, v. 26, p. 349-382. 
Silberman, M.L., and Berger, B.R., 1985, Relationship of trace-element patterns to alteration and morphology in epithermal precious-metal deposits, in Berger, B.R., and Bethke, P.M., eds., Geology and Geochemistry of epithermal systems: Reviews in Economic Geology, v. 2, p. 203-232.

Silberman, M.L., Breit, F., and Lawrence, E.F., 1995, Geology and ore deposits of Bodie Hills, Northern Mono Basin Region: 1996 Fall Field Trip Guidebook, Geological Society of Nevada, Reno, Nevada, Special Publication No. 22, 65 p.

Silberman, M.L., and Chesterman, C.W., 1991, A description of the Bodie Hills and Bodie mining district, Mono County, California with annotated road log from Bridgeport to Bodie, in Schafer, R.W., Bonham, H.F., and Silberman, M.L., eds., Diverse tectonic setting for epithermal volcanichosted precious metal deposits along the Nevada-California border, Great Basin Symposium Field Trip 9, Geological Society of Nevada, Reno, Nev., p. 601-618.

Silberman, M.L., and McKee, E.H., 1972, A summary of radiometric age determinations on Tertiary volcanic rocks from Nevada and eastern California: part II, western Nevada: Isochron-West, no. 4, p. 7-28.

Smailbegovic, Amer, 2002, Structural and lithologic constraints to mineralization in Aurora, Nevada and Bodie, CA mining districts, observed and interpreted with aerospace geophysical data: University of Nevada Reno, Ph.D. dissertation, $261 \mathrm{p}$.

Speed, R.C., 1977, Excelsior Formation, west central Nevada - Stratigraphic appraisal, new divisions, and paleogeographic interpretations, in Stewart, J.H., Stevens, C.H., and Fritsche, A.E., eds., Paleozoic paleogeography of the western United States: Society of Economic Paleontologists and Mineralogists, Pacific Coast Paleogeography Symposium 1, p. 325-336.

Stanford Geological Survey, 1961, Geologic map of Swauger Creek-Masonic Mountain area, Mono County, California: Stanford, Calif., Stanford University, scale 1:31,680, available at http://www-sul.stanford.edu/depts/branner/images/ maps/JamesGsmith-BIG.jpg.

Stewart, J.H., 1988, Tectonics of the Walker Lane belt, western Great Basin: Mesozoic and Cenozoic deformation in a zone of shear, in Ernst, W.G., ed., Metamorphism and crustal evolution of the western United States: Englewood Cliffs, N.J., Prentice Hall, p. 681-713.

Stewart, J.H., 1992, Walker Lane belt, Nevada and Californiaan overview, in Craig, S.D., ed., Walker Lane Symposium proceedings volume, Geological Society of Nevada, Reno, Nev., p. 1-16.
Stone, J.G., 1982, Siskon Corporation assets, document 04100018, 6 p., available at http://data.nbmg.unr.edu/ Public/MiningDistricts/0410/04100018.pdf.

Streckeisen, A., 1976, To each plutonic rock its proper name: Earth-Science Reviews, v. 12, p. 1-33.

Stretch, R.H., 1867, Annual report of the State Mineralogist of the State of Nevada for 1866: Carson City, Nev., Joseph E. Eckley, State Printer, $151 \mathrm{p}$.

Sylvester, A.G., 1988, Strike-slip faults: Geological Society of America Bulletin, v. 100, p. 1666-1703.

Tingley, J.V., 1990, Mineral resource inventory, Bureau of Land Management, Carson City District, Nevada: Nevada Bureau of Mines and Geology Open-File Report 90-1, $257 \mathrm{p}$.

Turner, H.W., 1908, The vein-system of the Standard Mine, Bodie, Cal.: Bi-Monthly Bulletin of the American Institute of Mining Engineers, no. 22, July, p. 12.

Vanderburg, W.O., 1937, Reconnaissance of mining districts in Mineral County, Nevada: U.S. Bureau of Mines Information Circular 6941, 79 p.

Vikre, P.G., 1989, Fluid-mineral relations in the Comstock Lode: Economic Geology, v. 84, p. 1574-1613.

Vikre, P.G., 2000, Elemental sulfur $\left(\mathrm{S}^{\circ}\right)$ deposits and $\mathrm{S}^{\circ}$ associated with precious metals, mercury, and thermal springs in the Great Basin, in Cluer, J.K., Price, J.G., Struhsacker, E.M., Hardyman, R.F., and Morris, C.L., eds., Geology and Ore Deposits 2000: Geological Society of Nevada Symposium Proceedings, Reno, Nev., p. 735-767.

Vikre, P.G., 2007, Sinter-vein correlations at Buckskin Mountain, National district, Humboldt County, Nevada: Economic Geology, v. 102, p. 193-224.

Vikre, P.G., and Henry, C.D., 2011, Quartz-alunite alteration cells in the southern segment of the ancestral Cascades magmatic arc, in Steininger, R., and Pennell, B., eds., Symposium Proceedings, Great Basin Evolution and Metallogeny: Geological Society of Nevada, Reno, Nev., p. 701-745.

Ward, J.M., 1992, The Cinnabar Canyon sulfur deposit, in Wessel, G.R., and Wimberly, B.H., eds., Native sulfur developments in geology and exploration: Society for Mining, Metallurgy, and Exploration, Inc., p. 159-164.

Wasson, J., 1978, Bodie and Esmeralda: San Francisco, Spaulding, Barto and Co., Steam Book and Job Printers, $60 \mathrm{p}$.

Wedertz, F.S., 1969, Bodie 1859-1900: Bishop, Calif., Community Printing and Publishing, $211 \mathrm{p}$. 
Wesnousky, S.G., 2005, Active faulting in the Walker Lane: Tectonics, v. 24, no. 3, DOI 10.1029/2004TC001645, 35 p.

Whiting, H.A., 1888, Mono County: California State Mining Bureau, Eighth Annual Report of the State Mineralogist, p. 382-401.

Wisser, E., 1960, Relation of ore deposition to doming in the North American cordillera: Geological Society of America Memoir 77, 177 p.
Wolfe, J.A., 1995, Paleoclimatic estimates from Tertiary leaf assemblages: Annual Review of Earth and Planetary Sciences, v. 23, p. 119-142.

Wolfe, J.A., Schorn, H.E., Forest, C.E., and Molnar, P., 1997, Paleobotanical evidence for high altitudes in Nevada during the Miocene: Science, v. 276, p. 1672-1675. 


\section{Appendixes}

1-1. Minor element concentrations in rock samples from the Masonic Mining District.

1-2. Minor element concentrations in rock samples from the Red Wash-East Walker River alteration zone.

1-3. Minor element concentrations in rock samples from the East Brawley Peak alteration zone.

1-4. Minor element concentrations in rock samples from the Sawtooth Ridge alteration zone.

1-5. Minor element concentrations in rock samples from the Aurora Canyon alteration zone.

1-6. Minor element concentrations in rock samples from the Potato Peak alteration zone.

1-7. Minor element concentrations in rock samples from the Aurora Mining District.

1-8. Minor element concentrations in rock samples from the Four Corners alteration zone.

1-9. Minor element concentrations in rock samples from the Paramount-Bald Peak alteration zone.

1-10. Minor element concentrations in rock samples from the Cinnabar Canyon-US 395 alteration zone.

1-11. Minor element concentrations in rock samples from the Bodie Mining District.

1-12. Minor element concentrations in rock samples of Spring Peak sinter. 
Table 1-1. Minor element concentrations in rock samples from the Masonic Mining District.

[-, no data]

\begin{tabular}{|c|c|c|c|c|c|c|c|c|c|c|c|c|c|c|}
\hline $\begin{array}{l}\text { Sample } \\
\text { number }\end{array}$ & Description & Latitude & Longitude & $\begin{array}{c}\text { Au } \\
\mathrm{ppm}\end{array}$ & $\begin{array}{c}\mathrm{Hg} \\
\mathrm{ppm}\end{array}$ & $\begin{array}{l}\text { Al } \\
\%\end{array}$ & $\begin{array}{l}\mathrm{Ca} \\
\%\end{array}$ & $\begin{array}{l}\mathrm{Fe} \\
\%\end{array}$ & $\begin{array}{l}\mathbf{K} \\
\%\end{array}$ & $\begin{array}{c}\mathrm{Mg} \\
\%\end{array}$ & $\begin{array}{c}\mathrm{Na} \\
\%\end{array}$ & $\begin{array}{l}\mathbf{S} \\
\%\end{array}$ & $\begin{array}{l}\mathrm{Ti} \\
\%\end{array}$ & $\begin{array}{c}\mathrm{Ag} \\
\mathrm{ppm}\end{array}$ \\
\hline \multicolumn{15}{|c|}{ 2007-12 samples } \\
\hline MAS09-3 & $\begin{array}{l}\text { Quartz-enargite matrix breccia; upper } \\
\text { Pittsburgh-Liberty Mine dump }\end{array}$ & 38.35711 & -119.11837 & 27.6 & 14.7 & 0.22 & 0.03 & 0.28 & 0.03 & 0.01 & $<0.01$ & 0.34 & 0.49 & 136 \\
\hline MAS09-3A & $\begin{array}{l}\text { Quartz-enargite matrix breccia; upper } \\
\text { Pittsburgh-Liberty Mine dump }\end{array}$ & 38.35744 & -119.12021 & 53.9 & 70 & 0.39 & 0.14 & 1.24 & 0.03 & 0.01 & 0.01 & 1.85 & 0.02 & 395 \\
\hline 07-BA-39A & Open cut dump, Sarita Mine & 38.36008821 & -119.1258767 & 25.2 & 4.92 & 1.88 & 0.03 & 3.51 & 0.34 & $<0.01$ & 0.06 & 2.84 & 0.11 & 22 \\
\hline 07-BA-39B & Open cut dump, Sarita Mine & 38.36008821 & -119.1258767 & 9.21 & 1.76 & 3.22 & 0.06 & 1.71 & 0.66 & $<0.01$ & 0.17 & 1.58 & 0.16 & 15 \\
\hline $12-\mathrm{BA}-21 \mathrm{~A}$ & Sarita Mine, banded sulfide sediments & 38.36093606 & -119.1260979 & 4.57 & 85.7 & 0.35 & 0.19 & 1.5 & 0.05 & 0.04 & 0.01 & 1.12 & 0.57 & 238 \\
\hline 12-BA-21B & Sarita Mine, banded sulfide sediments & 38.36093606 & -119.1260979 & 82.3 & 27 & 0.18 & 0.01 & 0.66 & 0.02 & $<0.01$ & $<0.01$ & 0.05 & 0.86 & 99 \\
\hline 07-BA-35 & Success Mine dump & 38.34030246 & -119.1558718 & 0.209 & 14.3 & 3.22 & 0.07 & 1.07 & 0.37 & $<0.01$ & 0.04 & 1.32 & 0.25 & $<1$ \\
\hline 07-BA-35B & Pyrite-rich alteration, Success Mine dump & 38.34030246 & -119.1558718 & 0.246 & 8.02 & 5.87 & 0.02 & 0.55 & 2.73 & $<0.01$ & 0.14 & 4.92 & 0.22 & $<1$ \\
\hline 07-BA-36 & Chemung Mine dump & 38.3500062 & -119.1470806 & 0.059 & 8.65 & 3.43 & 0.04 & 1.09 & 1.52 & $<0.01$ & 0.1 & 2.81 & 0.31 & 9 \\
\hline 07-BA-37 & Bladed alunite in vuggy silica, Chemung Mine & 38.3500062 & -119.1470806 & 0.164 & 20.1 & 2.91 & 0.03 & 0.76 & 0.47 & 0.01 & 0.06 & 0.96 & 0.12 & 25 \\
\hline 07-BA-40 & Coarse alunite, Pittsburgh-Liberty Mine dump & 38.36546144 & -119.1160664 & 0.052 & 0.26 & 9.77 & 0.02 & 0.27 & 2.73 & $<0.01$ & 0.26 & 4.3 & 0.07 & $<1$ \\
\hline 07-BA-41 & $\begin{array}{l}\text { Quartz-pyrite alteration, Pittsburgh-Liberty } \\
\text { Mine dump }\end{array}$ & 38.36546144 & -119.1160664 & 0.048 & 2.14 & 6.01 & 0.02 & 2.52 & 2.78 & $<0.01$ & 0.11 & 5.67 & $<0.01$ & 4 \\
\hline 07MS5 & Breccia, Chemung Mine & 38.34973 & -119.14801 & 2.55 & 22.9 & 0.75 & 0.06 & 0.55 & 0.05 & 0.03 & 0.01 & 0.09 & 0.15 & 114 \\
\hline $07 \mathrm{MS} 3$ & Vuggy silica breccia, Chemung Mine & 38.3499 & -119.14761 & 0.241 & 22.8 & 0.39 & 0.06 & 0.35 & 0.04 & $<0.01$ & $<0.01$ & 0.2 & 0.24 & 83 \\
\hline 07MS2 & Tan and black chalcedony, Chemung Mine & 38.34945 & -119.14761 & 0.221 & 3.51 & 2.99 & 0.02 & 0.91 & 0.17 & $<0.01$ & 0.01 & 1.15 & 0.11 & 1 \\
\hline MAS11-11 & Gray-black multigenerational sulfidic breccia & 38.34021 & -119.15672 & 0.178 & 1.59 & 3.49 & 0.08 & 1.8 & 1.06 & $<0.01$ & 0.16 & 3.85 & 0.28 & 4 \\
\hline \multirow[t]{2}{*}{ MAS11-11A } & $\begin{array}{l}\text { Brecciated sedimentary rocks with banded } \\
\text { quartz-sulfide-alunite matrix }\end{array}$ & 38.356679 & -119.11899 & 1.96 & 15.7 & 7.73 & 0.09 & 0.64 & 3.18 & $<0.01$ & 0.25 & $>5$ & 0.54 & 53 \\
\hline & & & & $\begin{array}{c}\text { Au } \\
\text { ppm }\end{array}$ & $\begin{array}{c}\mathrm{Hg} \\
\mathrm{ppm}\end{array}$ & & & & & & & & & $\begin{array}{c}\mathrm{Ag} \\
\mathrm{ppm}\end{array}$ \\
\hline \multicolumn{15}{|c|}{1988 samples } \\
\hline MD88-1 & Chemung Mine dump & 38.34955 & -119.14959 & 6.36 & 28.7 & & & & & & & & & 136.3 \\
\hline MD88-1C & Chemung Mine dump & 38.34955 & -119.14959 & 2.92 & 31.9 & & & & & & & & & 198.6 \\
\hline MD88-3C & Success Mine dump & 38.34019 & -119.15659 & 0.34 & 18.7 & & & & & & & & & $<1.7$ \\
\hline MD88-4 & Sarita Mine dump & 38.36052 & -119.12716 & 6.15 & 27.6 & & & & & & & & & 119.7 \\
\hline MD88-4A & Sarita Mine dump & 38.36052 & -119.12716 & 11.56 & 43.1 & & & & & & & & & 302.3 \\
\hline MD88-4C & Sarita Mine dump & 38.36052 & -119.12716 & 11.66 & 16.3 & & & & & & & & & 44.9 \\
\hline MD88-5A & Masonic mill dump & 38.36705 & -119.11901 & 40.09 & 17.5 & & & & & & & & & 106 \\
\hline MD88-5B & Masonic mill dump & 38.36705 & -119.11901 & 36.79 & 31.9 & & & & & & & & & 114.9 \\
\hline
\end{tabular}

MD88-5B Masonic mill dump 
Table 1-1. Minor element concentrations in rock samples from the Masonic Mining District.—Continued

[-, no data]

\begin{tabular}{|c|c|c|c|c|c|c|c|c|c|c|c|c|c|c|c|c|c|}
\hline $\begin{array}{l}\text { Sample } \\
\text { number }\end{array}$ & $\begin{array}{c}\text { As } \\
\mathrm{ppm}\end{array}$ & $\begin{array}{c}\mathrm{Ba} \\
\mathrm{ppm}\end{array}$ & $\begin{array}{c}\mathrm{Be} \\
\mathrm{ppm}\end{array}$ & $\begin{array}{c}\mathrm{Bi} \\
\mathrm{ppm}\end{array}$ & $\begin{array}{c}\text { Cd } \\
\text { ppm }\end{array}$ & $\begin{array}{c}\mathrm{Ce} \\
\mathrm{ppm}\end{array}$ & $\begin{array}{c}\text { Co } \\
\text { ppm }\end{array}$ & $\begin{array}{c}\mathrm{Cr} \\
\mathrm{ppm}\end{array}$ & $\begin{array}{c}\text { Cs } \\
\mathrm{ppm}\end{array}$ & $\begin{array}{c}\mathrm{Cu} \\
\mathrm{ppm}\end{array}$ & $\begin{array}{c}\text { Ga } \\
\text { ppm }\end{array}$ & $\begin{array}{l}\text { In } \\
\text { ppm }\end{array}$ & $\begin{array}{c}\text { La } \\
\text { ppm }\end{array}$ & $\begin{array}{c}\text { Li } \\
\text { ppm }\end{array}$ & $\begin{array}{l}\text { Mn } \\
\text { ppm }\end{array}$ & $\begin{array}{l}\text { Mo } \\
\text { ppm }\end{array}$ & $\begin{array}{l}\mathrm{Nb} \\
\mathrm{ppm}\end{array}$ \\
\hline \multicolumn{18}{|c|}{ 2007-12 samples } \\
\hline MAS09-3 & 1,040 & 1,530 & 1.1 & 1,050 & 0.6 & 5.18 & 0.3 & 3 & $<5$ & 3,140 & 3.49 & 0.35 & 2.8 & 2 & 14 & 15.5 & 8.4 \\
\hline MAS09-3A & $>10,000$ & 242 & $<0.1$ & 4,310 & 0.7 & 5.54 & 0.6 & 2 & $<5$ & $>50,000$ & 3.68 & 0.49 & 3.5 & 3 & 15 & 6.91 & $<0.1$ \\
\hline 07-BA-39A & 145 & 478 & 0.6 & 189 & $<0.1$ & 8.53 & 6 & 7 & $<5$ & 179 & 11.8 & 0.08 & 4.4 & 16 & 95 & 5.13 & 1.9 \\
\hline 07-BA-39B & 146 & 548 & 0.2 & 57.1 & $<0.1$ & 12.8 & 0.4 & 8 & $<5$ & 72.8 & 22.6 & 0.17 & 7 & 12 & 78 & 1.74 & 2.2 \\
\hline 12-BA-21A & 549 & 652 & 0.7 & 2,780 & 0.5 & 7.05 & 3.3 & 6 & $<5$ & 1,310 & 4.83 & 0.27 & 3.8 & 7 & 50 & 15.4 & 8.6 \\
\hline 12-BA-21B & 315 & 562 & 0.8 & 2,610 & 0.5 & 4.31 & 0.6 & 5 & $<5$ & 325 & 3.91 & 0.17 & 2.3 & 4 & 45 & 3.04 & 13.9 \\
\hline 07-BA-35 & 256 & 1,230 & 0.4 & 0.06 & 0.3 & 35.1 & 6.1 & 8 & $<5$ & 25.1 & 10.4 & 0.07 & 18 & 18 & 56 & 4.54 & 7.7 \\
\hline 07-BA-35B & 81 & 547 & 0.2 & 0.1 & 0.2 & 27.5 & 2.4 & 9 & $<5$ & 15.9 & 13.7 & 0.02 & 16.1 & 1 & 20 & 0.41 & 8 \\
\hline 07-BA-36 & 50 & 2,750 & 0.4 & 0.56 & $<0.1$ & 30.4 & 0.8 & 15 & $<5$ & 16.9 & 29 & 0.1 & 16.7 & 4 & 26 & 5.03 & 3.7 \\
\hline 07-BA-37 & 40 & 1,940 & 0.4 & 1.25 & $<0.1$ & 11.5 & 0.8 & 7 & $<5$ & 11.2 & 8.98 & $<0.02$ & 6.7 & 7 & 42 & 3.19 & 3.5 \\
\hline 07-BA-40 & 12 & 535 & 0.3 & 0.92 & $<0.1$ & 9.74 & 0.3 & 2 & $<5$ & 4.8 & 20.9 & 0.31 & 4.9 & 11 & 14 & 0.3 & 3.7 \\
\hline 07-BA-41 & 66 & 693 & $<0.1$ & 7.06 & 0.3 & 12.1 & 5.5 & 8 & $<5$ & 49.5 & 53.2 & 0.46 & 7.7 & 3 & 9 & 0.38 & 0.3 \\
\hline 07MS5 & 59 & 1,020 & 0.6 & 15.8 & $<0.1$ & 18 & 0.6 & 5 & $<5$ & 15.8 & 2.18 & 0.04 & 8.9 & 4 & 30 & 4.18 & 3.1 \\
\hline 07MS3 & 35 & 6,120 & 0.3 & 24.7 & $<0.1$ & 17.8 & 0.7 & 5 & $<5$ & 7.9 & 1.28 & 0.02 & 10 & 2 & 52 & 5.73 & 4.5 \\
\hline 07MS2 & 67 & 244 & 0.4 & 0.06 & $<0.1$ & 22.5 & 4.2 & 6 & $<5$ & 11 & 11 & $<0.02$ & 10.6 & 4 & 25 & 2.4 & 2.5 \\
\hline MAS11-11 & 46 & 209 & 0.2 & 13.3 & $<0.1$ & 32.9 & 3.3 & 7 & $<5$ & 68.8 & 31.8 & 0.06 & 17.4 & 5 & 28 & 0.89 & 4.5 \\
\hline MAS11-11A & 788 & 97 & 0.3 & 4,340 & 0.3 & 49.8 & 0.3 & 15 & $<5$ & 191 & 66.5 & 0.31 & 26 & 3 & 29 & 4.37 & 8.1 \\
\hline & $\begin{array}{c}\text { As } \\
\text { ppm }\end{array}$ & & & $\begin{array}{c}\mathrm{Bi} \\
\mathrm{ppm}\end{array}$ & & & & & & $\begin{array}{c}\mathrm{Cu} \\
\mathrm{ppm}\end{array}$ & & & & & & & \\
\hline \multicolumn{18}{|c|}{1988 samples } \\
\hline MD88-1 & 592 & & & 1 & & & & & & 1,270 & & & & & & & \\
\hline MD88-1C & 588 & & & 24.8 & & & & & & 2,700 & & & & & & & \\
\hline MD88-3C & 526 & & & 0.3 & & & & & & 56 & & & & & & & \\
\hline MD88-4 & 680 & & & 0.034 & & & & & & 163 & & & & & & & \\
\hline MD88-4A & 3,107 & & & 0.093 & & & & & & 2,900 & & & & & & & \\
\hline MD88-4C & 174 & & & 916 & & & & & & 600 & & & & & & & \\
\hline MD88-5A & 265 & & & 2,900 & & & & & & 3,500 & & & & & & & \\
\hline MD88-5B & 370 & & & 3,110 & & & & & & 1,230 & & & & & & & \\
\hline
\end{tabular}


Table 1-1. Minor element concentrations in rock samples from the Masonic Mining District.-Continued

$[-$, no data $]$

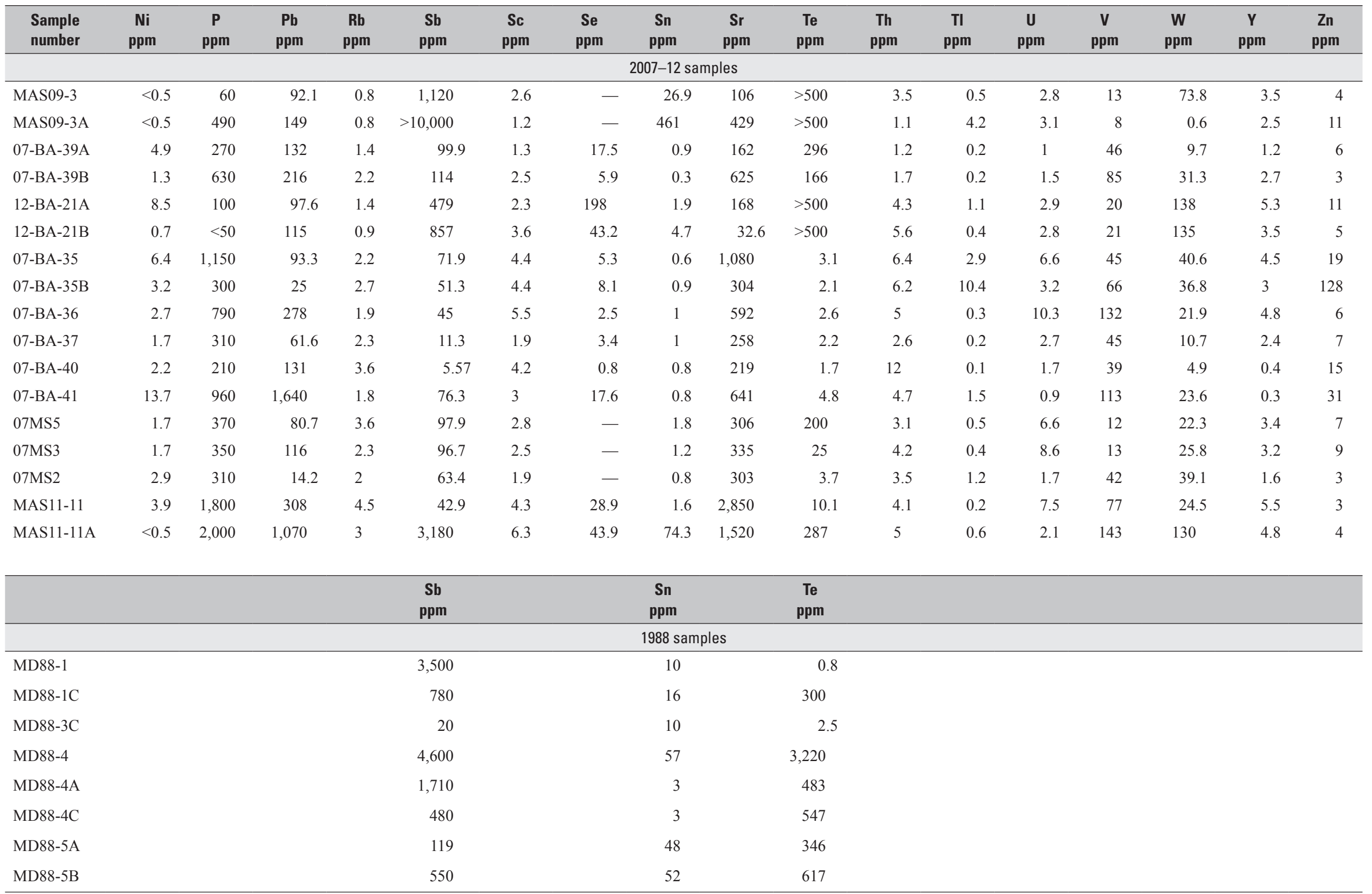


Table 1-2. Minor element concentrations in rock samples from the Red Wash-East Walker River alteration zone.

[Fe, iron; FeOx, iron oxide; - , no data $]$

\begin{tabular}{|c|c|c|c|c|c|c|c|c|c|c|c|c|c|c|}
\hline $\begin{array}{l}\text { Sample } \\
\text { number }\end{array}$ & Description & Latitude & Longitude & $\begin{array}{c}\text { Au } \\
\text { ppm }\end{array}$ & $\begin{array}{c}\mathrm{Hg} \\
\mathrm{ppm}\end{array}$ & $\begin{array}{l}\text { Al } \\
\%\end{array}$ & $\begin{array}{l}\mathrm{Ca} \\
\%\end{array}$ & $\begin{array}{l}\mathrm{Fe} \\
\%\end{array}$ & $\begin{array}{l}\mathbf{K} \\
\%\end{array}$ & $\begin{array}{c}\mathrm{Mg} \\
\%\end{array}$ & $\begin{array}{l}\mathrm{Na} \\
\%\end{array}$ & $\begin{array}{l}\mathbf{S} \\
\%\end{array}$ & $\begin{array}{l}\mathrm{Ti} \\
\%\end{array}$ & $\begin{array}{c}\mathrm{Ag} \\
\mathrm{ppm}\end{array}$ \\
\hline 09-E02 & - & - & - & - & 1.42 & 4 & - & - & 0.03 & 0.01 & 0.02 & 0.96 & 0.22 & 1.2 \\
\hline 09-E04 & - & - & - & - & 2.7 & 4.86 & - & - & 0.05 & 0.02 & 0.02 & 0.11 & 0.28 & 1.2 \\
\hline 09-E09 & Silicified with quartz veins & - & - & $<0.005$ & 0.35 & 7.15 & 0.23 & 4 & 2.04 & 0.02 & 0.67 & $>5$ & 0.19 & $<1$ \\
\hline 09-E10 & - & - & - & - & 0.4 & 2.14 & - & - & 0.35 & 0.1 & 0.08 & 0.93 & 0.07 & $<0.5$ \\
\hline 09-E11 & Vuggy, silica-cut quartz veins & - & - & $<0.005$ & 0.07 & 5.86 & 0.17 & 0.44 & 1.39 & $<0.01$ & 0.67 & 4.32 & 0.29 & $<1$ \\
\hline 09-E12 & Clastic sediment; Fe-cemented & - & - & $<0.005$ & 0.2 & 0.62 & 0.19 & 12 & 0.08 & 0.03 & 0.02 & 0.19 & 0.15 & $<1$ \\
\hline 09-E13 & Volcaniclastic silicified rib with Fe & - & - & 0.006 & 0.09 & 0.36 & 0.16 & 12 & 0.02 & 0.03 & $<0.01$ & 0.14 & 0.06 & $<1$ \\
\hline 09-E14 & - & - & - & - & 0.45 & 0.19 & - & - & 0.02 & 0.01 & 0.01 & 0.1 & 0.32 & $<0.5$ \\
\hline 09-E015 & - & - & - & - & 1.68 & 0.14 & - & - & 0.01 & 0.01 & $<0.01$ & 0.04 & 0.26 & $<0.5$ \\
\hline 09-E16 & Fe-rich volcaniclastic sediment; silicified & - & - & 0.01 & 0.01 & 0.42 & 0.18 & 2.21 & 0.05 & 0.01 & 0.01 & 0.24 & 0.13 & $<1$ \\
\hline 09-E18 & $\begin{array}{l}\text { Fe on fractures in volcaniclastic; sediment } \\
\text { silicified }\end{array}$ & - & - & $<0.005$ & 0.07 & 4.99 & 0.45 & 13 & 1.05 & 0.01 & 0.56 & 3.94 & 0.1 & $<1$ \\
\hline 09-E19 & Breccia with silicified quartz vein & - & - & $<0.005$ & $<0.01$ & 8.43 & 7.76 & 4.34 & 1.13 & 1.69 & 2.05 & 0.03 & 0.34 & $<1$ \\
\hline 09-E20 & Breccia with silicified quartz vein & - & - & $<0.005$ & 0.82 & 2.27 & 0.08 & 1.35 & 0.3 & $<0.01$ & 0.34 & 1.69 & 0.14 & $<1$ \\
\hline 09-E23 & Silicified tuff cut by $\mathrm{Fe}$ on fractures & - & - & $<0.005$ & 0.38 & 5.55 & 0.16 & 8.85 & 0.31 & 0.02 & 0.1 & 0.99 & 0.16 & $<1$ \\
\hline 09-E24 & $\begin{array}{l}\text { Vuggy silica float cut by Fe-stained quartz } \\
\text { veins }\end{array}$ & 38.40844 & -119.09776 & 0.006 & 0.14 & 4.76 & 0.14 & 7.93 & 1.35 & 0.02 & 0.25 & 2.98 & 0.28 & $<1$ \\
\hline 09-E25 & Vuggy silica cut by Fe-stained quartz veins & 38.40843 & -119.09809 & $<0.005$ & 0.05 & 3.81 & 0.12 & 5.9 & 0.71 & 0.01 & 0.44 & 2.81 & 0.1 & $<1$ \\
\hline \multirow[t]{2}{*}{ 09-E27 } & Silica core of alteration cut by Fe veinlets & 38.41013 & -119.10394 & 0.03 & 5.19 & 2.3 & 0.09 & $>15$ & 0.59 & $<0.01$ & 0.12 & 1.43 & 0.14 & $<1$ \\
\hline & & Latitude & Longitude & $\begin{array}{c}\text { Au } \\
\text { ppb }\end{array}$ & $\begin{array}{l}\mathrm{Pd} \\
\mathrm{ppb}\end{array}$ & $\begin{array}{c}\mathrm{Pt} \\
\mathrm{ppb}\end{array}$ & $\begin{array}{l}\text { Al } \\
\%\end{array}$ & $\begin{array}{c}\mathrm{Ca} \\
\%\end{array}$ & $\begin{array}{l}\mathrm{Fe} \\
\%\end{array}$ & $\begin{array}{l}\mathbf{K} \\
\%\end{array}$ & $\begin{array}{c}\mathrm{Mg} \\
\%\end{array}$ & $\begin{array}{c}\mathrm{Na} \\
\%\end{array}$ & $\begin{array}{l}\mathbf{S} \\
\%\end{array}$ & $\begin{array}{l}\mathrm{Ti} \\
\%\end{array}$ \\
\hline RW11-1 & $\begin{array}{l}\text { Brick-red (FeOx), soft, variably leached volca- } \\
\text { niclastic deposits }\end{array}$ & 38.40473 & -119.06708 & 21 & 2 & 1.6 & 0.73 & 0.15 & 0.63 & 0.07 & 0.07 & 0.03 & 0.08 & 0.33 \\
\hline RW11-2ME & $\begin{array}{l}\text { Silicified, FeOx-stained volcaniclastics, vari- } \\
\text { ably leached, resistant }\end{array}$ & 38.407 & -119.07178 & 4 & $<1$ & 0.5 & 5.53 & 0.39 & 0.73 & 1.33 & 0.01 & 0.71 & 4.31 & 0.47 \\
\hline RW11-3ME & $\begin{array}{l}\text { Silicified, FeOx-stained Masonic andesite with } \\
\text { clay-altered phenocrysts }\end{array}$ & 38.40191 & -119.06982 & 3 & $<1$ & $<0.5$ & 7.48 & 0.27 & 3.77 & 0.9 & 0.02 & 0.54 & 3.47 & 0.41 \\
\hline RW11-4ME & $\begin{array}{l}\text { Beige-brick-red, clay-altered, partly silicified } \\
\text { volcaniclastics }\end{array}$ & 38.40318 & -119.07082 & 6 & $<1$ & 0.5 & 4.81 & 0.26 & 3.22 & 1.4 & 0.02 & 0.56 & 4.35 & 0.14 \\
\hline RW11-5ME & $\begin{array}{l}\text { Silicified, clay-alunite-altered, variably sorted } \\
\text { volcaniclastics, some FeOx }\end{array}$ & 38.4006 & -119.06973 & 4 & $<1$ & $<0.5$ & 6.82 & 0.16 & 4.33 & 2.15 & 0.02 & 0.84 & $>5$ & 0.34 \\
\hline
\end{tabular}


Table 1-2. Minor element concentrations in rock samples from the Red Wash-East Walker River alteration zone.-Continued

[Fe, iron; $\mathrm{FeOx}$, iron oxide; - , no data]

\begin{tabular}{|c|c|c|c|c|c|c|c|c|c|c|c|c|c|c|c|c|c|c|}
\hline $\begin{array}{l}\text { Sample } \\
\text { number }\end{array}$ & $\begin{array}{l}\text { As } \\
\mathrm{ppm}\end{array}$ & $\begin{array}{l}\text { Ba } \\
\text { ppm }\end{array}$ & $\begin{array}{c}\mathrm{Be} \\
\mathrm{ppm}\end{array}$ & $\begin{array}{c}\mathrm{Bi} \\
\mathrm{ppm}\end{array}$ & $\begin{array}{c}\text { Cd } \\
\text { ppm }\end{array}$ & $\begin{array}{l}\text { Ce } \\
\text { ppm }\end{array}$ & $\begin{array}{c}\text { Co } \\
\text { ppm }\end{array}$ & $\begin{array}{c}\text { Cr } \\
\text { ppm }\end{array}$ & $\begin{array}{c}\text { Cs } \\
\text { ppm }\end{array}$ & $\begin{array}{c}\text { Cu } \\
\text { ppm }\end{array}$ & $\begin{array}{c}\text { Ga } \\
\text { ppm }\end{array}$ & $\begin{array}{c}\text { In } \\
\text { ppm }\end{array}$ & $\begin{array}{l}\text { La } \\
\text { ppm }\end{array}$ & $\begin{array}{c}\mathrm{Li} \\
\mathrm{ppm}\end{array}$ & $\begin{array}{l}\text { Mn } \\
\text { ppm }\end{array}$ & $\begin{array}{l}\text { Mo } \\
\text { ppm }\end{array}$ & $\begin{array}{c}\mathrm{Nb} \\
\mathrm{ppm}\end{array}$ & $\begin{array}{c}\mathrm{Ni} \\
\mathrm{ppm}\end{array}$ \\
\hline 09-E02 & 9 & 560 & $<0.5$ & 7 & 0.05 & $<0.5$ & 2 & 21 & 44 & 0.63 & 20 & - & 20 & - & 11 & 4 & - & 1 \\
\hline 09-E04 & 8 & 130 & $<0.5$ & 4 & 0.08 & $<0.5$ & 3 & 23 & 107 & 2.08 & 20 & - & 20 & - & 41 & 18 & - & 1 \\
\hline 09-E09 & 28 & 181 & 0.3 & 1.8 & $<0.1$ & 42.7 & 0.9 & 9 & $<5$ & 34.7 & 27.7 & 0.06 & 22.5 & $<1$ & 39 & 1.98 & 3.6 & 1.3 \\
\hline 09-E10 & 65 & 1,120 & 0.7 & $<2$ & 0.27 & 0.5 & $<1$ & 76 & 62 & 25 & 20 & - & 10 & - & 126 & 14 & - & 7 \\
\hline 09-E11 & 8 & 346 & 0.5 & 4.36 & $<0.1$ & 97.2 & 0.4 & 6 & $<5$ & 7.9 & 22.2 & $<0.02$ & 44.3 & $<1$ & 33 & 0.96 & 4.5 & 0.9 \\
\hline 09-E12 & 47 & 1,240 & 0.4 & 0.69 & $<0.1$ & 20.6 & 1.4 & 10 & $<5$ & 33.2 & 2.02 & $<0.02$ & 11 & 2 & 182 & 6.32 & 2.4 & 1 \\
\hline 09-E13 & 42 & 1,160 & 0.3 & 0.66 & 0.2 & 4.94 & 2 & 8 & $<5$ & 42.5 & 4.94 & 0.03 & 2.2 & 1 & 168 & 23.5 & 1.1 & 2 \\
\hline 09-E14 & 12 & 2,410 & $<0.5$ & 2 & 0.04 & $<0.5$ & $<1$ & 15 & 16 & 0.21 & $<10$ & - & $<10$ & - & 12 & 1 & - & $<1$ \\
\hline 09-E015 & 8 & 360 & $<0.5$ & 2 & 0.01 & $<0.5$ & 1 & 20 & 9 & 0.27 & $<10$ & - & $<10$ & - & 21 & 2 & - & 1 \\
\hline 09-E16 & 34 & 1,240 & 0.2 & 0.59 & $<0.1$ & 14.8 & 1.4 & 3 & $<5$ & 17.1 & 2.07 & $<0.02$ & 7.8 & 9 & 109 & 21.5 & 2.5 & 2.1 \\
\hline 09-E18 & 477 & 385 & 0.2 & 0.9 & $<0.1$ & 82.4 & 1.2 & 14 & $<5$ & 33.4 & 22.9 & 0.06 & 43.8 & $<1$ & 59 & 24 & 1.9 & $<0.5$ \\
\hline 09-E19 & $<1$ & 1,320 & 1.4 & $<0.04$ & $<0.1$ & 50.6 & 30.1 & 146 & $<5$ & 33.2 & 20.3 & 0.05 & 30.3 & 5 & 789 & 0.29 & 5 & 117 \\
\hline 09-E20 & 11 & 1,120 & 0.1 & 0.96 & $<0.1$ & 25.8 & 0.6 & 5 & $<5$ & 14.4 & 4.31 & 0.04 & 15.3 & $<1$ & 25 & 3.24 & 4.5 & 1.2 \\
\hline 09-E23 & 41 & 1,100 & 0.3 & 0.52 & $<0.1$ & 31.8 & 0.9 & 22 & $<5$ & 148 & 22.6 & 0.07 & 17.6 & 13 & 33 & 68 & 1.9 & $<0.5$ \\
\hline 09-E24 & 50 & 512 & 0.8 & 1.29 & $<0.1$ & 80.9 & 1 & 30 & $<5$ & 70.3 & 26.9 & 0.12 & 43.8 & 2 & 88 & 11.5 & 7.3 & 1.9 \\
\hline 09-E25 & 43 & 869 & 0.5 & 0.43 & 0.1 & 35 & 2 & 11 & $<5$ & 87.7 & 18.1 & 0.06 & 19.6 & $<1$ & 70 & 8.33 & 2.2 & 3.1 \\
\hline \multirow[t]{2}{*}{ 09-E27 } & 205 & 731 & 0.2 & 0.82 & 0.2 & 39.5 & 5.5 & 93 & $<5$ & 189 & 52.1 & 0.12 & 23 & 3 & 42 & 168 & 1.5 & 8.8 \\
\hline & $\begin{array}{c}\mathrm{Ag} \\
\mathrm{ppm}\end{array}$ & $\begin{array}{c}\text { As } \\
\text { ppm }\end{array}$ & $\begin{array}{c}\mathrm{Ba} \\
\mathrm{ppm}\end{array}$ & $\begin{array}{c}\mathrm{Be} \\
\mathrm{ppm}\end{array}$ & $\begin{array}{c}\mathrm{Bi} \\
\mathrm{ppm}\end{array}$ & $\begin{array}{l}\text { Cd } \\
\text { ppm }\end{array}$ & $\begin{array}{c}\text { Ce } \\
\text { ppm }\end{array}$ & $\begin{array}{c}\text { Co } \\
\text { ppm }\end{array}$ & $\underset{\mathrm{ppm}}{\mathrm{Cr}}$ & $\begin{array}{c}\text { Cs } \\
\text { ppm }\end{array}$ & $\begin{array}{c}\text { Cu } \\
\text { ppm }\end{array}$ & $\begin{array}{c}\text { Ga } \\
\text { ppm }\end{array}$ & $\begin{array}{c}\mathrm{Hg} \\
\mathrm{ppm}\end{array}$ & $\begin{array}{l}\text { In } \\
\text { ppm }\end{array}$ & $\begin{array}{l}\text { La } \\
\text { ppm }\end{array}$ & $\begin{array}{c}\mathrm{Li} \\
\mathrm{ppm}\end{array}$ & $\begin{array}{l}\text { Mn } \\
\text { ppm }\end{array}$ & $\begin{array}{l}\text { Mo } \\
\text { ppm }\end{array}$ \\
\hline RW11-1 & $<1$ & 10 & 1,000 & 0.2 & 0.18 & 0.1 & 12 & 1.2 & 4 & $<5$ & 20.7 & 2.03 & 0.04 & $<0.02$ & 6.5 & 17 & 131 & 6.11 \\
\hline RW11-2ME & $<1$ & 16 & 109 & 0.6 & 0.2 & $<0.1$ & 41.3 & 0.9 & 15 & $<5$ & 8 & 14.9 & 0.01 & 0.04 & 19.9 & 2 & 80 & 3.14 \\
\hline RW11-3ME & $<1$ & 31 & 134 & 0.3 & 1.37 & $<0.1$ & 64.1 & 0.3 & 20 & $<5$ & 39.3 & 23.5 & 0.13 & 0.07 & 32.6 & 4 & 21 & 2.46 \\
\hline RW11-4ME & $<1$ & 21 & 89 & 0.2 & 1.57 & $<0.1$ & 31.5 & 0.7 & 9 & $<5$ & 6.5 & 12.7 & 0.06 & 0.02 & 15.3 & $<1$ & 39 & 21 \\
\hline RW11-5ME & $<1$ & 36 & 82 & 0.4 & 0.6 & $<0.1$ & 51.4 & 0.2 & 22 & $<5$ & 24.8 & 22.8 & 0.09 & 0.05 & 26.3 & 1 & 20 & 3.72 \\
\hline
\end{tabular}


Table 1-2. Minor element concentrations in rock samples from the Red Wash-East Walker River alteration zone.-Continued

$[\mathrm{Fe}$, iron, $\mathrm{FeOx}$, iron oxide; - , no data]

\begin{tabular}{|c|c|c|c|c|c|c|c|c|c|c|c|c|c|c|c|c|c|c|}
\hline $\begin{array}{l}\text { Sample } \\
\text { number }\end{array}$ & $\begin{array}{c}P \\
\mathrm{ppm}\end{array}$ & $\begin{array}{c}\mathrm{Pb} \\
\mathrm{ppm}\end{array}$ & $\begin{array}{c}\mathbf{R b} \\
\mathbf{p p m}\end{array}$ & $\begin{array}{c}\text { Sb } \\
\text { ppm }\end{array}$ & $\begin{array}{c}\text { Sc } \\
\text { ppm }\end{array}$ & $\begin{array}{c}\text { Sn } \\
\text { ppm }\end{array}$ & $\begin{array}{c}\mathrm{Sr} \\
\mathrm{ppm}\end{array}$ & $\begin{array}{c}\text { Te } \\
\text { ppm }\end{array}$ & $\begin{array}{c}\text { Th } \\
\text { ppm }\end{array}$ & $\begin{array}{c}\mathrm{TI} \\
\mathrm{ppm}\end{array}$ & $\underset{\mathrm{ppm}}{\mathbf{U}}$ & $\begin{array}{c}\mathbf{V} \\
\mathrm{ppm}\end{array}$ & $\underset{\mathbf{p p m}}{\mathbf{W}}$ & $\begin{array}{c}\mathrm{Y} \\
\mathrm{ppm}\end{array}$ & $\begin{array}{c}\mathrm{Zn} \\
\mathrm{ppm}\end{array}$ & $\begin{array}{c}\text { Se } \\
\text { ppm }\end{array}$ & $\begin{array}{l}\text { C } \\
\%\end{array}$ & \\
\hline 09-E02 & 680 & 258 & - & 11 & 4 & - & 881 & - & $<20$ & $<10$ & $<10$ & 76 & $<10$ & - & 3 & - & - & \\
\hline 09-E04 & 910 & 136 & - & 15 & 5 & - & 990 & - & $<20$ & $<10$ & $<10$ & 77 & 10 & - & 15 & - & - & \\
\hline 09-E09 & 1,840 & 16.3 & 11.3 & 1.07 & 4 & 0.9 & 815 & 1 & 4.9 & 0.8 & 0.9 & 163 & 0.2 & 4.1 & 6 & - & - & \\
\hline 09-E10 & 2,430 & 21 & - & $<5$ & 3 & - & 849 & - & $<20$ & $<10$ & 10 & 104 & $<10$ & - & 47 & - & - & \\
\hline 09-E11 & 2,030 & 17.7 & 2.8 & 1.28 & 5.5 & 1.5 & 1,090 & 0.4 & 10.5 & $<0.1$ & 1 & 151 & 0.3 & 2.9 & 6 & - & - & \\
\hline 09-E12 & 1,810 & 7.2 & 2.4 & 0.31 & 1.4 & 0.4 & 379 & 0.1 & 2.7 & $<0.1$ & 1.5 & 31 & 0.2 & 2.1 & 20 & - & - & \\
\hline 09-E13 & 660 & 5.2 & 1.1 & 0.37 & 0.9 & 0.8 & 42.2 & 0.4 & 1.6 & $<0.1$ & 1.1 & 73 & 0.3 & 2.5 & 16 & - & - & \\
\hline 09-E14 & 40 & 7 & - & 7 & 1 & - & 38 & - & $<20$ & $<10$ & $<10$ & 6 & $<10$ & - & $<2$ & - & - & \\
\hline 09-E015 & 30 & 4 & - & 8 & $<1$ & - & 19 & - & $<20$ & $<10$ & $<10$ & 4 & $<10$ & - & $<2$ & - & - & \\
\hline 09-E16 & 870 & 23.4 & 1.5 & 2.35 & 0.5 & 0.6 & 190 & 1 & 4.6 & 0.2 & 1.3 & 38 & 0.6 & 1.7 & 4 & - & - & \\
\hline 09-E18 & 2,290 & 23.2 & 3.3 & 2.67 & 2.7 & 0.7 & 1,390 & 5.4 & 10 & 0.2 & 1.2 & 286 & 0.3 & 2 & 7 & - & - & \\
\hline 09-E19 & 1,340 & 12.3 & 11 & 0.16 & 19.4 & 0.8 & 1,060 & $<0.1$ & 3.1 & $<0.1$ & 0.9 & 112 & $<0.1$ & 13.1 & 79 & - & - & \\
\hline 09-E20 & 870 & 15.4 & 1.4 & 1.29 & 2.8 & 0.7 & 1,010 & 0.3 & 3.2 & 0.2 & 1.1 & 38 & 0.7 & 2.9 & 5 & - & - & \\
\hline 09-E23 & 1,910 & 66 & 0.9 & 0.61 & 2.7 & 2.4 & 2,570 & 2.3 & 2 & $<0.1$ & 0.6 & 125 & 0.7 & 2 & 22 & - & - & \\
\hline 09-E24 & 2,300 & 43.1 & 4.7 & 1.43 & 7.4 & 1.1 & 1,190 & 6.6 & 14.7 & $<0.1$ & 3.5 & 137 & 1.3 & 6.2 & 23 & - & - & \\
\hline 09-E25 & 1,260 & 34.4 & 2.5 & 0.55 & 3.5 & 0.9 & 1,120 & 0.3 & 3.8 & 0.2 & 1.7 & 122 & 0.6 & 3.2 & 11 & - & - & \\
\hline \multirow[t]{2}{*}{ 09-E27 } & 1,670 & 34.2 & 0.7 & 1.85 & 5.3 & 1.1 & 1,210 & 6.2 & 3.8 & $<0.1$ & 0.4 & 508 & 47.5 & 1.6 & 7 & - & - & \\
\hline & $\begin{array}{c}\mathrm{Nb} \\
\mathrm{ppm}\end{array}$ & $\underset{\mathrm{ppm}}{\mathrm{Ni}}$ & $\begin{array}{c}P \\
\text { ppm }\end{array}$ & $\begin{array}{l}\mathrm{Pb} \\
\mathrm{ppm}\end{array}$ & $\begin{array}{c}\text { Rb } \\
\text { ppm }\end{array}$ & $\begin{array}{c}\text { Sb } \\
\text { ppm }\end{array}$ & $\begin{array}{c}\text { Sc } \\
\text { ppm }\end{array}$ & $\begin{array}{c}\mathrm{Se} \\
\mathrm{ppm}\end{array}$ & $\begin{array}{c}\text { Sn } \\
\text { ppm }\end{array}$ & $\begin{array}{c}\mathrm{Sr} \\
\mathrm{ppm}\end{array}$ & $\begin{array}{c}\mathrm{Te} \\
\mathrm{ppm}\end{array}$ & $\begin{array}{c}\text { Th } \\
\text { ppm }\end{array}$ & $\begin{array}{c}\mathrm{TI} \\
\mathrm{ppm}\end{array}$ & $\begin{array}{c}\mathrm{U} \\
\mathrm{ppm}\end{array}$ & $\begin{array}{c}\mathrm{V} \\
\mathrm{ppm}\end{array}$ & $\begin{array}{c}\text { W } \\
\text { ppm }\end{array}$ & $\begin{array}{c}\mathrm{Y} \\
\mathrm{ppm}\end{array}$ & $\begin{array}{c}\mathrm{Zn} \\
\mathrm{ppm}\end{array}$ \\
\hline RW11-1 & 4.5 & 1.8 & 490 & 8.5 & 2.4 & 10.7 & 0.6 & 0.3 & 1 & 139 & 0.7 & 2.4 & 0.2 & 0.7 & 20 & 1.1 & 1.1 & 7 \\
\hline RW11-2ME & 7.8 & 0.9 & 1,260 & 20.5 & 4 & 3.86 & 7.3 & 1 & 1.5 & 816 & 1.1 & 8.1 & 0.2 & 2.4 & 111 & 1.3 & 4.2 & 3 \\
\hline RW11-3ME & 5.2 & 0.6 & 1,960 & 15.1 & 3.2 & 1.22 & 5.5 & 6.6 & 1.6 & 1,260 & 1.6 & 6.6 & 0.2 & 2.2 & 199 & 0.5 & 3.5 & 3 \\
\hline RW11-4ME & 2.1 & 1 & 1,800 & 22.7 & 8.5 & 2.52 & 3.3 & 1.2 & 2.3 & 348 & 0.7 & 5.6 & 0.5 & 0.9 & 70 & 0.5 & 1.6 & 11 \\
\hline RW11-5ME & 4.9 & $<0.5$ & 1,630 & 16.1 & 5.6 & 1.36 & 6.5 & 7 & 1.2 & 952 & 2.1 & 8.8 & 2 & 1.4 & 200 & 0.6 & 2.7 & 3 \\
\hline
\end{tabular}


Table 1-3. Minor element concentrations in rock samples from the East Brawley Peak alteration zone.

$[-$, no data $]$

\begin{tabular}{|c|c|c|c|c|c|c|c|c|c|c|c|c|c|c|c|c|}
\hline $\begin{array}{l}\text { Sample } \\
\text { number }\end{array}$ & Description & Latitude & Longitude & $\begin{array}{c}\text { Au } \\
\text { ppm }\end{array}$ & $\begin{array}{c}\mathrm{Hg} \\
\mathrm{ppm}\end{array}$ & $\begin{array}{l}\text { Al } \\
\%\end{array}$ & $\begin{array}{l}\text { Ca } \\
\%\end{array}$ & $\begin{array}{l}\mathrm{Fe} \\
\%\end{array}$ & $\begin{array}{l}\mathbf{K} \\
\% \\
\end{array}$ & $\begin{array}{c}\mathrm{Mg} \\
\%\end{array}$ & $\begin{array}{l}\mathrm{Na} \\
\%\end{array}$ & $\begin{array}{l}\mathbf{S} \\
\% \\
\end{array}$ & $\begin{array}{l}\mathrm{Ti} \\
\% \\
\end{array}$ & $\begin{array}{c}\mathrm{Ag} \\
\mathrm{ppm}\end{array}$ & $\begin{array}{c}\text { As } \\
\mathrm{ppm}\end{array}$ & $\begin{array}{c}\text { Ba } \\
\mathrm{ppm}\end{array}$ \\
\hline 08-BA-4 & Andesite altered to kaolinite & 38.25567 & -118.90875 & $<0.005$ & 0.34 & 5.32 & 0.17 & 2.56 & 0.06 & 0.02 & 0.02 & 0.29 & 0.31 & $<1$ & 30 & 844 \\
\hline 10-BA-23 & Quartz-dickite altered rhyolite & 38.27127 & -118.91707 & $<0.005$ & 1.8 & $<0.01$ & $<0.01$ & $<0.01$ & $<0.01$ & $<0.01$ & $<0.01$ & $<0.01$ & $<0.01$ & $<1$ & 35 & $<5$ \\
\hline 10-BA-24 & Quartz-dickite alteration & 38.27114 & -118.91754 & 0.009 & 1.11 & 5.73 & 0.01 & 0.09 & 0.02 & $<0.01$ & $<0.01$ & 0.03 & 0.06 & $<1$ & 10 & 458 \\
\hline 10-BA-25 & $\begin{array}{l}\text { Quartz-dickite alteration, head } \\
\text { of landslide }\end{array}$ & 38.26963 & -118.91960 & 0.017 & 0.37 & 0.91 & 0.03 & 0.68 & 0.03 & $<0.01$ & $<0.01$ & 0.12 & 0.43 & $<1$ & 168 & 2,500 \\
\hline
\end{tabular}

Table 1-3. Minor element concentrations in rock samples from the East Brawley Peak alteration zone.-Continued

$[-$, no data $]$

\begin{tabular}{|c|c|c|c|c|c|c|c|c|c|c|c|c|c|c|c|c|}
\hline $\begin{array}{l}\text { Sample } \\
\text { number }\end{array}$ & $\begin{array}{c}\mathrm{Be} \\
\mathrm{ppm}\end{array}$ & $\begin{array}{c}\mathrm{Bi} \\
\mathrm{ppm}\end{array}$ & $\begin{array}{l}\text { Cd } \\
\text { oon }\end{array}$ & $\begin{array}{c}\text { Ce } \\
\text { ppm }\end{array}$ & $\begin{array}{c}\text { Co } \\
\text { ppm }\end{array}$ & $\begin{array}{c}\mathrm{Cr} \\
\mathrm{ppm}\end{array}$ & $\begin{array}{c}\text { Cs } \\
\text { ppm }\end{array}$ & $\begin{array}{c}\mathrm{Cu} \\
\mathrm{ppm}\end{array}$ & $\begin{array}{c}\text { Ga } \\
\text { ppm }\end{array}$ & $\begin{array}{c}\text { In } \\
\text { ppm }\end{array}$ & $\begin{array}{l}\text { La } \\
\text { ppm }\end{array}$ & $\begin{array}{c}\mathrm{Li} \\
\mathrm{ppm}\end{array}$ & $\begin{array}{c}\text { Mn } \\
\text { ppm }\end{array}$ & $\begin{array}{l}\text { Mo } \\
\text { ppm }\end{array}$ & $\begin{array}{c}\mathrm{Nb} \\
\mathrm{ppm}\end{array}$ & $\begin{array}{c}\mathrm{Ni} \\
\mathrm{ppm}\end{array}$ \\
\hline $08-B A-4$ & 0.3 & 0.53 & $<0.1$ & 86.2 & 0.2 & 9 & $<5$ & 28.5 & 22.5 & $<0.02$ & 49.6 & 19 & 26 & 2.48 & 7.8 & $<0.5$ \\
\hline $10-\mathrm{BA}-23$ & 0.9 & 0.14 & $<0.1$ & 46.3 & 0.1 & $<1$ & $<5$ & $<0.5$ & 10.1 & $<0.02$ & 30.7 & $<1$ & $<5$ & 0.8 & 9.7 & $<0.5$ \\
\hline 10-BA-24 & 0.2 & 0.52 & $<0.1$ & 38.9 & 0.2 & 1 & $<5$ & 3 & 14 & $<0.02$ & 24.2 & 12 & 8 & 1.59 & 12.1 & 0.5 \\
\hline $10-B A-25$ & 0.6 & 0.12 & $<0.1$ & 24.9 & 0.2 & 3 & $<5$ & 9.6 & 4.15 & $<0.02$ & 16.2 & 5 & 9 & 32.3 & 9.8 & 0.6 \\
\hline
\end{tabular}

Table 1-3. Minor element concentrations in rock samples from the East Brawley Peak alteration zone.-Continued

$[-$, no data $]$

\begin{tabular}{|c|c|c|c|c|c|c|c|c|c|c|c|c|c|c|c|c|}
\hline $\begin{array}{l}\text { Sample } \\
\text { number }\end{array}$ & $\underset{\mathrm{ppm}}{\mathbf{P}}$ & $\begin{array}{c}\mathrm{Pb} \\
\mathrm{ppm}\end{array}$ & $\begin{array}{c}\text { Rb } \\
\text { ppm }\end{array}$ & $\begin{array}{c}\text { Sb } \\
\text { ppm }\end{array}$ & $\begin{array}{c}\text { Sc } \\
\text { ppm }\end{array}$ & $\begin{array}{c}\text { Sn } \\
\text { ppm }\end{array}$ & $\begin{array}{c}\text { Sr } \\
\text { ppm }\end{array}$ & $\begin{array}{c}\text { Te } \\
\text { ppm }\end{array}$ & $\begin{array}{c}\text { Th } \\
\text { ppm }\end{array}$ & $\begin{array}{c}\mathrm{TI} \\
\text { ppm }\end{array}$ & $\underset{\text { ppm }}{\text { U }}$ & $\begin{array}{c}\text { V } \\
\text { ppm }\end{array}$ & $\begin{array}{c}\text { W } \\
\text { ppm }\end{array}$ & $\begin{array}{c}\mathrm{Y} \\
\mathrm{ppm}\end{array}$ & $\begin{array}{c}\mathrm{Zn} \\
\mathrm{ppm}\end{array}$ & $\begin{array}{c}\text { Se } \\
\text { ppm }\end{array}$ \\
\hline 08-BA-4 & 1,780 & 49.4 & 1.4 & 6.43 & 3.4 & 0.8 & 1,290 & 1.8 & 11.1 & $<0.1$ & 2.1 & 74 & 10 & 4.6 & 4 & - \\
\hline 10-BA-23 & $<50$ & 11.2 & 2.1 & 16 & 2.1 & 0.6 & $<0.5$ & $<0.1$ & 19 & 0.1 & 8.6 & $<1$ & 5.9 & 9.4 & $<1$ & - \\
\hline 10-BA-24 & 110 & 7.4 & 1.2 & 13 & 2.4 & 1 & 59.3 & $<0.1$ & 28.6 & 0.1 & 10.2 & 28 & 4.8 & 5.5 & 3 & - \\
\hline 10-BA-25 & 340 & 19.5 & 1.2 & 20.6 & 1.9 & 1.3 & 297 & $<0.1$ & 4.9 & 0.1 & 1.1 & 38 & 42.6 & 2.3 & 5 & - \\
\hline
\end{tabular}


Table 1-4. Minor element concentrations in rock samples from the Sawtooth Ridge alteration zone.

[FeOx, iron oxide; bxd, brecciated; alt, altered; chal, chalcedony; lim, limonite; bx, breccia; hem, hematite; - , no data]

\begin{tabular}{|c|c|c|c|c|c|c|c|c|c|c|c|c|c|c|c|}
\hline $\begin{array}{l}\text { Sample } \\
\text { number }\end{array}$ & Latitude & Longitude & Description & $\begin{array}{l}\text { Au } \\
\text { ppb }\end{array}$ & $\begin{array}{l}\text { Pd } \\
\text { ppb }\end{array}$ & $\begin{array}{c}\mathrm{Pt} \\
\mathbf{p p b}\end{array}$ & $\begin{array}{l}\text { Al } \\
\%\end{array}$ & $\begin{array}{l}\text { Ca } \\
\%\end{array}$ & $\begin{array}{l}\mathrm{Fe} \\
\%\end{array}$ & $\begin{array}{l}\mathbf{K} \\
\%\end{array}$ & $\begin{array}{c}\mathrm{Mg} \\
\%\end{array}$ & $\begin{array}{c}\mathrm{Na} \\
\%\end{array}$ & $\begin{array}{l}\mathbf{S} \\
\%\end{array}$ & $\begin{array}{l}\mathrm{Ti} \\
\%\end{array}$ & $\begin{array}{c}\mathrm{Ag} \\
\mathrm{ppm}\end{array}$ \\
\hline SAW11-1ME & 38.29305 & -118.90932 & $\begin{array}{l}\text { Brecciated, } \mathrm{FeOx} \text {-stained white } \\
\text { rhyolite }\end{array}$ & 16 & $<1$ & $<0.5$ & 5.96 & 0.08 & 0.43 & 0.11 & 0.07 & 0.04 & 0.07 & 0.08 & 3 \\
\hline SAW11-2ME & 38.29442 & -118.91269 & $\begin{array}{l}\text { Bxd FeOx-stained (limonite) rhyo- } \\
\text { lite alt to chal, opal }\end{array}$ & 16 & $<1$ & $<0.5$ & 6.03 & 0.05 & 0.11 & 0.08 & 0.02 & 0.03 & 0.05 & 0.06 & 2 \\
\hline SAW11-3ME & 38.29452 & -118.91475 & $\begin{array}{l}\text { White-beige bxd rhyolite, alt to } \\
\text { chal, opal }\end{array}$ & 6 & $<1$ & $<0.5$ & 7.42 & 0.09 & 0.18 & 0.19 & 0.02 & 0.02 & 0.31 & 0.1 & $<1$ \\
\hline SAW11-4ME & 38.29772 & -118.91724 & $\begin{array}{l}\text { White-beige bxd rhyolite, minor } \\
\text { FeOx (lim+hem) }\end{array}$ & 3 & $<1$ & $<0.5$ & 11.9 & 0.16 & 0.7 & 3.31 & 0.06 & 0.09 & $>5$ & 0.06 & $<1$ \\
\hline SAW11-5ME & 38.30095 & -118.91615 & $\begin{array}{l}\text { Dump; angular rhyolite clasts in } \\
\text { heavy FeOx (lim+hem) matrix }\end{array}$ & 9 & $<1$ & $<0.5$ & 2.33 & 0.09 & 21 & 0.87 & 0.01 & 0.05 & 1.56 & 0.03 & $<1$ \\
\hline SAW11-7ME & 38.29756 & -118.91457 & $\begin{array}{l}\text { White-beige bxd rhyolite, minor } \\
\text { FeOx (lim+hem) }\end{array}$ & 3 & $<1$ & 0.5 & 9.3 & 0.1 & 0.27 & 0.24 & 0.04 & 0.03 & 0.38 & 0.08 & $<1$ \\
\hline SAW11-8ME & 38.29097 & -118.90810 & $\begin{array}{l}\text { Beige rhyolite flow and flow bx, } \\
\text { minor } \mathrm{FeOx}\end{array}$ & 7 & $<1$ & $<0.5$ & 4.92 & 0.21 & 0.77 & 3.47 & 0.09 & 0.57 & 0.12 & 0.05 & $<1$ \\
\hline SAW11-9ME & 38.29036 & -118.91657 & $\begin{array}{l}\text { White bxd rhyolite with chal, opal, } \\
\text { alunite matrix and veins }\end{array}$ & 2 & $<1$ & $<0.5$ & 6.51 & 0.06 & 0.1 & 1.87 & 0.02 & 0.05 & 3.22 & 0.06 & $<1$ \\
\hline SAW11-10ME & 38.29010 & -118.91155 & Beige-red rhyolite and bxd rhyolite & 3 & $<1$ & $<0.5$ & 5.93 & 0.07 & 0.35 & 0.07 & 0.01 & 0.02 & 0.05 & 0.05 & $<1$ \\
\hline SAW11-11ME & 38.28904 & -118.90930 & Bxd rhyolite, FeOx-stained & 3 & $<1$ & $<0.5$ & 6.24 & 0.31 & 2.14 & 1.92 & 0.3 & 3.32 & 0.21 & 0.37 & $<1$ \\
\hline 07-BA-33 & 38.29023 & -118.91201 & $\begin{array}{l}\text { Argillized tuff with secondary silica, } \\
\text { Aurora Mine Road }\end{array}$ & $<0.005$ & - & - & 4.38 & 0.07 & 0.62 & 0.06 & $<0.01$ & 0.01 & 0.22 & 0.04 & $<1$ \\
\hline
\end{tabular}


Table 1-4. Minor element concentrations in rock samples from the Sawtooth Ridge alteration zone.-Continued

[FeOx, iron oxide; bxd, brecciated; alt, altered; chal, chalcedony; lim, limonite; bx, breccia; hem, hematite; - , no data]

\begin{tabular}{|c|c|c|c|c|c|c|c|c|c|c|c|c|c|c|c|c|c|c|}
\hline $\begin{array}{l}\text { Sample } \\
\text { number }\end{array}$ & $\begin{array}{l}\text { As } \\
\mathrm{ppm}\end{array}$ & $\begin{array}{l}\text { Ba } \\
\mathrm{ppm}\end{array}$ & $\begin{array}{l}\text { Be } \\
\mathrm{ppm}\end{array}$ & $\begin{array}{c}\mathrm{Bi} \\
\mathrm{ppm}\end{array}$ & $\begin{array}{c}\text { Cd } \\
\text { ppm }\end{array}$ & $\begin{array}{l}\mathrm{Ce} \\
\mathrm{ppm}\end{array}$ & $\begin{array}{l}\text { Co } \\
\text { ppm }\end{array}$ & $\underset{\mathrm{ppm}}{\mathrm{Cr}}$ & $\begin{array}{l}\text { Cs } \\
\text { ppm }\end{array}$ & $\begin{array}{c}\mathrm{Cu} \\
\mathrm{ppm}\end{array}$ & $\begin{array}{c}\mathrm{Ga} \\
\mathrm{ppm}\end{array}$ & $\begin{array}{c}\mathrm{Hg} \\
\mathrm{ppm}\end{array}$ & $\underset{\mathrm{ppm}}{\text { In }}$ & $\begin{array}{l}\text { La } \\
\text { ppm }\end{array}$ & $\begin{array}{c}\mathrm{Li} \\
\mathrm{ppm}\end{array}$ & $\begin{array}{l}\text { Mn } \\
\text { ppm }\end{array}$ & $\begin{array}{l}\text { Mo } \\
\text { ppm }\end{array}$ & $\begin{array}{l}\mathrm{Nb} \\
\mathrm{ppm}\end{array}$ \\
\hline SAW11-1ME & 42 & 503 & 0.9 & 0.37 & $<0.1$ & 16.6 & 0.7 & 2 & 7 & 27.8 & 14.4 & 2.11 & $<0.02$ & 12.5 & 157 & 57 & 5.22 & 7.7 \\
\hline SAW11-2ME & 22 & 298 & 0.6 & 0.49 & $<0.1$ & 16.3 & 0.2 & 1 & 11 & 18.3 & 15.4 & 0.61 & $<0.02$ & 14.6 & 70 & 14 & 3.08 & 9.7 \\
\hline SAW11-3ME & 8 & 720 & 0.3 & 0.42 & $<0.1$ & 31.7 & 0.3 & 3 & 7 & 15.6 & 16.6 & 0.3 & 0.02 & 19.8 & 51 & 12 & 1.6 & 9.3 \\
\hline SAW11-4ME & 12 & 156 & 0.7 & 0.38 & $<0.1$ & 85.2 & 0.8 & 45 & 6 & 18.3 & 76.8 & 0.07 & 0.03 & 63.3 & 44 & 56 & 2.38 & 7.7 \\
\hline SAW11-5ME & 354 & 504 & 2.6 & 0.3 & $<0.1$ & 33.3 & 0.6 & 8 & 7 & 21.6 & 11.3 & 0.51 & $<0.02$ & 21.5 & 3 & 60 & 25.3 & 3.7 \\
\hline SAW11-7ME & 25 & 631 & 0.3 & 0.49 & $<0.1$ & 43.2 & 0.2 & 4 & 8 & 10 & 18.2 & 0.12 & 0.03 & 27.6 & 78 & 18 & 13.4 & 10.4 \\
\hline SAW11-8ME & 289 & 901 & 1.4 & 0.09 & 0.1 & 45 & 0.6 & 2 & 12 & 10 & 12.3 & 1.63 & $<0.02$ & 25.4 & 37 & 62 & 4.15 & 8 \\
\hline SAW11-9ME & 9 & 190 & 0.3 & 0.36 & $<0.1$ & 14.3 & 0.2 & 3 & 8 & 3.5 & 17.8 & 1.61 & $<0.02$ & 10.6 & 18 & $<5$ & 1.53 & 9.2 \\
\hline SAW11-10ME & 17 & 299 & 1.6 & 0.1 & $<0.1$ & 43.9 & 0.8 & $<1$ & $<5$ & 5.9 & 10.3 & 0.75 & $<0.02$ & 26.4 & 53 & 23 & 4 & 7.9 \\
\hline SAW11-11ME & 17 & 1,060 & 0.9 & $<0.04$ & $<0.1$ & 13.7 & 4.8 & 20 & 5 & 28.2 & 17.7 & 0.74 & 0.03 & 7.1 & 26 & 110 & 0.24 & 6.2 \\
\hline 07-BA-33 & 33 & 300 & 1.9 & 0.08 & $<0.1$ & 21.7 & 0.5 & 3 & $<5$ & 7.5 & 7.88 & 7.88 & $<0.02$ & 11 & 41 & 35 & 18.5 & 6.1 \\
\hline
\end{tabular}

Table 1-4. Minor element concentrations in rock samples from the Sawtooth Ridge alteration zone.-Continued

[FeOx, iron oxide; bxd, brecciated; alt, altered; chal, chalcedony; lim, limonite; bx, breccia; hem, hematite; - , no data]

\begin{tabular}{|c|c|c|c|c|c|c|c|c|c|c|c|c|c|c|c|c|c|}
\hline $\begin{array}{l}\text { Sample } \\
\text { number }\end{array}$ & $\begin{array}{c}\mathrm{Ni} \\
\mathrm{ppm}\end{array}$ & $\begin{array}{c}P \\
\text { ppm }\end{array}$ & $\begin{array}{c}\mathrm{Pb} \\
\mathrm{ppm}\end{array}$ & $\begin{array}{c}\mathrm{Rb} \\
\mathrm{ppm}\end{array}$ & $\begin{array}{c}\text { Sb } \\
\text { ppm }\end{array}$ & $\begin{array}{c}\text { Sc } \\
\text { ppm }\end{array}$ & $\begin{array}{c}\text { Se } \\
\text { ppm }\end{array}$ & $\begin{array}{c}\text { Sn } \\
\text { ppm }\end{array}$ & $\begin{array}{c}\text { Sr } \\
\mathrm{ppm}\end{array}$ & $\begin{array}{c}\text { Te } \\
\text { ppm }\end{array}$ & $\begin{array}{c}\text { Th } \\
\text { ppm }\end{array}$ & $\begin{array}{c}\text { TI } \\
\text { ppm }\end{array}$ & $\underset{\mathrm{ppm}}{\mathrm{U}}$ & $\begin{array}{c}\mathrm{V} \\
\mathrm{ppm}\end{array}$ & $\begin{array}{c}\text { W } \\
\text { ppm }\end{array}$ & $\begin{array}{c}\mathrm{Y} \\
\mathrm{ppm}\end{array}$ & $\begin{array}{c}\mathrm{Zn} \\
\mathrm{ppm}\end{array}$ \\
\hline SAW11-1ME & 1.6 & 270 & 31.3 & 7.1 & 85.3 & 1.1 & 0.7 & 1.2 & 217 & 1.6 & 11.4 & 0.1 & 9 & 31 & 8.8 & 3.4 & 10 \\
\hline SAW11-2ME & $<0.5$ & 150 & 46.4 & 5 & 24.4 & 1.2 & 0.4 & 1.3 & 120 & 3.8 & 16.3 & 0.2 & 7 & 14 & 3.4 & 2.8 & 4 \\
\hline SAW11-3ME & 1.1 & 740 & 30.5 & 4.9 & 9.45 & 1.3 & $<0.2$ & 1.2 & 199 & 0.5 & 16.6 & 0.1 & 9.2 & 37 & 10.6 & 2.9 & 5 \\
\hline SAW11-4ME & 3.1 & 1,680 & 25.8 & 7.6 & 7 & 2.1 & $<0.2$ & 0.9 & 1,740 & 0.4 & 41.9 & 0.1 & 7.6 & 131 & 16.5 & 4.9 & 8 \\
\hline SAW11-5ME & 0.6 & 1,590 & 27.1 & 6.4 & 25.8 & 1.7 & 1 & 0.7 & 259 & 0.2 & 21.3 & $<0.1$ & 9.1 & 190 & 45.2 & 3.9 & 16 \\
\hline SAW11-7ME & 0.8 & 550 & 33.2 & 4.7 & 6.08 & 2 & 0.4 & 1.1 & 417 & 0.2 & 23 & 0.4 & 12.8 & 78 & 11.3 & 9 & 7 \\
\hline SAW11-8ME & 1.2 & 380 & 32.1 & 138 & 97.7 & 0.7 & $<0.2$ & 0.7 & 241 & 0.1 & 24.8 & 1.3 & 7.9 & 33 & 11.5 & 16.1 & 13 \\
\hline SAW11-9ME & $<0.5$ & 210 & 34.2 & 6.7 & 9.24 & 1.8 & $<0.2$ & 0.9 & 113 & 0.1 & 9.9 & 0.1 & 7.4 & 30 & 6 & 1.3 & 2 \\
\hline SAW11-10ME & 2.5 & 410 & 34.2 & 3.2 & 10.5 & 2.7 & 0.5 & 0.9 & 295 & 1.4 & 25.6 & $<0.1$ & 11.7 & 57 & 6.1 & 7 & 22 \\
\hline SAW11-11ME & 19.7 & 570 & 9.8 & 53.6 & 15.4 & 9.8 & 0.3 & 1.1 & 531 & 1 & 2.9 & 0.3 & 1.2 & 83 & 28.2 & 3.3 & 42 \\
\hline $07-B A-33$ & 0.8 & 120 & 12.2 & 2 & 5.18 & 1.1 & 1.8 & 0.6 & 56.2 & $<0.1$ & 32.1 & $<0.1$ & 10.3 & 17 & 2 & 4 & 7 \\
\hline
\end{tabular}


Table 1-5. Minor element concentrations in rock samples from the Aurora Canyon alteration zone.

\begin{tabular}{|c|c|c|c|c|c|c|c|c|c|c|c|c|c|c|c|c|}
\hline $\begin{array}{l}\text { Sample } \\
\text { number }\end{array}$ & Latitude & Longitude & Description & $\begin{array}{c}\mathrm{Au} \\
\mathrm{ppm}\end{array}$ & $\begin{array}{c}\mathrm{Hg} \\
\mathrm{ppm}\end{array}$ & $\begin{array}{l}\text { Al } \\
\%\end{array}$ & $\begin{array}{l}\mathrm{Ca} \\
\%\end{array}$ & $\begin{array}{l}\mathrm{Fe} \\
\%\end{array}$ & $\begin{array}{l}\mathbf{K} \\
\%\end{array}$ & $\begin{array}{c}\mathrm{Mg} \\
\%\end{array}$ & $\begin{array}{c}\mathrm{Na} \\
\%\end{array}$ & $\begin{array}{l}\mathbf{S} \\
\%\end{array}$ & $\begin{array}{l}\mathrm{Ti} \\
\%\end{array}$ & $\begin{array}{c}\mathrm{Ag} \\
\mathrm{ppm}\end{array}$ & $\begin{array}{c}\text { As } \\
\text { ppm }\end{array}$ & $\begin{array}{c}\mathrm{Ba} \\
\mathrm{ppm}\end{array}$ \\
\hline РP09-20 & 38.25336 & -119.13584 & Quartz-alunite-clay-altered andesite & $<0.005$ & 10 & 3.22 & 0.07 & 6.87 & 1.13 & $<0.01$ & 0.12 & 2.55 & 0.08 & $<1$ & 67 & 380 \\
\hline PР09-21 & 38.26387 & -119.12638 & Silicified and brecciated andesite & $<0.005$ & 3.11 & 6.63 & 0.16 & 4.64 & 1.71 & 0.03 & 0.73 & $>5$ & 0.1 & $<1$ & 480 & 116 \\
\hline РP09-22 & 38.257 & -119.13689 & Quartz-alunite-altered andesite & $<0.005$ & 0.8 & 0.44 & 0.13 & 0.1 & 0.04 & 0.01 & $<0.01$ & 0.06 & 0.09 & $<1$ & 8 & 221 \\
\hline PР09-23 & 38.25974 & -119.13051 & Quartz-clay-altered andesite & $<0.005$ & 20.6 & 0.48 & 0.03 & 0.57 & 0.03 & 0.01 & $<0.01$ & 0.09 & 0.23 & $<1$ & 192 & 1,360 \\
\hline 08-BA-43 & 38.25330 & -119.13567 & Silicified andesite with alunite veins & $<0.005$ & 0.23 & 6.68 & 0.13 & 0.3 & 2.75 & $<0.01$ & 0.18 & $>5$ & 0.19 & $<1$ & 26 & 106 \\
\hline 08-BA-44 & 38.256910 & -119.13795 & Quartz-alunite-altered andesite & $<0.005$ & 0.59 & 10.2 & 0.54 & 1.32 & 1.22 & 0.03 & 2.19 & $>5$ & 0.58 & $<1$ & 25 & 87 \\
\hline 08-BA-45 & 38.256325 & -119.13673 & Fine-grained alunite & $<0.005$ & 0.09 & 6.22 & 0.08 & 0.53 & 2.21 & 0.01 & 0.36 & 4.71 & 0.11 & $<1$ & 11 & 135 \\
\hline 09-BA-45 & 38.270139 & -119.13000 & Silicified hematitic breccia & 0.018 & 1.9 & 0.22 & 0.02 & 0.75 & 0.01 & $<0.01$ & $<0.01$ & 0.23 & 0.1 & $<1$ & 81 & 8,870 \\
\hline
\end{tabular}

Table 1-5. Minor element concentrations in rock samples from the Aurora Canyon alteration zone.-Continued

\begin{tabular}{|c|c|c|c|c|c|c|c|c|c|c|c|c|c|c|c|c|}
\hline $\begin{array}{l}\text { Sample } \\
\text { number }\end{array}$ & $\begin{array}{c}\mathrm{Be} \\
\mathrm{ppm}\end{array}$ & $\begin{array}{c}\mathrm{Bi} \\
\mathrm{ppm}\end{array}$ & $\begin{array}{l}\text { Cd } \\
\text { ppm }\end{array}$ & $\begin{array}{c}\text { Ce } \\
\text { ppm }\end{array}$ & $\begin{array}{c}\text { Co } \\
\text { ppm }\end{array}$ & $\begin{array}{c}\mathrm{Cr} \\
\mathrm{ppm}\end{array}$ & $\begin{array}{c}\text { Cs } \\
\text { ppm }\end{array}$ & $\begin{array}{c}\text { Cu } \\
\text { ppm }\end{array}$ & $\begin{array}{c}\text { Ga } \\
\text { ppm }\end{array}$ & $\begin{array}{c}\text { In } \\
\text { ppm }\end{array}$ & $\begin{array}{c}\text { La } \\
\text { ppm }\end{array}$ & $\begin{array}{c}\text { Li } \\
\text { ppm }\end{array}$ & $\begin{array}{l}\text { Mn } \\
\text { ppm }\end{array}$ & $\begin{array}{l}\text { Mo } \\
\text { ppm }\end{array}$ & $\begin{array}{c}\mathrm{Nb} \\
\mathrm{ppm}\end{array}$ & $\underset{\mathrm{ppm}}{\mathrm{Ni}}$ \\
\hline PP09-20 & 0.3 & 2.15 & $<0.1$ & 49.1 & 0.9 & 16 & $<5$ & 35.1 & 9.62 & 0.03 & 27.9 & 3 & 23 & 4.86 & 1.9 & 0.8 \\
\hline PP09-21 & 0.4 & 2.18 & $<0.1$ & 32.6 & 1 & 14 & $<5$ & 19.3 & 20.9 & 0.05 & 17.7 & 5 & 64 & 2.02 & 1.7 & 1.7 \\
\hline РP09-22 & 0.3 & 1.37 & $<0.1$ & 7 & 0.3 & 3 & $<5$ & 8.4 & 0.65 & $<0.02$ & 3.7 & 7 & 28 & 1.07 & 1.1 & 0.6 \\
\hline РP09-23 & 0.1 & 4.52 & $<0.1$ & 10.7 & 0.5 & 5 & $<5$ & 19.6 & 2.28 & 0.03 & 5.9 & 26 & 13 & 1.19 & 3.3 & 1.2 \\
\hline 08-BA-43 & 0.4 & 2.23 & $<0.1$ & 108 & 0.6 & 22 & $<5$ & 7.7 & 13.8 & 0.04 & 56.7 & 2 & 20 & 2.67 & 4.6 & 1.3 \\
\hline 08-BA-44 & 0.4 & 2.34 & 0.2 & 90.4 & 0.6 & 37 & $<5$ & 31.7 & 26 & $<0.02$ & 46.2 & 4 & 151 & 3.66 & 13.8 & 1.9 \\
\hline 08-BA-45 & 0.2 & 0.61 & $<0.1$ & 23.9 & 0.3 & 33 & $<5$ & 2.6 & 11.7 & $<0.02$ & 15.3 & 1 & 30 & 1.54 & 2 & $<0.5$ \\
\hline 09-BA-45 & 0.1 & 2.37 & $<0.1$ & 2.51 & 2 & 2 & $<5$ & 15.2 & 0.58 & $<0.02$ & 2 & $<1$ & 73 & 6.32 & 1.5 & 2.2 \\
\hline
\end{tabular}

Table 1-5. Minor element concentrations in rock samples from the Aurora Canyon alteration zone.-Continued

\begin{tabular}{|c|c|c|c|c|c|c|c|c|c|c|c|c|c|c|c|}
\hline $\begin{array}{l}\text { Sample } \\
\text { number }\end{array}$ & $\begin{array}{c}P \\
\text { ppm }\end{array}$ & $\begin{array}{c}\mathrm{Pb} \\
\mathrm{ppm}\end{array}$ & $\begin{array}{c}\text { Rb } \\
\text { ppm }\end{array}$ & $\begin{array}{c}\text { Sb } \\
\text { ppm }\end{array}$ & $\begin{array}{c}\text { Sc } \\
\text { ppm }\end{array}$ & $\begin{array}{c}\text { Sn } \\
\text { ppm }\end{array}$ & $\begin{array}{c}\text { Sr } \\
\text { ppm }\end{array}$ & $\begin{array}{c}\text { Te } \\
\text { ppm }\end{array}$ & $\begin{array}{l}\text { Th } \\
\text { ppm }\end{array}$ & $\begin{array}{c}\text { TI } \\
\text { ppm }\end{array}$ & $\underset{\mathrm{ppm}}{\mathrm{U}}$ & $\begin{array}{c}\mathbf{V} \\
\mathrm{ppm}\end{array}$ & $\begin{array}{c}\text { W } \\
\text { ppm }\end{array}$ & $\begin{array}{c}\mathrm{Y} \\
\mathrm{ppm}\end{array}$ & $\begin{array}{c}\mathrm{Zn} \\
\mathrm{ppm}\end{array}$ \\
\hline PP09-20 & 1,640 & 23.5 & 3 & 2.39 & 2.2 & 0.8 & 533 & 0.5 & 10 & 0.3 & 1.5 & 102 & 0.5 & 2.2 & 8 \\
\hline РP09-21 & 1,290 & 13.9 & 5.6 & 13.5 & 3 & 0.7 & 827 & 3.7 & 3.9 & 0.2 & 0.8 & 164 & 2.5 & 2 & 10 \\
\hline PP09-22 & 2,240 & 1.8 & 1.4 & 83 & 1.2 & 0.4 & 53.5 & 0.6 & 1.5 & $<0.1$ & 0.7 & 5 & 0.6 & 1.9 & 11 \\
\hline PР09-23 & 270 & 30.5 & 2.1 & 33.2 & 2.8 & 0.9 & 205 & 1.9 & 3 & 0.7 & 2.2 & 17 & 6 & 2.2 & 4 \\
\hline $08-B A-43$ & 2,490 & 58.2 & 6.8 & 2.97 & 4.9 & 1 & 1,020 & 0.2 & 18.5 & 2.2 & 3.3 & 104 & 1 & 4.4 & 6 \\
\hline 08-BA-44 & 3,310 & 17.6 & 6.8 & 4.42 & 6.4 & 1.8 & 458 & 0.5 & 10.9 & 0.8 & 2.5 & 93 & 1.7 & 8.2 & 13 \\
\hline 08-BA-45 & 570 & 10.5 & 4 & 7.91 & 4.1 & 0.9 & 561 & 0.4 & 3.1 & $<0.1$ & 0.5 & 67 & 1.2 & 2.4 & 3 \\
\hline 09-BA-45 & 170 & 3.8 & 1.1 & 4.93 & 1.6 & 0.6 & 77.6 & 4.1 & 1.8 & 0.1 & 1.3 & 11 & 0.3 & 1.8 & 4 \\
\hline
\end{tabular}


Table 1-6. Minor element concentrations in rock samples from the Potato Peak alteration zone.

\begin{tabular}{|c|c|c|c|c|c|c|c|c|c|c|c|c|c|c|c|c|}
\hline $\begin{array}{l}\text { Sample } \\
\text { number }\end{array}$ & Latitude & Longitude & Description & $\begin{array}{c}\text { Au } \\
\text { ppm }\end{array}$ & $\begin{array}{c}\mathrm{Hg} \\
\mathrm{ppm}\end{array}$ & $\begin{array}{l}\text { Al } \\
\%\end{array}$ & $\begin{array}{l}\mathrm{Ca} \\
\%\end{array}$ & $\begin{array}{l}\mathrm{Fe} \\
\%\end{array}$ & $\begin{array}{l}\mathbf{K} \\
\%\end{array}$ & $\begin{array}{c}\mathrm{Mg} \\
\%\end{array}$ & $\begin{array}{l}\mathrm{Na} \\
\%\end{array}$ & $\begin{array}{l}\mathbf{S} \\
\%\end{array}$ & $\begin{array}{l}\mathrm{Ti} \\
\%\end{array}$ & $\begin{array}{c}\mathrm{Ag} \\
\mathrm{ppm}\end{array}$ & $\begin{array}{l}\text { As } \\
\mathrm{ppm}\end{array}$ & $\begin{array}{l}\text { Ba } \\
\text { ppm }\end{array}$ \\
\hline РОТРК08-1 & 38.24439 & -119.10512 & $\begin{array}{l}\text { Silicified volcaniclastic breccia; vuggy } \\
\text { quartz, cinnabar, barite matrix }\end{array}$ & 0.903 & 171,339 & 0.62 & 0.02 & 2.29 & 0.12 & 0.01 & $<0.01$ & 3.74 & 0.29 & 1 & 281 & 76 \\
\hline POTPK09-20 & 38.24398 & -119.10379 & $\begin{array}{l}\text { Volcaniclastic deposits replaced by } \\
\text { fine-grained quartz and kaolinite }\end{array}$ & $<0.005$ & 17.4 & 8.08 & 0.21 & 7.58 & 0.27 & 0.05 & 0.02 & 0.28 & 0.4 & $<1$ & 138 & 832 \\
\hline 08-BA-46 & 38.244298 & -119.10385 & $\begin{array}{l}\text { Silicified volcaniclastic deposits with } \\
\text { alunite matrix }\end{array}$ & $<0.005$ & 0.71 & 3.99 & 0.11 & 3.83 & 1.16 & $<0.01$ & 0.29 & 3.22 & 0.09 & $<1$ & 79 & 401 \\
\hline 08-BA-47 & 38.244298 & -119.10385 & Silicified breccia with cinnabar matrix & 0.064 & 19,400 & 0.26 & 0.02 & 0.54 & 0.03 & $<0.01$ & $<0.01$ & 0.27 & 0.1 & $<1$ & 51 & 128 \\
\hline 08-BA-48 & 38.244298 & -119.10385 & $\begin{array}{l}\text { Volcaniclastic deposits altered to } \\
\text { dickite }\end{array}$ & $<0.005$ & 9.97 & 8.89 & 0.14 & 0.3 & 0.08 & 0.02 & $<0.01$ & 0.31 & 0.4 & $<1$ & 91 & 1,250 \\
\hline 08-BA-49 & 38.246409 & -119.09876 & $\begin{array}{l}\text { Volcaniclastic deposits altered to } \\
\text { dickite and pyrite }\end{array}$ & 0.093 & 5.15 & 5.19 & 0.04 & 1.79 & 0.02 & $<0.01$ & $<0.01$ & 2.09 & 0.07 & 1 & 29 & 438 \\
\hline
\end{tabular}

Table 1-6. Minor element concentrations in rock samples from the Potato Peak alteration zone.-Continued

\begin{tabular}{|c|c|c|c|c|c|c|c|c|c|c|c|c|c|c|c|c|}
\hline $\begin{array}{l}\text { Sample } \\
\text { number }\end{array}$ & $\begin{array}{c}\mathrm{Be} \\
\mathrm{ppm}\end{array}$ & $\begin{array}{c}\mathrm{Bi} \\
\mathrm{ppm}\end{array}$ & $\begin{array}{c}\text { Cd } \\
\text { ppm }\end{array}$ & $\begin{array}{c}\text { Ce } \\
\text { ppm }\end{array}$ & $\begin{array}{c}\text { Co } \\
\text { ppm }\end{array}$ & $\begin{array}{c}\mathrm{Cr} \\
\mathrm{ppm}\end{array}$ & $\begin{array}{c}\text { Cs } \\
\text { ppm }\end{array}$ & $\begin{array}{c}\mathrm{Cu} \\
\mathrm{ppm}\end{array}$ & $\begin{array}{c}\text { Ga } \\
\text { ppm }\end{array}$ & $\begin{array}{c}\text { In } \\
\text { ppm }\end{array}$ & $\begin{array}{c}\text { La } \\
\text { ppm }\end{array}$ & $\begin{array}{c}\text { Li } \\
\text { ppm }\end{array}$ & $\begin{array}{c}\mathrm{Mn} \\
\mathrm{ppm}\end{array}$ & $\begin{array}{l}\text { Mo } \\
\text { ppm }\end{array}$ & $\begin{array}{l}\text { Nb } \\
\text { ppm }\end{array}$ & $\begin{array}{c}\mathrm{Ni} \\
\mathrm{ppm}\end{array}$ \\
\hline РОТРК08-1 & 0.4 & 1.32 & 0.3 & 37.5 & 5.9 & 12 & $<5$ & 30 & 2.01 & 0.12 & 16.6 & 22 & 8 & 17.2 & 9.5 & 12.9 \\
\hline РОТРК09-20 & 1 & 0.27 & $<0.1$ & 81.8 & 0.3 & 99 & $<5$ & 29.4 & 21.1 & 0.13 & 41.5 & 52 & 9 & 3.94 & 8.2 & 1 \\
\hline 08-BA-46 & 0.3 & 18.5 & $<0.1$ & 87.7 & 0.6 & 26 & $<5$ & 13.2 & 21.7 & 0.05 & 39.4 & 1 & 6 & 13 & 1.6 & 0.9 \\
\hline 08-BA-47 & 0.2 & 5.17 & $<0.1$ & 9.5 & 0.7 & 4 & $<5$ & 27.6 & 0.7 & $<0.02$ & 4.5 & 10 & 8 & 12.1 & 1.7 & 2.3 \\
\hline 08-BA-48 & 0.4 & 8.32 & $<0.1$ & 75.4 & 0.2 & 24 & $<5$ & 6.9 & 28.4 & 0.03 & 35 & 82 & 10 & 12.2 & 8.6 & 0.5 \\
\hline 08-BA-49 & 0.3 & 3.85 & $<0.1$ & 49.9 & 4.8 & 18 & $<5$ & 17.1 & 15.7 & $<0.02$ & 24.6 & 73 & $<5$ & 3.43 & 2.3 & 13.6 \\
\hline
\end{tabular}

Table 1-6. Minor element concentrations in rock samples from the Potato Peak alteration zone.-Continued

\begin{tabular}{|c|c|c|c|c|c|c|c|c|c|c|c|c|c|c|c|}
\hline $\begin{array}{l}\text { Sample } \\
\text { number }\end{array}$ & $\begin{array}{c}P \\
\text { ppm }\end{array}$ & $\begin{array}{c}\mathrm{Pb} \\
\mathrm{ppm}\end{array}$ & $\begin{array}{c}\text { Rb } \\
\text { ppm }\end{array}$ & $\begin{array}{c}\text { Sb } \\
\text { ppm }\end{array}$ & $\begin{array}{c}\text { Sc } \\
\text { ppm }\end{array}$ & $\begin{array}{c}\text { Sn } \\
\text { ppm }\end{array}$ & $\begin{array}{c}\mathrm{Sr} \\
\mathrm{ppm}\end{array}$ & $\begin{array}{c}\text { Te } \\
\text { ppm }\end{array}$ & $\begin{array}{l}\text { Th } \\
\text { ppm }\end{array}$ & $\begin{array}{c}\text { TI } \\
\text { ppm }\end{array}$ & $\begin{array}{c}\text { U } \\
\text { ppm }\end{array}$ & $\begin{array}{c}\text { V } \\
\mathrm{ppm}\end{array}$ & $\begin{array}{c}\text { W } \\
\text { ppm }\end{array}$ & $\begin{array}{c}\mathrm{Y} \\
\mathrm{ppm}\end{array}$ & $\begin{array}{c}\mathrm{Zn} \\
\mathrm{ppm}\end{array}$ \\
\hline РОТРК08-1 & 250 & 61.4 & 4.6 & 98.4 & 5.3 & 0.9 & 172 & 2.6 & 10.4 & 3.8 & 5.6 & 14 & 13.5 & 15.7 & 43 \\
\hline РОТРК09-20 & 3,000 & 59 & 11.6 & 10.3 & 12.4 & 1.8 & 1,220 & 0.8 & 21 & 0.8 & 3.9 & 265 & 6.1 & 4.9 & 7 \\
\hline 08-BA-46 & 2310 & 33 & 4 & 6.96 & 8.9 & 0.9 & 1,040 & 0.4 & 21.4 & 0.2 & 2 & 81 & 2.5 & 1.6 & 2 \\
\hline 08-BA-47 & 230 & 4.7 & 1.2 & 20.3 & 0.8 & 1.3 & 148 & 0.3 & 3.2 & 0.3 & 1.6 & 9 & 1.3 & 1.8 & 5 \\
\hline 08-BA-48 & 1,960 & 17.2 & 2.4 & 14.5 & 6.7 & 1.7 & 1,120 & 1 & 17.9 & 0.2 & 3.6 & 166 & 10.1 & 6.1 & 15 \\
\hline 08-BA-49 & 850 & 22.5 & 1 & 7.75 & 2.3 & 0.7 & 875 & 0.8 & 13.2 & 0.5 & 1.2 & 60 & 1.9 & 1.7 & 2 \\
\hline
\end{tabular}


Table 1-7. Minor element concentrations in rock samples from the Aurora Mining District.

$[\mathrm{K}$, potassium; - , no data $]$

\begin{tabular}{|c|c|c|c|c|c|c|c|c|c|c|c|c|c|c|c|c|}
\hline $\begin{array}{l}\text { Sample } \\
\text { number }\end{array}$ & Latitude & Longitude & Description' & $\begin{array}{c}\text { Au } \\
\text { ppm }\end{array}$ & $\begin{array}{c}\mathrm{Hg} \\
\mathrm{ppm}\end{array}$ & $\begin{array}{l}\text { Al } \\
\%\end{array}$ & $\begin{array}{l}\mathrm{Ca} \\
\%\end{array}$ & $\begin{array}{l}\mathrm{Fe} \\
\%\end{array}$ & $\begin{array}{l}\mathbf{K} \\
\% \\
\end{array}$ & $\begin{array}{c}\mathrm{Mg} \\
\%\end{array}$ & $\begin{array}{l}\mathrm{Na} \\
\%\end{array}$ & $\begin{array}{l}\mathbf{S} \\
\%\end{array}$ & $\begin{array}{l}\mathrm{Ti} \\
\%\end{array}$ & $\begin{array}{c}\mathrm{Ag} \\
\mathrm{ppm}\end{array}$ & $\begin{array}{c}\text { As } \\
\mathrm{ppm}\end{array}$ & $\begin{array}{c}\mathrm{Ba} \\
\mathrm{ppm}\end{array}$ \\
\hline AUR10-1 & 38.27118 & -118.89644 & Dream adit dump; Bald Eagle vein? & 0.005 & 0.73 & 2.77 & 0.03 & 0.12 & 0.93 & $<0.01$ & 0.17 & 1.98 & 0.15 & $<1$ & 40 & 550 \\
\hline AUR11-10ME & 38.27321 & -118.90045 & $\begin{array}{l}\text { Iregularly banded quartz vein with } \\
\text { sulfide streaks, clots; Cortez-Utah }\end{array}$ & 0.121 & 0.02 & 0.84 & 0.06 & 0.28 & 0.32 & 0.05 & 0.01 & 0.17 & 0.02 & 11 & 29 & 72 \\
\hline AUR11-12 & 38.27019 & -118.9017 & $\begin{array}{l}\text { Irregularly banded quartz vein, } \\
\text { minor sulfides; Seminole }\end{array}$ & 2 & 0.43 & 0.68 & 0.03 & 0.54 & 0.26 & 0.04 & $<0.01$ & 0.57 & $<0.01$ & 32 & 17 & 34 \\
\hline AUR11-15 & 38.27321 & -118.89905 & $\begin{array}{l}\text { Quartz vein, minor sulfides; } \\
\text { Gladiator }\end{array}$ & 0.505 & 0.61 & 1.69 & 0.09 & 0.39 & 0.68 & 0.1 & 0.02 & 0.34 & 0.04 & 22 & 87 & 246 \\
\hline AUR11-16 & 38.28483 & -118.8924 & $\begin{array}{l}\text { Pyritic quartz stockwork, dump; } \\
\text { Wide West }\end{array}$ & 1.62 & 0.06 & 1.27 & 0.04 & 1.96 & 0.88 & 0.08 & 0.02 & 1.63 & 0.04 & 29 & 257 & 245 \\
\hline AUR11-17A & 38.27727 & -118.88483 & $\begin{array}{l}\text { Quartz-sulfide vein, mine dump; } \\
\text { drainage between Middle-Marti- } \\
\text { nez Hills }\end{array}$ & 8.16 & 0.03 & 1.31 & 0.07 & 0.67 & 0.63 & 0.04 & 0.02 & 0.39 & 0.02 & 6 & 4,290 & 198 \\
\hline AUR11-19ME & 38.29572 & -118.89484 & $\begin{array}{l}\text { Quartz-K-mica vein, open cut, rhyo- } \\
\text { lite of Aurora }\end{array}$ & 0.026 & 0.16 & 3.07 & 0.08 & 0.1 & 0.17 & 0.02 & $<0.01$ & 0.01 & 0.03 & $<1$ & 87 & 229 \\
\hline 12-BA-19A & 38.26533 & -118.90017 & $\begin{array}{l}\text { Esmeralda vein, sulfide dump } \\
\text { sample }\end{array}$ & 84.8 & 0.29 & 1.26 & 0.05 & 0.44 & 0.44 & 0.06 & 0.02 & 0.51 & 0.02 & 1,110 & 511 & 142 \\
\hline 12-BA-19B & 38.26533 & -118.90017 & $\begin{array}{l}\text { Esmeralda vein, sulfide dump } \\
\text { sample }\end{array}$ & 65.1 & 0.2 & 0.99 & 0.05 & 0.43 & 0.35 & 0.06 & 0.01 & 0.29 & 0.01 & 1,370 & 438 & 121 \\
\hline NE-1 & 38.30685 & -118.84810 & $\begin{array}{l}\text { New Esmeralda Mine, quartz vein } \\
\text { with black sulfides }\end{array}$ & 3.42 & 1.18 & 0.55 & 0.09 & 0.1 & 0.1 & 0.03 & 0.01 & 0.02 & $<0.01$ & 42 & 29 & 106 \\
\hline NE-2 & 38.30685 & -118.84810 & $\begin{array}{l}\text { New Esmeralda Mine, quartz vein } \\
\text { with black sulfides }\end{array}$ & 0.658 & 0.23 & 0.32 & 0.1 & 0.09 & 0.05 & 0.04 & 0.01 & $<0.01$ & $<0.01$ & 20 & 23 & 40 \\
\hline 11-BA-52C & 38.30685 & -118.84810 & $\begin{array}{l}\text { New Esmeralda Mine, quartz vein } \\
\text { with black sulfides }\end{array}$ & 0.102 & 0.09 & 0.68 & 0.06 & 0.21 & 0.15 & 0.03 & 0.02 & $<0.01$ & 0.02 & 8 & 45 & 80 \\
\hline 11-BA-52D & 38.30685 & -118.84810 & $\begin{array}{l}\text { New Esmeralda Mine, quartz vein } \\
\text { with black sulfides }\end{array}$ & 0.224 & 0.1 & 0.89 & 0.07 & 0.25 & 0.2 & 0.04 & 0.01 & $<0.01$ & 0.02 & 5 & 56 & 92 \\
\hline
\end{tabular}


Table 1-7. Minor element concentrations in rock samples from the Aurora Mining District.—Continued

$[\mathrm{K}$, potassium; - , no data $]$

\begin{tabular}{|c|c|c|c|c|c|c|c|c|c|c|c|c|c|c|c|c|c|c|}
\hline $\begin{array}{l}\text { Sample } \\
\text { number }\end{array}$ & $\begin{array}{c}\mathrm{Be} \\
\mathrm{ppm}\end{array}$ & $\begin{array}{c}\text { Bi } \\
\text { ppm }\end{array}$ & $\begin{array}{c}\text { Cd } \\
\text { ppm }\end{array}$ & $\begin{array}{l}\text { Ce } \\
\text { ppm }\end{array}$ & $\begin{array}{c}\text { Co } \\
\text { ppm }\end{array}$ & $\underset{\mathrm{ppm}}{\mathrm{Cr}}$ & $\begin{array}{c}\text { Cs } \\
\text { ppm }\end{array}$ & $\begin{array}{c}\text { Cu } \\
\text { ppm }\end{array}$ & $\begin{array}{c}\text { Ga } \\
\text { ppm }\end{array}$ & $\begin{array}{c}\text { In } \\
\text { ppm }\end{array}$ & $\begin{array}{l}\text { La } \\
\text { ppm }\end{array}$ & $\begin{array}{c}\text { Li } \\
\text { ppm }\end{array}$ & $\begin{array}{l}\text { Mn } \\
\text { ppm }\end{array}$ & $\begin{array}{l}\text { Mo } \\
\text { ppm }\end{array}$ & $\begin{array}{c}\mathrm{Nb} \\
\mathrm{ppm}\end{array}$ & $\begin{array}{c}\mathrm{Ni} \\
\mathrm{ppm}\end{array}$ & $\begin{array}{c}P \\
\text { ppm }\end{array}$ & $\begin{array}{c}\mathrm{Pb} \\
\mathrm{ppm}\end{array}$ \\
\hline AUR10-1 & $<0.1$ & 1.3 & $<0.1$ & 9.16 & 0.2 & 7 & $<5$ & 4.2 & 15.5 & $<0.02$ & 7.7 & $<1$ & $<5$ & 0.83 & 3 & $<0.5$ & 450 & 47.6 \\
\hline AUR11-10ME & 1.1 & 0.89 & 0.3 & 6.77 & 0.4 & 1 & $<5$ & 36.9 & 2.39 & $<0.02$ & 3.5 & 73 & 27 & 111 & 0.7 & 2.7 & 60 & 19.1 \\
\hline AUR11-12 & 0.7 & 0.46 & $<0.1$ & 2.91 & 0.1 & 1 & $<5$ & 26.4 & 1.43 & $<0.02$ & 2.1 & 66 & 80 & 57.8 & $<0.1$ & 0.9 & $<50$ & 62.6 \\
\hline AUR11-15 & 1.6 & 1.16 & 0.5 & 13.1 & 1 & 1 & 13 & 29.1 & 6.53 & $<0.02$ & 5.9 & 89 & 39 & 1,310 & 1.4 & 3.1 & 170 & 17.3 \\
\hline AUR11-16 & 1.4 & 3.58 & 0.5 & 20 & 0.5 & 3 & 7 & 131 & 4.06 & $<0.02$ & 13 & 150 & 40 & 924 & 0.5 & 0.7 & 170 & 56.9 \\
\hline AUR11-17A & 1.9 & 0.17 & $<0.1$ & 14 & 0.2 & 2 & $<5$ & 13.6 & 2.36 & $<0.02$ & 9.4 & 99 & 40 & 129 & 1.1 & 1.3 & 120 & 7.7 \\
\hline AUR11-19ME & 0.9 & 0.31 & $<0.1$ & 13 & 0.2 & 1 & $<5$ & 9.6 & 7.73 & $<0.02$ & 8.3 & 107 & 16 & 13.5 & 4.2 & 1.7 & 110 & 17 \\
\hline 12-BA-19A & 0.8 & 0.04 & 3.3 & 5.06 & 0.5 & 1 & $<5$ & 1,090 & 2.02 & $<0.02$ & 2.8 & 85 & 51 & 53.4 & 0.8 & 1.3 & $<50$ & 47.9 \\
\hline 12-BA-19B & 0.7 & 0.08 & 1.8 & 1.95 & 0.4 & $<1$ & $<5$ & 367 & 1.77 & $<0.02$ & 1.2 & 92 & 49 & 94.6 & 0.3 & 1.2 & $<50$ & 84.6 \\
\hline NE-1 & 2 & 37.4 & $<0.1$ & 0.48 & 0.2 & $<1$ & 8 & 13.9 & 1.4 & $<0.02$ & $<0.5$ & 119 & 24 & 12.1 & 0.1 & 1.6 & $<50$ & 5 \\
\hline NE-2 & 2 & 13.8 & $<0.1$ & 0.7 & 1 & $<1$ & $<5$ & 7.7 & 3.92 & $<0.02$ & $<0.5$ & 63 & 167 & 1.1 & 0.1 & 12.5 & 80 & 1.1 \\
\hline $11-\mathrm{BA}-52 \mathrm{C}$ & 1.4 & 1.85 & 0.2 & 2.64 & 28.7 & 2 & 6 & 10.9 & 1.52 & $<0.02$ & 1 & 130 & 826 & 11.1 & 0.3 & 93.5 & 60 & 2.4 \\
\hline 11-BA-52D & 1.3 & 1.34 & 0.2 & 3.23 & 44 & 2 & 5 & 12.9 & 1.78 & $<0.02$ & 1.2 & 123 & 1,100 & 17.6 & 0.3 & 127 & 70 & 1.4 \\
\hline
\end{tabular}

Table 1-7. Minor element concentrations in rock samples from the Aurora Mining District.—Continued

$[\mathrm{K}$, potassium; - , no data $]$

\begin{tabular}{|c|c|c|c|c|c|c|c|c|c|c|c|c|c|c|}
\hline $\begin{array}{l}\text { Sample } \\
\text { number }\end{array}$ & $\begin{array}{c}\mathbf{R b} \\
\mathrm{ppm}\end{array}$ & $\begin{array}{c}\text { Sb } \\
\text { ppm }\end{array}$ & $\begin{array}{c}\text { Sc } \\
\text { ppm }\end{array}$ & $\begin{array}{c}\text { Se } \\
\text { ppm }\end{array}$ & $\begin{array}{c}\text { Sn } \\
\text { ppm }\end{array}$ & $\begin{array}{c}\mathrm{Sr} \\
\mathrm{ppm}\end{array}$ & $\begin{array}{c}\text { Te } \\
\text { ppm }\end{array}$ & $\begin{array}{c}\text { Th } \\
\text { ppm }\end{array}$ & $\begin{array}{c}\mathrm{TI} \\
\text { ppm }\end{array}$ & $\underset{\mathrm{ppm}}{\mathbf{U}}$ & $\begin{array}{c}\mathbf{V} \\
\mathrm{ppm}\end{array}$ & $\begin{array}{c}\text { W } \\
\text { ppm }\end{array}$ & $\begin{array}{c}\mathbf{Y} \\
\mathrm{ppm}\end{array}$ & $\begin{array}{c}\mathrm{Zn} \\
\mathrm{ppm}\end{array}$ \\
\hline AUR10-1 & 0.6 & 8.84 & 0.8 & - & 3.4 & 404 & 0.6 & 2.4 & $<0.1$ & 0.2 & 18 & 0.4 & 0.7 & 1 \\
\hline AUR11-10ME & 24 & 18.6 & 0.4 & 0.4 & 0.2 & 23.4 & 1.1 & 0.4 & 0.5 & 0.7 & 11 & 2.7 & 5 & 19 \\
\hline AUR11-12 & 20.5 & 25.8 & 0.1 & 2.9 & 0.7 & 14.2 & 0.4 & $<0.2$ & 0.3 & 0.5 & 9 & 3.9 & 7.7 & 8 \\
\hline AUR11-15 & 52.9 & 79 & 0.6 & 1 & 0.4 & 49.4 & 1.3 & 0.7 & 12.3 & 1.1 & 24 & 6.3 & 7.4 & 11 \\
\hline AUR11-16 & 62.8 & 64.1 & 1.3 & 1.9 & 0.3 & 138 & 3.7 & 0.2 & 3.6 & 0.2 & 52 & 10.7 & 3.5 & 4 \\
\hline AUR11-17A & 34.3 & 69.8 & 0.3 & 2.2 & 0.3 & 44.4 & 0.2 & 0.6 & 0.8 & 0.3 & 5 & 0.6 & 4.6 & 7 \\
\hline AUR11-19ME & 15.3 & 20.8 & 1 & 0.7 & 0.4 & 54.1 & $<0.1$ & 9.3 & 0.2 & 4.4 & 43 & 3.7 & 4.7 & 8 \\
\hline 12-BA-19A & 20.9 & 264 & 0.3 & 203 & 0.2 & 21.8 & 15.7 & 0.4 & 0.3 & 0.1 & 8 & 1 & 0.6 & 195 \\
\hline 12-BA-19B & 20.7 & 275 & 0.2 & 198 & 0.2 & 20 & 7.5 & $<0.2$ & 0.2 & $<0.1$ & 8 & 1.2 & 0.4 & 70 \\
\hline NE-1 & 10.8 & 267 & $<0.1$ & 3.7 & 0.1 & 35.5 & 13 & $<0.2$ & 0.6 & $<0.1$ & 3 & 1.3 & 0.2 & 4 \\
\hline NE-2 & 4.9 & 226 & $<0.1$ & 0.8 & $<0.1$ & 47.7 & 6.6 & $<0.2$ & 0.6 & $<0.1$ & 2 & 0.7 & 56.5 & 9 \\
\hline $11-\mathrm{BA}-52 \mathrm{C}$ & 12.2 & 88.7 & 0.3 & 0.2 & 0.1 & 45.3 & 0.4 & 0.2 & 6 & 0.1 & 5 & 1.7 & 8.8 & 70 \\
\hline 11-BA-52D & 15.3 & 67.5 & 0.3 & $<0.2$ & 0.2 & 42.6 & 0.6 & 0.3 & 9.4 & 0.1 & 7 & 2.1 & 7 & 104 \\
\hline
\end{tabular}


Table 1-8. Minor element concentrations in rock samples from the Four Corners alteration zone.

[Fe, iron; Mn, manganese]

\begin{tabular}{|c|c|c|c|c|c|c|c|c|c|c|c|c|c|c|c|c|}
\hline $\begin{array}{l}\text { Sample } \\
\text { number }\end{array}$ & Latitude & Longitude & Description & $\begin{array}{c}\mathrm{Au} \\
\mathrm{ppm}\end{array}$ & $\begin{array}{c}\mathrm{Hg} \\
\mathrm{ppm}\end{array}$ & $\begin{array}{l}\text { Al } \\
\%\end{array}$ & $\begin{array}{l}\mathrm{Ca} \\
\%\end{array}$ & $\begin{array}{l}\mathrm{Fe} \\
\%\end{array}$ & $\begin{array}{l}\mathbf{K} \\
\% \\
\end{array}$ & $\begin{array}{c}\mathrm{Mg} \\
\%\end{array}$ & $\begin{array}{c}\mathrm{Na} \\
\%\end{array}$ & $\begin{array}{l}\mathbf{S} \\
\%\end{array}$ & $\begin{array}{l}\mathrm{Ti} \\
\%\end{array}$ & $\begin{array}{c}\mathrm{Ag} \\
\mathrm{ppm}\end{array}$ & $\begin{array}{c}\text { As } \\
\text { ppm }\end{array}$ & $\begin{array}{c}\text { Ba } \\
\text { ppm }\end{array}$ \\
\hline $08 \mathrm{HC} 1$ & 38.28055 & -119.10158 & Red mud layer & 0.005 & 0.84 & 0.77 & 0.35 & 1.56 & 0.07 & 0.02 & 0.02 & 0.2 & 0.53 & $<1$ & 19 & 717 \\
\hline $08 \mathrm{HC} 2$ & 38.28055 & -119.10158 & Silt/sand sediment below mud & $<0.005$ & 0.08 & 0.34 & 0.1 & 0.39 & 0.04 & $<0.01$ & 0.02 & 0.06 & 0.69 & $<1$ & 8 & 118 \\
\hline $08 \mathrm{HC} 3$ & 38.28055 & -119.10158 & Red sand below mud & $<0.005$ & 0.65 & 1.4 & 0.29 & 0.52 & 0.11 & 0.03 & 0.03 & 0.23 & 0.71 & $<1$ & 12 & 443 \\
\hline 08HC4 & 38.28067 & -119.10175 & Coarse pebble/sand & $<0.005$ & 0.22 & 0.2 & 0.15 & 1.65 & 0.02 & $<0.01$ & 0.01 & 0.12 & 0.69 & $<1$ & 8 & 730 \\
\hline $08 \mathrm{HC} 5$ & 38.28046 & -119.10162 & $\mathrm{Fe}$ and $\mathrm{Mn}$ oxide breccia & 0.006 & 6.2 & 0.51 & 0.08 & 12.9 & 0.05 & $<0.01$ & 0.02 & 0.06 & 0.85 & $<1$ & 408 & 327 \\
\hline 08HC6 & 38.28049 & -119.10157 & White opalite breccia & $<0.005$ & 0.39 & 0.2 & 0.44 & 0.19 & 0.08 & 0.01 & 0.02 & 0.26 & 0.16 & $<1$ & 12 & 114 \\
\hline $08 \mathrm{HC} 7$ & 38.28049 & -119.10157 & Black massive benatile & $<0.005$ & 15.1 & 0.39 & 0.08 & 12.5 & 0.06 & $<0.01$ & 0.02 & 0.04 & 0.55 & $<1$ & 353 & 934 \\
\hline $08 \mathrm{HC} 8$ & 38.28094 & -119.09985 & Knob of Fe oxide breccia & $<0.005$ & 9.9 & 1.22 & 0.44 & 4.32 & 0.48 & 0.05 & 0.03 & 0.66 & 0.31 & $<1$ & 1,190 & 2,490 \\
\hline 08-BA-30 & 38.28048 & -119.10142 & $\begin{array}{l}\text { Red hematitc silicified breccia with } \\
\text { fragments of white silica }\end{array}$ & $<0.005$ & 0.49 & 0.23 & 0.02 & 1.09 & 0.03 & $<0.01$ & 0.02 & $<0.01$ & 0.24 & $<1$ & 17 & 52 \\
\hline 08-BA-31 & 38.28062 & -119.09941 & $\begin{array}{l}\text { Silicified jarosite-rich breccia with } \\
\text { blocks of flow-banded andesite? }\end{array}$ & 0.061 & 0.17 & 1.33 & 0.12 & 2.27 & 0.47 & 0.07 & 0.02 & 0.45 & 0.39 & $<1$ & 3,510 & 1,380 \\
\hline
\end{tabular}

Table 1-8. Minor element concentrations in rock samples from the Four Corners alteration zone.-Continued

[Fe, iron; Mn, manganese]

\begin{tabular}{|c|c|c|c|c|c|c|c|c|c|c|c|c|c|c|c|c|}
\hline $\begin{array}{l}\text { Sample } \\
\text { number }\end{array}$ & $\begin{array}{l}\text { Be } \\
\text { ppm }\end{array}$ & $\begin{array}{c}\mathrm{Bi} \\
\mathrm{ppm}\end{array}$ & $\begin{array}{c}\text { Cd } \\
\text { ppm }\end{array}$ & $\begin{array}{c}\mathrm{Ce} \\
\mathrm{ppm}\end{array}$ & $\begin{array}{c}\text { Co } \\
\text { ppm }\end{array}$ & $\begin{array}{c}\mathrm{Cr} \\
\mathrm{ppm}\end{array}$ & $\begin{array}{c}\text { Cs } \\
\mathrm{ppm}\end{array}$ & $\begin{array}{c}\mathrm{Cu} \\
\mathrm{ppm}\end{array}$ & $\begin{array}{c}\mathrm{Ga} \\
\mathrm{ppm}\end{array}$ & $\begin{array}{c}\text { In } \\
\text { ppm }\end{array}$ & $\begin{array}{l}\text { La } \\
\text { ppm }\end{array}$ & $\begin{array}{c}\text { Li } \\
\text { ppm }\end{array}$ & $\begin{array}{l}\text { Mn } \\
\text { ppm }\end{array}$ & $\begin{array}{l}\text { Mo } \\
\text { ppm }\end{array}$ & $\begin{array}{c}\mathrm{Nb} \\
\mathrm{ppm}\end{array}$ & $\underset{\mathrm{ppm}}{\mathrm{Ni}}$ \\
\hline $08 \mathrm{HC1}$ & 0.8 & 1.97 & 0.7 & 11.1 & 6.5 & 19 & 8 & 13.3 & 1.68 & 0.02 & 5.5 & 86 & 772 & 1.02 & 4.3 & 4.9 \\
\hline $08 \mathrm{HC} 2$ & 0.5 & 0.63 & $<0.1$ & 3.77 & 0.4 & 11 & 6 & 5.3 & 1.2 & $<0.02$ & 1.8 & 77 & 27 & 0.21 & 8.3 & 0.9 \\
\hline 08HC3 & 0.6 & 0.59 & $<0.1$ & 9.42 & 1.1 & 18 & 8 & 13.7 & 2.56 & $<0.02$ & 4.9 & 81 & 86 & 0.71 & 3.9 & 2.3 \\
\hline 08HC4 & 0.2 & 0.93 & $<0.1$ & 2.33 & 0.7 & 11 & $<5$ & 3.8 & 1.52 & $<0.02$ & 1.6 & 57 & 43 & 0.6 & 7.6 & 0.7 \\
\hline 08HC5 & 0.6 & 9.13 & $<0.1$ & 16.6 & 2.2 & 33 & 7 & 16.8 & 4.06 & 0.98 & 6.6 & 68 & 129 & 9.72 & 3.3 & 1.1 \\
\hline 08HC6 & 0.2 & 1.54 & $<0.1$ & 1.85 & 1.2 & 8 & $<5$ & 32.5 & 0.86 & $<0.02$ & 0.7 & 15 & 82 & 1.11 & 0.7 & 1.6 \\
\hline 08HC7 & 0.8 & 135 & $<0.1$ & 14.6 & 1.4 & 21 & 5 & 25.4 & 5.48 & 0.49 & 6.6 & 52 & 75 & 8 & 2.9 & 3 \\
\hline 08HC8 & 1.4 & 0.2 & 0.3 & 21.8 & 2.1 & 47 & 8 & 6.9 & 21.9 & 0.06 & 15.8 & 83 & 279 & 1.28 & 3.6 & 3.1 \\
\hline 08-BA-30 & 0.3 & 1.6 & $<0.1$ & 0.77 & 0.2 & 3 & $<5$ & 7.2 & 1.6 & $<0.02$ & $<0.5$ & 42 & 44 & 0.73 & 1.7 & $<0.5$ \\
\hline 08-BA-31 & 0.7 & 0.27 & 0.1 & 35 & 0.6 & 9 & 9 & 20.4 & 17.6 & 0.09 & 20.9 & 28 & 46 & 2.35 & 4 & 2 \\
\hline
\end{tabular}


Table 1-8. Minor element concentrations in rock samples from the Four Corners alteration zone.-Continued [Fe, iron; Mn, manganese]

\begin{tabular}{|c|c|c|c|c|c|c|c|c|c|c|c|c|c|c|c|}
\hline $\begin{array}{l}\text { Sample } \\
\text { number }\end{array}$ & $\begin{array}{c}P \\
\text { ppm }\end{array}$ & $\begin{array}{c}\mathrm{Pb} \\
\mathrm{ppm}\end{array}$ & $\begin{array}{c}\mathbf{R b} \\
\mathbf{p p m}\end{array}$ & $\begin{array}{c}\text { Sb } \\
\text { ppm }\end{array}$ & $\begin{array}{c}\text { Sc } \\
\mathrm{ppm}\end{array}$ & $\begin{array}{c}\text { Sn } \\
\text { ppm }\end{array}$ & $\begin{array}{c}\mathrm{Sr} \\
\mathrm{ppm}\end{array}$ & $\begin{array}{c}\text { Te } \\
\text { ppm }\end{array}$ & $\begin{array}{l}\text { Th } \\
\text { ppm }\end{array}$ & $\begin{array}{c}\mathrm{TI} \\
\mathrm{ppm}\end{array}$ & $\underset{\mathrm{ppm}}{\mathrm{U}}$ & $\begin{array}{c}\mathrm{V} \\
\mathrm{ppm}\end{array}$ & $\begin{array}{c}\text { W } \\
\text { ppm }\end{array}$ & $\begin{array}{c}\mathrm{Y} \\
\mathrm{ppm}\end{array}$ & $\begin{array}{c}\mathrm{Zn} \\
\mathrm{ppm}\end{array}$ \\
\hline $08 \mathrm{HCl}$ & 1,080 & 21.7 & 6.6 & 52.1 & 1.8 & 1 & 135 & 2 & 1.4 & 0.3 & 0.7 & 38 & 24.3 & 3 & 24 \\
\hline $08 \mathrm{HC} 2$ & 130 & 7.1 & 4.2 & 42.6 & 1.2 & 0.6 & 33.3 & 0.6 & 0.5 & 0.2 & 0.2 & 13 & 4.6 & 0.4 & 4 \\
\hline $08 \mathrm{HC} 3$ & 950 & 10.8 & 8.5 & 53.3 & 2.3 & 0.7 & 186 & 1.3 & 1.2 & 0.2 & 0.6 & 26 & 3.3 & 1.5 & 14 \\
\hline $08 \mathrm{HC} 4$ & 120 & 2.9 & 1.9 & 48.4 & 0.7 & 1.4 & 25.9 & 0.8 & 0.3 & $<0.1$ & 0.4 & 22 & 24.6 & 1 & 3 \\
\hline $08 \mathrm{HC} 5$ & 760 & 201 & 4.8 & 20.6 & 2.9 & 2 & 150 & 3.3 & 3.7 & 0.3 & 1.3 & 56 & 5.3 & 2.5 & 10 \\
\hline 08HC6 & 2,080 & 4.5 & 2 & 30.5 & 0.9 & 1.2 & 32.2 & 1.4 & 0.3 & $<0.1$ & 0.3 & 6 & 2 & 0.8 & 8 \\
\hline $08 \mathrm{HC} 7$ & 1,020 & 421 & 3.9 & 109 & 3.8 & 3.3 & 76.9 & 18.1 & 3.4 & 0.3 & 1.7 & 24 & 25.6 & 3.3 & 16 \\
\hline $08 \mathrm{HC} 8$ & 2,720 & 84.7 & 32.3 & 69.2 & 9.8 & 1 & 559 & $<0.1$ & 16.6 & 1.3 & 1 & 166 & 74.5 & 2.3 & 15 \\
\hline 08-BA-30 & $<50$ & 3.6 & 3.2 & 51 & 0.5 & 0.5 & 8.7 & 0.2 & $<0.2$ & 0.1 & 0.2 & 22 & 7.5 & 0.4 & 5 \\
\hline 08-BA-31 & 3,850 & 795 & 32.5 & 152 & 27.6 & 1.5 & 826 & 0.9 & 41.8 & 0.7 & 1.5 & 28 & 18.3 & 3.2 & 12 \\
\hline
\end{tabular}


Table 1-9. Minor element concentrations in rock samples from the Paramount-Bald Peak alteration zone.

[Hg, mercury; HgS, mercury sulfide; mm, millimeter; cb, cinnabar; py, pyrite; —, no data]

\begin{tabular}{|c|c|c|c|c|c|c|c|c|c|}
\hline $\begin{array}{l}\text { Sample } \\
\text { number }\end{array}$ & Latitude & Longitude & Description & Location & $\begin{array}{c}\text { Au } \\
\mathrm{ppm}\end{array}$ & $\begin{array}{c}\mathrm{Hg} \\
\mathrm{ppm}\end{array}$ & $\begin{array}{l}\text { Al } \\
\%\end{array}$ & $\begin{array}{l}\mathrm{Ca} \\
\%\end{array}$ & $\begin{array}{l}\mathrm{Fe} \\
\%\end{array}$ \\
\hline ATAS06-1 & 38.26255 & -119.01192 & Sinter with mm-thick black layers, intact terrace, Atastra Creek & Atastra Creek & 0.004 & 1.56 & 0.61 & 0.03 & 0.05 \\
\hline 06-BA-5 & 38.2621 & -119.0125 & Silicified fault underlying sinter terrace; Atastra Creek & Atastra Creek & 0.009 & 0.85 & 1.02 & 0.03 & 0.15 \\
\hline 06-BA-6 & 38.2621 & -119.0125 & Banded sinter with black bands; Atastra Creek & Atastra Creek & 0.005 & 0.12 & 0.71 & 0.03 & 0.22 \\
\hline 06-BA-7 & 38.2643 & -119.0074 & Chalcedony veins cutting tuff of Paramount; Atastra Creek & Atastra Creek & $<0.005$ & 13.4 & 3.38 & 0.13 & 2.24 \\
\hline 06-BA-8 & 38.2643 & -119.0074 & Chalcedony veins cutting tuff of Paramount; Atastra Creek & Atastra Creek & $<0.005$ & 4.65 & 3.81 & 0.09 & 0.73 \\
\hline $11-\mathrm{BA}-43$ & 38.26169 & -119.00869 & $\begin{array}{l}\text { Fe-oxide-silica altered lower Eureka Valley Tuff overlying strongly argillized } \\
\text { Paramount tuff and sediments }\end{array}$ & Atastra Creek & 0.01 & 5.94 & 0.61 & 0.13 & 3.9 \\
\hline $11-\mathrm{BA}-33 \mathrm{~A}$ & 38.34568 & -118.98167 & Chalcedony-pyrite vein cutting silicified Paramount tuff and sediments & Hilton Springs & 2.64 & 3.94 & 1.89 & 0.03 & 1.38 \\
\hline 11-BA-33B & 38.34568 & -118.98167 & Silicified pyritic wall rock from 11-BA-33A & Hilton Springs & 1.62 & 44.1 & 3.03 & 0.07 & 0.71 \\
\hline $11-\mathrm{BA}-34 \mathrm{~A}$ & 38.29883 & -118.99753 & $\begin{array}{l}\text { Silicified finely laminated sediments in Paramount tuff and sediment se- } \\
\text { quence }\end{array}$ & Hilton Springs & 0.023 & 0.23 & 0.7 & 0.07 & 0.26 \\
\hline 11-BA-34B & 38.29883 & -118.99753 & $\begin{array}{l}\text { Silicified finely laminated sediments in Paramount tuff and sediment se- } \\
\text { quence }\end{array}$ & Hilton Springs & 0.542 & 2.25 & 0.97 & 0.05 & 1.82 \\
\hline $11-\mathrm{BA}-35 \mathrm{~A}$ & 38.29805 & -118.99864 & $\begin{array}{l}\text { Silicified finely laminated sediments in Paramount tuff and sediment se- } \\
\text { quence }\end{array}$ & Hilton Springs & 0.026 & 2.06 & 1.03 & 0.07 & 1.38 \\
\hline 11-BA-35B & 38.29805 & -118.99864 & $\begin{array}{l}\text { Silicified finely laminated sediments in Paramount tuff and sediment se- } \\
\text { quence }\end{array}$ & Hilton Springs & 0.061 & 4.17 & 0.6 & 0.06 & 0.51 \\
\hline PMT06-1 & 38.27787 & -119.05766 & $\begin{array}{l}\text { 5-foot chalcedonic quartz vein with white clay pockets, long dozer cut, } \\
\text { Paramount Mine }\end{array}$ & Paramount Mine hill & 0.007 & 137 & 0.35 & 0.03 & 0.12 \\
\hline PMT06-1A & 38.27787 & -119.05766 & $\begin{array}{l}\text { 5-foot chalcedonic quartz vein with white clay pockets, long dozer cut, } \\
\text { Paramount Mine }\end{array}$ & Paramount Mine hill & 0.034 & 71.5 & 0.29 & 0.03 & 0.08 \\
\hline РMT06-2 & 38.27823 & -119.05859 & $\begin{array}{l}\text { Dense } 7 \text {-foot chalcedonic quartz vein with minor cb, py; upper adit, Para- } \\
\text { mount Mine }\end{array}$ & Paramount Mine hill & 0.061 & 1,600 & 0.36 & 0.01 & 0.06 \\
\hline РMT06-3 & 38.27729 & -119.06083 & Sinter blocks, west dismembered terrace, Paramount Mine hill & Paramount Mine hill & 0.018 & 1.35 & 0.22 & 0.02 & 0.1 \\
\hline 07PM1 & 38.2773 & -119.0595 & Sinter & Paramount Mine hill & 0.017 & 0.53 & 0.1 & 0.07 & 0.07 \\
\hline 07PM2 & 38.2773 & -119.0595 & Quartz carbonate breccia & Paramount Mine hill & 0.237 & 1.23 & 2.2 & 0.04 & 0.42 \\
\hline 07PM4 & 38.2777 & -119.0577 & Chalcedony vein cutting breccia & Paramount Mine hill & 0.495 & 94.2 & 2.26 & 0.02 & 0.51 \\
\hline 07PM6 & 38.2759 & -119.0539 & Silicified tuff cut by quartz veins & Paramount Mine hill & 0.209 & 16.4 & 1.63 & 0.1 & 1.25 \\
\hline 07PM8 & 38.2779 & -119.0566 & White to tan chalcedonic sinter & Paramount Mine hill & 0.017 & 2.45 & 0.3 & 0.02 & 0.17 \\
\hline 07PM9 & 38.2778 & -119.0566 & Sinter cut by red chalcedony & Paramount Mine hill & 0.032 & 1.48 & 1.18 & 0.04 & 0.3 \\
\hline 07PM10 & 38.2778 & -119.0566 & Red chalcedony in sinter breccia & Paramount Mine hill & 0.067 & 2.71 & 1.89 & 0.02 & 0.62 \\
\hline 07PM11 & 38.2778 & -119.0566 & White sinter clasts in breccia & Paramount Mine hill & 0.011 & 0.24 & 0.13 & 0.02 & 0.16 \\
\hline 07PM14 & 38.2792 & -119.0598 & Calcines from Paramount $\mathrm{Hg}$ Mine & Paramount Mine hill & 0.103 & 17.4 & 3.06 & 0.18 & 0.5 \\
\hline 07PM12 & 38.2789 & -119.0592 & $\mathrm{HgS}$ in silicified tuff & Paramount Mine hill & 0.063 & 516 & 0.33 & 0.02 & 0.13 \\
\hline 07-BA-20 & 38.2769 & -119.0569 & Laminated gray silica, possible pool sinter near Paramount Mine & Paramount Mine hill & 0.917 & 1.51 & 1.05 & 0.05 & 0.22 \\
\hline 07-BA-20A & 38.2769 & -119.0569 & Laminated gray silica, possible pool sinter near Paramount Mine & Paramount Mine hill & 3.57 & 4.28 & 2.61 & 0.09 & 0.31 \\
\hline
\end{tabular}


Table 1-9. Minor element concentrations in rock samples from the Paramount-Bald Peak alteration zone.-Continued

\begin{tabular}{|c|c|c|c|c|c|c|c|c|c|c|c|c|c|c|}
\hline $\begin{array}{l}\text { Sample } \\
\text { number }\end{array}$ & $\begin{array}{l}\mathbf{K} \\
\%\end{array}$ & $\begin{array}{c}\mathrm{Mg} \\
\%\end{array}$ & $\begin{array}{l}\mathrm{Na} \\
\%\end{array}$ & $\begin{array}{l}\mathbf{S} \\
\%\end{array}$ & $\begin{array}{l}\mathrm{Ti} \\
\%\end{array}$ & $\begin{array}{c}\mathrm{Ag} \\
\mathrm{ppm}\end{array}$ & $\begin{array}{c}\text { As } \\
\text { ppm }\end{array}$ & $\begin{array}{c}\text { Ba } \\
\text { ppm }\end{array}$ & $\begin{array}{c}\mathrm{Be} \\
\mathrm{ppm}\end{array}$ & $\begin{array}{c}\mathrm{Bi} \\
\mathrm{ppm}\end{array}$ & $\begin{array}{c}\text { Cd } \\
\text { ppm }\end{array}$ & $\begin{array}{c}\text { Ce } \\
\text { ppm }\end{array}$ & $\begin{array}{c}\text { Co } \\
\text { ppm }\end{array}$ & $\underset{\mathrm{ppm}}{\mathrm{Cr}}$ \\
\hline ATAS06-1 & 0.04 & $<0.01$ & $<0.01$ & 0.02 & 0.07 & $<1$ & 80 & 1,050 & $<5$ & $<0.1$ & $<0.2$ & 16.2 & $<0.5$ & $<10$ \\
\hline 06-BA-5 & 0.07 & 0.02 & 0.01 & 0.39 & 0.12 & $<1$ & 67 & 687 & 7.1 & 0.13 & $<0.1$ & 19.6 & 0.4 & 26 \\
\hline 06-BA-6 & 0.06 & 0.01 & 0.01 & 0.07 & 0.07 & $<1$ & 93 & 1,060 & 6.7 & 0.08 & $<0.1$ & 13.8 & 0.2 & 9 \\
\hline 06-BA-7 & 1.15 & 0.08 & 0.21 & 1.7 & 0.16 & $<1$ & 122 & 340 & 3.8 & $<0.04$ & 0.1 & 51.1 & 21.3 & 13 \\
\hline 06-BA-8 & 0.27 & 0.06 & 0.05 & 0.12 & 0.2 & $<1$ & 47 & 1,910 & 4.5 & $<0.04$ & $<0.1$ & 37.7 & 2.1 & 19 \\
\hline 11-BA-43 & 0.11 & 0.02 & 0.02 & 0.01 & 0.14 & $<1$ & 61 & 407 & 5.9 & 0.13 & $<0.1$ & 69.7 & 1.2 & 6 \\
\hline $11-\mathrm{BA}-33 \mathrm{~A}$ & 1.99 & 0.02 & 0.03 & 1.15 & 0.04 & 18 & 643 & 602 & 1.4 & 0.13 & $<0.1$ & 15.2 & 0.6 & 4 \\
\hline 11-BA-33B & 2.97 & 0.02 & 0.03 & 0.1 & 0.05 & 7 & 288 & 2,810 & 1.4 & 0.17 & $<0.1$ & 30.5 & 0.5 & 4 \\
\hline $11-\mathrm{BA}-34 \mathrm{~A}$ & 0.18 & 0.02 & 0.01 & 0.08 & 0.02 & 1 & 37 & 203 & 3.5 & 0.15 & $<0.1$ & 5.01 & 0.8 & 3 \\
\hline 11-BA-34B & 0.33 & 0.04 & $<0.01$ & 0.39 & 0.04 & 8 & 377 & 2,310 & 4.5 & 0.13 & $<0.1$ & 20.9 & 0.8 & 5 \\
\hline $11-\mathrm{BA}-35 \mathrm{~A}$ & 0.18 & 0.02 & 0.01 & 0.28 & 0.03 & 3 & 236 & 2,530 & 6.1 & 0.1 & $<0.1$ & 5.72 & 1.4 & 4 \\
\hline 11-BA-35B & 0.12 & 0.01 & 0.02 & 0.24 & 0.03 & 1 & 205 & 145 & 4.1 & 0.06 & $<0.1$ & 7.31 & 7.2 & 3 \\
\hline РMT06-1 & 0.09 & $<0.01$ & $<0.01$ & $<0.01$ & 0.02 & $<1$ & 40 & 758 & 9 & $<0.1$ & $<0.2$ & 1.5 & $<0.5$ & $<10$ \\
\hline PMT06-1A & 0.06 & $<0.01$ & $<0.01$ & $<0.01$ & 0.02 & $<1$ & $<30$ & 217 & 8 & $<0.1$ & $<0.2$ & 1.7 & $<0.5$ & $<10$ \\
\hline PMT06-2 & 0.06 & $<0.01$ & $<0.01$ & $<0.01$ & 0.02 & $<1$ & $<30$ & 863 & 6 & $<0.1$ & $<0.2$ & 2.9 & 0.6 & $<10$ \\
\hline PMT06-3 & 0.02 & $<0.01$ & $<0.01$ & $<0.01$ & $<0.01$ & $<1$ & $<30$ & 41.5 & 25 & $<0.1$ & $<0.2$ & 0.4 & $<0.5$ & 10 \\
\hline 07PM1 & 0.03 & $<0.01$ & 0.01 & 0.03 & $<0.01$ & $<1$ & 17 & 115 & 9.5 & $<0.04$ & $<0.1$ & 0.97 & 0.2 & 3 \\
\hline 07PM2 & 1.37 & 0.03 & 0.03 & 0.02 & 0.04 & $<1$ & 40 & 268 & 6.1 & 0.16 & 0.1 & 29.4 & 0.9 & 4 \\
\hline 07PM4 & 0.11 & $<0.01$ & 0.01 & 0.1 & 0.06 & 5 & 170 & 931 & 6.7 & 0.09 & $<0.1$ & 26.3 & 0.2 & 3 \\
\hline 07PM6 & 1.63 & 0.02 & 0.02 & 0.37 & 0.11 & 2 & 580 & 621 & 8.4 & $<0.04$ & 0.2 & 23.3 & 1.3 & 4 \\
\hline 07PM8 & 0.06 & $<0.01$ & 0.01 & 0.02 & $<0.01$ & $<1$ & 28 & 412 & 9.5 & $<0.04$ & $<0.1$ & 2.12 & 0.6 & 4 \\
\hline 07PM9 & 0.08 & $<0.01$ & 0.01 & 0.05 & 0.05 & $<1$ & 72 & 506 & 9.3 & $<0.04$ & $<0.1$ & 10.7 & 0.9 & 6 \\
\hline 07PM10 & 0.16 & 0.03 & 0.01 & 0.04 & 0.06 & $<1$ & 90 & 357 & 6.5 & 0.05 & $<0.1$ & 18.1 & 0.8 & 8 \\
\hline 07PM11 & 0.03 & $<0.01$ & 0.01 & $<0.01$ & $<0.01$ & $<1$ & 18 & 56 & 13.9 & $<0.04$ & $<0.1$ & 1.09 & 0.5 & 3 \\
\hline 07PM14 & 0.17 & 0.04 & 0.07 & 0.03 & 0.22 & $<1$ & 55 & 586 & 3.6 & 0.13 & $<0.1$ & 40.5 & 2.3 & 10 \\
\hline 07PM12 & 0.06 & $<0.01$ & 0.01 & 0.03 & 0.24 & $<1$ & 5 & 584 & 2.9 & $<0.04$ & $<0.1$ & 3.91 & 0.3 & 4 \\
\hline 07-BA-20 & 0.78 & $<0.01$ & 0.02 & 0.03 & $<0.01$ & 6 & 19 & 559 & 11.3 & 0.13 & $<0.1$ & 2.35 & 0.8 & 8 \\
\hline 07-BA-20A & 2.61 & 0.06 & 0.05 & 0.04 & 0.04 & 3 & 38 & 883 & 7.7 & 0.04 & $<0.1$ & 7.43 & 0.4 & 3 \\
\hline
\end{tabular}


Table 1-9. Minor element concentrations in rock samples from the Paramount-Bald Peak alteration zone.-Continued

[Hg, mercury; HgS, mercury sulfide; mm, millimeter; cb, cinnabar; py, pyrite; —, no data]

\begin{tabular}{|c|c|c|c|c|c|c|c|c|c|c|c|c|c|c|}
\hline $\begin{array}{l}\text { Sample } \\
\text { number }\end{array}$ & $\begin{array}{l}\text { Cs } \\
\text { ppm }\end{array}$ & $\begin{array}{c}\mathrm{Cu} \\
\mathrm{ppm}\end{array}$ & $\begin{array}{c}\mathrm{Ga} \\
\mathrm{ppm}\end{array}$ & $\begin{array}{l}\text { In } \\
\text { ppm }\end{array}$ & $\begin{array}{l}\text { La } \\
\text { ppm }\end{array}$ & $\begin{array}{c}\text { Li } \\
\text { ppm }\end{array}$ & $\begin{array}{l}\mathrm{Mn} \\
\mathrm{ppm}\end{array}$ & $\begin{array}{l}\text { Mo } \\
\text { ppm }\end{array}$ & $\begin{array}{l}\mathrm{Nb} \\
\mathrm{ppm}\end{array}$ & $\underset{\mathrm{ppm}}{\mathrm{Ni}}$ & $\begin{array}{c}P \\
\text { ppm }\end{array}$ & $\begin{array}{c}\mathrm{Pb} \\
\mathrm{ppm}\end{array}$ & $\begin{array}{c}\mathrm{Rb} \\
\mathrm{ppm}\end{array}$ & $\begin{array}{c}\text { Sb } \\
\text { ppm }\end{array}$ \\
\hline ATAS06-1 & 7.9 & $<5$ & 27 & $<0.2$ & 9.2 & 30 & - & 3 & 3 & $<5$ & - & 7 & 4.6 & 364 \\
\hline 06-BA-5 & 10 & 3.6 & 57.2 & $<0.02$ & 9.8 & 34 & 45 & 5.82 & 4.1 & 12.7 & 330 & 9.8 & 6.3 & 347 \\
\hline 06-BA-6 & 10 & 4.9 & 45.7 & $<0.02$ & 7 & 32 & 32 & 3.29 & 2.6 & 12.5 & 190 & 6.8 & 6 & 477 \\
\hline 06-BA-7 & 28 & 23.8 & 9.01 & $<0.02$ & 24.3 & 79 & 52 & 2.87 & 6.1 & 12.1 & 140 & 18.5 & 66.7 & 95.6 \\
\hline 06-BA-8 & 20 & 12.6 & 9.27 & $<0.02$ & 19.4 & 84 & 46 & 1.1 & 6.7 & 7.5 & 140 & 23.6 & 19.7 & 255 \\
\hline 11-BA-43 & 25 & 25.4 & 2.95 & $<0.02$ & 33.7 & 62 & 56 & 1.18 & 7.1 & 1.6 & 200 & 28.1 & 11.5 & 291 \\
\hline 11-BA-33A & 9 & 12 & 3.07 & $<0.02$ & 8.7 & 124 & 14 & 1 & 2.9 & 1.1 & 300 & 12 & 112 & 55.5 \\
\hline 11-BA-33B & 9 & 9.8 & 3.93 & $<0.02$ & 20.3 & 100 & 17 & 0.84 & 5.9 & 1.2 & 720 & 19.4 & 171 & 77.4 \\
\hline 11-BA-34A & 39 & 7.9 & 4.7 & $<0.02$ & 2.6 & 49 & 71 & 0.6 & 0.8 & 1.5 & 60 & 3.5 & 28.4 & 367 \\
\hline 11-BA-34B & 20 & 10.6 & 5.03 & $<0.02$ & 15.5 & 65 & 35 & 1.43 & 2.5 & 1.7 & 680 & 25 & 34 & 239 \\
\hline $11-\mathrm{BA}-35 \mathrm{~A}$ & 24 & 8.9 & 4.01 & $<0.02$ & 3.6 & 54 & 23 & 1.26 & 1.2 & 1.9 & 90 & 10.5 & 20.7 & 222 \\
\hline 11-BA-35B & 25 & 3.2 & 5.84 & $<0.02$ & 3.9 & 65 & 18 & 0.82 & 0.9 & 9.8 & 70 & 4.9 & 17.4 & 262 \\
\hline PMT06-1 & 15.8 & 7 & 8 & $<0.2$ & 1.5 & 40 & - & $<2$ & $<1$ & 8 & - & $<5$ & 12 & 916 \\
\hline РMT06-1A & 14.8 & $<5$ & 15 & $<0.2$ & 1.3 & 50 & - & $<2$ & $<1$ & 11 & - & $<5$ & 10.3 & 530 \\
\hline PMT06-2 & 11.8 & 8 & 12 & $<0.2$ & 3.3 & 80 & - & $<2$ & $<1$ & 6 & - & 7 & 9 & 644 \\
\hline РМТ06-3 & 6.1 & 8 & 12 & $<0.2$ & 0.3 & 60 & - & $<2$ & $<1$ & 12 & - & $<5$ & 3.7 & 204 \\
\hline 07PM1 & 6 & 0.9 & 9.99 & $<0.02$ & 0.7 & 18 & 69 & 0.6 & 0.2 & 0.5 & 60 & 0.9 & 3.4 & 396 \\
\hline 07PM2 & 10 & 2.6 & 7.64 & $<0.02$ & 16.9 & 82 & 67 & 0.38 & 1.6 & 1.8 & 140 & 5.7 & 90.3 & 159 \\
\hline 07PM4 & 11 & 22.7 & 6.27 & $<0.02$ & 13.4 & 11 & 29 & 0.43 & 2.8 & $<0.5$ & 240 & 9.5 & 9.3 & 111 \\
\hline 07PM6 & 13 & 5.3 & 7.33 & $<0.02$ & 13.8 & 70 & 117 & 3.65 & 0.6 & 1 & 200 & 5.9 & 119 & 2,890 \\
\hline 07PM8 & 10 & 1.3 & 7.07 & $<0.02$ & 1.1 & 122 & 99 & 0.45 & 0.1 & 1.1 & $<50$ & 1.4 & 7 & 101 \\
\hline 07PM9 & 12 & 5.3 & 6.27 & $<0.02$ & 5.4 & 81 & 98 & 0.82 & 1.7 & 1.3 & 90 & 3.4 & 9.3 & 120 \\
\hline 07PM10 & 15 & 6.7 & 5.06 & $<0.02$ & 11.4 & 162 & 76 & 0.82 & 1.8 & 1.4 & 380 & 4.7 & 19.9 & 109 \\
\hline 07PM11 & 6 & 1.5 & 8.93 & $<0.02$ & 0.6 & 18 & 186 & 1.22 & $<0.1$ & 1.1 & $<50$ & 1.2 & 4.3 & 198 \\
\hline 07PM14 & 9 & 6.5 & 12.5 & $<0.02$ & 22.7 & 106 & 54 & 0.92 & 6 & 3.2 & 340 & 38.9 & 14.6 & 399 \\
\hline 07PM12 & 9 & 1.1 & 1.51 & $<0.02$ & 2.1 & 96 & 124 & 1.85 & 6.6 & 0.8 & $<50$ & 3.8 & 7.5 & 250 \\
\hline 07-BA-20 & 18 & 4.9 & 6.02 & $<0.02$ & 1.1 & 53 & 140 & 0.95 & 0.2 & 1.6 & 60 & 4.9 & 72.9 & 130 \\
\hline $\begin{array}{c}07-\mathrm{BA}- \\
20 \mathrm{~A}\end{array}$ & 34 & 10.4 & 8.85 & $<0.02$ & 5.4 & 83 & 48 & 0.19 & 0.7 & 3.7 & 80 & 5.2 & 192 & 81.8 \\
\hline
\end{tabular}


Table 1-9. Minor element concentrations in rock samples from the Paramount-Bald Peak alteration zone.-Continued

[Hg, mercury; HgS, mercury sulfide; mm, millimeter; cb, cinnabar; py, pyrite; - , no data]

\begin{tabular}{|c|c|c|c|c|c|c|c|c|c|c|c|c|c|}
\hline $\begin{array}{l}\text { Sample } \\
\text { number }\end{array}$ & $\begin{array}{c}\text { Sc } \\
\text { ppm }\end{array}$ & $\begin{array}{c}\text { Sn } \\
\text { ppm }\end{array}$ & $\begin{array}{c}\mathrm{Sr} \\
\mathrm{ppm}\end{array}$ & $\begin{array}{c}\text { Te } \\
\text { ppm }\end{array}$ & $\begin{array}{c}\text { Th } \\
\text { ppm }\end{array}$ & $\begin{array}{c}\text { TI } \\
\text { ppm }\end{array}$ & $\begin{array}{c}\mathbf{U} \\
\mathrm{ppm}\end{array}$ & $\begin{array}{c}\mathbf{V} \\
\mathrm{ppm}\end{array}$ & $\begin{array}{c}\text { W } \\
\text { ppm }\end{array}$ & $\begin{array}{c}Y \\
\text { ppm }\end{array}$ & $\begin{array}{c}\mathrm{Zn} \\
\mathrm{ppm}\end{array}$ & $\begin{array}{c}\text { Se } \\
\mathrm{ppm}\end{array}$ & $\begin{array}{l}\text { C } \\
\%\end{array}$ \\
\hline ATAS06-1 & $<5$ & $<1$ & 340 & $<0.5$ & 3.3 & 1.8 & 0.79 & 11 & 19 & 1.5 & 6 & $<0.2$ & $<0.01$ \\
\hline 06-BA-5 & 0.9 & 0.5 & 456 & $<0.1$ & 5.7 & 0.8 & 0.7 & 18 & 125 & 1 & 3 & - & - \\
\hline 06-BA-6 & 0.5 & 0.4 & 257 & $<0.1$ & 4.1 & 1.6 & 0.5 & 11 & 20.9 & 0.7 & 5 & - & - \\
\hline 06-BA-7 & 2.7 & 0.9 & 155 & $<0.1$ & 6.9 & 2.1 & 8.7 & 47 & 123 & 4.5 & 9 & - & - \\
\hline 06-BA-8 & 2.7 & 1.3 & 72.6 & $<0.1$ & 9 & 0.3 & 4.9 & 28 & 69.7 & 3.5 & 6 & - & - \\
\hline 11-BA-43 & 2.1 & 0.7 & 45.8 & $<0.1$ & 14.2 & 0.3 & 5.4 & 83 & 147 & 6.3 & 13 & 0.3 & - \\
\hline 11-BA-33A & 1 & 0.4 & 194 & 0.1 & 6.1 & 3.4 & 3.1 & 6 & 5 & 2.8 & 2 & - & - \\
\hline 11-BA-33B & 1.8 & 0.5 & 491 & $<0.1$ & 9.5 & 4.7 & 4.7 & 14 & 15.9 & 6.2 & 10 & 0.9 & - \\
\hline $11-B A-34 \mathrm{~A}$ & 0.8 & 0.3 & 106 & 0.2 & 2.5 & 0.7 & 0.9 & 9 & 2.9 & 1 & 3 & 0.4 & - \\
\hline 11-BA-34B & 1.6 & 0.4 & 361 & $<0.1$ & 4.9 & 0.9 & 3.1 & 23 & 21.6 & 4.1 & 9 & 0.7 & - \\
\hline 11-BA-35A & 1 & 0.3 & 209 & $<0.1$ & 2.7 & 0.8 & 2.2 & 19 & 7.8 & 1.8 & 6 & $<0.2$ & - \\
\hline 11-BA-35B & 1.5 & 0.3 & 102 & $<0.1$ & 2.5 & 1.9 & 6.1 & 20 & 5.9 & 2.5 & 14 & $<0.2$ & - \\
\hline PMT06-1 & $<5$ & 2 & 80.4 & $<0.5$ & 0.3 & 0.7 & 0.27 & $<5$ & 16 & 0.9 & $<5$ & 0.6 & $<0.01$ \\
\hline РMT06-1A & $<5$ & $<1$ & 49.6 & $<0.5$ & 0.4 & $<0.5$ & 0.35 & $<5$ & 7 & 0.8 & $<5$ & 0.3 & $<0.01$ \\
\hline РМT06-2 & $<5$ & 1 & 59.6 & $<0.5$ & 0.6 & $<0.5$ & 0.36 & $<5$ & 10 & 1 & 6 & 0.3 & 0.01 \\
\hline РМТ06-3 & 8 & $<1$ & 25.8 & $<0.5$ & $<0.1$ & $<0.5$ & 0.06 & 8 & 2 & $<0.5$ & 9 & $<0.2$ & $<0.01$ \\
\hline 07PM1 & 0.2 & $<0.1$ & 20.2 & 0.1 & $<0.2$ & 0.4 & 0.1 & 1 & 1.1 & 0.2 & $<1$ & - & - \\
\hline 07PM2 & 2.3 & 0.5 & 114 & 0.1 & 3.1 & 1.2 & 1.1 & 18 & 6.1 & 2.8 & 5 & - & - \\
\hline 07PM4 & 1.7 & 0.5 & 181 & $<0.1$ & 4.2 & 0.3 & 1.7 & 15 & 10.7 & 2.7 & 2 & - & - \\
\hline 07PM6 & 2.3 & 0.5 & 135 & $<0.1$ & 3.7 & 6 & 1.8 & 21 & 7.5 & 4.2 & 8 & - & - \\
\hline 07PM8 & 0.3 & $<0.1$ & 45.5 & $<0.1$ & 0.4 & 0.3 & 0.1 & 1 & 0.6 & 0.4 & 3 & - & - \\
\hline 07PM9 & 2.3 & 0.3 & 114 & $<0.1$ & 2.2 & 0.5 & 0.8 & 10 & 8.5 & 2.9 & 3 & - & - \\
\hline 07PM10 & 2.5 & 0.4 & 104 & 0.1 & 2.5 & 0.7 & 0.8 & 14 & 14.4 & 2 & 11 & - & - \\
\hline 07PM11 & 0.2 & $<0.1$ & 19.2 & $<0.1$ & $<0.2$ & 0.2 & $<0.1$ & 1 & 0.7 & 0.2 & $<1$ & - & - \\
\hline 07PM14 & 3.4 & 1.2 & 285 & $<0.1$ & 8.3 & 0.5 & 2.2 & 25 & 59.4 & 5.4 & 9 & - & - \\
\hline 07PM12 & 2 & 0.8 & 45.6 & $<0.1$ & 3.2 & 0.4 & 1.6 & 6 & 28.9 & 2.6 & 2 & - & - \\
\hline 07-BA-20 & 0.5 & 0.2 & 129 & 0.1 & 0.4 & 1.8 & 0.2 & 5 & 0.7 & 0.3 & 6 & 0.6 & - \\
\hline 07-BA-20A & 1.2 & 0.4 & 116 & $<0.1$ & 2 & 4.7 & 0.8 & 13 & 2.6 & 1.6 & 6 & 0.3 & - \\
\hline
\end{tabular}


Table 1-9. Minor element concentrations in rock samples from the Paramount-Bald Peak alteration zone.-Continued

[Hg, mercury; HgS, mercury sulfide; mm, millimeter; cb, cinnabar; py, pyrite; —, no data]

\begin{tabular}{|c|c|c|c|c|c|c|c|c|c|}
\hline $\begin{array}{l}\text { Sample } \\
\text { number }\end{array}$ & Latitude & Longitude & Description1 & Location & $\begin{array}{c}\text { Au } \\
\text { ppm }\end{array}$ & $\begin{array}{c}\mathrm{Hg} \\
\mathrm{ppm}\end{array}$ & $\begin{array}{l}\text { Al } \\
\%\end{array}$ & $\begin{array}{l}\text { Ca } \\
\%\end{array}$ & $\begin{array}{l}\mathrm{Fe} \\
\%\end{array}$ \\
\hline $07-B A-21$ & 38.2767 & -119.0567 & Altered tuff, Paramount Mine & Paramount Mine hill & 0.015 & 0.12 & 3.21 & 0.1 & 0.38 \\
\hline 07-BA-22 & 38.2767 & -119.0567 & Banded chalcedony vein with local bladed texture, Paramount Mine & Paramount Mine hill & 0.741 & 5.03 & 1.18 & 0.05 & 0.45 \\
\hline 07-BA-24 & 38.2778 & -119.0577 & Chalcedony vein in open cut, Paramount Mine & Paramount Mine hill & 0.057 & 16.3 & 0.7 & 0.02 & 0.87 \\
\hline $07-B A-25$ & 38.2788 & -119.0591 & Leached, silicified pumiceous tuff, Paramount Mine dump & Paramount Mine hill & 0.054 & 213 & 0.34 & 0.02 & 0.1 \\
\hline 08-BA-13 & 38.27807 & -119.05771 & Leached pumice-rich tuff & Paramount Mine hill & 0.017 & 0.24 & 4.21 & 0.06 & 0.46 \\
\hline 08PT1 & 38.2675 & -119.0642 & Quartz-carbonate & SW Paramount hill & 0.017 & 0.57 & 2.43 & 0.06 & 4 \\
\hline 08РT2 & 38.2675 & -119.0642 & Argillically-altered, unwelded tuff & SW Paramount hill & $<0.005$ & 1.77 & 4.01 & 0.06 & 1.37 \\
\hline 08РТ3 & 38.2679 & -119.0640 & Breccia with silicified quartz vein & SW Paramount hill & 0.089 & 1.42 & 0.92 & 0.05 & 0.38 \\
\hline 08PT4 & 38.2682 & -119.0634 & Chalcedony-quartz veins & SW Paramount hill & 1.99 & 4.16 & 1.66 & 0.06 & 0.96 \\
\hline 08PT6 & 38.2688 & -119.0615 & Black silicified tuff & SW Paramount hill & 0.033 & 1.37 & 4.78 & 0.05 & 1.54 \\
\hline 08РT9 & 38.2686 & -119.0593 & Quartz vein adjacent to waste pile & SW Paramount hill & 0.422 & 34.4 & 0.4 & 0.06 & 2.66 \\
\hline 08PT11 & 38.2683 & -119.0564 & Porphyritic block of dacite breccia & SW Paramount hill & 0.022 & 0.02 & 7.65 & 0.09 & 1.76 \\
\hline 08РТ13 & 38.2680 & -119.0667 & Banded chalcedony vein with sulfides in dacite breccia & SW Paramount hill & 0.21 & 14.4 & 1.11 & 0.06 & 1.28 \\
\hline 08PT14 & 38.2701 & -119.0666 & Chalcedonic banded vein cutting breccia & SW Paramount hill & 0.2 & 0.26 & 1.87 & 0.06 & 0.35 \\
\hline 08PT15 & 38.2713 & -119.0686 & Tuff with red-brown matrix & SW Paramount hill & 0.03 & 2.63 & 4.81 & 0.23 & 1.31 \\
\hline 09-BA-59 & 38.2682 & -119.0606 & Silicified tuff locally with cinnabar & SW Paramount hill & 0.125 & 10.2 & 1.46 & 0.09 & 1.98 \\
\hline 09-BA-60 & 38.2682 & -119.0627 & $\begin{array}{l}\text { 3-inch banded white quartz vein with carbonate pseudomorphs; local fine- } \\
\text { grained pyrite }\end{array}$ & SW Paramount hill & 1.68 & 2.85 & 0.9 & 0.04 & 0.53 \\
\hline 09-BA-60A & 38.2682 & -119.0627 & $\begin{array}{l}\text { 3-inch banded white quartz vein with carbonate pseudomorphs; local fine- } \\
\text { grained pyrite }\end{array}$ & SW Paramount hill & 2.05 & 0.75 & 0.58 & 0.02 & 0.23 \\
\hline 08PT16 & 38.2699 & -119.0515 & Silicified tuff breccia with black matrix & $\begin{array}{l}\text { South Paramount Mine } \\
\text { hill }\end{array}$ & $<0.005$ & 0.01 & 0.62 & 0.04 & 0.2 \\
\hline 08PT7C & 38.2731 & -119.0570 & Quartz vein with carbonate pseudomorphs & $\begin{array}{l}\text { South Paramount Mine } \\
\text { hill }\end{array}$ & $<0.005$ & 0.24 & 5.74 & 0.17 & 1.37 \\
\hline 09-BA-51 & 38.26194 & -119.04214 & Hydrothermally brecciated silicified tuff; possible vent for laminated sinter? & SW Paramount basin & 0.016 & 0.12 & 1.06 & 0.15 & 0.28 \\
\hline 09-BA-52 & 38.2651 & -119.0449 & Silicified conglomeratic breccia; locally hematite rich & SW Paramount basin & 0.125 & 0.37 & 0.66 & 0.08 & 0.76 \\
\hline 08-BA-17 & 38.27596 & -119.03622 & Silicified breccia & SW Paramount basin & $<0.005$ & 3.83 & 0.47 & 0.05 & 1.39 \\
\hline 08-BA-18 & 38.27651 & -119.03602 & Prospect pit in silicified breccia with cinnabar + barite(?) & SW Paramount basin & $<0.005$ & 1,290 & 0.22 & 0.03 & 0.08 \\
\hline 10-BA-32 & 38.26275 & -119.03353 & Silicified knob with strong E-W jointing & SW Paramount basin & $<0.005$ & 0.99 & 4.88 & 0.03 & 0.34 \\
\hline $10-B A-33$ & 38.26275 & -119.03353 & Pumice-rich tuff & SW Paramount basin & $<0.005$ & 0.26 & 4.37 & 0.34 & 0.68 \\
\hline
\end{tabular}


Table 1-9. Minor element concentrations in rock samples from the Paramount-Bald Peak alteration zone.-Continued

[Hg, mercury; HgS, mercury sulfide; mm, millimeter; cb, cinnabar; py, pyrite; —, no data]

\begin{tabular}{|c|c|c|c|c|c|c|c|c|c|c|c|c|c|c|}
\hline $\begin{array}{l}\text { Sample } \\
\text { number }\end{array}$ & $\begin{array}{l}\mathbf{K} \\
\%\end{array}$ & $\begin{array}{c}\mathbf{M g} \\
\%\end{array}$ & $\begin{array}{c}\mathrm{Na} \\
\%\end{array}$ & $\begin{array}{l}\mathbf{S} \\
\%\end{array}$ & $\begin{array}{l}\mathrm{Ti} \\
\%\end{array}$ & $\begin{array}{c}\mathrm{Ag} \\
\mathrm{ppm}\end{array}$ & $\begin{array}{c}\text { As } \\
\mathrm{ppm}\end{array}$ & $\begin{array}{c}\mathrm{Ba} \\
\mathrm{ppm}\end{array}$ & $\begin{array}{c}\mathrm{Be} \\
\mathrm{ppm}\end{array}$ & $\begin{array}{c}\mathrm{Bi} \\
\mathrm{ppm}\end{array}$ & $\underset{\mathrm{ppm}}{\mathrm{Cd}}$ & $\begin{array}{c}\mathrm{Ce} \\
\mathrm{ppm}\end{array}$ & $\begin{array}{c}\text { Co } \\
\text { ppm }\end{array}$ & $\underset{\mathrm{ppm}}{\mathrm{Cr}}$ \\
\hline 07-BA-21 & 4.2 & 0.02 & 0.04 & 0.02 & 0.07 & $<1$ & 22 & 941 & 3.6 & 0.05 & $<0.1$ & 42.8 & 0.3 & 2 \\
\hline 07-BA-22 & 1 & 0.02 & 0.03 & 0.04 & 0.03 & 13 & 89 & 657 & 19.6 & $<0.04$ & 0.2 & 7.72 & 0.4 & 5 \\
\hline 07-BA-24 & 0.12 & $<0.01$ & 0.03 & 0.03 & 0.03 & $<1$ & 89 & 1,530 & 10.3 & $<0.04$ & $<0.1$ & 6.89 & 0.1 & 4 \\
\hline 07-BA-25 & 0.08 & $<0.01$ & 0.02 & 0.03 & 0.22 & $<1$ & 7 & 1,030 & 4.6 & $<0.04$ & $<0.1$ & 7.38 & 0.2 & 4 \\
\hline 08-BA-13 & 0.1 & 0.03 & 0.02 & 0.04 & 0.13 & $<1$ & 63 & 413 & 2.7 & 0.16 & 0.2 & 43 & 1.4 & 2 \\
\hline 08PT1 & 1.86 & 0.03 & 0.05 & 0.02 & 0.08 & $<1$ & 324 & 436 & 5.3 & 0.06 & 0.2 & 28.5 & 3.8 & 19 \\
\hline 08РT2 & 4.15 & 0.12 & 0.08 & 0.04 & 0.33 & $<1$ & 387 & 907 & 2.6 & 0.07 & $<0.1$ & 27.2 & 0.5 & 3 \\
\hline 08РT3 & 0.27 & 0.05 & 0.02 & 0.05 & 0.03 & $<1$ & 57 & 339 & 7.6 & $<0.04$ & $<0.1$ & 14.6 & 0.3 & 9 \\
\hline 08PT4 & 1.6 & 0.02 & 0.03 & 0.06 & 0.05 & 7 & 116 & 714 & 6.2 & $<0.04$ & $<0.1$ & 11 & 0.6 & 22 \\
\hline 08PT6 & 5.65 & 0.03 & 0.07 & 0.05 & 0.1 & $<1$ & 270 & 1,830 & 2.8 & 0.08 & $<0.1$ & 53.3 & 0.5 & 12 \\
\hline 08РТ9 & 0.15 & 0.01 & 0.01 & 0.14 & $<0.01$ & $<1$ & 896 & 1,460 & 12.6 & 0.09 & $<0.1$ & 4.22 & 0.8 & 13 \\
\hline 08PT11 & 5.58 & 0.09 & 0.46 & 0.01 & 0.19 & $<1$ & 73 & 1,820 & 1.8 & $<0.04$ & $<0.1$ & 48 & 2.9 & 6 \\
\hline 08РT13 & 0.91 & 0.02 & 0.03 & 0.65 & 0.04 & 1 & 133 & 291 & 2 & $<0.04$ & $<0.1$ & 6.6 & 0.3 & 12 \\
\hline 08РТ14 & 2.01 & 0.02 & 0.03 & 0.12 & 0.08 & $<1$ & 128 & 373 & 3.4 & $<0.04$ & $<0.1$ & 16.3 & 0.5 & 7 \\
\hline 08РT15 & 5.81 & 0.09 & 0.08 & 0.11 & 0.24 & $<1$ & 13 & 1,460 & 3.1 & 0.06 & 0.1 & 54.5 & 4.3 & 5 \\
\hline 09-BA-59 & 1.41 & 0.06 & 0.02 & 0.58 & 0.1 & $<1$ & 4,000 & 2,540 & 4.2 & $<0.04$ & $<0.1$ & 17.6 & 0.8 & 2 \\
\hline 09-BA-60 & 0.71 & 0.01 & $<0.01$ & 0.3 & 0.04 & 5 & 696 & 605 & 3.3 & $<0.04$ & $<0.1$ & 8.2 & 0.4 & 2 \\
\hline 09-BA-60A & 0.38 & $<0.01$ & $<0.01$ & $<0.01$ & 0.02 & 1 & 79 & 150 & 3.6 & $<0.04$ & $<0.1$ & 3.4 & 0.4 & 1 \\
\hline 08РT16 & 0.17 & 0.01 & 0.12 & 0.09 & 0.7 & $<1$ & 15 & 1,490 & 0.2 & 0.45 & $<0.1$ & 9.03 & 0.4 & 11 \\
\hline 08РT7C & 3.75 & 0.45 & 0.04 & 0.03 & 0.31 & $<1$ & 222 & 740 & 3.7 & 0.1 & $<0.1$ & 80.5 & 1.6 & 3 \\
\hline 09-BA-51 & 0.1 & 0.02 & 0.01 & 0.07 & 0.48 & $<1$ & 23 & 367 & 0.7 & 0.24 & 0.2 & 14.2 & 1.5 & 6 \\
\hline 09-BA-52 & 0.08 & 0.02 & 0.02 & 0.1 & 0.46 & $<1$ & 151 & 957 & 0.8 & 0.16 & $<0.1$ & 14.2 & 0.9 & 2 \\
\hline 08-BA-17 & 0.04 & 0.01 & $<0.01$ & 0.15 & 0.62 & $<1$ & 219 & 4,440 & 0.5 & 0.51 & 0.1 & 5.97 & 0.7 & 6 \\
\hline 08-BA-18 & 0.03 & $<0.01$ & $<0.01$ & 0.04 & 0.26 & $<1$ & 14 & 1,180 & 0.5 & 0.22 & $<0.1$ & 2.92 & 0.2 & 2 \\
\hline $10-B A-32$ & 0.06 & $<0.01$ & 0.01 & 0.07 & 0.29 & $<1$ & 66 & 758 & 0.7 & 0.06 & $<0.1$ & 53.6 & 0.2 & 6 \\
\hline 10-BA-33 & 0.08 & 0.01 & $<0.01$ & 0.19 & 0.07 & $<1$ & 133 & 223 & 0.6 & 0.38 & $<0.1$ & 30.2 & 0.3 & 3 \\
\hline
\end{tabular}


Table 1-9. Minor element concentrations in rock samples from the Paramount-Bald Peak alteration zone.-Continued

[Hg, mercury; HgS, mercury sulfide; mm, millimeter; cb, cinnabar; py, pyrite; - , no data]

\begin{tabular}{|c|c|c|c|c|c|c|c|c|c|c|c|c|c|c|}
\hline $\begin{array}{l}\text { Sample } \\
\text { number }\end{array}$ & $\begin{array}{c}\text { Cs } \\
\text { ppm }\end{array}$ & $\begin{array}{c}\mathrm{Cu} \\
\mathrm{ppm}\end{array}$ & $\begin{array}{c}\text { Ga } \\
\text { ppm }\end{array}$ & $\begin{array}{c}\text { In } \\
\text { ppm }\end{array}$ & $\begin{array}{l}\text { La } \\
\text { ppm }\end{array}$ & $\begin{array}{c}\mathrm{Li} \\
\mathrm{ppm}\end{array}$ & $\begin{array}{c}\mathrm{Mn} \\
\mathrm{ppm}\end{array}$ & $\begin{array}{l}\text { Mo } \\
\text { ppm }\end{array}$ & $\begin{array}{l}\mathrm{Nb} \\
\mathrm{ppm}\end{array}$ & $\begin{array}{c}\mathrm{Ni} \\
\mathrm{ppm}\end{array}$ & $\begin{array}{c}P \\
\text { ppm }\end{array}$ & $\begin{array}{c}\mathrm{Pb} \\
\mathrm{ppm}\end{array}$ & $\begin{array}{c}\mathbf{R b} \\
\mathbf{p p m}\end{array}$ & $\begin{array}{c}\text { Sb } \\
\text { ppm }\end{array}$ \\
\hline 07-BA-21 & 18 & 2 & 7.6 & $<0.02$ & 22.5 & 83 & 72 & 0.2 & 2.5 & 0.6 & 150 & 14.3 & 264 & 49.6 \\
\hline 07-BA-22 & 29 & 6 & 21.2 & $<0.02$ & 4.2 & 79 & 41 & 0.36 & 0.8 & 2.4 & 70 & 4 & 85.3 & 151 \\
\hline 07-BA-24 & 22 & 5.4 & 12.3 & $<0.02$ & 4 & 39 & 27 & 0.21 & 0.1 & 1.7 & $<50$ & 2.7 & 16.4 & 122 \\
\hline 07-BA-25 & 11 & 4.6 & 2.27 & $<0.02$ & 4.1 & 79 & 67 & 0.27 & 1.5 & 1.3 & $<50$ & 6.8 & 10.2 & 231 \\
\hline 08-BA-13 & 6 & 6.3 & 11.8 & 0.03 & 24.3 & 49 & 170 & 0.62 & 8.5 & 2.3 & 330 & 13.3 & 8.6 & 59.7 \\
\hline 08PT1 & 7 & 18.4 & 4.44 & $<0.02$ & 18.8 & 111 & 175 & 0.93 & 1.3 & 7.5 & 1,080 & 6.3 & 117 & 65 \\
\hline 08РT2 & 21 & 11.9 & 11.7 & 0.03 & 15 & 90 & 31 & 0.35 & 7 & 0.5 & 140 & 9.2 & 312 & 69.2 \\
\hline 08РT3 & 30 & 4.3 & 2.71 & $<0.02$ & 6.7 & 121 & 22 & 1.57 & 0.3 & 1.2 & 130 & 2.4 & 31.5 & 363 \\
\hline 08PT4 & 10 & 6.7 & 4.02 & $<0.02$ & 6.1 & 101 & 59 & 0.88 & 0.6 & 2.5 & 380 & 4.1 & 98.1 & 104 \\
\hline 08РT6 & 11 & 6.2 & 11 & 0.03 & 32.1 & 58 & 39 & 0.67 & 2.9 & 1.2 & 590 & 11.7 & 414 & 50.8 \\
\hline 08РT9 & $<5$ & 8.2 & 3.47 & $<0.02$ & 1.5 & 48 & 28 & 2 & $<0.1$ & 1.3 & 280 & 1.3 & 5.2 & 620 \\
\hline 08PT11 & 11 & 13 & 18 & 0.03 & 26.9 & 16 & 96 & 0.48 & 3.5 & 2.7 & 920 & 15.8 & 351 & 18.5 \\
\hline 08РТ13 & 12 & 7.2 & 2.03 & $<0.02$ & 4.2 & 139 & 33 & 0.4 & 0.6 & $<0.5$ & 540 & 8.4 & 64 & 120 \\
\hline 08РT14 & 15 & 4.3 & 6.48 & $<0.02$ & 8.7 & 59 & 23 & 0.41 & 1.8 & 1.1 & 210 & 4.2 & 142 & 57 \\
\hline 08PT15 & 15 & 13.3 & 11.4 & 0.03 & 32.3 & 90 & 97 & 0.41 & 6.2 & 3.8 & 470 & 12.1 & 457 & 54 \\
\hline 09-BA-59 & 24 & 105 & 4.4 & $<0.02$ & 8.8 & 90 & 35 & 0.93 & 2.4 & 0.5 & 490 & 5.4 & 110 & 197 \\
\hline 09-BA-60 & 8 & 3.7 & 4.98 & $<0.02$ & 3.7 & 81 & 28 & 2.34 & 0.3 & $<0.5$ & 80 & 3.4 & 49 & 349 \\
\hline 09-BA-60A & $<5$ & 3 & 4.77 & $<0.02$ & 1.8 & 84 & 54 & 0.48 & 0.1 & 1.1 & 80 & 2.4 & 27.2 & 55.1 \\
\hline 08РT16 & 32 & 5.2 & 1.02 & $<0.02$ & 5.6 & 1 & 12 & 2.29 & 18.5 & 6.2 & 150 & 17.4 & 22.7 & 0.81 \\
\hline 08РT7C & 56 & 3.5 & 16.4 & 0.04 & 41 & 36 & 93 & 0.6 & 12 & 1.2 & 1,640 & 19.7 & 403 & 56.6 \\
\hline 09-BA-51 & 6 & 18.4 & 3.1 & $<0.02$ & 7.8 & 45 & 161 & 2.44 & 8.5 & 1.6 & 940 & 15.4 & 7 & 52.2 \\
\hline 09-BA-52 & $<5$ & 12.5 & 4.01 & $<0.02$ & 7 & 33 & 98 & 4.38 & 9.7 & 1.1 & 250 & 15.7 & 4.9 & 64.7 \\
\hline 08-BA-17 & $<5$ & 11.2 & 0.98 & $<0.02$ & 4.3 & 25 & 74 & 2.38 & 23.8 & 2.9 & 360 & 6.2 & 2.1 & 29.7 \\
\hline 08-BA-18 & $<5$ & 4.9 & 0.89 & $<0.02$ & 2 & 17 & 36 & 0.61 & 9 & 0.8 & $<50$ & 5 & 1.4 & 4.89 \\
\hline 10-BA-32 & 6 & 5.4 & 10.8 & $<0.02$ & 29.6 & 42 & 25 & 4.23 & 8 & 0.7 & 170 & 8.7 & 3.9 & 56.2 \\
\hline $10-B A-33$ & 6 & 7.7 & 11.4 & $<0.02$ & 16.3 & 48 & 31 & 1.98 & 13.8 & 0.6 & 150 & 17.9 & 4.5 & 35.4 \\
\hline
\end{tabular}


Table 1-9. Minor element concentrations in rock samples from the Paramount-Bald Peak alteration zone.-Continued

[Hg, mercury; HgS, mercury sulfide; mm, millimeter; cb, cinnabar; py, pyrite; —, no data]

\begin{tabular}{|c|c|c|c|c|c|c|c|c|c|c|c|c|c|}
\hline $\begin{array}{l}\text { Sample } \\
\text { number }\end{array}$ & $\begin{array}{c}\text { Sc } \\
\text { ppm }\end{array}$ & $\begin{array}{c}\text { Sn } \\
\text { ppm }\end{array}$ & $\begin{array}{c}\text { Sr } \\
\text { ppm }\end{array}$ & $\begin{array}{c}\text { Te } \\
\text { ppm }\end{array}$ & $\begin{array}{c}\text { Th } \\
\text { ppm }\end{array}$ & $\begin{array}{c}\text { TI } \\
\text { ppm }\end{array}$ & $\underset{\mathrm{ppm}}{\mathrm{U}}$ & $\begin{array}{c}\mathrm{V} \\
\mathrm{ppm}\end{array}$ & $\begin{array}{c}\text { W } \\
\text { ppm }\end{array}$ & $\begin{array}{c}\mathrm{Y} \\
\mathrm{ppm}\end{array}$ & $\begin{array}{c}\mathrm{Zn} \\
\mathrm{ppm}\end{array}$ & $\begin{array}{c}\text { Se } \\
\text { ppm }\end{array}$ & $\begin{array}{l}\text { C } \\
\%\end{array}$ \\
\hline 07-BA-21 & 1.3 & 0.7 & 54.8 & $<0.1$ & 6.3 & 1.9 & 2.1 & 25 & 2 & 4.1 & 9 & $<0.2$ & - \\
\hline 07-BA-22 & 1 & 0.3 & 121 & $<0.1$ & 1.2 & 1.7 & 0.5 & 72 & 2.6 & 1.5 & 20 & 1.3 & - \\
\hline 07-BA-24 & 0.9 & 0.2 & 74.4 & $<0.1$ & 1.3 & 0.4 & 0.8 & 18 & 9.8 & 0.9 & 4 & $<0.2$ & - \\
\hline 07-BA-25 & 2.2 & 0.5 & 50.6 & $<0.1$ & 4.1 & 0.2 & 1.8 & 5 & 2.3 & 2.5 & 2 & 0.4 & - \\
\hline 08-BA-13 & 2.7 & 1.1 & 69.9 & 0.1 & 13.2 & 0.1 & 4.3 & 29 & 16.6 & 10.1 & 19 & - & - \\
\hline 08PT1 & 3.2 & 0.3 & 114 & $<0.1$ & 2.5 & 1.7 & 1.7 & 33 & 3.3 & 5.3 & 83 & - & - \\
\hline 08РT2 & 7 & 1.3 & 62.2 & $<0.1$ & 8 & 5.4 & 2.8 & 70 & 10.6 & 6.8 & 6 & - & - \\
\hline 08РT3 & 1.3 & 0.3 & 92.7 & $<0.1$ & 1.2 & 1.1 & 0.4 & 16 & 1.3 & 1.6 & 3 & - & - \\
\hline 08РT4 & 1.5 & 0.3 & 102 & $<0.1$ & 1.3 & 1.6 & 0.6 & 12 & 2.4 & 1.5 & 9 & - & - \\
\hline 08PT6 & 3.2 & 0.9 & 195 & $<0.1$ & 5.4 & 7.3 & 1.8 & 37 & 3.5 & 5.7 & 22 & - & - \\
\hline 08РТ9 & 0.9 & $<0.1$ & 67.7 & $<0.1$ & 0.2 & 13.7 & 0.5 & 8 & 16.7 & 2.2 & 14 & - & - \\
\hline 08PT11 & 5.9 & 0.8 & 356 & $<0.1$ & 8.1 & 10.8 & 2.6 & 55 & 13.3 & 5.1 & 21 & - & - \\
\hline 08РT13 & 1.8 & 0.3 & 87.1 & $<0.1$ & 0.9 & 3.7 & 1 & 17 & 2.5 & 0.9 & 2 & - & - \\
\hline 08РT14 & 2.3 & 0.3 & 106 & $<0.1$ & 2.1 & 2.1 & 0.9 & 25 & 4.8 & 2.2 & 5 & - & - \\
\hline 08PT15 & 5.2 & 1.2 & 314 & $<0.1$ & 8.4 & 8 & 3.1 & 49 & 7.4 & 14.7 & 53 & - & - \\
\hline 09-BA-59 & 2.1 & 0.7 & 240 & $<0.1$ & 3.2 & 6.8 & 1.7 & 17 & 4.3 & 3.4 & 3 & 1 & - \\
\hline 09-BA-60 & 0.8 & 0.8 & 77.6 & $<0.1$ & 1 & 3.8 & 0.4 & 6 & 1.1 & 1.6 & 1 & 0.5 & - \\
\hline 09-BA-60A & 0.5 & 0.3 & 41 & $<0.1$ & 0.5 & 0.4 & 0.2 & 5 & 0.7 & 0.7 & 3 & $<0.2$ & - \\
\hline 08РТ16 & 3.5 & 3.3 & 101 & 0.1 & 6 & 1.7 & 3.8 & 10 & 1.3 & 2.4 & 3 & - & - \\
\hline 08РT7C & 6.9 & 1.9 & 60.7 & $<0.1$ & 14.2 & 5.5 & 4.9 & 30 & 13.7 & 11.9 & 22 & - & - \\
\hline 09-BA-51 & 1.5 & 2 & 82.9 & 0.3 & 4.9 & 0.2 & 4.3 & 27 & 37.2 & 3.3 & 9 & - & - \\
\hline 09-BA-52 & 1.4 & 1.4 & 70.3 & $<0.1$ & 7.7 & 0.2 & 3.4 & 53 & 83.3 & 4.2 & 6 & 0.4 & - \\
\hline 08-BA-17 & 5.7 & 2.5 & 123 & 0.2 & 5.4 & $<0.1$ & 6.2 & 38 & 27.7 & 9.4 & 13 & - & - \\
\hline 08-BA-18 & 2.2 & 0.8 & 44.5 & 0.2 & 4 & $<0.1$ & 3.5 & 5 & 5.4 & 3 & 15 & - & - \\
\hline 10-BA-32 & 4.4 & 1.1 & 79.5 & 0.1 & 14.2 & 5.5 & 4.1 & 62 & 21.9 & 7.4 & 3 & - & - \\
\hline $10-B A-33$ & 1.7 & 0.7 & 65.8 & 0.2 & 20.9 & 1.2 & 4 & 16 & 6.4 & 4.5 & 4 & - & - \\
\hline
\end{tabular}


Table 1-10. Minor element concentrations in rocks samples from the Cinnabar Canyon-US 395 alteration zone.

[alt, alteration; DDH, diamond drill hole; Fe, iron; FeOx, iron oxide; HgS, mercury sulfide; K, potassium; RDH, rotary drill hole; S, sulfur]

\begin{tabular}{|c|c|c|c|c|c|c|c|c|c|c|c|}
\hline $\begin{array}{l}\text { Sample } \\
\text { number }\end{array}$ & Description & Latitude & Longitude & $\begin{array}{c}\text { Au } \\
\text { ppm }\end{array}$ & $\begin{array}{c}\mathrm{Hg} \\
\mathrm{ppm}\end{array}$ & $\begin{array}{l}\text { Al } \\
\%\end{array}$ & $\begin{array}{l}\mathrm{Ca} \\
\%\end{array}$ & $\begin{array}{l}\mathrm{Fe} \\
\%\end{array}$ & $\begin{array}{l}\mathbf{K} \\
\%\end{array}$ & $\begin{array}{c}\mathrm{Mg} \\
\%\end{array}$ & $\begin{array}{c}\mathrm{Na} \\
\%\end{array}$ \\
\hline CCD7 & Cinnabar Canyon S resource DDH & 38.19268 & -119.1597 & 0.084 & 28.9 & 0.07 & 0.02 & 1.62 & 0.01 & 0.01 & $<0.01$ \\
\hline CCD8B & Cinnabar Canyon $\mathrm{S}$ resource DDH & 38.19087 & -119.1597 & 0.018 & 42.6 & 0.07 & 0.05 & 2.16 & 0.01 & 0.02 & $<0.01$ \\
\hline $\mathrm{CCD} 16$ & Cinnabar Canyon S resource DDH & 38.19317 & -119.16045 & 0.014 & 84.1 & 0.14 & 0.05 & 3.96 & 0.02 & 0.02 & 0.02 \\
\hline 07-BA-10 & $\begin{array}{l}\text { S resource RDH cuttings, opal-montmorillonite-altered } \\
\text { porphyritic dacite }\end{array}$ & 38.18924 & -119.15404 & $<0.005$ & 0.24 & 0.44 & 0.03 & 0.58 & 0.03 & $<0.01$ & 0.06 \\
\hline 07-BA-11 & Silicified volcaniclastic breccia & 38.18967 & -119.15578 & $<0.005$ & 0.14 & 0.08 & 0.02 & 0.05 & $<0.01$ & 0.01 & $<0.01$ \\
\hline $07 \mathrm{CC} 1$ & Calmono $\mathrm{Hg}$ Mine; $\mathrm{HgS}$ in altered andesite & 38.18625 & -119.15728 & 0.037 & 92 & 8.62 & 0.22 & 0.97 & 1.89 & 0.05 & 0.58 \\
\hline $07 \mathrm{CC} 2$ & Calmono $\mathrm{Hg}$ Mine; $\mathrm{HgS}$ in altered andesite opal & 38.18625 & -119.15728 & $<0.005$ & 337 & 8.18 & 0.16 & 2.14 & 1.32 & 0.03 & 0.36 \\
\hline $07 \mathrm{CC} 5$ & Calmono $\mathrm{Hg}$ Mine; calcines from $\mathrm{Hg}$ mine & 38.18625 & -119.15728 & 0.006 & 21.6 & 8.67 & 0.58 & 4.99 & 0.98 & 0.19 & 0.38 \\
\hline 07CC6 & Calmono Hg Mine; sulfide in white opal & 38.18625 & -119.15728 & $<0.005$ & 0.71 & 0.26 & 0.06 & 0.54 & 0.11 & $<0.01$ & 0.01 \\
\hline 07-BA-8 & Cinnabar Canyon, argillized/opal-altered porphyritic dacite & 38.2765 & -119.16040 & 0.03 & 0.11 & 9.12 & 0.13 & 0.42 & 0.23 & 0.05 & 0.04 \\
\hline 07-BA-9 & Silicified, Fe-oxide-rich breccia, Cinnabar Canyon & 38.2736 & -119.13960 & 0.009 & 66.5 & 0.36 & 0.04 & 6.14 & 0.07 & $<0.01$ & 0.03 \\
\hline 07-BA-14 & Argillized andesite with opal pods, Cinnabar Canyon & 38.2907 & -119.1406 & $<0.005$ & 181 & 7.81 & 0.12 & 3.63 & 1.44 & 0.03 & 0.31 \\
\hline 07-BA-16 & Quarry in acid-leached breccia, mouth of Cinnabar Canyon & 38.2984 & -119.1387 & $<0.005$ & 0.55 & 0.44 & 0.05 & 0.23 & 0.13 & 0.01 & 0.06 \\
\hline $08 \mathrm{CC} 3$ & Argillic-leached lithic tuff & 38.17418 & -119.1523 & $<0.005$ & 0.03 & 9.59 & 0.1 & 1.33 & 2.93 & 0.04 & 1.49 \\
\hline $08 \mathrm{CC} 4$ & Biotite rhyolite porphyry flow & 38.17166 & -119.15484 & $<0.005$ & 0.01 & 7.42 & 1.35 & 1.23 & 3.47 & 0.31 & 2.63 \\
\hline $08 \mathrm{CC} 5$ & Plagioclase-K-feldspar dacite porphyry & 38.17445 & -119.15487 & $<0.005$ & $<0.01$ & 7.68 & 3.04 & 3.12 & 2.83 & 1.21 & 2.8 \\
\hline $08 \mathrm{CC} 6$ & Porphyritic andesite with fractures & 38.17403 & -119.15355 & $<0.005$ & 0.03 & 0.51 & 0.06 & 2.16 & 0.14 & $<0.01$ & 0.08 \\
\hline $08 \mathrm{CC} 7$ & Fault zone in dacite breccia & 38.18449 & -119.15257 & $<0.005$ & 0.04 & 3.42 & 0.14 & 2.12 & 0.17 & 0.04 & 0.07 \\
\hline $08 \mathrm{CC} 8$ & Andesite porphyry with plagioclase phenocrysts & 38.18832 & -119.14996 & $<0.005$ & 0.21 & 0.13 & 0.02 & 2.76 & 0.07 & $<0.01$ & 0.06 \\
\hline 08CC9 & Knob of opalized porphyritic andesite & 38.18931 & -119.14887 & $<0.005$ & 0.07 & 0.27 & 0.05 & 0.31 & 0.14 & 0.01 & 0.04 \\
\hline $08 \mathrm{CC} 10$ & Partially leached dacite porphyry & 38.19052 & -119.14950 & $<0.005$ & 0.01 & 7.19 & 0.69 & 2.29 & 2.61 & 0.33 & 1.52 \\
\hline $08 \mathrm{CC} 11$ & Opalized andesite & 38.18790 & -119.14996 & $<0.005$ & 0.15 & 0.18 & 0.03 & 0.63 & 0.11 & $<0.01$ & 0.02 \\
\hline $08 \mathrm{CC} 12$ & South end of opalite hill & 38.18754 & -119.14703 & $<0.005$ & 0.15 & 1.38 & 0.09 & 0.43 & 0.27 & 0.03 & 0.1 \\
\hline $08 \mathrm{CC} 13$ & White opal cutting opalized porphyritic andesite & 38.18605 & -119.15802 & $<0.005$ & 0.05 & 6.02 & 0.1 & 1.02 & 2.48 & 0.01 & 0.12 \\
\hline $08 \mathrm{CC} 14$ & Hematite and goethite cemented breccia & 38.19149 & -119.15797 & $<0.005$ & 10.2 & 1.26 & 0.06 & 23.6 & 0.07 & $<0.01$ & 0.02 \\
\hline 08CC15B & Altered & 38.19207 & -119.15808 & $<0.005$ & 57.7 & 0.2 & 0.03 & 2.09 & 0.07 & $<0.01$ & 0.05 \\
\hline $08 \mathrm{CC} 16$ & Massive chalcedony breccia & 38.19147 & -119.15773 & $<0.005$ & 0.13 & 0.13 & $<0.01$ & 0.06 & $<0.01$ & $<0.01$ & $<0.01$ \\
\hline $08 \mathrm{CC} 17$ & Andesite with fractures filled by opal & 38.19324 & -119.15959 & 0.008 & 15.6 & 0.13 & 0.03 & 3.34 & 0.03 & $<0.01$ & 0.01 \\
\hline $08 \mathrm{CC} 21$ & Andesite with plagioclase phenocrysts & 38.19104 & -119.15895 & $<0.005$ & 106 & 0.06 & $<0.01$ & 4.19 & 0.01 & $<0.01$ & $<0.01$ \\
\hline $08 \mathrm{CC} 22$ & Kaolinite north of road with some pyrite & 38.19871 & -119.17207 & $<0.005$ & 0.08 & 6.34 & 0.39 & 1.01 & 2.14 & 0.11 & 0.61 \\
\hline $08 \mathrm{CC} 23$ & Tan opalite/porphyritic dacite & 38.18489 & -119.17728 & $<0.005$ & 0.04 & 0.34 & 0.1 & 0.82 & 0.07 & 0.03 & 0.02 \\
\hline $08 \mathrm{CC} 24$ & Opalite-chalcedony & 38.18813 & -119.17698 & $<0.005$ & 0.48 & 0.08 & 0.02 & 0.08 & 0.01 & $<0.01$ & 0.01 \\
\hline $08 \mathrm{CC} 25$ & Opalite brecciated chalcedony with sulfides & 38.18680 & -119.17733 & 0.028 & 0.67 & 0.33 & 0.02 & 0.19 & 0.09 & $<0.01$ & 0.02 \\
\hline $39509-3$ & $\begin{array}{l}\text { White-beige, quartz-clay-alunite-altered volcaniclastics, US } 395 \\
\text { layback }\end{array}$ & 38.20793 & -119.22751 & $<0.005$ & 1.28 & 2.11 & 0.08 & 0.84 & 0.44 & $<0.01$ & 0.29 \\
\hline $39509-6$ & $\begin{array}{l}\text { Quartz-clay-alunite-altered porphyritic volcanic rock, Hot Springs } \\
\text { Canyon }\end{array}$ & 38.22064 & -119.19188 & $<0.005$ & 1.41 & 8.23 & 0.36 & 3.18 & 1.88 & 0.05 & 0.67 \\
\hline $39509-8$ & Quartz-clay-altered porphyritic volcanic rock, Hot Springs Canyon & 38.21008 & -119.1871 & $<0.005$ & 1.97 & 5.63 & 0.14 & 3.29 & 1.78 & 0.06 & 0.45 \\
\hline $39509-9$ & $\begin{array}{l}\text { Brown, coarse volcaniclastics, minor FeOx, upper Hot Springs } \\
\text { Canyon }\end{array}$ & 38.2056 & -119.18252 & $<0.005$ & 4.96 & 7.94 & 0.93 & 2.63 & 2.84 & 0.3 & 1.63 \\
\hline
\end{tabular}


Table 1-10. Minor element concentrations in rocks samples from the Cinnabar Canyon-US 395 alteration zone.-Continued

[alt, alteration; DDH, diamond drill hole; Fe, iron; FeOx, iron oxide; HgS, mercury sulfide; K, potassium; RDH, rotary drill hole; S, sulfur]

\begin{tabular}{|c|c|c|c|c|c|c|c|c|c|c|c|c|c|c|}
\hline $\begin{array}{l}\text { Sample } \\
\text { number }\end{array}$ & $\begin{array}{l}\mathbf{S} \\
\%\end{array}$ & $\begin{array}{l}\mathrm{Ti} \\
\%\end{array}$ & $\begin{array}{c}\mathrm{Ag} \\
\mathrm{ppm}\end{array}$ & $\begin{array}{c}\text { As } \\
\text { ppm }\end{array}$ & $\begin{array}{c}\text { Ba } \\
\text { ppm }\end{array}$ & $\begin{array}{l}\mathrm{Be} \\
\mathrm{ppm}\end{array}$ & $\begin{array}{c}\mathrm{Bi} \\
\mathrm{ppm}\end{array}$ & $\begin{array}{c}\text { Cd } \\
\text { ppm }\end{array}$ & $\begin{array}{c}\text { Ce } \\
\text { ppm }\end{array}$ & $\begin{array}{c}\text { Co } \\
\text { ppm }\end{array}$ & $\begin{array}{c}\mathrm{Cr} \\
\mathrm{ppm}\end{array}$ & $\begin{array}{c}\text { Cs } \\
\text { ppm }\end{array}$ & $\begin{array}{c}\text { Cu } \\
\text { ppm }\end{array}$ & $\begin{array}{c}\mathrm{Ga} \\
\mathrm{ppm}\end{array}$ \\
\hline CCD7 & 1.87 & 0.39 & 17 & 50 & 428 & $<0.1$ & 50.6 & 0.2 & 2.59 & 32.1 & 9 & $<5$ & 53.3 & 0.57 \\
\hline CCD8B & 2.42 & 0.71 & 2 & 32 & 164 & $<0.1$ & 67.3 & 0.2 & 0.72 & 35.7 & 7 & $<5$ & 31.7 & 0.5 \\
\hline CCD16 & 4.58 & 1.08 & 20 & 68 & 49 & $<0.1$ & 125 & 0.6 & 2.47 & 25.3 & 16 & $<5$ & 111 & 0.74 \\
\hline 07-BA-10 & 0.75 & 0.76 & $<1$ & 53 & 1,650 & $<0.1$ & 1.62 & 0.4 & 5.49 & 4.4 & 4 & $<5$ & 20.2 & 1.64 \\
\hline 07-BA-11 & 0.02 & 0.41 & $<1$ & 3 & 584 & $<0.1$ & 12 & $<0.1$ & 0.47 & 0.1 & 2 & $<5$ & 4.1 & 0.39 \\
\hline $07 \mathrm{CC} 1$ & 0.08 & 0.67 & $<1$ & 16 & 1,630 & 2.3 & 0.11 & $<0.1$ & 101 & 0.6 & 43 & $<5$ & 5.7 & 23.6 \\
\hline $07 \mathrm{CC} 2$ & 0.32 & 0.62 & 1 & 30 & 1,180 & 2.2 & 0.1 & $<0.1$ & 92.3 & 1.1 & 39 & $<5$ & 40.6 & 22.4 \\
\hline $07 \mathrm{CC} 5$ & 0.13 & 0.57 & $<1$ & 92 & 1,240 & 1.7 & 1.55 & 0.1 & 67.3 & 3.3 & 65 & $<5$ & 43.4 & 23.9 \\
\hline 07CC6 & 0.2 & 0.46 & 3 & 129 & 407 & 0.1 & 0.85 & 0.2 & 4.63 & 1.8 & 6 & $<5$ & 4.2 & 1.5 \\
\hline 07-BA-8 & 0.42 & 0.39 & 2 & 3 & 1,810 & 0.5 & 0.35 & 0.5 & 57.1 & 0.9 & 96 & $<5$ & 48.2 & 25.2 \\
\hline 07-BA-9 & 0.06 & 0.9 & $<1$ & 33 & 995 & 0.5 & 87.7 & 0.2 & 5.68 & 9.4 & 23 & $<5$ & 67.8 & 3.36 \\
\hline 07-BA-14 & 1 & 0.55 & $<1$ & 49 & 1,640 & 1.5 & 0.34 & $<0.1$ & 71.1 & 1.1 & 54 & $<5$ & 52.7 & 25.2 \\
\hline 07-BA-16 & 0.13 & 0.47 & $<1$ & 32 & 3,920 & $<0.1$ & 0.21 & $<0.1$ & 6.18 & 0.2 & 8 & 9 & 4.1 & 1.98 \\
\hline $08 \mathrm{CC} 3$ & 7.14 & 0.28 & $<1$ & 252 & 306 & 0.2 & 0.13 & $<0.1$ & 43.4 & 0.2 & 23 & 14 & 7.6 & 20.7 \\
\hline $08 \mathrm{CC} 4$ & 0.04 & 0.14 & $<1$ & 6 & 1,970 & 2.3 & 0.16 & $<0.1$ & 39.1 & 3 & 2 & $<5$ & 9.6 & 18.6 \\
\hline $08 \mathrm{CC} 5$ & 0.03 & 0.35 & $<1$ & 2 & 1,300 & 2.7 & 0.06 & $<0.1$ & 71 & 15.5 & 75 & $<5$ & 17.3 & 19.8 \\
\hline 08CC6 & 0.08 & 0.36 & $<1$ & 396 & 504 & $<0.1$ & 0.17 & 0.1 & 9.17 & 0.7 & 10 & 12 & 17.7 & 6.63 \\
\hline $08 \mathrm{CC} 7$ & 0.1 & 0.53 & $<1$ & 190 & 542 & 0.5 & 0.29 & 0.3 & 8.96 & 2.5 & 38 & 5 & 23.9 & 3.7 \\
\hline $08 \mathrm{CC} 8$ & 1.79 & 0.62 & $<1$ & 298 & 1,870 & $<0.1$ & 44.7 & 1.3 & 1 & 24.2 & 24 & $<5$ & 12.2 & 1.18 \\
\hline 08СC9 & 0.31 & 0.48 & $<1$ & 14 & 2,460 & $<0.1$ & 10.8 & 0.1 & 3.88 & 11 & 7 & $<5$ & 7.2 & 1.23 \\
\hline $08 \mathrm{CC} 10$ & 0.14 & 0.46 & $<1$ & 9 & 2,200 & 1.4 & 0.16 & $<0.1$ & 86.7 & 3.3 & 100 & 5 & 15.8 & 24.7 \\
\hline $08 \mathrm{CC} 11$ & 0.35 & 0.7 & $<1$ & 124 & 3,490 & $<0.1$ & 30 & 0.2 & 2.46 & 13 & 16 & $<5$ & 11.5 & 1.12 \\
\hline $08 \mathrm{CC} 12$ & 0.3 & 1.04 & $<1$ & 28 & 1,630 & 0.3 & 52.3 & $<0.1$ & 34.9 & 0.9 & 18 & $<5$ & 5.4 & 15.5 \\
\hline $08 \mathrm{CC} 13$ & 4.23 & 0.62 & $<1$ & 84 & 1,510 & 0.5 & 0.12 & $<0.1$ & 44.2 & 0.7 & 28 & $<5$ & 69.5 & 16.2 \\
\hline 08CC14 & 0.27 & 1.47 & $<1$ & 38 & 1,810 & 1.7 & 14.7 & 0.3 & 22.5 & 3.1 & 77 & $<5$ & 174 & 14.7 \\
\hline 08CC15B & 2.75 & 0.47 & 8 & 74 & 438 & 0.1 & 216 & 0.2 & 1.77 & 19.2 & 19 & $<5$ & 14.2 & 0.98 \\
\hline $08 \mathrm{CC} 16$ & 0.02 & 0.48 & $<1$ & $<1$ & 296 & 0.1 & 0.64 & $<0.1$ & 2.17 & 0.2 & 12 & $<5$ & 2.3 & 0.37 \\
\hline $08 \mathrm{CC} 17$ & 3.78 & 1.26 & 10 & 31 & 273 & 0.3 & 32.8 & 0.1 & 3.86 & 15 & 10 & $<5$ & 45.4 & 0.43 \\
\hline $08 \mathrm{CC} 21$ & 4.47 & 0.91 & 7 & 37 & 242 & 0.1 & 101 & 0.3 & 2.38 & 44.4 & 17 & $<5$ & 27.9 & 0.78 \\
\hline $08 \mathrm{CC} 22$ & 0.19 & 0.39 & $<1$ & 15 & 1,770 & 1.4 & 0.26 & $<0.1$ & 61.6 & 0.7 & 21 & $<5$ & 8.5 & 21 \\
\hline $08 \mathrm{CC} 23$ & 0.18 & 1.01 & $<1$ & 78 & 5,880 & 0.1 & 0.2 & $<0.1$ & 1.75 & 0.5 & 13 & $<5$ & 6.9 & 3.97 \\
\hline $08 \mathrm{CC} 24$ & 0.06 & 0.15 & $<1$ & 1 & 1,200 & $<0.1$ & 0.06 & $<0.1$ & 1.25 & 0.4 & 1 & $<5$ & 1.8 & 0.28 \\
\hline $08 \mathrm{CC} 25$ & 0.4 & 3.47 & $<1$ & 3 & 8,120 & $<0.1$ & 0.06 & $<0.1$ & 1.72 & 0.1 & 44 & $<5$ & 6.2 & 0.88 \\
\hline 39509-3 & 1.85 & 0.26 & $<1$ & 15 & 632 & 0.2 & 0.28 & $<0.1$ & 20.9 & 0.2 & 10 & $<5$ & 3.9 & 4.51 \\
\hline 39509-6 & 0.74 & 0.4 & $<1$ & 31 & 1,450 & 1.6 & 0.53 & $<0.1$ & 85.2 & 0.6 & 12 & 7 & 15.2 & 17.5 \\
\hline 39509-8 & 2.4 & 0.38 & $<1$ & 28 & 346 & 0.7 & 0.79 & $<0.1$ & 50.7 & 1.4 & 6 & $<5$ & 16.7 & 20.6 \\
\hline 39509-9 & 1 & 0.48 & $<1$ & 14 & 1,260 & 2.2 & 0.45 & $<0.1$ & 53.6 & 1.9 & 25 & 6 & 16.6 & 19 \\
\hline
\end{tabular}


Table 1-10. Minor element concentrations in rocks samples from the Cinnabar Canyon-US 395 alteration zone.—Continued

[alt, alteration; DDH, diamond drill hole; Fe, iron; FeOx, iron oxide; HgS, mercury sulfide; K, potassium; RDH, rotary drill hole; S, sulfur]

\begin{tabular}{|c|c|c|c|c|c|c|c|c|c|c|c|c|}
\hline $\begin{array}{l}\text { Sample } \\
\text { number }\end{array}$ & $\begin{array}{c}\text { In } \\
\text { ppm }\end{array}$ & $\begin{array}{l}\text { La } \\
\text { ppm }\end{array}$ & $\begin{array}{c}\text { Li } \\
\text { ppm }\end{array}$ & $\begin{array}{l}\text { Mn } \\
\text { ppm }\end{array}$ & $\begin{array}{l}\text { Mo } \\
\text { ppm }\end{array}$ & $\begin{array}{c}\mathrm{Nb} \\
\mathrm{ppm}\end{array}$ & $\begin{array}{c}\mathrm{Ni} \\
\mathrm{ppm}\end{array}$ & $\begin{array}{c}P \\
\text { ppm }\end{array}$ & $\begin{array}{c}\mathrm{Pb} \\
\mathrm{ppm}\end{array}$ & $\begin{array}{c}\mathbf{R b} \\
\mathbf{p p m}\end{array}$ & $\begin{array}{c}\text { Sb } \\
\text { ppm }\end{array}$ & $\begin{array}{c}\text { Se } \\
\text { ppm }\end{array}$ \\
\hline CCD7 & 0.03 & 1 & 5 & 23 & 2.42 & 11.3 & 43.6 & $<50$ & 63.2 & 0.4 & 63.6 & - \\
\hline CCD8B & $<0.02$ & $<0.5$ & 4 & 25 & 2.4 & 14.3 & 42.3 & $<50$ & 88.8 & 0.5 & 72.5 & - \\
\hline CCD16 & 0.08 & 1.5 & 3 & 81 & 2.24 & 24.7 & 32.3 & 60 & 185 & 1.1 & 84.7 & - \\
\hline $07-B A-10$ & 0.03 & 2.9 & 2 & 9 & 2.03 & 17.3 & 15.5 & 120 & 266 & 1.8 & 22.2 & - \\
\hline 07-BA-11 & $<0.02$ & $<0.5$ & 12 & 9 & 0.65 & 8.7 & 1 & 60 & 3.5 & 0.4 & 8.65 & - \\
\hline $07 \mathrm{CC} 1$ & $<0.02$ & 47.3 & 24 & 23 & 3.44 & 13.9 & 1.7 & 1,560 & 20.2 & 82.3 & 3.73 & - \\
\hline $07 \mathrm{CC} 2$ & 0.04 & 44.2 & 17 & 38 & 3.19 & 11.3 & 2.4 & 1,520 & 21.3 & 30.4 & 3.39 & - \\
\hline $07 \mathrm{CC} 5$ & 0.06 & 33.4 & 11 & 64 & 3.23 & 11.6 & 6.3 & 1,050 & 7,510 & 41.5 & 53.3 & - \\
\hline 07CC6 & 0.02 & 3 & $<1$ & 12 & 1.42 & 6.2 & 2.7 & 180 & 71.3 & 3.6 & 4.17 & - \\
\hline 07-BA-8 & 0.06 & 31 & 11 & 17 & 1.44 & 9.4 & 5.1 & 1,790 & 82.6 & 3.3 & 19.2 & - \\
\hline 07-BA-9 & 0.04 & 3.8 & 3 & 96 & 4.25 & 14.1 & 15.5 & 760 & 82.3 & 3.9 & 106 & 25.7 \\
\hline 07-BA-14 & 0.07 & 38.9 & 22 & 25 & 2.52 & 10.2 & 3 & 1,050 & 29.5 & 33.6 & 4.39 & $<0.2$ \\
\hline 07-BA-16 & $<0.02$ & 3.2 & $<1$ & 15 & 3.21 & 9 & 1.6 & 150 & 16.1 & 10.6 & 0.83 & - \\
\hline $08 \mathrm{CC} 3$ & 0.1 & 19.2 & 1 & 5 & 8.41 & 8.8 & 1.2 & 1,840 & 30.6 & 106 & 0.73 & - \\
\hline $08 \mathrm{CC} 4$ & $<0.02$ & 21.2 & 23 & 262 & 1.59 & 5.5 & 2.5 & 510 & 36.3 & 85.5 & 1.01 & - \\
\hline $08 \mathrm{CC} 5$ & 0.03 & 36.4 & 16 & 416 & 0.91 & 9.9 & 71.5 & 1,540 & 20.2 & 102 & 0.56 & - \\
\hline 08CC6 & 0.07 & 5.6 & $<1$ & 6 & 4.55 & 10.7 & 5.4 & 330 & 45.9 & 12.7 & 0.76 & - \\
\hline $08 \mathrm{CC} 7$ & 0.09 & 5.7 & 2 & 70 & 8.36 & 12.5 & 20.6 & 640 & 136 & 7.5 & 1.3 & - \\
\hline $08 \mathrm{CC} 8$ & 0.1 & 0.8 & $<1$ & 6 & 2.31 & 15.3 & 19.6 & 130 & 239 & 1.6 & 162 & - \\
\hline 08CC9 & $<0.02$ & 2.1 & $<1$ & 7 & 1.82 & 8.7 & 15.7 & 230 & 25.6 & 2.5 & 14.1 & - \\
\hline $08 \mathrm{CC} 10$ & 0.04 & 44.3 & 3 & 73 & 7.82 & 10.9 & 16.1 & 1,550 & 21 & 91.6 & 1.15 & - \\
\hline $08 \mathrm{CC} 11$ & $<0.02$ & 1.8 & $<1$ & 6 & 31.4 & 7.1 & 30.3 & 950 & 107 & 1.8 & 67.8 & - \\
\hline $08 \mathrm{CC} 12$ & 0.04 & 22.1 & 3 & 23 & 6.45 & 22.8 & 2.4 & 1,070 & 140 & 9.7 & 34.7 & - \\
\hline $08 \mathrm{CC} 13$ & 0.15 & 30.9 & 2 & 19 & 2.47 & 10.4 & 2.4 & 1,320 & 81.1 & 8.7 & 0.83 & - \\
\hline $08 \mathrm{CC} 14$ & 0.16 & 16.1 & 3 & 103 & 16 & 31 & 5.7 & 2,180 & 171 & 2 & 43.6 & - \\
\hline 08CC15B & $<0.02$ & 1.2 & 3 & 9 & 2.1 & 9.9 & 34.9 & 80 & 174 & 3.1 & 231 & - \\
\hline $08 \mathrm{CC} 16$ & $<0.02$ & 1.4 & 4 & 6 & 0.7 & 10.5 & 0.6 & 160 & 3.4 & 0.4 & 3.71 & - \\
\hline $08 \mathrm{CC} 17$ & $<0.02$ & 2.2 & 3 & 22 & 1.74 & 24.1 & 17.3 & $<50$ & 107 & 1.5 & 59.1 & - \\
\hline $08 \mathrm{CC} 21$ & $<0.02$ & 0.9 & 6 & 65 & 1.99 & 13.1 & 46.5 & 50 & 237 & 0.6 & 111 & - \\
\hline $08 \mathrm{CC} 22$ & 0.03 & 36 & 4 & 28 & 1.74 & 13.1 & 1.5 & 1,020 & 25.4 & 78.2 & 0.83 & - \\
\hline $08 \mathrm{CC} 23$ & $<0.02$ & 1.3 & $<1$ & 23 & 5.33 & 18.2 & 1.3 & 140 & 67.4 & 3.7 & 8.31 & - \\
\hline $08 \mathrm{CC} 24$ & $<0.02$ & 0.9 & $<1$ & 18 & 0.82 & 2.7 & 0.9 & $<50$ & 2.7 & 0.8 & 0.44 & - \\
\hline $08 \mathrm{CC} 25$ & $<0.02$ & 1.9 & $<1$ & 6 & 15.3 & 64.7 & 0.7 & 110 & 11.9 & 1.1 & 1.02 & - \\
\hline $39509-3$ & $<0.02$ & 9.7 & $<1$ & $<5$ & 1.24 & 4.3 & 0.8 & 430 & 6.1 & 5.3 & 1.93 & - \\
\hline $39509-6$ & 0.05 & 39.6 & 9 & 25 & 2.23 & 11.5 & 2.4 & 2,870 & 21.9 & 52 & 3.74 & - \\
\hline $39509-8$ & 0.05 & 29.1 & 5 & 24 & 1.79 & 10.9 & 2.7 & 1,340 & 23.1 & 22.8 & 2.19 & - \\
\hline 39509-9 & 0.04 & 31 & 4 & 102 & 1.99 & 13.5 & 2.8 & 1,200 & 21.5 & 109 & 1.69 & - \\
\hline
\end{tabular}


Table 1-10. Minor element concentrations in rocks samples from the Cinnabar Canyon-US 395 alteration zone.-Continued

[alt, alteration; DDH, diamond drill hole; Fe, iron; FeOx, iron oxide; HgS, mercury sulfide; K, potassium; RDH, rotary drill hole; S, sulfur]

\begin{tabular}{|c|c|c|c|c|c|c|c|c|c|c|c|}
\hline $\begin{array}{l}\text { Sample } \\
\text { number }\end{array}$ & $\begin{array}{c}\text { Sc } \\
\text { ppm }\end{array}$ & $\begin{array}{c}\text { Sn } \\
\text { ppm }\end{array}$ & $\begin{array}{c}\mathrm{Sr} \\
\mathrm{ppm}\end{array}$ & $\begin{array}{c}\text { Te } \\
\text { ppm }\end{array}$ & $\begin{array}{c}\text { Th } \\
\text { ppm }\end{array}$ & $\begin{array}{c}\text { TI } \\
\text { ppm }\end{array}$ & $\begin{array}{c}\text { U } \\
\text { ppm }\end{array}$ & $\begin{array}{c}\text { V } \\
\text { ppm }\end{array}$ & $\begin{array}{c}\text { W } \\
\text { ppm }\end{array}$ & $\begin{array}{c}\mathrm{Y} \\
\mathrm{ppm}\end{array}$ & $\begin{array}{c}\mathrm{Zn} \\
\mathrm{ppm}\end{array}$ \\
\hline CCD7 & 1.4 & 4.8 & 29.7 & 4.3 & 0.9 & 2 & 2.2 & 4 & 2.5 & 1.2 & 9 \\
\hline CCD8B & 0.7 & 9.3 & 16.8 & 1.8 & 1 & 3.4 & 1.4 & 5 & 2.9 & 0.6 & 3 \\
\hline CCD16 & 3.1 & 6.5 & 42.2 & 2.2 & 1.5 & 6.4 & 4.3 & 9 & 7.2 & 3.4 & 12 \\
\hline 07-BA-10 & 4.2 & 2.8 & 64.4 & 1.9 & 3.3 & 5.9 & 5.9 & 16 & 7.2 & 7 & 6 \\
\hline 07-BA-11 & 0.6 & 3.2 & 4.6 & 0.2 & 0.3 & $<0.1$ & 1.3 & 4 & 1.1 & 0.2 & 1 \\
\hline $07 \mathrm{CC} 1$ & 14 & 2.5 & 719 & $<0.1$ & 12.4 & 0.6 & 4.7 & 153 & 3.6 & 18.8 & 7 \\
\hline $07 \mathrm{CC} 2$ & 16.2 & 2.1 & 657 & $<0.1$ & 16.4 & 0.8 & 4.7 & 153 & 2.5 & 21 & 8 \\
\hline $07 \mathrm{CC} 5$ & 16.6 & 2 & 388 & 0.2 & 17.1 & 0.9 & 4.4 & 173 & 3.4 & 9.2 & 30 \\
\hline 07CC6 & 1.9 & 2.1 & 112 & 2.8 & 1.4 & 2.7 & 2.9 & 10 & 2.7 & 0.4 & 1 \\
\hline 07-BA-8 & 17.3 & 1.2 & 1,180 & 1 & 12.9 & 0.1 & 2.8 & 167 & 1.4 & 3.2 & 43 \\
\hline 07-BA-9 & 4 & 13.9 & 51.4 & 7 & 3.7 & 0.1 & 5.1 & 15 & 1.3 & 3.4 & 17 \\
\hline 07-BA-14 & 15.5 & 1.8 & 420 & 0.2 & 24.5 & 1.3 & 4.9 & 192 & 1.9 & 11.4 & 12 \\
\hline 07-BA-16 & 1.2 & 1 & 71.8 & 0.1 & 3.1 & 1.1 & 1.8 & 14 & 1.7 & 0.7 & 4 \\
\hline $08 \mathrm{CC} 3$ & 8.7 & 1.1 & 1,640 & 0.5 & 12 & 20.1 & 1.8 & 149 & 1.3 & 2.1 & 5 \\
\hline $08 \mathrm{CC} 4$ & 3 & 0.8 & 869 & $<0.1$ & 6 & 0.5 & 2.2 & 28 & 2.3 & 5.9 & 44 \\
\hline $08 \mathrm{CC} 5$ & 12.1 & 1.2 & 829 & $<0.1$ & 14.8 & 0.7 & 5.3 & 107 & 0.9 & 14.4 & 62 \\
\hline 08CC6 & 2.1 & 2.2 & 144 & 0.3 & 3.3 & 3.7 & 3.6 & 14 & 1.7 & 0.6 & 3 \\
\hline $08 \mathrm{CC} 7$ & 3.3 & 2 & 77.8 & 0.2 & 3.5 & 1.4 & 5.2 & 66 & 1.9 & 2.5 & 23 \\
\hline $08 \mathrm{CC} 8$ & 3.1 & 8.1 & 17.8 & 6.1 & 0.7 & 9.8 & 3.4 & 7 & 2.5 & 0.1 & 4 \\
\hline 08CC9 & 2 & 4 & 193 & 1.8 & 1.4 & 1.7 & 1.5 & 6 & 1.1 & 0.9 & 2 \\
\hline $08 \mathrm{CC} 10$ & 18.7 & 1.2 & 945 & $<0.1$ & 14.6 & 0.4 & 6.6 & 155 & 2.3 & 12.3 & 23 \\
\hline $08 \mathrm{CC} 11$ & 8.9 & 18.7 & 57.6 & 5.6 & 0.8 & 3 & 6.1 & 5 & 12 & 0.2 & 7 \\
\hline $08 \mathrm{CC} 12$ & 5.8 & 5 & 1,070 & 8.7 & 31.1 & 1.5 & 5.8 & 23 & 12.2 & 3 & 10 \\
\hline $08 \mathrm{CC} 13$ & 9.5 & 1.8 & 794 & $<0.1$ & 11.1 & 0.5 & 8 & 94 & 1.8 & 4.3 & 10 \\
\hline $08 \mathrm{CC} 14$ & 4.9 & 27.2 & 1,330 & 0.7 & 5.7 & $<0.1$ & 6 & 90 & 5 & 3.8 & 43 \\
\hline 08CC15B & 1.5 & 7.8 & 50.1 & 4.8 & 0.8 & 10.9 & 1.4 & 5 & 9.3 & 0.6 & 6 \\
\hline $08 \mathrm{CC} 16$ & 1 & 6.2 & 12.2 & $<0.1$ & 0.3 & $<0.1$ & 0.8 & 4 & 0.8 & 0.3 & 1 \\
\hline $08 \mathrm{CC} 17$ & 2 & 4.4 & 60 & 0.8 & 1.7 & 1.3 & 2.6 & 14 & 6.1 & 1.4 & 4 \\
\hline $08 \mathrm{CC} 21$ & 0.8 & 8.4 & 37.4 & 3.4 & 0.7 & 5.6 & 1 & 5 & 2.3 & 0.6 & 8 \\
\hline $08 \mathrm{CC} 22$ & 8.4 & 1.6 & 342 & 1.1 & 16.3 & 1.4 & 5.5 & 64 & 1.5 & 7.8 & 10 \\
\hline $08 \mathrm{CC} 23$ & 3.1 & 2 & 58.9 & 3.7 & 2.3 & 1.3 & 8.3 & 33 & 2.2 & 2.5 & 3 \\
\hline $08 \mathrm{CC} 24$ & 0.4 & 0.2 & 48.7 & $<0.1$ & $<0.2$ & $<0.1$ & 0.1 & 3 & 0.4 & 0.3 & $<1$ \\
\hline $08 \mathrm{CC} 25$ & 1.9 & 2.5 & 89.9 & $<0.1$ & 0.9 & $<0.1$ & 0.9 & 16 & 3.8 & 0.3 & 2 \\
\hline $39509-3$ & 2.3 & 0.7 & 186 & 0.7 & 2.9 & 0.1 & 0.9 & 40 & 1.1 & 1.3 & 3 \\
\hline 39509-6 & 7.7 & 1.6 & 1,380 & 0.4 & 13.6 & 0.3 & 4.4 & 101 & 1.8 & 7.3 & 24 \\
\hline $39509-8$ & 5.5 & 1.4 & 885 & 0.7 & 10.7 & 0.7 & 3.4 & 51 & 1.2 & 1.9 & 15 \\
\hline 39509-9 & 12.6 & 1.4 & 730 & 1.3 & 15 & 0.8 & 5.3 & 118 & 1.7 & 9.2 & 23 \\
\hline
\end{tabular}


Table 1-11. Minor element concentrations in rock samples from the Bodie Mining District.

[cm, centimeter; K, potassium; Kspar, potassium feldspar; - , no data]

\begin{tabular}{|c|c|c|c|c|c|c|c|c|c|c|c|}
\hline $\begin{array}{l}\text { Sample } \\
\text { number }\end{array}$ & Description, Location & Latitude & Longitude & $\begin{array}{c}\text { Au } \\
\text { ppm }\end{array}$ & $\begin{array}{c}\mathrm{Hg} \\
\mathrm{ppm}\end{array}$ & $\begin{array}{l}\text { Al } \\
\%\end{array}$ & $\begin{array}{l}\mathrm{Ca} \\
\%\end{array}$ & $\begin{array}{l}\mathrm{Fe} \\
\%\end{array}$ & $\begin{array}{l}\mathbf{K} \\
\%\end{array}$ & $\begin{array}{c}\mathbf{M g} \\
\%\end{array}$ & $\begin{array}{l}\mathrm{Na} \\
\%\end{array}$ \\
\hline \multicolumn{12}{|c|}{ Sinter } \\
\hline BODB06-4A & Sinter, silicified volcaniclastics, Bodie Bluff & 38.21883 & -119.99921 & 0.011 & 0.44 & 0.36 & 0.04 & 0.07 & 0.07 & $<0.01$ & $<0.01$ \\
\hline BODB06-4B1 & Sinter, silicified volcaniclastics, Bodie Bluff & 38.21883 & -119.99921 & 0.014 & 0.23 & 0.45 & 0.08 & 0.18 & 0.17 & $<0.01$ & $<0.01$ \\
\hline BODB06-4B2 & Sinter, silicified volcaniclastics, Bodie Bluff & 38.21883 & -119.99921 & 0.01 & 0.42 & 0.44 & 0.07 & 0.17 & 0.2 & $<0.01$ & $<0.01$ \\
\hline 07-BA-3A & Sinter block, Bodie Bluff & 38.21923 & -118.99823 & 0.007 & 0.15 & 0.35 & 0.04 & 0.15 & 0.24 & $<0.01$ & 0.02 \\
\hline 07-BA-3B & Sinter block, Bodie Bluff & 38.21923 & -118.99823 & 0.008 & 0.09 & 0.16 & 0.02 & 0.05 & 0.06 & $<0.01$ & 0.03 \\
\hline BB13-SINA & Dismembered sinter, Bodie Bluff summit & 38.21924 & -118.99822 & 0.051 & 0.06 & 0.38 & 0.02 & 0.11 & 0.11 & $<0.01$ & 0.03 \\
\hline BB13-SINB & Dismembered sinter, Bodie Bluff summit & 38.21924 & -118.99822 & 0.004 & 0.01 & 0.15 & 0.02 & 0.07 & 0.08 & $<0.01$ & 0.03 \\
\hline BB13-CLD & Sinter clast in volcaniclastic deposits, Bodie Bluff summit & 38.21883 & -119.99921 & 0.008 & 0.01 & 0.1 & 0.01 & 0.07 & 0.03 & $<0.01$ & $<0.01$ \\
\hline BB13-CLH & Sinter clast in volcaniclastic deposits, Bodie Bluff summit & 38.21881 & -119.9992 & 0.051 & $<0.01$ & 0.16 & 0.07 & 0.05 & 0.1 & $<0.01$ & 0.02 \\
\hline BB13-CLI & Sinter clast in volcaniclastic deposits, Bodie Bluff summit & 38.21841 & -119.99921 & 0.018 & $<0.01$ & 0.08 & 0.04 & 0.05 & 0.02 & $<0.01$ & $<0.01$ \\
\hline BB13-CLK & Sinter clast in volcaniclastic deposits, Bodie Bluff summit & 38.21883 & -119.99919 & 0.002 & $<0.01$ & 0.11 & 0.05 & 0.05 & 0.02 & $<0.01$ & 0.01 \\
\hline BB13-CLL & Sinter clast in volcaniclastic deposits, Bodie Bluff summit & 38.21884 & -119.99921 & 0.002 & $<0.01$ & 0.12 & 0.03 & 0.11 & 0.03 & $<0.01$ & 0.01 \\
\hline \multicolumn{12}{|c|}{ Incline series veins } \\
\hline BB13-VEINA & Incline veins next to sinter, Bodie Bluff summit & 38.21975 & -118.99942 & 0.965 & 0.02 & 1.41 & 0.04 & 0.1 & 2.28 & $<0.01$ & 0.05 \\
\hline BB13-VEINB & Incline veins next to sinter, Bodie Bluff summit & 38.22047 & -118.99931 & $>10$ & 0.07 & 1.13 & 0.05 & 0.06 & 1.71 & $<0.01$ & 0.03 \\
\hline BODB06-3 & Banded quartz vein, dump, Bodie Bluff & 38.21783 & -119.99832 & 5 & 0.54 & 0.15 & $<0.01$ & 0.02 & 0.03 & $<0.01$ & $<0.01$ \\
\hline $11-B A-26 A$ & Vein, Upper Hobart Tunnel dump, Bodie Bluff & 38.21968 & -119.00265 & 5.93 & 0.08 & 2.61 & 0.09 & 0.38 & 2.29 & 0.05 & 0.18 \\
\hline 11-BA-26B & Vein, Upper Hobart Tunnel dump, Bodie Bluff & 38.21968 & -119.00265 & 146 & 2.97 & 1.91 & 0.04 & 0.04 & 2.28 & $<0.01$ & 0.03 \\
\hline 11-BA-26C & Vein, Upper Hobart Tunnel dump, Bodie Bluff & 38.21968 & -119.00265 & 107 & 0.1 & 3.55 & 0.06 & 0.79 & 4.6 & 0.1 & 0.07 \\
\hline BOD11-11D & Banded quartz-Kspar vein, minor sulfides & 38.21497 & -119.00273 & 1.84 & 1.39 & 0.81 & 0.07 & 0.17 & 0.48 & 0.04 & 0.02 \\
\hline BOD11-12 & Banded quartz-Kspar vein, minor sulfides & 38.21591 & -119.003 & 0.061 & 0.39 & 4.08 & 0.03 & 0.12 & 4.58 & 0.02 & 0.05 \\
\hline BOD11-13 & Banded quartz-Kspar vein, minor sulfides & 38.21497 & -119.00356 & 12.9 & 0.1 & 4.09 & 0.07 & 0.99 & 4.91 & 0.09 & 0.17 \\
\hline BOD11-14 & Banded quartz-K-mica vein, minor fluorite & 38.21725 & -119.00039 & 10.1 & 0.55 & 1.99 & 0.04 & 0.18 & 2.39 & $<0.01$ & 0.03 \\
\hline BOD11-18A & Quartz vein, minor sulfide & 38.21434 & -119.00523 & 21.2 & 0.06 & 1.63 & 0.03 & 0.34 & 1.78 & 0.02 & 0.04 \\
\hline BOD11-19 & Banded quartz-Kspar vein, minor sulfides & 38.21872 & -119.00031 & 46 & 1.96 & 2.65 & 0.04 & 0.07 & 3.43 & $<0.01$ & 0.04 \\
\hline BOD13-1A & SW summit Standard Hill & 38.21482 & -119.00456 & 4,860 & 0.12 & 1.36 & 0.04 & 0.14 & 1.44 & $<0.01$ & 0.05 \\
\hline BOD13-2B & SW slope Standard Hill & 38.21568 & -119.00385 & 2,740 & 0.09 & 0.63 & $<0.01$ & 0.09 & 0.97 & $<0.01$ & 0.01 \\
\hline BOD13-5B & Upper Hobart Tunnel dump & 38.21971 & -119.00266 & 2,280 & 0.11 & 5.52 & 0.08 & 2.13 & 4.46 & 0.03 & 0.1 \\
\hline BOD13-5C & Upper Hobart Tunnel dump & 38.21971 & -119.00266 & $>10,000$ & 2.81 & 5.34 & 0.02 & 0.49 & 2.51 & 0.01 & 0.08 \\
\hline
\end{tabular}


Table 1-11. Minor element concentrations in rock samples from the Bodie Mining District.-Continued

[cm, centimeter; K, potassium; Kspar, potassium feldspar; -, no data]

\begin{tabular}{|c|c|c|c|c|c|c|c|c|c|c|c|c|c|c|}
\hline $\begin{array}{l}\text { Sample } \\
\text { number }\end{array}$ & $\begin{array}{l}\mathbf{S} \\
\%\end{array}$ & $\begin{array}{l}\mathrm{Ti} \\
\%\end{array}$ & $\begin{array}{c}\mathrm{Ag} \\
\mathrm{ppm}\end{array}$ & $\begin{array}{c}\text { As } \\
\text { ppm }\end{array}$ & $\begin{array}{c}\mathrm{Ba} \\
\mathrm{ppm}\end{array}$ & $\begin{array}{c}\mathrm{Be} \\
\mathrm{ppm}\end{array}$ & $\begin{array}{c}\mathrm{Bi} \\
\mathrm{ppm}\end{array}$ & $\begin{array}{c}\text { Cd } \\
\text { ppm }\end{array}$ & $\begin{array}{c}\text { Ce } \\
\text { ppm }\end{array}$ & $\begin{array}{c}\text { Co } \\
\text { ppm }\end{array}$ & $\begin{array}{c}\mathrm{Cr} \\
\mathrm{ppm}\end{array}$ & $\begin{array}{c}\text { Cs } \\
\text { ppm }\end{array}$ & $\begin{array}{c}\text { Cu } \\
\text { ppm }\end{array}$ & $\begin{array}{c}\text { Ga } \\
\text { ppm }\end{array}$ \\
\hline \multicolumn{15}{|c|}{ Sinter } \\
\hline BODB06-4A & $<0.01$ & 0.01 & 1 & $<30$ & 150 & $<5$ & $<0.1$ & $<0.2$ & 1.6 & 0.5 & $<10$ & 25.4 & $<5$ & 10 \\
\hline BODB06-4B1 & $<0.01$ & 0.02 & $<1$ & 100 & 315 & $<5$ & $<0.1$ & $<0.2$ & 2.7 & $<0.5$ & $<10$ & 34.8 & $<5$ & 6 \\
\hline BODB06-4B2 & $<0.01$ & 0.02 & $<1$ & 90 & 211 & $<5$ & $<0.1$ & $<0.2$ & 2.7 & $<0.5$ & $<10$ & 37.2 & $<5$ & 4 \\
\hline 07-BA-3A & 0.02 & 0.02 & $<1$ & 35 & 278 & 1.1 & $<0.04$ & $<0.1$ & 4.12 & 0.4 & 5 & 23 & 1.3 & 8.16 \\
\hline 07-BA-3B & $<0.01$ & $<0.01$ & $<1$ & 20 & 33 & 0.6 & 0.04 & 0.5 & 2.19 & 0.2 & 3 & 20 & 2.6 & 12 \\
\hline BB13-SINA & 0.02 & $<0.01$ & $<1$ & 22 & 39 & 1.6 & $<0.04$ & $<0.1$ & 3.03 & 0.6 & 4 & 25 & 82.2 & 20.6 \\
\hline BB13-SINB & $<0.01$ & $<0.01$ & $<1$ & 16 & 33 & 0.6 & 0.06 & $<0.1$ & 0.81 & 0.1 & 5 & 21 & 9.5 & 14.3 \\
\hline BB13-CLD & $<0.01$ & $<0.01$ & $<1$ & 17 & 52 & 0.3 & 0.09 & $<0.1$ & 0.33 & $<0.1$ & 3 & 6 & 10.9 & 8.47 \\
\hline BB13-CLH & 0.03 & $<0.01$ & $<1$ & 12 & 52 & 2.3 & 0.14 & $<0.1$ & 0.73 & 0.1 & 4 & 16 & 12.6 & 61.6 \\
\hline BB13-CLI & 0.02 & $<0.01$ & $<1$ & 15 & 67 & 0.4 & 0.19 & $<0.1$ & 0.57 & $<0.1$ & 4 & $<5$ & 3.1 & 7.12 \\
\hline BB13-CLK & 0.02 & $<0.01$ & $<1$ & 12 & 59 & 0.2 & $<0.04$ & $<0.1$ & 0.58 & 0.2 & 4 & 5 & 5.2 & 4.82 \\
\hline BB13-CLL & 0.02 & $<0.01$ & $<1$ & 29 & 88 & 0.3 & $<0.04$ & $<0.1$ & 1.35 & 0.1 & 6 & 9 & 10.4 & 2.2 \\
\hline \multicolumn{15}{|c|}{ Incline series veins } \\
\hline BB13-VEINA & $<0.01$ & $<0.01$ & 37 & 4 & 28 & 0.7 & 0.05 & $<0.1$ & 0.88 & 0.6 & 2 & 12 & 8.3 & 1.67 \\
\hline BB13-VEINB & $<0.01$ & $<0.01$ & 135 & 5 & 27 & 1.6 & 0.06 & $<0.1$ & 0.34 & 0.7 & 1 & 14 & 7.1 & 1.21 \\
\hline BODB06-3 & $<0.01$ & $<0.01$ & $<1$ & $<30$ & 31.9 & $<5$ & $<0.1$ & $<0.2$ & 0.7 & $<0.5$ & $<10$ & 15.4 & $<5$ & 17 \\
\hline $11-\mathrm{BA}-26 \mathrm{~A}$ & 0.07 & 0.09 & 41 & 104 & 1,290 & 4.4 & 0.31 & $<0.1$ & 13.7 & 0.3 & 2 & 23 & 22.7 & 5.31 \\
\hline 11-BA-26B & $<0.01$ & $<0.01$ & 268 & 8 & 86 & 1.5 & 0.04 & $<0.1$ & 0.36 & 1.2 & 1 & 8 & 5.6 & 2.06 \\
\hline 11-BA-26C & $<0.01$ & 0.06 & 122 & 27 & 250 & 2.5 & 0.07 & $<0.1$ & 7.41 & 22.6 & 8 & 15 & 34.4 & 5.91 \\
\hline BOD11-11D & 0.11 & $<0.01$ & 17 & 41 & 330 & 4.3 & 80.8 & $<0.1$ & 2.74 & 0.3 & 1 & 13 & 9.1 & 4.28 \\
\hline BOD11-12 & 0.01 & $<0.01$ & 4 & 11 & 497 & 2.7 & 8.52 & $<0.1$ & 8.75 & 7.6 & 1 & 10 & 10 & 3.91 \\
\hline BOD11-13 & 0.1 & 0.1 & 53 & 71 & 479 & 3.1 & 1.08 & $<0.1$ & 10.8 & 3.2 & 4 & 9 & 12.7 & 7.45 \\
\hline BOD11-14 & 0.01 & $<0.01$ & 51 & 17 & 93 & 2.8 & 2.39 & $<0.1$ & 2.3 & 0.4 & 1 & 11 & 3.6 & 2.5 \\
\hline BOD11-18A & 0.23 & 0.05 & 800 & 286 & 269 & 1.2 & 0.39 & $<0.1$ & 8.37 & 0.3 & 2 & 6 & 5.8 & 7.24 \\
\hline BOD11-19 & $<0.01$ & $<0.01$ & 153 & 11 & 44 & 5.5 & 1.93 & $<0.1$ & 1.24 & 0.2 & $<1$ & 11 & 11.7 & 3.71 \\
\hline BOD13-1A & 0.02 & $<0.01$ & 23 & 9 & 78 & 1.1 & 0.08 & $<0.1$ & 3.34 & 23.1 & 2 & 6 & 12.6 & 1.11 \\
\hline BOD13-2B & $<0.01$ & $<0.01$ & 11 & 8 & 42 & 0.9 & 0.07 & $<0.1$ & 2.02 & 9.2 & 2 & $<5$ & 11.2 & 0.8 \\
\hline BOD13-5B & 1.93 & 0.1 & 71 & 949 & 578 & 1.5 & 0.12 & $<0.1$ & 24.3 & 2.8 & 8 & 18 & 48.5 & 8.9 \\
\hline BOD13-5C & 0.01 & 0.03 & 254 & 108 & 199 & 1.6 & 0.07 & $<0.1$ & 4.53 & 0.4 & 3 & 15 & 34.7 & 5.52 \\
\hline
\end{tabular}


Table 1-11. Minor element concentrations in rock samples from the Bodie Mining District.-Continued

[cm, centimeter; K, potassium; Kspar, potassium feldspar; - , no data]

\begin{tabular}{|c|c|c|c|c|c|c|c|c|c|c|c|c|}
\hline $\begin{array}{l}\text { Sample } \\
\text { number }\end{array}$ & $\begin{array}{c}\text { In } \\
\text { ppm }\end{array}$ & $\begin{array}{l}\text { La } \\
\text { ppm }\end{array}$ & $\begin{array}{c}\mathrm{Li} \\
\mathrm{ppm}\end{array}$ & $\begin{array}{l}\text { Mn } \\
\text { ppm }\end{array}$ & $\begin{array}{l}\text { Mo } \\
\text { ppm }\end{array}$ & $\begin{array}{c}\mathrm{Nb} \\
\mathrm{ppm}\end{array}$ & $\begin{array}{c}\mathrm{Ni} \\
\mathrm{ppm}\end{array}$ & $\begin{array}{c}P \\
\text { ppm }\end{array}$ & $\begin{array}{c}\mathrm{Pb} \\
\mathrm{ppm}\end{array}$ & $\begin{array}{c}\mathbf{R b} \\
\mathbf{p p m}\end{array}$ & $\begin{array}{c}\text { Sb } \\
\text { ppm }\end{array}$ & $\begin{array}{c}\text { Sc } \\
\text { ppm }\end{array}$ \\
\hline \multicolumn{13}{|c|}{ Sinter } \\
\hline BODB06-4A & $<0.2$ & 1.5 & 70 & - & 4 & $<1$ & 6 & - & $<5$ & 10.1 & 539 & $<5$ \\
\hline BODB06-4B1 & $<0.2$ & 2.2 & 100 & - & 7 & $<1$ & 13 & - & $<5$ & 19.1 & 279 & $<5$ \\
\hline BODB06-4B2 & $<0.2$ & 1.9 & 120 & - & 7 & $<1$ & 8 & - & 8 & 20.5 & 245 & $<5$ \\
\hline $07-B A-3 A$ & $<0.02$ & 3.1 & 57 & 127 & 2.64 & 0.3 & 0.9 & $<50$ & 1.8 & 24.5 & 136 & 0.8 \\
\hline 07-BA-3B & $<0.02$ & 5 & 45 & 24 & 3.21 & $<0.1$ & 1.1 & $<50$ & 56.5 & 7.7 & 333 & 0.4 \\
\hline BB13-SINA & $<0.02$ & 1.6 & 43 & 45 & 4.83 & 0.1 & 3.5 & $<50$ & 1.1 & 7.5 & 863 & 0.3 \\
\hline BB13-SINB & $<0.02$ & $<0.5$ & 37 & 42 & 4.3 & $<0.1$ & 1.9 & $<50$ & $<0.5$ & 5.8 & 819 & 0.2 \\
\hline BB13-CLD & $<0.02$ & $<0.5$ & 20 & 34 & 5.82 & $<0.1$ & 1.8 & $<50$ & $<0.5$ & 1.4 & 425 & 0.1 \\
\hline BB13-CLH & $<0.02$ & $<0.5$ & 36 & 19 & 2.55 & $<0.1$ & 2 & $<50$ & 1 & 6.8 & 522 & 0.1 \\
\hline BB13-CLI & $<0.02$ & $<0.5$ & 9 & 15 & 3.11 & $<0.1$ & 2 & $<50$ & $<0.5$ & 1.3 & 1,190 & $<0.1$ \\
\hline BB13-CLK & $<0.02$ & 0.6 & 18 & 22 & 3.92 & $<0.1$ & 2.4 & $<50$ & $<0.5$ & 1.4 & 369 & 0.1 \\
\hline BB13-CLL & $<0.02$ & 0.7 & 17 & 28 & 4.12 & $<0.1$ & 5.8 & $<50$ & 0.8 & 2.1 & 675 & 0.2 \\
\hline \multicolumn{13}{|c|}{ Incline series veins } \\
\hline BB13-VEINA & $<0.02$ & $<0.5$ & 88 & 42 & 3.47 & $<0.1$ & 7.7 & $<50$ & 1.4 & 116 & 18.7 & 0.1 \\
\hline BB13-VEINB & $<0.02$ & $<0.5$ & 87 & 41 & 2.77 & $<0.1$ & 1.9 & $<50$ & 1.6 & 77.7 & 23.2 & $<0.1$ \\
\hline BODB06-3 & $<0.2$ & 1 & 30 & - & 5 & $<1$ & 7 & - & $<5$ & 5.3 & $>1,000$ & $<5$ \\
\hline 11-BA-26A & $<0.02$ & 6.9 & 64 & 17 & 11.9 & 2.2 & 0.6 & 220 & 11.8 & 166 & 56.8 & 1.7 \\
\hline 11-BA-26B & $<0.02$ & $<0.5$ & 130 & 24 & 0.28 & $<0.1$ & $<0.5$ & $<50$ & 3.5 & 133 & 11.7 & $<0.1$ \\
\hline 11-BA-26C & $<0.02$ & 3.2 & 128 & 564 & 6.07 & 1.6 & 14 & 120 & 5.8 & 317 & 25.5 & 1.2 \\
\hline BOD11-11D & $<0.02$ & 1.1 & 101 & 41 & 1.63 & $<0.1$ & 3.1 & 120 & 18.6 & 34.7 & 58.3 & 1.6 \\
\hline BOD11-12 & $<0.02$ & 1.9 & 123 & 471 & 1.27 & 0.2 & 15.2 & $<50$ & 10.3 & 247 & 19.1 & 0.5 \\
\hline BOD11-13 & $<0.02$ & 5.8 & 132 & 268 & 0.52 & 2.2 & 10 & 310 & 7.8 & 275 & 14.3 & 2.1 \\
\hline BOD11-14 & $<0.02$ & 1.3 & 55 & 94 & 5.85 & 0.1 & 1.3 & 70 & 3.9 & 161 & 27.1 & 0.4 \\
\hline BOD11-18A & $<0.02$ & 5.1 & 153 & 24 & 3.82 & 1 & 1 & 140 & 13.7 & 108 & 48.5 & 1.2 \\
\hline BOD11-19 & $<0.02$ & 0.8 & 56 & 30 & 0.53 & $<0.1$ & 0.8 & 60 & 5.3 & 214 & 21.3 & 0.2 \\
\hline BOD13-1A & $<0.02$ & 0.9 & 206 & 875 & 1.43 & $<0.1$ & 12.2 & $<50$ & 1.9 & 71.7 & 20.2 & 0.2 \\
\hline BOD13-2B & $<0.02$ & 0.6 & 15 & 447 & 0.62 & $<0.1$ & 8.2 & $<50$ & 1.3 & 51.1 & 19.1 & 0.1 \\
\hline BOD13-5B & 0.02 & 13.5 & 45 & 41 & 6.12 & 3.3 & 6.9 & 430 & 13.8 & 373 & 49 & 2.5 \\
\hline BOD13-5C & $<0.02$ & 3.4 & 71 & 24 & 2.15 & 0.7 & 2.2 & 120 & 4.5 & 373 & 38.3 & 0.7 \\
\hline
\end{tabular}


Table 1-11. Minor element concentrations in rock samples from the Bodie Mining District.—Continued

[cm, centimeter; K, potassium; Kspar, potassium feldspar; - , no data]

\begin{tabular}{|c|c|c|c|c|c|c|c|c|c|c|c|c|}
\hline $\begin{array}{l}\text { Sample } \\
\text { number }\end{array}$ & $\begin{array}{c}\text { Se } \\
\text { ppm }\end{array}$ & $\begin{array}{c}\text { Sn } \\
\text { ppm }\end{array}$ & $\begin{array}{c}\mathrm{Sr} \\
\mathrm{ppm}\end{array}$ & $\begin{array}{c}\text { Te } \\
\text { ppm }\end{array}$ & $\begin{array}{l}\text { Th } \\
\text { ppm }\end{array}$ & $\begin{array}{c}\text { TI } \\
\text { ppm }\end{array}$ & $\underset{\mathrm{ppm}}{\mathrm{U}}$ & $\begin{array}{c}\mathbf{V} \\
\mathrm{ppm}\end{array}$ & $\begin{array}{c}\text { W } \\
\text { ppm }\end{array}$ & $\begin{array}{c}\mathrm{Y} \\
\mathrm{ppm}\end{array}$ & $\begin{array}{c}\mathrm{Zn} \\
\mathrm{ppm}\end{array}$ & $\begin{array}{l}\text { C } \\
\%\end{array}$ \\
\hline \multicolumn{13}{|c|}{ Sinter } \\
\hline BODB06-4A & $<0.2$ & $<1$ & 43.5 & $<0.5$ & 0.2 & $<0.5$ & 0.14 & $<5$ & 5 & 0.5 & $<5$ & 0.02 \\
\hline BODB06-4B1 & 0.5 & $<1$ & 66.5 & $<0.5$ & 0.2 & 0.9 & 0.16 & 10 & 16 & 0.9 & 7 & 0.03 \\
\hline BODB06-4B2 & 0.4 & $<1$ & 70 & $<0.5$ & 0.2 & 1.2 & 0.16 & 12 & 16 & 0.7 & 8 & $<0.01$ \\
\hline 07-BA-3A & $<0.2$ & 0.1 & 46.7 & $<0.1$ & 0.7 & 0.4 & 0.2 & 6 & 4.5 & 0.7 & $<1$ & - \\
\hline 07-BA-3B & $<0.2$ & $<0.1$ & 13.8 & 0.4 & 0.3 & 0.3 & 0.1 & 3 & 3.3 & 0.7 & 8 & - \\
\hline BB13-SINA & $<0.2$ & 0.5 & 20.6 & $<0.1$ & 0.3 & 0.3 & 0.1 & 5 & 3.6 & 0.4 & 4 & 0.03 \\
\hline BB13-SINB & $<0.2$ & 0.2 & 10.8 & $<0.1$ & $<0.2$ & 0.1 & $<0.1$ & 2 & 2.4 & 0.3 & 1 & 0.01 \\
\hline BB13-CLD & $<0.2$ & 0.2 & 6.9 & $<0.1$ & $<0.2$ & $<0.1$ & $<0.1$ & 3 & 0.5 & 0.1 & 2 & 0.01 \\
\hline BB13-CLH & $<0.2$ & 0.5 & 15.6 & $<0.1$ & $<0.2$ & $<0.1$ & $<0.1$ & 2 & 1.8 & 0.2 & 5 & 0.03 \\
\hline BB13-CLI & $<0.2$ & 0.3 & 6.6 & $<0.1$ & $<0.2$ & $<0.1$ & $<0.1$ & 2 & 0.7 & 0.2 & 2 & 0.02 \\
\hline BB13-CLK & $<0.2$ & 0.4 & 10.1 & $<0.1$ & $<0.2$ & $<0.1$ & $<0.1$ & 2 & 0.2 & 0.3 & 2 & 0.02 \\
\hline BB13-CLL & $<0.2$ & 0.3 & 11.7 & $<0.1$ & 0.2 & $<0.1$ & 0.1 & 5 & 0.8 & 0.3 & 2 & 0.03 \\
\hline \multicolumn{13}{|c|}{ Incline series veins } \\
\hline BB13-VEINA & 1.9 & 0.2 & 86 & $<0.1$ & $<0.2$ & 1.2 & $<0.1$ & 2 & 0.4 & 0.2 & 19 & 0.02 \\
\hline BB13-VEINB & 2.2 & 0.4 & 101 & $<0.1$ & $<0.2$ & 1 & $<0.1$ & 1 & 0.3 & $<0.1$ & 10 & 0.06 \\
\hline BODB06-3 & 0.2 & $<1$ & 11.1 & $<0.5$ & $<0.1$ & $<0.5$ & $<0.05$ & $<5$ & 10 & $<0.5$ & 9 & 0.09 \\
\hline 11-BA-26A & - & 0.5 & 191 & 0.9 & 2.1 & 1.8 & 0.8 & 16 & 4.9 & 2.4 & 10 & - \\
\hline 11-BA-26B & - & $<0.1$ & 101 & $<0.1$ & $<0.2$ & 1.8 & $<0.1$ & $<1$ & $<0.1$ & $<0.1$ & 4 & - \\
\hline 11-BA-26C & - & 0.6 & 104 & $<0.1$ & 1.4 & 4.9 & 0.8 & 13 & 4.6 & 2 & 43 & - \\
\hline BOD11-11D & 0.9 & 1.2 & 143 & 4.4 & $<0.2$ & 0.5 & 5.9 & 5 & 1.6 & 8.8 & 12 & - \\
\hline BOD11-12 & $<0.2$ & 0.5 & 120 & 0.7 & 0.3 & 4.4 & 0.3 & 4 & 4.6 & 2.3 & 11 & - \\
\hline BOD11-13 & 0.3 & 0.4 & 186 & $<0.1$ & 2.2 & 4.2 & 1.9 & 23 & 2.5 & 4.1 & 37 & - \\
\hline BOD11-14 & 0.3 & 0.3 & 132 & 0.2 & $<0.2$ & 1.9 & 0.5 & 2 & 1.7 & 3.7 & 2 & - \\
\hline BOD11-18A & 8.9 & 0.4 & 78 & $<0.1$ & 1.9 & 1.9 & 3.2 & 664 & 1.7 & 8.1 & 5 & - \\
\hline BOD11-19 & 1.6 & 0.2 & 145 & 0.2 & $<0.2$ & 2.8 & 0.7 & 3 & 0.2 & 5.8 & 4 & - \\
\hline BOD13-1A & $<0.2$ & 0.2 & 70.7 & $<0.1$ & 0.2 & 2.2 & $<0.1$ & 2 & 0.8 & 0.7 & 21 & 0.01 \\
\hline BOD13-2B & $<0.2$ & 0.2 & 28.3 & $<0.1$ & $<0.2$ & 1.2 & $<0.1$ & 2 & 0.7 & 0.7 & 9 & 0.01 \\
\hline BOD13-5B & 1.5 & 1.1 & 131 & $<0.1$ & 3.3 & 8.8 & 1.3 & 23 & 8.3 & 4.2 & 11 & 0.03 \\
\hline BOD13-5C & 5.3 & 0.8 & 150 & $<0.1$ & 0.8 & 6 & 0.4 & 6 & 1.9 & 1 & 11 & 0.01 \\
\hline
\end{tabular}


Table 1-11. Minor element concentrations in rock samples from the Bodie Mining District.-Continued

[cm, centimeter; K, potassium; Kspar, potassium feldspar; —, no data]

\begin{tabular}{|c|c|c|c|c|c|c|c|c|c|c|c|}
\hline $\begin{array}{l}\text { Sample } \\
\text { number }\end{array}$ & Description, Location & Latitude & Longitude & $\begin{array}{c}\mathrm{Au} \\
\mathrm{ppm}\end{array}$ & $\begin{array}{c}\mathrm{Hg} \\
\mathrm{ppm}\end{array}$ & $\begin{array}{l}\text { Al } \\
\%\end{array}$ & $\begin{array}{l}\text { Ca } \\
\%\end{array}$ & $\begin{array}{l}\mathrm{Fe} \\
\%\end{array}$ & $\begin{array}{l}\mathbf{K} \\
\% \\
\end{array}$ & $\begin{array}{c}\mathrm{Mg} \\
\%\end{array}$ & $\begin{array}{c}\mathrm{Na} \\
\%\end{array}$ \\
\hline \multicolumn{12}{|c|}{ Burgess series veins } \\
\hline $11-\mathrm{BA}-22 \mathrm{~A}$ & Bodie Mine dump, Standard Hill & 38.21257 & -119.00402 & 10.7 & 0.14 & 1.67 & 0.07 & 0.1 & 1.81 & 0.28 & 0.03 \\
\hline 11-BA-22B & Bodie Mine dump, Standard Hill & 38.21257 & -119.00402 & 4.62 & 0.08 & 1.64 & 0.03 & 0.05 & 1.83 & 0.19 & 0.03 \\
\hline $11-\mathrm{BA}-22 \mathrm{C}$ & Bodie Mine dump, Standard Hill & 38.21257 & -119.00402 & 65 & 0.27 & 3.86 & 0.14 & 0.52 & 5.06 & 0.49 & 0.07 \\
\hline 11-BA-22D & Bodie Mine dump, Standard Hill & 38.21257 & -119.00402 & 1.69 & 0.09 & 1.62 & 0.08 & 0.54 & 1.87 & 0.07 & 0.04 \\
\hline 11-BA-22E & Bodie Mine dump, Standard Hill & 38.21257 & -119.00402 & 19.8 & 0.07 & 1.33 & 0.1 & 0.39 & 0.81 & 0.14 & $<0.01$ \\
\hline 07-BA-2 & Quartz vein bladed texture south of Bodie Bluff & 38.21595 & -119.00299 & 1.34 & 7.72 & 4.1 & 0.15 & 1.88 & 4.98 & 0.02 & 0.69 \\
\hline 99-DJ-71A & Banded quartz vein, Bulwer Mine dump, Standard Hill & 38.21452 & -119.00385 & 20 & 0.103 & 1.41 & 0.13 & 0.57 & 1.56 & 0.08 & 0.13 \\
\hline 99-DJ-71B & Pyritic quartz vein, Bulwer Mine dump, Standard Hill & 38.21452 & -119.00385 & 1 & $<0.096$ & 4.84 & 0.36 & 1.54 & 6.71 & 0.04 & 0.08 \\
\hline 99-DJ-71C & Pyritic quartz vein, Bulwer Mine dump, Standard Hill & 38.21452 & -119.00385 & 1.55 & $<0.095$ & 6.58 & 0.31 & 1.38 & 9.3 & 0.04 & 0.11 \\
\hline 99-DJ-71D & Silicified wall rock(?) with pyrite, Bulwer Mine dump & 38.21452 & -119.00385 & 0.11 & $<0.091$ & 5.52 & 0.26 & 2.11 & 7.89 & 0.35 & 0.11 \\
\hline \multicolumn{12}{|c|}{ Silver Hill series veins } \\
\hline BODB07-8 & Quartz-sulfide-K-mica breccia, Contention dump & 38.20524 & -119.0056 & $>10$ & 1.43 & 2.12 & 0.21 & 0.66 & 0.82 & 0.05 & $<0.01$ \\
\hline 09-BA-28A & Red Cloud Mine dump & 38.20151 & -119.00363 & 3.85 & 1.6 & 2.16 & 0.34 & 0.39 & 0.87 & 0.03 & 0.03 \\
\hline 09-BA-28B & Red Cloud Mine dump & 38.20151 & -119.00363 & 37.9 & 0.72 & 1.08 & 0.1 & 1.99 & 0.46 & 0.03 & 0.01 \\
\hline 09-BA-28C & Red Cloud Mine dump & 38.20151 & -119.00363 & 23.3 & 2.05 & 1.38 & 0.31 & 0.3 & 0.57 & 0.02 & 0.01 \\
\hline $09-\mathrm{BA}-28 \mathrm{H}$ & Red Cloud Mine dump & 38.20151 & -119.00363 & 0.61 & 0.14 & 2.73 & 0.11 & 0.88 & 1.1 & 0.04 & 0.02 \\
\hline 09-BA-28I & Red Cloud Mine dump & 38.20151 & -119.00363 & 2.05 & 0.1 & 3.14 & 0.15 & 3.72 & 3.31 & 0.04 & 0.06 \\
\hline 07-BA-5A & Silver Hill dump samples, Bodie & 38.20517 & -119.00479 & 6.81 & 2.76 & 1.54 & 0.11 & 0.92 & 0.64 & 0.04 & 0.02 \\
\hline 07-BA-5B & Silver Hill dump samples, Bodie & 38.20517 & -119.00479 & 13.3 & 0.77 & 1.43 & 0.22 & 0.48 & 0.59 & 0.04 & 0.02 \\
\hline 99-DJ-70A & sulfide-rich vein, Silver Hill & 38.20517 & -119.00479 & 0.03 & 0.759 & 1.07 & 0.71 & 1.87 & 0.54 & 0.13 & 0.01 \\
\hline 99-DJ-70B & 1-cm-wide quartz vein, Silver Hill & 38.20517 & -119.00479 & 0.027 & 0.967 & 1.22 & 0.65 & 1.76 & 0.64 & 0.13 & 0.02 \\
\hline 99-DJ-72A & Sulfide-rich quartz vein, Red Cloud Mine & 38.20151 & -119.00363 & 13 & 0.34 & 1.94 & 0.29 & 2.62 & 0.93 & 0.03 & 0.03 \\
\hline 99-DJ-72B & Sulfide-rich quartz vein, Red Cloud Mine & 38.20151 & -119.00363 & 0.403 & 0.213 & 3.27 & 0.22 & 1.25 & 1.45 & 0.09 & 0.03 \\
\hline 11-BA-6E & Red Cloud Mine dump & 38.20130 & -119.00460 & 42.8 & 0.12 & 2.31 & 0.04 & 0.17 & 1.05 & 0.07 & $<0.01$ \\
\hline 11-BA-7A & Oro Mine dump & 38.20420 & -119.00649 & 1.71 & 1.35 & 1.46 & 0.18 & 2.77 & 1.38 & 0.03 & 0.02 \\
\hline 11-BA-7E & Oro Mine dump & 38.20420 & -119.00649 & 0.052 & 0.22 & 4.03 & 0.16 & 0.68 & 4.26 & 0.15 & 0.05 \\
\hline 11-BA-7F & Oro Mine dump & 38.20420 & -119.00649 & 7.8 & 1.12 & 2.21 & 0.19 & 1.69 & 0.9 & 0.03 & 0.02 \\
\hline 11-BA-9A & Contention Mine dump & 38.20547 & -119.00472 & 2.04 & 0.4 & 1.08 & 0.23 & 0.51 & 0.46 & 0.03 & $<0.01$ \\
\hline 11-BA-9B & Contention Mine dump & 38.20547 & -119.00472 & 16.9 & 0.44 & 2.77 & 0.15 & 0.99 & 1.15 & 0.06 & 0.01 \\
\hline
\end{tabular}


Table 1-11. Minor element concentrations in rock samples from the Bodie Mining District.—Continued

[cm, centimeter; K, potassium; Kspar, potassium feldspar; - , no data]

\begin{tabular}{|c|c|c|c|c|c|c|c|c|c|c|c|c|c|c|}
\hline $\begin{array}{l}\text { Sample } \\
\text { number }\end{array}$ & $\begin{array}{l}\mathbf{S} \\
\%\end{array}$ & $\begin{array}{l}\mathrm{Ti} \\
\%\end{array}$ & $\begin{array}{c}\mathrm{Ag} \\
\mathrm{ppm}\end{array}$ & $\begin{array}{c}\text { As } \\
\text { ppm }\end{array}$ & $\begin{array}{c}\mathrm{Ba} \\
\mathrm{ppm}\end{array}$ & $\begin{array}{c}\mathrm{Be} \\
\mathrm{ppm}\end{array}$ & $\begin{array}{c}\mathrm{Bi} \\
\mathrm{ppm}\end{array}$ & $\begin{array}{c}\text { Cd } \\
\text { ppm }\end{array}$ & $\begin{array}{c}\mathrm{Ce} \\
\mathrm{ppm}\end{array}$ & $\begin{array}{c}\text { Co } \\
\text { ppm }\end{array}$ & $\begin{array}{c}\mathrm{Cr} \\
\mathrm{ppm}\end{array}$ & $\begin{array}{c}\text { Cs } \\
\text { ppm }\end{array}$ & $\begin{array}{c}\mathrm{Cu} \\
\mathrm{ppm}\end{array}$ & $\begin{array}{c}\text { Ga } \\
\text { ppm }\end{array}$ \\
\hline \multicolumn{15}{|c|}{ Burgess series veins } \\
\hline 11-BA-22A & 0.04 & $<0.01$ & 327 & 5 & 60 & 0.7 & 0.69 & 0.1 & 0.88 & 1.1 & $<1$ & $<5$ & 51.2 & 2.12 \\
\hline 11-BA-22B & 0.03 & $<0.01$ & 212 & $<1$ & 58 & 0.4 & 0.3 & $<0.1$ & 0.54 & 0.6 & $<1$ & $<5$ & 24.1 & 1.37 \\
\hline $11-\mathrm{BA}-22 \mathrm{C}$ & 0.41 & 0.05 & 243 & 129 & 424 & 0.6 & 0.29 & 0.3 & 11.8 & 1.9 & 2 & 7 & 74.5 & 4.18 \\
\hline 11-BA-22D & 0.33 & 0.08 & 164 & 51 & 309 & 0.9 & 0.32 & 0.1 & 15.1 & 1.9 & 3 & 5 & 185 & 3.28 \\
\hline $11-B A-22 E$ & 0.24 & 0.04 & 171 & 7 & 52 & 0.8 & 1.46 & 3 & 8.22 & 0.9 & 2 & 5 & 24.6 & 6.45 \\
\hline 07-BA-2 & 1.86 & 0.1 & 13 & 335 & 736 & 0.6 & 0.12 & $<0.1$ & 12.5 & 1.4 & 4 & 6 & 8.2 & 6.14 \\
\hline 99-DJ-71A & - & 0.05 & 41.6 & 12.6 & 154 & 1 & $<0.244$ & $<0.097$ & - & 2 & - & - & 9.94 & 0.588 \\
\hline 99-DJ-71B & - & 0.39 & 20.8 & 45.1 & 164 & 1 & 0.743 & $<0.096$ & - & 2 & - & - & 16.8 & 1.24 \\
\hline 99-DJ-71C & - & 0.36 & 23.2 & 45.5 & 240 & 1 & 0.665 & $<0.095$ & - & $<2$ & - & - & 6.77 & 1.33 \\
\hline 99-DJ-71D & - & 0.25 & 3.68 & 21.4 & 183 & 1 & $<0.229$ & $<0.091$ & - & 5 & - & - & 9.88 & 2.52 \\
\hline \multicolumn{15}{|c|}{ Silver Hill series veins } \\
\hline BODB07-8 & 0.09 & 0.04 & 312 & 250 & 173 & $<5$ & 72 & 29.6 & 15 & 1.8 & $<10$ & 12.1 & $>10,000$ & 11 \\
\hline 09-BA-28A & 0.48 & 0.01 & 430 & 573 & 464 & 0.4 & 9.57 & 1.2 & 4.94 & 0.7 & 2 & 7 & 8,790 & 17.9 \\
\hline 09-BA-28B & 2.46 & 0.05 & 3,090 & 196 & 119 & 0.2 & 309 & 57.4 & 9.51 & 3.8 & 3 & $<5$ & 25,400 & 6.31 \\
\hline 09-BA-28C & 0.9 & 0.02 & 837 & 534 & 195 & 0.3 & 106 & 36.3 & 11.8 & 1.5 & 2 & $<5$ & 11,800 & 12.7 \\
\hline 09-BA-28H & 1.01 & 0.08 & 26 & 33 & 307 & 0.4 & 3.63 & 0.1 & 13.2 & 1.7 & 3 & 8 & 517 & 17.3 \\
\hline 09-BA-28I & 4.8 & 0.24 & 115 & 84 & 75 & 0.5 & 21.1 & 1.9 & 14.2 & 11 & 8 & $<5$ & 442 & 7.71 \\
\hline 07-BA-5A & 3.38 & 0.04 & 72 & 62 & 122 & 0.3 & 37.6 & 406 & 14.4 & 1.9 & 3 & 5 & 6,990 & 63.7 \\
\hline 07-BA-5B & 0.86 & 0.01 & 56 & 185 & 153 & 0.5 & 38.6 & 16.9 & 8.46 & 1.6 & 2 & 7 & 8,930 & 9.21 \\
\hline 99-DJ-70A & - & 0.27 & 4.75 & 56.5 & 296 & 1 & 0.797 & $<0.097$ & - & 6 & - & - & 9.14 & $<0.484$ \\
\hline 99-DJ-70B & - & 0.31 & 5.21 & 47.2 & 244 & 1 & 1.07 & $<0.094$ & - & 6 & - & - & 10.3 & $<0.47$ \\
\hline 99-DJ-72A & - & 0.09 & 298 & 127 & 182 & $<1$ & 29.4 & 9.76 & - & 4 & - & - & 5,072 & 0.972 \\
\hline 99-DJ-72B & - & 0.13 & 18.1 & 27.5 & 252 & 1 & 2.96 & 0.261 & - & 3 & - & - & 500 & $<0.491$ \\
\hline 11-BA-6E & 0.13 & 0.02 & 352 & 68 & 120 & 0.5 & 1.48 & 0.7 & 4.23 & 0.4 & 1 & 7 & 218 & 5.9 \\
\hline 11-BA-7A & $>5$ & 0.08 & 171 & 49 & 225 & 0.3 & 82.1 & 258 & 28.3 & 7 & 3 & $<5$ & 33,100 & 40.9 \\
\hline 11-BA-7E & 0.78 & 0.1 & 9 & 23 & 818 & 0.7 & 0.58 & 0.6 & 18.5 & 2 & 3 & 12 & 151 & 6.37 \\
\hline 11-BA-7F & 2.55 & 0.09 & 432 & 248 & 126 & 0.3 & 41.8 & 42.5 & 12.7 & 5.9 & 5 & $<5$ & 14,600 & 9.63 \\
\hline 11-BA-9A & 0.85 & 0.03 & 249 & 124 & 114 & 0.3 & 28.7 & 7.5 & 14.7 & 1.2 & 2 & $<5$ & 6,290 & 6.53 \\
\hline 11-BA-9B & 1.72 & 0.07 & 305 & 36 & 163 & 0.4 & 65.8 & 9.4 & 14.8 & 1.8 & 3 & 13 & 10,700 & 16.4 \\
\hline
\end{tabular}


Table 1-11. Minor element concentrations in rock samples from the Bodie Mining District.-Continued

[cm, centimeter; K, potassium; Kspar, potassium feldspar; - , no data]

\begin{tabular}{|c|c|c|c|c|c|c|c|c|c|c|c|c|}
\hline $\begin{array}{l}\text { Sample } \\
\text { number }\end{array}$ & $\begin{array}{l}\text { In } \\
\text { ppm }\end{array}$ & $\begin{array}{l}\text { La } \\
\text { ppm }\end{array}$ & $\begin{array}{c}\mathrm{Li} \\
\mathrm{ppm}\end{array}$ & $\begin{array}{l}\mathrm{Mn} \\
\mathrm{ppm}\end{array}$ & $\begin{array}{l}\text { Mo } \\
\text { ppm }\end{array}$ & $\begin{array}{l}\mathrm{Nb} \\
\mathrm{ppm}\end{array}$ & $\underset{\mathrm{ppm}}{\mathrm{Ni}}$ & $\begin{array}{c}P \\
\text { ppm }\end{array}$ & $\begin{array}{c}\mathrm{Pb} \\
\mathrm{ppm}\end{array}$ & $\begin{array}{c}\mathrm{Rb} \\
\mathrm{ppm}\end{array}$ & $\begin{array}{c}\text { Sb } \\
\text { ppm }\end{array}$ & $\begin{array}{c}\text { Se } \\
\text { ppm }\end{array}$ \\
\hline \multicolumn{13}{|c|}{ Burgess series veins } \\
\hline $11-\mathrm{BA}-22 \mathrm{~A}$ & $<0.02$ & $<0.5$ & 85 & 179 & 0.48 & $<0.1$ & 2.5 & $<50$ & 30.3 & 113 & 12.9 & - \\
\hline 11-BA-22B & $<0.02$ & $<0.5$ & 83 & 107 & 0.26 & $<0.1$ & 1.8 & $<50$ & 10.3 & 97.7 & 8.21 & - \\
\hline $11-\mathrm{BA}-22 \mathrm{C}$ & 0.03 & 6.6 & 56 & 272 & 8.87 & 2.1 & 4.7 & 190 & 59.8 & 241 & 23.5 & - \\
\hline 11-BA-22D & $<0.02$ & 8.3 & 84 & 67 & 13.7 & 2.8 & 2.1 & 180 & 36.1 & 85.1 & 26.3 & - \\
\hline 11-BA-22E & 0.06 & 4.9 & 51 & 99 & 1.34 & 1.3 & 0.8 & 120 & 239 & 42.5 & 6.06 & - \\
\hline 07-BA-2 & $<0.02$ & 8.6 & 38 & 20 & 7.23 & 2.4 & 3.1 & 260 & 27.8 & 254 & 56.8 & 1.5 \\
\hline 99-DJ-71A & - & 2 & - & 153 & 2.48 & 3 & 15 & 80 & 2.93 & - & 1.02 & $<1$ \\
\hline 99-DJ-71B & - & 19 & - & 75 & 56.3 & 14 & 8 & 350 & 30.5 & - & 2.83 & 4 \\
\hline 99-DJ-71C & - & 17 & - & 61 & 54.1 & 9 & 5 & 280 & 29.5 & - & 2.61 & 5 \\
\hline 99-DJ-71D & - & 19 & - & 147 & 2.62 & 6 & 17 & 790 & 12.5 & - & 2.4 & 5 \\
\hline $\begin{array}{l}\text { Sample } \\
\text { number }\end{array}$ & $\begin{array}{l}\text { In } \\
\text { ppm }\end{array}$ & $\begin{array}{l}\text { La } \\
\text { ppm }\end{array}$ & $\begin{array}{l}\text { Li } \\
\text { ppm }\end{array}$ & $\begin{array}{l}\text { Mn } \\
\text { ppm }\end{array}$ & $\begin{array}{l}\text { Mo } \\
\text { ppm }\end{array}$ & $\begin{array}{c}\mathrm{Nb} \\
\mathrm{ppm}\end{array}$ & $\underset{\mathrm{ppm}}{\mathrm{Ni}}$ & $\begin{array}{c}P \\
\text { ppm }\end{array}$ & $\begin{array}{l}\mathrm{Pb} \\
\mathrm{ppm}\end{array}$ & $\begin{array}{c}\mathrm{Rb} \\
\mathrm{ppm}\end{array}$ & $\begin{array}{c}\text { Sb } \\
\text { ppm }\end{array}$ & $\begin{array}{c}\text { Sc } \\
\text { ppm }\end{array}$ \\
\hline \multicolumn{13}{|c|}{ Silver Hill series veins } \\
\hline BODB07-8 & 1.6 & 8.3 & 50 & - & 14 & 1 & 7 & - & 2,630 & 43.9 & $>1,000$ & $<5$ \\
\hline 09-BA-28A & 0.35 & 2.6 & 38 & 84 & 8.89 & 0.4 & 1.6 & 730 & 1,520 & 41.3 & 126 & 0.3 \\
\hline 09-BA-28B & 4.06 & 5.8 & 24 & 28 & 48.6 & 1.5 & 1.4 & 370 & 2,260 & 20.3 & 3,080 & 0.6 \\
\hline $09-\mathrm{BA}-28 \mathrm{C}$ & 3.08 & 6.1 & 32 & 39 & 14 & 0.4 & $<0.5$ & 1,470 & 2,870 & 27 & 6,380 & 0.4 \\
\hline $09-\mathrm{BA}-28 \mathrm{H}$ & 0.1 & 7.8 & 40 & 35 & 6.12 & 2.5 & 2.7 & 500 & 549 & 56.5 & 37.3 & 0.9 \\
\hline 09-BA-28I & 0.4 & 8.5 & 23 & 48 & 16.7 & 4.8 & 15.1 & 460 & 1,880 & 148 & 22.5 & 3.8 \\
\hline $07-B A-5 A$ & 10.7 & 6.6 & 43 & 55 & 8.15 & 1.1 & 2.3 & 450 & $<0.5$ & 28.7 & 510 & 0.5 \\
\hline 07-BA-5B & 0.7 & 4.4 & 34 & 56 & 6.85 & 0.3 & 1.7 & 960 & 2,170 & 32.3 & 3,910 & 0.4 \\
\hline 99-DJ-70A & - & 19 & - & 76 & 119 & 8 & 13 & 730 & 26.7 & - & 4.64 & 3 \\
\hline 99-DJ-70B & - & 25 & - & 68 & 162 & 9 & 16 & 1,360 & 31.9 & - & 6.91 & 3 \\
\hline 99-DJ-72A & - & 10 & - & 51 & 13.7 & 3 & 17 & 860 & 1,112 & - & 1,457 & $<1$ \\
\hline 99-DJ-72B & - & 9 & - & 77 & 7.76 & 5 & 8 & 250 & 145 & - & 33.2 & - \\
\hline 11-BA-6E & 0.05 & 2.3 & 52 & 54 & 1.46 & 0.9 & 1 & 140 & 96.4 & 65.5 & 149 & 0.3 \\
\hline 11-BA-7A & 13.2 & 15.1 & 23 & 57 & 37.3 & 3.3 & 7.7 & 530 & 19,000 & 53.6 & 394 & 1.4 \\
\hline 11-BA-7E & 0.06 & 10.3 & 52 & 61 & 7.85 & 4.8 & 2.9 & 340 & 62.6 & 231 & 23.1 & 1.5 \\
\hline 11-BA-7F & 3.31 & 6.7 & 52 & 37 & 78.5 & 2 & 5 & 570 & 1,280 & 45.1 & 4,830 & 1.1 \\
\hline 11-BA-9A & 0.37 & 7.1 & 33 & 21 & 5.9 & 1.1 & 1.4 & 680 & 1,190 & 27 & 758 & 0.5 \\
\hline 11-BA-9B & 0.78 & 8.3 & 34 & 35 & 13.7 & 2.5 & 2 & 380 & 778 & 58.2 & 880 & 1 \\
\hline
\end{tabular}


Table 1-11. Minor element concentrations in rock samples from the Bodie Mining District.—Continued

[cm, centimeter; K, potassium; Kspar, potassium feldspar; —, no data]

\begin{tabular}{|c|c|c|c|c|c|c|c|c|c|c|c|c|}
\hline $\begin{array}{l}\text { Sample } \\
\text { number }\end{array}$ & $\begin{array}{c}\text { Sc } \\
\text { ppm }\end{array}$ & $\begin{array}{c}\text { Sn } \\
\text { ppm }\end{array}$ & $\begin{array}{c}\text { Sr } \\
\mathrm{ppm}\end{array}$ & $\begin{array}{c}\text { Te } \\
\mathrm{ppm}\end{array}$ & $\begin{array}{c}\text { Th } \\
\text { ppm }\end{array}$ & $\begin{array}{c}\mathrm{TI} \\
\mathrm{ppm}\end{array}$ & $\begin{array}{c}\text { U } \\
\mathrm{ppm}\end{array}$ & $\begin{array}{c}\mathrm{V} \\
\mathrm{ppm}\end{array}$ & $\begin{array}{c}\mathrm{W} \\
\mathrm{ppm}\end{array}$ & $\begin{array}{c}\mathrm{Y} \\
\mathrm{ppm}\end{array}$ & $\begin{array}{c}\mathrm{Zn} \\
\mathrm{ppm}\end{array}$ & $\begin{array}{l}\text { C } \\
\%\end{array}$ \\
\hline \multicolumn{13}{|c|}{ Burgess series veins } \\
\hline $11-\mathrm{BA}-22 \mathrm{~A}$ & $<0.1$ & 0.4 & 39.1 & 3 & $<0.2$ & 1.4 & $<0.1$ & 4 & 0.5 & 0.2 & 34 & - \\
\hline 11-BA-22B & $<0.1$ & 0.2 & 36.2 & 1.3 & $<0.2$ & 1.2 & $<0.1$ & 3 & 0.3 & 0.1 & 20 & - \\
\hline $11-\mathrm{BA}-22 \mathrm{C}$ & 0.9 & 0.3 & 170 & 3 & 2.3 & 3.6 & 0.8 & 7 & 6.1 & 2 & 100 & - \\
\hline 11-BA-22D & 1.2 & 0.5 & 68.4 & 0.3 & 3.2 & 1.5 & 1.1 & 19 & 4.7 & 2.4 & 11 & - \\
\hline $11-B A-22 \mathrm{E}$ & 0.6 & 0.3 & 43.3 & 0.9 & 1.6 & 0.7 & 0.7 & 22 & 18.6 & 1.1 & 464 & - \\
\hline 07-BA-2 & 0.7 & 0.4 & 147 & 0.2 & 2.9 & 7.7 & 0.8 & 13 & 2.1 & 1.4 & 6 & - \\
\hline 99-DJ-71A & $<0.975$ & $<2$ & 79 & $<0.487$ & - & $<0.487$ & - & 9 & $<4$ & $<2$ & 23 & - \\
\hline 99-DJ-71B & 1.36 & 2 & 154 & $<0.48$ & - & 0.554 & - & 50 & 17 & 5 & 6.82 & - \\
\hline 99-DJ-71C & 2.05 & $<2$ & 205 & $<0.477$ & - & $<0.477$ & - & 48 & 13 & 4 & 7.99 & - \\
\hline 99-DJ-71D & $<0.914$ & $<2$ & 331 & $<0.457$ & - & 0.667 & - & 44 & $<4$ & 5 & 24.4 & - \\
\hline $\begin{array}{l}\text { Sample } \\
\text { number }\end{array}$ & $\begin{array}{c}\text { Se } \\
\text { ppm }\end{array}$ & $\begin{array}{c}\text { Sn } \\
\mathrm{ppm}\end{array}$ & $\begin{array}{c}\mathrm{Sr} \\
\mathrm{ppm}\end{array}$ & $\begin{array}{c}\text { Te } \\
\text { ppm }\end{array}$ & $\begin{array}{c}\text { Th } \\
\text { ppm }\end{array}$ & $\begin{array}{c}\mathrm{TI} \\
\mathrm{ppm}\end{array}$ & $\begin{array}{c}\text { U } \\
\mathrm{ppm}\end{array}$ & $\begin{array}{c}V \\
\mathrm{ppm}\end{array}$ & $\begin{array}{c}\text { W } \\
\text { ppm }\end{array}$ & $\begin{array}{c}\mathrm{Y} \\
\mathrm{ppm}\end{array}$ & $\begin{array}{c}\mathrm{Zn} \\
\mathrm{ppm}\end{array}$ & $\begin{array}{l}\mathbf{C} \\
\%\end{array}$ \\
\hline \multicolumn{13}{|c|}{ Silver Hill series veins } \\
\hline BODB07-8 & 4.6 & 67 & 40.4 & 181 & 2 & 0.7 & 1 & 24 & 3 & 2.1 & 1,870 & $<0.01$ \\
\hline 09-BA-28A & - & 67.1 & 35.4 & 19.8 & 0.6 & 0.9 & 0.1 & 17 & 1.1 & 0.3 & 31 & - \\
\hline 09-BA-28B & - & 183 & 12.2 & $>500$ & 1.6 & 0.4 & 0.4 & 14 & 2.4 & 0.7 & 3,530 & - \\
\hline $09-\mathrm{BA}-28 \mathrm{C}$ & - & 205 & 26.9 & 234 & 1.1 & 1.2 & 0.3 & 18 & 1.2 & 0.5 & 2,600 & - \\
\hline $09-\mathrm{BA}-28 \mathrm{H}$ & - & 15.2 & 33.8 & 8.4 & 3.3 & 0.9 & 1.2 & 22 & 6.1 & 1.3 & 9 & - \\
\hline 09-BA-28I & - & 0.7 & 78 & 8.5 & 2.3 & 3.1 & 1.2 & 38 & 22 & 3.2 & 210 & - \\
\hline 07-BA-5A & 85.4 & 2.7 & 25 & 280 & 1.7 & 0.6 & 0.5 & 19 & 1.9 & 1.1 & 27,900 & - \\
\hline 07-BA-5B & 7.9 & 36.5 & 28.9 & 86.9 & 0.8 & 0.5 & 0.2 & 18 & 1 & 1.1 & 1,380 & - \\
\hline 99-DJ-70A & $<0.969$ & $<2$ & 24 & $<0.484$ & - & 0.569 & - & 26 & 21 & 4 & 10.8 & - \\
\hline 99-DJ-70B & $<0.94$ & $<2$ & 19 & $<0.47$ & - & 0.615 & - & 33 & 30 & 4 & 9.79 & - \\
\hline 99-DJ-72A & 13.5 & 54 & 64 & 110 & - & $<0.492$ & - & 25 & $<4$ & $<2$ & 618 & - \\
\hline 99-DJ-72B & 1.64 & 12 & 34 & 4.94 & - & $<0.491$ & - & 48 & 9 & 2 & 14.8 & - \\
\hline 11-BA-6E & - & 3.7 & 5.5 & 34.1 & 1 & 0.7 & 0.3 & 13 & 1.7 & 0.5 & 49 & - \\
\hline 11-BA-7A & - & 17.9 & 48 & 135 & 7.2 & 1.5 & 0.7 & 12 & 2.5 & 2 & 20,700 & - \\
\hline 11-BA-7E & - & 0.8 & 157 & 2.4 & 4 & 3.2 & 1.2 & 17 & 6.1 & 2.5 & 41 & - \\
\hline 11-BA-7F & - & 47.8 & 52.7 & 191 & 3.2 & 1 & 1 & 21 & 4 & 1.5 & 1,470 & - \\
\hline 11-BA-9A & - & 10.5 & 18 & 41.7 & 1.7 & 0.4 & 0.5 & 9 & 1.2 & 2.7 & 479 & - \\
\hline 11-BA-9B & - & 70.7 & 18.6 & 230 & 2.7 & 0.9 & 0.8 & 29 & 4.5 & 1.5 & 674 & - \\
\hline
\end{tabular}


Table 1-11. Minor element concentrations in rock samples from the Bodie Mining District.-Continued

[cm, centimeter; K, potassium; Kspar, potassium feldspar; - , no data]

\begin{tabular}{|c|c|c|c|c|c|c|c|c|c|c|c|c|c|}
\hline $\begin{array}{l}\text { Sample } \\
\text { number }\end{array}$ & Description, Location & Latitude & Longitude & $\begin{array}{c}\text { Au } \\
\text { ppm }\end{array}$ & $\begin{array}{c}\mathrm{Hg} \\
\mathrm{ppm}\end{array}$ & $\begin{array}{c}\text { Pd } \\
\text { ppb }\end{array}$ & $\begin{array}{c}\mathrm{Pt} \\
\mathrm{ppb}\end{array}$ & $\begin{array}{l}\text { Al } \\
\%\end{array}$ & $\begin{array}{l}\mathrm{Ca} \\
\%\end{array}$ & $\begin{array}{l}\mathrm{Fe} \\
\%\end{array}$ & $\begin{array}{l}\mathbf{K} \\
\%\end{array}$ & $\begin{array}{c}\mathrm{Mg} \\
\%\end{array}$ & $\begin{array}{l}\mathrm{Na} \\
\%\end{array}$ \\
\hline \multicolumn{14}{|c|}{ Silver Hill series veins } \\
\hline 11-BA-10A & Addenda Mine dump & 38.20556 & -119.00543 & 1,150 & 0.38 & - & - & 2.65 & 0.25 & 1.32 & 1.02 & 0.03 & 0.02 \\
\hline 11-BA-10B & Addenda Mine dump & 38.20556 & -119.00543 & 579 & 0.91 & - & - & 2.66 & 0.25 & 1.11 & 1.11 & 0.03 & 0.02 \\
\hline BOD11-1ME & Quartz-sulfide, minor K-mica vein, Oro dump & 38.20432 & -119.00746 & 77 & 0.82 & 1 & 2.3 & 2.25 & 0.27 & 5.51 & 2.28 & 0.05 & 0.04 \\
\hline BOD11-2ME & Banded quartz-Kspar, minor sulfide vein, Noonday dump & 38.20023 & -119.00991 & $>10$ & 0.22 & $<1$ & $<0.5$ & 5.83 & $<0.01$ & 0.06 & 4.72 & $<0.01$ & 0.08 \\
\hline BOD11-2AME & Quartz-sulfide-K-mica breccia, Contention dump & 38.20524 & -119.0056 & 29 & 3.24 & 3 & 2.4 & 1.42 & 0.21 & 1.18 & 0.54 & 0.02 & 0.01 \\
\hline BOD11-5ABCME & Quartz-sulfide breccia, Red Cloud dump & 38.20133 & -119.00588 & $>10$ & 1.34 & $<1$ & $<0.5$ & 1.81 & 0.14 & 0.44 & 1.01 & 0.06 & 0.02 \\
\hline BOD11-22A & Quartz vein with chalcopyrite, pyrite & 38.21209 & -119.00122 & 6.75 & 1.46 & - & - & 1.13 & 0.02 & 0.42 & 0.67 & 0.02 & 0.01 \\
\hline BOD11-22B & Quartz vein with chalcopyrite, pyrite & 38.21209 & -119.00122 & 1.23 & 1.24 & - & - & 3.83 & 0.1 & 0.44 & 1.74 & 0.09 & 0.03 \\
\hline $\begin{array}{l}\text { Sample } \\
\text { number }\end{array}$ & Description, Location & Latitude & Longitude & $\begin{array}{c}\text { Au } \\
\text { ppm }\end{array}$ & $\begin{array}{c}\mathrm{Hg} \\
\mathrm{ppm}\end{array}$ & $\begin{array}{l}\text { Al } \\
\%\end{array}$ & $\begin{array}{l}\mathrm{Ca} \\
\%\end{array}$ & $\begin{array}{l}\mathrm{Fe} \\
\%\end{array}$ & $\begin{array}{l}\mathbf{K} \\
\%\end{array}$ & $\begin{array}{c}\mathbf{M g} \\
\%\end{array}$ & $\begin{array}{c}\mathrm{Na} \\
\%\end{array}$ & $\begin{array}{l}\mathbf{S} \\
\%\end{array}$ & $\begin{array}{l}\mathrm{Ti} \\
\%\end{array}$ \\
\hline \multicolumn{14}{|c|}{ Uncorrelated veins } \\
\hline $11-B A-21 A$ & Noonday Mine dump & 38.20037 & -119.00919 & 5.81 & 0.06 & 1.13 & 23.4 & 0.02 & 1.6 & 0.03 & 0.02 & 0.04 & $<0.01$ \\
\hline
\end{tabular}

Table 1-11. Minor element concentrations in rock samples from the Bodie Mining District.—Continued

[cm, centimeter; K, potassium; Kspar, potassium feldspar; - , no data]

\begin{tabular}{|c|c|c|c|c|c|c|c|c|c|c|c|c|c|c|}
\hline $\begin{array}{l}\text { Sample } \\
\text { number }\end{array}$ & $\begin{array}{l}\mathbf{S} \\
\%\end{array}$ & $\begin{array}{l}\mathrm{Ti} \\
\%\end{array}$ & $\begin{array}{c}\mathrm{Ag} \\
\mathrm{ppm}\end{array}$ & $\begin{array}{c}\text { As } \\
\text { ppm }\end{array}$ & $\begin{array}{c}\mathrm{Ba} \\
\mathrm{ppm}\end{array}$ & $\begin{array}{c}\mathrm{Be} \\
\mathrm{ppm}\end{array}$ & $\begin{array}{c}\mathrm{Bi} \\
\mathrm{ppm}\end{array}$ & $\begin{array}{c}\text { Cd } \\
\text { ppm }\end{array}$ & $\begin{array}{c}\text { Ce } \\
\text { ppm }\end{array}$ & $\begin{array}{c}\text { Co } \\
\text { ppm }\end{array}$ & $\begin{array}{c}\mathrm{Cr} \\
\mathrm{ppm}\end{array}$ & $\begin{array}{c}\text { Cs } \\
\text { ppm }\end{array}$ & $\begin{array}{c}\text { Cu } \\
\text { ppm }\end{array}$ & $\begin{array}{c}\text { Ga } \\
\text { ppm }\end{array}$ \\
\hline \multicolumn{15}{|c|}{ Silver Hill series veins } \\
\hline 11-BA-10A & 2.11 & 0.08 & 335 & 507 & 163 & 0.3 & 552 & 46.4 & 12.7 & 3.1 & 5 & 7 & 24,400 & 21.4 \\
\hline 11-BA-10B & 2.58 & 0.07 & 250 & 858 & 163 & 0.3 & 478 & 70.5 & 11.1 & 2.6 & 4 & 6 & 30,600 & 19.8 \\
\hline BOD11-1ME & $>5$ & 0.09 & 1,080 & 206 & 160 & 0.3 & 61.5 & 181 & 21.8 & 5.9 & 4 & $<5$ & $>50,000$ & 12.9 \\
\hline BOD11-2ME & 0.02 & $<0.01$ & 180 & 11 & 92 & 1.1 & 0.33 & 0.2 & 1.81 & 1.1 & $<1$ & 14 & 91.7 & 5.16 \\
\hline BOD11-2AME & 3.27 & 0.06 & 497 & 1,210 & 91 & 0.2 & 156 & 101 & 11.4 & 5.3 & 5 & $<5$ & 45,600 & 8.55 \\
\hline BOD11-5ABCME & 0.59 & 0.04 & 1,030 & 416 & 311 & 0.3 & 34.5 & 15.8 & 11.8 & 0.8 & 3 & 7 & 4,060 & 7.76 \\
\hline BOD11-22A & 0.64 & 0.03 & 2,900 & 236 & 27 & 0.4 & 169 & 22.6 & 14.1 & 17.3 & 2 & $<5$ & 9,090 & 5.85 \\
\hline BOD11-22B & 0.4 & 0.12 & 326 & 31 & 49 & 0.9 & 30.9 & 2.8 & 25.1 & 12.6 & 2 & 5 & 3,760 & 20.7 \\
\hline $\begin{array}{l}\text { Sample } \\
\text { number }\end{array}$ & $\begin{array}{c}\mathrm{Ag} \\
\mathrm{ppm}\end{array}$ & $\begin{array}{c}\text { As } \\
\mathrm{ppm}\end{array}$ & $\begin{array}{c}\mathrm{Ba} \\
\mathrm{ppm}\end{array}$ & $\begin{array}{c}\mathrm{Be} \\
\mathrm{ppm}\end{array}$ & $\begin{array}{c}\mathrm{Bi} \\
\mathrm{ppm}\end{array}$ & $\begin{array}{c}\text { Cd } \\
\text { ppm }\end{array}$ & $\begin{array}{c}\mathrm{Ce} \\
\mathrm{ppm}\end{array}$ & $\begin{array}{c}\text { Co } \\
\text { ppm }\end{array}$ & $\begin{array}{c}\mathrm{Cr} \\
\mathrm{ppm}\end{array}$ & $\begin{array}{c}\text { Cs } \\
\mathrm{ppm}\end{array}$ & $\begin{array}{c}\mathrm{Cu} \\
\mathrm{ppm}\end{array}$ & $\begin{array}{c}\text { Ga } \\
\mathrm{ppm}\end{array}$ & $\begin{array}{c}\text { In } \\
\text { ppm }\end{array}$ & $\begin{array}{c}\text { La } \\
\text { ppm }\end{array}$ \\
\hline \multicolumn{15}{|c|}{ Uncorrelated veins } \\
\hline 11-BA-21A & 137 & $<1$ & 22 & 20.2 & 1.36 & 0.2 & 0.35 & 0.4 & $<1$ & $<5$ & 68.2 & 1.04 & $<0.02$ & $<0.5$ \\
\hline
\end{tabular}


Table 1-11. Minor element concentrations in rock samples from the Bodie Mining District.—Continued

[cm, centimeter; K, potassium; Kspar, potassium feldspar; - , no data]

\begin{tabular}{|c|c|c|c|c|c|c|c|c|c|c|c|c|c|}
\hline $\begin{array}{l}\text { Sample } \\
\text { number }\end{array}$ & $\underset{\text { ppm }}{\text { In }}$ & $\begin{array}{l}\text { La } \\
\text { ppm }\end{array}$ & $\begin{array}{c}\mathrm{Li} \\
\mathrm{ppm}\end{array}$ & $\begin{array}{l}\text { Mn } \\
\text { ppm }\end{array}$ & $\begin{array}{l}\text { Mo } \\
\text { ppm }\end{array}$ & $\begin{array}{c}\mathrm{Nb} \\
\mathrm{ppm}\end{array}$ & $\begin{array}{c}\mathrm{Ni} \\
\mathrm{ppm}\end{array}$ & $\begin{array}{c}P \\
\mathbf{p p m}\end{array}$ & $\begin{array}{c}\mathrm{Pb} \\
\mathrm{ppm}\end{array}$ & $\begin{array}{l}\text { Rb } \\
\text { ppm }\end{array}$ & $\begin{array}{c}\text { Sb } \\
\text { ppm }\end{array}$ & $\begin{array}{l}\text { Se } \\
\text { ppm }\end{array}$ & $\begin{array}{c}\text { Sc } \\
\text { ppm }\end{array}$ \\
\hline \multicolumn{14}{|c|}{ Silver Hill series veins } \\
\hline 11-BA-10A & 4.05 & 7.3 & 36 & 20 & 38 & 2.6 & $<0.5$ & 1,160 & 2,180 & 52.8 & 6,780 & 1.1 & - \\
\hline 11-BA-10B & 5.14 & 6.8 & 28 & 24 & 44.1 & 1.8 & $<0.5$ & 1,080 & 2,970 & 55.6 & $>10,000$ & 1 & - \\
\hline BOD11-1ME & 13.2 & 10.9 & 26 & 75 & 28.7 & 1.1 & 5.9 & 750 & 4,890 & 76.8 & 3,580 & 47.1 & 0.8 \\
\hline BOD11-2ME & $<0.02$ & 1.1 & 71 & 83 & 0.63 & 1.3 & $<0.5$ & $<50$ & 17.6 & 273 & 39.5 & 1.4 & 0.2 \\
\hline BOD11-2AME & 5.01 & 6.7 & 33 & 38 & 28.8 & 1.1 & $<0.5$ & 1,180 & 2,710 & 24.8 & $>10,000$ & 36.6 & 0.6 \\
\hline BOD11-5ABCME & 1.51 & 6.3 & 51 & 37 & 16.5 & 1.2 & 0.8 & 600 & 1,600 & 52.1 & 983 & 58.3 & 0.3 \\
\hline BOD11-22A & 1.49 & 8.2 & 43 & 25 & 7.62 & 0.8 & 9 & 150 & 329 & 38.5 & 962 & 4.5 & 0.5 \\
\hline BOD11-22B & 0.35 & 15.4 & 49 & 42 & 3.84 & 4 & 9.9 & 310 & 225 & 94.7 & 191 & 2.5 & 1.9 \\
\hline $\begin{array}{l}\text { Sample } \\
\text { number }\end{array}$ & $\begin{array}{c}\mathrm{Li} \\
\mathrm{ppm}\end{array}$ & $\begin{array}{l}\mathrm{Mn} \\
\mathrm{ppm}\end{array}$ & $\begin{array}{l}\text { Mo } \\
\text { ppm }\end{array}$ & $\begin{array}{c}\mathrm{Nb} \\
\mathrm{ppm}\end{array}$ & $\begin{array}{c}\mathrm{Ni} \\
\mathrm{ppm}\end{array}$ & $\begin{array}{c}P \\
\mathrm{ppm}\end{array}$ & $\begin{array}{l}\mathrm{Pb} \\
\mathrm{ppm}\end{array}$ & $\begin{array}{c}\mathbf{R b} \\
\mathrm{ppm}\end{array}$ & $\begin{array}{c}\text { Sb } \\
\text { ppm }\end{array}$ & $\begin{array}{c}\text { Sc } \\
\mathrm{ppm}\end{array}$ & $\begin{array}{c}\text { Se } \\
\mathrm{ppm}\end{array}$ & $\begin{array}{c}\text { Sn } \\
\text { ppm }\end{array}$ & $\begin{array}{c}\mathrm{Sr} \\
\mathrm{ppm}\end{array}$ \\
\hline \multicolumn{14}{|c|}{ Uncorrelated veins } \\
\hline $11-\mathrm{BA}-21 \mathrm{~A}$ & 51 & 311 & 0.18 & $<0.1$ & $<0.5$ & $<50$ & 12.7 & 89.9 & 26.4 & $<0.1$ & & 0.8 & 811 \\
\hline
\end{tabular}

Table 1-11. Minor element concentrations in rock samples from the Bodie Mining District.-Continued

[cm, centimeter; K, potassium; Kspar, potassium feldspar; —, no data]

\begin{tabular}{|c|c|c|c|c|c|c|c|c|c|c|}
\hline $\begin{array}{l}\text { Sample } \\
\text { number }\end{array}$ & $\begin{array}{c}\text { Sn } \\
\text { ppm }\end{array}$ & $\begin{array}{c}\mathrm{Sr} \\
\mathrm{ppm}\end{array}$ & $\begin{array}{c}\text { Te } \\
\text { ppm }\end{array}$ & $\begin{array}{c}\text { Th } \\
\text { ppm }\end{array}$ & $\begin{array}{c}\mathrm{TI} \\
\mathrm{ppm}\end{array}$ & $\underset{\text { ppm }}{U}$ & $\begin{array}{c}\mathbf{V} \\
\mathrm{ppm}\end{array}$ & $\begin{array}{c}\text { W } \\
\text { ppm }\end{array}$ & $\begin{array}{c}\mathrm{Y} \\
\mathrm{ppm}\end{array}$ & $\begin{array}{c}\mathrm{Zn} \\
\mathrm{ppm}\end{array}$ \\
\hline \multicolumn{11}{|c|}{ Silver Hill series veins } \\
\hline 11-BA-10A & 192 & 52.1 & $>500$ & 3.4 & 0.8 & 1.2 & 31 & 10.7 & 1.6 & 3,780 \\
\hline 11-BA-10B & 258 & 32.4 & $>500$ & 2.9 & 0.8 & 0.9 & 36 & 7 & 1.9 & 6,870 \\
\hline BOD11-1ME & 37.6 & 68 & 340 & 3.3 & 2.6 & 0.7 & 12 & 2.6 & 1.3 & 11,800 \\
\hline BOD11-2ME & 1.1 & 139 & 4 & $<0.2$ & 6.8 & $<0.1$ & $<1$ & 3.9 & 0.3 & 12 \\
\hline BOD11-2AME & 68.4 & 39.1 & 340 & 2 & 0.7 & 0.7 & 18 & 3.8 & 1 & 5,760 \\
\hline BOD11-5ABCME & 132 & 27.7 & 128 & 1.6 & 0.9 & 0.4 & 17 & 1.9 & 1 & 1,410 \\
\hline BOD11-22A & 26.9 & 42.4 & 53.9 & 1.4 & 0.7 & 3 & 15 & 2.6 & 9 & 2,260 \\
\hline BOD11-22B & 7.1 & 57 & 11.9 & 4.6 & 1.2 & 2 & 39 & 15.1 & 7.6 & 246 \\
\hline $\begin{array}{l}\text { Sample } \\
\text { number }\end{array}$ & $\begin{array}{c}\text { Te } \\
\text { ppm }\end{array}$ & $\begin{array}{l}\text { Th } \\
\text { ppm }\end{array}$ & $\begin{array}{c}\text { TI } \\
\text { ppm }\end{array}$ & $\underset{\mathrm{ppm}}{\mathrm{U}}$ & $\begin{array}{c}\mathrm{V} \\
\mathrm{ppm}\end{array}$ & $\begin{array}{c}\mathrm{W} \\
\mathrm{ppm}\end{array}$ & $\begin{array}{c}\mathrm{Y} \\
\mathrm{ppm}\end{array}$ & $\begin{array}{c}\text { Zn } \\
\text { ppm }\end{array}$ & $\begin{array}{l}\text { C } \\
\%\end{array}$ & \\
\hline \multicolumn{11}{|c|}{ Uncorrelated veins } \\
\hline $11-\mathrm{BA}-21 \mathrm{~A}$ & 2.5 & $<0.2$ & 1.1 & $<0.1$ & $<1$ & 2.1 & 0.2 & 16 & - & \\
\hline
\end{tabular}


Table 1-12. Minor element concentrations in rock samples of Spring Peak sinter and subjacent rocks.

\begin{tabular}{|c|c|c|c|c|c|c|c|c|c|c|c|c|}
\hline $\begin{array}{l}\text { Sample } \\
\text { number }\end{array}$ & Description & Latitude & Longitude & $\begin{array}{c}\mathrm{Au} \\
\mathrm{ppm}\end{array}$ & $\begin{array}{c}\mathrm{Hg} \\
\mathrm{ppm}\end{array}$ & $\begin{array}{l}\text { Pd } \\
\text { ppb }\end{array}$ & $\begin{array}{c}\mathrm{Pt} \\
\mathrm{ppb}\end{array}$ & $\begin{array}{l}\text { A } \\
\%\end{array}$ & $\begin{array}{l}\mathrm{Ca} \\
\%\end{array}$ & $\begin{array}{l}\mathrm{Fe} \\
\%\end{array}$ & $\begin{array}{l}\mathbf{K} \\
\%\end{array}$ & $\begin{array}{c}\mathrm{Mg} \\
\%\end{array}$ \\
\hline 06-BA-2 & Banded quartz vein beneath sinter & 38.24908 & -118.85782 & 0.026 & 0.19 & - & - & 0.66 & 0.09 & 0.08 & 0.2 & 0.01 \\
\hline SPK06-1 & Sinter, north edge of terrace & 38.24928 & -118.85268 & 0.042 & 0.84 & - & - & 0.33 & 0.03 & 0.08 & 0.06 & $<0.01$ \\
\hline SPK06-2 & Sinter, prospect pit & 38.24868 & -118.85293 & 0.0066 & 0.1 & - & - & 0.18 & 0.04 & 0.04 & 0.02 & $<0.01$ \\
\hline SPK06-3 & Sinter, north edge of terrace & 38.24932 & -118.85239 & 0.053 & 1.02 & - & - & 0.2 & 0.03 & 0.04 & 0.04 & $<0.01$ \\
\hline SPK11-10 & Silicified, pyritic clastic sediments, sub-sinter & 38.24770 & -118.85113 & 0.007 & 3.63 & - & - & 5.38 & 0.37 & 1.8 & 3.63 & 0.16 \\
\hline SPK11-1ME & Silicified pyritic tuff beneath sinter & 38.24853 & -118.84904 & 0.004 & 1.28 & 3 & $<0.5$ & 5.16 & 0.44 & 0.95 & 3.8 & 0.1 \\
\hline SPK11-4ME & White-beige, granitic rock altered to quartz, clay & 38.24960 & -118.86053 & 0.003 & 6.05 & $<1$ & $<0.5$ & 6.3 & 0.09 & 0.97 & 1.77 & 0.03 \\
\hline SPK11-2ME & Banded vein beneath sinter, in granitic rock & 38.24876 & -118.85513 & 0.126 & 26.5 & $<1$ & $<0.5$ & 0.66 & 0.14 & 0.19 & 0.34 & 0.01 \\
\hline
\end{tabular}

Table 1-12. Minor element concentrations in rock samples of Spring Peak sinter and subjacent rocks.—Continued

\begin{tabular}{|c|c|c|c|c|c|c|c|c|c|c|c|c|c|c|c|c|}
\hline $\begin{array}{l}\text { Sample } \\
\text { number }\end{array}$ & $\begin{array}{c}\mathrm{Na} \\
\%\end{array}$ & $\begin{array}{l}S \\
\%\end{array}$ & $\begin{array}{l}\mathrm{Ti} \\
\%\end{array}$ & $\begin{array}{c}\mathrm{Ag} \\
\mathrm{ppm}\end{array}$ & $\begin{array}{l}\text { As } \\
\mathrm{ppm}\end{array}$ & $\begin{array}{l}\text { Ba } \\
\text { ppm }\end{array}$ & $\begin{array}{c}\mathrm{Be} \\
\mathrm{ppm}\end{array}$ & $\begin{array}{c}\mathrm{Bi} \\
\mathrm{ppm}\end{array}$ & $\underset{\text { ppm }}{\text { Cd }}$ & $\begin{array}{l}\text { Ce } \\
\text { ppm }\end{array}$ & $\begin{array}{l}\text { Co } \\
\text { ppm }\end{array}$ & $\underset{\mathrm{ppm}}{\mathrm{Cr}}$ & $\begin{array}{c}\text { Cs } \\
\text { ppm }\end{array}$ & $\begin{array}{c}\mathrm{Cu} \\
\mathrm{ppm}\end{array}$ & $\begin{array}{l}\mathrm{Ga} \\
\mathrm{ppm}\end{array}$ & $\underset{\mathrm{ppm}}{\text { In }}$ \\
\hline 06-BA-2 & 0.02 & $<0.01$ & $<0.01$ & 2 & 28 & 52 & 1.9 & $<0.04$ & $<0.1$ & 1.16 & 0.3 & 5 & 24 & 2 & 2.68 & $<0.02$ \\
\hline SPK06-1 & $<0.01$ & 0.01 & $<0.01$ & 1 & $<30$ & 85 & 11 & 0.5 & $<0.2$ & 1.7 & 0.8 & $<10$ & 61.1 & 40 & 11 & $<0.2$ \\
\hline SPK06-2 & $<0.01$ & $<0.01$ & $<0.01$ & $<1$ & $<30$ & 90 & $<5$ & $<0.1$ & $<0.2$ & 0.4 & $<0.5$ & $<10$ & 12.2 & 7 & 18 & $<0.2$ \\
\hline SPK06-3 & $<0.01$ & $<0.01$ & $<0.01$ & $<1$ & - & - & - & - & - & - & - & - & - & - & - & $<0.2$ \\
\hline SPK11-10 & 0.54 & 1.45 & 0.22 & $<1$ & 1,560 & 731 & 4.3 & 0.14 & $<0.1$ & 29.3 & 9.7 & 4 & 44 & 117 & 18.8 & 0.03 \\
\hline SPK11-1ME & 0.95 & 0.12 & 0.19 & $<1$ & 252 & 815 & 2 & 0.62 & $<0.1$ & 26.2 & 1.2 & 3 & 71 & 18.8 & 12.1 & 0.02 \\
\hline SPK11-4ME & 0.08 & 0.26 & 0.15 & $<1$ & 293 & 1,440 & 0.4 & 0.07 & $<0.1$ & 46.6 & 0.3 & 2 & 115 & 19.9 & 15.4 & $<0.02$ \\
\hline SPK11-2ME & 0.03 & 0.03 & $<0.01$ & $<1$ & 62 & 178 & 1.2 & $<0.04$ & $<0.1$ & 4.13 & 0.1 & 2 & 110 & 6.5 & 5.81 & $<0.02$ \\
\hline
\end{tabular}


Table 1-12. Minor element concentrations in rock samples of Spring Peak sinter and subjacent rocks. - Continued

\begin{tabular}{|c|c|c|c|c|c|c|c|c|c|c|c|c|}
\hline $\begin{array}{l}\text { Sample } \\
\text { number }\end{array}$ & $\begin{array}{l}\text { La } \\
\text { ppm }\end{array}$ & $\begin{array}{c}\mathbf{L i} \\
\text { ppm }\end{array}$ & $\begin{array}{l}\text { Mn } \\
\text { ppm }\end{array}$ & $\begin{array}{l}\text { Mo } \\
\text { ppm }\end{array}$ & $\begin{array}{l}\mathrm{Nb} \\
\mathrm{ppm}\end{array}$ & $\begin{array}{c}\mathrm{Ni} \\
\mathrm{ppm}\end{array}$ & $\begin{array}{c}P \\
\text { ppm }\end{array}$ & $\begin{array}{c}\mathrm{Pb} \\
\mathrm{ppm}\end{array}$ & $\begin{array}{c}\mathbf{R b} \\
\mathbf{p p m}\end{array}$ & $\begin{array}{c}\text { Sb } \\
\text { ppm }\end{array}$ & $\begin{array}{c}\text { Sc } \\
\text { ppm }\end{array}$ & $\begin{array}{c}\text { Se } \\
\text { ppm }\end{array}$ \\
\hline 06-BA-2 & 0.6 & 123 & 138 & 36.3 & $<0.1$ & 1.1 & 70 & 1.5 & 22.1 & 272 & 0.2 & $<0.2$ \\
\hline SPK06-1 & 0.9 & 20 & - & $<2$ & $<1$ & $<5$ & - & $<5$ & 13.2 & 664 & $<5$ & $<0.2$ \\
\hline SPK06-2 & 0.3 & 20 & - & $<2$ & $<1$ & 8 & - & $<5$ & 5.4 & 835 & $<5$ & $<0.2$ \\
\hline SPK06-3 & 1 & 30 & - & $<2$ & $<1$ & 6 & - & $<5$ & 7.6 & $>1,000$ & $<5$ & 0.4 \\
\hline SPK11-10 & 15.3 & 75 & 90 & 2.04 & 4.3 & 3.1 & 810 & 10.6 & 236 & 208 & 7.7 & $<0.2$ \\
\hline SPK11-1ME & 12.8 & 93 & 49 & 2.23 & 5.4 & 0.9 & 490 & 12.3 & 219 & 259 & 5.2 & $<0.2$ \\
\hline SPK11-4ME & 24.6 & 6 & 27 & 7.64 & 6.7 & $<0.5$ & 320 & 11.9 & 75.7 & 242 & 1.6 & $<0.2$ \\
\hline SPK11-2ME & 2.5 & 36 & 21 & 2.79 & 0.4 & $<0.5$ & 420 & 1.4 & 28.5 & 566 & $<0.1$ & $<0.2$ \\
\hline
\end{tabular}

Table 1-12. Minor element concentrations in rock samples of Spring Peak sinter and subjacent rocks.-Continued

\begin{tabular}{lccccccccccc}
\hline \multicolumn{1}{c}{$\begin{array}{c}\text { Sample } \\
\text { number }\end{array}$} & $\begin{array}{c}\mathbf{S n} \\
\mathbf{p p m}\end{array}$ & $\begin{array}{c}\mathbf{S r} \\
\mathbf{p p m}\end{array}$ & $\begin{array}{c}\text { Te } \\
\mathbf{p p m}\end{array}$ & $\begin{array}{c}\text { Th } \\
\mathbf{p p m}\end{array}$ & $\begin{array}{c}\text { TI } \\
\mathbf{p p m}\end{array}$ & $\begin{array}{c}\mathbf{U} \\
\mathbf{p p m}\end{array}$ & $\begin{array}{c}\mathbf{V} \\
\mathbf{p p m}\end{array}$ & $\begin{array}{c}\mathbf{W} \\
\mathbf{p p m}\end{array}$ & $\begin{array}{c}\mathbf{Y} \\
\mathbf{p p m}\end{array}$ & $\begin{array}{c}\mathbf{Z n} \\
\mathbf{p p m}\end{array}$ & $\begin{array}{c}\mathbf{C} \\
\mathbf{\%}\end{array}$ \\
\hline 06-BA-2 & $<0.1$ & 97.9 & $<0.1$ & 0.2 & 0.4 & 0.2 & $<1$ & 0.5 & 1.4 & $<1$ & - \\
SPK06-1 & $<1$ & 39.9 & $<0.5$ & 0.4 & 1.1 & 0.23 & 6 & 3 & $<0.5$ & 8 & 0.01 \\
SPK06-2 & $<1$ & 21.3 & $<0.5$ & $<0.1$ & $<0.5$ & 0.1 & $<5$ & 1 & $<0.5$ & - & 0.02 \\
SPK06-3 & $<1$ & 22.5 & $<0.5$ & $<0.1$ & $<0.5$ & 0.22 & $<5$ & 5 & 0.5 & $<5$ & 0.05 \\
SPK11-10 & 1.5 & 166 & $<0.1$ & 5.6 & 14 & 2.3 & 124 & 42.4 & 11.5 & 27 & - \\
SPK11-1ME & 0.9 & 271 & $<0.1$ & 6.4 & 3.9 & 2.2 & 82 & 73.2 & 6.6 & 9 & - \\
SPK11-4ME & 0.9 & 531 & $<0.1$ & 13.2 & 2.7 & 6.2 & 28 & 37 & 3 & 6 & - \\
SPK11-2ME & 0.2 & 122 & $<0.1$ & 1.3 & 3.1 & 0.7 & 4 & 2.2 & 2.6 & 3 & - \\
\hline
\end{tabular}


Menlo Park Publishing Service Center, California

Manuscript approved for publication January 23, 2015

Edited by Sarah Nagorsen

Layout and design by Kay Naugle 


\section{$\frac{\mathbb{3}}{3}$}

ISSN 2328-0328 (online)

http://dx.doi.org/10.3133/sir20155012 